RAFAEL RIBEIRO PLÁCIDO

\title{
ANÁLISES DE CAMPO E LABORATÓRIO DO COMPORTAMENTO AO LONGO DO TEMPO DE MUROS DE SOLOS TROPICAIS FINOS REFORÇADOS COM GEOSSINTÉTICOS
}

Tese apresentada à Escola Politécnica da Universidade de São Paulo, como parte dos requisitos para a obtenção do Título de Doutor em Ciências.

São Paulo 

RAFAEL RIBEIRO PLÁCIDO

\section{ANÁLISES DE CAMPO E LABORATÓRIO DO COMPORTAMENTO AO LONGO DO TEMPO DE MUROS DE SOLOS TROPICAIS FINOS REFORÇADOS COM GEOSSINTÉTICOS}

Tese apresentada à Escola Politécnica da Universidade de São Paulo, como parte dos requisitos para a obtenção do Título de Doutor em Ciências.

Área de concentração:

Engenharia Geotécnica

Orientador:

Prof. Dr. Marcos Massao Futai

São Paulo 
Este exemplar foi revisado e corrigido em relação à versão original, sob responsabilidade única do autor e com a anuência de seu orientador.

São Paulo, de de

Assinatura do autor:

Assinatura do orientador:

\section{Catalogação-na-publicação}

\section{Plácido, Rafael Ribeiro}

Análises de campo e laboratório do comportamento ao longo do tempo de muros de solos tropicais finos reforçados com geossintéticos / R. R.

Plácido -- versão corr. -- São Paulo, 2016.

$399 \mathrm{p}$.

Tese (Doutorado) - Escola Politécnica da Universidade de São Paulo. Departamento de Engenharia de Estruturas e Geotécnica.

1.Geossintéticos 2.Fluência 3.Relaxação 4.Muros reforçados 5.Solos tropicais I.Universidade de São Paulo. Escola Politécnica. Departamento de Engenharia de Estruturas e Geotécnica II.t. 
À minha família Dedico esta tese 



\section{AGRADECIMENTOS}

Ao meu orientador, Prof. Dr. Marcos Massao Futai, pela orientação, dedicação e pela confiança depositada no meu trabalho. Agradeço também pelas lições profissionais e pelo positivismo transmitido durante toda a elaboração desta tese.

Ao Prof. Dr. Bendito de Souza Bueno (em memória) por ser o grande incentivador e o responsável pelo início das minhas atividades acadêmicas. Meus sinceros agradecimentos por tudo o que proporcionou enquanto esteve presente.

À minha família, em especial aos meus pais Roberto e llka, pelo intenso apoio e compreensão durante 0 desenvolvimento dessa importante e árdua etapa profissional.

À minha esposa Thelma Kamiji pela compreensão, pelo incentivo, pelo constante apoio e pela contribuição técnica dada durante a elaboração deste trabalho.

Ao Prof. Dr. Fernando Portelinha, por disponibilizar as informações referentes à obra "Bairro Novo" na cidade de Campinas, utilizada como referência neste trabalho e pela imprescindível contribuição técnica dada ao trabalho. Agradeço também pelos constantes incentivos, pela amizade e pelos momentos de descontração.

Ao Prof. Dr. Orêncio Monje e ao Prof. Dr. Jefferson Lins por disponibilizarem as instalações e os equipamentos do Laboratório de Geossintéticos da Escola de Engenharia de São Carlos que foram de extrema importância para a realização desta tese.

A todos os funcionários do Departamento de Engenharia de Estruturas e Geotécnica da EP-USP e do Departamento de Geotecnia da EESC-USP, pelo apoio constante.

A todos os integrantes do Laboratório de Geossintéticos da EESC/USP, em especial aos amigos Clever Valentin, Manuel Izidoro e Walter Costa pela dedicação, pela ajuda constante e pelas sugestões imprescindíveis na execução dos ensaios de 
laboratório. Agradeço também pelas brincadeiras, pelas risadas e por sempre tornarem os momentos em São Carlos mais descontraídos.

Ao Eng. Eugenio Pabst, da empresa Interact Assessoria Técnica em Engenharia, pelo fornecimento do software Plaxis $2 \mathrm{D} \mathrm{AE}$ e por todo o apoio concedido ao longo do desenvolvimento deste trabalho.

À Geosoluções Engenharia Geotécnica e Ambiental, em especial aos engenheiros Victor Pimentel, Vinícius Rocha e José Orlando Avesani Neto por fornecer recursos materiais e financeiros para a elaboração dos ensaios de laboratório.

À Ober Geossintéticos, em especial ao Eng. Fernando Lavoie, pela amizade e pelo fornecimento de materiais.

À Petróleo Brasileiro S.A. (Petrobras) pelo apoio concedido por meio do º Prêmio Petrobras de Tecnologia.

Ao Conselho Nacional de Desenvolvimento Científico e Tecnológico (CNPq), pela bolsa de estudos concedida para o desenvolvimento dessa pesquisa (convênio Petrobras/CNPq).

A todos aqueles que participaram direta ou indiretamente no desenvolvimento do trabalho e no crescimento profissional e pessoal do autor, em especial aos amigos Danilo Pereira Kubitza, Daniel Plana Robert, Danilo França, Julio Antonio Zambrano Ferreira e Natália de Souza Correia. 


\section{RESUMO}

\section{PLÁCIDO, R. R. Análises de campo e laboratório do comportamento ao longo}

do tempo de muros de solos tropicais finos reforçados com geossintéticos. 2016. 385 f. Tese (Doutorado) - Escola Politécnica, Universidade de São Paulo, São Paulo, 2016.

Este trabalho apresenta um estudo sobre o comportamento ao longo do tempo de estruturas em solos finos reforçados com geossintéticos. O programa de atividades desenvolvido para este fim compreendeu três etapas: leituras de deformações de uma estrutura real de solo reforçado com geossintéticos, ensaios de laboratório de fluência confinada e isolada e modelagens computacionais da obra de referência. A estrutura real foi monitorada em duas seções distintas, sendo uma delas construída em geotêxteis não tecidos e a outra em geotêxteis tecidos. As leituras de deformação foram realizadas por um período de quatro anos. As condições da obra real foram utilizadas como referência para o planejamento dos ensaios de fluência em isolamento e confinamento. Os ensaios confinados foram conduzidos inicialmente no equipamento de fluência confinada desenvolvido por Costa (2004), no qual o carregamento é imposto de forma indireta ao reforço. Os ensaios foram realizados empregando o mesmo solo de aterro da obra real, com diferentes níveis de carregamento vertical $(140,200,300$ e $400 \mathrm{kPa})$ e com diferentes umidades de compactação (8\%, 11,7\% e 16\%). Os ensaios com carregamento de $140 \mathrm{kPa}$ foram repetidos no equipamento de fluência confinada-acelerada desenvolvido por França (2011), permitindo uma comparação teórica e prática entre os dois equipamento utilizados. Ensaios adicionais foram realizados para avaliar o comportamento ao longo do tempo de geossintéticos confinados submetidos a um processo de inundação do solo. E para finalizar a campanha de ensaios foram realizados testes para a verificação do incremento de cargas nos reforços devido aos efeitos da compactação do maciço. As modelagens computacionais foram realizadas empregando o software Plaxis 2D. A partir dos modelos numéricos foi possível verificar os mecanismos desenvolvidos ao longo do tempo de estruturas de solos reforçados com geossintéticos. A modelagem numérica permitiu extrapolar o comportamento da estrutura para outro tipo de reforço (geogrelha) e para tempos bem mais elevados do que os tempos reais de leitura. As previsões de 
comportamento foram realizadas para tempos de até 100 anos. Os resultados da campanha de ensaios mostraram que os reforços confinados em solo estão sujeitos aos fenômenos da fluência e da relaxação ao longo do tempo. Os resultados mostraram que as taxas de fluência e de relaxação foram mais elevadas para os maiores carregamentos verticais. Os ensaios adicionais mostraram que os reforços sofreram um incremento significativo de carga devido aos efeitos da compactação e que a rigidez confinada dos reforços praticamente não se alterou devido aos efeitos da inundação. A previsão do comportamento do muro de referência utilizando o MEF mostrou que a estrutura deve apresentar baixos níveis de deformação para períodos de até 100 anos. A análise conjunta de todos os resultados obtidos ao longo do trabalho permitiu o desenvolvimento de um modelo analítico que permite a previsão do comportamento de muros reforçados com geossintéticos a partir de resultados de ensaios de fluência em isolamento. A aplicação do modelo proposto para o caso do muro real mostrou uma boa coerência entre os resultados previstos e os resultados medidos em campo.

Palavras-chave: Geossintéticos. Fluência. Relaxação. Confinamento. Muros reforçados. Solos tropicais. 


\begin{abstract}
PLÁCIDO, R. R. Field and laboratory analysis of time dependent behavior of geosynthetic reinforced soil walls with fine soil. 2016. $385 \mathrm{f}$. Thesis - Polytechnic School, University of Sao Paulo, São Paulo, 2016.
\end{abstract}

This dissertation presents a study on time-dependent behavior of geosynthetic reinforced soil walls with fine soil. The testing program comprised of three distinct steps: field assessment of an instrumented geotextile reinforced soil wall, in-air and in-soil laboratory creep tests, and numerical analysis of the instrumented wall. Reinforcement strains were monitored in two different cross-sections: one built with nonwoven geotextile and the other built with woven geotextile. The strains were monitored during four years of service. The field conditions were used as the basis for planning in-air and in-soil creep tests. The in-soil creep tests were initially conducted using the confined-creep test apparatus developed by Costa (2004), which simulates the typical load transfer mechanism in reinforced soil structures. The in-soil tests were performed using the same soil used in the instrumented wall. These tests were carried out at different levels of vertical load (140,200, 300 and $400 \mathrm{kPa}$ ) at the optimum water content (11.7\%) and at different compaction water content of the soil $(8 \%, 11.7 \%$ and $16 \%)$ at $140 \mathrm{kPa}$. The tests with $140 \mathrm{kPa}$ of vertical load were replicated using the confined-accelerated creep test apparatus developed by França (2011). These tests allowed a theoretical and practical comparison between the two different in-soil creep testing apparatuses utilized in the testing program. Additional in-soil creep tests were conducted to evaluate the behavior of confined geosynthetics with time submitted to flooding of the top soil layer above the reinforcement. Compaction tests were also performed to check the increase of reinforcement loads due to soil compaction. Numerical modelling was carried out with the Finite Element Method (FEM) using Plaxis 2D. The numerical models allowed evaluation of the geotechnical mechanisms developed with time on geosynthetic reinforced soil wall structures. These models were also used to predict timedependent strains for longer periods (until 100 years) and for different types of reinforcements. The results of the testing program showed that the reinforcements confined in soil presented creep and stress relaxation behavior with time. The results also showed that the creep and relaxation rates were higher for larger vertical loads. 
It was observed that the confined stiffness of the reinforcement was virtually the same regardless the occurrence of flooding in the top soil layer. Additionally, the compaction tests showed that the larger the difference of the soil compaction water content from the optimum, the larger the loads in the reinforcement. Behavior prediction of the monitored, full-scale wall using FEM showed that the structure should have low strain levels for periods up to 100 years. The laboratory test results and the mechanisms learned from the FEM analysis allowed the development of an analytical model for predicting geosynthetic-reinforced soil wall behavior from results of in-air creep tests. The strain results of the analytical model applied to the monitored full-scale wall showed that the predicted strains are in good agreement with the field strains.

Keywords: Geosynthetics. Creep. Stress relaxation. Confinement. Reinforced walls. Fine soils. 


\section{LISTA DE FIGURAS}

Figura 2.1 - Deformação de um elemento de solo com e sem reforço (BENJAMIM, 2006).

Figura 2.2 - Ruptura por cisalhamento de solo com e sem reforço (BENJAMIM, 2006).

Figura 2.3 - Comportamento de talude com e sem reforço (adaptado de JONES, 2000).

Figura 2.4 - Estrutura em solo reforçado com faixa com menor grau de compactação.

Figura 2.5 - Arranjos de reforços ensaiados por Lanz e Palmeira (1994) . ...............56

Figura 2.6 - Arranjos de reforços avaliados por Ho e Rowe (1996).......................57

Figura 2.7 - Tipos de arranjo testados por Pedroso (2000).................................58

Figura 2.8 - Deslocamentos horizontais para diferentes arranjos (Pedroso, 2000).. 59

Figura 2.9 - Superfícies de ruptura linear e bi-linear (BENJAMIM, 2006). 62

Figura 2.10 - Limites granulométricos recomendados pela NCMA (1998), FHWA (2001) e KOERNER (2012) (KOERNER; SOONG 2001). 65

Figura 2.11 - Padrões de deslocamentos horizontais em faces de muros de solo reforçado, Costa (2004) ............................................................. 70

Figura 2.12 - Esquema básico dos módulos construídos por Benjamim (2006).......78

Figura 2.13 - Vista geral do Protótipo № 1 construído por Benjamim (2006). ..........78

Figura 2.14 - Instrumentação dos protótipos (BENJAMIM, 2006)..........................80

Figura 2.15 - Superfícies potenciais de ruptura: a) Protótipo 5; b) Protótipo 6 (BENJAMIM, 2006).

Figura 2.16 - Deslocamentos horizontais nas faces dos protótipos: a) Protótipo 5; b) Protótipo 6 (BENJAMIM, 2006).

Figura 2.17 - Deformações verticais registradas para: a) Protótipo 5; b) Protótipo 6 (BENJAMIM, 2006).

Figura 2.18 - Perfil esquemático da seção construída e instrumentada por Riccio Filho (2007).

Figura 2.19 - Solos utilizados na composição do aterro reforçado com geogrelhas (RICCIO FILHO, 2007).

Figura 2.20 - Curva granulométrica dos solos utilizados como material de aterro (RICCIO FILHO, 2007). 
Figura 2.21 - Distribuição dos esforços de tração ao longo do reforço R3 (RICCIO FILHO, 2007)... 87

Figura 2.22 - Deformação específica do reforço da camada número 6 (RICCIO FILHO, 2007).

Figura 2.23 - Deslocamentos horizontais nos inclinômetros de face (RICCIO FILHO, 2007). 88

Figura 2.24 - Deslocamentos horizontais na face do muro ao final da construção (RICCIO FILHO, 2007). 88

Figura 2.25 - Deslocamentos verticais medidos pelas placas magnéticas localizadas próximas à face do muro (RICCIO FILHO, 2007). 89

Figura 2.26 - Caixa metálica de ensaios de grande porte (PORTELINHA, 2012).... 90 Figura 2.27 - Seções típicas dos protótipos construídos por Portelinha (2012):

a) Face em argamassa; b) Face envelopada. 90

Figura 2.28 - Curva de distribuição granulométrica do solo (PORTELINHA, 2012). 91

Figura 2.29 - Localização típica da instrumentação utilizada nos protótipos

(PORTELINHA, 2012). 92

Figura 2.30 - Distribuição dos deslocamentos de face ao longo da altura do protótipo M1 (PORTELINHA, 2012). 93

Figura 2.31 - Distribuição das deformações ao longo do comprimento dos reforços de geotêxteis do protótipo M1: (a) camada 5; (b) camada 4; (c) camada 3; (d) camada 2 (PORTELINHA, 2012). 94

Figura 2.32 - Distribuição das forças medidas e teóricas nos reforços dos protótipos

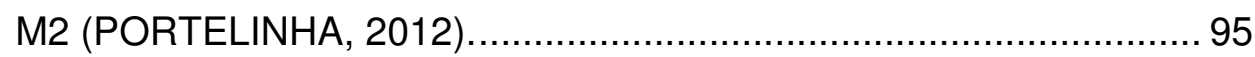

Figura 2.33 - Vista geral da estrutura instrumentada (PORTELINHA, 2012) .......... 96

Figura 2.34 - Seção de projeto e instrumentação da obra (PORTELINHA, 2012). . 96

Figura 2.35 - Distribuição das deformações ao longo do comprimento dos reforços da seção de geotêxteis não tecidos (PORTELINHA, 2012)................ 97

Figura 2.36 - Distribuição das deformações ao longo do comprimento dos reforços da seção de geotêxteis tecidos (PORTELINHA, 2012)....................... 98

Figura 2.37 - Fases da deformação por fluência em geossintéticos (FRANÇA, 2011). 100

Figura 2.38 - Representação gráfica empregada em ensaios de fluência em geossintéticos (FRANÇA, 2011). 102 
Figura 2.39 - Representação gráfica das deformações por fluência proposta por Zornberg; Byler e Knudsen (2004).

Figura 2.40 - Procedimento para a determinação das curvas isócronas: a) Curva convencional (deformação x tempo para diferentes carregamentos); b)

Curvas isócronas (carregamento $x$ deformação para diferentes tempos); (FRANÇA, 2011).

Figura 2.41 - Resultados típicos de um ensaio de fluência: a) Curva convencional (deformação-tempo para diferentes carregamentos); b) Curvas isócronas (carregamento-deformação para diferentes tempos); (COSTA, 2004). 106

Figura 2.42 - Resultados típicos de um ensaio de relaxação: a) Curva convencional (carregamento-tempo para diferentes deformações); b) Curvas isócronas (carregamento-deformação para diferentes tempos); (COSTA, 2004). 106

Figura 2.43 - Caso em que a rigidez por fluência é inferior à rigidez por relaxação (COSTA, 2004).

Figura 2.44 - Caso em que a rigidez por fluência é superior à rigidez por relaxação (COSTA, 2004). 108

Figura 2.45 - Deformação das fibras de um geotêxtil tecido submetido a uma solicitação de tração - a) Sentido longitudinal à aplicação do carregamento; b) Sentido transversal à aplicação do carregamento (adaptado de DEN HOEDT, 1986).

Figura 2.46 - Curva de fluência para diferentes polímeros - a) 20\% da resistência última à tração; b) 60\% da resistência última à tração (adaptado de DEN HOEDT, 1986).

Figura 2.47 - Influência do nível de carregamento no comportamento em relação à fluência de geossintéticos (adaptado de SIMONINI; GOTTARDI, 2003).

Figura 2.48 - Efeito da velocidade de carregamento na fluência de uma geogrelha de PEAD submetida a um carregamento de $40 \%$ de sua resistência última à tração (adaptado de RIMOLDI; MONTANELLI, 1993)

Figura 2.49 - Efeito do tempo de carregamento no recalque do topo da estrutura para carga constante (adaptado de GOTTARDI; SIMONINI, 2000)..115 
Figura 2.50 - Comportamento de um geotêxtil tecido para diferentes velocidades de carregamentos em ensaio de tração (adaptado de ANDRAWES et al., 1984).

Figura 2.51 - Influência da temperatura nas deformações por fluência de uma geomembrana de poliamida (SCAFFARO et al., 2008).

Figura 2.52 - Resultados de ensaios confinados e não confinados de fluência de geotêxteis - a) Não tecido, termoligado, 33\% PEAD e 67\% PP; b) Não tecido, 100\% PET, agulhado (MCGOWN, ANDRAWES E KABIR, 1982).

Figura 2.53 - Curva de compatibilidade para determinação do equilíbrio em solos reforçados a) Resistência do solo mobilizada por deformação lateral; b) Curva isócrona do reforço; c) curva de compatibilidade de deformação (McGOWN et al., 1998).

Figura 2.54 - Tipos de ensaios para investigar as deformações ao longo do tempo de geossintéticos. 124

Figura 2.55 - Equipamento empregado nos ensaios de fluência não confinada

(Adaptado de ASTM D-5262, 2007). 125

Figura 2.56 - Translação horizontal dos resultados de ensaios de fluência conduzidos em temperaturas diferentes com o mesmo nível de carregamento (FRANÇA, 2011).

Figura 2.57 - Exemplo da variação do fator de translação com a temperatura de ensaio para uma geogrelha de PEAD (adaptado de FARRAG, 1998).

Figura 2.58 - Configuração empregada em ensaios confinados de fluência em geossintético na qual o carregamento é aplicado diretamente ao corpo de prova (COSTA, 2004). 130

Figura 2.59 - Sistema de confinamento empregado em estudo pioneiro sobre o efeito do confinamento do solo em fluência de geossintéticos (MCGOWN; ANDRAWES; KABIR, 1982). 132

Figura 2.60 - Equipamento para ensaios de fluência confinada e acelerada em geossintéticos desenvolvido por França (2011).

Figura 2.61 - Esquema geral de um equipamento em que o solo solicita o geossintético (adaptado de COSTA, 2004). 134

Figura 2.62 - Esquema geral do equipamento proposto por Wu e Hong (1994)... 135 
Figura 2.63 - Esquema geral do equipamento proposto por Wu e Helwany (1996). 136

Figura 2.64 - Esquema geral do equipamento proposto por Helwany e Shih (1998).

Figura 2.65 - Representação esquemática do equipamento desenvolvido por Costa (2004). 139

Figura 2.66 - Vista geral do equipamento desenvolvido por Costa (2004). 140

Figura 2.67 - Princípio do mecanismo de transmissão de cargas no equipamento desenvolvido por Costa (2004).

Figura 2.68 - Fator de redução devido à fluência obtido através da curva de ruptura por fluência (COSTA, 1999).

Figura 3.1 - Fluxograma de atividades desenvolvidas. 148

Figura 3.2 - Evolução da construção do muro em solo reforçado ao longo do tempo.

Figura 3.3 - Instrumentação: (a) hastes mecânicas e tensiômetro; (b) seções instrumentadas (PORTELINHA, 2012).

Figura 3.4 - Condições atuais do muro de solo reforçado utilizado como referência. 152

Figura 3.5 - Curva granulométrica do solo local. 153

Figura 3.6 - Curva de compactação Proctor Normal. 153

Figura 3.7 - Resultados dos ensaios de triaxiais do tipo CU para o solo local: (a) Gráfico tensão-deformação; (b) Envoltória de resistência. 154

Figura 3.8 - Resultados dos ensaios de triaxiais do tipo CD para o solo local: (a) Gráfico tensão-deformação; (b) Envoltória de resistência. 155

Figura 3.9 - Variação dos parâmetros de resistência do solo em função da umidade de compactação: (a) Intercepto de coesão; (b) Ângulo de atrito interno.

Figura 3.10 - Variação do módulo de deformabilidade em função da umidade de compactação do solo obtido por meio dos ensaios triaxiais do tipo CD.

Figura 3.11 - Resultados dos ensaios de fluência realizados com o solo local. .....158

Figura 3.12 - Curva de retenção de água do solo utilizado nesta pesquisa. 159

Figura 3.13 - Resultados dos ensaios de tração para os geotêxteis tecidos, não tecidos e geogrelhas. 
Figura 3.14 - Equipamento empregado nos ensaios de fluência não confinada (Adaptado de ASTM D-5262, 2007).

Figura 3.15 - Vista geral dos ensaios de fluência não confinada em andamento para:

a) geotêxteis tecidos e não tecidos; b) geogrelhas. 163

Figura 3.16 - Representação esquemática do equipamento de interação solo-reforço desenvolvido por Costa (2004), com o sistema de aplicação de cargas modificado. 165

Figura 3.17 - Sistema desenvolvido para a aplicação de carregamentos verticais: a)

Vista geral; b) Sistema de guias para garantir a verticalidade do carregamento. 166

Figura 3.18 - Sistema de leitura de deslocamentos internos no reforço: a) Sensor de deslocamento potenciométrico; b) Posicionamento dos sensores na mesa fixa. 167

Figura 3.19 - Evolução do estado de tensões no ensaio de fluência confinada representado por: a) círculos de Mohr; b) trajetória das tensões...... 167

Figura 3.20 - Esquema geral de instrumentação do reforço. ................................. 168

Figura 3.21 - Vista esquemática do sistema desenvolvido para a realização da inundação do solo. 171

Figura 3.22 - Equipamento de fluência confinada acelerada: (a) esquema geral; (b) fotografia do equipamento com ensaio em andamento (FRANÇA, 2011). 173

Figura 3.23 - Configuração final do corpo de prova de geossintético instrumentado. .

Figura 3.24 - Sistema para medição dos deslocamentos internos ao reforço........ 175

Figura 3.25 - Módulo de rigidez em função do tempo para cada tipo de reforço obtido por meio de ensaios de fluência convencional extrapolado para um período de 100 anos. 183

Figura 3.26 - Vista geral do modelo numérico desenvolvido para a simulação dos ensaios confinados no equipamento de interação solo-reforço.

Figura 3.27 - Vista geral do modelo numérico desenvolvido para a simulação das seções instrumentadas do muro de referência de Campinas. 186

Figura 4.1 - Resultados dos ensaios de fluência em isolamento para geotêxteis não tecidos: (a) deformações em escala normal; (b) deformações em 
escala logarítmica; (c) deformações pelo método de Zornberg; Byler e Knudsen (2004). 193

Figura 4.2 - Resultados dos ensaios de fluência em isolamento para geotêxteis tecidos: (a) deformações em escala normal; (b) deformações em escala logarítmica; (c) deformações pelo método de Zornberg; Byler e Knudsen (2004). 194

Figura 4.3 - Resultados dos ensaios de fluência em isolamento para geogrelhas: (a) deformações em escala normal; (b) deformações em escala logarítmica; (c) deformações pelo método de Zornberg; Byler e Knudsen (2004) 196

Figura 4.4 - Resultados dos ensaios de fluência confinada para geotêxteis não tecidos para diferentes carregamentos verticais: (a) Variação da carga no reforço ao longo do tempo em escala normal; (b) Variação da carga no reforço ao longo do tempo em escala semi-logarítmica; (c) Variação das deformações ao longo do tempo em escala semi-logarítmica; (d) Variação das deformações por fluência ao longo do tempo pelo método de Zornberg; Byler e Knudsen (2004). 200

Figura 4.5 - Resultados dos ensaios de fluência confinada para geotêxteis tecidos para diferentes carregamentos verticais: (a) Variação da carga no reforço ao longo do tempo em escala normal; (b) Variação da carga no reforço ao longo do tempo em escala semi-logarítmica; (c) Variação das deformações ao longo do tempo em escala semi-logarítmica; (d) Variação das deformações por fluência ao longo do tempo pelo método de Zornberg; Byler e Knudsen (2004). 202

Figura 4.6 - Resultados dos ensaios de fluência confinada para geogrelhas para diferentes carregamentos verticais: (a) Variação da carga no reforço ao longo do tempo em escala normal; (b) Variação da carga no reforço ao longo do tempo em escala logarítmica; (c) Variação das deformações ao longo do tempo em escala logarítmica; (d) Variação das deformações por fluência ao longo do tempo pelo método de Zornberg; Byler e Knudsen (2004) 204

Figura 4.7 - Variação da carga nos reforços em função da deformação para os ensaios confinados realizados no equipamento desenvolvido por Costa 
(2004) para: (a) Geotêxteis não tecidos; (b) Geotêxteis tecidos; (c)

Geogrelhas.

207

Figura 4.8 - Comparação entre os resultados dos ensaios de fluência confinada e não confinada para geotêxteis não tecidos: (a) Variação das deformações ao longo do tempo pelo método da equação logarítmica;

(b) Variação das deformações por fluência ao longo do tempo pelo método de Zornberg; Byler e Knudsen (2004).

Figura 4.9 - Análise comparativa entre os resultados dos ensaios confinados e não confinados em função do nível de carregamento vertical para geotêxteis não tecidos: (a) Variação do parâmetro "a" do Método da Equação Logarítmica; (b) Variação do parâmetro "b" do Método da Equação Logarítmica;. (c) Variação do parâmetro $\varepsilon_{0}$ do Método proposto por Zornberg; Byler e Knudsen (2004); (d) Variação do parâmetro $T_{\alpha}$ do Método proposto por Zornberg; Byler e Knudsen (2004)

Figura 4.10 - Comparação entre os resultados dos ensaios de fluência confinada e não confinada para geotêxteis tecidos: (a) Variação das deformações ao longo do tempo pelo método da equação logarítmica; (b) Variação das deformações por fluência ao longo do tempo pelo método de Zornberg; Byler e Knudsen (2004).

Figura 4.11 - Análise comparativa entre os resultados dos ensaios confinados e não confinados em função do nível de carregamento vertical para geotêxteis tecidos: (a) Variação do parâmetro "a" do Método da Equação Logarítmica; (b) Variação do parâmetro "b" do Método da Equação Logarítmica;. (c) Variação do parâmetro $\varepsilon_{0}$ do Método proposto por Zornberg; Byler e Knudsen (2004); (d) Variação do parâmetro T $\alpha$ do Método proposto por Zornberg; Byler e Knudsen (2004).

Figura 4.12 - Resultados dos ensaios de fluência confinada para geogrelhas para diferentes carregamentos verticais: (a) Variação das deformações ao longo do tempo pelo método da equação logarítmica; (b) Variação das deformações por fluência ao longo do tempo pelo método de Zornberg; Byler e Knudsen (2004). 
Figura 4.13 - Análise comparativa entre os resultados dos ensaios confinados e não confinados em função do nível de carregamento vertical para geogrelhas: (a) Variação do parâmetro "a" do Método da Equação Logarítmica; (b) Variação do parâmetro "b" do Método da Equação Logarítmica;. (c) Variação do parâmetro $\varepsilon_{0}$ do Método proposto por Zornberg; Byler e Knudsen (2004); (d) Variação do parâmetro $T_{\alpha}$ do Método proposto por Zornberg; Byler e Knudsen (2004).

Figura 4.14 - Variação da rigidez dos reforços em função do tempo para os ensaios de fluência em isolamento, fluência confinada e ensaio de tração para:

(a) Geotêxteis não tecidos; (b) Geotêxteis tecidos; (c) Geogrelhas. .225

Figura 4.15 - Comparação entre os resultados dos ensaios confinados, executados no equipamento de interação solo-reforço, para cada tipo de geossintético para as seguintes tensões verticais: (a) $140 \mathrm{kPa}$; (b) 200 $\mathrm{kPa}$; (c) $300 \mathrm{kPa}$; (d) $400 \mathrm{kPa}$. 229

Figura 4.16 - Variação do módulo de rigidez confinado em função do tempo para os geotêxteis não tecidos, geotêxteis tecidos e geogrelhas sob diferentes níveis de carregamento vertical. 230

Figura 4.17 - Variação das deformações máximas em função do nível de tensão vertical aplicada para os ensaios confinados executados no equipamento de interação solo-reforço.

Figura 4.18 - Variação do parâmetro "a" em função do nível de tensão vertical aplicada para os ensaios confinados executados no equipamento de interação solo-reforço.

Figura 4.19 - Variação do parâmetro "b" em função do nível de tensão vertical aplicada para os ensaios confinados executados no equipamento de interação solo-reforço.

Figura 4.20 - Variação do parâmetro $T_{\alpha}$ em função do nível de tensão vertical aplicada para os ensaios confinados executados no equipamento de interação solo-reforço.

Figura 4.21 - Variação da relação $\mathrm{T} / \mathrm{T}_{\text {ult }}$ em função do carregamento vertical para diferentes tipos de reforço.

Figura 4.22 - Umidades de compactação utilizadas nos ensaios. 
Figura 4.23 - Resultados dos ensaios de fluência confinada para geotêxteis não tecidos para diferentes umidades de compactação do solo: (a) Variação da carga no reforço ao longo do tempo; (b) Variação das deformações ao longo do tempo pelo método da equação logarítmica; (c) Variação das deformações por fluência ao longo do tempo pelo método de Zornberg; Byler e Knudsen (2004); (d) Variação do módulo de rigidez ao longo do tempo; (e) Trajetórias dos carregamentos e deformações para as diferentes umidades de compactação. 239

Figura 4.24 - Resultados dos ensaios de fluência confinada para geotêxteis tecidos para diferentes umidades de compactação do solo: (a) Variação da carga no reforço ao longo do tempo; (b) Variação das deformações ao longo do tempo pelo método da equação logarítmica; (c) Variação das deformações por fluência ao longo do tempo pelo método de Zornberg; Byler e Knudsen (2004); (d) Variação do módulo de rigidez ao longo do tempo; (e) Trajetórias dos carregamentos e deformações para as diferentes umidades de compactação.

Figura 4.25 - Variação da deformação máxima em função da umidade de compactação para os ensaios confinados executados no equipamento desenvolvido por Costa (2004).

Figura 4.26 - Variação do parâmetro "a" em função da umidade de compactação para os ensaios confinados executados no equipamento desenvolvido por Costa (2004).

Figura 4.27 - Variação do parâmetro "b" em função da umidade de compactação para os ensaios confinados executados no equipamento desenvolvido por Costa (2004). 245

Figura 4.28 - Variação do parâmetro T $\alpha$ em função da umidade de compactação para os ensaios confinados executados no equipamento desenvolvido por Costa (2004).

Figura 4.29 - Variação do módulo de rigidez confinado em função da umidade de compactação para os ensaios confinados executados no equipamento desenvolvido por Costa (2004). 247

Figura 4.30 - Variação da relação $\mathrm{T} / \mathrm{T}_{\text {ult }}$ em função da umidade de compactação do solo. 
Figura 4.31 - Resultados dos ensaios de fluência confinada com inundação para geotêxteis não tecidos: (a) Variação da carga no reforço ao longo do tempo; (b) Variação das deformações ao longo do tempo em escala normal; (c) Variação das deformações ao longo do tempo em escala logarítmica; (d) Variação do módulo de rigidez confinada ao longo do tempo; (e) Trajetória das cargas e deformações no reforço.

Figura 4.32 - Resultados dos ensaios de fluência confinada com inundação para geotêxteis tecidos: (a) Variação da carga no reforço ao longo do tempo; (b) Variação das deformações ao longo do tempo em escala normal; (c) Variação das deformações ao longo do tempo em escala logarítmica; (d) Variação do módulo de rigidez confinada ao longo do tempo; (e) Trajetória das cargas e deformações no reforço.

Figura 4.33 - Resultados dos ensaios de fluência confinada com inundação para geogrelhas: (a) Variação da carga no reforço ao longo do tempo; (b) Variação das deformações ao longo do tempo em escala normal; (c) Variação das deformações ao longo do tempo em escala logarítmica; (d) Variação do módulo de rigidez confinada ao longo do tempo; (e) Trajetória das cargas e deformações no reforço. 257

Figura 4.34 - Resultados dos ensaios de compactação realizados para geotêxtil não tecido, geotêxtil tecido e geogrelha.

Figura 4.35 - Variação da carga no reforço em função do número de golpes acumulado para cada tipo de reforço.

Figura 4.36 - Vista geral do modelo numérico desenvolvido para a simulação dos ensaios confinados na caixa de testes desenvolvida por Costa (2004).

Figura 4.37 - Deslocamentos horizontais obtidos no modelo numérico para simulação do ensaio confinado na caixa de testes desenvolvida por Costa (2004) com geotêxtil não tecido.

Figura 4.38 - Tensões horizontais obtidas no modelo numérico para simulação do ensaio confinado na caixa de testes desenvolvida por Costa (2004) com geotêxtil não tecido.

Figura 4.39 - Resultados do modelo calibrado para o caso dos geotêxteis não tecidos. 
Figura 4.40 - Resultados do modelo calibrado para o caso dos geotêxteis tecidos. 267

Figura 4.41 - Resultados do modelo calibrado para o caso das geogrelhas.......... 268

Figura 4.42 - Gráficos obtidos na modelagem computacional para a correlação entre a tensão vertical aplicada no ensaio confinado e: (a) Parâmetro "a";

(b) Parâmetro "b". 270

Figura 4.43 - Trajetória de tensões na região central das paredes da caixa de testes calculada a partir da simulação numérica do ensaio com geotêxtil não tecido. 271

Figura 4.44 - Trajetória de tensões na região central das paredes da caixa de testes calculada a partir da simulação numérica do ensaio com geotêxtil tecido.

Figura 4.45 - Trajetória de tensões na região central das paredes da caixa de testes calculada a partir da simulação numérica do ensaio com geogrelha.272 Figura 4.46 - Variação dos carregamentos e das deformações ao longo dos reforços para: a) Geotêxteis não tecidos; b) Geotêxteis tecidos; c) Geogrelhas. 274

Figura 4.47 - Trajetória de tensões nos ensaios de fluência confinada de geotêxteis não tecidos. 276

Figura 4.48 - Trajetória de tensões nos ensaios de fluência confinada de geotêxteis tecidos. 276

Figura 4.49 - Trajetória de tensões nos ensaios de fluência confinada de geogrelhas.

Figura 4.50 - Estado de tensões no maciço nos ensaios confinados de geotêxteis não tecidos: (a) Tensões horizontais $x$ verticais; (b) variação do coeficiente de empuxo ativo $\left(k_{a}\right)$ para diferentes tensões verticais... 279

Figura 4.51 - Estado de tensões no maciço nos ensaios confinados de geotêxteis tecidos: (a) Tensões horizontais $x$ verticais; (b) variação do coeficiente de empuxo ativo $\left(\mathrm{k}_{\mathrm{a}}\right)$ para diferentes tensões verticais. 279

Figura 4.52 - Estado de tensões no maciço nos ensaios confinados de geogrelhas:

(a) Tensões horizontais $x$ verticais; (b) variação do coeficiente de empuxo ativo $\left(k_{\mathrm{a}}\right)$ para diferentes tensões verticais. 280

Figura 4.53 - Comparação entre os coeficientes de empuxo reforçados $\left(\mathrm{K}_{\mathrm{a}, \mathrm{r}}\right)$ ao final do ensaio para os diferentes reforços testados. 
Figura 4.54 - Variação dos parâmetros de deformação e rigidez em função de $T / T_{\text {ult }}$ para os geotêxteis não tecidos: (a) variação do parâmetro "a" da equação logarítmica; (b) Variação do parâmetro "b" da equação logarítmica; (c) Variação do módulo de rigidez 283

Figura 4.55 - Variação dos parâmetros de deformação e rigidez em função de $\mathrm{T} / \mathrm{T}_{\text {ult }}$ para os geotêxteis tecidos: (a) variação do parâmetro "a" da equação logarítmica; (b) Variação do parâmetro "b" da equação logarítmica; (c) Variação do módulo de rigidez. .285

Figura 4.56 - Variação dos parâmetros de deformação e rigidez em função de $\mathrm{T} / \mathrm{T}_{\text {ult }}$ para as geogrelhas: (a) variação do parâmetro "a" da equação logarítmica; (b) Variação do parâmetro "b" da equação logarítmica; (c) Variação do módulo de rigidez. 287

Figura 4.57 - Dados de variação dos parâmetros "a" e "b" em função de $T / T_{\text {ult }}$ apresentados por Kamiji (2006) para: (a) geotêxtil não tecido de polipropileno com resistência de $1,5 \mathrm{kN} / \mathrm{m}$; (b) geotêxtil não tecido de polipropileno com resistência de 4,39 kN/m; (c) geotêxtil não tecido de poliéster com resistência de $3,98 \mathrm{kN} / \mathrm{m}$. .288

Figura 4.58 - Dados de variação dos parâmetros $\varepsilon_{0}$ e $T \alpha$ em função de $T / T_{\text {ult }}$ apresentados por França (2011) para: (a) geotêxtil não tecido de poliéster com resistência de $13,9 \mathrm{kN} / \mathrm{m}$; (b) geotêxtil tecido de polipropileno com resistência de $50,9 \mathrm{kN} / \mathrm{m}$; (c) geogrelha de poliéster com resistência de $37,3 \mathrm{kN} / \mathrm{m}$. 289

Figura 4.59 - Dados de variação dos parâmetros "a" e "b" em função de $T / T_{\text {ult }}$ apresentados por Avesani (2013) para: (a) geotêxtil não tecido de poliéster com resistência de $14,1 \mathrm{kN} / \mathrm{m}$; (b) geotêxtil tecido de poliéster com resistência de 19,7 kN/m. 290

Figura 4.60 - Curvas de ajuste para cada tipo de reforço ensaiado para os parâmetros: (a) $J(1 \mathrm{~h})$; (b) $\mathrm{V}_{\mathrm{J}}$ 292

Figura 4.61 - Resultados dos ensaios de fluência confinada executados no equipamento de fluência confinada-acelerada para geotêxteis não tecidos, para duas temperaturas diferentes: (a) Variação das deformações ao longo do tempo; (b) Variação das deformações ao longo do tempo pelo método da equação logarítmica; (c) Variação das 
deformações ao longo do tempo extrapolado - Curva Mestra; (d) Variação da rigidez confinada ao longo do tempo.

Figura 4.62 - Resultados dos ensaios de fluência confinada executados no equipamento de fluência confinada-acelerada para geotêxteis tecidos, para duas temperaturas diferentes: (a) Variação das deformações ao longo do tempo; (b) Variação das deformações ao longo do tempo pelo método da equação logarítmica; (c) Variação das deformações ao longo do tempo extrapolado - Curva Mestra; (d) Variação da rigidez confinada ao longo do tempo. 297

Figura 4.63 - Resultados dos ensaios de fluência confinada executados no equipamento de fluência confinada-acelerada para geogrelha, para duas temperaturas diferentes: (a) Variação das deformações ao longo do tempo; (b) Variação das deformações ao longo do tempo pelo método da equação logarítmica; (c) Variação das deformações ao longo do tempo extrapolado - Curva Mestra; (d) Variação da rigidez confinada ao longo do tempo. 299

Figura 4.64 - Comparação entre os resultados dos ensaios confinados, executados no equipamento de fluência confinada-acelerada, e resultados dos ensaios não confinados, para geotêxteis não tecidos: (a) Variação das deformações ao longo do tempo pelo método da equação logarítmica; (b) Variação das deformações por fluência ao longo do tempo pelo método de Zornberg; Byler e Knudsen (2004). 302

Figura 4.65 - Comparação entre os resultados dos ensaios confinados, executados no equipamento de fluência confinada-acelerada, e resultados dos ensaios não confinados, para geotêxteis tecidos: (a) Variação das deformações ao longo do tempo pelo método da equação logarítmica; (b) Variação das deformações por fluência ao longo do tempo pelo método de Zornberg; Byler e Knudsen (2004) 303

Figura 4.66 - Comparação entre os resultados dos ensaios confinados, executados no equipamento de fluência confinada-acelerada, e resultados dos ensaios não confinados, para geogrelhas: (a) Variação das deformações ao longo do tempo pelo método da equação logarítmica; (b) Variação das deformações por fluência ao longo do tempo pelo método de Zornberg; Byler e Knudsen (2004) 304 
Figura 4.67 - Comparação entre os resultados obtidos nos ensaios confinados executados nos equipamentos de interação solo-reforço e fluência confinada-acelerada para geotêxteis não tecidos: (a) Método logarítmico; (b) Método de Zornberg; Byler e Knudsen (2004); (c) Variação do módulo de rigidez ao longo do tempo; (d) Variação da deformação em função da carga.

Figura 4.68 - Comparação entre os resultados obtidos nos ensaios confinados executados nos equipamentos de interação solo-reforço e fluência confinada-acelerada para geotêxteis tecidos: (a) Método logarítmico; (b) Método de Zornberg; Byler e Knudsen (2004); (c) Variação do módulo de rigidez ao longo do tempo; (d) Variação da deformação em função da carga

Figura 4.69 - Comparação entre os resultados obtidos nos ensaios confinados executados nos equipamentos de interação solo-reforço e fluência confinada-acelerada para geogrelhas: (a) Método logarítmico; (b) Método de Zornberg; Byler e Knudsen (2004); (c) Variação do módulo de rigidez ao longo do tempo; (d) Variação da deformação em função da carga. 312

Figura 4.70 - Comparação entre os comportamentos típicos observados nos equipamentos de interação solo-reforço e fluência confinadaacelerada

Figura 5.1 - Posicionamento dos níveis de leitura E01, E02 e E03 ao longo da seção instrumentada.

Figura 5.2 - Deslocamentos internos para a seção em geotêxteis não tecidos na elevação: (a) 0,8 m (E01); (b) 1,6 m (E02); (c) 5,2 m (E03).

Figura 5.3 - Deslocamentos internos para a seção em geotêxteis tecidos na elevação: (a) 0.8 m (E01); (b) 1.6 m (E02); (c) 5.2 m (E03).

Figura 5.4 - Resultados das leituras de deslocamentos internos na seção em geotêxtil não tecido, elevação 0,8 m (E01): (a) deslocamentos relativos; (b) curvas sigmoides de deformação; (c) deformações máximas ao longo do tempo.

Figura 5.5 - Resultados das leituras de deslocamentos internos na seção em geotêxtil não tecido, elevação 1,6 m (E02): (a) deslocamentos 
relativos; (b) curvas sigmoides de deformação; (c) deformações máximas ao longo do tempo.

Figura 5.6 - Resultados das leituras de deslocamentos internos na seção em geotêxtil não tecido, elevação 5,2 m (E03): (a) deslocamentos relativos; (b) curvas sigmoides de deformação; (c) deformações máximas ao longo do tempo.

Figura 5.7 - Resultados das leituras de deslocamentos internos na seção em geotêxtil tecido, elevação 0,8 m (E01): (a) deslocamentos relativos; (b) curvas sigmoides de deformação; (c) deformações máximas ao longo do tempo. 333

Figura 5.8 - Resultados das leituras de deslocamentos internos na seção em geotêxtil tecido, elevação 1,6 m (E02): (a) deslocamentos relativos; (b) curvas sigmoides de deformação; (c) deformações máximas ao longo do tempo.

Figura 5.9 - Resultados das leituras de deslocamentos internos na seção em geotêxtil tecido, elevação 5,2 m (E03): (a) deslocamentos relativos; (b) curvas sigmoides de deformação; (c) deformações máximas ao longo do tempo.

Figura 5.10 - Distribuição das deformações medidas e teóricas no muro de referência de Campinas para a seção em: (a) geotêxtil não tecido; (b) geotêxtil tecido. 337

Figura 5.11 - Distribuição das deformações ao longo do comprimento dos reforços da seção de geotêxteis não tecidos (linhas E01, E02 e E03). 338

Figura 5.12 - Distribuição das deformações ao longo do comprimento dos reforços da seção de geotêxteis tecidos (linhas E01, E02 e E03). 338

Figura 5.13 Comparação entre os resultados dos ensaios de fluência em laboratório utilizando o equipamento de interação solo-reforço desenvolvido por Costa (2004) e os resultados de campo, para geotêxteis não tecidos pelos métodos: (a) da curva logarítmica; (b) de Zornberg; Byler e Knudsen (2004). 340

Figura 5.14 - Comparação entre os resultados dos ensaios de fluência em laboratório utilizando o equipamento de interação solo-reforço desenvolvido por Costa (2004) e os resultados de campo, para 
geotêxteis tecidos pelos métodos: (a) da curva logarítmica; (b) de Zornberg; Byler e Knudsen (2004).

Figura 5.15 - Comparação entre os resultados dos ensaios de fluência em laboratório utilizando o equipamento de fluência confinada-acelerada desenvolvido por França (2011) e os resultados de campo, para geotêxteis não tecidos pelos métodos: (a) da curva logarítmica; (b) de Zornberg; Byler e Knudsen (2004). 343

Figura 5.16 - Comparação entre os resultados dos ensaios de fluência em laboratório utilizando o equipamento de fluência confinada-acelerada desenvolvido por França (2011) e os resultados de campo, para geotêxteis tecidos pelos métodos: (a) da curva logarítmica; (b) de Zornberg; Byler e Knudsen (2004).

Figura 5.17 - Módulos de rigidez em função do tempo adotados para os diferentes reforços nas modelagens computacionais.

Figura 5.18 - Calibração do modelo numérico para a seção em solo reforçado com geotêxtil não tecido: (a) Comparação entre as deformações lidas na instrumentação e as deformações previstas no modelo numérico para a seção E02; (b) Ajuste das deformações pelo método da equação logarítmica para os resultados da instrumentação de campo e para os resultados obtidos no modelo numérico.

Figura 5.19 - Calibração do modelo numérico para a seção em solo reforçado com geotêxtil tecido: (a) Comparação entre as deformações lidas na instrumentação e as deformações previstas no modelo numérico para a seção E02; (b) Ajuste das deformações pelo método da equação logarítmica para os resultados da instrumentação de campo e para os resultados obtidos no modelo numérico. 350

Figura 5.20 - Resultados da simulação numérica para a seção em geotêxtil não tecido para um tempo imediatamente após o término da construção do muro: (a) Malha deformada; (b) Deslocamentos horizontais; (c) Tensões efetivas horizontais; (d) Histórico de plastificação do aterro reforçado.

Figura 5.21 - Resultados da simulação numérica para a seção em geotêxtil tecido para um tempo imediatamente após o término da construção do muro: (a) Malha deformada; (b) Deslocamentos horizontais; (c) Tensões 
efetivas horizontais; (d) Histórico de plastificação do aterro reforçado.

Figura 5.22 - Extrapolação dos resultados do modelo numérico para um período máximo de 100 anos para a seção em geotêxtil não tecido, seção instrumentada E02: (a) Variação das deformações ao longo do reforço para diferentes tempos; (b) Variação das deformações máximas ao longo do tempo. 358

Figura 5.23 - Extrapolação dos resultados do modelo numérico para um período máximo de 100 anos para a seção em geotêxtil tecido, seção instrumentada E02: (a) Variação das deformações ao longo do reforço para diferentes tempos; (b) Variação das deformações máximas ao longo do tempo. 360

Figura 5.24 - Extrapolação dos resultados do modelo numérico utilizando geogrelhas como reforço, para um período de 100 anos, para a quinta linha de reforço: (a) Variação das deformações ao longo do reforço para diferentes tempos; (b) Variação das deformações máximas ao longo do tempo.

Figura 5.25 - Estimativa da variação das deformações ao longo do tempo para as linhas de reforços $n^{\circ} 3,5,7,9$ e 11 para os modelos numéricos de solos reforçados com: (a) Geotêxteis não tecidos; (b) Geotêxteis tecidos; (c) Geogrelhas.

Figura 5.26 - Cargas nos reforços e posição da superfície de ruptura no período pós-construtivo e após 100 anos de construção obtidos nos modelos numéricos dos muros executados com: (a) Geotêxtil não tecido; (b) Geotêxtil tecido; (c) Geogrelha.

Figura 5.27 - Comparação entre os resultados dos ensaios de fluência confinada, leituras de campo e previsão de deformações por meio da modelagem computacional para: a) seção reforçada com geotêxteis não tecidos; b) seção reforçada com geotêxteis tecidos.

Figura 5.28 - Relação entre a posição do reforço ao longo da altura do muro e os parâmetros "a" e "b" para: (a) geotêxteis não tecidos; (b) geotêxteis tecidos; (c) geogrelhas. 
Figura 5.29 - Comparação entre os resultados da instrumentação de campo, da modelagem computacional e do modelo analítico proposto para: (a) geotêxteis não tecidos; (b) geotêxteis tecidos...................................373 



\section{LISTA DE TABELAS}

Tabela 2.1 - Fatores que influenciam no comportamento das estruturas (BENJAMIM, 2006 - modificado). 50

Tabela 2.2 - Importância dos fatores que influenciam no comportamento das estruturas de solo reforçado (JONES, 1990).

Tabela 2.3 - Resumos das especificações de solos para muros reforçados com geossintéticos em diferentes países (ZORNBERG; LESHCHINSKY, 2003).

Tabela 2.4 - Casos históricos de muros e taludes em solos reforçados com geossintéticos (BATHURST et al., 2008 - Modificado).

Tabela 2.5 - Características principais dos solos e dos geotêxteis utilizados (BENJAMIM, 2006).

Tabela 2.6 - Parâmetros geotécnicos dos solos de aterro utilizados na pesquisa (BENJAMIM, 2006).

Tabela 2.7 - Resultados dos ensaios de caracterização dos geotêxteis utilizados na pesquisa (BENJAMIM, 2006). 79

Tabela 2.8 - Resultados dos ensaios de caracterização dos solos empregados no aterro (RICCIO FILHO, 2007).

Tabela 2.9 - Parâmetros de resistência ao cisalhamento dos solos empregados no aterro (RICCIO FILHO, 2007)

Tabela 2.10 - Especificação técnica dos reforços utilizados no muro reforçado (RICCIO FILHO, 2007). .86

Tabela 2.11 - Características dos protótipos construídos (PORTELINHA, 2012)....90

Tabela 2.12 - Parâmetros de resistência do solo empregado nos protótipos (PORTELINHA, 2012).

Tabela 2.13 - Propriedades características dos geotêxteis empregados na pesquisa (PORTELINHA, 2012).

Tabela 2.14 - Fatores de redução sugeridos para geotêxteis (KOERNER, 2005)..143

Tabela 3.1- Módulos de deformabilidade obtidos nos ensaios triaxiais do tipo CU e CD. 155

Tabela 3.2- Condições de carregamento para os ensaios de fluência do solo. .....158 Tabela 3.3- Propriedades mecânicas dos geotêxteis não tecidos, tecidos e geogrelhas. 
Tabela 3.4- Propriedades mecânicas dos geotêxteis não tecidos, tecidos e geogrelhas.

Tabela 3.5 - Programa de ensaios de fluência confinada para o equipamento de interação solo-reforço

Tabela 3.6 - Programa de ensaios de fluência confinada para o equipamento desenvolvido por França (2011).

Tabela 3.7 - Programa de ensaios de compactação realizados no equipamento de interação solo-reforço. 179

Tabela 3.8 - Parâmetros geotécnicos empregados nas análises numéricas. 185

Tabela 3.9 - Parâmetros geotécnicos empregados nas análises numéricas. 187

Tabela 3.10 - Períodos de tempo para os quais foram calculadas as deformações pós-construção nos reforços.

Tabela 4.1 - Resumo das análises de fluência não confinada para os geotêxteis não tecidos, tecidos e geogrelhas por meio do método da equação logarítmica e pelo método proposto por Zornberg; Byler e Knudsen (2004).

Tabela 4.2 - Valores de cargas estabilizadas para os ensaios de fluência confinada.

Tabela 4.3 - Valores de cargas ao final dos ensaios de fluência confinada. 247

Tabela 4.4 - Valores dos carregamentos nos reforços sem e com os efeitos da compactação. 262

Tabela 4.5 - Valores de $\mathrm{K}_{\mathrm{a}, \mathrm{r}}$ obtidos por meio das análises numéricas. 275

Tabela 4.6 - Parâmetros de ajuste para as Equações de $\mathrm{J}(1 \mathrm{~h})$ e $\mathrm{V}_{\mathrm{J}}$. 292

Tabela 5.1 - Comparação geral dos parâmetros "a" e "b" obtidos a partir de diferentes abordagens.

Tabela 5.2 - Comparação entre as taxas de fluência obtidas em campo, MEF e laboratório, para todos os níveis instrumentados. 365

Tabela 5.3 - Calculo do módulo de rigidez pelo modelo de comportamento proposto.

Tabela 5.4 - Cálculo das deformações nos reforços para diferentes tempos. 372 


\section{LISTA DE ABREVIATURAS}

ABNT Associação Brasileira de Normas Técnicas

ASTM American Society for Testing and Materials

EESC Escola de Engenharia de São Carlos

FHWA Federal Highway Administration

GG Geogrelha

GNT Geotêxtil não tecido

GT Geotêxtil tecido

ISO International Organization for Standardization

NBR Norma Brasileira

PA Poliamida

PE Polietileno

PEAD Polietileno de alta densidade

PET Poliéster

PP Polipropileno

USP Universidade de São Paulo

WLF Equação desenvolvida por Williams, Landel e Ferry (1955) 



\section{LISTA DE SÍMBOLOS}

$\begin{array}{ll}a, b & \text { Constantes de ajuste logarítmico das curvas de fluência e relaxação } \\ \alpha_{T} & \text { Fator de translação } \\ c & \text { Coesão do solo } \\ \mathrm{C}_{1} \text { e C2 } & \text { Constantes empíricas empregadas na Equação WLF } \\ \varepsilon & \text { Deformação total } \\ \varepsilon_{0} & \text { Deformação inicial } \\ \varepsilon_{f} & \text { Deformação por fluência } \\ \phi & \text { Ângulo de atrito interno do solo } \\ \mathrm{f}_{\mathrm{m}} & \text { Fator de redução devido a incertezas estatísticas. } \\ \mathrm{FR} & \text { Fator de redução devido à degradação biológica } \\ \mathrm{FR} & \text { Fator de redução devido aos danos de instalação } \\ \mathrm{FR} & \text { Fator de redução devido à degradação química } \\ \mathrm{FR} & \text { Fator de redução devido à fluência } \\ \gamma & \text { Peso específico do solo } \\ \gamma_{\mathrm{d}} & \text { Peso específico seco do solo } \\ \mathrm{H} & \text { Altura do muro } \\ \mathrm{IP} & \text { Índice de plasticidade do solo } \\ \mathrm{J} & \text { Módulo de rigidez } \\ \mathrm{J}(1 \mathrm{~h}) & \text { rigidez inicial do reforço para uma hora de ensaio } \\ \mathrm{J}_{\mathrm{med}} & \text { Módulo de rigidez médio } \\ \mathrm{K}_{\mathrm{a}} & \text { Coeficiente de empuxo ativo do solo } \\ \mathrm{K}_{\mathrm{a}, \mathrm{r}} & \text { Coeficiente de empuxo ativo do solo reforçado } \\ \mathrm{LL} & \text { Limite de liquidez do solo } \\ \mathrm{LP} & \text { Limite de plasticidade do solo } \\ \sigma_{1} & \text { Tensão principal maior } \\ \sigma_{3} & \text { Tensão principal menor } \\ \sigma_{V} & \text { Tensão vertical } \\ \mathrm{T} & \text { Força de tração mobilizada no reforço } \\ \mathrm{t} & \text { Tempo } \\ \mathrm{T}_{\alpha} & \text { Índice de fluência } \\ \end{array}$




$\begin{array}{ll}T_{\alpha, i} & \text { Índice de fluência do ensaio com temperatura elevada } \\ T_{\alpha, R} & \text { Índice de fluência do ensaio na temperatura de referência } \\ T_{a d m} & \text { Resistência à tração admissível do geossintético } \\ t_{R} & \text { Tempo para que um processo ocorra na temperatura de referência } \\ t_{T} & \text { Tempo para que um processo ocorra na temperatura elevada } \\ T_{u l t} & \text { Resistência última do reforço } \\ V_{J} & \text { Tendência à redução da rigidez do ensaio de fluência em isolamento } \\ w & \text { Teor de umidade do solo } \\ z & \text { Profundidade }\end{array}$




\section{SUMÁRIO}

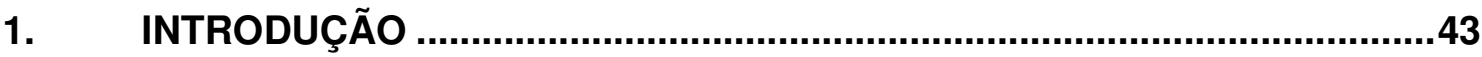

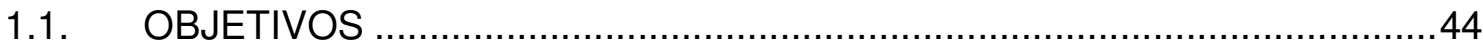

1.2. ORGANIZAÇÃO DO TRABALHO

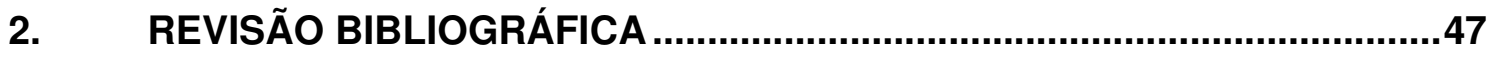

2.1 ESTRUTURAS DE SOLO REFORÇADO COM GEOSSINTÉTICOS...........47

2.2 FATORES QUE INFLUENCIAM NO COMPORTAMENTO DAS ESTRUTURAS DE CONTENÇÃO EM SOLO REFORÇADO ………...........49

2.2.1 Condições do solo de fundação..............................................................52

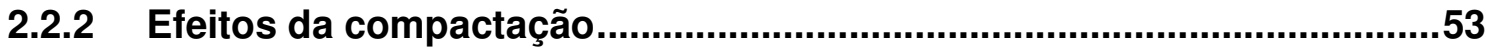

2.2.3 Efeitos da geometria interna do muro ...................................................55

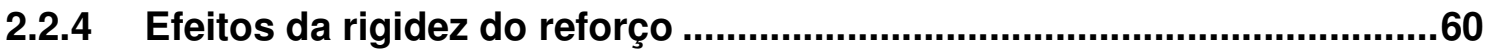

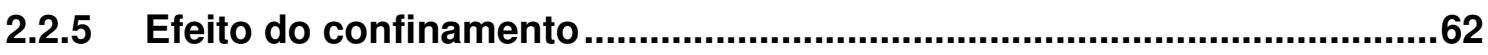

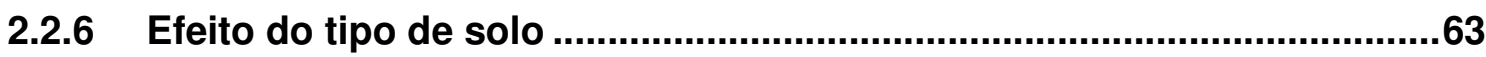

2.3 COMPORTAMENTO MECÂNICO DE ESTRUTURAS DE CONTENÇÃO EM SOLO REFORÇADO COM GEOSSINTÉTICOS .........................................68

2.4 RELATOS DE CASOS DE MUROS EM SOLO REFORÇADO UTILIZANDO SOLOS TROPICAIS COMO MATERIAL DE ATERRO ................................76

2.4.1 Protótipos instrumentados por Benjamim (2006)....................................77

2.4.2 Muro instrumentado por Riccio Filho (2007) .........................................82

2.4.3 Protótipos e muro instrumentados por Portelinha (2012) .......................89

2.5 COMPORTAMENTO DEPENDENTE DO TEMPO DOS GEOSSINTÉTICOS

2.5.1 Representação gráfica da fluência e relaxação em geossintéticos .....101

2.5.2 Módulos de rigidez por fluência e relaxação .........................................105

2.5.3 Fatores que afetam a fluência em geossintéticos .................................109

2.5.4 Ensaios para a avaliação de fluência em geossintéticos ......................122 
2.6 CONSIDERAÇÃO DA FLUÊNCIA EM PROJETOS DE SOLO REFORÇADO 142

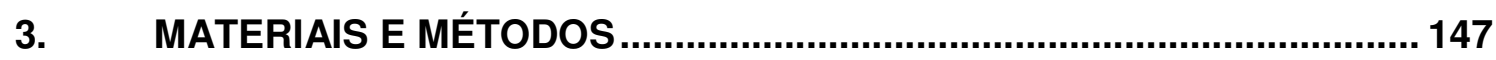

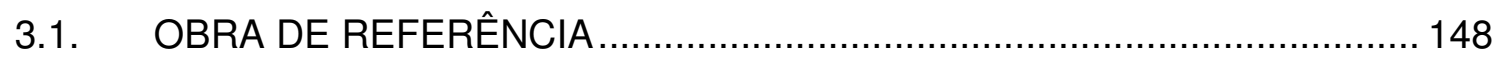

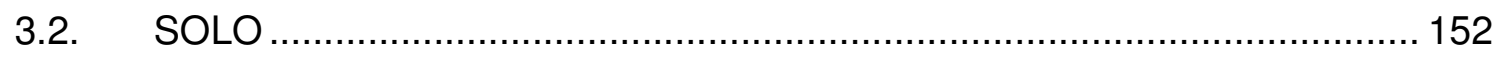

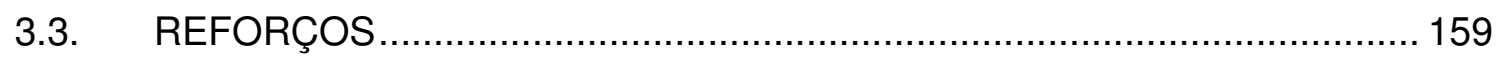

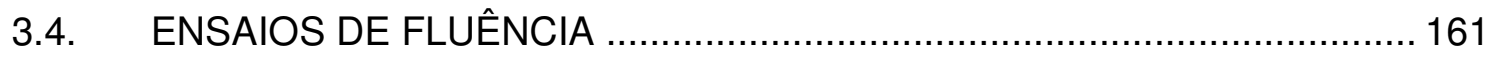

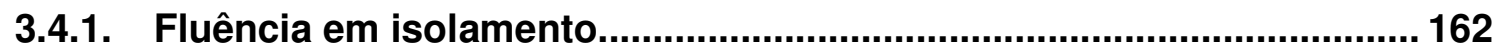

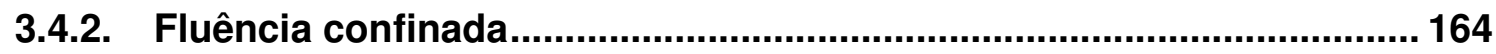

3.5. ENSAIOS DE TENSÕES INDUZIDAS POR COMPACTAÇÃO NO

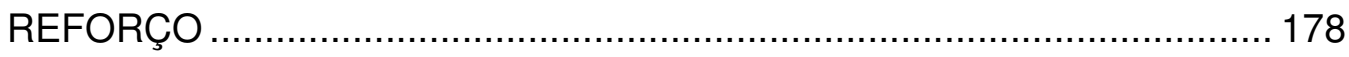

3.6. MÉTODO DE CÁLCULO DAS DEFORMAÇÕES NOS REFORÇOS ......... 179

3.7. MÉTODOS DE CÁLCULO EMPREGADOS PARA ANÁLISES DE FLUÊNCIA 180

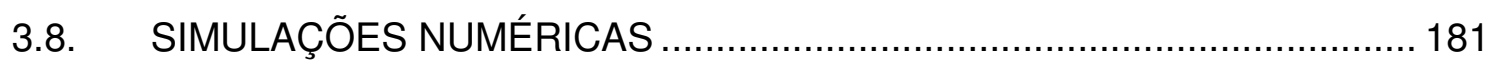

3.8.1. Simulação numérica dos ensaios de fluência confinada ...................... 182

3.8.2. Simulação numérica da obra de referência ........................................... 186

4. RESULTADOS DOS ENSAIOS DE LABORATÓRIO .............................. 191

4.1. ENSAIOS DE FLUÊNCIA EM ISOLAMENTO .......................................... 191

4.2. ENSAIOS DE FLUÊNCIA CONFINADA REALIZADOS NO EQUIPAMENTO DE INTERAÇÃO SOLO-REFORÇO ................................................... 198

4.2.1. Resultados obtidos nos ensaios confinados realizados com diferentes níveis de carregamento vertical......................................................... 198

4.2.2. Resultados e análises dos ensaios confinados realizados com

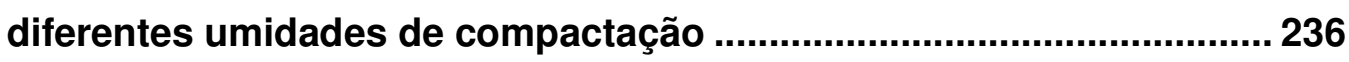

4.2.3. Resultados e análises dos ensaios confinados com inundação......... 249

4.2.4. Resultados e análises dos ensaios de tensões induzidas por compactação no reforço 
4.2.5. Análise numérica dos ensaios confinados .262

4.2.6. Análise do estado de tensões do maciço nos ensaios confinados .....275

4.2.7. Análise conjunta dos resultados dos ensaios de fluência 281

4.3. ENSAIOS DE FLUÊNCIA REALIZADOS NO EQUIPAMENTO DE FLUÊNCIA CONFINADA-ACELERADA ..........................................293

4.3.1. Resultados dos ensaios...................................................................293

4.3.2. Análise da influência do confinamento na fluência dos reforços para os ensaios confinados 300

4.4. COMPARAÇÃO ENTRE OS RESULTADOS OBTIDOS NO EQUIPAMENTO DE INTERAÇÃO SOLO-REFORÇO E NO EQUIPAMENTO DE FLUÊNCIA CONFINADA-ACELERADA. 305

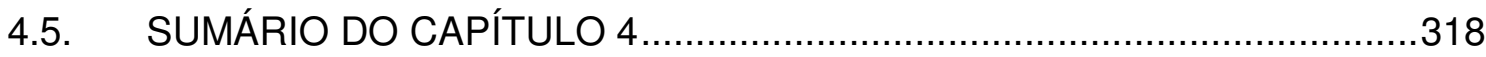

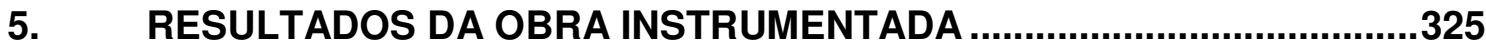

5.1. RESULTADOS OBTIDOS NAS LEITURAS DOS INSTRUMENTOS .........326

5.2. COMPARAÇÃO ENTRE OS RESULTADOS DE FLUÊNCIA OBTIDOS EM CAMPO E LABORATÓRIO 339

5.3. MODELAGEM COMPUTACIONAL DO MURO DE REFERÊNCIA ............346

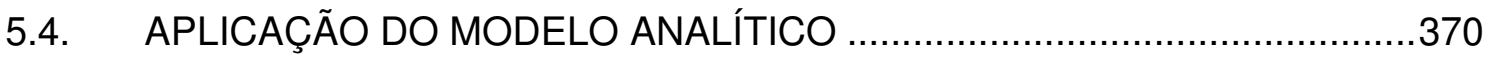

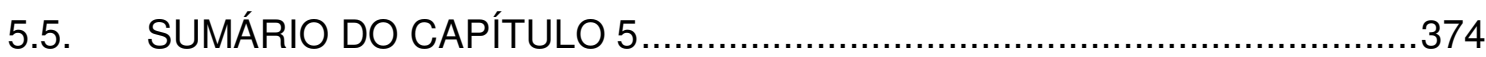

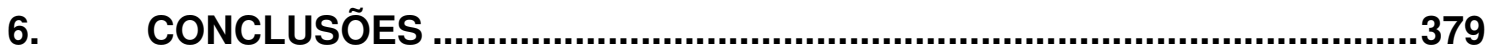





\section{INTRODUÇÃO}

A utilização de geossintéticos em obras de engenharia civil constitui, atualmente, prática crescente graças às diversas vantagens que estes materiais oferecem. Os geossintéticos têm ampla aplicação em técnicas de solo reforçado, para a estabilização de cortes em terrenos naturais ou de taludes de aterros. O desempenho destas obras depende da interação mobilizada entre as inclusões, geralmente planares e dispostas convenientemente no interior do maciço, e o seu solo constituinte.

Além das vantagens técnicas, os geossintéticos também se destacam pela facilidade de aplicação do material, pela rapidez da construção e ainda pela redução significativa de custos quando comparado com soluções convencionais. Entretanto, no Brasil, apesar destas claras vantagens, as soluções convencionais ainda figuram em primeiro plano para grande parte das estruturas de contenção.

Talvez, uma possível explicação para isto seja o desconhecimento do real desempenho das estruturas reforçadas com geossintéticos, principalmente no que concerne aos deslocamentos acumulados ao longo do tempo, o que pode afetar de maneira significativa o comportamento da estrutura em longo prazo.

Quando se trata de projetos de muros em solos reforçados, as deformações dependentes do tempo dos geossintéticos são propriedades importantes a serem consideradas. Os geossintéticos são materiais poliméricos e, portanto, susceptíveis aos efeitos da fluência e relaxação. Isto pode resultar em problemas relacionados a deformações excessivas e até mesmo ruptura da estrutura em casos extremos.

No dimensionamento de estruturas de solo reforçado com geossintéticos, costumase incorporar o fator relacionado à fluência do reforço por meio da aplicação de um fator de redução à resistência última do material. A magnitude deste fator geralmente é determinada com base em ensaios de fluência do geossintético isolado, e apresenta valores que podem variar entre 2 e 5, segundo dados encontrados na bibliografia. Entretanto, é importante lembrar que o comportamento ao longo do tempo de estruturas reforçadas com geossintéticos não depende essencialmente das propriedades de fluência do reforço em isolamento. Este comportamento está associado também às propriedades geotécnicas do solo que compõe o maciço. Segundo Wu e Helwany (1996), quando o solo apresenta menor 
susceptibilidade à fluência em relação ao reforço, a menor tendência à fluência do solo tende a restringir a tendência à fluência do reforço. Por essa razão, uma análise do comportamento do conjunto solo-reforço se torna essencial.

É notável que os procedimentos para o dimensionamento de estruturas em solos reforçados com geossintéticos atualmente empregados têm resultado em obras com excelente desempenho, apresentando deformações pouco significativas ao longo tempo. Em geral, as deformações registradas em obras instrumentadas têm apresentado magnitudes inferiores aos valores previstos. Isto é um indicativo de que as condições consideradas em projeto e nos métodos de previsão de comportamento dessas estruturas devem ser muito conservadoras quando comparadas com as condições reais de trabalho.

Apesar da importância do tema, são escassos os trabalhos encontrados na bibliografia que tratam de forma conjunta sobre o comportamento em longo prazo dos geossintéticos e do solo que compõe o maciço. Mais raros ainda são os trabalhos que analisam os efeitos da fluência de reforços quando submetidos à condições de trabalho de obras reais.

Esses aspectos demonstram a importância do tema e se apresentam como a principal motivação para o desenvolvimento deste trabalho, cujo escopo constituiu a elaboração de ensaios de fluência confinada considerando como referência uma obra real, em solo reforçado com geotêxteis tecidos e não tecidos, construída na cidade de Campinas.

\subsection{OBJETIVOS}

Tendo em vista os aspectos anteriormente apresentados, observa-se a necessidade de se complementar os conceitos e as formas de avaliação da fluência de geossintéticos, de forma a considerar a interação entre o solo e o reforço e também as condições reais de trabalho em que o reforço encontra-se submetido. $\mathrm{Na}$ intenção de melhor contribuir no entendimento dessa questão, o presente trabalho teve os seguintes objetivos específicos:

a) Avaliar o comportamento ao longo do tempo de uma estrutura real instrumentada de muro reforçado com geotêxteis por meio de leituras de 
campo, ensaios em laboratório de fluência isolada e confinada, e por meio de modelagem computacional;

b) Avaliar o comportamento ao longo do tempo de geotêxteis não tecidos, geotêxteis tecidos e geogrelhas por meio de ensaios de fluência confinada conduzidos com diferentes níveis de carregamentos verticais e diferentes umidades de compactação do solo envolvente;

c) Avaliar os efeitos da inundação do solo no comportamento ao longo do tempo de geossintéticos por meio de ensaios de fluência confinada submetidos a um processo de inundação;

d) Verificar em laboratório os incrementos de carga em geossintéticos confinados devido aos efeitos da compactação do solo por meio do uso adaptado de um equipamento de fluência confinada;

e) Comparar em termos práticos e teóricos os resultados de ensaios de fluência confinada de geossintéticos empregando dois diferentes equipamentos, que possuem princípios de funcionamento distintos, procurando determinar as vantagens, desvantagens e a melhor aplicação para cada um deles;

f) Apresentar um modelo matemático que permite a previsão do comportamento de geossintéticos confinados a partir dos resultados de ensaios de fluência em isolamento.

\subsection{ORGANIZAÇÃO DO TRABALHO}

Esta tese foi divida em seis capítulos de forma a facilitar o entendimento do leitor em relação às premissas consideradas e aos trabalhos desenvolvidos. O Capítulo 2 apresenta os principais conceitos relacionados a estruturas em solos reforçados com geossintéticos bem como os fatores que afetam o seu comportamento ao longo do tempo. O Capítulo 3, por sua vez, apresenta a caracterização dos materiais envolvidos neste estudo e os métodos de análises empregados. O Capítulo 4 apresenta os resultados e as análises referentes à campanha de ensaios realizada em laboratório. Os resultados e as análises referentes à estrutura real instrumentada 
são apresentados no Capítulo 5. Por fim, o Capítulo 6 expõe as principais conclusões obtidas neste estudo. 


\section{REVISÃo BIBLIOGRÁFICA}

Neste capítulo são apresentados inicialmente conceitos relacionados ao princípio de funcionamento de estruturas de contenção em solo reforçado com geossintéticos e os principais fatores que afetam o comportamento mecânico destas estruturas. Posteriormente são apresentados relatos de estruturas reais instrumentadas, mostrando, para cada caso, as características geométricas da obra, as principais propriedades do solo de aterro e o comportamento da estrutura em termos de deformações e forças nos reforços. Em seguida discorre-se sobre o comportamento dependente do tempo de geossintéticos apresentando conceitos fundamentais referentes à fluência e relaxação. Ao final do capítulo são apresentados os ensaios que geralmente são empregados para a determinação do comportamento ao longo do tempo de geossintéticos e como os resultados dos ensaios de fluência são considerados em projetos de solos reforçados.

\subsection{ESTRUTURAS DE SOLO REFORÇADO COM GEOSSINTÉTICOS}

Em maciços de solo reforçado, a inclusão de geossintéticos como elemento de reforço do material de aterro propicia uma redistribuição global das tensões e deformações, permitindo a adoção de estruturas com faces verticais (muros) ou maciços mais íngremes (taludes) com menor volume de aterro compactado (VERTEMATTI, 2004).

Uma massa de solo reforçado pode ser considerada uma estrutura análoga ao concreto armado, já que as propriedades mecânicas do maciço são melhoradas com a utilização de reforços posicionados paralelamente à direção das deformações principais, de forma a compensar a falta de resistência à tração do solo (FHWA, 2001).

A técnica de solo reforçado se baseia, portanto, na interação entre o solo e a inclusão de reforço, sendo que a transferência de tensões entre estes elementos ocorre por atrito e/ou por resistência passiva, dependendo da geometria do reforço.

Se um maciço de solo qualquer, não reforçado, for submetido à ação de uma determinada tensão vertical $\left(\sigma_{1}\right)$, este elemento sofrerá uma deformação correspondente. Se neste mesmo elemento de solo, sob a ação do mesmo 
carregamento $\sigma_{1}$, forem adicionadas inclusões de reforço, como tiras metálicas, geogrelhas ou geotêxteis, por exemplo, estas deformações serão significativamente menores. A Figura 2.1 ilustra este mecanismo.

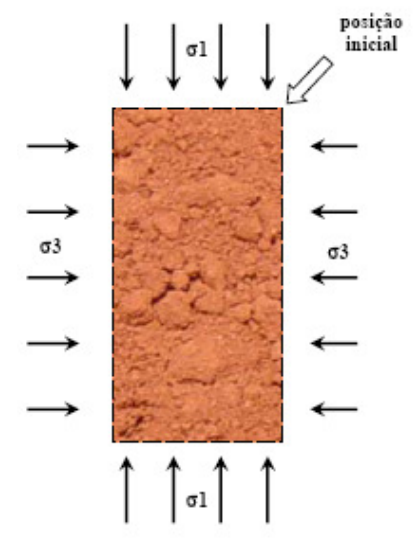

a) posição inicial

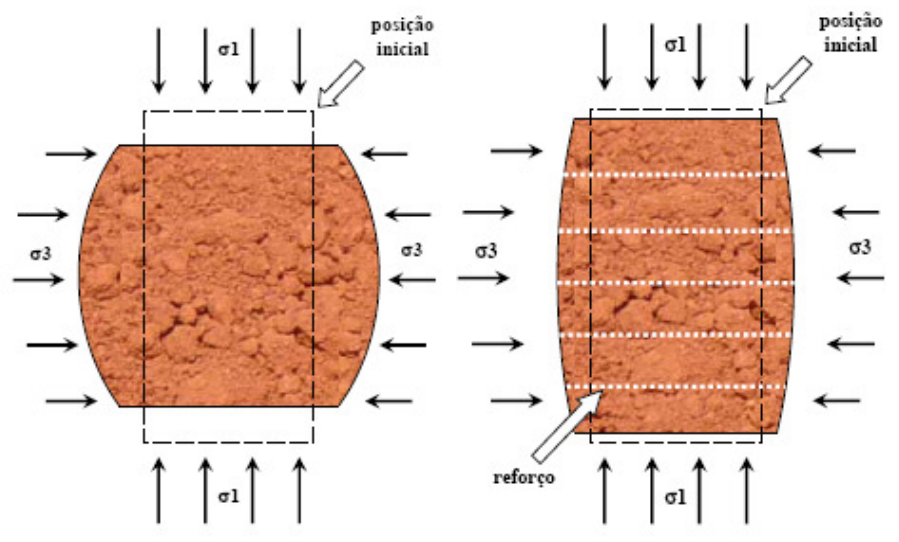

b) solo sem reforço

c) solo com reforço

Figura 2.1 - Deformação de um elemento de solo com e sem reforço (BENJAMIM, 2006).

O mesmo raciocínio pode ser feito para um elemento de solo, que ao ser carregado por uma tensão $\sigma_{1}$, sofre ruptura por cisalhamento. A inserção de inclusões de reforço no elemento de solo pode reduzir significativamente a possibilidade de ruptura do mesmo, já que as inclusões, quando posicionadas de forma adequada, interceptam a cunha de ruptura (Figura 2.2).

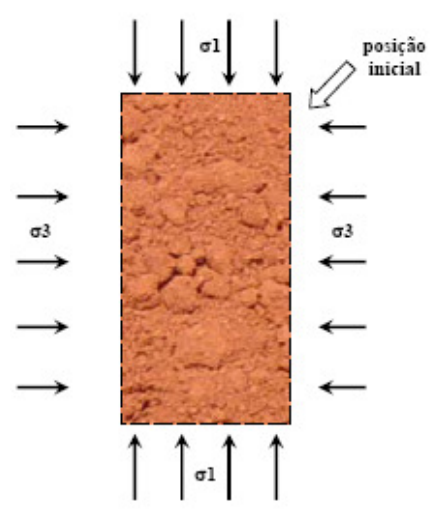

a) posição inicial

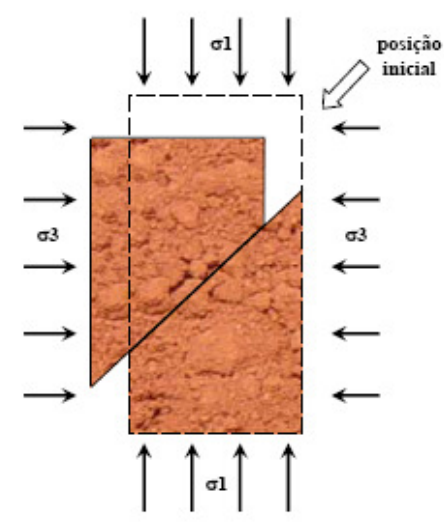

b) solo sem reforço

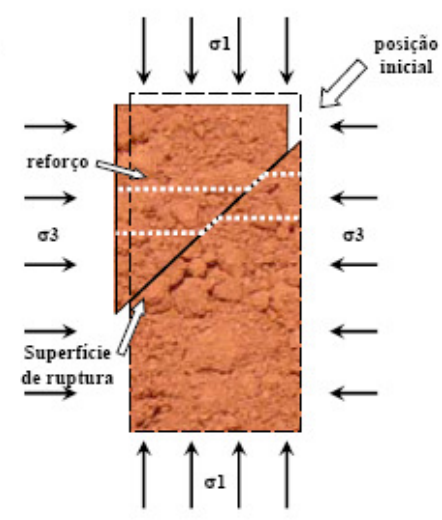

c) solo reforçado

Figura 2.2 - Ruptura por cisalhamento de solo com e sem reforço (BENJAMIM, 2006). 
Em estruturas reais de solo reforçado, os mesmos mecanismos apresentados podem ocorrer (Figura 2.3). Se um maciço qualquer de solo não reforçado, submetido aos esforços de peso próprio e também de carregamentos externos, atinge uma situação crítica, ocorre um deslocamento de massa do solo segundo uma superfície preferencial de ruptura, levando o sistema ao colapso. Se o mesmo maciço, submetido aos mesmos esforços, for reforçado com inclusões distribuídas convenientemente no interior da massa de solo, ocorrerá uma transferência de esforços entre o solo e o reforço, gerando tensões de tração nas inclusões. Estas inclusões, desde que possuam resistência à tração e comprimento de ancoragem compatíveis com a solicitação, garantem a estabilidade do maciço.

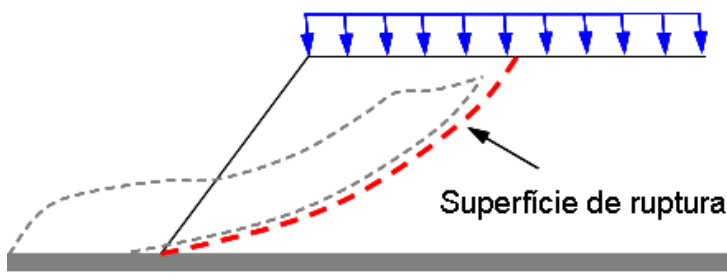

a) Sem reforço

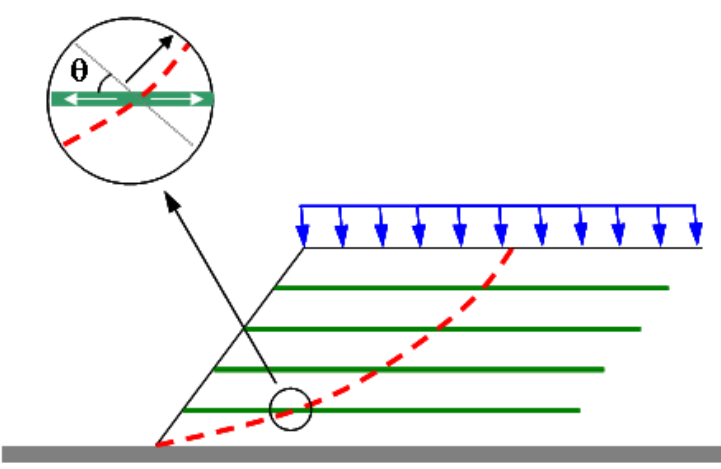

b) Com reforço

Figura 2.3 - Comportamento de talude com e sem reforço (adaptado de JONES, 2000).

\subsection{FATORES QUE INFLUENCIAM NO COMPORTAMENTO DAS ESTRUTURAS DE CONTENÇÃO EM SOLO REFORÇADO}

O desempenho de estruturas reforçadas com geossintéticos está associado a diversos fatores, que vão desde o processo de fabricação da inclusão até o processo executivo da obra. Estes fatores devem ser analisados cuidadosamente na etapa de projeto de tal forma a garantir, além de um desempenho satisfatório do maciço reforçado, economia e segurança na obra.

Os principais fatores que influenciam no comportamento das estruturas de contenção em solo reforçado são: comprimento e espaçamento das inclusões, forma de ligação do reforço na face (engastada ou envelopada), disposição das inclusões 
ao longo da altura do muro, espessura da camada de compactação, energia e forma de compactação, existência ou não da face (que pode ser construída antes, durante ou após a execução do maciço), o escoramento do muro e o tipo de solo. A Tabela 2.1 mostra os principais fatores que afetam diretamente ou indiretamente 0 desempenho de maciços reforçados com geossintéticos.

Tabela 2.1 - Fatores que influenciam no comportamento das estruturas (BENJAMIM, 2006 modificado).

\begin{tabular}{|c|c|c|}
\hline Propriedades do reforço & Geometria interna & Aspectos construtivos \\
\hline $\begin{array}{l}\text { - } \text { Composição polimérica } \\
\text { - } \text { Processo de fabricação } \\
\text { - } \text { Rigidez } \\
\text { - } \text { Durabilidade } \\
\text { - Transmissividade }\end{array}$ & $\begin{array}{l}\text { - Espaçamento } \\
\text { - } \text { Comprimento } \\
\text { - Posição } \\
\text { - Orientação }\end{array}$ & $\begin{array}{l}\text { - Método construtivo } \\
\text { - Método de compactação } \\
\text { - Conexão reforço / face } \\
\text { - Tipo de face }\end{array}$ \\
\hline Propriedades do solo & Estado do solo & Propriedades da estrutura \\
\hline $\begin{array}{ll}\text { - } & \text { Granulometria } \\
\text { - } & \text { Forma das partículas } \\
\text { - } & \text { Propriedades de resistência } \\
\text { - } & \text { Propriedades de rigidez }\end{array}$ & $\begin{array}{ll}\text { - } & \text { Peso específico } \\
\text { - } & \text { Estado de tensões } \\
\text { - } & \text { Grau de saturação } \\
\text { - } & \text { Permeabilidade }\end{array}$ & $\begin{array}{l}\text { - } \text { Geometria } \\
\text { - } \text { Estética } \\
\text { - } \text { Vida útil } \\
\text { - } \\
\text { Finalidade da obra }\end{array}$ \\
\hline
\end{tabular}

Maciços de solo reforçado com geossintéticos são estruturas complexas, e a determinação do grau de importância que cada um dos elementos que compõem a estrutura exerce sobre seu comportamento se torna uma tarefa nada fácil. Jones (1990) elaborou a Tabela 2.2 que aponta a importância relativa dos fatores que influenciam o comportamento de estruturas de solo reforçado. 
Tabela 2.2 - Importância dos fatores que influenciam no comportamento das estruturas de solo reforçado (JONES, 1990).

Fatores

\begin{tabular}{|c|c|c|c|c|c|c|}
\hline Aplicação & 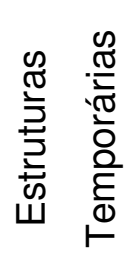 & $\begin{array}{l}\frac{\pi}{7} \\
\frac{1}{7} \\
0 \\
\frac{\pi}{0} \\
\frac{0}{>}\end{array}$ & 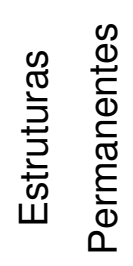 & 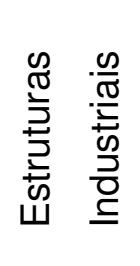 & 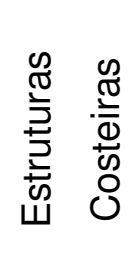 & 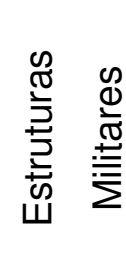 \\
\hline Drenagem & $* \star *$ & $* * *$ & $* * *$ & $* * *$ & $* * *$ & $* * *$ \\
\hline Distorção & * & * & $* * *$ & * & * & * \\
\hline $\begin{array}{l}\text { Condições do } \\
\text { subsolo }\end{array}$ & ** & ** & ** & ** & $* * *$ & $* * *$ \\
\hline $\begin{array}{l}\text { Propriedades do } \\
\text { aterro }\end{array}$ & * & ** & $* * *$ & ** & $* * *$ & ** \\
\hline $\begin{array}{l}\text { Propriedades do } \\
\text { Reforço }\end{array}$ & * & ** & $\star \star \star *$ & ** & $* * *$ & ** \\
\hline Face & * & * & $* * *$ & * & ** & $* *$ \\
\hline Estética & * & * & $* * *$ & * & ** & * \\
\hline Durabilidade & * & * & $* \star *$ & * & $* * *$ & $* * *$ \\
\hline $\begin{array}{l}\text { Velocidade de } \\
\text { construção }\end{array}$ & $\star * *$ & ** & ** & ** & ** & $* * *$ \\
\hline
\end{tabular}

* Importância secundária ** Importante *** Muito Importante

Jones (1990) salienta ainda que a prática construtiva pode ter uma influência marcante nas características comportamentais de um maciço reforçado. Por isso, o autor afirma que o método construtivo é fundamental no comportamento final da estrutura. É importante lembrar ainda que a finalidade para a qual a obra será executada, e as condições da estrutura em serviço, são os fatores principais na determinação do tipo de estrutura e método construtivo adotados.

A seguir são apresentados e discutidos outros fatores que afetam o comportamento das estruturas de solo reforçado com geossintéticos. 


\subsubsection{Condições do solo de fundação}

As características do solo de fundação de um maciço reforçado com geossintéticos, como os parâmetros de resistência e rigidez, por exemplo, são fundamentais em projetos deste tipo de estrutura.

Maciços de solo reforçado com geossintéticos são estruturas flexíveis, e por esse motivo tem apresentado, como uma de suas características, a capacidade de resistir aos recalques da fundação, sejam eles totais ou diferenciais. Na realidade, nenhum dos métodos de projeto disponíveis considera os efeitos de recalque do solo de fundação.

A função do geossintético em uma estrutura de solo reforçado é garantir a estabilidade do aterro compactado e não necessariamente de combater os seus recalques. Nesse sentido, mesmo os geossintéticos teoricamente mais rígidos, como as geogrelhas, têm-se mostrado pouco eficientes para cumprir essa finalidade, embora possam minimizar os recalques diferenciais do aterro (BUENO e ARAMAKI, 1998).

Trabalho apresentado por Fahel; Palmeira e Campos (1999) mostra o potencial do uso de geossintéticos como reforço de estruturas de contenção em aterros que apresentam possibilidade de ocorrência de recalques diferenciais. Os resultados mostraram que a flexibilidade das estruturas minimizou os danos provocados pelos recalques diferenciais, quando comparados a outras estruturas mais rígidas.

Benjamim; Bueno e Zornberg (2007) apresentaram resultados da instrumentação de um protótipo de estrutura de contenção, com 4,0 m de altura, construído sobre uma fundação com baixa capacidade de carga. Os resultados mostraram que, ao contrário dos resultados dos deslocamentos dentro do maciço reforçado, onde os maiores deslocamentos se desenvolveram próximo da face da estrutura, os deslocamentos da fundação apresentaram os maiores deslocamentos na seção central da zona reforçada. Os autores salientam a importância da rigidez da fundação no mecanismo de deformação da estrutura. Segundo os autores, um muro construído sobre uma fundação rígida gira sobre o seu pé, enquanto um muro construído sobre solo mole gira pelo seu topo, devido a um significante movimento da fundação. 


\subsubsection{Efeitos da compactação}

A compactação de um solo pode ser realizada por meio da aplicação de um processo estático ou dinâmico, tendo por objetivo diminuir o seu volume decorrente de uma redução do índice de vazios. A compactação resulta em um solo de menor permeabilidade e compressibilidade, e maior resistência ao cisalhamento.

Apesar das claras ações benéficas da compactação, muito cuidado deve ser tomado na execução desta etapa. A execução da compactação de forma não cuidadosa, pode influenciar de maneira negativa no comportamento de um muro reforçado, como por exemplo, danos mecânicos nas inclusões, e ainda um aumento considerável das tensões horizontais nas proximidades da face do muro, o que certamente acarretará em deslocamentos excessivos nesta região.

Segundo Cousens e Pinto (1996), apesar do efeito da compactação ser relativamente bem estudado para muros de contenção tradicionais, tal fato não ocorre para o caso de solos reforçados, já que poucas investigações têm sido realizadas para melhor compreender seu comportamento.

Segundo Ehrlich e Becker (2009), no campo, o solo passa por um complexo caminho de tensões, em razão dos vários ciclos de carga e descarga ocasionados pela passagem dos equipamentos de compactação.

Ao longo dos anos, diversos autores têm estudado o acréscimo de tensões horizontais em estruturas de contenção devido aos efeitos de compactação. Dentre os principais trabalhos publicados, podem-se citar os de Rowe (1954), Sowers et al. (1957), D’Appolonia et al. (1969), Broms (1971), Ingold (1979) e Duncan e Seed (1986), que se aplicam aos muros de contenção tradicionais. Para muros de solo reforçado, os principais trabalhos que consideram os efeitos da compactação são os de Thamm; Krieger e Lesniewska (1990), Karpurapu e Bathurst (1992), Ehrlich e Mitchell (1994), Cousens e Pinto (1996), e mais recentemente Saramago (2002), Bathurst et al. (2009), Ehrlich, Mirmoradi e Saramago (2012) e Mirmoradi e Ehrlich (2015).

O trabalho realizado por Bathurst et al. (2009), apresenta o resultado de monitoramentos realizados em quatro muros, construídos em verdadeira grandeza, com 3,60 m de altura, reforçados com geogrelhas. Os autores apontaram que o efeito da compactação na magnitude das deformações decorrentes dos esforços horizontais gerados, é tão importante quando a rigidez da inclusão. Segundo os 
autores, conforme os muros eram carregados, atenuava-se o efeito da compactação nos deslocamentos horizontais e nos esforços gerados nas inclusões.

Trabalho apresentado por Cousens e Pinto (1996) mostra que durante a execução de um muro em solo reforçado o coeficiente do empuxo é inicialmente alto e, à medida que o aterro vai prosseguindo, há uma diminuição do seu valor até um ponto, a partir do qual, o efeito da compactação mostra-se desprezível.

Loiola (2001) realizou análises numéricas para estudar a influência da compactação do solo simulando muros com $5 \mathrm{~m}$ de atura, construídos com solo não coesivo e reforços com diferentes valores de rigidez. O autor verificou que a compactação do solo apresentou a tendência de induzir maiores forças de tração nos reforços, sendo essa tendência mais acentuada para as estruturas que empregam reforços menos rígidos.

Para reduzir o efeito da compactação nas estruturas de contenção, alguns autores sugerem reduzir o grau de compactação do solo em uma faixa próxima à face. Isto provocaria uma diminuição do empuxo lateral e, consequentemente, dos deslocamentos da estrutura.

Trabalhos como os de McGown; Andrawes e Murray (1988), Andrawes et al. (1990), Karpurapu e Bathurst (1992) e Marques et al. (1994), foram realizados com o intuito de demonstrar a viabilidade do uso de uma camada compressível, ou com menor grau de compactação, numa região situada entre o aterro e o paramento do muro (Figura 2.4). Isto permite o controle de deformações laterais e, consequentemente, menores tensões horizontais atuantes na face do muro.

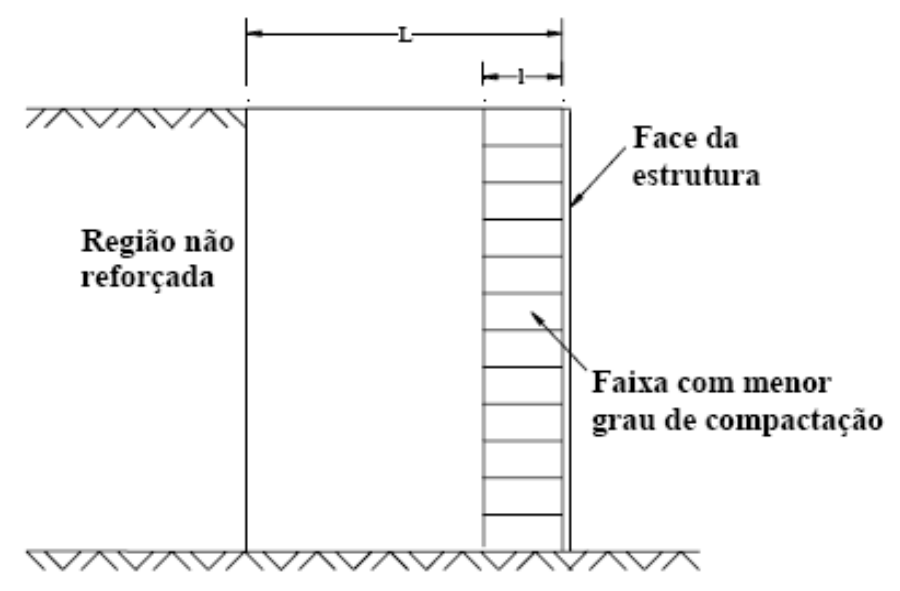

Figura 2.4 - Estrutura em solo reforçado com faixa com menor grau de compactação. 
Karpurapu e Bathurst (1992) por meio de resultados de simulações numéricas, elaboraram ábacos que permitem a previsão de tensões e deslocamentos da face de estruturas reforçadas para diversos tipos de solo, largura da faixa compressível e grau de compactação desta faixa.

Trabalho apresentado por Marques et al. (1994) conclui que na execução do aterro deve-se deixar uma faixa com menor grau de compactação próxima ao muro com largura de pelo menos $50 \mathrm{~cm}$, com o objetivo de reduzir as pressões horizontais sobre o muro, diminuindo assim, os deslocamentos da face.

\subsubsection{Efeitos da geometria interna do muro}

A distribuição dos reforços no interior do maciço é um importante fator que merece destaque no projeto e execução de estruturas reforçadas com geossintéticos. $\mathrm{Na}$ bibliografia, não são muitos os trabalhos dedicados a este tema, o que reforça ainda mais a sua necessidade de estudo.

Trabalho realizado por Lanz e Palmeira (1994), apresenta um estudo em modelos reduzidos sobre o comportamento de estruturas de contenção em solo reforçado com geossintéticos com diferentes geometrias internas. Os modelos foram construídos em uma caixa rígida, com base de 1500 × $500 \mathrm{~mm}$ e altura de $500 \mathrm{~mm}$. A face frontal da caixa de testes era transparente, o que permitiu a observação dos mecanismos de ruptura e de deslocamentos. O material de preenchimento utilizado foi uma areia limpa e uniforme e o material de reforço utilizado foi um geotêxtil não tecido agulhado de poliéster, com gramatura $75 \mathrm{~g} / \mathrm{m}^{2}$. Os arranjos de reforços ensaiados são apresentados na Figura 2.5. 

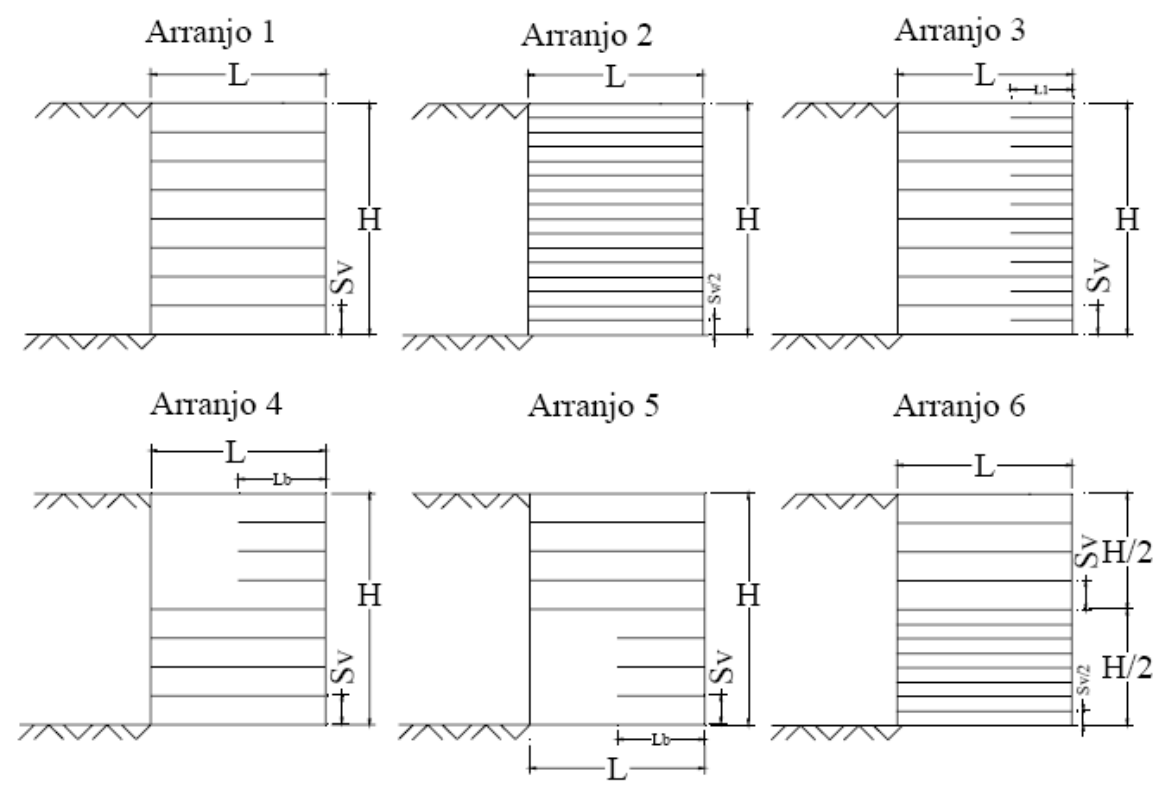

Figura 2.5 - Arranjos de reforços ensaiados por Lanz e Palmeira (1994).

Os resultados dos ensaios mostraram que a magnitude dos deslocamentos da face é função do espaçamento entre os reforços, sendo que para muros com maior densidade dos reforços, menores foram os deslocamentos. Os ensaios mostraram ainda que para menores comprimentos de reforços, maiores foram os deslocamentos observados, sendo que reduções de $50 \%$ do comprimento representaram acréscimos de $100 \%$ no deslocamento horizontal da face.

Outro importante trabalho encontrado na bibliografia é o publicado por Ho e Rowe (1996). Os autores avaliaram os efeitos de parâmetros geométricos, tais como o comprimento do reforço, o número de camadas, a distribuição dos reforços e também a altura total do muro no comportamento de estruturas reforçadas com geossintéticos. As análises foram realizadas por meio de modelagens numéricas baseadas no método dos elementos finitos (MEF), utilizando o software AFENA.

O efeito do comprimento do reforço $(L)$ foi examinado considerando reforços com diferentes comprimentos e mantendo a altura do muro $(\mathrm{H})$ constante. Foram avaliadas relações $L / H$ entre 0,3 e 1,25. Para a avaliação da influência do número de camadas de reforço no comportamento do sistema, foram realizadas análises com 4 , 6 e 12 camadas de inclusões, mantendo-se fixos os valores de altura do muro (6 m), e rigidez das inclusões. $O$ trabalho avaliou ainda as tensões na zona reforçada do 
solo e as forças desenvolvidas nos reforços para quatro diferentes esquemas de distribuição das camadas de reforço (Figura 2.6).

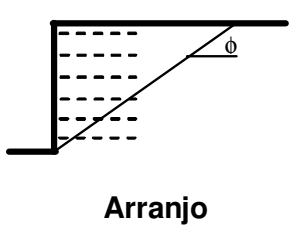

(A)

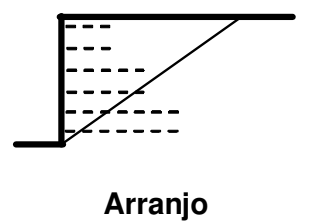

(C)

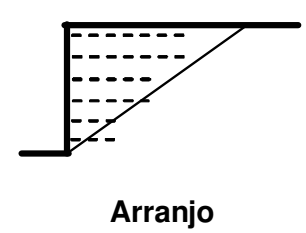

(B)

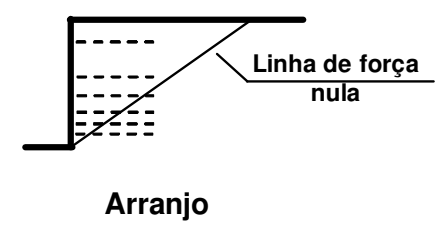

(D)

Figura 2.6 - Arranjos de reforços avaliados por Ho e Rowe (1996).

Os autores mostraram que o parâmetro geométrico que exerce maior influência no comportamento das estruturas avaliadas é o comprimento do reforço. Para relações $\mathrm{L} / \mathrm{H}$ iguais ou maiores a 0,7 , em que $\mathrm{L}$ é o comprimento do reforço e $\mathrm{H}$ é a altura do muro, em geral ocorreram variações muito pequenas nas tensões observadas no solo e no reforço. Entretanto, para relações L/H menores que 0,7, os valores do empuxo lateral na região atrás da zona reforçada são elevados, e, portanto, não devem ser desprezados, já que conduzem a um aumento significativo das forças exercidas nos reforços.

Os resultados numéricos mostraram ainda que, para um muro com altura $(\mathrm{H})$ constante, o uso de diferentes números de camadas de reforço, geralmente resulta em relações similares de $T_{\max } / S_{v}$ (em que $T_{\max }$ é a máxima força exercida no reforço e $S_{v}$ é o espaçamento vertical entre as camadas). Isto indica que o esforço exercido na inclusão de reforço é diretamente proporcional ao espaçamento entre as inclusões, sendo esta observação válida apenas para reforços com mesma rigidez. Outra importante conclusão do trabalho realizado por Ho e Rowe (1996) foi que a aproximação geralmente utilizada por projetistas, que costumam adotar geometrias de muros com reforços igualmente espaçados, e inclusões com comprimentos iguais a $70 \%$ da altura do muro, fornece uma distribuição eficiente dos esforços nas inclusões. As configurações testadas com espaçamentos diferentes entre as 
inclusões se mostraram menos eficientes e não são recomendadas para o tipo de muro avaliado.

Pedroso (2000) avaliou, por meio do Método dos Elementos Finitos (MEF), influência da geometria interna das inclusões nos deslocamentos da face de muros reforçados com geotêxteis. O autor avaliou três diferentes tipos de arranjo, conforme apresentado na Figura 2.7.
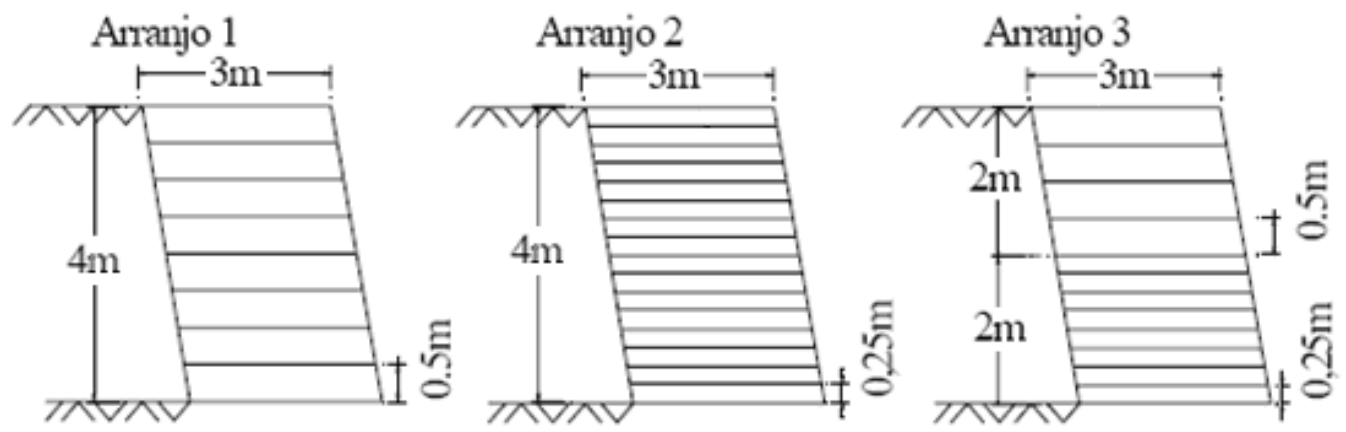

Figura 2.7 - Tipos de arranjo testados por Pedroso (2000).

Os parâmetros adotados foram de uma areia média fina pouco argilosa, e de um geotêxtil não tecido com rigidez de $40 \mathrm{kN} / \mathrm{m}$. Os arranjos 1 e 2 avaliados apresentavam espaçamentos e comprimentos constantes para toda a seção, enquanto no arranjo 3, o espaçamento na metade superior era o dobro do espaçamento da metade inferior. Os deslocamentos horizontais obtidos pelo autor são apresentados na Figura 2.8 que segue. 


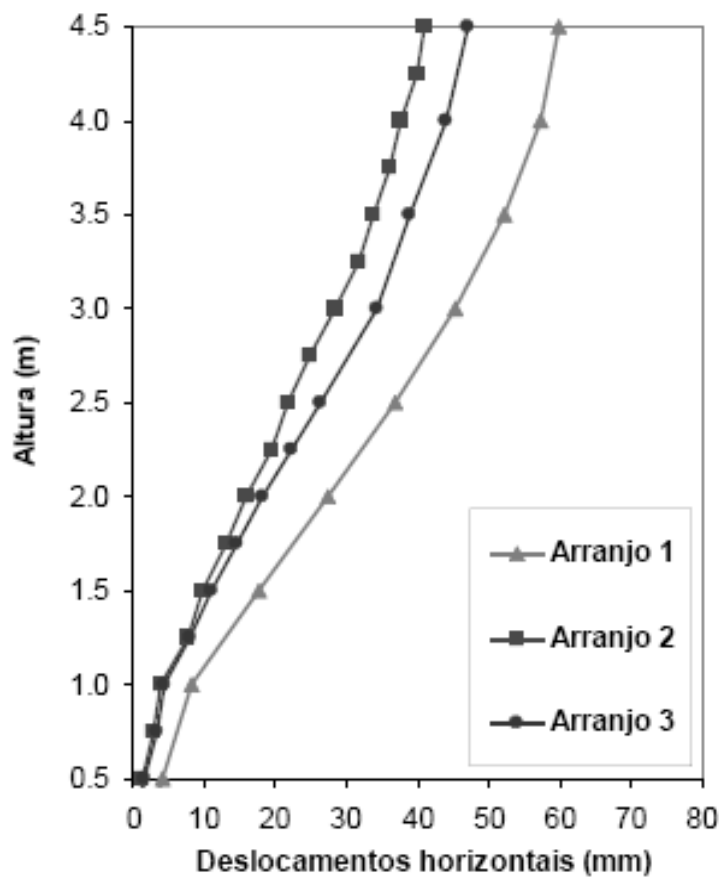

Figura 2.8 - Deslocamentos horizontais para diferentes arranjos (Pedroso, 2000).

Os resultados mostraram que os arranjos 1, 2 e 3 apresentaram deslocamentos máximos da face da ordem de $60 \mathrm{~mm}, 40 \mathrm{~mm}$ e $50 \mathrm{~mm}$, respectivamente. Segundo o autor, os menores deslocamentos obtidos nas estruturas 2 e 3 se devem à maior densidade de reforço, o que conduz a menores esforços de tração mobilizados em cada inclusão.

O autor salienta que o arranjo 3 apresentou deslocamento horizontal máximo da ordem de $15 \%$ maior do que o arranjo 2, ou seja, os deslocamentos permaneceram com a mesma ordem de grandeza, porém houve cerca de $25 \%$ de redução no volume de material utilizado para a construção do muro. Por este motivo o autor sugere a utilização de um espaçamento vertical menor na parte inferior da estrutura de contenção e um espaçamento maior na parte superior.

Outra contribuição importante sob o aspecto geométrico de estruturas de solo reforçadas com geossintéticos se deve a Benjamim (2006). O autor construiu oito protótipos de estrutura de contenção em solo reforçado com geotêxtil, com 4,0 m de altura cada. Todas as estruturas foram instrumentadas, principalmente visando os deslocamentos, para avaliar o comportamento de campo. 
Os resultados das instrumentações comprovaram que quanto maior é a densidade dos reforços, menores são os deslocamentos e as cargas nas inclusões. Entretanto, a pesquisa não permitiu a avaliação qualitativa da influência da geometria das inclusões no desempenho do sistema. Segundo o autor, a estrutura com menor densidade de reforços apresentou deslocamentos muito superiores aos da estrutura com mais reforços, e configurações intermediárias não foram testadas.

\subsubsection{Efeitos da rigidez do reforço}

A rigidez e a resistência à tração de materiais geossintéticos governam 0 comportamento tensão-deformação do material, que por sua vez influencia sobremaneira nos mecanismos de interação entre o solo e o reforço. As tensões de cisalhamento mobilizadas e os deslocamentos no maciço reforçado podem apresentar variações significativas em seu valor e forma de distribuição, de acordo com as tensões e deformações axiais mobilizadas na inclusão. Resultados encontrados na bibliografia mostram que, em geral, quanto mais rígido o reforço, menores são as deformações no maciço.

Trabalho publicado por Abramento (1995) mostra que o comportamento de sistemas de solo reforçado com reforços extensíveis é significativamente diferente do comportamento de sistemas de solo reforçado com reforços de metal relativamente inextensíveis. O autor executou, em laboratório, ensaios de arrancamento utilizando dois tipos de inclusões planares: aço e nylon. O solo utilizado foi uma areia compacta. O autor concluiu que para as inclusões de aço, consideradas relativamente inextensíveis, a distribuição de esforços na inclusão, bem como o comportamento tensão-deslocamento, se mostraram praticamente lineares. Por outro lado, os ensaios realizados com inclusões de nylon, consideradas extensíveis, apresentaram respostas não lineares no que se refere à distribuição dos esforços ao longo da inclusão e ao comportamento tensão-deslocamento.

Segundo Oliveira (2006), em maciços reforçados com inclusões perfeitamente rígidas ou inextensíveis, há significativa restrição das deformações laterais e o estado de tensão em repouso tende a se estabelecer. Por outro lado, se elementos perfeitamente flexíveis ou extensíveis forem empregados, a massa irá se deslocar 
lateralmente com magnitude suficiente para estabelecer o equilíbrio no estado ativo. Segundo o autor, a rigidez do reforço, é, portanto, um parâmetro essencial para a definição do estado de tensões e deslocamentos de estruturas de contenção em solo reforçado sob condições de trabalho.

Zornberg; Sitar e Mitchell (1998) estabeleceram um critério para caracterizar os reforços como extensíveis ou inextensíveis. Segundo os autores, o reforço é considerado extensível se a deformação alcançada pelo elemento de reforço na ruptura exceder o deslocamento horizontal necessário para desenvolver um estado plástico ativo no solo. Por outro lado, o reforço é considerado inextensível se a deformação por tração na ruptura for significativamente menor que o deslocamento horizontal necessário para desenvolver um estado plástico ativo no solo.

Dados encontrados na bibliografia mostram que o aumento da rigidez da inclusão produz reduções dos deslocamentos horizontais das estruturas de contenção em solo reforçado. Isto se deve ao fato de que os reforços mais rígidos precisam sofrer menores deslocamentos para que mobilizem maiores forças de tração (ADIB; MITCHELL; CHRISTOPHER, 1990 e ROWE; HO, 1998).

No que concerne à mobilização das forças de tração ao longo da altura da estrutura, pesquisas têm mostrado que as tensões desenvolvidas nos reforços são altamente dependentes da rigidez axial dos reforços. Isto significa que quanto mais rígido for o reforço, maiores serão as tensões de tração desenvolvidas. Além disso, as forças de tração aumentam com o acréscimo das tensões geostáticas provocadas pelo aumento da altura da estrutura (HO; ROWE, 1996).

Mitchell e Villet (1987) mostraram ainda que a rigidez das inclusões de solos reforçados afeta significativamente a forma da superfície de ruptura. No caso de reforços inextensíveis, ou seja, inclusões metálicas, a superfície de ruptura hipotética é bi-linear. Para reforços extensíveis, ou seja, geogrelhas e geotêxteis, ela assume a forma linear. A Figura 2.9 apresenta esquematicamente a forma desses dois tipos de superfícies de ruptura. 


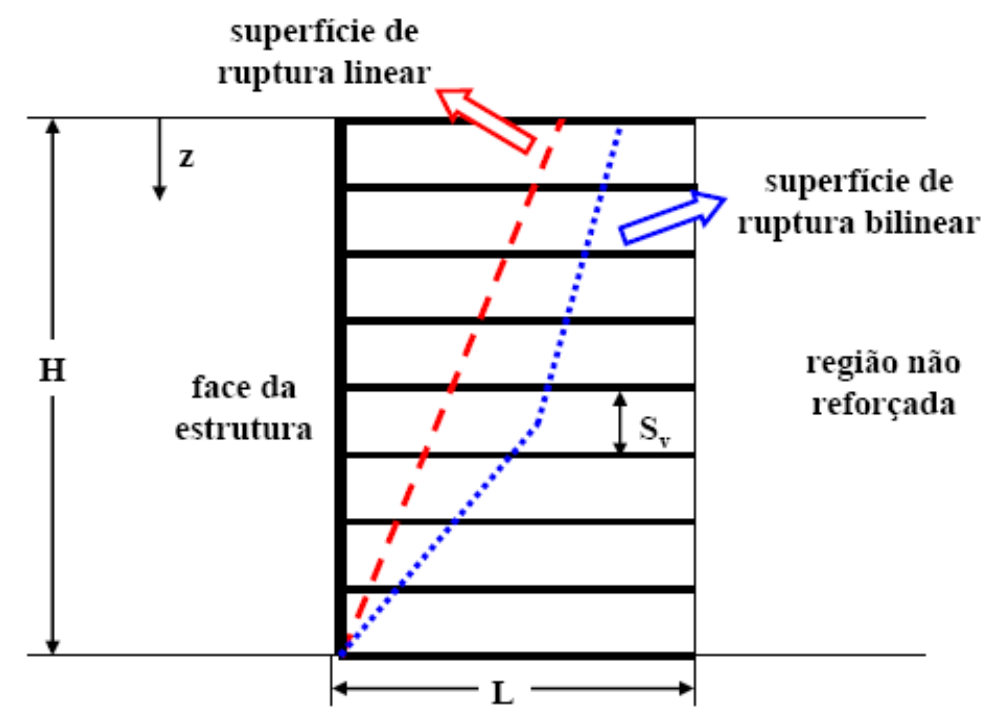

Figura 2.9 - Superfícies de ruptura linear e bi-linear (BENJAMIM, 2006).

\subsubsection{Efeito do confinamento}

Os geossintéticos, particularmente aqueles materiais que são compressíveis, como os geotêxteis não tecidos, sofrem ação do confinamento no solo quando enterrados e apresentam rigidez superior à do material sem confinamento.

Entende-se que, quando o geotêxtil é confinado no solo, não apenas as partículas penetram a matriz têxtil da manta e promovem uma restrição ao movimento, como o confinamento aproxima suas fibras, aumentando a força de atrito entre elas e, portanto, dando maior rigidez ao produto. No entanto, tem-se constatado que a aproximação das fibras é o fator mais importante no processo, já que o imbricamento da matriz têxtil pelas partículas de solo é de menor importância na maioria dos casos, exceto quando se utilizam solos granulares limpos (KAMIJI, 2006).

Segundo Gomes (1992), a ação do confinamento consiste basicamente em dificultar o processo de reorientação das fibras têxteis na direção do esforço aplicado. Esse mecanismo está intimamente associado à estrutura interna dos geotêxteis, tendendo a ser majorado no caso de geotêxteis não tecidos, para os quais as propriedades resistentes das fibras constituintes condicionam o comportamento global à tração. 
Mendes (2006) atribui o aumento da rigidez à tração de geotêxteis submetidos ao confinamento a dois mecanismos preponderantes:

- A tensão de confinamento provoca uma densificação da estrutura aumentando o atrito entre os filamentos e reduzindo os espaços por onde estes poderiam se movimentar durante a solicitação de tração;

- A interpenetração de grãos de solo entre os filamentos ocupando parte dos vazios da manta geotêxtil (impregnação) cria mais obstáculos, dificultando a reorientação dos filamentos durante a solicitação de tração.

Mendes (2006) realizou ensaios de tração confinada com três diferentes gramaturas de geotêxteis nãotecidos $\left(200,400\right.$ e $\left.600 \mathrm{~g} / \mathrm{m}^{2}\right)$. Como material de interface de confinamento foram utilizados três solos arenosos com diferentes granulometrias. Segundo o autor o acréscimo de rigidez devido à tensão confinante, em relação aos valores de rigidez para materiais não confinados, variou de $280 \%$ a $560 \%$, dependendo do tipo de geotêxtil e do material de interface empregado. O autor observou ainda que os maiores incrementos de rigidez devido à tensão foram observados para os menores níveis de deformação do reforço. Para deformações maiores que 5\% o aumento da tensão confinante não provocou incrementos significativos nos valores de rigidez à tração dos geotêxteis.

\subsubsection{Efeito do tipo de solo}

No que se refere ao material de aterro a ser utilizado para se executar estruturas de solo reforçado com geossintéticos, é comum encontrar na bibliografia internacional a preferência pela escolha de materiais granulares, com baixo teor de finos e bem graduados. Em geral, o uso de solos finos em estruturas de solo reforçado é desaconselhado por diversas instruções normativas desde o estágio inicial do desenvolvimento desta técnica. Apenas materiais granulares são recomendados nas especificações de obras públicas nos países do hemisfério norte.

O Brasil não possui especificações próprias, e em diversos casos têm-se empregado recomendações de outros países, como as da BS 8006 (1995), NCMA (1998), FHWA (1998) e AASHTO (2002). Dessa maneira, seguindo-se estas especificações, 
em muitos locais, a execução deste tipo de obra pode tornar-se inviável pela falta de material específico próximo ao local da construção (Patias, 2005).

A Norma Britânica BS 8006 (1995) apresenta recomendações para a escolha do tipo de solo dependentes de critérios físicos do material, e também de critérios mecânicos, químicos e eletroquímicos.

Quanto às restrições granulométricas, não é recomendado o uso de solo com mais de $10 \%$ de materiais finos (\% passante na peneira \#200 - abertura de 0,075 mm). A norma não apresenta restrições quanto à plasticidade dos materiais. $O$ critério mecânico admite que os materiais de aterros permanentes apresentem comportamento puramente friccional ou ainda friccional e coesivo. Para solos com comportamento puramente coesivos, as especificações não recomendam a sua utilização em estruturas com altura maior que 1,5 m.

Já as recomendações da National Concrete Masonry Association (NCMA, 1998) são menos conservadoras. A norma admite solos com até $35 \%$ de material passante na peneira \#200. Solos mais finos podem também ser utilizados, uma vez que sejam consideradas as seguintes implementações em projeto: instalação de sistemas internos de drenagem; utilização de solos com baixo a moderado potencial de expansão, e a não consideração da parcela coesiva de resistência ao cisalhamento nas análises de estabilidade.

As recomendações da Federal Highway Administration (FHWA, 1998) e American Association of State Highway and Transportation Officials (AASHTO, 2002), que regulamentam as especificações para a construção de obras públicas de solo reforçado nos Estados Unidos, são exatamente as mesmas e não toleram materiais de aterros de estruturas reforçadas com mais de $15 \%$ de materiais finos. Ambas as normas recomendam que o índice de plasticidade para o material de aterro seja menor que $6 \%$ para muros reforçados, $20 \%$ para taludes reforçados, e livres de matéria orgânica. A preocupação com o índice de plasticidade se deve ao fato de que quanto maior é a plasticidade do solo reforçado, maior é a possibilidade de fluência do mesmo, principalmente associado a elevações de umidade.

A Figura 2.10 apresenta a graduação limite dentro da zona reforçada para estruturas de contenção em solo reforçado com geossintéticos segundo as recomendações da NCMA (1998), FHWA (1998) e Koerner (2012). 


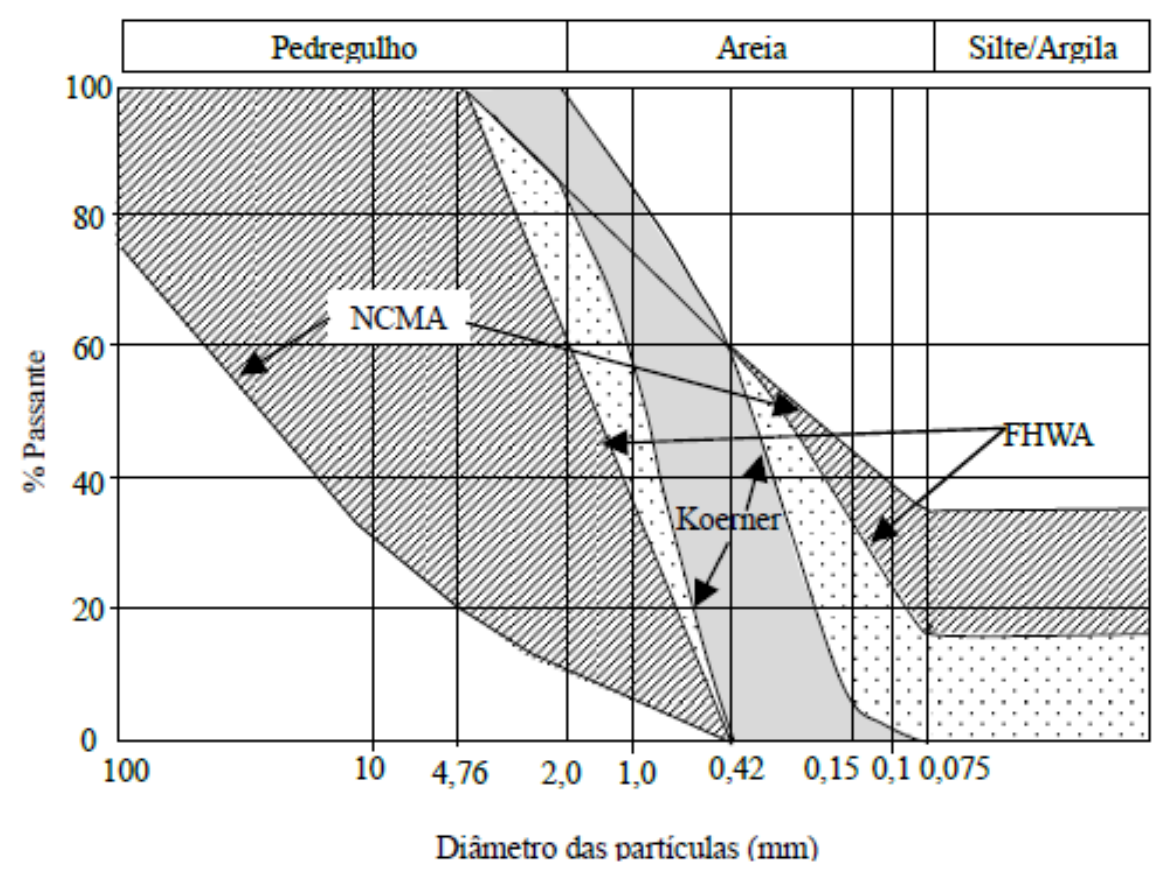

Figura 2.10 - Limites granulométricos recomendados pela NCMA (1998), FHWA (2001) e KOERNER (2012) (KOERNER; SOONG 2001).

Como se pode observar, as restrições técnicas estabelecidas nas normas e recomendações disponíveis resultam em faixas muito estreitas de solos que podem ser utilizados em estruturas reforçadas. De fato, solos que se enquadram nas faixas granulométricas estabelecidas são raramente encontrados no local da obra. No caso do Brasil, onde não existem especificações para este tipo de obra, o uso de solo fino é bastante corriqueiro e o resultado final é satisfatório, o que está, muitas vezes, associado ao uso de solos tropicais (VILAR; BUENO, 2008).

Apesar das recomendações internacionais indicarem os solos granulares como as melhores alternativas na construção de aterros reforçados, é possível encontrar no Brasil diversos casos de obras com excelente desempenho em que foram utilizados solos finos como materiais de aterro. Segundo Benjamim (2006), em geral, sob o aspecto mecânico, um solo adequado para a construção de aterros não reforçados, também será satisfatório para aterros reforçados. De acordo com o autor, a prática da engenharia brasileira mostra que, se forem tomados os devidos cuidados com a drenagem e a compactação, as estruturas de solo reforçado com materiais coesivos 
podem apresentar um comportamento igual ou até mesmo superior comparado com os muros construídos com solos puramente granulares.

Benjamim (2006) destacou também que quando se utiliza um solo com alto teor de finos, medidas apropriadas devem ser levadas em conta para garantir a estabilidade do talude, como por exemplo, realizar a compactação do solo no ramo seco da curva de compactação de Proctor. A geração de pressões neutras no solo, tanto durante a fase construtiva como também por infiltração pós-construção, pode ser evitada com a adoção de técnicas adequadas de drenagem e, particularmente, com o uso de reforços permeáveis atuando no sentido de dissipação do excesso de pressões neutras. Com isso, a função de drenagem do geotêxtil se torna essencial.

De acordo com Zornberg e Mitchell (1994), os reforços como os geotêxteis não tecidos agulhados podem aumentar consideravelmente a estabilidade de muros construídos com solos argilosos. Quando são utilizados geotêxteis não tecidos, dependendo do grau de saturação de compactação, suas características drenantes permitem que um solo fino envolvido pelos mesmos permaneça sob elevada sucção, o que aumenta sua resistência ao cisalhamento e, portanto, sua estabilidade.

Patias (2005) realizou uma avaliação quanto ao uso de solos tropicais (não convencionais) em estruturas de solo reforçado. A autora verificou que a combinação de solos finos com reforços permeáveis resultou num ganho de resistência em termos de ângulo de atrito interno e em termos de coesão, além de promover a drenagem da água dos corpos de prova ensaiados.

Como se pode observar, existem diversos critérios de projeto e especificações técnicas que se aplicam a obras de solos reforçados com geossintéticos, cada qual adaptado às realidades locais de sua aplicação. Um artigo publicado por Zornberg e Leshchinsky (2003) apresenta uma compilação dos diferentes critérios de projetos de muros de solo reforçado pelo mundo, incluindo normas da Austrália, Brasil, Canadá, Alemanha, Hong Kong, Itália, Japão, Reino Unido e Estados Unidos, abordando não somente especificações para seleção do material de aterro, mas também métodos de cálculo, seleção dos parâmetros de resistência do solo e reforço, resistência de interface, etc. (Tabela 2.3). 
Tabela 2.3 - Resumos das especificações de solos para muros reforçados com geossintéticos em diferentes países (ZORNBERG; LESHCHINSKY, 2003).

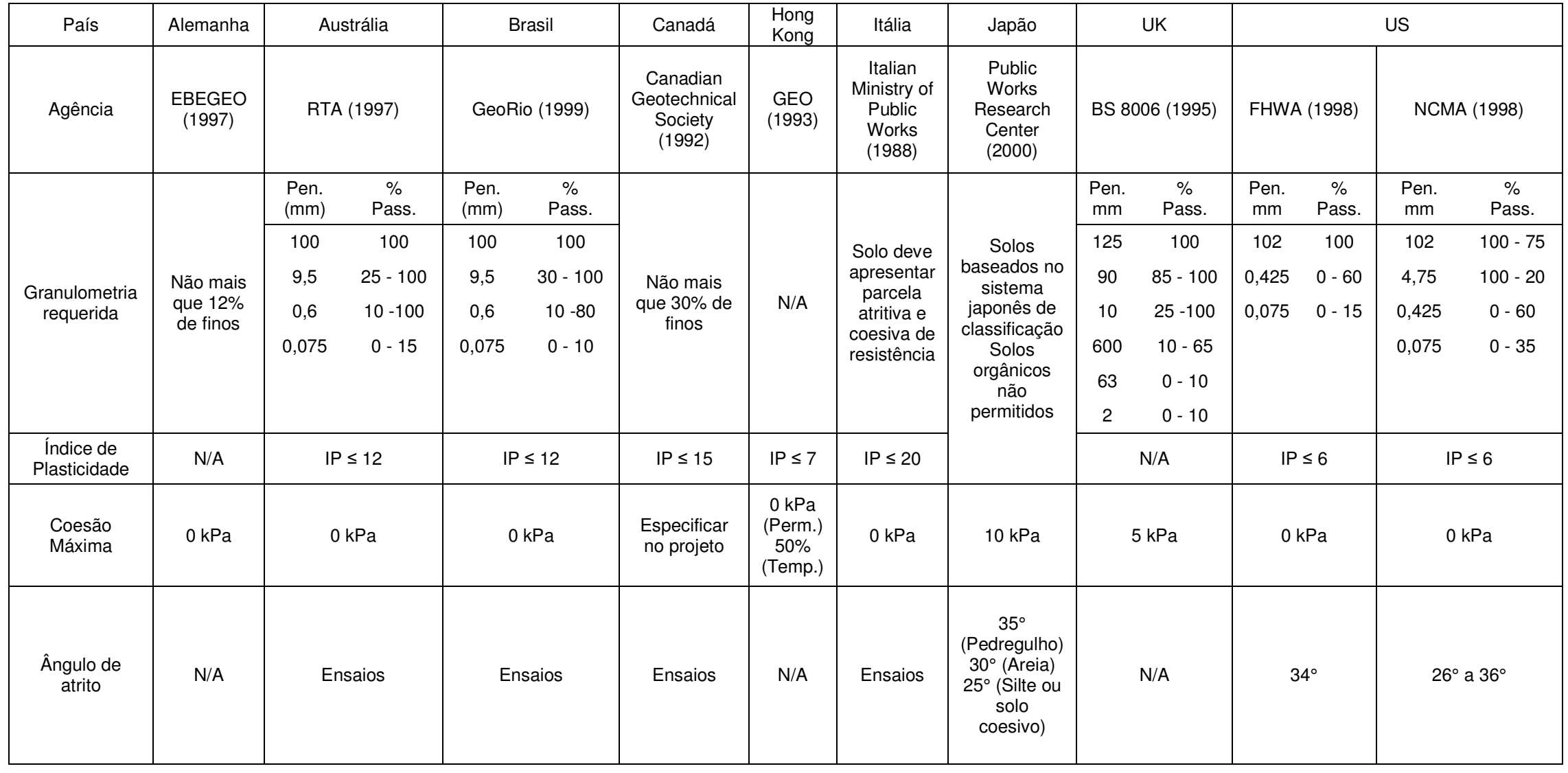




\subsection{COMPORTAMENTO MECÂNICO DE ESTRUTURAS DE CONTENÇÃO EM SOLO REFORÇADO COM GEOSSINTÉTICOS}

De forma geral, a magnitude das deformações são maiores para estruturas reforçadas com geossintéticos do que para as estruturas convencionais de concreto. Para as estruturas em solo reforçado, as deformações ocorrem tanto durante o processo construtivo da estrutura quanto após a sua construção. As deformações pós-construção geralmente são atribuídas à fluência do solo e do material de reforço, e também às sobrecargas aplicadas na superfície.

Uma maneira de minimizar as deformações em estruturas de solo reforçado com geossintéticos é a utilização de materiais mais rígidos e com menores índices de fluência. Como será discutido mais adiante, a rigidez e os índices de fluência do material em isolamento não são tão importantes, sendo mais relevantes as propriedades dos materiais quando confinados no solo.

Para que uma estrutura de solo reforçado apresente comportamento adequado é importante que as deformações nos reforços sejam limitadas de forma a evitar a ruptura do solo local e de forma a evitar o comprometimento do uso final da estrutura. Allen e Bathurst (2003) sugerem que na maioria dos casos, pelo menos para solos granulares, as deformações nos reforços sejam mantidas abaixo de 3 a $5 \%$ para que a ruptura do solo seja evitada. Jones (1992) sugere o limite de $1 \%$ de deformação para movimentos pós-construção em relação à altura da estrutura. Segundo Van Zanten (1986), geralmente 5 a 6\% podem ser aceitas como deformações máximas sob condições de trabalho. Petrick e Baslík (1988) sugerem valores de deformações que dependem do tipo e da importância da estrutura, e podem variar de 3 a 15\%.

Uma compilação de dados presentes na literatura foi apresentada por Costa (2004) com relação à magnitude de deformações e deslocamentos observados em obras instrumentadas e em protótipos de muros de solo reforçado com geossintéticos. Os casos apresentados nessa compilação possuíam altura variando de 2,0 m a 12,6 m, diferentes carregamentos e tipos de solo, face e reforço. De forma geral, os deslocamentos observados foram pequenos e o máximo deslocamento apresentado na face após o período construtivo encontra-se em torno de $0,5 \%$ a $1,0 \%$ da altura 
da contenção. Já as deformações máximas nos reforços variaram de 0,4\% a 1,2\% para as geogrelhas e de $0,7 \%$ a $3,0 \%$ para os geotêxteis.

Costa (2004) apresentou ainda um padrão de deslocamentos horizontais observados na face das estruturas em solo reforçado. Segundo o autor, a identificação do padrão de deslocamento horizontal nas faces das estruturas reforçadas não é uma tarefa simples, já que depende de fatores como o tipo de escoramento durante a construção, do tipo de face empregada, tipo de solo e reforço, e também da forma de aplicação do carregamento vertical sobre a estrutura. A Figura 2.11 apresenta os padrões de deslocamentos horizontais identificados por Costa (2004).

Um dos principais aspectos que podem ser observados, e que parecem de forma geral, ser um consenso entre os autores que tratam do assunto, é o fato dos níveis de deslocamentos observados em estruturas instrumentadas serem muito baixos, denotando um desempenho satisfatório deste tipo de estrutura. Alguns autores (ALLEN et al, 1992; TSUKADA, 1998; COSTA, 2004) atribuem as menores deformações e deslocamentos em relação aos valores esperados, ao conservadorismo existente nos métodos de projeto.

Segundo Rowe e Ho (1992) os muros são estruturas cujo comportamento depende de quatro elementos básicos: solo de aterro, reforço, face e fundação. Os métodos geralmente não consideram as interações possíveis entre esses elementos e consequentemente não são capazes de descrever adequadamente 0 comportamento real das estruturas.

No caso específico do Brasil é comum a realização do dimensionamento de estruturas reforçadas com geossintéticos desprezando a parcela de resistência de coesão do solo. A não consideração da coesão no dimensionamento de estruturas reforçadas certamente é um dos motivos dos reduzidos valores de deslocamentos observados. Ehrlich et al. (1994) relatam um caso em que a massa de solo argiloso poderia manter-se estável sem a presença dos reforços devido à elevada coesão em virtude da condição não saturada do aterro.

Considerando estes aspectos, espera-se que, por consequência das baixas deformações, as solicitações nos reforços também sejam baixas.

Costa (2004) apresenta uma compilação de resultados de muros instrumentados apresentados por Andrawes et al. (1986), Jewell e Grenwood (1988), Balleger e Wu (1993), Cazzuffi et al. (1997) e Yuan et al. (1998). Os resultados desta compilação 
mostram que para deformações situadas entre 1\% e 2\%, os níveis de carregamento no reforço correspondem a aproximadamente entre $10 \%$ e $20 \%$.

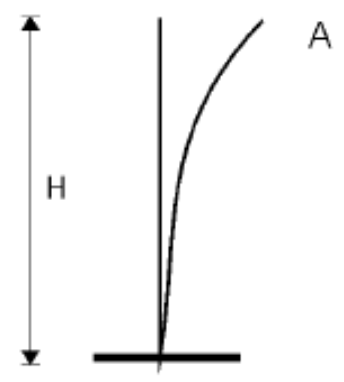

Bathurst (1992) Marques (1994)

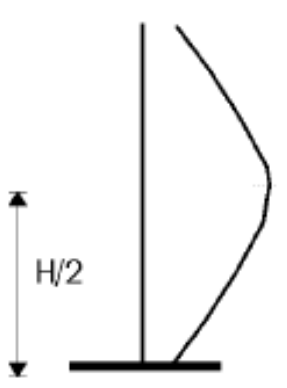

Tsukada (1998)

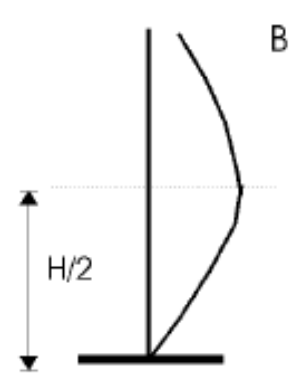

WU (1992)

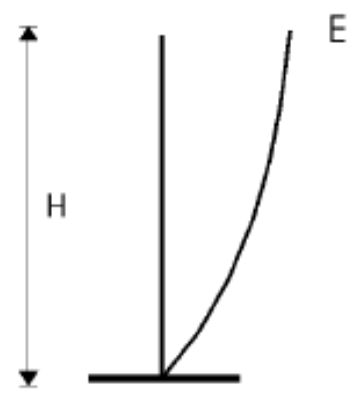

Pedroso (2000)

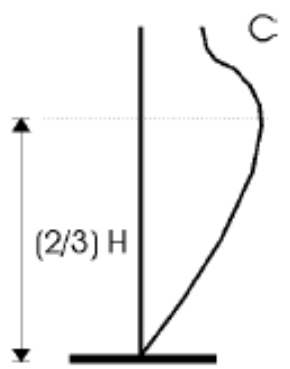

Benigni et al. (1996)

Figura 2.11 - Padrões de deslocamentos horizontais em faces de muros de solo reforçado, Costa (2004).

A Tabela 2.4 apresenta um resumo de 55 casos históricos de obras reais e casos experimentais, de muros instrumentados em solo reforçado que tiveram seus resultados publicados na bibliografia especializada. Nesta tabela são apresentadas as principais características geotécnicas da obra, as características geométricas da estrutura, as propriedades dos reforços empregados e ainda os principais resultados em termos de deformações e esforços obtidos (ou estimados) nos reforços.

A Tabela 2.4 se baseia na compilação de dados apresentados por Bathurst et al. (2008), sendo suas informações complementadas com dados publicados de muros instrumentados localizados no Brasil e no exterior.

Os resultados de obras reais e muros experimentais apresentados na bibliografia mostram que, em geral, em condições de trabalho, as deformações nas estruturas 
em solo reforçado são muito baixas, normalmente inferiores a $2 \%$. Obviamente, para os casos em que o muro experimental foi desenvolvido de forma subdimensionada, justamente para se observar o comportamento de estruturas com estas características, as deformações observadas foram bem mais elevadas.

Com relação aos esforços mobilizados nos reforços, em condições de trabalho, geralmente as cargas são relativamente baixas. Dos casos históricos apresentados, em $55 \%$ das vezes as cargas mobilizadas nos elementos em relação às suas resistências últimas ( $\left.\mathrm{T} / \mathrm{T}_{\text {ult }}\right)$ foram inferiores a $5 \%$. Em quase $80 \%$ dos casos as resistências mobilizadas foram inferiores a 10\%, e em apenas 2 casos, os quais representam $4 \%$ do total, as resistências mobilizadas nos reforços foram maiores que $20 \%$.

Ao se comparar os dados apresentados nas Tabelas 2.10 a 2.13 em termos de tipo de solo, certo equilíbrio pode ser observado. Dos 55 casos relatados, 27 deles utilizaram solos não coesivos em sua construção. Para estes casos observou-se uma deformação média de $1,5 \%$ dos reforços. Para os casos em solos coesivos, a deformação média foi de 2,0\%. Em relação aos esforços mobilizados nos reforços, a relação $\mathrm{T} / \mathrm{T}_{\text {ult }}$ média para os solos não coesivos foi de aproximadamente $9 \%$. Já para os solos coesivos a relação $\mathrm{T} / \mathrm{T}_{\text {ult }}$ média foi de aproximadamente $5 \%$.

Observa-se que, de forma geral, os muros construídos em solos granulares apresentaram menores deformações e maiores esforços mobilizados quando comparados aos casos construídos em solos coesivos.

Obviamente a comparação entre os resultados considerando-se apenas o tipo de solo de aterro é muito superficial. O comportamento geral das estruturas depende também de outros fatores, como o tipo de reforço, a interação solo-reforço, a geometria da estrutura, tipo de face, as condições de trabalho, e diversos outros fatores que foram discutidos anteriormente. 
Tabela 2.4 - Casos históricos de muros e taludes em solos reforçados com geossintéticos (BATHURST et al., 2008 - Modificado).

\begin{tabular}{|c|c|c|c|c|c|c|c|c|c|c|c|c|c|}
\hline \multirow[b]{2}{*}{ Caso } & \multirow[b]{2}{*}{ Referência } & \multirow[b]{2}{*}{ Local / Caso Histórico } & \multirow[b]{2}{*}{$\begin{array}{l}\text { Altura } \\
(\mathrm{m})\end{array}$} & \multirow[b]{2}{*}{$\begin{array}{l}\text { Sobrecarga } \\
\text { (kPa) }\end{array}$} & \multicolumn{3}{|c|}{ Solo de Aterro } & \multirow[b]{2}{*}{ Tipo de Face } & \multicolumn{5}{|c|}{ Geossintético } \\
\hline & & & & & $\begin{array}{c}\gamma \\
\left(\mathrm{kN} / \mathrm{m}^{3}\right)\end{array}$ & $\begin{array}{l}\phi \\
\left({ }^{\circ}\right)\end{array}$ & $\begin{array}{c}\mathrm{c} \\
(\mathrm{kPa})\end{array}$ & & Tipo de Reforço & $\begin{array}{c}\text { Resistência } \\
\text { Última - Tult } \\
(\mathrm{kN} / \mathrm{m})\end{array}$ & $\begin{array}{c}\varepsilon \\
(\%)\end{array}$ & $\begin{array}{c}\mathrm{T} \\
(\mathrm{kN} / \mathrm{m})\end{array}$ & $\begin{array}{c}\text { T/Tult } \\
(\%)\end{array}$ \\
\hline 1 & Bright et al. (1994) & $\begin{array}{l}\text { Tanque Verde Wall (GW5) } \\
\qquad 1984\end{array}$ & 4,70 & 0 & 19,6 & 53 & 0 & Painéis de concreto & \multirow{2}{*}{$\begin{array}{l}\text { Geogrelha } \\
\text { uniaxial PEAD }\end{array}$} & 73,00 & 0,33 & 1,12 & 1,53 \\
\hline 2 & Christopher (1993) & $\begin{array}{c}\text { Algonquin Wall (GW8) } \\
1988\end{array}$ & 6,10 & 0 & 20,4 & 43 & 0 & Painéis de concreto & & 67,80 & 0,76 & 3,80 & 5,60 \\
\hline 3 & Christopher (1993) & $\begin{array}{c}\text { Algonquin Wall (GW10) } \\
1988\end{array}$ & 5,90 & 0 & 20,4 & 43 & 0 & Envelopado & $\begin{array}{l}\text { Geotêxtil Não } \\
\text { Tecido }\end{array}$ & 19,30 & 2,00 & 3,50 & 18,13 \\
\hline 4 & $\begin{array}{l}\text { Bathurst e Benjamin } \\
\text { (1990) }\end{array}$ & RMC Wall (GW14) 1989 & 3,00 & 0 & 18 & 55 & 0 & Painéis de alumínio & \multirow{2}{*}{$\begin{array}{l}\text { Geogrelha } \\
\text { biaxial PP }\end{array}$} & 12,00 & 0,42 & 0,38 & 3,17 \\
\hline 5 & Bathurst et al. (1993a) & RMC Wall (GW15) 1989 & 3,00 & 0 & 18 & 55 & 0 & Painéis de alumínio & & 12,00 & 0,61 & 0,53 & 4,42 \\
\hline 6 & $\begin{array}{c}\text { Knight and Valsangkar } \\
\text { (1993) }\end{array}$ & $\begin{array}{c}\text { Fredericton, New } \\
\text { Brunswick Wall (GW18) } \\
1990\end{array}$ & 6,10 & 0 & 20,4 & 45 & 0 & Painéis de concreto & $\begin{array}{l}\text { Geogrelha } \\
\text { uniaxial PEAD }\end{array}$ & 73,00 & 0,50 & 2,50 & 3,42 \\
\hline 7 & PWRI (1988) & $\begin{array}{l}\text { PWRI Test Wall (GW21) } \\
1988\end{array}$ & 4,00 & 0 & 16,7 & 31 & 0 & $\begin{array}{l}\text { Painéis de madeira } \\
\text { compensada }\end{array}$ & $\begin{array}{l}\text { Geogrelha } \\
\text { biaxial PP }\end{array}$ & 18,20 & 4,62 & 6,01 & 33,02 \\
\hline 8 & Tajiri et al. (1996) & $\begin{array}{l}\text { PWRI Test Wall (GW22) } \\
1996\end{array}$ & 6,00 & 0 & 16,7 & 48 & 0 & Painél de EPS & \multirow{8}{*}{$\begin{array}{c}\text { Geogrelha } \\
\text { uniaxial PEAD }\end{array}$} & 59,80 & 1,23 & 4,67 & 7,81 \\
\hline 9 & Tajiri et al. (1996) & $\begin{array}{l}\text { PWRI Test Wall (GW23) } \\
1996\end{array}$ & 6,00 & 0 & 16,7 & 48 & 0 & Painéis de concreto & & 59,80 & 1,09 & 4,14 & 6,92 \\
\hline 10 & Tajiri et al. (1996) & $\begin{array}{l}\text { PWRI Test Wall (GW24) } \\
1996\end{array}$ & 6,00 & 0 & 16,7 & 48 & 0 & Painéis de concreto & & 59,80 & 0,82 & 3,12 & 5,22 \\
\hline 11 & Tajiri et al. (1996) & $\begin{array}{c}\text { PWRI Test Wall (GW25) } \\
1996 \\
\end{array}$ & 6,00 & 0 & 16,7 & 48 & 0 & Blocos de alvenaria & & 59,80 & 0,50 & 1,90 & 3,18 \\
\hline 12 & Allen and Bathurst (2006) & $\begin{array}{l}\text { WSDOT SR-18 Wall } \\
\text { (GW26C) } 2005\end{array}$ & 10,70 & 0 & 22 & 54 & 0 & Blocos de alvenaria & & 62,50 & 1,60 & 5,61 & 8,98 \\
\hline 13 & Allen and Bathurst (2006) & $\begin{array}{l}\text { WSDOT SR-18 Wall } \\
\text { (GW26C) } 2005\end{array}$ & 10,70 & 0 & 22 & 54 & 0 & $\begin{array}{c}\text { Bloco de alvenaria com } \\
\text { preenchimento } \\
\text { granular }\end{array}$ & & 71,10 & N.I. & N.I. & N.I. \\
\hline 14 & Allen and Bathurst (2006) & $\begin{array}{l}\text { WSDOT SR-18 Wall } \\
\text { (GW26C) } 2005\end{array}$ & 10,70 & 0 & 22 & 54 & 0 & $\begin{array}{l}\text { Bloco de alvenaria com } \\
\text { preenchimento } \\
\text { granular }\end{array}$ & & 117,00 & N.I. & N.I. & N.I. \\
\hline 15 & Dados não Publicados & $\begin{array}{l}\text { WSDOT SR-18 Wall } \\
\text { (GW26D) }\end{array}$ & 5,50 & 0 & 22 & 54 & 0 & Não Informado & & 62,50 & 0,50 & 1,23 & 1,97 \\
\hline
\end{tabular}


Continuação

\begin{tabular}{|c|c|c|c|c|c|c|c|c|c|c|c|c|c|}
\hline \multirow[b]{2}{*}{ Caso } & \multirow[b]{2}{*}{ Referência } & \multirow[b]{2}{*}{ Local / Caso Histórico } & \multirow[b]{2}{*}{$\begin{array}{l}\text { Altura } \\
(\mathrm{m})\end{array}$} & \multirow[b]{2}{*}{$\begin{array}{l}\text { Sobrecarga } \\
\quad(\mathrm{kPa})\end{array}$} & \multicolumn{3}{|c|}{ Solo de Aterro } & \multirow[b]{2}{*}{ Tipo de Face } & \multicolumn{5}{|c|}{ Geossintético } \\
\hline & & & & & $\begin{array}{c}\gamma \\
\left(\mathrm{kN} / \mathrm{m}^{3}\right)\end{array}$ & $\begin{array}{l}\phi \\
\left({ }^{\circ}\right)\end{array}$ & $\begin{array}{c}\mathrm{c} \\
(\mathrm{kPa})\end{array}$ & & Tipo de Reforço & $\begin{array}{c}\text { Resistência } \\
\text { Última - Tult } \\
\text { (kN/m) }\end{array}$ & $\varepsilon(\%)$ & $\begin{array}{c}\mathrm{T} \\
(\mathrm{kN} / \mathrm{m})\end{array}$ & $\begin{array}{l}\text { T/Tult } \\
(\%)\end{array}$ \\
\hline 16 & PWRI et al. (1988) & PWRI Wall (GW27) 1987 & 4 & 0,5 & 17 & 29 & 4,9 & Gabião & \multirow{12}{*}{$\begin{array}{l}\text { Geogrelha } \\
\text { uniaxial PEAD }\end{array}$} & 71,4 & 2,05 & 8,2 & 11,48 \\
\hline 17 & PWRI et al. (1988) & PWRI Wall (GW28) 1987 & 4 & 0,5 & 17 & 29 & 4,9 & Gabião & & 71,4 & 2,65 & 10,6 & 14,85 \\
\hline 18 & PWRI et al. (1988) & PWRI Wall (GW29) 1987 & 4 & 0,5 & 17 & 29 & 4,9 & Envelopado & & 71,4 & 2,80 & 11,2 & 15,69 \\
\hline 19 & Ochiai e Fukuda (1996) & PWRI Wall (GW30) 1995 & 8 & 0 & 18,5 & 31 & 10 & $\begin{array}{c}\text { Bloco de alvenaria com } \\
\text { preenchimento } \\
\text { granular }\end{array}$ & & 59,8 & 0,52 & 1,98 & 3,31 \\
\hline 20 & Yamanouchi et al. (1986a) & $\begin{array}{c}\text { Kagoshima Wall (GW31) } \\
1984\end{array}$ & 4 & 0,4 & 15,2 & 44 & 4,9 & Envelopado & & 71,4 & 0,23 & 0,92 & 1,29 \\
\hline 21 & Yamanouchi et al. (1986b) & $\begin{array}{c}\text { Yamaguchi Wall (GW32) } \\
\text { sections L \& R } 1985\end{array}$ & 6 & 0,4 & 17,4 & 40 & 12,8 & Painéis de concreto & & 71,4 & 0,12 & 0,48 & 0,67 \\
\hline 22 & Yamanouchi et al. (1986b) & $\begin{array}{c}\text { Yamaguchi Wall (GW32) } \\
\text { sections L \& R } 1985\end{array}$ & 6 & 0,4 & 17,4 & 40 & 12,8 & Painéis de concreto & & 71,4 & 0,19 & 0,76 & 1,06 \\
\hline 23 & Farrag et al. 2004 & LTRC (GW33i) 1998 & 5,4 & 0 & 18,8 & 28 & 1,4 & $\begin{array}{l}\text { Bloco de alvenaria com } \\
\text { preenchimento } \\
\text { granular }\end{array}$ & & 35 & 2,00 & 2 & 5,71 \\
\hline 24 & Farrag et al. 2004 & LTRC (GW33ii) 1998 & 5,4 & 0 & 18,8 & 28 & 1,4 & $\begin{array}{l}\text { Bloco de alvenaria com } \\
\text { preenchimento } \\
\text { granular }\end{array}$ & & 70 & 1,81 & 4,53 & 6,47 \\
\hline 25 & Farrag et al. 2004 & LTRC (GW33iii) 1998 & 5,4 & 0 & 18,8 & 28 & 1,4 & $\begin{array}{l}\text { Bloco de alvenaria com } \\
\text { preenchimento } \\
\text { granular }\end{array}$ & & 114 & 1,15 & 5,75 & 5,04 \\
\hline 26 & PWRC (1995) & (GW40) 1992 & 4 & 0 & 16,2 & 40 & 2 & Painéis de concreto & & 32 & 0,49 & 0,83 & 2,59 \\
\hline 27 & PWRC (1995) & (GW42) 1992 & 4 & 0 & 15,5 & 40 & 2 & $\begin{array}{l}\text { Painéis de madeira } \\
\text { compensada }\end{array}$ & & 59,8 & 0,68 & 2,72 & 4,55 \\
\hline 28 & $\begin{array}{c}\text { Fannin and Hermann } \\
(1990)\end{array}$ & $\begin{array}{l}\text { Oslo, Norway, Section J } \\
\text { and N (GW7) } 1987\end{array}$ & 4,8 & 1,75 & 17 & 46 & 0 & Arame soldado & \multirow{2}{*}{$\begin{array}{l}\text { Geogrelha } \\
\text { uniaxial PEAD }\end{array}$} & 53,1 & 0,42 & 1,47 & 2,77 \\
\hline 29 & $\begin{array}{c}\text { Fannin and Hermann } \\
(1990)\end{array}$ & $\begin{array}{l}\text { Oslo, Norway, Section J } \\
\text { and N (GW7) } 1987\end{array}$ & 4,8 & 1,3 & 17 & 46 & 0 & Arame soldado & & 53,1 & 0,63 & 2,21 & 4,16 \\
\hline 30 & Bathurst et al. (1993b) & $\begin{array}{c}\text { Algonquin, USA (GW9) } \\
1988\end{array}$ & 6,1 & 1,2 & 20,4 & 43 & 0 & $\begin{array}{l}\text { Bloco de alvenaria com } \\
\text { preenchimento } \\
\text { granular }\end{array}$ & Geogrelha PET & 39,2 & 0,63 & 1,26 & 3,21 \\
\hline
\end{tabular}


Continuação

\begin{tabular}{|c|c|c|c|c|c|c|c|c|c|c|c|c|c|}
\hline \multirow[b]{2}{*}{ Caso } & \multirow[b]{2}{*}{ Referência } & \multirow[b]{2}{*}{ Local / Caso Histórico } & \multirow[b]{2}{*}{$\begin{array}{l}\text { Altura } \\
(\mathrm{m})\end{array}$} & \multirow[b]{2}{*}{$\begin{array}{l}\text { Sobrecarga } \\
\quad(\mathrm{kPa})\end{array}$} & \multicolumn{3}{|c|}{ Solo de Aterro } & \multirow[b]{2}{*}{ Tipo de Face } & \multicolumn{5}{|c|}{ Geossintético } \\
\hline & & & & & $\begin{array}{c}\gamma \\
\left(\mathrm{kN} / \mathrm{m}^{3}\right)\end{array}$ & $\begin{array}{l}\phi \\
\left({ }^{\circ}\right)\end{array}$ & $\begin{array}{c}\mathrm{c} \\
(\mathrm{kPa})\end{array}$ & & Tipo de Reforço & $\begin{array}{c}\text { Resistência } \\
\text { Última - Tult } \\
\text { (kN/m) }\end{array}$ & $\varepsilon(\%)$ & $\begin{array}{c}\mathrm{T} \\
(\mathrm{kN} / \mathrm{m})\end{array}$ & $\begin{array}{l}\text { T/Tult } \\
(\%)\end{array}$ \\
\hline 31 & Allen et al. (1992) & $\begin{array}{l}\text { Rainer Avenue, USA } \\
\text { (GW16) } 1989\end{array}$ & 12,60 & 2,7 & 21,1 & 54 & 0 & Envelopado & \multirow{4}{*}{$\begin{array}{c}\text { Geotêxtil tecido } \\
\text { PP }\end{array}$} & 31 & 4,33 & 5,2 & 16,77 \\
\hline 32 & Allen et al. (1992) & $\begin{array}{l}\text { Rainer Avenue, USA } \\
\text { (GW16) } 1989\end{array}$ & 12,60 & 2,7 & 21,1 & 54 & 0 & Envelopado & & 62 & N.I. & N.I. & N.I. \\
\hline 33 & Allen et al. (1992) & $\begin{array}{c}\text { Rainer Avenue, USA } \\
\text { (GW16) } 1989\end{array}$ & 12,60 & 2,7 & 21,1 & 54 & 0 & Envelopado & & 92 & N.I. & N.I. & N.I. \\
\hline 34 & Allen et al. (1992) & $\begin{array}{l}\text { Rainer Avenue, USA } \\
\text { (GW16) } 1989\end{array}$ & 12,60 & 2,7 & 21,1 & 54 & 0 & Envelopado & & 186 & N.I. & N.I. & N.I. \\
\hline 35 & Carruba et al. (1999) & $\begin{array}{c}\text { Vicenza, Italy (GW2Ohp) } \\
1998\end{array}$ & 4,00 & 2,4 & 21,1 & 55 & 8 & Arame soldado & $\begin{array}{c}\text { Geogrelha } \\
\text { uniaxial PEAD }\end{array}$ & 56,3 & 0,29 & 0,87 & 1,55 \\
\hline 36 & Carruba et al. (1999) & $\begin{array}{c}\text { Vicenza, Italy (GW20pp) } \\
1998\end{array}$ & 4,00 & 2,5 & 21,1 & 55 & 8 & Arame soldado & $\begin{array}{l}\text { Geogrelha } \\
\text { uniaxial PP }\end{array}$ & 20,9 & 0,61 & 0,55 & 2,63 \\
\hline 37 & $\begin{array}{l}\text { Nakane et al. (1990); } \\
\text { Onodera et al. (2004) }\end{array}$ & PWRI Wall (GW35) 1990 & 4,50 & 0,5 & 18,6 & 24 & 4,9 & $\begin{array}{l}\text { Gabião preenchido } \\
\text { com sacos de areia }\end{array}$ & \multirow{6}{*}{$\begin{array}{c}\text { Geogrelha } \\
\text { uniaxial PEAD }\end{array}$} & 59,8 & 0,42 & 1,6 & 2,68 \\
\hline 38 & Miki et al. (1992) & PWRI Wall (GW36) 1991g & 6,30 & 0 & 16 & 45 & 2 & $\begin{array}{l}\text { Sacaria (não } \\
\text { envelopado) }\end{array}$ & & 59,8 & 0,41 & 1,56 & 2,61 \\
\hline 39 & Yamanouchi et al. (1986a) & $\begin{array}{c}\text { Kagoshima Wall (GW37) } \\
1984\end{array}$ & 6,00 & 0,9 & 14,7 & 51 & 2,5 & Sacaria (envelopado) & & 71,4 & 0,25 & 1 & 1,40 \\
\hline 40 & Itoh et al. (1988) & Nagano Wall (GW38) 1987 & 7,50 & 0,5 & 16,1 & 25 & 12 & Sacaria (envelopado) & & 71,4 & 0,50 & 2 & 2,80 \\
\hline 41 & Abe et al. (1989) & $\begin{array}{c}\text { Saitama Wall (GW39) } \\
1989 \\
\end{array}$ & 8,70 & 0,9 & 19,7 & 51 & 17 & Sacaria (envelopado) & & 59,8 & 0,18 & 0,68 & 1,14 \\
\hline 42 & PWRC (1995) & (GW41) 1992 & 4,00 & 0 & 16 & 40 & 2 & Sacaria & & 59,8 & 0,42 & 1,68 & 2,81 \\
\hline 43 & Benjamim (2006) - P1 & $\begin{array}{c}\text { Nova Odessa, São Paulo, } \\
\text { Brasil } \\
\end{array}$ & 4,00 & 0 & ni & 32 & 15 & Envelopado & $\begin{array}{l}\text { Geotêxtil Não } \\
\text { Tecido PP }\end{array}$ & 16,7 & 1,61 & 1,047 & 6,27 \\
\hline 44 & Benjamim (2006) - P7 & $\begin{array}{c}\text { Nova Odessa, São Paulo, } \\
\text { Brasil }\end{array}$ & 4,00 & 0 & ni & 32 & 15 & Envelopado & $\begin{array}{l}\text { Geotêxtil Não } \\
\text { Tecido PP }\end{array}$ & 10 & 28,00 & N.I. & - \\
\hline 45 & Saramago (2002) & Laboratório & 6,20 & Variável & 20,5 & 44 & 0 & Bloco & $\begin{array}{c}\text { Geogrelha } \\
\text { Fortrac } 80 / 30- \\
20 \\
\end{array}$ & 80 & N.I. & 7,95 & 9,94 \\
\hline
\end{tabular}


Continuação

\begin{tabular}{|c|c|c|c|c|c|c|c|c|c|c|c|c|c|}
\hline \multirow[b]{2}{*}{ Caso } & \multirow[b]{2}{*}{ Referência } & \multirow[b]{2}{*}{ Local / Caso Histórico } & \multirow[b]{2}{*}{$\begin{array}{l}\text { Altura } \\
(\mathrm{m})\end{array}$} & \multirow[b]{2}{*}{$\begin{array}{l}\text { Sobrecarga } \\
\qquad(\mathrm{kPa})\end{array}$} & \multicolumn{3}{|c|}{ Solo de Aterro } & \multirow[b]{2}{*}{ Tipo de Face } & \multicolumn{5}{|c|}{ Geossintético } \\
\hline & & & & & $\begin{array}{c}\gamma \\
\left(k N / m^{3}\right)\end{array}$ & $\begin{array}{l}\phi \\
\left({ }^{\circ}\right)\end{array}$ & $\begin{array}{c}\mathrm{c} \\
(\mathrm{kPa})\end{array}$ & & Tipo de Reforço & $\begin{array}{c}\text { Resistência } \\
\text { Última - Tult } \\
\text { (kN/m) }\end{array}$ & $\varepsilon(\%)$ & $\begin{array}{c}\mathrm{T} \\
(\mathrm{kN} / \mathrm{m})\end{array}$ & $\begin{array}{c}\text { T/Tult } \\
(\%)\end{array}$ \\
\hline 46 & Riccio Filho (2007) & $\begin{array}{c}\text { São José dos Campos, SP, } \\
\text { Brasil }\end{array}$ & 4,2 & 0 & 20,1 & 25 & 42 & Bloco & $\begin{array}{c}\text { Geogrelha } \\
\text { Fortrac } 35 / 20- \\
20 \\
\end{array}$ & 35 & 2,80 & 7,1 & 20,29 \\
\hline 47 & Riccio Filho (2007) & $\begin{array}{c}\text { São José dos Campos, SP, } \\
\text { Brasil }\end{array}$ & 4,2 & 0 & 20,1 & 25 & 42 & Bloco & $\begin{array}{c}\text { Geogrelha } \\
\text { Fortrac 55/30- } \\
20 \\
\end{array}$ & 55 & 1,60 & 6,5 & 11,82 \\
\hline 48 & Fannin (2001) & & 4,8 & 49 & Areia & 0 & 0 & Sacaria & $\begin{array}{c}\text { Geogrelha } \\
\text { Biaxial }\end{array}$ & 20,5 & 1,30 & 3,4 & 16,59 \\
\hline 49 & Alli (1993) & Malásia & 7 & 0 & 0 & 0 & 0 & ni & $\begin{array}{l}\text { Geogrelha } \\
\text { PEAD }\end{array}$ & N.I. & N.I. & 6,5 & --- \\
\hline 50 & Tsukada et al. (1998) & --- & 8 & 9,8 & 18,6 & 29 & 0 & Bloco & $\begin{array}{l}\text { Geogrelha } \\
\text { PEAD }\end{array}$ & 55 & 1,00 & 8,8 & 16,00 \\
\hline 51 & $\begin{array}{l}\text { Naemura e Miki (1996) - } \\
\text { S1 }\end{array}$ & Japão & 7 & 26 & 19 & 30 & 36 & Envelopado & $\begin{array}{l}\text { Geotêxtil Não } \\
\text { Tecido }\end{array}$ & 38 & 0,50 & N.I. & N.I. \\
\hline 52 & Bruno (1997) & Rio de Janeiro, RJ, Brasil & 3,9 & 0 & N.I. & 35 & 0 & Tijolo de concreto & $\begin{array}{l}\text { Geotêxtil Não } \\
\text { Tecido de } \\
\text { Poliester } \\
\end{array}$ & 20 & 6,90 & 3,8 & 19 \\
\hline 53 & Portelinha (2012) & $\begin{array}{c}\text { São Carlos, SP, Brasil - } \\
\text { Muro M1 }\end{array}$ & 1,8 & 100 & 17,9 & 32 & 28 & $\begin{array}{l}\text { Argamassa de cimento } \\
\text { com tela metálica }\end{array}$ & $\begin{array}{l}\text { Geotêxtil Não } \\
\text { Tecido PET }\end{array}$ & 10 & 0,40 & 0,07 & 0,70 \\
\hline 54 & Portelinha (2012) & $\begin{array}{c}\text { São Carlos, SP, Brasil - } \\
\text { Muro M2 }\end{array}$ & 1,8 & 100 & 17,9 & 32 & 20,2 & $\begin{array}{c}\text { Argamassa de cimento } \\
\text { com tela metálica }\end{array}$ & $\begin{array}{l}\text { Geotêxtil Não } \\
\text { Tecido PET }\end{array}$ & 10 & 1,46 & 0,32 & 3,20 \\
\hline 55 & Portelinha (2012) & $\begin{array}{c}\text { São Carlos, SP, Brasil - } \\
\text { Muro M3 }\end{array}$ & 1,8 & 100 & 17,9 & 32 & 25,8 & $\begin{array}{l}\text { Argamassa de cimento } \\
\text { com tela metálica }\end{array}$ & $\begin{array}{l}\text { Geotêxtil Não } \\
\text { Tecido PET }\end{array}$ & 10 & 1,60 & 0,26 & 2,60 \\
\hline
\end{tabular}


Conforme se pode observar, nos diversos casos apresentados neste item, os níveis de deformações e carregamentos nos reforço são, de forma geral, muito baixos em estruturas sob condições de trabalho. Isto é um indicativo de que, para estas estruturas, muito provavelmente as deformações por fluência dos reforços não devem ser significativas.

\subsection{RELATOS DE CASOS DE MUROS EM SOLO REFORÇADO UTILIZANDO SOLOS TROPICAIS COMO MATERIAL DE ATERRO}

Conforme destacado anteriormente, o Brasil não possui especificações próprias para o dimensionamento e construção de estruturas de contenção em solo reforçado com geossintéticos. Em geral, as estruturas aqui construídas contrariam as especificações internacionais, que costumam restringir os materiais de aterro apenas a solos granulares, com baixo teor de finos e bem graduados. Entretanto, a prática da engenharia brasileira tem mostrado que estruturas de contenção em solos reforçados que utilizam materiais coesivos na composição do aterro tem apresentado comportamento igual ou até mesmo superior quando comparados a aterros executados com solos puramente granulares. Vale lembrar, que para estes casos, cuidados especiais devem ser tomados em relação ao sistema de drenagem e ao processo de compactação do aterro.

A seguir são apresentados alguns casos nacionais de muros instrumentados, construídos em solo reforçado com geossintéticos, nos quais foram utilizados solos tropicais como material de aterro. Nos casos apresentados a seguir, procurou-se manter ênfase nos aspectos de maior interesse para esta tese, como por exemplo, as propriedades geotécnicas do solo empregado, as características mecânicas do geossintético utilizado e, consequentemente, os resultados obtidos pela instrumentação, como os deslocamentos na face da estrutura, os deslocamentos internos no maciço, as deformações dos reforços, a localização da superfície potencial de ruptura e as deformações registradas nas estruturas ao longo do tempo. 


\subsubsection{Protótipos instrumentados por Benjamim (2006)}

Uma importante contribuição para o entendimento do comportamento geotécnico de estruturas de solo reforçado com geossintéticos utilizando solos tropicais como material de aterro foi apresentada por Benjamim (2006).

O autor construiu e instrumentou oito protótipos de estruturas de contenção em solo reforçado, utilizando geotêxteis tecidos e não tecidos como reforço, e três diferentes tipos de solos para compor o aterro compactado. A Tabela 2.5 mostra um resumo das principais características de cada estrutura.

Tabela 2.5 - Características principais dos solos e dos geotêxteis utilizados (BENJAMIM, 2006).

\begin{tabular}{|c|c|c|c|c|c|}
\hline \multirow[b]{2}{*}{ Muro } & \multicolumn{2}{|c|}{ Geossintético } & \multicolumn{2}{|c|}{ Geometria } & \multirow{2}{*}{$\begin{array}{c}\text { Solo } \\
\text { Granulometria } \\
\text { ABNT } 6502\end{array}$} \\
\hline & $\begin{array}{c}\text { Processo de } \\
\text { Fabricação }\end{array}$ & Polímero & $\begin{array}{c}\text { Espaçamento } \\
\text { Vertical }\end{array}$ & $\begin{array}{l}\text { Comprimento } \\
\text { da Inclusão }\end{array}$ & \\
\hline 1 & Não tecido & PET & Constante $40 \mathrm{~cm}$ & $3,0 \mathrm{~m}$ & $\begin{array}{c}\text { Areia média a } \\
\text { grossa }\end{array}$ \\
\hline 2 & Não tecido & PET & $\begin{array}{c}\text { Variável } 30 \text { até } 60 \\
\mathrm{~cm}\end{array}$ & $3,0 \mathrm{~m}$ & $\begin{array}{c}\text { Areia média a } \\
\text { grossa }\end{array}$ \\
\hline 3 & Não tecido & PP & $\begin{array}{l}\text { Variável de } 30 \text { até } \\
\qquad 50 \mathrm{~cm}\end{array}$ & $3,0 \mathrm{~m}$ & Areia siltosa \\
\hline 4 & Tecido & PP & $\begin{array}{l}\text { Variável de } 30 \text { até } \\
\qquad 50 \mathrm{~cm}\end{array}$ & $3,0 \mathrm{~m}$ & Areia siltosa \\
\hline 5 & Não tecido & PP & Constante $40 \mathrm{~cm}$ & $3,0 \mathrm{~m}$ & Argila siltosa \\
\hline 6 & Tecido & PP & Constante $40 \mathrm{~cm}$ & $3,0 \mathrm{~m}$ & Argila siltosa \\
\hline 7 & Não tecido & PP & Constante $36 \mathrm{~cm}$ & $3,0 \mathrm{~m}$ & $\begin{array}{c}\text { Areia média a } \\
\text { grossa }\end{array}$ \\
\hline 8 & Tecido & PP & Constante $40 \mathrm{~cm}$ & $3,0 \mathrm{~m}$ & $\begin{array}{c}\text { Areia média a } \\
\text { grossa }\end{array}$ \\
\hline
\end{tabular}

Os muros desenvolvidos por Benjamim (2006) foram construídos aos pares em unidades confinadas com estruturas de madeira. A Figura 2.12 apresenta um esquema geral dos módulos básicos, com as dimensões médias que foram atribuídas aos protótipos. A Figura 2.13 mostra uma vista geral do Protótipo Número 1 construído pelo autor. 


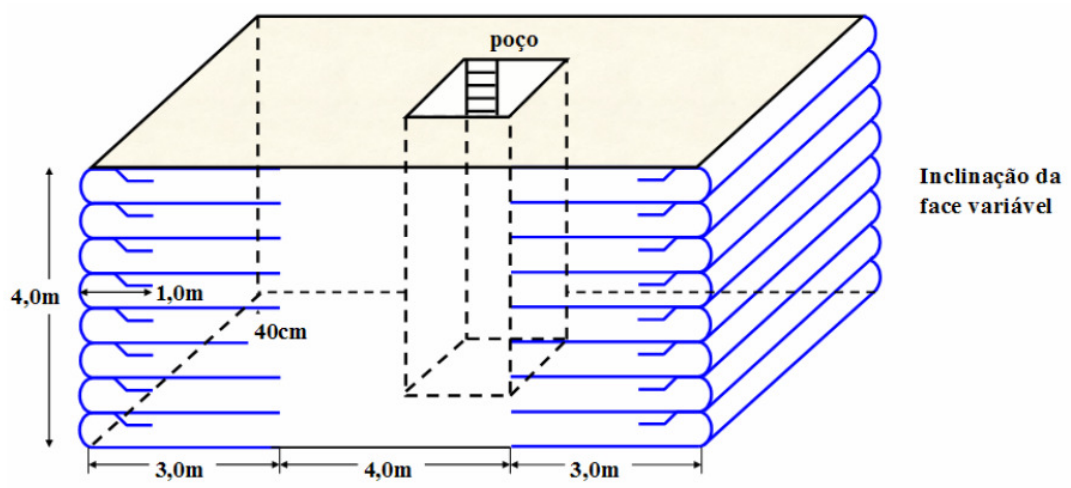

Figura 2.12 - Esquema básico dos módulos construídos por Benjamim (2006).

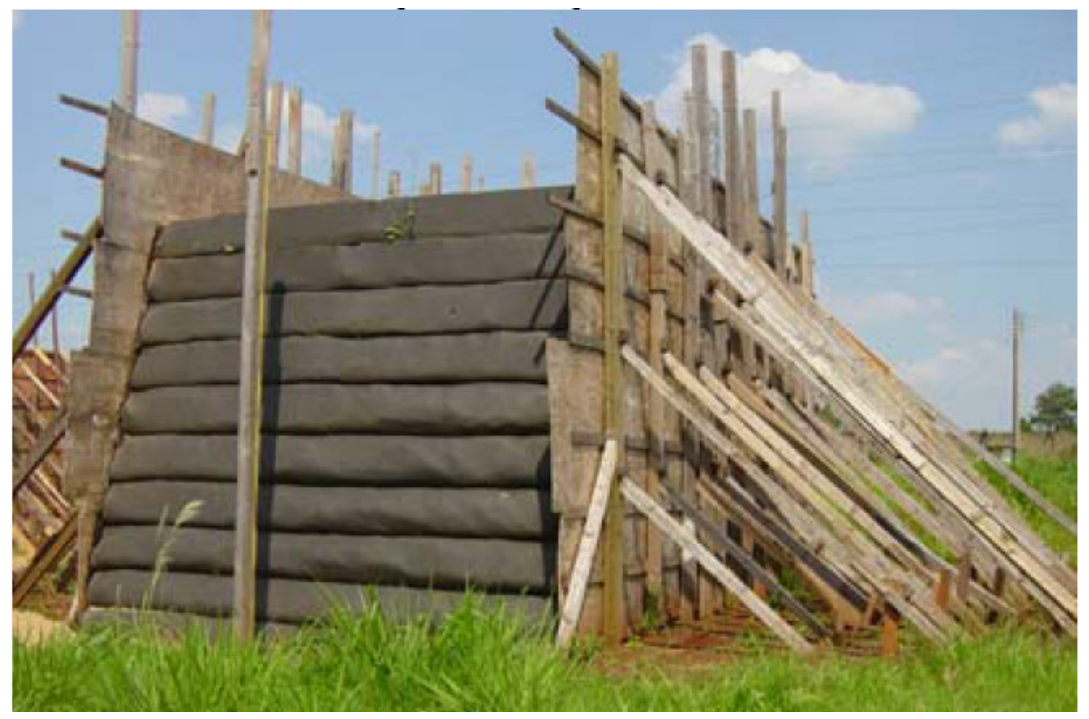

Figura 2.13 - Vista geral do Protótipo № 1 construído por Benjamim (2006).

Para a caracterização do solo de fundação local, foram realizadas sondagens de simples reconhecimento (SPT), as quais indicaram a presença de um solo residual de basalto, basicamente composto por uma argila vermelha, com resistência crescente com a profundidade e nível d’água a 12,80 m da superfície.

Conforme citado anteriormente, três solos distintos, dois coesivos e um granular, foram utilizados como materiais de aterro na pesquisa. 
A Tabela 2.6 apresenta os parâmetros geotécnicos dos solos de aterro empregados na pesquisa, obtidos por meio de ensaios de laboratório.

Tabela 2.6 - Parâmetros geotécnicos dos solos de aterro utilizados na pesquisa (BENJAMIM, 2006).

\begin{tabular}{ccccccc}
\hline Solo & $\begin{array}{c}\text { Classificação } \\
\text { Unificada }\end{array}$ & LL (\%) & LP (\%) & IP & $\phi\left(^{\circ}\right)$ & c (kPa) \\
\hline São Pedro & $\begin{array}{c}\text { Areia média } \\
\text { a fina (SP) }\end{array}$ & - & - & - & 32 & 15 \\
Hortolândia & $\begin{array}{c}\text { Areia siltosa } \\
\text { (SM) }\end{array}$ & 17 & 15 & 2 & 30 & 55 \\
Nova & $\begin{array}{c}\text { Argila pouco } \\
\text { plástica com } \\
\text { areia (CL) }\end{array}$ & 41 & 31 & 10 & 27 & 54 \\
\hline
\end{tabular}

Como elementos de reforço foram utilizados quatro tipos de geotêxteis, sendo um deles tecido e os outros três não tecidos. A Tabela 2.7 apresenta os principais resultados dos ensaios de caracterização dos geotêxteis empregados na pesquisa.

Tabela 2.7 - Resultados dos ensaios de caracterização dos geotêxteis utilizados na pesquisa (BENJAMIM, 2006).

\begin{tabular}{cccccc}
\hline $\begin{array}{c}\text { Tipo de } \\
\text { Geotêxtil }\end{array}$ & Polímero & $\begin{array}{c}\text { Gramatura } \\
\left(\mathrm{g} / \mathrm{m}^{2}\right)\end{array}$ & $\begin{array}{c}\text { Espessura } \\
(\mathrm{mm})\end{array}$ & $\begin{array}{c}\text { Resistência } \\
\text { à tração } \\
(\mathrm{kN} / \mathrm{m})\end{array}$ & $\begin{array}{c}\text { Deformação } \\
\text { na ruptura } \\
(\%)\end{array}$ \\
\hline Tecido & PP & 204,4 & 1,26 & 13,94 & 22,67 \\
Não tecido & PP & 175,0 & 2,04 & 10,01 & 65,68 \\
Não tecido & PET & 166,3 & 2,66 & 8,12 & 95,85 \\
Não tecido & PP & 251,4 & 2,35 & 16,68 & 49,36 \\
\hline
\end{tabular}

Para o registro do comportamento dos protótipos, os muros foram instrumentados com medidores de deslocamentos de face, extensômetros magnéticos verticais e medidores de deslocamentos horizontais dos reforços (tell-tales). A Figura 2.14 mostra uma seção típica contendo os detalhes da instrumentação utilizada. 


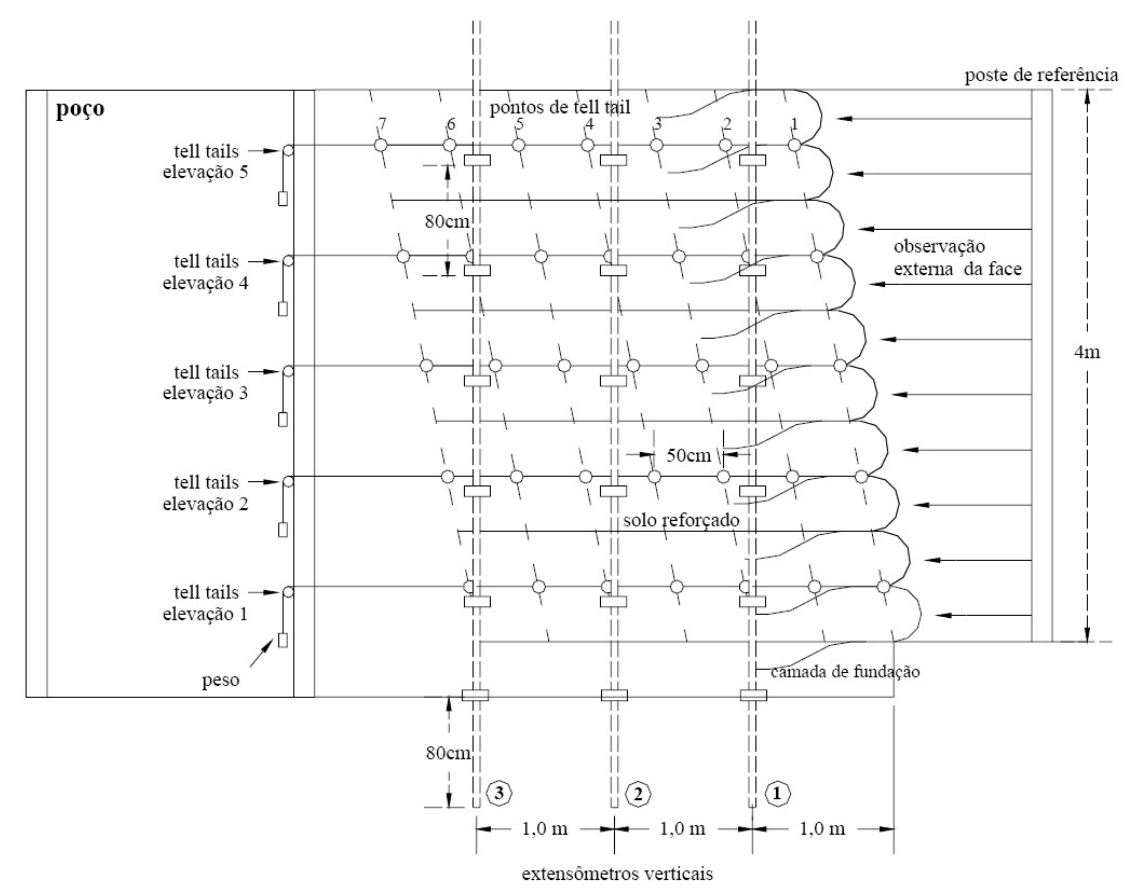

Figura 2.14 - Instrumentação dos protótipos (BENJAMIM, 2006).

Segundo Benjamim (2006), os protótipos 5 e 6, construídos com solo argilo-siltoso, foram os que apresentaram melhores resultados entre todos os construídos. Segundo o autor, estes muros foram os que obtiveram as mais baixas movimentações dos maciços reforçados.

Os resultados mostram que as deformações no protótipo 6 foram muito pequenas, não ultrapassando $0,2 \%$ em toda a estrutura, constituindo-se na melhor combinação solo-reforço entre todos os protótipos construídos. De acordo com o autor, diversos fatores contribuíram para isso, incluindo a alta rigidez do reforço, a natureza laterítica do solo, fornecendo uma alta resistência para o solo compactado, e também a baixa permeabilidade desse solo. $O$ protótipo 5 apresentou um comportamento bem parecido com o protótipo 6, para as três camadas inferiores, não ultrapassando $0,2 \%$ em todas as camadas. Entretanto, as duas camadas superiores apresentaram deformações mais altas, atingindo 0,8\% na cota 2,8 $\mathrm{m}$, e $1,2 \%$ na cota $3,6 \mathrm{~m}$. As Figuras mostradas na sequência ilustram os resultados obtidos nas instrumentações dos protótipos 5 e 6 . A Figura 2.15 mostra as superfícies potenciais de ruptura, a Figura 2.16 mostra os deslocamentos horizontais registrados nas faces dos protótipos e a Figura 2.17 mostra os deslocamentos verticais obtidos por meio dos extensômetros magnéticos verticais. 


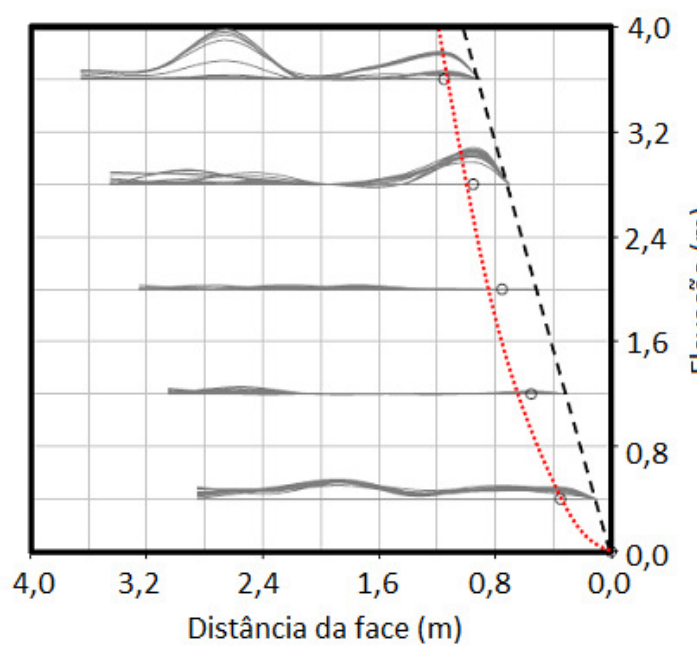

a)

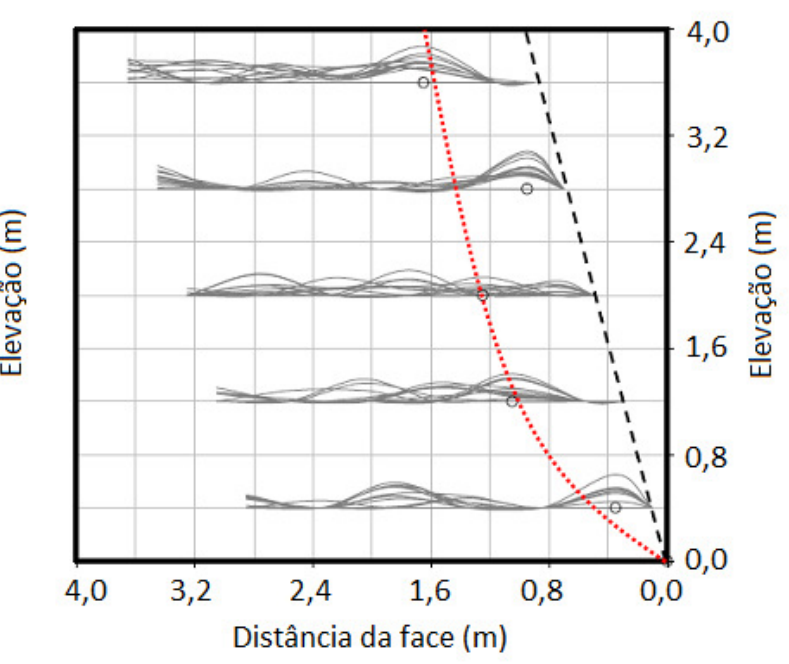

b)

Figura 2.15 - Superfícies potenciais de ruptura: a) Protótipo 5; b) Protótipo 6 (BENJAMIM, 2006).

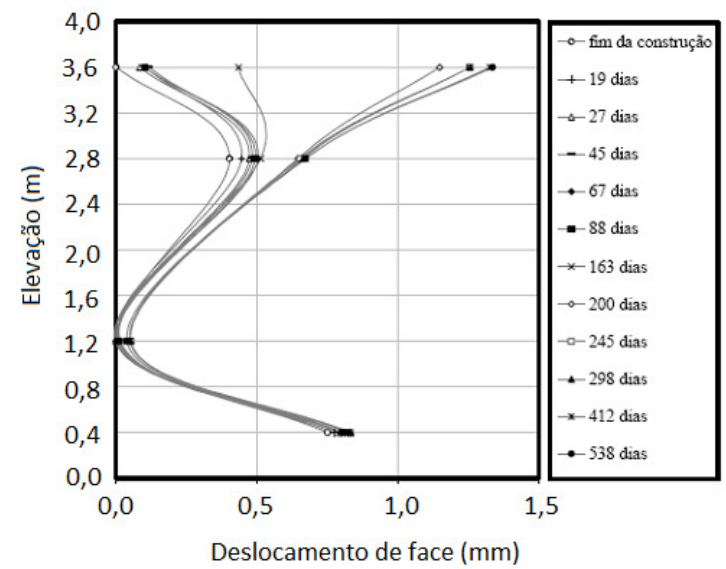

a)

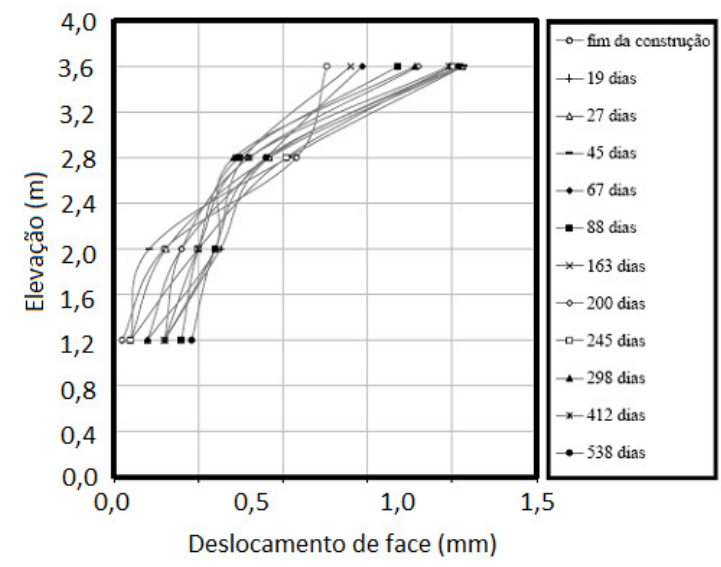

b)

Figura 2.16 - Deslocamentos horizontais nas faces dos protótipos: a) Protótipo 5; b) Protótipo 6 (BENJAMIM, 2006). 


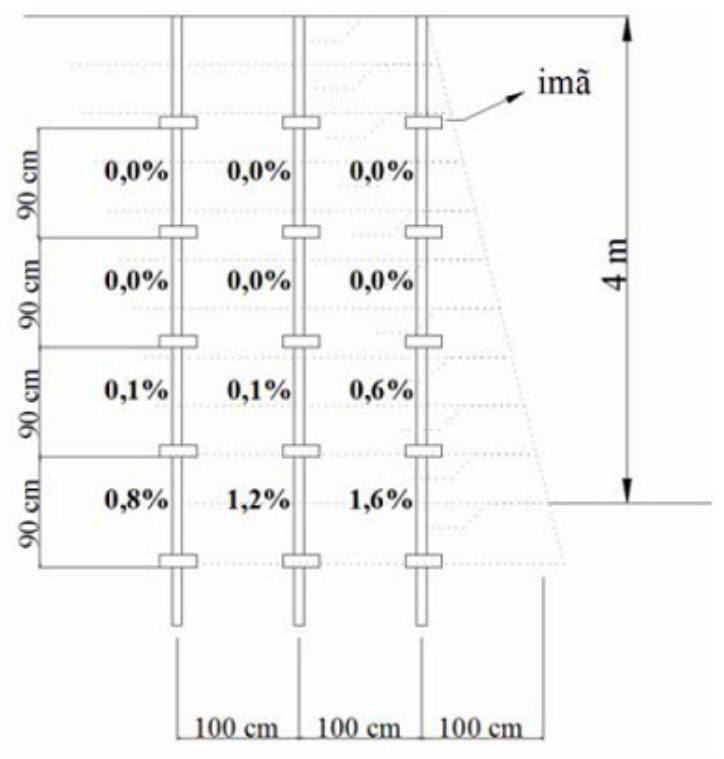

a)

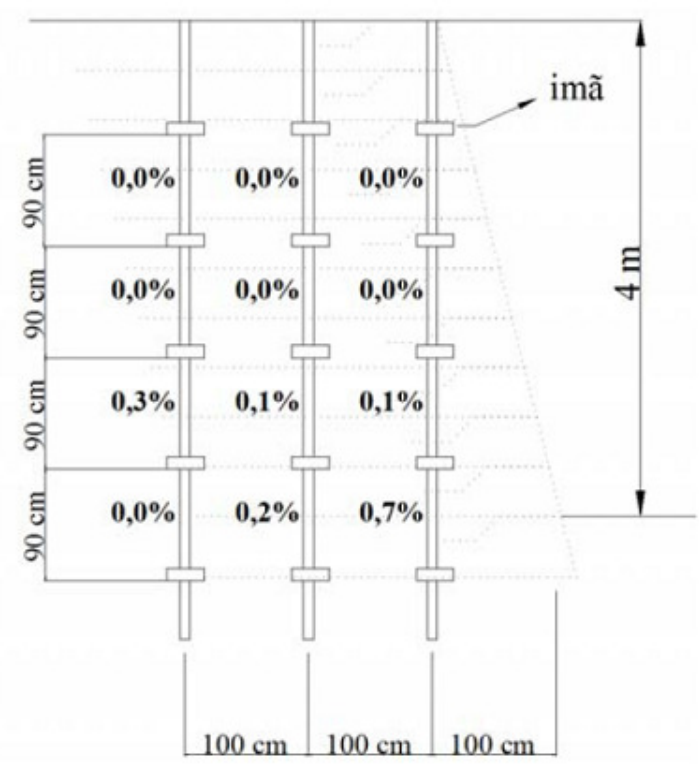

b)

Figura 2.17 - Deformações verticais registradas para: a) Protótipo 5; b) Protótipo 6 (BENJAMIM, 2006).

\subsubsection{Muro instrumentado por Riccio Filho (2007)}

Outra importante contribuição para o entendimento do comportamento geotécnico de muros de solo reforçado, utilizando como material de aterro solos finos tropicais, foi realizada por Riccio Filho (2007).

$O$ autor efetuou um estudo em uma estrutura real de solo reforçado, localizada numa via de ligação entre as rodovias Presidente Dutra e Carvalho Pinto (SP-070). A obra em questão constitui-se de um muro de solo residual com finos, reforçado com geogrelhas, que contém parte do aterro situado no local onde a via foi construída. O autor instrumentou tal estrutura, a qual se encontra sob condições reais de campo, com o intuito de avaliar os aspectos que, em maior ou menor grau, exercem influência nas tensões e deformações nesse tipo de obra.

Neste estudo foram monitorados os esforços atuantes na face, as tensões verticais próximas à fundação, a tração e as deformações nos reforços. Movimentos verticais e horizontais do corpo do aterro reforçado foram também acompanhados, bem como o deslocamento horizontal externo da face. 
A Figura 2.18 apresenta um esquema geral da seção instrumentada, com as dimensões da obra em estudo, bem como a legenda referente aos instrumentos empregados.

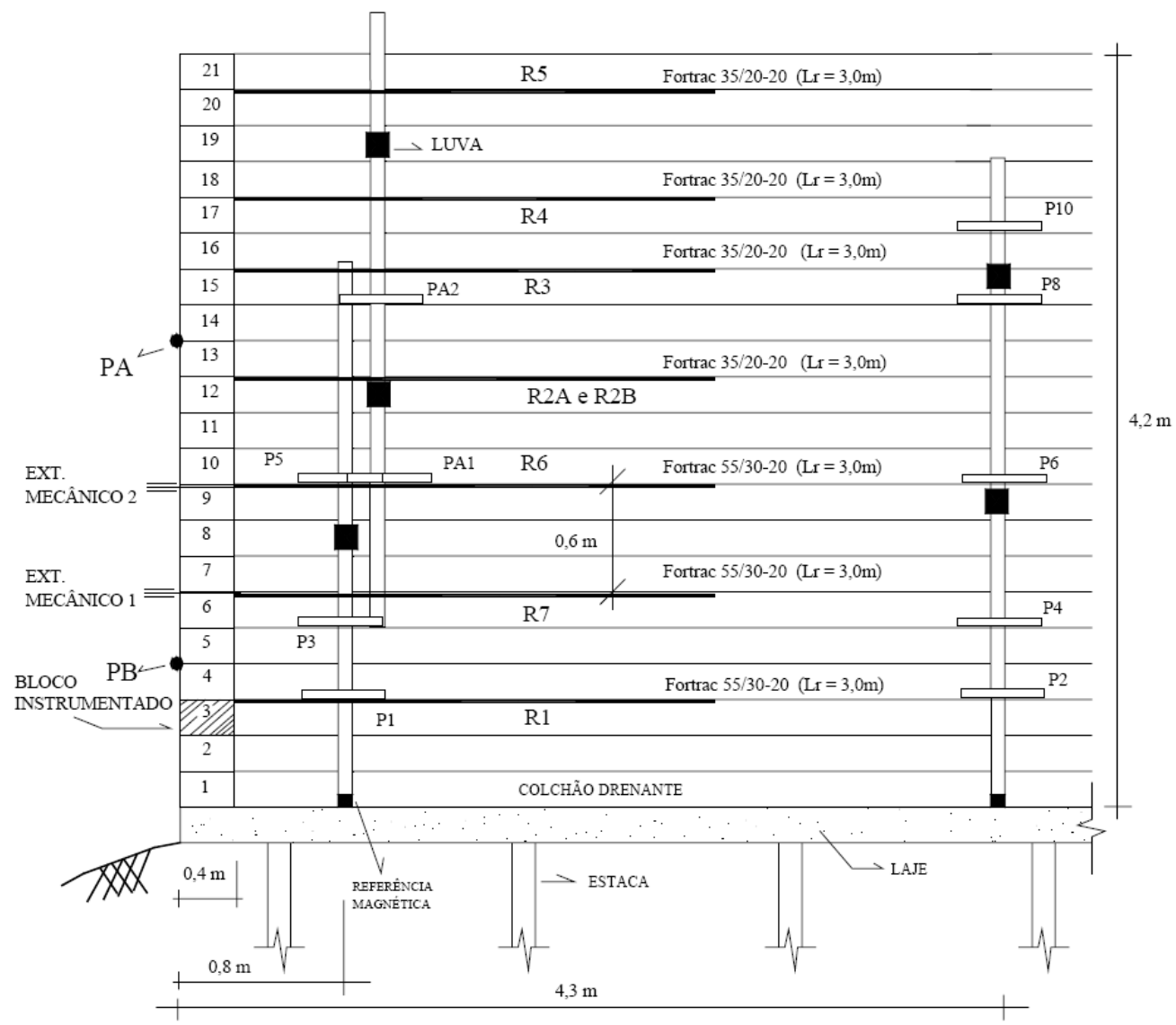

Figura 2.18 - Perfil esquemático da seção construída e instrumentada por Riccio Filho (2007).

Observa-se que o muro instrumentado possui 4,20m de altura, e é reforçado com geogrelhas com $3 \mathrm{~m}$ de comprimento, espaçada verticalmente a cada 0,6 m. Neste muro foram empregadas geogrelhas biaxiais com resistências nominais de $55 \mathrm{kN} / \mathrm{m}$ e $35 \mathrm{kN} / \mathrm{m}$, sendo a geogrelha mais resistente posicionada na porção inferior da estrutura de contenção.

No perfil esquemático mostrado na Figura 2.18, PA e PB representam os marcos topográficos, P1 a P10 representam as placas magnéticas de recalque, PA1 e PA2 representam as placas magnéticas auxiliares, $R 1$ a $R 4$ representam os reforços instrumentados e R5 a R7 representam os reforços não instrumentados. 
Como material de aterro da obra em questão, dois solos distintos foram empregados: argila arenosa amarela e argila arenosa vermelha. Conforme esquema apresentado na Figura 2.19, a argila arenosa vermelha foi empregada da camada número 2 até a camada número 5 e a argila arenosa amarela da camada número 6 até a camada número 21 (topo da estrutura).

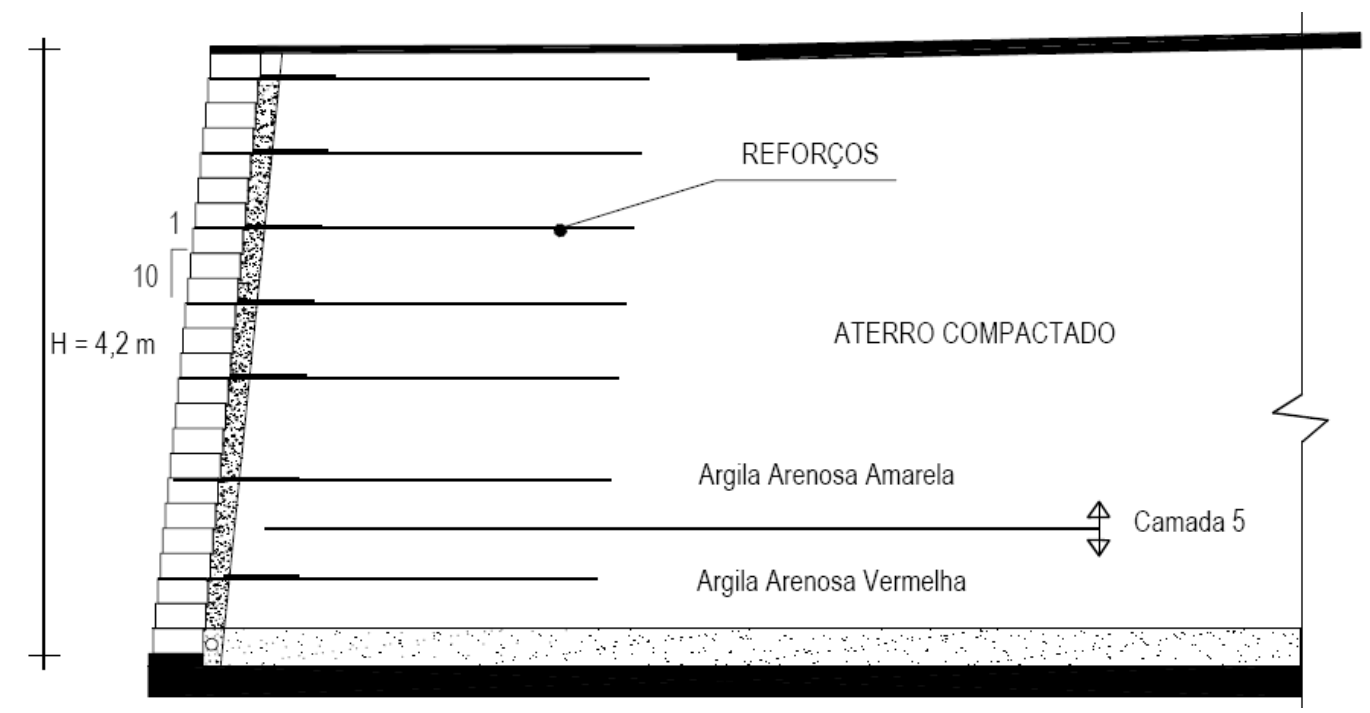

Figura 2.19 - Solos utilizados na composição do aterro reforçado com geogrelhas (RICCIO FILHO, 2007).

A Figura 2.20 apresenta as curvas granulométricas dos dois solos utilizados como materiais de aterro na obra em questão. Assim como destacado anteriormente, pode-se observar que se trata de um solo predominantemente argiloso, com elevada quantidade de material granular. Resultados dos ensaios de caracterização realizados pelo autor mostraram que os solos empregados para a construção do muro são altamente plásticos (Tabela 2.8).

Para a determinação dos parâmetros de resistência dos solos o autor realizou ensaios triaxiais de dois tipos distintos: ensaio com simetria axial $\left(\sigma_{1}>\sigma_{2}=\sigma_{3}\right)$ e ensaio no estado plano de deformação $\left(\sigma_{1} \neq \sigma_{2} \neq \sigma_{3}\right)$. Ambos os ensaios (triaxiais convencionais e de deformação plana) foram do tipo CW (ensaio com quantidade de água constante) com medida direta do valor da poro-pressão desenvolvida pelo solo na fase anterior ao adensamento, após o adensamento e durante o cisalhamento. Os corpos de prova foram adensados e drenados na umidade natural. Os resultados dos ensaios triaxiais são mostrados na Tabela 2.9. 


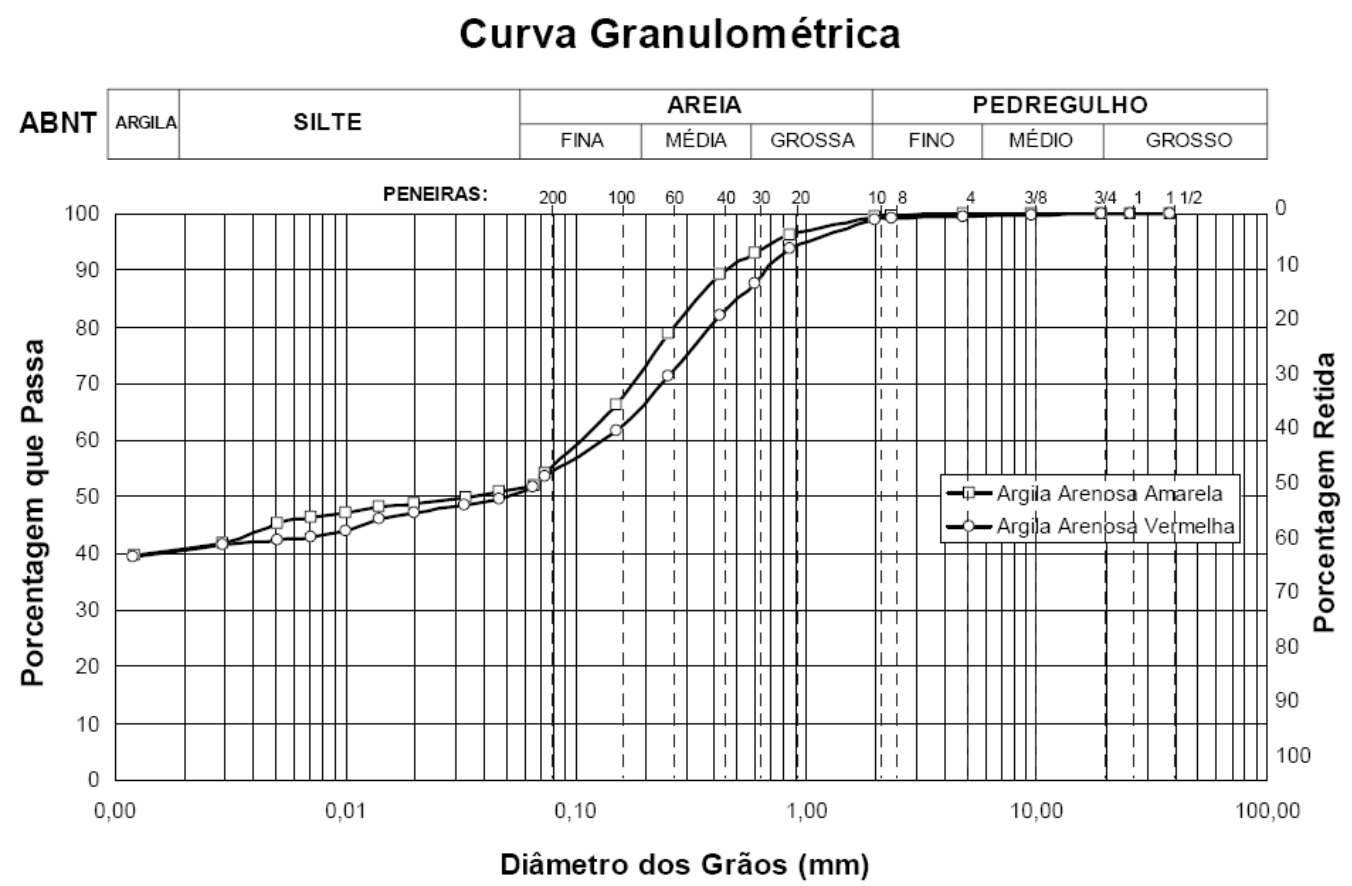

Figura 2.20 - Curva granulométrica dos solos utilizados como material de aterro (RICCIO FILHO, 2007).

Tabela 2.8 - Resultados dos ensaios de caracterização dos solos empregados no aterro (RICCIO FILHO, 2007).

\begin{tabular}{cccc}
\hline Solo & LL & LP & IP \\
\hline Argila Arenosa Vermelha & 48,5 & 20,1 & 28,4 \\
Argila Arenosa Amarela & 38,4 & 15,7 & 22,7 \\
\hline
\end{tabular}

Tabela 2.9 - Parâmetros de resistência ao cisalhamento dos solos empregados no aterro (RICCIO FILHO, 2007).

\begin{tabular}{ccccc}
\hline Solo & Cond. de Contorno & $\phi^{\prime}\left(^{\circ}\right)$ & $\mathrm{C}(\mathrm{kPa})$ & $\gamma_{\mathrm{h}}\left(\mathrm{kN} / \mathrm{m}^{3}\right)$ \\
\hline $\begin{array}{c}\text { Argila Arenosa } \\
\text { Vermelha }\end{array}$ & Def. plana & 38 & 50 & 19,95 \\
Argila Arenosa & Def. plana & 26 & 52 & 20,07 \\
Amarela & Axi-simétrica & 36 & 60 & 19,95 \\
\hline
\end{tabular}


A Tabela 2.10 apresenta os principais resultados dos ensaios de caracterização das geogrelhas empregadas na pesquisa.

Tabela 2.10 - Especificação técnica dos reforços utilizados no muro reforçado (RICCIO FILHO, 2007).

\begin{tabular}{|c|c|c|}
\hline Geogrelha & FORTRAC 35/20-20 & FORTRAC 55/30-20 \\
\hline Matéria prima principal & \multicolumn{2}{|c|}{$\begin{array}{l}\text { Filamento de Poliéster de alta tenacidade e baixa } \\
\text { fluência. }\end{array}$} \\
\hline Abertura de malha: & $20 \mathrm{~mm}$ & $20 \mathrm{~mm}$ \\
\hline Resistência à tração & (ABNT 12.824) & (ABNT 12.824) \\
\hline Longitudinal: & $\geq 35 \mathrm{KN} / \mathrm{m}$ & $\geq 55 \mathrm{KN} / \mathrm{m}$ \\
\hline $\begin{array}{l}\text { Transversal: } \\
\text { Módulo de rigidez } \\
\text { (ABNT 12.824) }\end{array}$ & $\geq 20 \mathrm{KN} / \mathrm{m}$ & $\geq 30 \mathrm{KN} / \mathrm{m}$ \\
\hline $\begin{array}{l}\text { Direção Longitudinal: } \\
\text { a 5\% de deformação }\end{array}$ & $\geq 260 \mathrm{KN} / \mathrm{m}$ & $\geq 400 \mathrm{KN} / \mathrm{m}$ \\
\hline $\begin{array}{l}\text { Deformação máxima na } \\
\text { resistência nominal (ABNT } \\
12.824)\end{array}$ & $\leq 12 \%$ & $\leq 12 \%$ \\
\hline \multicolumn{3}{|l|}{ Direção Longitudinal: } \\
\hline $\begin{array}{l}\text { Carga de ruptura por fluência } \\
\qquad\left(120 \text { anos, } \leq 30^{\circ} \mathrm{C}\right) \text { : }\end{array}$ & $\geq 21 \mathrm{KN} / \mathrm{m}$ & $\geq 33 \mathrm{KN} / \mathrm{m}$ \\
\hline $\begin{array}{l}\text { Carga de ruptura por fluência } \\
\qquad\left(2 \text { anos, } \leq 30^{\circ} \mathrm{C}\right) \text { : }\end{array}$ & $\geq 24 \mathrm{KN} / \mathrm{m}$ & $\geq 38 \mathrm{KN} / \mathrm{m}$ \\
\hline $\begin{array}{l}\text { Deformação por fluência } \\
\text { após } 2 \text { anos de } \\
\text { carregamento a } 50 \% \text { da } \\
\text { carga de ruptura: }\end{array}$ & $\leq 1 \%$ & $\leq 1 \%$ \\
\hline
\end{tabular}

A estrutura avaliada por Riccio Filho (2007) foi instrumentada por meio da utilização de medidores de carga nos reforços, células de tensão total, bloco instrumentado para medição de carga na face, medidores de deslocamentos verticais, inclinômetros, tensiômetros, extensômetros mecânicos, transdutores de temperatura e marcos topográficos de face.

Segundo o autor, a estrutura avaliada apresentou bom desempenho. As trações nos reforços apresentaram magnitude de $10 \%$ a $20 \%$ da tensão nominal máxima 
resistida pelas inclusões, sendo as deformações situadas entre 1,6\% e 2,7\% (Figura

\subsection{1 e Figura 2.22).}

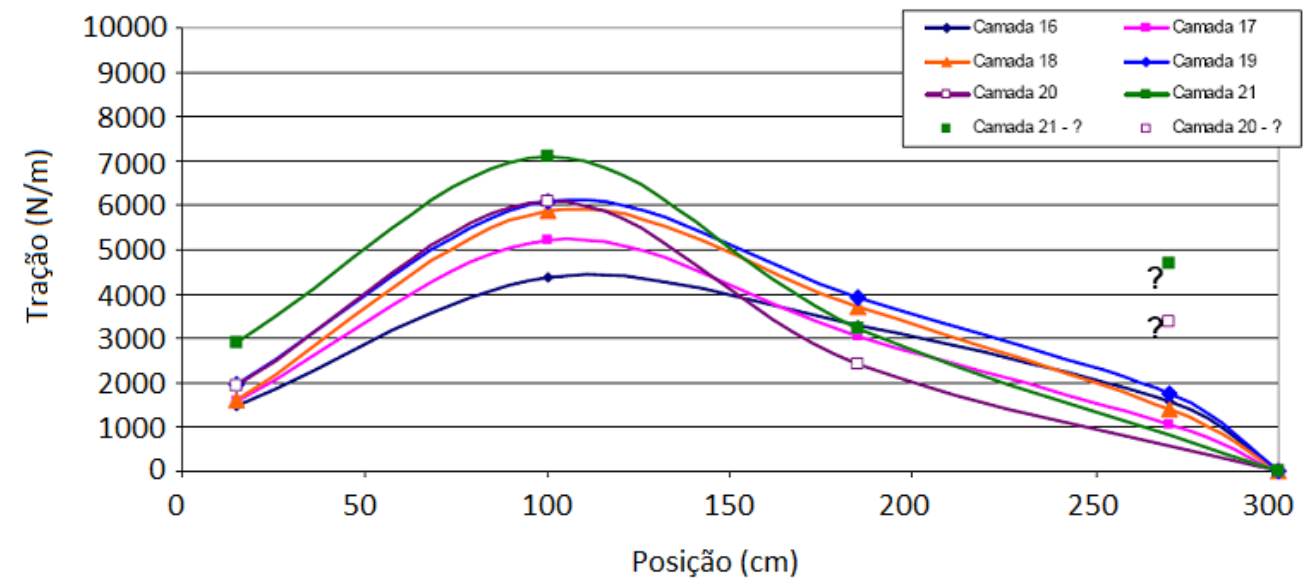

Figura 2.21 - Distribuição dos esforços de tração ao longo do reforço R3 (RICCIO FILHO, 2007).

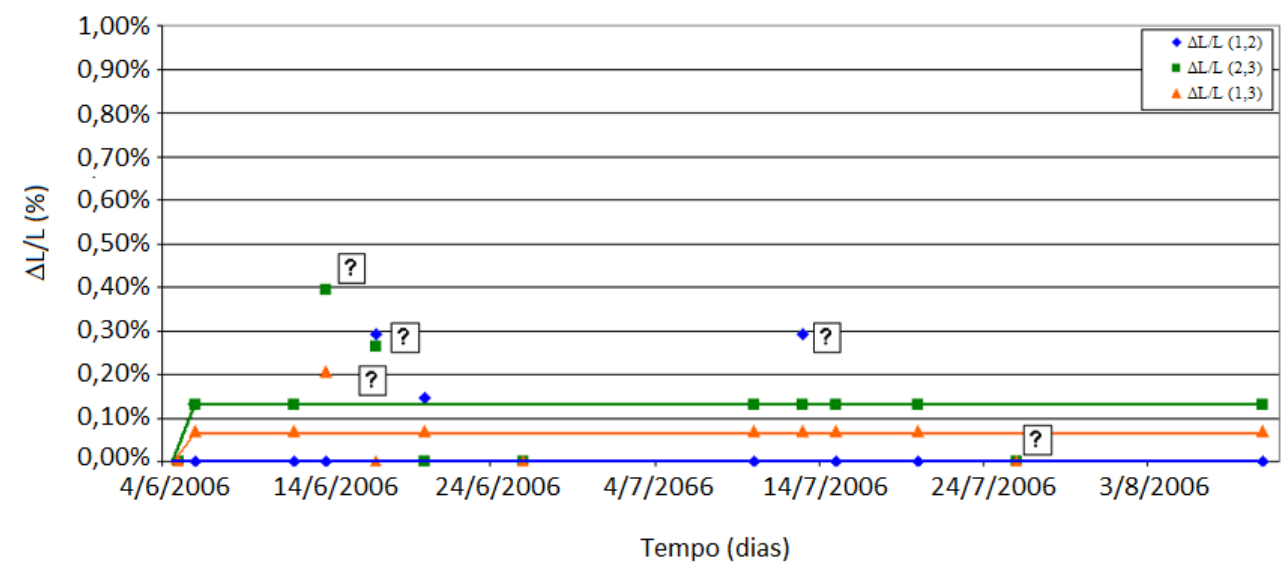

Figura 2.22 - Deformação específica do reforço da camada número 6 (RICCIO FILHO, 2007).

Conforme pode ser observado na Figura 2.23, os deslocamentos verticais máximos observados nos inclinômetros foram da ordem de $60 \mathrm{~mm}$, o que representa uma deformação de aproximadamente $1,4 \%$ da altura do muro. Este valor está dentro do esperado para estruturas deste tipo. 


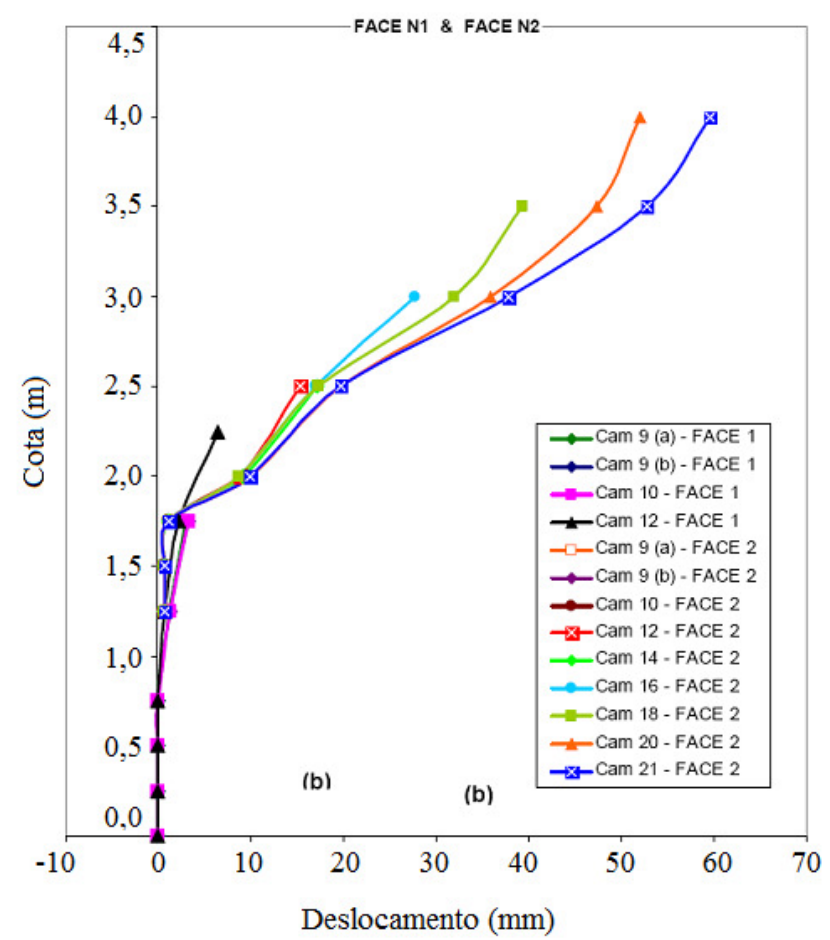

Figura 2.23 - Deslocamentos horizontais nos inclinômetros de face (RICCIO FILHO, 2007).

Já na Figura 2.24, observa-se que os deslocamentos horizontais medidos na face do muro ao término da construção, foram de aproximadamente $22 \mathrm{~mm}$. Este deslocamento corresponde a uma deformação da ordem de $0,5 \%$, que pode ser considerado um valor baixo para obras de solo reforçado com geossintéticos.

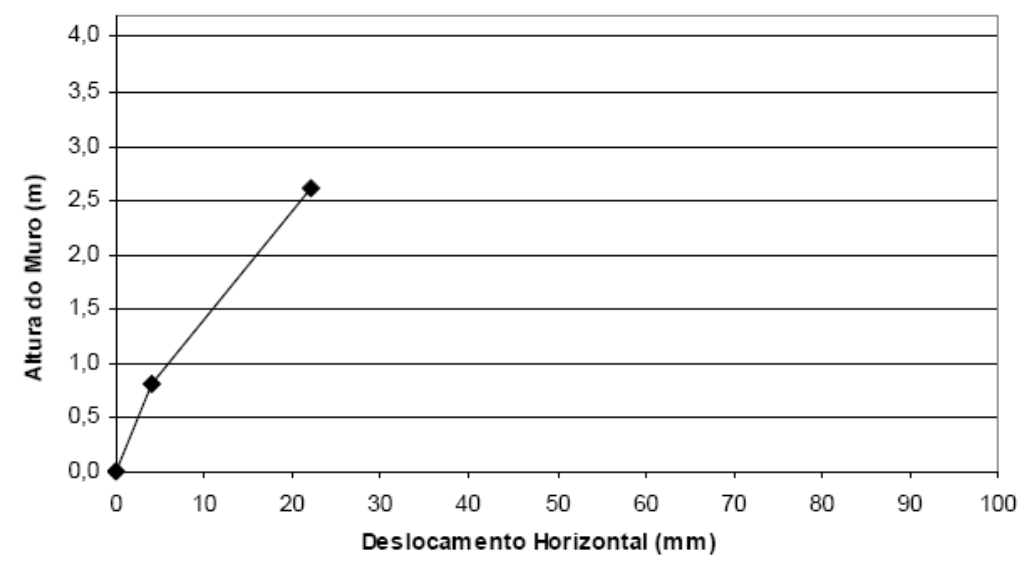

Figura 2.24 - Deslocamentos horizontais na face do muro ao final da construção (RICCIO FILHO, 2007). 


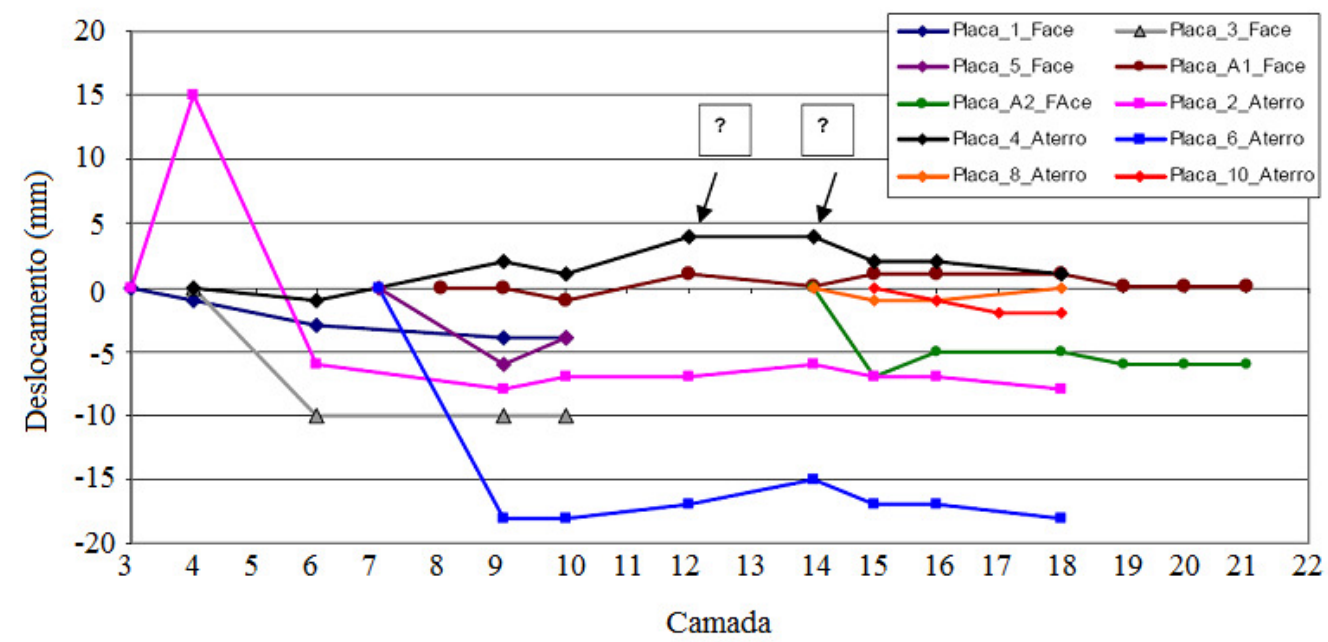

Figura 2.25 - Deslocamentos verticais medidos pelas placas magnéticas localizadas próximas à face do muro (RICCIO FILHO, 2007).

\subsubsection{Protótipos e muro instrumentados por Portelinha (2012)}

Seguindo a mesma linha de pesquisas em solos reforçados com geossintéticos utilizando solos tropicais como material de aterro, Portelinha (2012) apresentou uma importante contribuição.

O autor avaliou experimentalmente a influência do avanço da frente de umedecimento no comportamento de protótipos de muros de solos finos reforçados com geotêxteis não tecidos. Adicionalmente, o autor acompanhou o desempenho de uma estrutura real construída em campo, comparando o comportamento de duas seções distintas que utilizaram como reforço geotêxtil tecido e geotêxtil não tecido. A análise experimental realizada pelo autor constituiu na construção, em laboratório, de quatro protótipos de solo reforçado. Para tanto, foi utilizada uma caixa metálica desenvolvida especificamente para este fim. A caixa metálica empregada na construção dos protótipos é mostrada na Figura 2.26. As características dos protótipos executados são apresentadas na Tabela 2.11. 

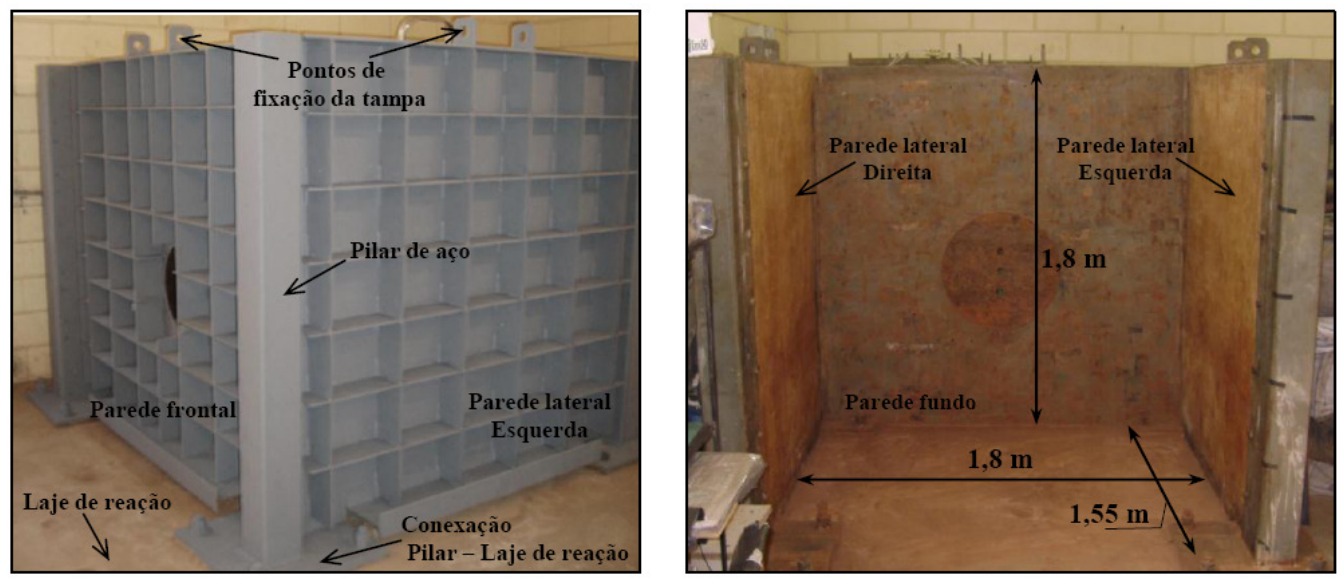

Figura 2.26 - Caixa metálica de ensaios de grande porte (PORTELINHA, 2012).

Tabela 2.11 - Características dos protótipos construídos (PORTELINHA, 2012).

\begin{tabular}{ccccccc}
\hline Protótipo & Designação & Solo & Reforço & $\begin{array}{c}\text { Esp. } \\
\text { vertical }\end{array}$ & $\begin{array}{c}\text { Comp. do } \\
\text { reforço }\end{array}$ & Face \\
\hline Muro 1 & M1 & & NT-PET & & & Argamassa \\
Muro 2 & M2 & Areia & NT-PET & & Argamassa \\
Muro 3 & M3 & argilosa & NT-PET & $30 \mathrm{~cm}$ & $150 \mathrm{~cm}$ & $\begin{array}{c}\text { Argamassa } \\
\text { Muro 4 }\end{array}$ \\
\hline
\end{tabular}

Conforme mostrado na Tabela 2.11 foram utilizados dois tipos de faces. Um deles em argamassa, e outro em geotêxtil exposto (envelopado). A geometria dos protótipos construídos por Portelinha (2012) são mostrados na Figura 2.27.

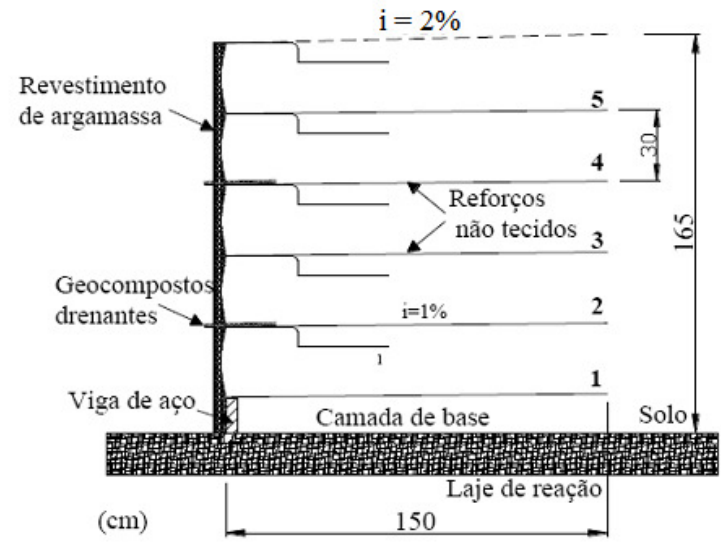

(a)

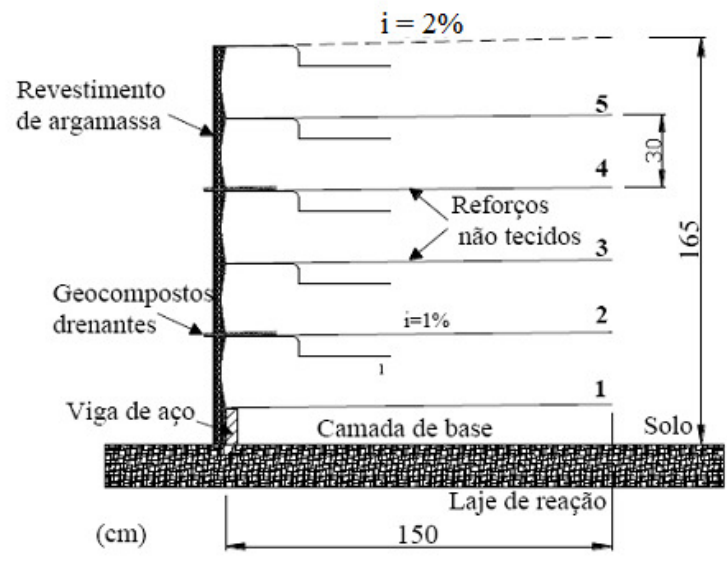

(b)

Figura 2.27 - Seções típicas dos protótipos construídos por Portelinha (2012): a) Face em argamassa; b) Face envelopada. 
Segundo Portelinha (2012), o solo utilizado na construção dos protótipos consiste num material típico do interior do Estado de São Paulo, coletado no Campus II da Universidade de São Paulo, cidade de São Carlos - SP. Esse é um solo laterítico cuja origem geológica é sedimentar cenozoica, produto do retrabalhamento dos materiais do Grupo Bauru e das Formações Serra Geral e Botucatu, através de transporte em meio aquoso, e depositado em formas de aluviões e coluviões (BJORNBERG, 1965), posteriormente laterizados. A curva granulométrica deste solo é apresentada na Figura 2.28.

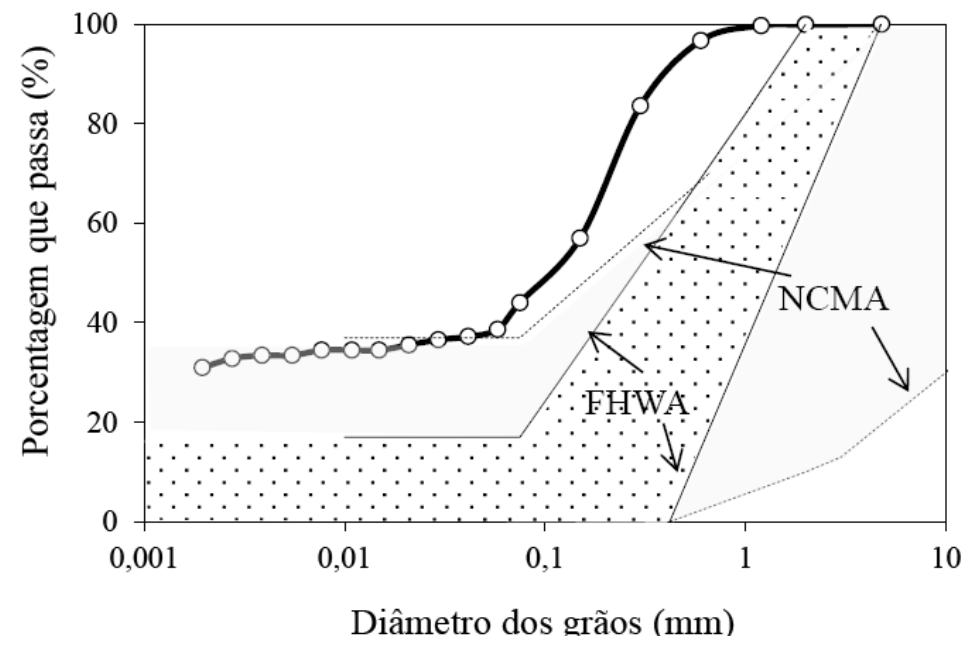

Figura 2.28 - Curva de distribuição granulométrica do solo (PORTELINHA, 2012).

Observa-se que se trata de uma areia argilosa, sendo a composição deste solo a seguinte: $56 \%$ a fração areia, $12 \%$ a fração silte e $32 \%$ a fração argila, classificado como SC segundo a classificação unificada.

Os parâmetros de resistência do solo empregado, obtidos por meio de ensaios triaxiais realizados pelo autor são apresentados na Tabela 2.12.

Tabela 2.12 - Parâmetros de resistência do solo empregado nos protótipos (PORTELINHA, 2012).

\begin{tabular}{ccccccc}
\hline Corpo de Prova & \multicolumn{3}{c}{ Triaxiais } & \multicolumn{2}{c}{$\begin{array}{c}\text { Cisalhamento } \\
\text { direto }\end{array}$} \\
\cline { 2 - 6 } & \multicolumn{3}{c}{$\mathrm{CD}$} & \multicolumn{2}{c}{$\mathrm{CU}$} & \\
\cline { 2 - 6 } & $\mathrm{c}^{\prime}(\mathrm{kPa})$ & $\phi^{\prime}\left({ }^{\circ}\right)$ & $\mathrm{c}^{\prime}(\mathrm{kPa})$ & $\phi^{\prime}\left({ }^{\circ}\right)$ & $\mathrm{c}^{\prime}(\mathrm{kPa})$ & $\phi^{\prime}\left({ }^{\circ}\right)$ \\
\hline Saturado (inundado) & 32 & 15 & 25 & 30 & 29 & 18 \\
Umidade inicial & 32 & 27 & 24,5 & 65 & 32 & 32 \\
\hline
\end{tabular}


Conforme salientado no início deste item, na pesquisa desenvolvida por Portelinha (2012) foram utilizados geotêxteis não tecidos. O autor utilizou dois tipos de geotêxteis não tecido: poliéster (PET) e polipropileno (PP). A Tabela 2.13 mostrada a seguir apresenta os principais resultados dos ensaios de caracterização dos geotêxteis empregados na pesquisa.

Tabela 2.13 - Propriedades características dos geotêxteis empregados na pesquisa (PORTELINHA, 2012).

\begin{tabular}{ccccc}
\hline \multirow{2}{*}{ Propriedade } & \multirow{2}{*}{ Unidade } & \multirow{2}{*}{ Norma } & \multicolumn{2}{c}{ Geotêxtil } \\
& & & NT-PET & NT-PP \\
\hline Gramatura & $\left(\mathrm{g} / \mathrm{m}^{2}\right)$ & ABNT NBR12568 & 300 & 600 \\
Espessura nominal & $(\mathrm{mm})$ & ABNT NBR12569 & 2,69 & 4,85 \\
Permissividade & $\left(\mathrm{s}^{-1}\right)$ & ASTM D 4491 & 1,96 & 0,43 \\
Abertura de filtração & $(\mu \mathrm{m})$ & AFNOR G 38017 & 93 & 71 \\
\hline
\end{tabular}

Para o registro do comportamento dos protótipos, os muros foram instrumentados com sensores de umidade, tensiômetros elétricos e mecânicos, células de tensão total, LVDT's, relógios comparadores e tell-tales. A Figura 2.29 a seguir mostra uma seção típica contendo os detalhes da instrumentação utilizada.

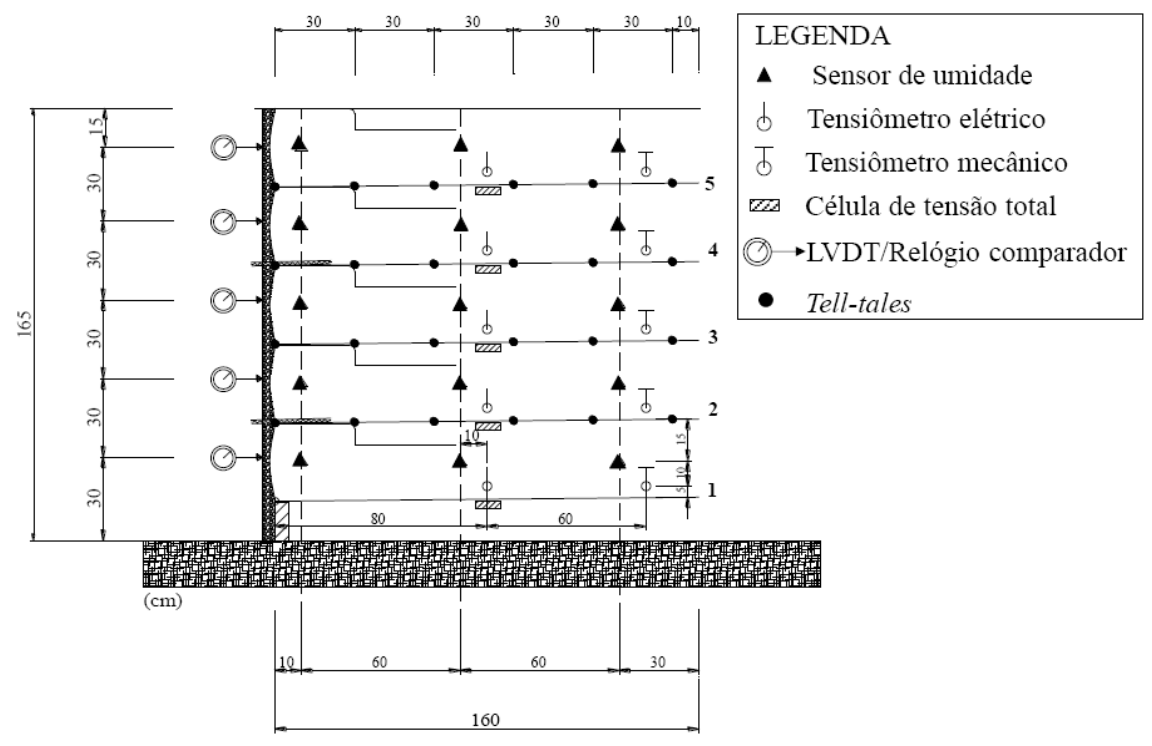

Figura 2.29 - Localização típica da instrumentação utilizada nos protótipos (PORTELINHA, 2012). 
Alguns dos resultados obtidos pelo autor são apresentados nas Figuras 2.30 a 2.32. A Figura 2.30 mostra a distribuição dos deslocamentos de face ao longo da altura do protótipo M1, a Figura 2.31 mostra a distribuição das deformações ao longo do comprimento dos reforços de geotêxteis do protótipo M1, e a Figura 2.32 exibe a distribuição das forças medidas e teóricas nos reforços dos protótipos M2.

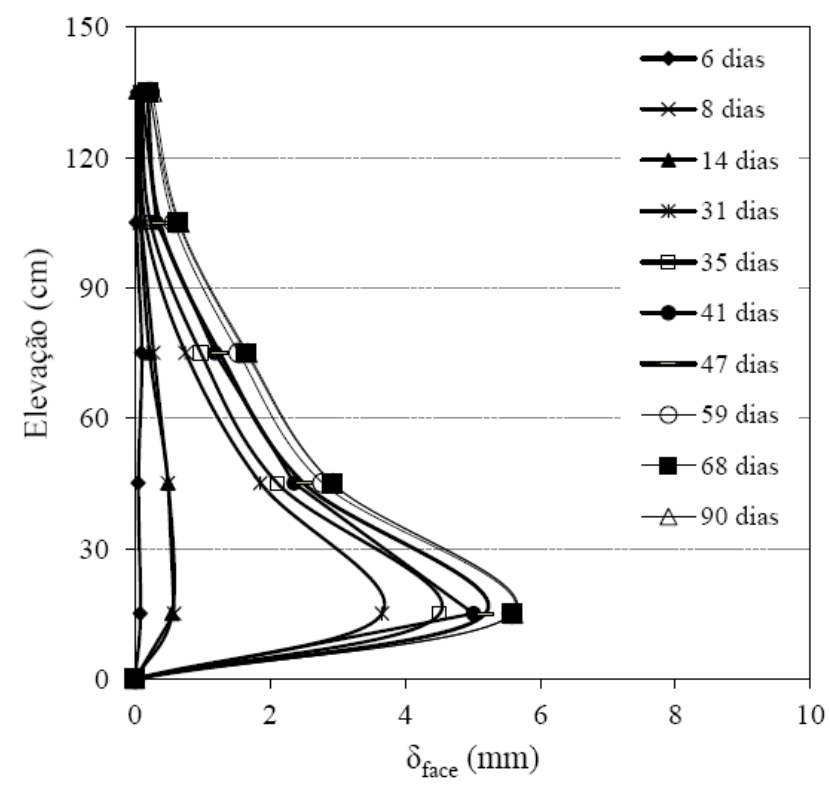

Figura 2.30 - Distribuição dos deslocamentos de face ao longo da altura do protótipo M1 (PORTELINHA, 2012). 
a)

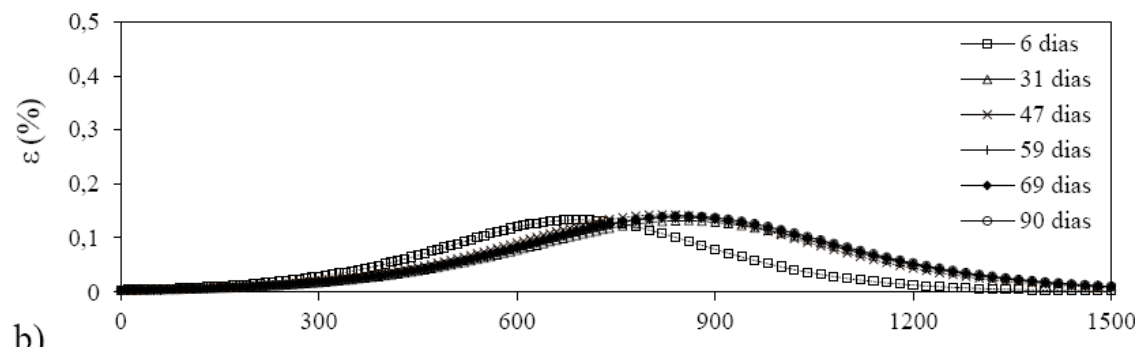

b) Distância da face (mm)

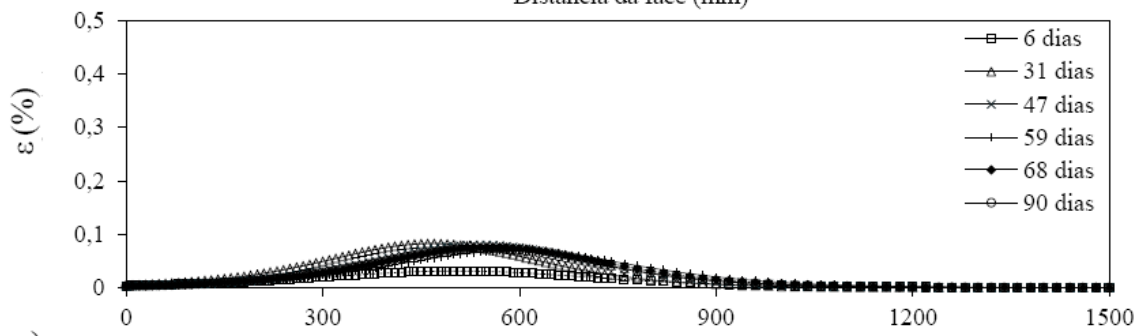

c)

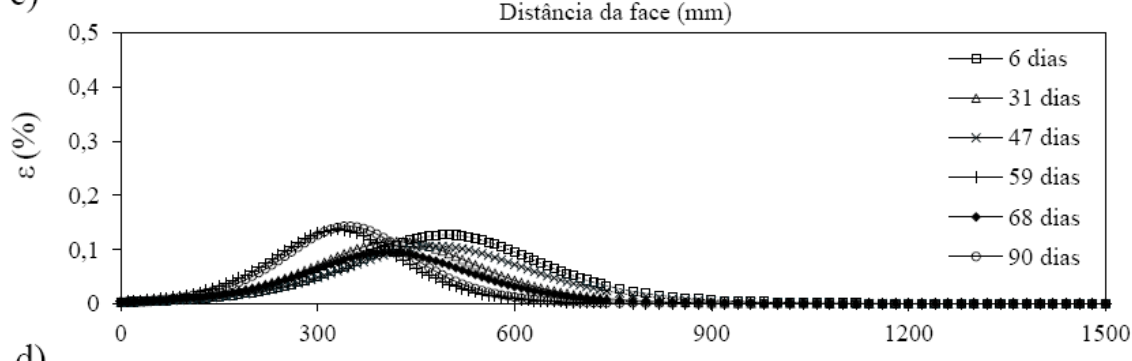

d)

Distância da face (mm)

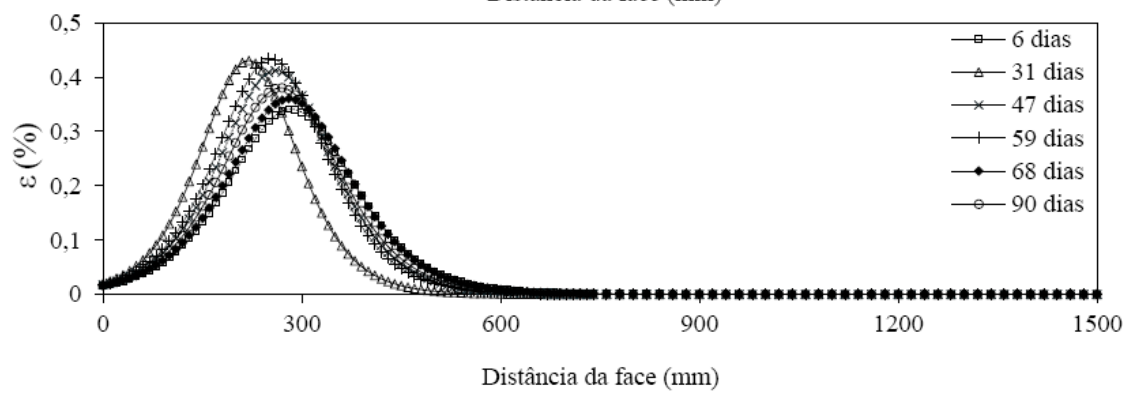

Figura 2.31 - Distribuição das deformações ao longo do comprimento dos reforços de geotêxteis do protótipo M1: (a) camada 5; (b) camada 4; (c) camada 3; (d) camada 2 (PORTELINHA, 2012). 

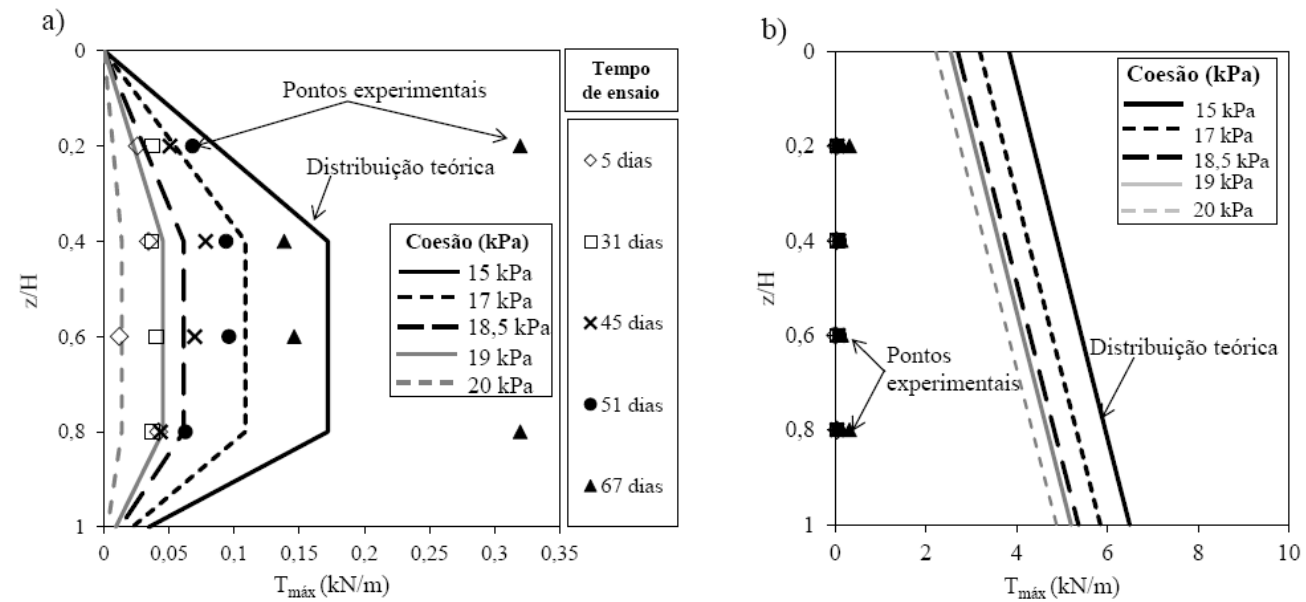

Figura 2.32 - Distribuição das forças medidas e teóricas nos reforços dos protótipos M2 (PORTELINHA, 2012).

Conforme mencionado anteriormente, Portelinha (2012) realizou uma análise complementar aos protótipos executados em laboratório, na qual acompanhou o desempenho de uma estrutura real construída em campo, comparando o comportamento de duas seções distintas que utilizaram como reforço geotêxteis tecidos e geotêxteis não tecidos.

A estrutura instrumentada pelo autor consiste em um muro de solo reforçado com geotêxteis com a função de contenção de um aterro construído para nivelar a área de implantação do conjunto habitacional Bairro Novo, na cidade de Campinas - SP. O sistema de contenção é composto por muros íngremes de solo reforçado $(1 \mathrm{H}$ : $10 \mathrm{~V}$ ) com altura de até 9 metros, construído com solo local fino. Um aterro compactado não reforçado de 3,4 metros de altura foi construído no topo desta estrutura. O muro de solo reforçado foi projetado com reforços de geotêxteis tecidos, incluindo uma seção experimental construída com geotêxteis não tecidos. As seções foram construídas com altura de 5,6 metros, e instrumentadas para comparações dos deslocamentos internos e deformações nos reforços. O geotêxtil não tecido utilizado possuía $40 \%$ da resistência à tração do geotêxtil tecido. Na Figura 2.33 é apresentada uma vista geral da estrutura instrumentada pelo autor. 


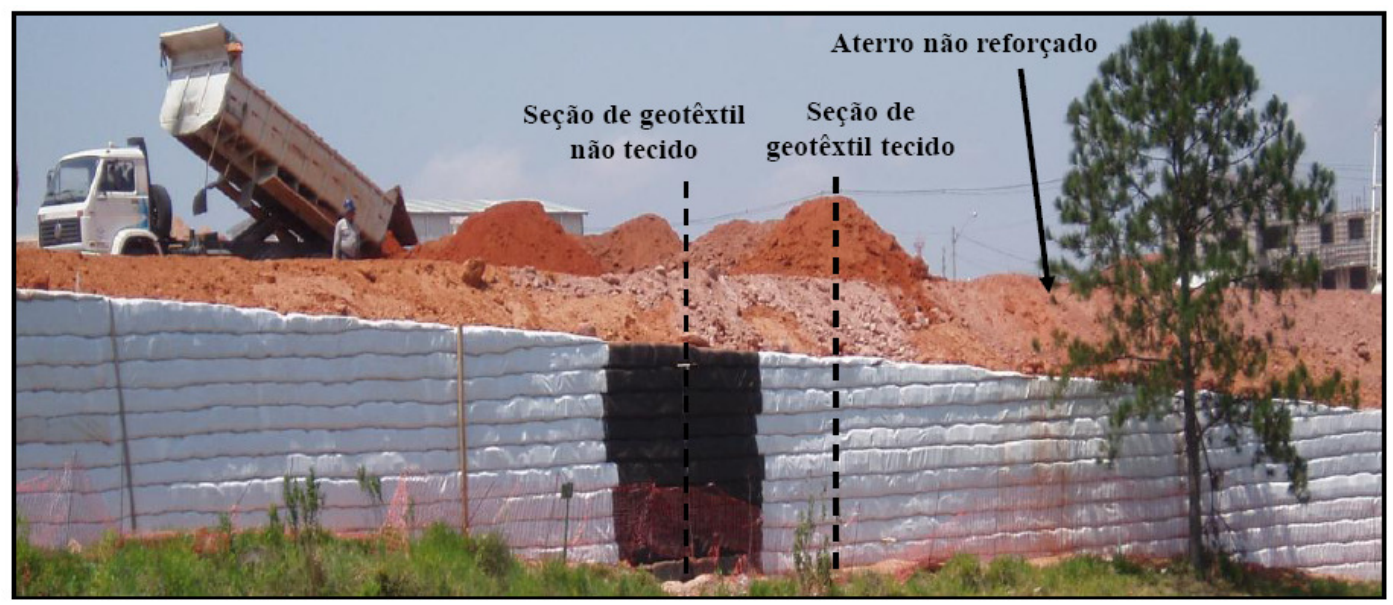

Figura 2.33 - Vista geral da estrutura instrumentada (PORTELINHA, 2012).

Uma seção típica contendo a geometria do muro, a geometria interna dos reforços empregados, bem como o posicionamento dos instrumentos para leitura de deslocamentos ao longo dos reforços (E01, E02 e E03) é apresentada na Figura 2.34 .

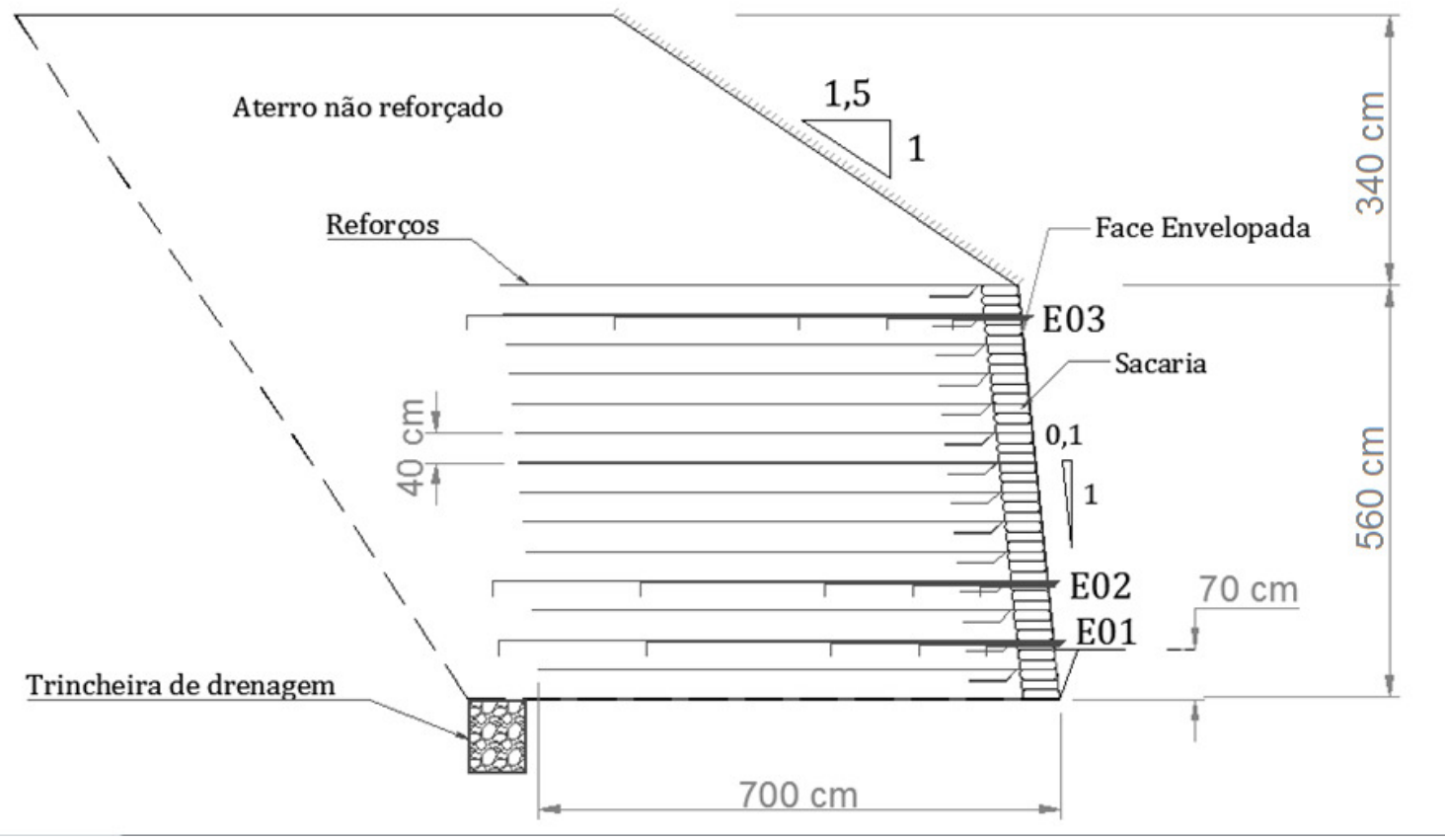

Figura 2.34 - Seção de projeto e instrumentação da obra (PORTELINHA, 2012).

Os resultados da instrumentação referentes ao monitoramento das deformações dos reforços são apresentados a seguir. A Figura 2.35 mostra a distribuição das 
deformações ao longo do comprimento dos reforços da seção de geotêxtil não tecido, enquanto a Figura 2.36 mostra a distribuição das deformações ao longo dos reforços da seção de geotêxtil tecido.

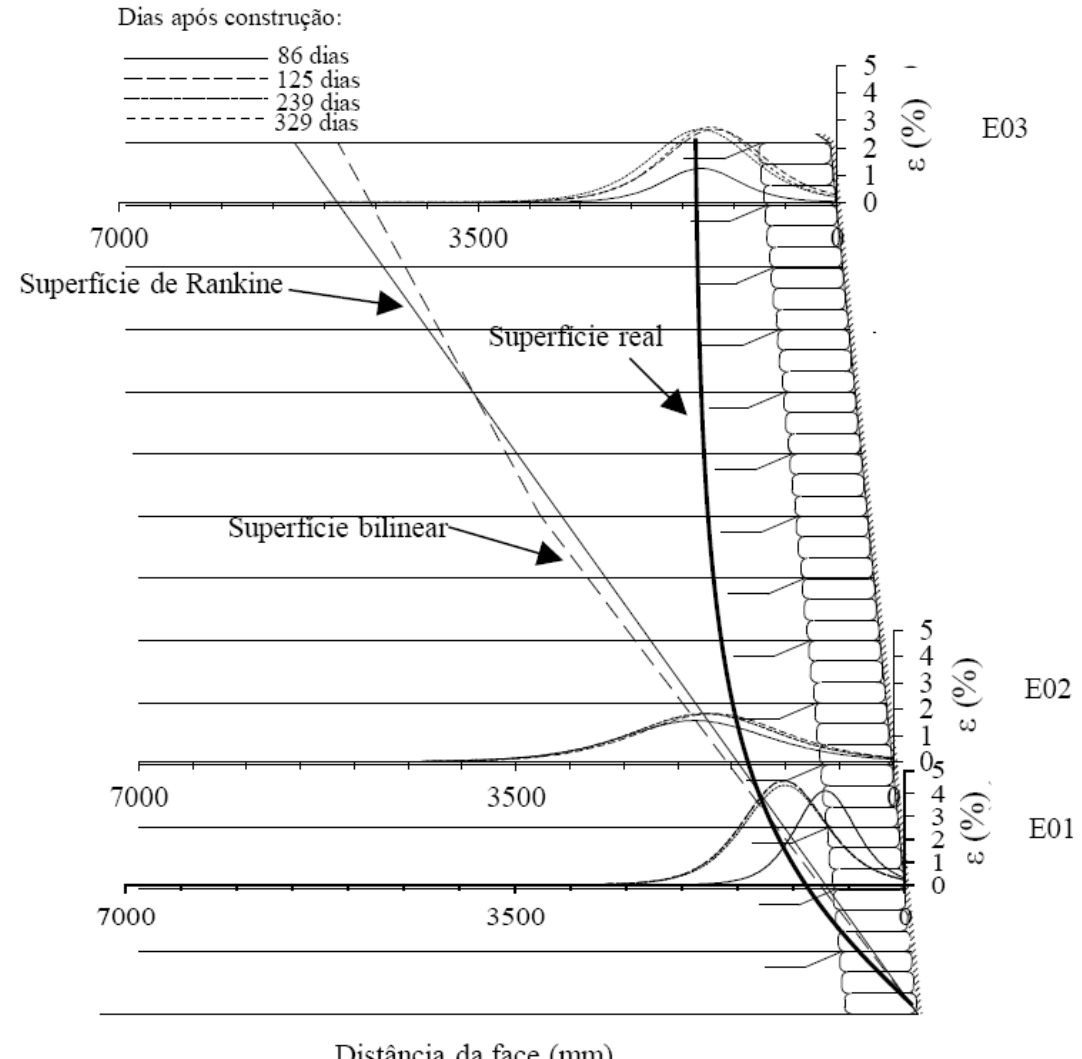

Figura 2.35 - Distribuição das deformações ao longo do comprimento dos reforços da seção de geotêxteis não tecidos (PORTELINHA, 2012). 


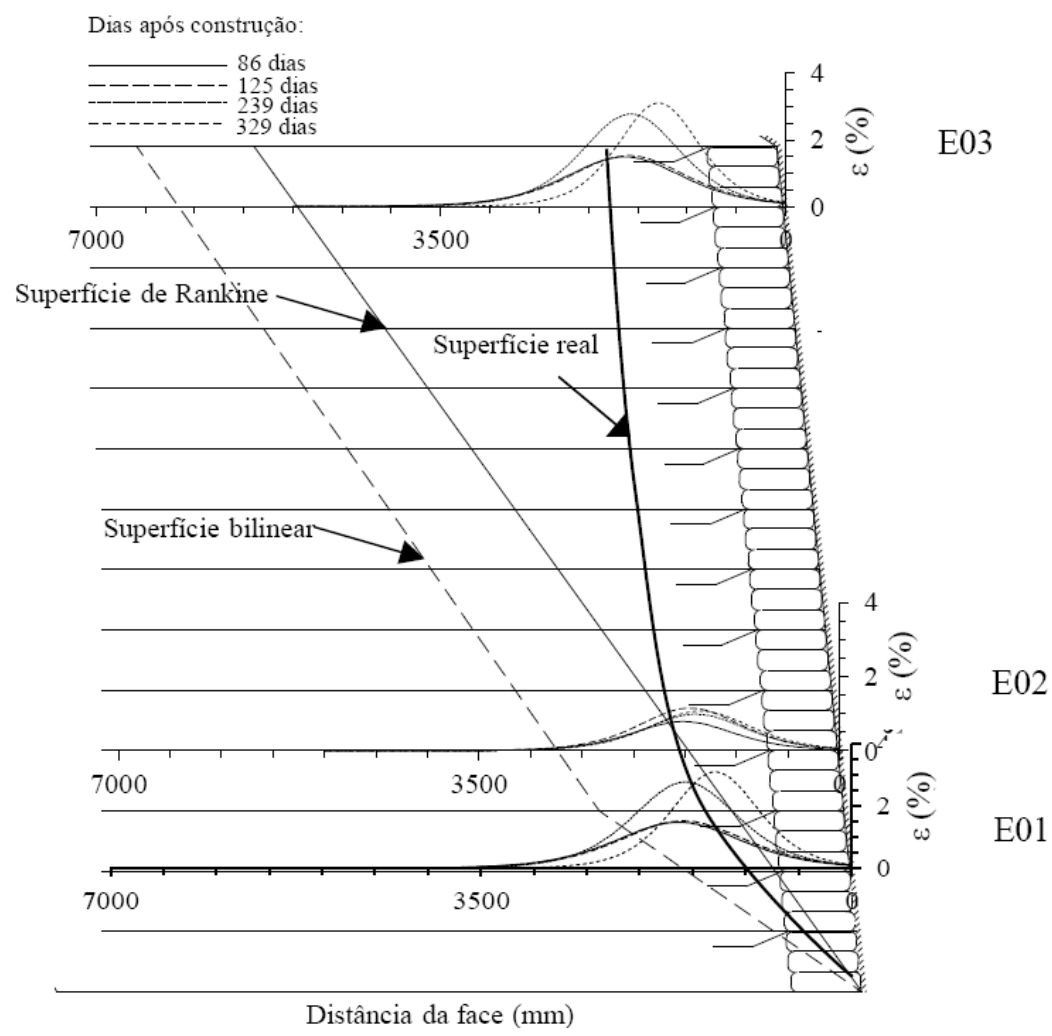

Figura 2.36 - Distribuição das deformações ao longo do comprimento dos reforços da seção de geotêxteis tecidos (PORTELINHA, 2012).

Portelinha (2012) destaca que tanto a estrutura reforçada com geotêxteis tecidos quanto a estrutura reforçada com geotêxteis não tecidos apresentaram o mesmo nível de deformações nas camadas instrumentadas E02 e E03, muito embora a rigidez à tração do geotêxtil não tecido seja significativamente menor. No entanto, o autor observou que as deformações na base da estrutura foram menores para o reforço mais rígido (tecido). Portelinha (2012) observou que as localizações dos picos de deformações nas camadas instrumentadas geraram superfícies de ruptura semelhantes para ambas as seções.

Quanto aos níveis de deformações, os resultados mostraram que, para o caso do muro construído com reforços não tecidos, os maiores valores foram observados na linha de instrumentação situada mais próxima ao pé do muro (E01). Nesta linha de instrumentação as deformações registradas foram da ordem de $4 \%$. Já para o caso da seção construída em reforços tecidos, nesta mesma linha de instrumentação, as deformações registradas foram da ordem de $3 \%$. 
Segundo Portelinha (2012) tanto os níveis de deslocamentos e deformações obtidos nos protótipo, quanto os níveis registrados na estrutura real instrumentada apresentam-se bem coerentes com o que se tem relatado na literatura.

É importante destacar que a estrutura real construída na cidade de Campinas que foi instrumentada por Portelinha (2012) foi utilizada como obra de referência para os ensaios e análises realizadas nesta tese. Os detalhes da utilização da obra para as análises de deformações ao longo do tempo e para o planejamento de ensaios de fluência confinada são apresentados no Capítulo 3.

\subsection{COMPORTAMENTO DEPENDENTE DO TEMPO DOS GEOSSINTÉTICOS}

O comportamento dependente do tempo de estruturas em solo reforçado está diretamente relacionado às propriedades reológicas do geossintético empregado.

Os geossintéticos são materiais poliméricos que apresentam um comportamento tensão-deformação dependente do tempo, no qual dois aspectos distintos podem ser identificados: fluência e relaxação.

Entende-se por fluência o fenômeno físico no qual um material se deforma sob ação de um carregamento constante (KOERNER, 2012). Segundo Msouti et al. (1997) tal fenômeno é dependente do tempo e se deve à natureza elastoviscoplástica do material. A relaxação, por outro lado, corresponde a uma diminuição da carga, no decorrer do tempo, quando a deformação do material é impedida, e permanece constante com o passar do tempo (COSTA, 2004).

Sawicki e Kazimierowicz-Frankowska (1998) salientam que os geossintéticos, que são materiais poliméricos, apresentam propriedades reológicas que influenciam no comportamento em longo prazo de estruturas de solo reforçado com estes materiais. Todos os materiais poliméricos exibem um comportamento dependente do tempo quando submetidos a solicitações de carregamento, ou seja, apresentam comportamentos relacionados aos fenômenos de fluência ou relaxação de tensões (LESHCHINNKY et al., 1997).

Os fenômenos de fluência e relaxação também podem ser interpretados como uma redução na rigidez do material ao longo do tempo. Esta redução pode ser quantificada se as relações carga-deformação forem estabelecidas ao longo de um determinado período. 
As deformações por fluência nos geossintéticos apresentam-se divididas em três fases: primária, secundária e terciária (CAZZUFFI et al., 1997; MIKI et al., 1990; FRANÇA, 2011). A Figura 2.37 identifica as fases mencionadas, sendo os resultados mostrados em termos de deformação ao longo do tempo e taxa de deformação ao longo do tempo.

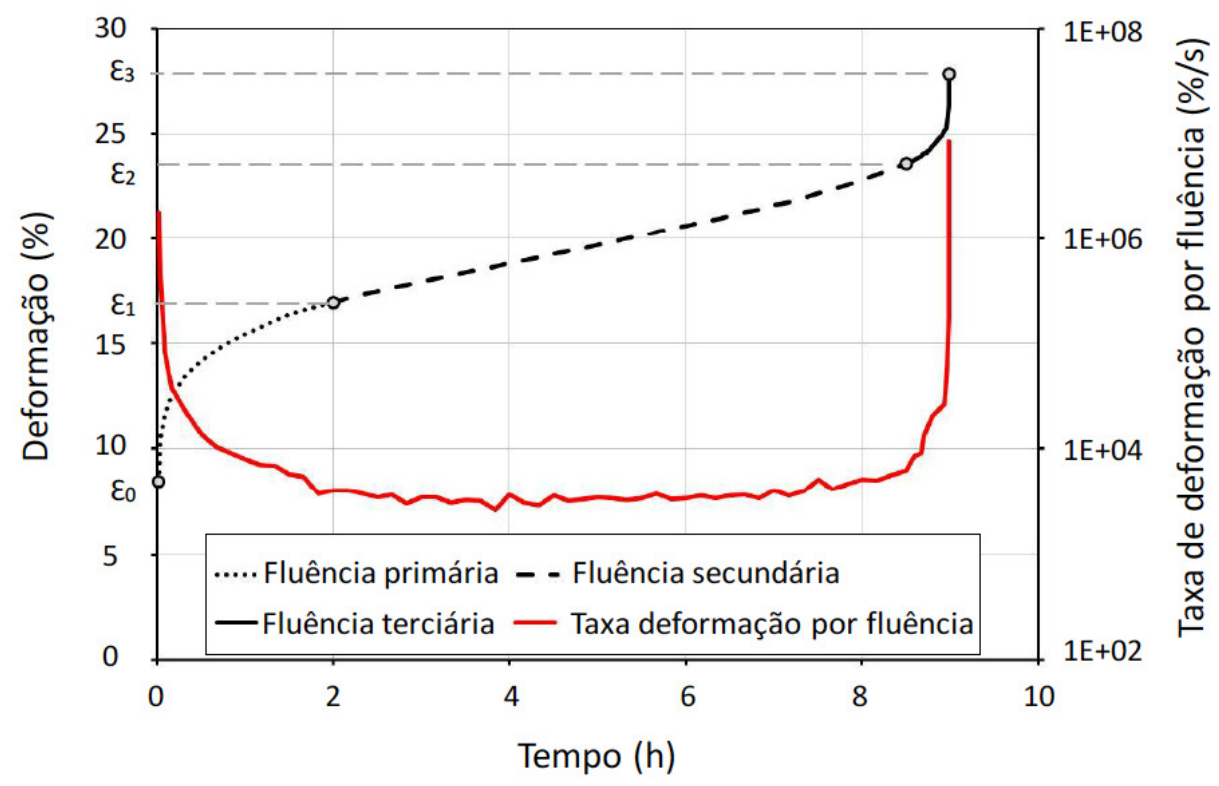

Figura 2.37 - Fases da deformação por fluência em geossintéticos (FRANÇA, 2011).

A Figura apresentada anteriormente mostra claramente as fases que compõem a fluência em geossintéticos. As deformações, em cada uma das fases observadas, se desenvolvem da seguinte forma:

- Fluência primária: nessa fase as deformações ocorrem em um curto período de tempo, e apresentam, como principal característica, um decréscimo nos valores de taxa de deformação por fluência. Segundo Costa (1999) a fluência primária depende principalmente da estrutura macroscópica do geossintético. França (2011) afirma que as deformações ocorridas nessa fase apresentam-se altamente não-lineares quando o tempo é expresso em escala natural;

- Fluência secundária: nessa fase o material escoa, e ao contrário do observado na fluência primária, a taxa de deformação torna-se praticamente constante com o tempo. Segundo França (2011) a fluência 
secundária apresenta-se praticamente linear tanto na representação do tempo em escala natural como em escala logarítmica;

- Fluência terciária: essa fase caracteriza-se por apresentar uma velocidade crescente de deformação, que pode culminar com a ruptura do material. Já a representação gráfica da fluência terciária apresenta-se curvilínea para as escalas de tempo natural e logarítmica (FRANÇA, 2011).

Conforme apresentado na Figura 2.37, quando os geossintéticos são submetidos a um carregamento inicial, apresentam uma deformação imediata, de caráter elástico, com magnitude igual a $\varepsilon_{0}$. Caso este carregamento inicial seja mantido, as deformações por fluência começam a se processar passando pelas fases primária $\left(\varepsilon_{1}\right)$, secundária $\left(\varepsilon_{2}\right)$ e terciária $\left(\varepsilon_{3}\right)$, anteriormente descritas.

Portanto, pode-se afirmar que para qualquer tempo $(\mathrm{t})$ a deformação total $(\varepsilon)$ devido à fluência pode ser obtida por meio do somatório das deformações ocorridas em cada estágio, acrescendo-se, ao efeito da fluência, a deformação que ocorre instantaneamente (eq. 2.1).

$$
\varepsilon(t)=\varepsilon_{0}+\varepsilon_{1}+\varepsilon_{2}+\varepsilon_{3}
$$

Em que:

$\varepsilon_{0}$ - deformação instantânea;

$\varepsilon_{1}, \varepsilon_{2}, \varepsilon_{3}$ - deformação primária, secundária e terciária, respectivamente.

\subsubsection{Representação gráfica da fluência e relaxação em geossintéticos}

Geralmente, os resultados dos ensaios de fluência são representados por meio de um gráfico que relaciona as deformações registradas nos corpos de prova com o tempo do ensaio a partir do início da aplicação do carregamento. Neste gráfico é comum plotar as deformações no eixo das ordenadas e o tempo, em escala logarítmica, no eixo das abscissas. A Figura 2.38 apresentada logo na sequência ilustra um resultado típico de um ensaio de fluência em geossintéticos. 


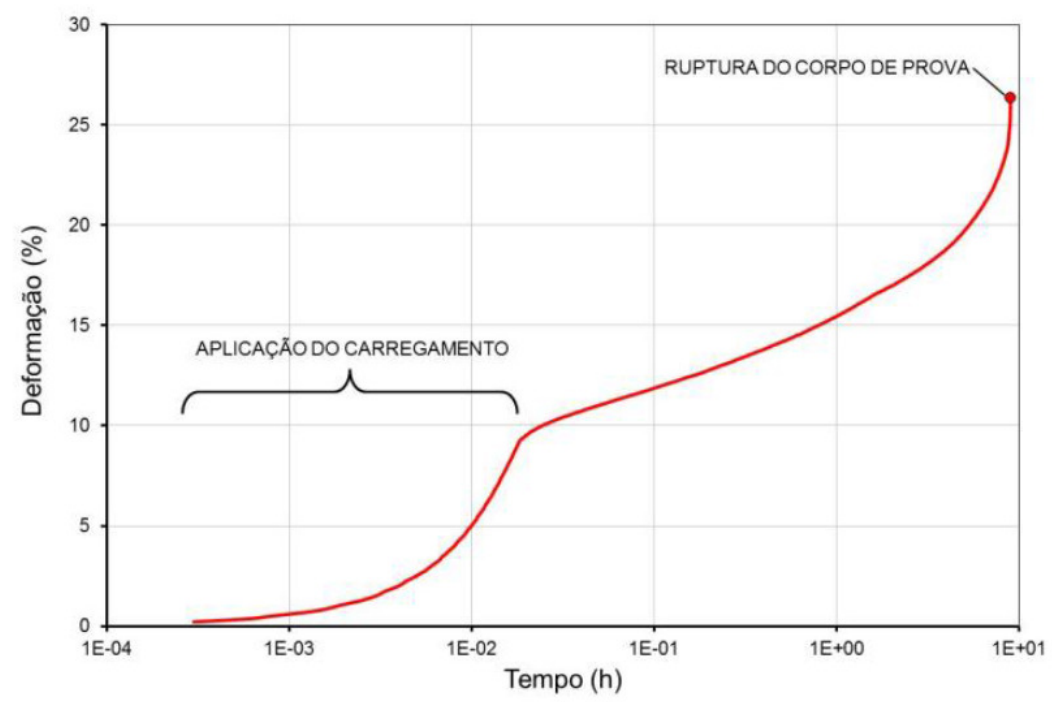

Figura 2.38 - Representação gráfica empregada em ensaios de fluência em geossintéticos (FRANÇA, 2011).

Como descrito anteriormente, o trecho linear do gráfico corresponde às fases primária e secundária das deformações por fluência. Tais deformações podem ser representadas pela seguinte equação eq. (2.2):

$$
\varepsilon=a+b \cdot \log (t)
$$

Em que:

$\varepsilon$ - deformação total;

$t$ - tempo de ensaio;

$a$ e $b$-constantes empregadas para realizar o ajuste linear dos dados em escala semi-logarítmica.

Ressalta-se que nesta equação, as constantes de ajustes a e b representam, respectivamente, a deformação inicial e a taxa de deformação por fluência.

É importante lembrar que, conforme descrito anteriormente, a deformação total que ocorre nos geossintéticos em ensaios de fluência, podem ser dividida em duas parcelas, sendo uma delas a deformação inicial $\left(\varepsilon_{0}\right)$ e a outra a deformação por fluência $\left(\varepsilon_{f}\right)$. Esta relação é apresentada na eq. (2.3). 


$$
\varepsilon=\varepsilon_{0}+\varepsilon_{f}
$$

Outra forma de representar os resultados de ensaios de fluência em geossintéticos foi desenvolvida por Zornberg; Byler e Knudsen (2004). Os autores apresentam um modelo de representação das deformações por fluência nos geossintéticos, em que as deformações por fluência $\left(\varepsilon_{f}\right)$ são caracterizadas pela inclinação do trecho linear das curvas de fluência, nomeada como índice de fluência $(T \alpha)$, e determinada pela eq. (2.4).

$$
\varepsilon_{f}=T_{\alpha} \cdot \log _{10}\left(\frac{t}{t_{0}}\right)
$$

Em que:

$\mathcal{E}_{f}$ - deformação por fluência;

T $\alpha$ - índice de fluência;

$t$ - valor de tempo arbitrário;

$t_{0}$ - tempo para o final de aplicação do carregamento, correspondente à deformação $\varepsilon_{0}$.

O índice $T_{\alpha}$ na equação proposta por Zornberg; Byler e Knudsen (2004) representa, portanto, a velocidade na qual as deformações por fluência ocorrem em um determinado geossintético. Assim, a comparação deste parâmetro em ensaios conduzidos sob diferentes condições, permite a avaliação da influência das condições do ensaio na fluência do material estudado. Segundo Zornberg; Byler e Knudsen (2004) essa abordagem é a mais adequada para quantificar a resposta em fluência dos geossintéticos a serem aplicados em estruturas reais de solo reforçado, já que o fator de fluência é determinado desconsiderando as deformações iniciais. 


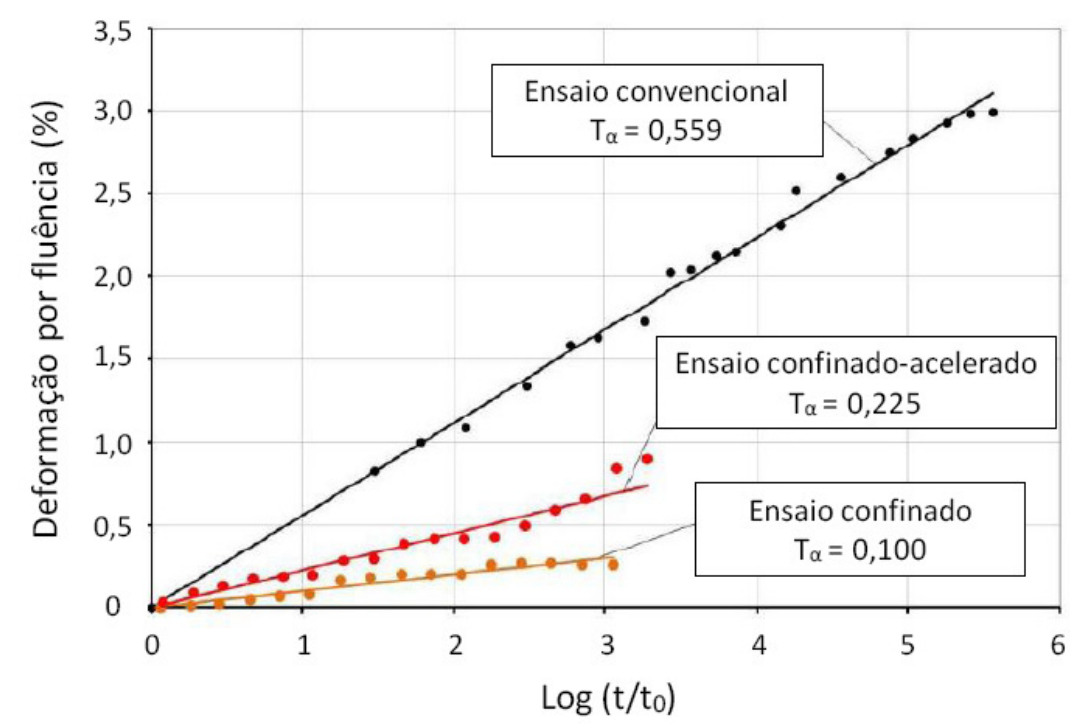

Figura 2.39 - Representação gráfica das deformações por fluência proposta por Zornberg; Byler e Knudsen (2004).

Outra forma usualmente empregada para representar as deformações por fluência em geossintéticos é a utilização de curvas isócronas. Tais curvas relacionam as deformações do material com o carregamento aplicado, para um tempo prédeterminado. Dessa forma, para a elaboração das curvas isócronas é necessária a execução de uma série de ensaios com o mesmo geossintético. Geralmente, os níveis de carregamento empregados nesses ensaios variam de $10 \%$ a $60 \%$ da resistência última (VERTEMATI, 2004; KOERNER, 2005).

A elaboração das curvas isócronas consiste na execução de uma série de ensaios de fluência com diferentes carregamentos. Posteriormente à execução destes ensaios, os dados são plotados em gráficos de forma diferente da convencional. $\mathrm{Na}$ forma convencional, os valores das deformações são apresentados em função do tempo, sendo as deformações mostradas no eixo das ordenadas e o tempo no eixo das abscissas. Neste caso, é possível se observar o comportamento deformaçãotempo para diferentes carregamentos. Nas curvas isócronas, o carregamento é apresentado no eixo das ordenadas e a deformação no eixo das abscissas. Assim, é possível se observar o comportamento carga-deformação em diferentes tempos (Figura 2.40). 


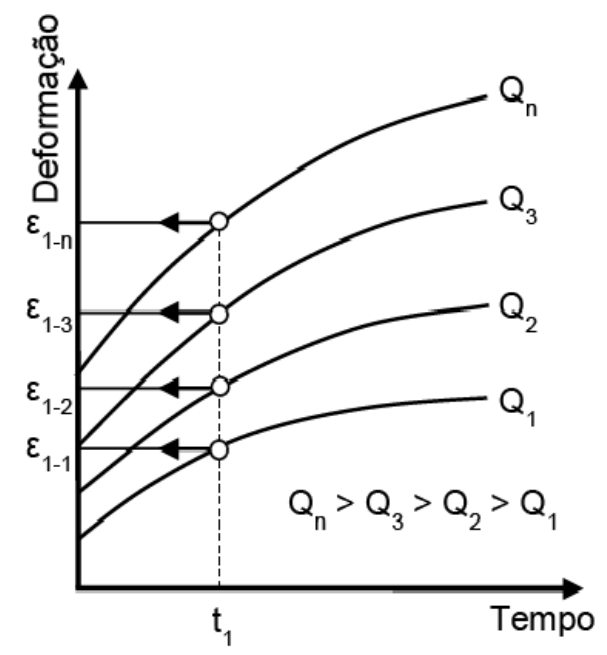

a)

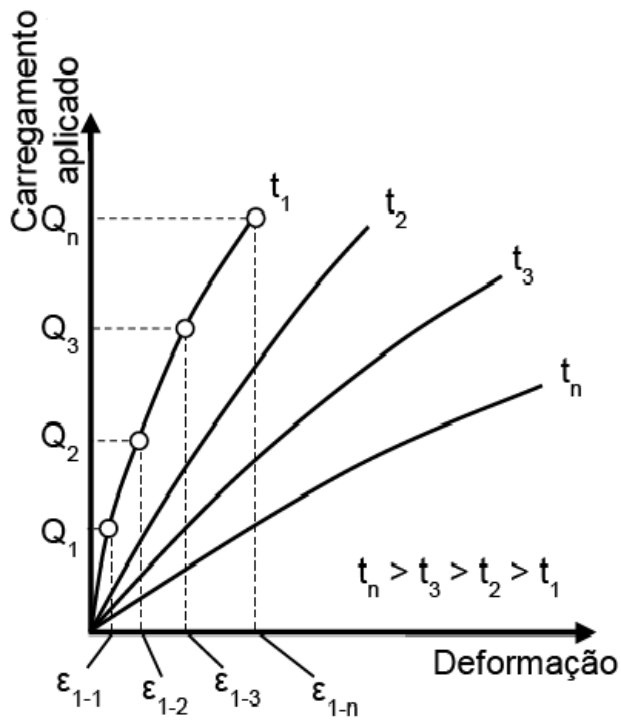

b)

Figura 2.40 - Procedimento para a determinação das curvas isócronas: a) Curva convencional (deformação $\mathrm{x}$ tempo para diferentes carregamentos); b) Curvas isócronas (carregamento $\mathrm{x}$ deformação para diferentes tempos); (FRANÇA, 2011).

\subsubsection{Módulos de rigidez por fluência e relaxação}

Como destacado anteriormente, o fenômeno da fluência pode ser interpretado também como uma diminuição da rigidez do geossintético ao longo do tempo. O mesmo raciocínio é valido para o fenômeno da relaxação.

Uma boa forma de se determinar a variação da rigidez do material ao longo do tempo é também por meio das curvas isócronas. Essas curvas representam a relação carregamento-deformação para uma mesmo tempo após a aplicação da carga.

A relação de um determinado valor de carga $(T)$ e sua respectiva deformação $(\varepsilon)$ representa a rigidez por fluência do material $\left(\mathrm{J}_{\text {fluência }}\right)$, conforme mostrado na Figura 2.41b. Por meio desta figura observa-se claramente a diminuição da inclinação das curvas com o aumento das horas, indicando que a rigidez do material diminui ao longo do tempo sob a ação de um carregamento constante.

Para estudos referentes à relaxação, a caracterização do comportamento pode ser efetuada por meio de ensaios em que a deformação do material é impedida ao longo 
do tempo após a aplicação do carregamento inicial. Obviamente a execução deste ensaio exige o monitoramento das cargas atuantes no geossintético.

De forma análoga aos ensaios de fluência, podem-se obter para a relaxação as curvas isócronas do ensaio. Similarmente aos ensaios de fluência, a relação entre um determinado carregamento $(T)$ e sua respectiva deformação $(\varepsilon)$ corresponde à rigidez por relaxação ( $\left.\mathrm{J}_{\text {relaxação }}\right)$, conforme apresentado na Figura 2.42b.

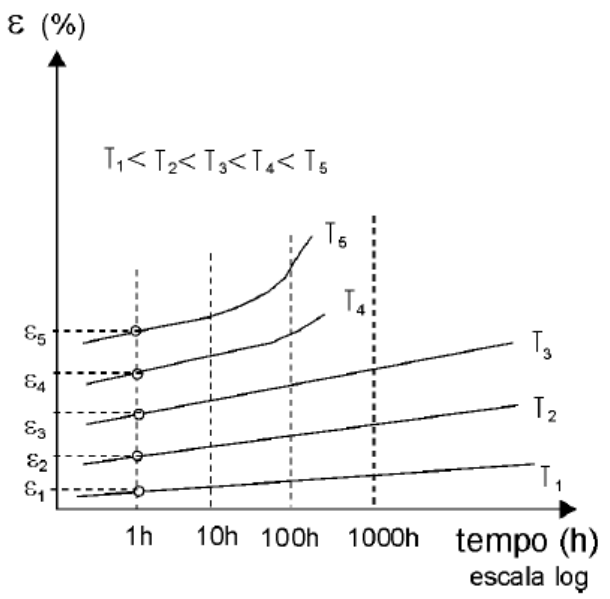

a)

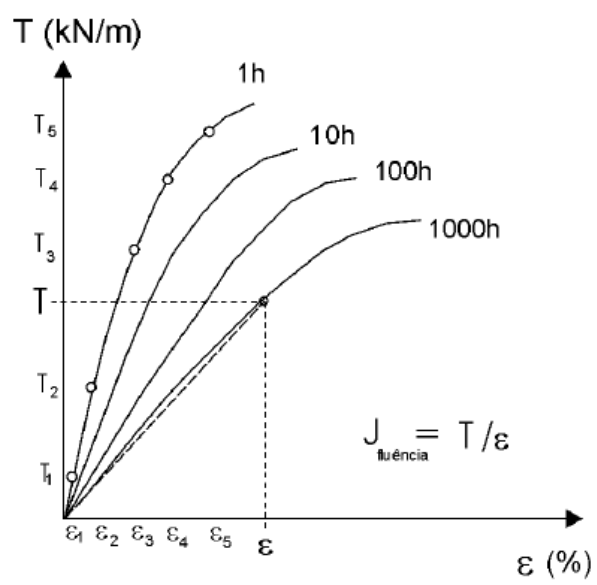

b)

Figura 2.41 - Resultados típicos de um ensaio de fluência: a) Curva convencional (deformação-tempo para diferentes carregamentos); b) Curvas isócronas (carregamento-deformação para diferentes tempos); (COSTA, 2004).

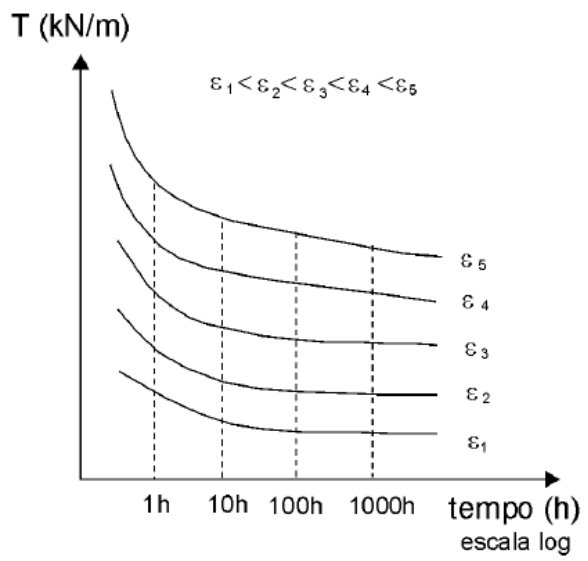

a)

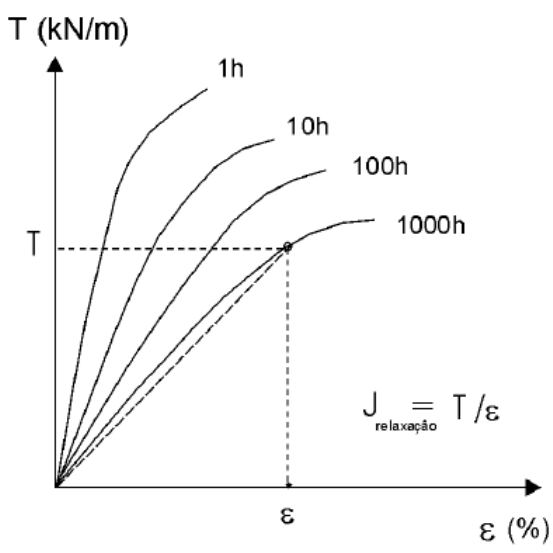

b)

Figura 2.42 - Resultados típicos de um ensaio de relaxação: a) Curva convencional (carregamentotempo para diferentes deformações); b) Curvas isócronas (carregamento-deformação para diferentes tempos); (COSTA, 2004). 
Para comparar os mecanismos que governam os fenômenos de fluência e relaxação, Costa (2004) apresenta graficamente a trajetória dos carregamentos nestes ensaios. Os gráficos foram elaborados considerando duas situações distintas: caso em que a rigidez por fluência é inferior à rigidez por relaxação e caso em que a rigidez por fluência é superior que a rigidez por relaxação.

No primeiro caso (Figura 2.43), o trecho $O A$ corresponde à fase de aplicação do carregamento, enquanto as fases $A B$ e $A C$ correspondem às fases de fluência $e$ relaxação respectivamente. Observa-se que o comportamento dependente do tempo, tanto em termos de fluência quanto em termos de relaxação, provoca uma redução da rigidez ao longo do tempo. No caso da fluência, a redução na rigidez ocorre por conta do aumento da deformação sob um carregamento constante. Já no caso da relaxação, em que a deformação é impedida com o passar do tempo, a diminuição da rigidez ocorre devido à redução da capacidade de carga do geossintético.

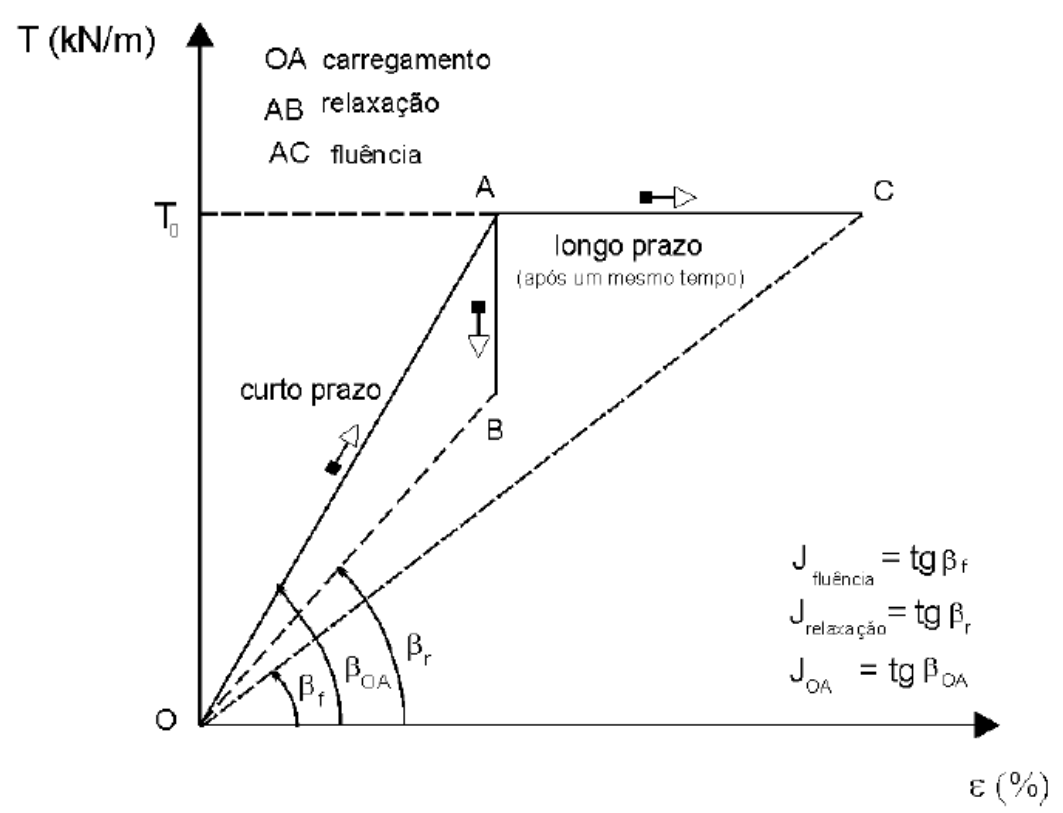

Figura 2.43 - Caso em que a rigidez por fluência é inferior à rigidez por relaxação (COSTA, 2004).

Segundo Costa (2004), se os módulos de rigidez obtidos por meio dos ensaios de fluência e relaxação fossem iguais, as curvas isócronas obtidas nos ensaios de fluência poderiam ser empregados para se determinar a diminuição das cargas nos 
geossintéticos quando sua deformação fosse impedida, suprimindo a necessidade de realização de ensaios de relaxação. Entretanto, a depender do material ensaiado, o módulo de rigidez obtido por ensaio fluência pode ser maior ou menor quando comparado ao módulo obtido por ensaio de relaxação.

A Figura 2.44 ilustra um caso em que o módulo de rigidez obtido por meio de ensaios de fluência é superior ao módulo de rigidez obtido por ensaios de relaxação.

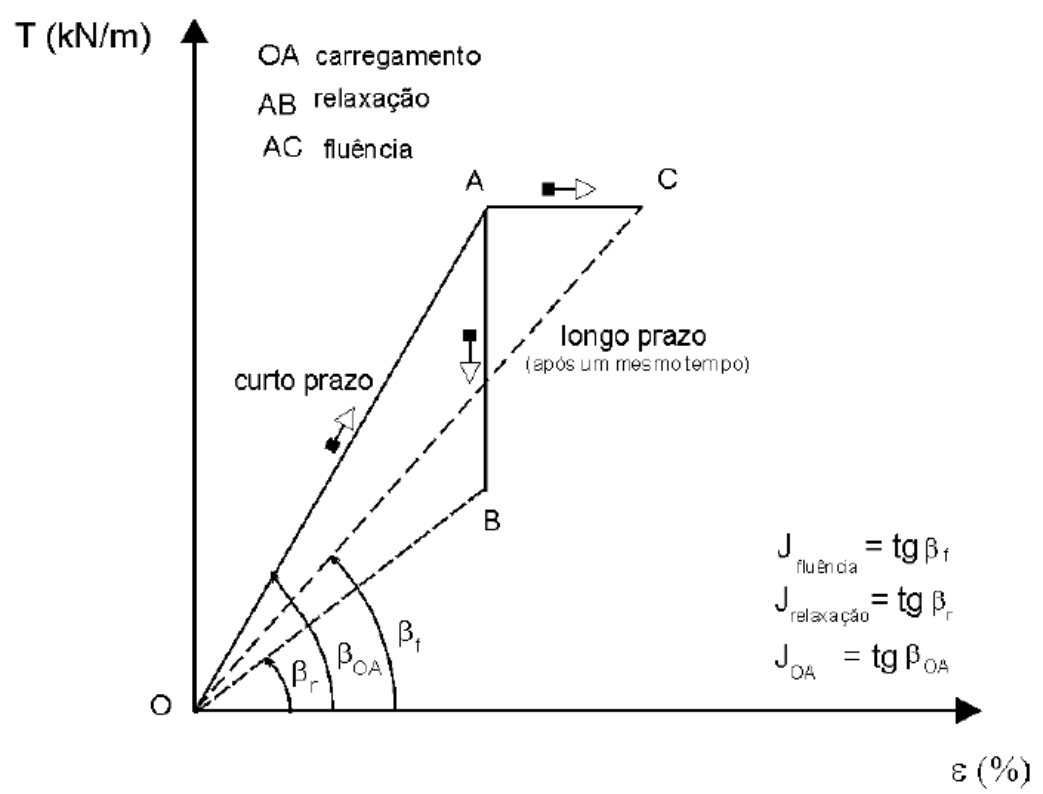

Figura 2.44 - Caso em que a rigidez por fluência é superior à rigidez por relaxação (COSTA, 2004).

Dados de ensaios de fluência e relaxação em geossintéticos encontrados na bibliografia indicam que o módulo de rigidez obtido por meio destes ensaios depende de diversos fatores, entre eles o tipo de material e as condições consideradas na execução do ensaio. De acordo com dados publicados por Thornton (2001), os módulos de rigidez para um geossintético de polipropileno são semelhantes para um baixo período de observação (da ordem de 20 minutos), sendo o módulo obtido por ensaio de relaxação ligeiramente inferior ao módulo obtido por ensaio de fluência. Entretanto, para períodos maiores de tempo, a situação se inverte, ou seja, o módulo de rigidez por fluência se torna menor que o módulo de rigidez por relaxação. 
Já os resultados apresentados por Walters (2002) indicam, para um geossintético de polipropileno, módulos de rigidez por relaxação inferiores aos módulos de rigidez por fluência.

Existem recentemente poucos trabalhos publicados que tratam o comportamento em longo prazo de geossintéticos sob o ponto de vista relaxação. Grande parte dos dados encontrados na bibliografia se refere apenas a ensaios de fluência. Por esta razão, a comparação do comportamento de materiais geossintéticos sob condições de fluência e relaxação se torna complexa. Não se dispõe atualmente de um banco de dados amplo com resultados de ensaios de relaxação em geossintéticos, fato este que impossibilita a determinação mais apurada dos fatores que governam seu comportamento.

\subsubsection{Fatores que afetam a fluência em geossintéticos}

O comportamento de fluência de materiais geossintéticos apresenta-se dependente de diversos aspectos. Dentre os principais aspectos pode-se destacar:

- Tipo de geossintético;

- Tipo de polímero;

- Nível de carregamento;

- Velocidade de carregamento;

- Temperatura;

- Confinamento.

A seguir é realizada uma explicação mais detalhada sobre a influência de cada um dos fatores separadamente.

\subsubsection{Tipo de geossintético}

O tipo de geossintético e sua forma de fabricação influenciam no desenvolvimento das deformações por fluência destes materiais. Dados encontrados na bibliografia mostram que, de maneira geral, dentre os principais geossintéticos empregados para fins de reforço de solos, os geotêxteis não tecidos mostram-se mais 
susceptíveis aos fenômenos de fluência, seguidos pelo geotêxteis tecidos e pelas geogrelhas (SHRESTHA; BELL, 1982). As deformações por fluência de materiais geossintéticos estão associadas ao rearranjo estrutural macroscópico das fibras quando tais materiais são solicitados por esforços de tração. Assim, materiais com maior grau de liberdade entre as fibras (como os geotêxteis não tecidos, por exemplo), apresentam maiores deformações por fluência quando comparados a outros materiais. Já materiais com menor grau de liberdade entre as fibras, ou materiais com fibras unidas (como as geogrelhas, por exemplo), apresentam menores deformações por fluência.

Den Hoedt (1986) demonstra que o processo de fabricação do geossintético pode ter um efeito significativo nas deformações por fluência. Segundo o autor, para o caso de geotêxteis tecidos, as fibras raramente são retilíneas e alinhadas com a direção do carregamento. Assim, a extensão das fibras devido à aplicação de um carregamento em uma direção está correlacionada com a contração na direção perpendicular, conforme mostrado na Figura 2.45.

No caso de geotêxteis não tecidos esse fenômeno é ainda mais acentuado, pois os fios que constituem o material não são retilíneos.

a) Seção longitudinal b) Seção transversal

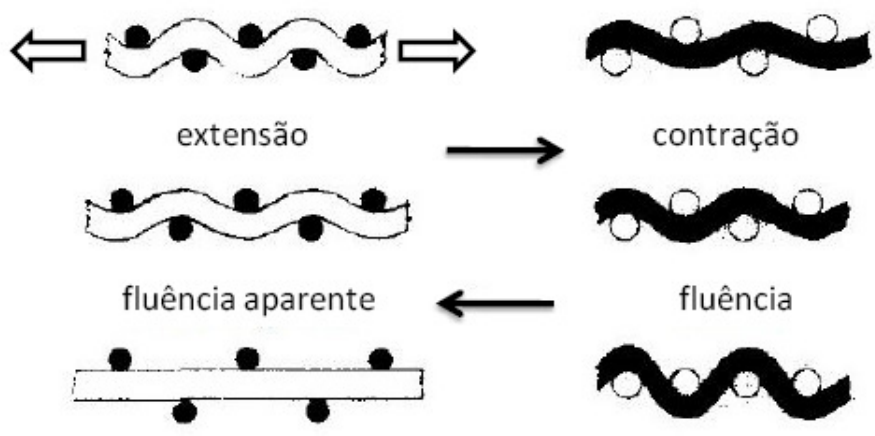

Figura 2.45 - Deformação das fibras de um geotêxtil tecido submetido a uma solicitação de tração a) Sentido longitudinal à aplicação do carregamento; b) Sentido transversal à aplicação do carregamento (adaptado de DEN HOEDT, 1986).

Ainda com relação aos geotêxteis não tecidos Shrestha e Bell (1982) destacam que a fluência ocorre de maneira mais pronunciada em geotêxteis confeccionados com filamentos contínuos, em oposição aos confeccionados com fibras cortadas. 
Outra observação importante realizada por Den Hoedt (1986) se refere à influência do método de fabricação dos geotêxteis não tecidos na fluência do material. Segundo 0 autor, geotêxteis não tecidos termoligados possuem menor susceptibilidade à fluência quando comparados aos geotêxteis não tecidos agulhados. Isto se deve ao fato de que o processo de fabricação dos geotêxteis termoligados garante maior rigidez proporcionada pelas ligações entre as fibras.

\subsubsection{Tipo de polímero}

O tipo e as propriedades dos polímeros que constituem um geossintético influenciam sobremaneira em seu comportamento sob o ponto de vista da fluência. Os geossintéticos, de maneira geral, são compostos basicamente por quatro tipos de polímeros, sendo eles: poliamida (PA), polietileno (PE), polipropileno (PP) e politereftalato de etileno $(\mathrm{PET})$, ou poliéster. No que se refere à susceptibilidade à fluência destes polímeros, o polietileno ( $P E$ ) aparece em primeiro lugar, seguido pelo polipropileno (PP), pela poliamida (PA) e, finalmente, pelo poliéster (PET) (DEN HOEDT, 1986; ABRAMENTO, 1995).

A estrutura dos polímeros apresenta duas morfologias típicas, amorfa e cristalina. $\mathrm{O}$ estado amorfo caracteriza-se por uma completa ausência de ordem entre as moléculas, ou seja, cada uma se entrelaça aleatoriamente com a outra. No estado cristalino, ao contrário, as moléculas são orientadas ou alinhadas, semelhantes à estrutura de um cristal. Como esses dois estados coexistem e a cristalinidade nunca atinge $100 \%$, os polímeros são em geral tidos como amorfos e semicristalinos (BUENO, 2004). De forma geral, quanto maior a cristalinidade do polímero, maior a sua rigidez, estabilidade dimensional, resistência química, resistência à abrasão, temperatura de fusão e de transição vítrea. Portanto, o grau de cristalinidade e a porcentagem de zonas amorfas controlam o comportamento das propriedades do polímero (VAN ZANTEN, 1986; DEN HOEDT, 1986). O comportamento tensãodeformação de curto prazo dos geossintéticos é determinado por deformações das regiões amorfas. Por outro lado, a porção cristalina tem um papel expressivo nos carregamentos prolongados. Por esta razão, a cristalinidade do polímero que compõe o geossintético apresenta-se como um aspecto muito importante a ser considerado no estudo da fluência. 
Segundo Den Hoedt (1986), em geral, o poliéster (PET) possui grau de cristalinidade menor que o polipropileno (PP) e o polietileno (PE). Segundo o autor, o poliéster possui uma cristalinidade da ordem de 30 a $40 \%$, enquanto o polipropileno possui uma cristalinidade que varia de 70 a $80 \%$ e o polietileno uma cristalinidade que varia de 75 a $85 \%$.

A Figura 2.46 ilustra a influência do tipo de polímero na fluência do geossintético, submetido a um carregamento de 20 e $60 \%$ da resistência última do material.

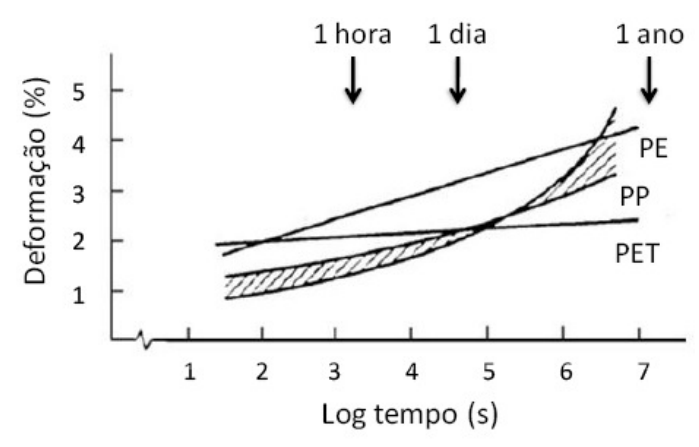

a)

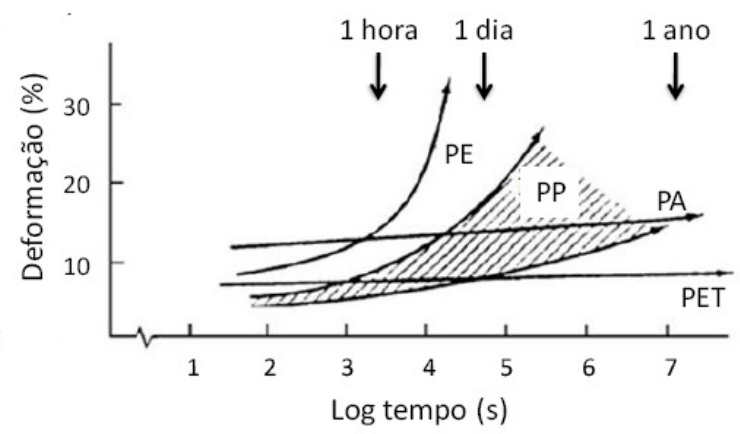

b)

Figura 2.46 - Curva de fluência para diferentes polímeros - a) 20\% da resistência última à tração; b) $60 \%$ da resistência última à tração (adaptado de DEN HOEDT, 1986).

O tipo de polímero também provoca comportamentos distintos no caso de ruptura. Para os geotêxteis de poliéster (PET), por exemplo, a deformação de ruptura em ensaios de fluência se aproxima daquela obtida em ensaios de tração convencionais, enquanto que no caso de geotêxteis de polipropileno, as deformações de ruptura por fluência são superiores às obtidas em ensaios de tração (MSOUTI et al, 1997). Segundo Den Hoedt (1986) isto ocorre, pois, no caso das poliolefinas (polipropileno e polietileno), ocorrem deslizamentos entre as cadeias poliméricas nas regiões cristalinas em situações de carregamentos de longo prazo.

\subsubsection{Nível de carregamento}

Um dos fatores mais importantes a serem considerados nas deformações por fluência de geossintéticos é o nível de carregamento ao qual o material é submetido. Koerner (2005) cita que este pode ser o fator mais significativo nos estudos de 
fluência de geossintéticos. Nos ensaios de fluência, o nível de carregamento é expresso como uma porcentagem da resistência última à tração obtida em ensaios de curta duração.

A Figura 2.47 mostrada na sequência ilustra a dependência do nível de carregamento nas deformações em longo prazo dos geossintéticos. Observa-se que maiores carregamento conduzem a maiores deformações por fluência.

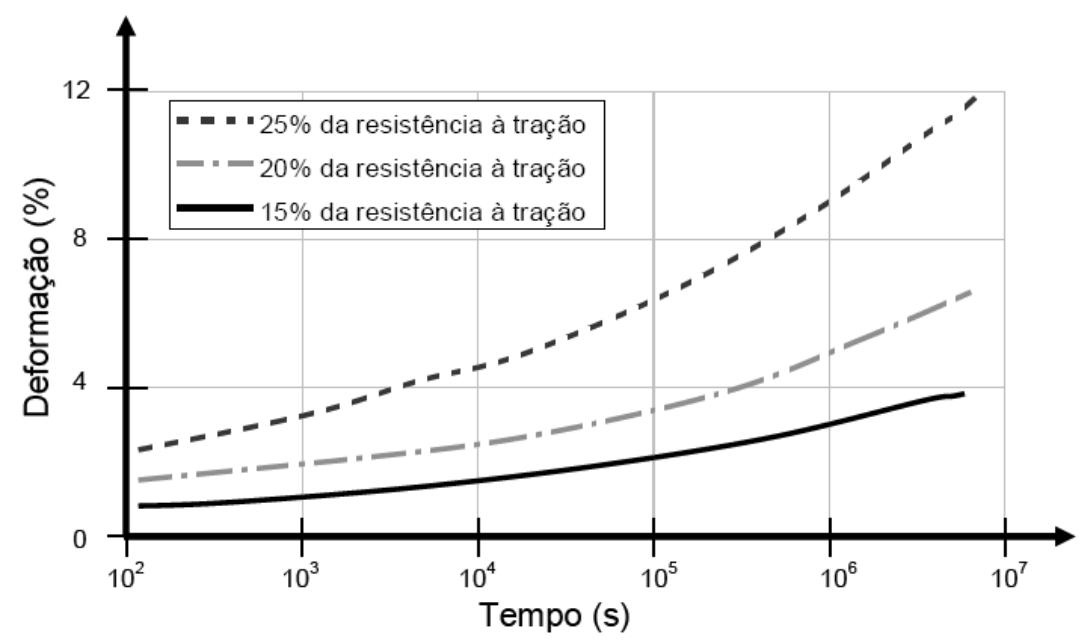

Figura 2.47 - Influência do nível de carregamento no comportamento em relação à fluência de geossintéticos (adaptado de SIMONINI; GOTTARDI, 2003).

\subsubsection{Velocidade de carregamento}

Dados encontrados na bibliografia apontam que as deformações por fluência nos geossintéticos são diretamente proporcionais às velocidades de aplicação do carregamento, ou seja, velocidades de aplicação maiores conduzem a deformações por fluência maiores.

Quando o carregamento é aplicado lentamente, as deformações dependentes do tempo já se manifestam durante o tempo de carregamento, e a deformação subsequente, quando a carga é mantida constante, é inicialmente reduzida.

A influência do tempo de carregamento no comportamento mecânico dos polímeros foi estudada por Rimoldi e Montanelli (1993). Os autores realizaram ensaios de fluência em geossintéticos em que se aplicava uma carga correspondente a $40 \%$ da 
resistência à tração, considerando três velocidades distintas de aplicação de carga. No primeiro ensaio o carregamento foi aplicado em 1 minuto, no segundo ensaio $o$ carregamento foi aplicado em 3 minutos e no terceiro ensaio o carregamento foi aplicado em 1 hora. Os resultados dos ensaios mostraram que a maior deformação inicial foi observada nos ensaios com maior tempo de aplicação de carga. Além disso, os autores constataram que a taxa de variação da fluência observada no início dos ensaios com maior tempo de aplicação de carga foi inferior à taxa de fluência observada nos ensaios com um menor tempo de aplicação de carga.

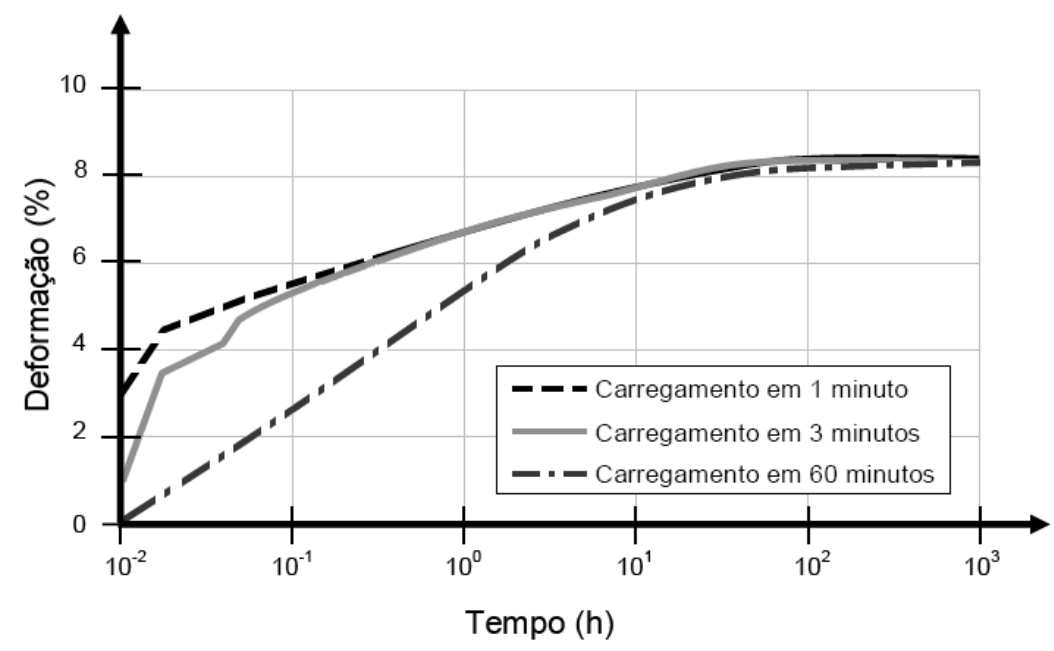

Figura 2.48 - Efeito da velocidade de carregamento na fluência de uma geogrelha de PEAD submetida a um carregamento de $40 \%$ de sua resistência última à tração (adaptado de RIMOLDI; MONTANELLI, 1993).

Estudos realizados por Gottardi e Simonini (2000) baseados em modelos de muros de solo reforçado também demonstraram o efeito da velocidade de carregamento na fluência. O material de aterro empregado era constituído por areia pura e o geossintético de reforço era um material de polipropileno (PP). Os ensaios foram realizados utilizando a mesma sobrecarga, porém, com quatro diferentes tempos de carregamento. A Figura 2.49 apresenta os recalques observados no topo das estruturas para os diferentes tempos de carregamento considerados.

Como se pode constatar na Figura 2.49, a taxa inicial de deslocamento com o tempo apresenta uma variação acentuada, dependendo da velocidade de carregamento. 
Quanto maior o tempo para aplicação da carga, menor a taxa de recalque, inicialmente verificada nos ensaios.

As maiores deformações iniciais observadas para carregamentos mais lentos podem ser explicadas pelo comportamento tensão-deformação do material. Com este intuito, Andrawes et al. (1984) avaliaram a influência desse fator no comportamento de diversos geossintéticos. Esta análise foi realizada por meio de ensaios de tração de curta duração. Os autores destacam que a variação da taxa de carregamento (ou taxa de deformação) influi apenas na deformação devido ao alongamento dos filamentos do geossintético, não sendo relevante nas deformações da macroestrutura do material. Portanto, os geossintéticos com macroestrutura mais homogênea, como os geotêxteis tecidos, por exemplo, apresentam deformações dependentes da velocidade do carregamento (Figura 2.50).

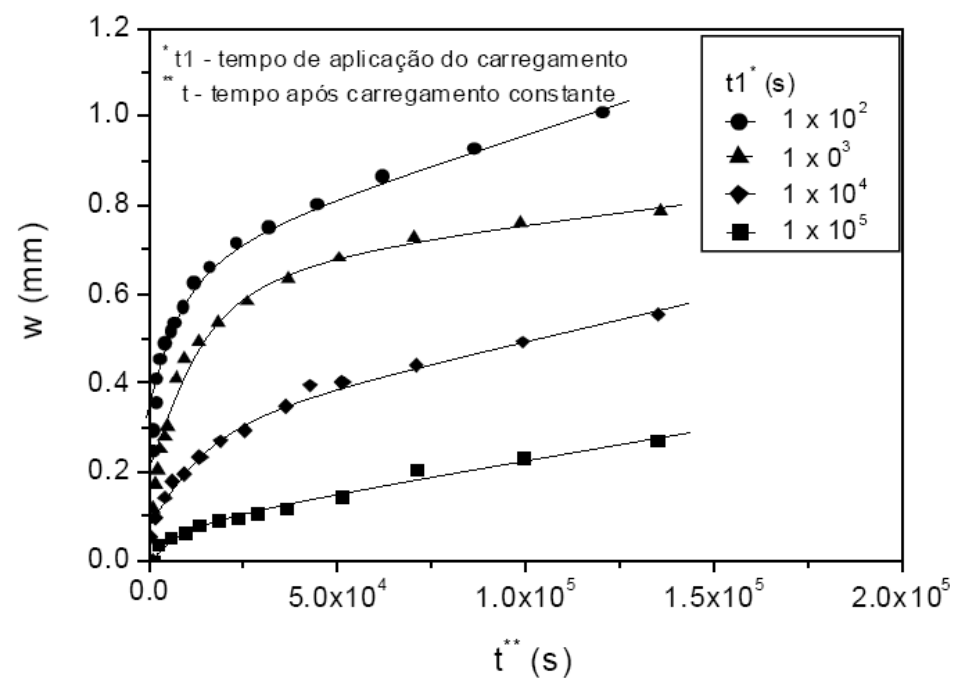

Figura 2.49 - Efeito do tempo de carregamento no recalque do topo da estrutura para carga constante (adaptado de GOTTARDI; SIMONINI, 2000). 


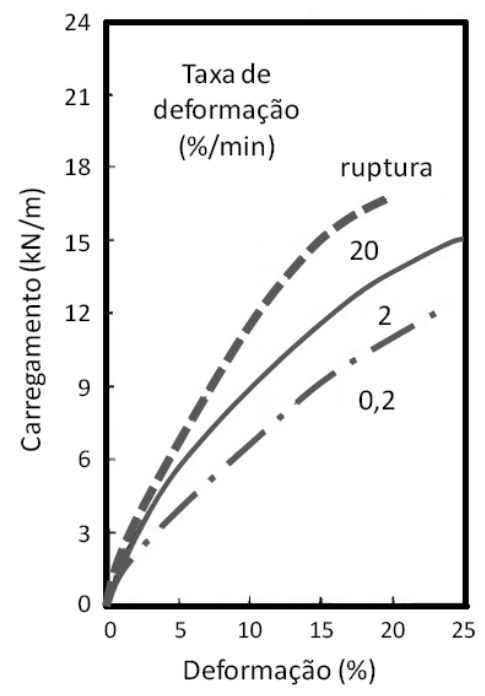

Figura 2.50 - Comportamento de um geotêxtil tecido para diferentes velocidades de carregamentos em ensaio de tração (adaptado de ANDRAWES et al., 1984).

\subsubsection{Temperatura}

É de conhecimento geral que o aumento da temperatura acelera o processo de deformações dependentes do tempo em materiais poliméricos. Por esta razão, é muito importante que esta variável seja controlada em ensaios de longa duração, como os de fluência e relaxação, exemplo.

Scaffaro et al. (2008) apresentam resultados de ensaios de fluência realizados para diferentes temperaturas em uma geomembrana de poliamida. A Figura 2.51 a seguir mostra os resultados obtidos pelos autores. 


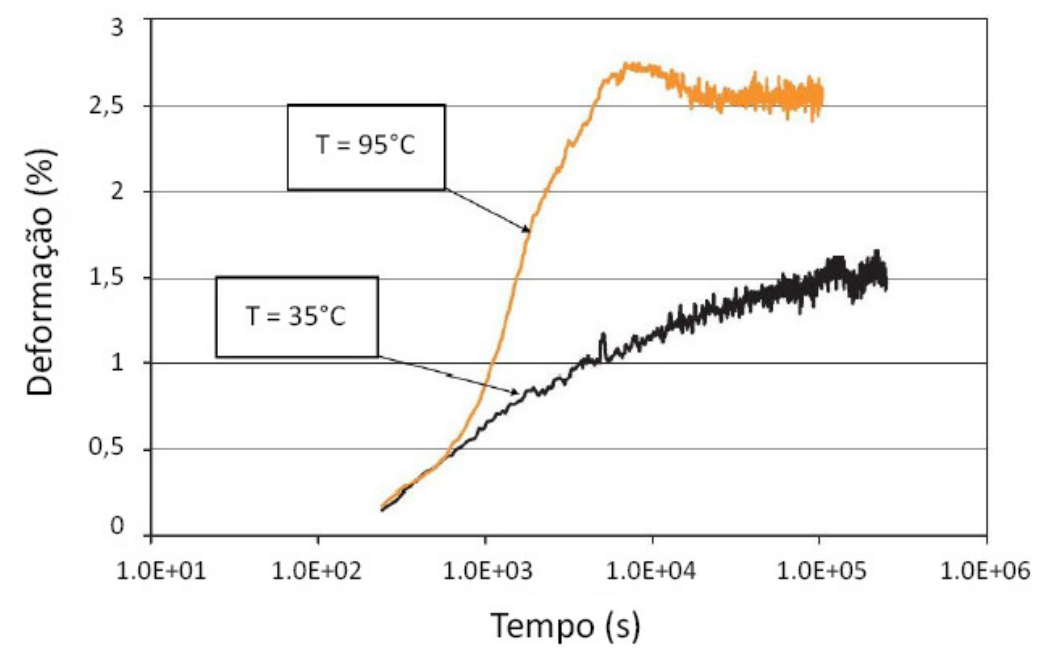

Figura 2.51 - Influência da temperatura nas deformações por fluência de uma geomembrana de poliamida (SCAFFARO et al., 2008).

A relação entre a fluência e a temperatura não deve ser generalizada para todos os tipos de polímeros utilizados em geossintéticos (FARRAG; SHIRAZI,1997). O efeito da temperatura depende da cristalinidade do polímero, estando, portanto, diretamente relacionada às suas propriedades térmicas. Segundo Constanzi (2003) o comportamento visco-elástico dos polímeros é regido por dois patamares distintos de temperatura: a temperatura de fusão cristalina $\left(T_{m}\right)$ e a temperatura de transição vítrea $\left(T_{g}\right)$. A temperatura de fusão cristalina é caracterizada como aquela a partir da qual o polímero encontra-se em seu estado fundido e não apresenta mais nenhuma região cristalina. Já a temperatura de transição vítrea é definida como aquela na qual o polímero passa do estado vítreo (sólido) para o estado de mobilidade, quando se torna essencialmente mais deformável (FERRY, 1980). Em vista disso, as deformações por fluência dos polímeros são mais significativas quando o material é submetido a um carregamento constante sob a ação de uma temperatura acima de seu valor de $\mathrm{T}_{\mathrm{g}}$.

\subsubsection{Confinamento em solo}

É comum encontrar na bibliografia exemplos de estruturas de solo reforçado que apresentaram deformações por fluência bastante inferiores àquelas previstas em projeto, estabelecidas com base em ensaios não confinados (MCGOWN; 
ANDRAWES e KABIR, 1982; DELMAS, 1988; COSTA, 2004; KAMIJI, 2006). Este fato indica que os projetos baseados em ensaios não confinados são bastante conservadores, e que o comportamento carregamento-deformação dos geossintéticos submetidos ao confinamento é bem diferente do comportamento dos geossintéticos estudados em isolamento.

As diferenças observadas entre resultados de ensaios confinados e ensaios em isolamento de fluência podem ser explicadas, em parte, pelo fato do confinamento reduzir a liberdade estrutural do geossintético, de forma a restringir o movimento relativo entre as fibras que compõem o material.

McGown et al. (1982) foram os primeiros pesquisadores a investigar o efeito do confinamento na fluência de geotêxteis. A Figura 2.52 demonstra os resultados obtidos por esses autores em ensaios com geotêxteis não tecidos, sem e com confinamento. Os resultados mostram que no caso do geotêxtil composto $33 \%$ por PEAD e $67 \%$ por PP (Figura 2.52a), o confinamento em solo reduziu tanto as deformações iniciais quanto as deformações dependentes do tempo, quando comparado com os resultados do ensaio realizado em isolamento. Por outro lado, o confinamento em solo não apresentou uma influência significativa nas deformações dependentes do tempo para o geotêxtil de PET, resultando numa redução significativa apenas das deformações iniciais (Figura 2.52b).

Segundo Msouti et al. (1997), a redução das deformações dependentes do tempo em geotêxteis não tecidos, deve-se ao fato de que, com o confinamento, a estricção da amostra é reduzida, de forma a restringir a movimentação das fibras e o alinhamento das mesmas na direção de aplicação da carga. $O$ autor salienta ainda que a estricção do material pode ser reduzida devido a três principais fatores, sendo eles o atrito solo-geotêxtil na direção perpendicular à solicitação, o aumento do atrito entre as fibras pela ação da tensão normal, e ainda uma possível impregnação de solo no material diminuindo a possibilidade de deslizamento entre as fibras. 

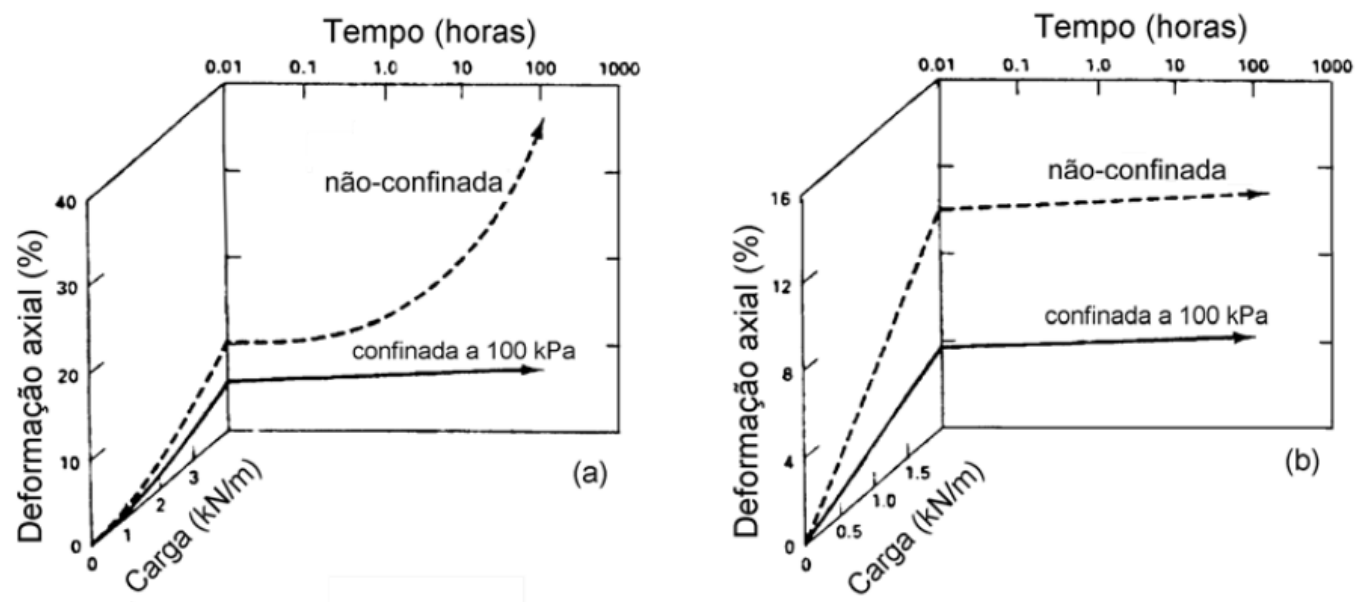

Figura 2.52 - Resultados de ensaios confinados e não confinados de fluência de geotêxteis - a) Não tecido, termoligado, 33\% PEAD e 67\% PP; b) Não tecido, 100\% PET, agulhado (MCGOWN, ANDRAWES E KABIR, 1982).

Além dos fatores citados anteriormente, outro importante aspecto a ser considerado se refere à influência do comportamento mecânico do solo nas deformações dependentes do tempo de geossintéticos.

Alguns autores, como McGown et al. (1998) e Koerner (2012), consideram que, em estruturas de solo reforçado, a resistência do solo mobilizada em curto prazo afeta as deformações ao longo do tempo dos geossintéticos. Outro aspecto relacionado ao solo de aterro, que pode ser capaz de modificar as deformações do geossintético, diz respeito às características de fluência do solo, conforme estudado por Helwany (1993).

Baseado na hipótese de compatibilidade de deformação solo-reforço, McGown et al. (1998) consideram que a resistência do solo mobilizada em curto prazo interfere nas deformações dependentes do tempo do reforço. Para a análise de deformações em muros de solo reforçado em condições de trabalho a hipótese de compatibilidade de deformação solo-reforço é frequentemente assumida. Esta hipótese estabelece que a deformação do solo na direção do reforço é igual à deformação do reforço, ou seja, não ocorre deslizamento relativo na interface solo-geossintético.

No estudo de compatibilidade de deformações, o equilíbrio solo-reforço é estabelecido com a igualdade das forças disponíveis no reforço em relação às forças requeridas para o equilíbrio do maciço de solo. 
O conceito de compatibilidade de deformação no caso de um muro escorado durante a construção pode ser ilustrado pela Figura 2.53. Inicialmente, o solo e o reforço não apresentam deformação, e a força requerida para o equilíbrio corresponde ao empuxo do solo na condição de repouso. Com a retirada do escoramento passam a ocorrer deformações e a força requerida para o equilíbrio diminui progressivamente até um valor mínimo correspondente à mobilização da resistência do estado crítico $\left(\sigma_{1}-\sigma_{3}\right)$. Por outro lado, a força disponível no reforço aumenta continuamente com o desenvolvimento das deformações, e o equilíbrio ocorre com a intersecção das duas curvas, conforme ilustrado na Figura 2.53c.

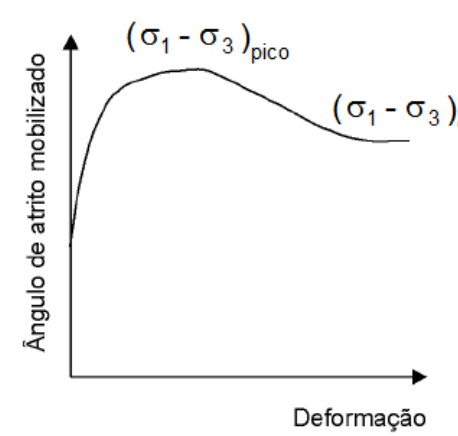

a)

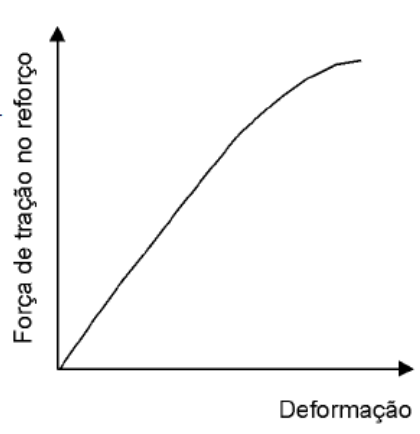

b)

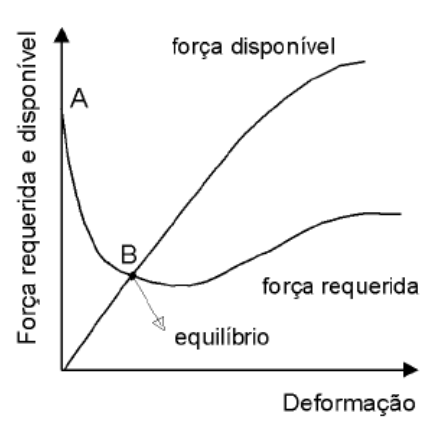

c)

Figura 2.53 - Curva de compatibilidade para determinação do equilíbrio em solos reforçados a) Resistência do solo mobilizada por deformação lateral; b) Curva isócrona do reforço; c) curva de compatibilidade de deformação (McGOWN et al., 1998).

Considerando o conceito de compatibilidade de deformação, caso o equilíbrio em curto prazo entre a força requerida e a disponível no reforço seja estabelecido antes da mobilização de resistência de pico do solo, quando o sistema começar a se deformar pela tendência de fluência do reforço, o acréscimo de deformação permitirá a mobilização de uma maior resistência do solo até que o pico seja atingido. A maior mobilização de resistência do solo provocará uma redução da força requerida no reforço (McGOWN et al., 1998). Assim, essa redução irá resultar em menores deformações ao longo do tempo, já que uma menor carga no reforço implica em menores efeitos de fluência. 
Outra possível situação corresponde ao estabelecimento do equilíbrio inicial com a mobilização de uma resistência entre o valor de pico e o crítico. Nesse caso, haveria um aumento da carga no reforço ao longo do tempo.

Considerando outra situação hipotética correspondente à mobilização de uma resistência em curto prazo equivalente ao estado crítico, deformação ao longo do tempo sob carga constante são esperadas.

Outro fator importante a ser considerado no comportamento em longo prazo de geossintéticos se refere à fluência do solo confinante. Alguns autores investigaram a interferência das deformações dependentes do tempo dos solos no comportamento dos geossintéticos, entretanto este tipo de estudo ainda é escasso.

Wu e Helwany (1996) avaliaram o comportamento de um elemento de solo reforçado, composto por um reforço entre duas camadas de solo, mediante a aplicação de uma carga vertical constante na superfície do elemento. Nesta investigação foram empregados dois tipos de geotêxteis, sendo um de polipropileno (PP) e outro não tecido termoligado. No primeiro caso utilizou-se como solo confinante uma areia, e em seguida, uma argila com grande tendência a apresentar fluência.

Os resultados publicados pelos autores indicaram que a deformação inicial dos geotêxteis confinados foi semelhante à deformação inicial do geotêxtil em isolamento. Por outro lado, as deformações ao longo do tempo foram bem diferentes ao se comparar os ensaios confinados com os ensaios dos geotêxteis isolados. Segundo os autores, para o caso da areia, o solo apresenta uma tendência de se deformar em uma menor taxa quando comparado ao geotêxtil isolado, sendo que o ensaio de fluência do geossintético em isolamento superestimou as deformações por um fator de aproximadamente 4. Em contraste, para o caso da argila, o solo apresenta uma taxa de deformação maior que a do geotêxtil, sendo que o ensaio do reforço isolado subestimou as deformações por um fator de aproximadamente 2,5.

No trabalho realizado por Wu e Helwany (1996) as deformações do reforço foram significativamente afetadas pelo solo confinante. Segundo os resultados publicados pelos autores, no caso em que o solo apresenta uma tendência de se deformar mais lentamente que o reforço, em virtude da resistência de interface por atrito e adesão existente entre os materiais, o solo irá restringir as deformações do geossintético. $O$ inverso ocorre para o caso em que o material confinante apresenta uma tendência 
de se deformar mais rapidamente que o reforço. Neste caso entende-se que o geossintético irá restringir as deformações do solo.

\subsubsection{Ensaios para a avaliação de fluência em geossintéticos}

De forma geral, os ensaios realizados para caracterizar a fluência de geossintéticos podem ser divididos em duas grandes categorias: ensaios não confinados (ou em isolamento) e ensaios confinados.

A presença ou não do confinamento leva em conta o fato de o corpo de prova avaliado estar ou não submetido aos efeitos de tensões confinantes durante a realização dos ensaios.

Os ensaios de fluência confinados claramente se aproximam mais de uma situação real de obra quando comparados aos ensaios de fluência em isolamento. Entretanto, devido à complexidade inerente aos equipamentos empregados nos ensaios confinados e na interpretação dos resultados dos mesmos, grande parte dos dados encontrados na bibliografia sobre fluência de geossintéticos provém de ensaios de laboratório nos quais o material é estudado isoladamente. Nestes ensaios, corpos de prova com $200 \mathrm{~mm}$ de largura por $200 \mathrm{~mm}$ de comprimento são submetidos a carregamentos constantes, sendo tais carregamentos uma porcentagem da resistência à tração, normalmente entre 10 e 60\%. Ao longo do ensaio, as deformações são registradas em tempos pré-estabelecidos, até que o material sofra ruptura ou o tempo limite seja atingido.

Um dos principais problemas associado aos ensaios de fluência não confinada se refere ao tempo requerido para que se obtenha uma resposta significativa (MATICHARD et al., 1990). A norma ISO 13431, por exemplo, indica que o tempo mínimo para os ensaios de fluência em isolamento deve ser de 1.000 horas, ou seja, cerca de 42 dias. Já a norma ASTM D-5262 indica um tempo de 10.000 horas, o que representa cerca de 1 ano e 3 meses de ensaio. A norma brasileira que prescreve o método para determinação do comportamento em deformação e na ruptura por fluência sob tração não confinada de geossintéticos é a NBR 15226:2005. Esta norma, a exemplo da ISO 13431, indica que os ensaios de fluência devem ser conduzidos por um tempo mínimo de 1.000 horas. 
Um recurso que pode ser empregado para superar o problema do tempo em ensaios de fluência consiste na utilização de temperaturas elevadas, já que a deformação por fluência dos geossintéticos é proporcional à temperatura sob a qual o ensaio é conduzido. Sendo assim, este princípio é empregado para acelerar a determinação do comportamento em fluência dos geossintéticos. Os ensaios realizados com este princípio são denominados ensaios acelerados. Na literatura, grande parte dos resultados publicados de ensaios acelerados se refere a condições não confinadas. Isto se deve, principalmente, à elevada complexidade dos equipamentos para a execução de ensaios confinados. Entretanto, com o avanço da tecnologia, já existem trabalhos recentes, como os de França (2011) e Avesani (2013) em que a aceleração do processo de fluência por meio do aumento de temperatura é aplicada em ensaios com a presença do confinamento.

Com relação aos ensaios de fluência que utilizam confinamento, não existe um consenso no que diz respeito ao procedimento de execução do ensaio, visto que estes ainda não se encontram normalizados. Segundo Costa (2004), considera-se que se podem distinguir duas abordagens distintas em ensaios com confinamento: ensaios nos quais a carga é aplicada diretamente ao geossintético e ensaios nos quais o solo solicita o geossintético.

No primeiro caso, o geossintético é confinado entre duas camadas de solo e uma força de tração é aplicada diretamente ao reforço, por meio de pesos mortos, por exemplo. Neste caso é possível avaliar o comportamento do reforço quando confinado em solo, considerando o efeito da tensão confinante, bem como uma eventual impregnação de partículas (COSTA, 2004; KAMIJI, 2006).

No outro tipo de ensaio, o geossintético é confinado entre duas camadas de solo que se encontram livres para se deformar. O carregamento é então aplicado ao solo, que ao se deformar, solicita o material de reforço. Neste caso pode-se avaliar, por exemplo, como a tendência à fluência do solo interfere na fluência do reforço.

Como salientado anteriormente, os ensaios para a caracterização de fluência de geossintéticos podem ser divididos em dois grandes grupos, conforme apresentado na Figura 2.54. 


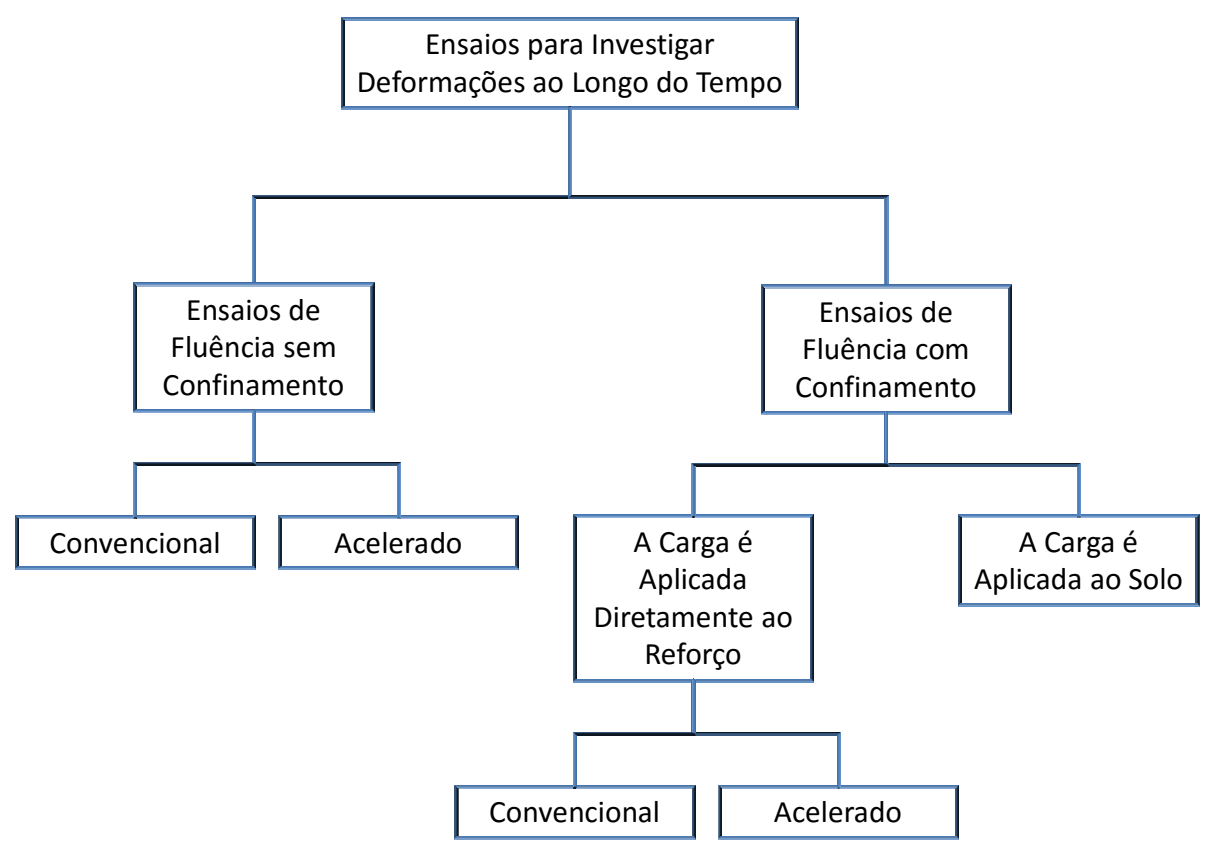

Figura 2.54 - Tipos de ensaios para investigar as deformações ao longo do tempo de geossintéticos.

\subsubsection{Ensaios de fluência convencional (em isolamento)}

Para a realização de ensaios não confinados de fluência existem algumas normas disponíveis: ISO 13431, ASTM D-5262, BS 6906 e NBR 15226.

Em geral, os equipamentos empregados para a realização de ensaios de fluência não confinados são considerados relativamente simples. Segundo Costa (1999), apesar de algumas variações do modelo básico, os equipamentos apresentam três partes principais: sistema de ancoragem, sistema para acompanhamento das deformações e sistema de aplicação de carga.

O esquema básico do equipamento para ensaios de fluência não confinada (em isolamento) é composto por um cavalete dotado de uma garra superior para fixação do corpo de prova e aplicação do carregamento (Figura 2.55). As garras para fixação do geossintético devem possuir, no mínimo, a mesma largura do corpo de prova e impedir o seu deslizamento. Durante o ensaio, um conjunto de pesos livres submete a amostra a um esforço de tração constante, ao passo que as deformações são registradas ao longo do tempo. 


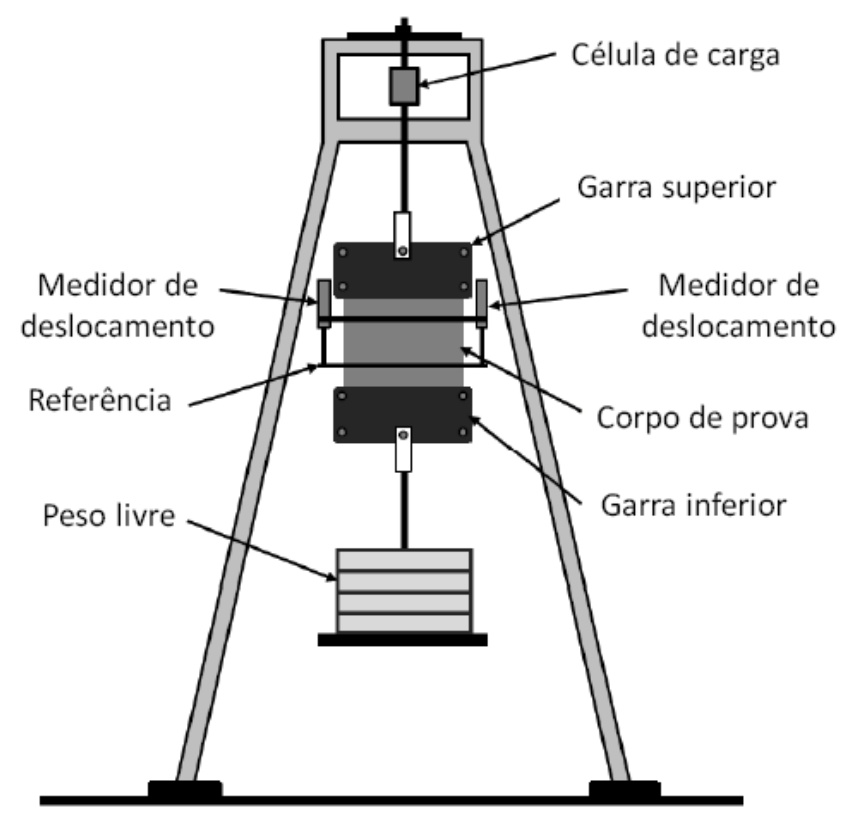

Figura 2.55 - Equipamento empregado nos ensaios de fluência não confinada (Adaptado de ASTM D-5262, 2007).

Segundo Costa (1999) e Kamiji (2006) para que não haja influência de fatores que possam afetar a qualidade dos resultados, algumas recomendações devem ser respeitadas:

- Deve-se evitar o escorregamento relativo entre as garras e o corpo de prova;

- As garras devem ser projetadas de tal modo que não danifiquem o material a ser ensaiado;

- Quanto ao equipamento, o suporte deve ser constituído de material rígido, para evitar deformações, e também estar isolado de vibrações;

- O carregamento deve ser aplicado de forma rápida e suave, mantendo-se constante durante todo o ensaio.

Para os ensaios de fluência convencional, duas abordagens distintas podem ser adotadas, dependendo do aspecto a ser investigado. Para casos em que a determinação do comportamento em deformação por fluência do geossintético ao longo do tempo é importante, carregamentos entre 10\% e 60\% da resistência última à tração do material são geralmente empregados. As normas recomendam que pelo menos quatro níveis de carregamento sejam aplicados em diferentes corpos de 
prova e que as deformações sejam registradas por um período entre 1.000 e 10.000 horas. Para casos em que a determinação da ruptura por fluência é importante, carregamentos entre $60 \%$ e $90 \%$ da resistência última à tração do material são aplicados. Para este caso, procede-se com o registro das deformações e do tempo até que o corpo de prova sofra ruptura. As normas recomendam a utilização de três corpos de prova para cada nível de carregamento utilizado.

\subsubsection{Ensaios acelerados de fluência}

Um dos maiores empecilhos relacionados aos ensaios convencionais de fluência é o tempo necessário para a sua execução. No entanto, devido ao comportamento dos geossintéticos diante ao aumento de temperatura, um recurso geralmente empregado para superar essa limitação é a utilização de temperaturas elevadas durante a execução do ensaio, juntamente com o emprego de ferramentas para tratamentos dos dados (ALLEN, 1991).

Segundo Farrag (1998), quando as deformações por fluência são apresentadas em função do tempo de ensaio em diferentes temperaturas, as curvas logarítmicas obtidas podem ser transladadas de forma a se sobreporem e permitirem a obtenção de uma curva única. Dessa forma, a realização de diferentes ensaios de fluência com corpos de prova submetidos ao mesmo nível de carregamento, mas em temperaturas diferentes, permite a construção de uma curva que representa as deformações do geossintéticos até um valor de tempo maior, denominada curva mestra de fluência (FRANÇA, 2011). A Figura 2.56 ilustra esse processo. 


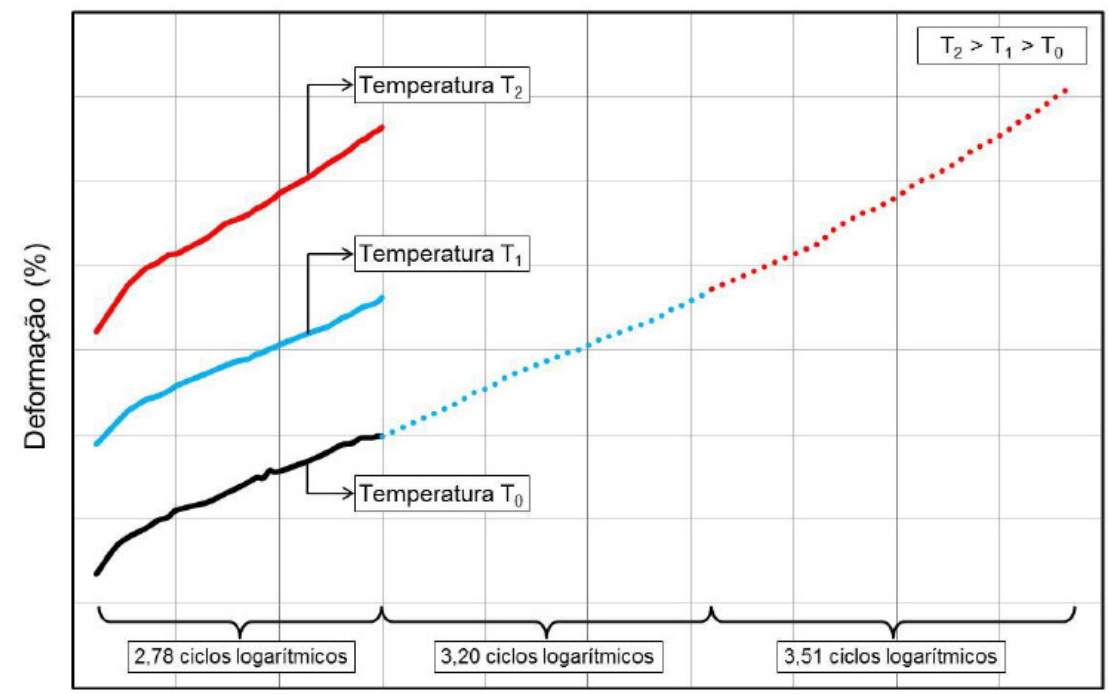

Log Tempo (h)

Figura 2.56 - Translação horizontal dos resultados de ensaios de fluência conduzidos em temperaturas diferentes com o mesmo nível de carregamento (FRANÇA, 2011).

O procedimento geralmente empregado em geossintéticos para a realização da translação horizontal dos dados obtidos em temperaturas elevadas foi elaborado por Williams et al. (1955) e introduz o conceito de fator de translação, (do inglês, shift fator). O fator de translação é definido como a razão entre o tempo necessário para que um processo viscoelástico ocorra em uma temperatura qualquer e o tempo necessário para que o mesmo processo ocorra em uma temperatura de referência (THORNTON; ALLEN; THOMAS, 1997). A relação de tempos que representa o fator de translação é mostrada na eq. (2.5).

$$
\alpha_{T}=\frac{t_{T}}{t_{R}}
$$

Em que $\alpha_{T}$ é o fator de translação, t t é o tempo necessário para que o referido processo ocorra na temperatura $T$ (elevada) e $t_{R}$ é o tempo necessário para que o referido processo ocorra na temperatura de referência, geralmente adotada como sendo a temperatura ambiente.

Quando se considera a deformação dos corpos de prova nos ensaios de fluência como processo em questão, essa equação assume a forma apresentada na eq. (2.6). 


$$
\varepsilon_{T_{0}}\left(T_{i j}, t\right)=\varepsilon_{T}\left(T, \frac{t}{a_{t}}\right)
$$

Em que $\varepsilon_{\mathrm{To}}$ é a deformação na temperatura de referência, T é a temperatura de referência, té o tempo, $\varepsilon_{\mathrm{T}}$ é a deformação em temperatura elevada e $\alpha_{\mathrm{T}}$ é o fator de translação.

O fator de translação pode assumir diferentes valores, determinados em função da diferença entre a temperatura de ensaios e a temperatura de referência. A Figura 2.57 ilustra essa relação entre o fator de translação e a temperatura a partir de resultados de ensaios de fluência conduzidos com uma geogrelha de PEAD (FARRAG, 1998).

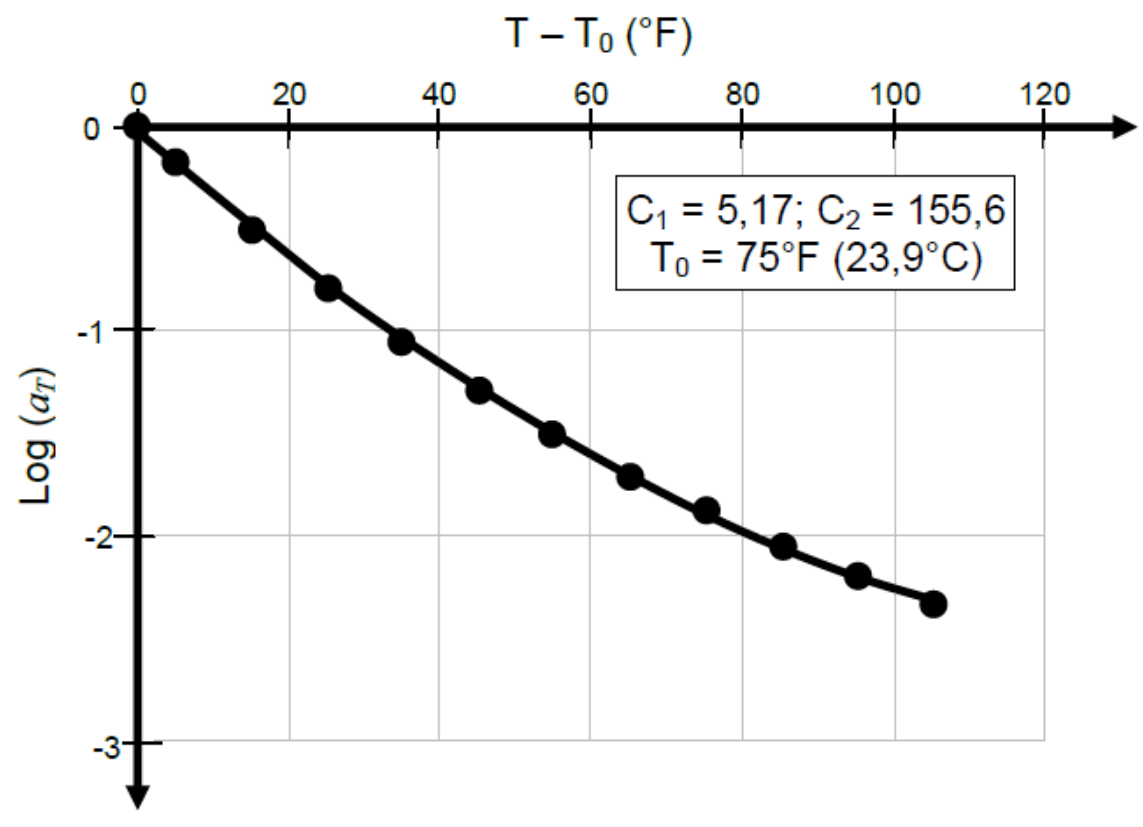

Figura 2.57 - Exemplo da variação do fator de translação com a temperatura de ensaio para uma geogrelha de PEAD (adaptado de FARRAG, 1998).

Esse fator é obtido empiricamente e é descrito pela Equação WLF, na eq. (2.7).

$$
\log \left(\alpha_{T}\right)=\frac{-\varepsilon_{1}\left(T-T_{0}\right)}{C_{2}+T-T_{0}}
$$

Em que $\mathrm{C}_{1}$ e $\mathrm{C}_{2}$ são constantes determinadas empiricamente. 
As constantes empíricas e dependem do tipo de polímero com o qual o geossintético foi fabricado, da temperatura de transição vítrea desse polímero e da temperatura de referência. A Equação WLF não é aplicável para valores de temperatura muito inferiores à temperatura de transição vítrea $(\mathrm{Tg})$ do polímero uma vez que prevê um crescimento monotônico do logaritmo de com o decréscimo da temperatura. Além disso, o logaritmo de seria igual a infinito quando $\mathrm{T}=\mathrm{T}-\mathrm{C} 2$. Contudo, entre $\mathrm{Tg}$ e $(\mathrm{Tg}+100)$, essa fórmula pode ser empregada para determinar o efeito da temperatura em processos mecânicos e dielétricos (WILLIAMS; LANDEL; FERRY, 1955).

O procedimento para aceleração da determinação do comportamento em fluência dos geossintéticos apresentado até aqui requer a utilização de vários corpos de prova, cada qual submetido a um mesmo nível de carregamento, mas em valores de temperatura diferentes. A partir desses ensaios e da translação horizontal dos resultados obtidos em temperatura elevada, pode-se formar a curva mestra do referido geossintético, num determinado nível de carregamento. Farrag e Shirazi (1997), Farrag (1998) e Jeon; Kim e Yoo (2002) apresentam estudos onde essa metodologia foi empregada para interpretar os resultados de ensaios de fluência em geossintéticos realizados em temperaturas elevadas.

Essa metodologia apresenta-se, portanto, como uma técnica de grande aplicabilidade nos ensaios acelerados de fluência. Contudo, o uso de diferentes corpos de prova para obtenção das curvas de fluência em temperaturas elevadas pode levar à produção de resultados incoerentes devido à variabilidade inerente ao processo de fabricação dos geossintéticos.

\subsubsection{Ensaios confinados de fluência em geossintéticos}

$\mathrm{Na}$ bibliografia especializada encontram-se diversos estudos relacionados à fluência confinada de materiais geossintéticos. Existem basicamente duas categorias de equipamentos para a realização de ensaios de fluência confinada, sendo que estas se diferenciam pela forma de transferência das solicitações de tração para o geossintético. Existem os equipamentos nos quais o carregamento é aplicado diretamente no reforço, de forma semelhante ao que ocorre nos ensaios de fluência 
convencional, e existem os equipamentos nos quais a tensão confinante é aplicada ao solo, e este, por sua vez, transfere os carregamentos ao material de reforço. Os detalhes dos principais equipamentos desenvolvidos para fins de ensaios de fluência confinada encontrados na bibliografia são descritos na sequência.

2.5.4.3.1 Ensaios nos quais a carga é aplicada diretamente no reforço

Nesta abordagem, o geossintético é confinado entre camadas de solo e uma força é aplicada diretamente ao material de reforço, por meio da utilização de pesos mortos, por exemplo, assim como realizado em ensaios de fluência em isolamento (ensaio convencional). Além da força de tração aplicada no reforço, emprega-se ainda, uma tensão vertical sobre o solo que confina o geossintético.

Segundo a FHWA (1998), os equipamentos para ensaios de fluência confinada que aplicam o carregamento diretamente no reforço se mostram mais adequados para isolar a influência do confinamento nos ensaios de fluência e tração, visto que nestes casos, a solicitação de tração é aplicada com uma taxa de deslocamento constante, ou seja, de forma idêntica ao que ocorre nos ensaios convencionais (não confinados). Uma configuração esquemática empregada em ensaios confinados de fluência em geossintético na qual o carregamento é aplicado diretamente ao corpo de prova pode ser vista na Figura 2.58.

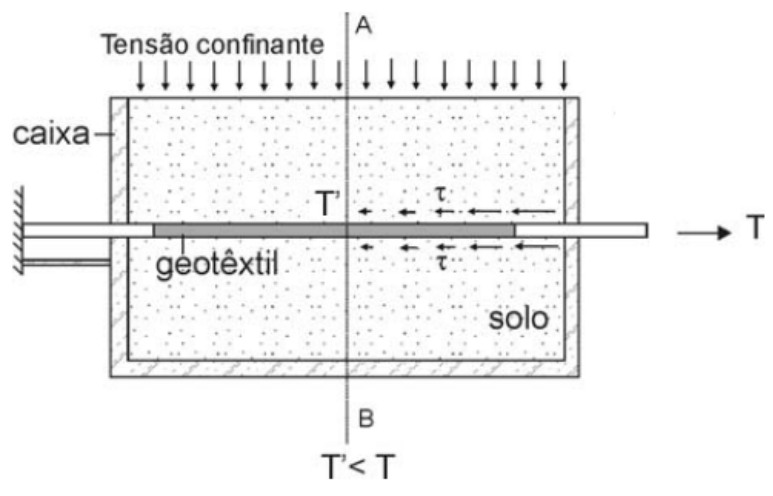

Figura 2.58 - Configuração empregada em ensaios confinados de fluência em geossintético na qual o carregamento é aplicado diretamente ao corpo de prova (COSTA, 2004). 
Uma desvantagem deste tipo de equipamento reside no fato de que ocorre um deslocamento relativo entre o solo confinante e o geossintético, provocando mobilizações de forças de atrito no contato. Esse processo resulta em um comportamento carga-alongamento que reflete dois mecanismos distintos: ação do confinamento e ação das forças de atrito e/ou adesão ao longo da interface (COSTA, 2004; KAMIJI, 2006). Segundo França (2011), a solicitação de tração que atinge o centro do corpo de prova ( $\left.T^{\prime}\right)$ é menor que a força aplicada na garra posicionada fora da câmara de ensaio (T).

Este fato dificulta a interpretação dos resultados dos ensaios, visto que as deformações por fluência obtidas em equipamentos que utilizam esta configuração certamente serão menores em função da redução da carga de tração atuante ao longo do corpo de prova. O fato de não levar em consideração esta redução nas forças de tração pode conduzir a erros de interpretação nos resultados dos ensaios, atribuindo-se erroneamente ao confinamento, a redução da fluência observada no geossintético.

McGown; Andrawes e Kabir (1982) apresentam os primeiros resultados de ensaios de fluência de geotêxteis não tecidos confinados por solo. No equipamento desenvolvido pelos autores, o geotêxtil é confinado em contato com camadas de solo de 10 ou $25 \mathrm{~mm}$ de espessura, em ambas as faces, sendo a tensão confinante aplicada por meio da utilização de bolsas pressurizadas por ar comprimido. Para a aplicação das forças de tração no reforço foi empregado um sistema composto por um conjunto de pesos. O equipamento desenvolvido por McGown; Andrawes e Kabir (1982) é apresentado de forma esquemática na Figura 2.59. 


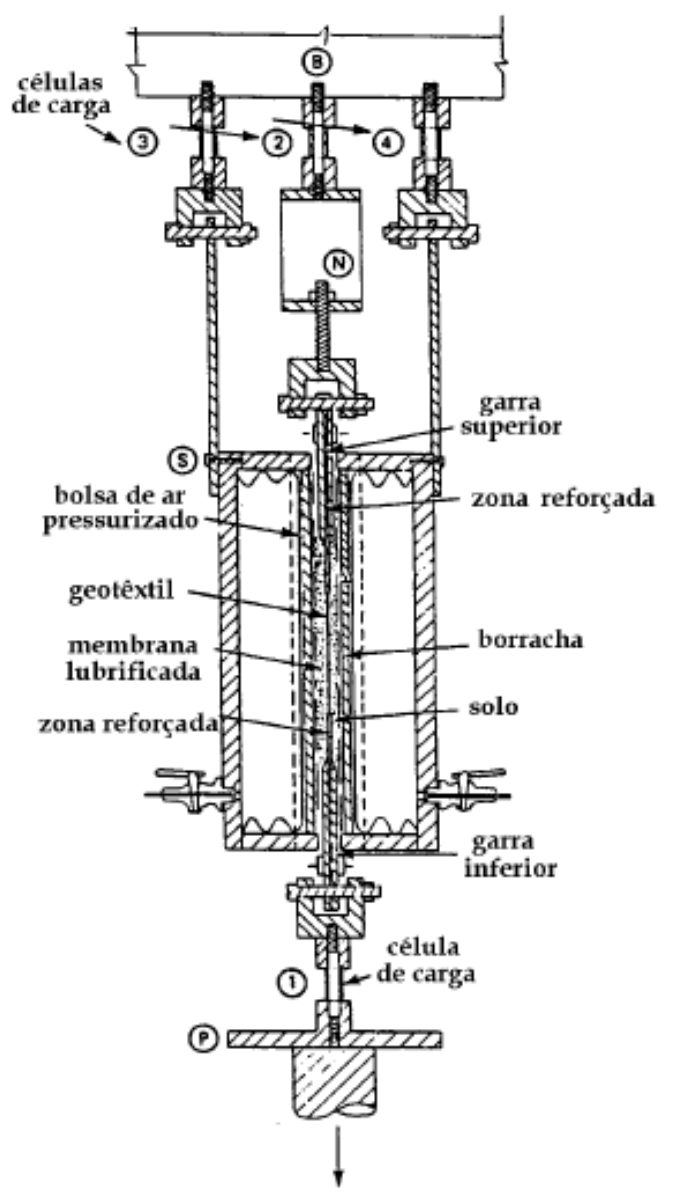

Figura 2.59 - Sistema de confinamento empregado em estudo pioneiro sobre o efeito do confinamento do solo em fluência de geossintéticos (MCGOWN; ANDRAWES; KABIR, 1982).

As principais dificuldades encontradas durante 0 desenvolvimento desse equipamento, segundo os próprios autores, se referem à manutenção do contato solo-geotêxtil durante o processo de deformação do geossintético, perfuração da bolsa por partículas de solo e ainda a transferência da carga aplicada em virtude das forças de atrito. Segundo Costa (2004) e Kamiji (2006), as principais críticas associadas a esse equipamento se referem às dificuldades de montagem do ensaio, principalmente na etapa de preparação do solo. Nos ensaios desenvolvidos por McGown; Andrawes e Kabir (1982), foram empregadas apenas camadas de areia. Entretanto, a necessidade de compactação, em casos de solos finos, deve constituir um empecilho no uso deste aparato, exigindo algum tipo de adaptação.

Em pesquisa recente, França (2011) desenvolveu um equipamento para ensaios de fluência confinada em geossintéticos, baseado no sistema clássico proposto por McGown; Andrawes e Kabir (1982). A diferença do novo equipamento em relação ao 
sistema clássico reside no fato de que no novo sistema o carregamento é aplicado em ambas as extremidades do reforço. O equipamento desenvolvido por França (2011) é capaz de realizar, simultaneamente, ensaios de fluência confinados e acelerados em geossintéticos. Tal ensaio é denominado de ensaio confinadoacelerado. A Figura 2.60 apresenta um esquema geral do equipamento desenvolvido por França (2011).

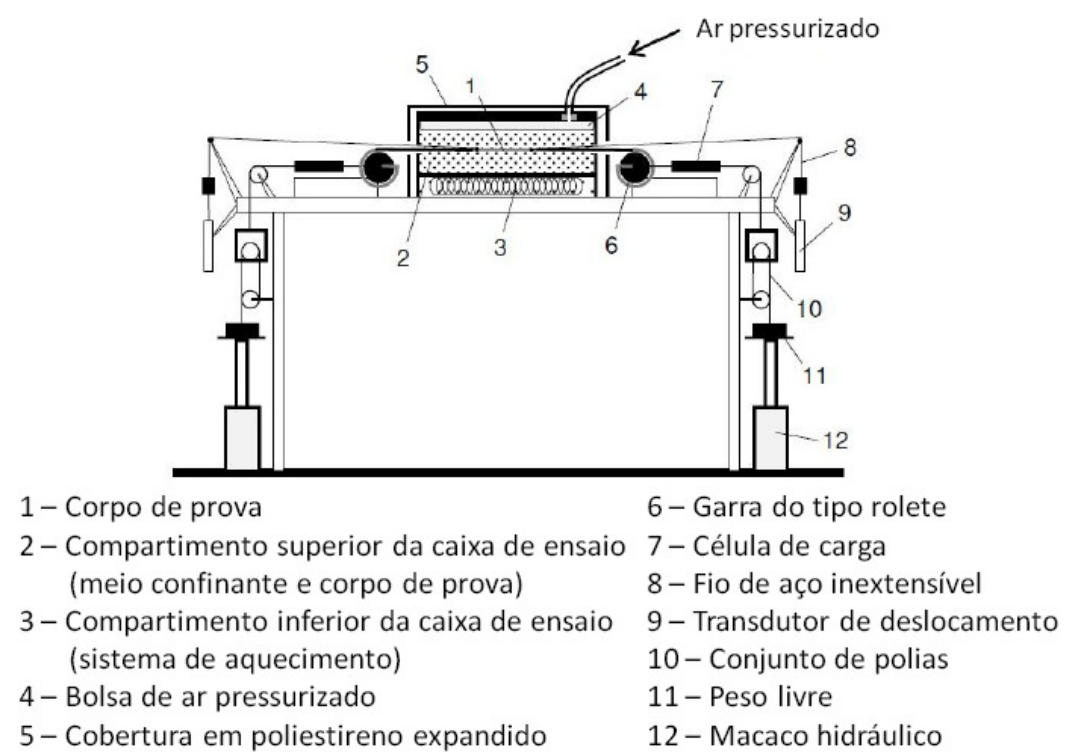

Figura 2.60 - Equipamento para ensaios de fluência confinada e acelerada em geossintéticos desenvolvido por França (2011).

Como pode ser observado, neste equipamento o corpo de prova é posicionado na parte superior de uma câmara, que pode ou não ser preenchida com solo de forma a simular a presença do meio confinante. Uma bolsa de ar pressurizado é utilizada sobre o solo, permitindo a aplicação de uma tensão vertical sobre o mesmo. 0 sistema de aquecimento, localizado no compartimento inferior da câmara de ensaio, conta com resistências elétricas para o desenvolvimento da temperatura desejada. O corpo de prova é fixado em garras do tipo rolete, que são conectadas ao sistema de carregamento, composto por conjunto de polias e pesos livres. O alongamento do material é medido durante o desenvolvimento do ensaio.

Resultados apresentados por França e Bueno (2011) e Avesani (2013) mostram que o equipamento é capaz de executar ensaios de fluência tanto em isolamento (não confinado) quanto confinados em solo. França (2011) afirma que é possível a 
realização de quatro diferentes tipos de ensaios de fluência em geossintéticos empregando esse equipamento: convencional, confinado, acelerado e conjuntamente confinado e acelerado.

\subsection{Ensaios nos quais o solo solicita o reforço}

Nesta abordagem de ensaios, de forma oposta ao que ocorre nos equipamentos apresentados anteriormente, o carregamento não é aplicado diretamente ao reforço. Nesta categoria de ensaios, o reforço se encontra localizado entre duas camadas de solo, e este, por sua vez, recebe um carregamento vertical, e por meio da interação solo-geossintético, solicita o reforço com uma força de tração. Destaca-se, que o processo de solicitação do geossintético é bem mais condizente com as condições presentes nas estruturas de solo reforçado, já que o solo solicita o material (COSTA, 2004).

A Figura 2.61 mostrada a seguir ilustra, de forma esquemática, um sistema de ensaio de fluência confinada em que o solo solicita o reforço.

Em pesquisas realizadas na bibliografia especializada, encontram-se alguns autores que buscaram o desenvolvimento de equipamentos para ensaios de fluência confinada com este princípio de funcionamento. A seguir são apresentados os principais equipamentos relatados na literatura com o intuito de expor e discutir suas principais características.

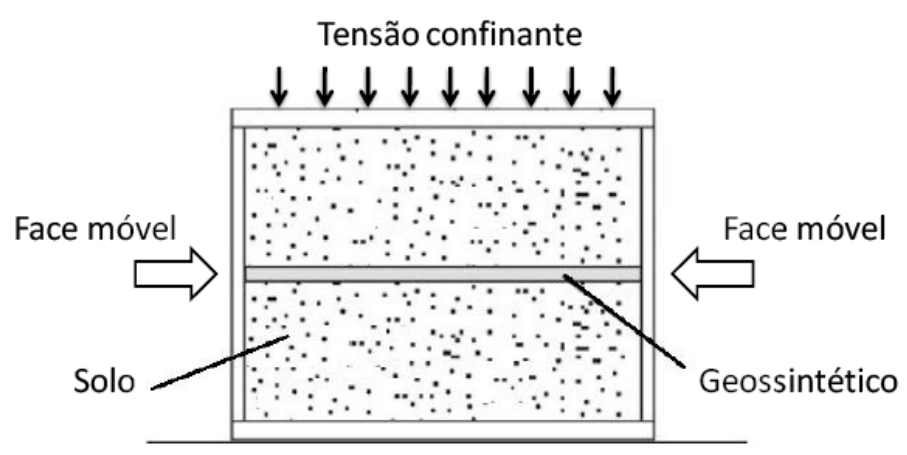

Figura 2.61 - Esquema geral de um equipamento em que o solo solicita o geossintético (adaptado de COSTA, 2004). 
Wu e Hong (1994) desenvolveram um equipamento para ensaios de fluência confinada baseado nos aparatos utilizados em ensaios de cisalhamento direto. Um esquema geral deste equipamento pode ser visto na Figura 2.62. No sistema proposto pelos autores, a aplicação da força de tração no reforço, o qual se encontra situado entre duas camadas de solo, é feita por meio do uso de um compressor, sendo que as tensões confinantes são aplicadas através de câmaras de ar.

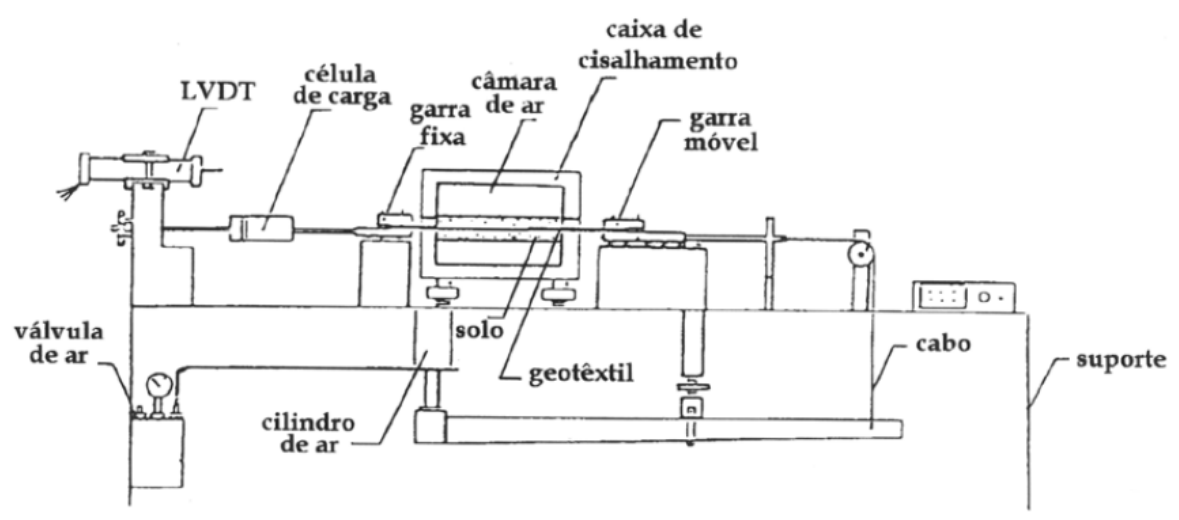

Figura 2.62 - Esquema geral do equipamento proposto por Wu e Hong (1994).

Wu e Helwany (1996) propuseram um equipamento constituído basicamente por um elemento de solo reforçado, inserido no interior de uma caixa rígida. Nesta proposta de equipamento, o elemento reforçado era composto por duas camadas de solo, pelo material de reforço e ainda por duas placas metálicas móveis que permitiam a deformação do solo e do reforço ao longo do tempo. O equipamento contava ainda com a presença de uma placa rígida, situada sobre o elemento de solo, responsável pela distribuição uniforme de uma carga constante aplicada sobre o elemento reforçado.

Segundo os autores, o aparato desenvolvido possuía flexibilidade para a realização de ensaios com elementos de solo de diferentes larguras e alturas. O monitoramento dos ensaios de comportamento em longo prazo era realizado por meio do emprego dos seguintes instrumentos: células de carga, transdutores de poro pressão, strain gages, potenciômetros e relógios comparadores. Um esquema geral do equipamento proposto por Wu e Helwany (1996) pode ser visto na Figura 2.63. 


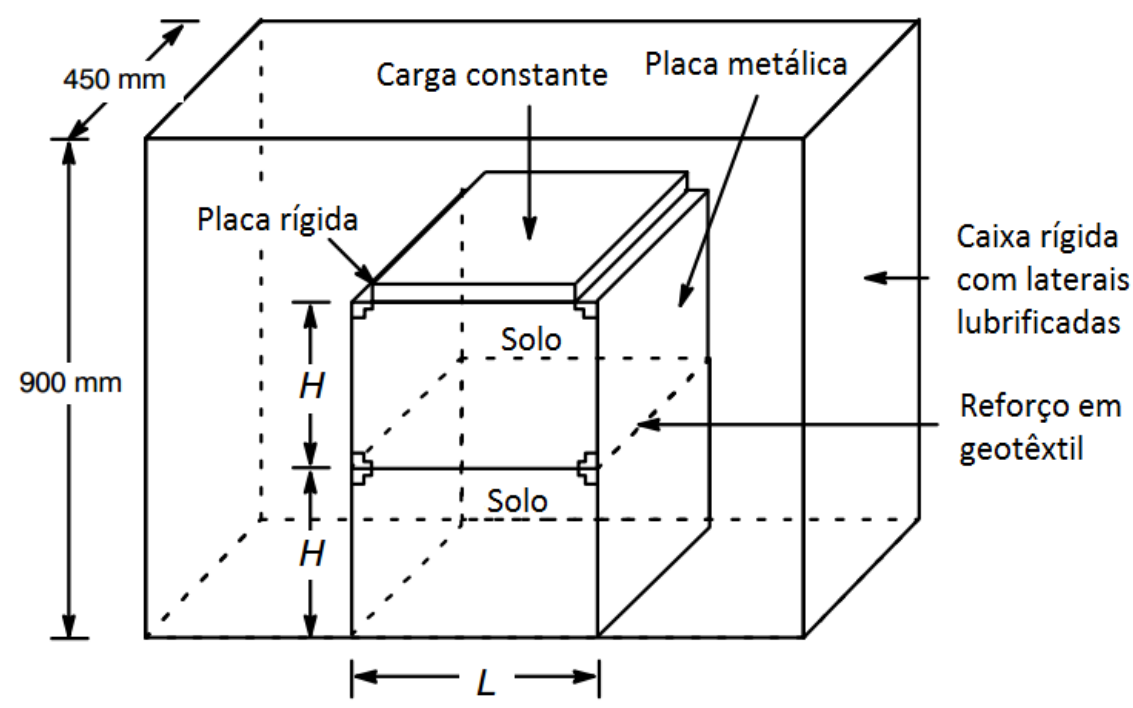

Dimensões:

Ensaios com areia:

$L=813 \mathrm{~mm}$

$H=305 \mathrm{~mm}$

Ensiaos com argila:

$L=457 \mathrm{~mm}$

$H=254 \mathrm{~mm}$

Figura 2.63 - Esquema geral do equipamento proposto por Wu e Helwany (1996).

Os autores realizaram ensaios com dois diferentes tipos de solo, uma areia e uma argila, e como material de reforço, empregaram um geotêxtil não tecido de polipropileno com resistência última de aproximadamente $6 \mathrm{kN} / \mathrm{m}$ e deformação na ruptura da ordem de $60 \%$.

Para efeitos de comparação, os autores realizaram ensaios de fluência em isolamento (não confinada) no geossintético empregado. Os ensaios em isolamento foram conduzidos com carregamentos correspondentes a $25 \%$, 35\% e $45 \%$ da carga última do reforço. Wu e Helwany (1996) utilizaram os resultados dos ensaios de fluência convencional para estimar os resultados dos ensaios confinados.

Os resultados publicados pelos autores mostraram que as deformações por fluência foram superestimadas, para ensaios com areias, por um fator de aproximadamente 4. Por outro lado, nos ensaios realizados com argilas, as deformações por fluência foram subestimadas por um fator de aproximadamente 2,5.

Os autores concluíram que o confinamento exerce um papel muito importante no comportamento em longo prazo de geossintéticos, indicando que erros podem acontecer ao se avaliar o potencial de ocorrência de fluência em obras reais de 
solos reforçados com geossintéticos, com base em ensaios de fluência convencional.

Helwany e Shih (1998) descrevem o desenvolvimento de um aparato capaz de medir simultaneamente a fluência e a relaxação em compostos de solo-reforço, que simulam o comportamento de materiais geossintéticos confinados em solo.

O equipamento desenvolvido pelos autores era constituído por uma caixa com capacidade para acomodar um corpo de prova com dimensões de $200 \times 300 \times 300$ $\mathrm{mm}$. Nesta configuração o reforço fica confinado entre duas camadas de solo, cada uma delas com espessura de 100 mm, e a tensão vertical, que simula a solicitação in situ de uma situação típica de obra em solo reforçado, é realizada por meio de bolsas de ar comprimido que aplicam uma tensão constante no topo e na base do corpo de prova. O equipamento conta ainda com a presença de uma bolsa de ar posicionada na lateral, que possibilita a aplicação de uma tensão confinante horizontal.

No equipamento proposto por Helwany e Shih (1998), uma das laterais é constituída por uma chapa de aço flexível, com 0,5 mm de espessura. Esta face é móvel e se encontra conectada ao reforço por meio de uma garra. A outra face do equipamento, oposta à face móvel é fixa, não apresentando deslocamento durante o ensaio. As demais faces do equipamento também são fixas, de forma a garantir a manutenção do estado plano de deformações. Um esquema geral do aparato proposto por Helwany e Shih (1998) é apresentado na Figura 2.64 a seguir. 


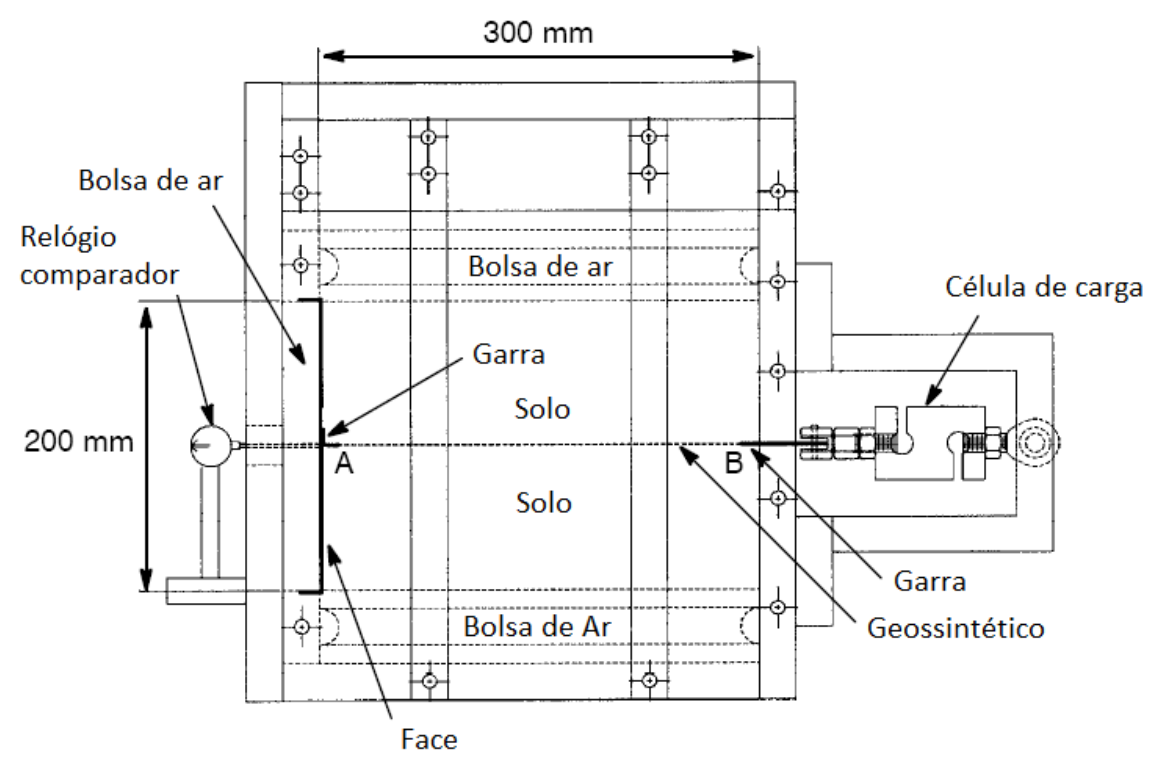

Figura 2.64 - Esquema geral do equipamento proposto por Helwany e Shih (1998).

Conforme pode ser observado na Figura 2.64, o equipamento conta com a presença de uma célula de carga situada no ponto $B$, que possibilita o registro da força que atua no geossintético. A desvantagem desse aparato reside no fato de que o mesmo não permite a obtenção das deformações no reforço. Entretanto, o equipamento descrito apresenta como grande vantagem a possibilidade de realização de ensaios de fluência e relaxação simultaneamente. Este fato mostra a importância do equipamento visto que os fenômenos de fluência e relaxação ocorrem de forma concomitante em estruturas de solo reforçado com geossintéticos.

Os primeiros ensaios realizados pelos autores foram executados empregando geotêxteis tecidos de polipropileno e dois diferentes tipos de solo: uma areia e uma argila. Os resultados dos ensaios permitiram aos autores concluírem que o comportamento dependente do tempo dos solos confinantes exerce grande influência sobre o comportamento em longo prazo de fluência e relaxação dos geossintéticos. Segundo Helwany e Shih (1998), a previsão do comportamento em longo prazo de estruturas de solo reforçado pode levar a erros ao se considerar apenas resultados de ensaios de fluência em isolamento.

Em termos de equipamentos para ensaios de fluência confinada em geossintéticos que se baseiam no princípio de funcionamento em que o solo solicita o reforço, o aparato mais moderno foi desenvolvido Costa (2004). É importante destacar que tal 
equipamento foi desenvolvido visando a obtenção tanto da carga quanto da deformação nos reforços.

O equipamento desenvolvido por Costa (2004) é composto basicamente por uma caixa fixa em uma mesa de apoio, um conjunto de garras para a fixação do geotêxtil, um sistema de bolsas pneumáticas para a aplicação das tensões verticais sobre o solo e um sistema para a obtenção de deformações no reforço por meio do uso de relógios comparadores. Neste equipamento, um corpo de prova de geossintético com dimensões de 200 x 200 mm é confinado entre camadas de solo de $100 \mathrm{~mm}$ de espessura. O reforço é instrumentado com tell-tales permitindo a obtenção das deformações em diferentes trechos do corpo de prova. Uma representação esquemática do equipamento proposto por Costa (2004) é mostrada na Figura 2.65.

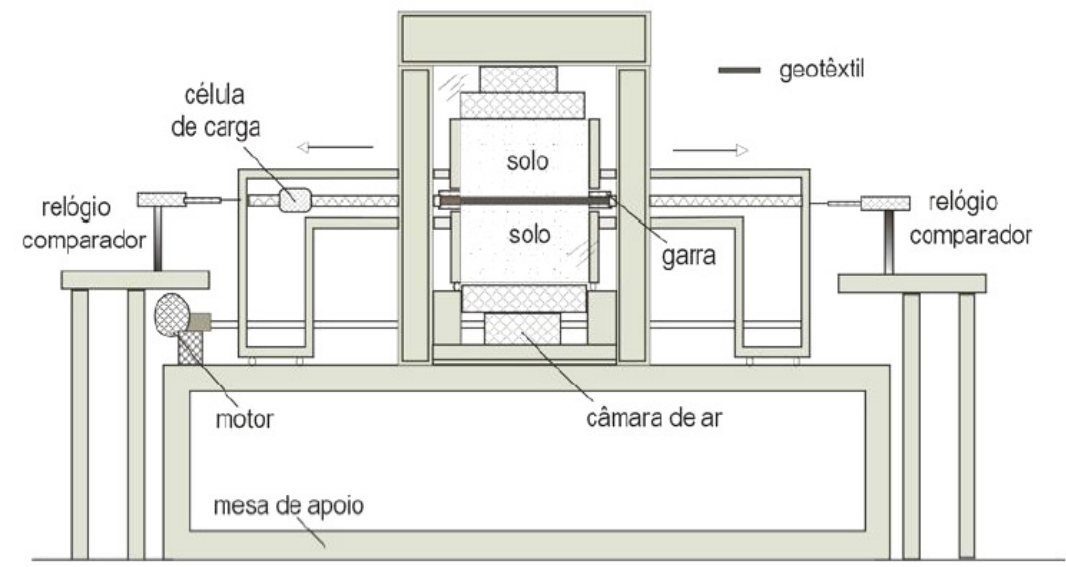

Figura 2.65 - Representação esquemática do equipamento desenvolvido por Costa (2004).

Com base em pesquisas realizadas na literatura é possível afirmar que este aparato representa um avanço em relação aos demais equipamentos descritos anteriormente. Isto se deve ao fato de que este equipamento permite o registro das deformações e das forças nos reforços, possibilitando, portanto, a avaliação da variação destes fatores ao longo do tempo. Além disso, tal equipamento permite a realização de ensaios de relaxação, e ainda, ensaios somente com solo, sem a presença do reforço. Ensaios que utilizam somente solo possibilitam a avaliação da fluência do material confinante e também uma estimativa da altura crítica do solo, ou seja, da profundidade na qual o empuxo se anula. Uma vista geral do equipamento desenvolvido por Costa (2004) é mostrada na Figura 2.66. 


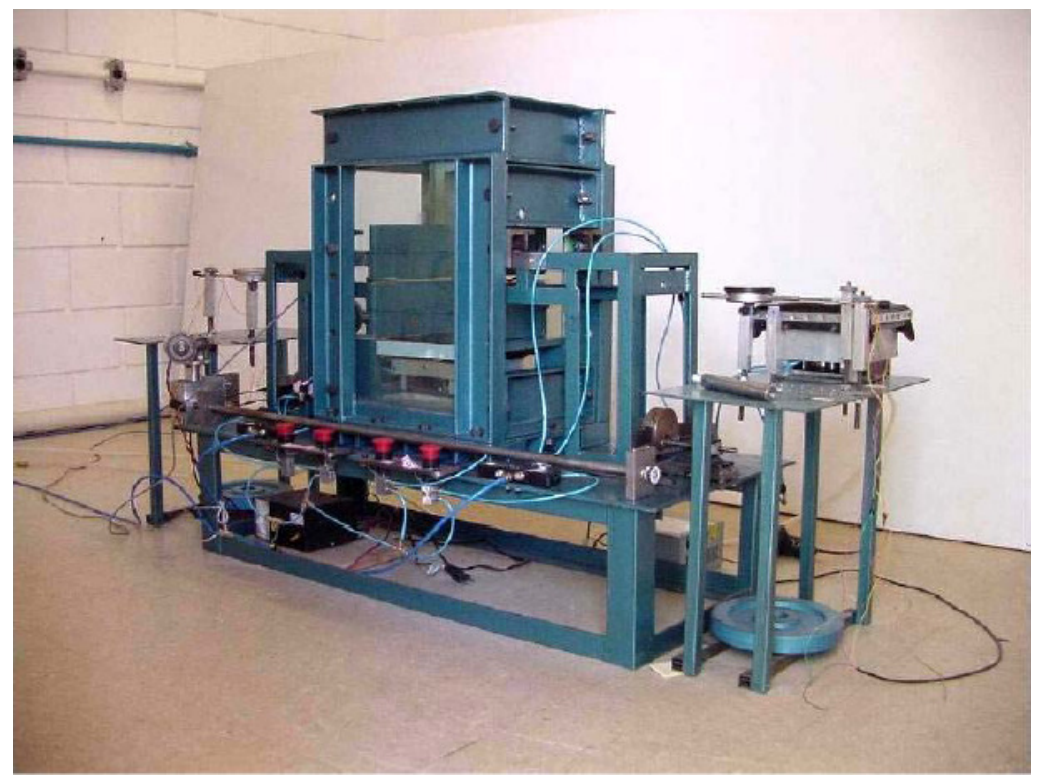

Figura 2.66 - Vista geral do equipamento desenvolvido por Costa (2004).

O princípio de funcionamento deste equipamento consiste na aplicação de uma tensão vertical sobre as camadas de solo por meio da utilização de câmaras de ar pressurizado, resultando no desenvolvimento de forças horizontais $\left(F_{h 1}\right.$ e $\left.F_{h 2}\right)$ sobre a parede móvel (Figura 2.67). Por consequência da ação de $F_{h 1}$ e $F_{h 2}$ a parede móvel tende a se movimentar, entretanto, seu movimento é limitado pela presença do reforço, o qual se encontra ligado ao pórtico por meio de um sistema de garras. Neste mecanismo, o geossintético se deforma e permite o deslocamento da lateral móvel até que os esforços no reforço atinjam um valor de equilíbrio igual a somatória de $F_{h 1}$ e $F_{h 2}$.

Neste equipamento, a célula de carga se encontra posicionada em um local estratégico, situada entre o pórtico e a garra que prende o reforço, permitindo assim o registro dos esforços resultantes no geossintético. 


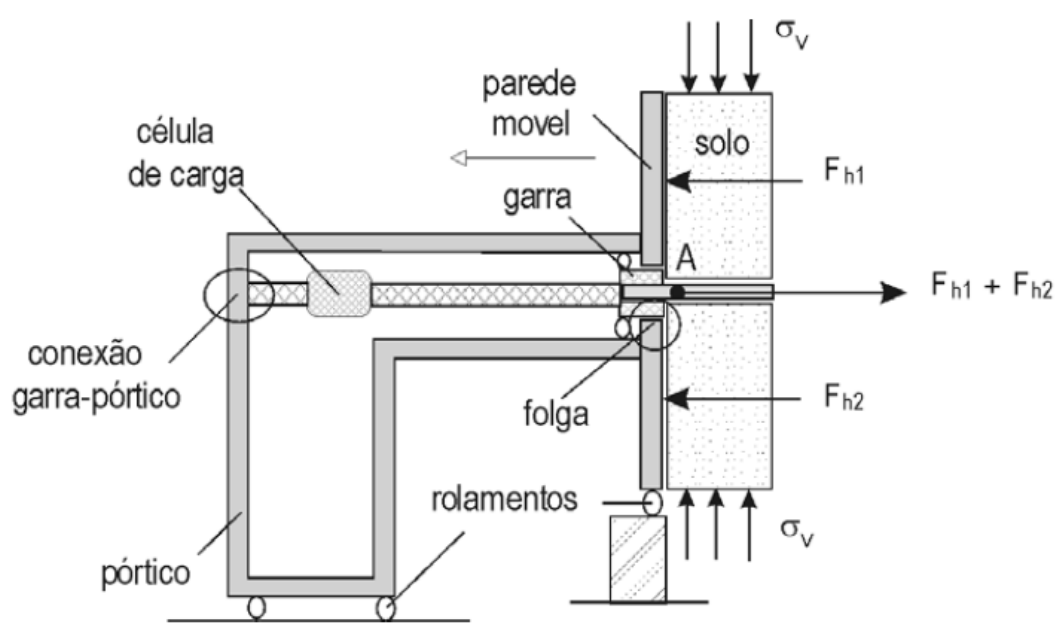

Figura 2.67 - Princípio do mecanismo de transmissão de cargas no equipamento desenvolvido por Costa (2004).

Dentre as principais vantagens deste equipamento salienta-se a possibilidade de realização de ensaios de fluência confinada que permitem o registro tanto das forças quanto das deformações atuantes nos reforços. Além disso, pode-se citar como vantagem o fato do equipamento permitir a realização de ensaios de relaxação dos geossintéticos. Outro fator importante a ser destacado neste aparato se refere ao princípio de funcionamento. Entende-se que, equipamentos de fluência confinada em que os carregamentos são aplicados ao solo e este, por sua vez, solicita o reforço, são mais realistas em relação aos equipamentos em que o reforço é solicitado diretamente por meio de pesos.

Entretanto, é importante salientar que a taxa de carregamento aplicada ao reforço neste tipo de ensaio não é a mesma quando comparada aos ensaios de fluência convencional. Este fato pode tornar mais complexa a comparação entre resultados de ensaios de fluência confinada com ensaios de fluência em isolamento (fluência convencional). Assim, sob o aspecto de comparação de resultados com ensaios convencionais, talvez os equipamentos que solicitam o reforço diretamente sejam mais interessantes, já que estes isolam os efeitos do confinamento. 


\subsection{CONSIDERAÇÃO DA FLUÊNCIA EM PROJETOS DE SOLO REFORÇADO}

De um modo geral, na elaboração de projetos de maciços de solo reforçado, costuma-se adotar a definição da resistência admissível dos geossintéticos por meio dos fatores de redução aplicados à resistência última à tração do material (FHWA, 1998; VERTEMATTI, 2004; KOERNER, 2005). Estes fatores de redução refletem os parâmetros que podem vir a influenciar na resistência do geossintético ao longo da vida útil da obra, como danos de instalação, degradação química e biológica dos reforços, fluência e incertezas na determinação de parâmetros. Os fatores de redução podem ser determinados a partir de ensaios ou de referência encontradas na literatura. A relação entre a resistência última do reforço e os fatores de redução para o cálculo da resistência admissível de projeto é expressa pela eq. (2.8).

$$
T_{a d m}=\frac{T_{u l t}}{F R_{D I} \times F R_{F} \times F R_{D Q} \times F R_{D B} \times f_{m}}
$$

Em que:

$T_{a d m}=$ Resistência à tração admissível do geossintético;

$T_{\text {ult }}=$ Resistência à tração do geossintético;

$F R_{D I}=$ Fator de redução devido aos danos de instalação;

$F R_{F}=$ Fator de redução devido à fluência;

$F R_{D Q}=$ Fator de redução devido à degradação química;

$F R_{D B}=$ Fator de redução devido à degradação biológica;

$f_{m}=$ Fator de redução devido a incertezas estatísticas da resistência do geossintético.

A Tabela 2.14 apresenta os valores de fator de redução sugeridos por Koerner (2005) a serem aplicados em geotêxteis empregados no projeto de diferentes estruturas. 
Tabela 2.14 - Fatores de redução sugeridos para geotêxteis (KOERNER, 2005).

\begin{tabular}{ccccc}
\hline Aplicação & $\begin{array}{c}\text { Danos de } \\
\text { instalação }\end{array}$ & Fluência* & $\begin{array}{c}\text { Degradação } \\
\text { química }\end{array}$ & $\begin{array}{c}\text { Degradação } \\
\text { biológica }\end{array}$ \\
\hline Muros reforçados & $1,1-2,0$ & $2,0-4,0$ & $1,0-1,5$ & $1,0-1,3$ \\
Aterros reforçados & $1,1-2,0$ & $2,0-3,5$ & $1,0-1,5$ & $1,0-1,3$ \\
Estabilização de taludes & $1,1-1,5$ & $2,0-3,0$ & $1,0-1,5$ & $1,0-1,3$ \\
Rodovias não pavimentadas & $1,1-2,0$ & $1,5-2,5$ & $1,0-1,5$ & $1,0-1,2$ \\
Melhoria da capacidade de & $1,1-2,0$ & $2,0-4,0$ & $1,0-1,5$ & $1,0-1,3$ \\
carga da fundação & & & & \\
\hline
\end{tabular}

* Os limites inferiores devem ser aplicados para vida útil curta ou em situações em que a fluência não é crítica.

O Fator de redução que considera a fluência $\left(F R_{F}\right)$ pode também ser determinado com base nas curvas de ruptura por fluência. A partir dessas curvas, os dados são extrapolados até que se atinja a vida útil da obra em questão. Com base nessa extrapolação obtém-se a solicitação máxima que pode ser aplicada ao geossintético. Quando expresso em relação à resistência à tração do geossintético $\left(T / T_{\text {ult }}\right)$, o inverso desse valor ( $T_{\text {fluência }}$ ) resulta no fator de redução por fluência $\left(F R_{F}\right)$. A Figura 2.68 ilustra esse procedimento.

É importante destacar que, embora simples, o método para a determinação do fator de redução por fluência pode gerar incertezas devido ao processo de extrapolação. Por essa razão, recomenda-se que o número de ciclos logaritmos a serem extrapolados nesse procedimento seja limitado em um determinado valor. Essa recomendação varia entre um (ASTM D5262; VERTEMATTI, 2004; JONES; CLARKE, 2007) e dois ciclos logarítmicos (SEGRESTIN; FREITAG, 2006). 


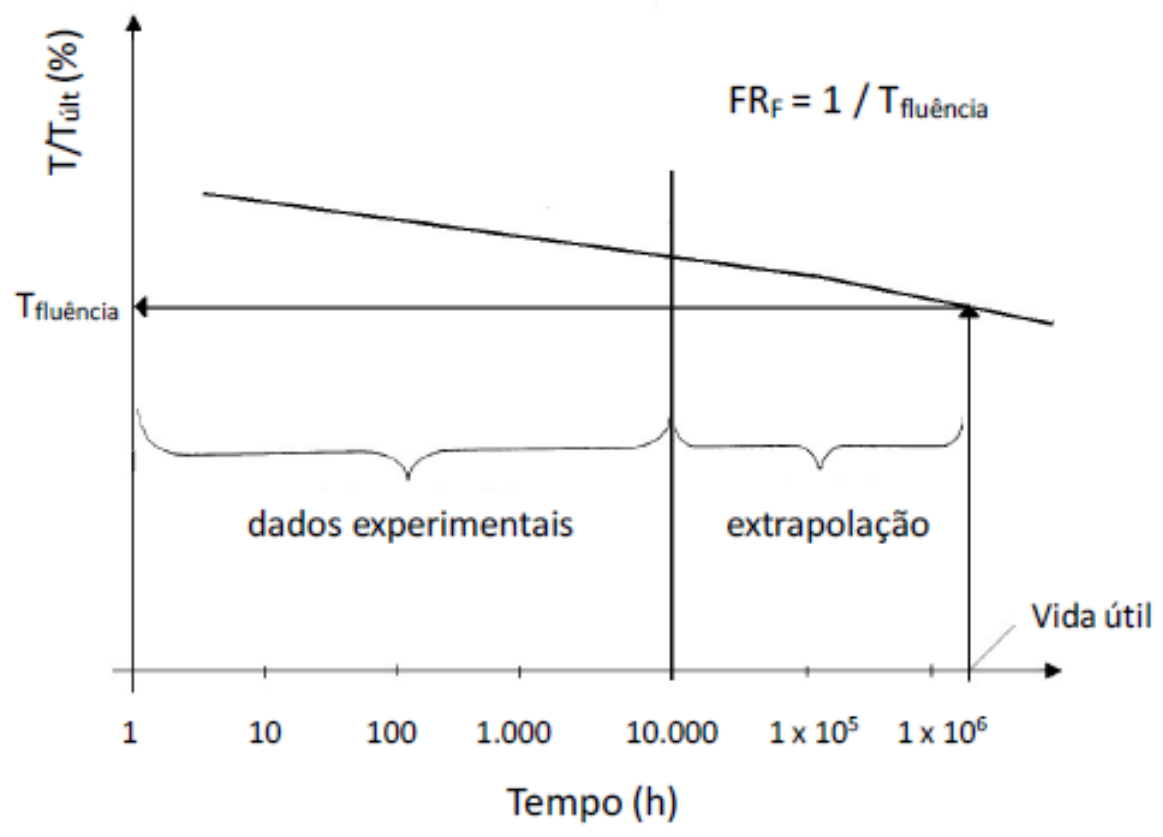

Figura 2.68 - Fator de redução devido à fluência obtido através da curva de ruptura por fluência (COSTA, 1999).

O procedimento para a determinação do fator de redução por fluência apresentado na Figura 2.68 engloba, além das deformações por fluência, outros aspectos que são inerentes ao processo executivo do método, como a redução da resistência do reforço devido à fluência, ruptura por fluência e deformações excessivas por fluência. Além disso, a influencia do confinamento do reforço em solo é um aspecto que pode ser significativo no comportamento em fluência sob tração de geossintéticos. Segundo Zornberg; Byler e Knudsen (2004), estes aspectos tem conduzido à obtenção de fatores de redução demasiadamente conservadores.

Conforme foi possível se observar na Tabela 2.14 os fatores de redução por fluência são os que possuem maiores magnitudes dentre os apresentados. Segundo Koerner (2005), o fator de redução por fluência para geotêxteis varia entre 2 e 4 . Para geogrelhas a faixa de variação fica entre 2 e 3. Já Vertematti (2004) propõe valores gerais, sem distinção para o tipo de reforço, variando entre 2 e 5. Com base nesses valores, pode-se afirmar que a resistência última dos reforços pode ser reduzida entre $50 \%$ e $80 \%$, apenas considerando o fator de redução por fluência. Ao se considerar os demais fatores, essa redução se torna ainda mais significativa. 
Avesani (2013) realizou ensaios de ruptura por fluência em geotêxteis não tecidos de poliéster em condição de confinamento, o que possibilitou a determinação do fator de redução devido à fluência para esse material. Segundo o autor, considerando-se uma vida útil de projeto entre 75 e 100 anos, obteve-se um fator de redução devido à fluência igual a 1,13. Este valor é significativamente menor que os valores apresentados na bibliografia. Avesani (2013) destaca que, em vista dos valores apresentados, considera-se que o fator de redução devido à fluência sugeridos na literatura técnica são conservadores e por essa razão, o autor recomenda que o confinamento em solo deva ser levado em consideração na determinação do comportamento em fluência sob tração dos geossintéticos. 


\section{MATERIAIS E MÉTODOS}

Esta pesquisa apresenta a avaliação do comportamento em longo prazo de estruturas em solo reforçado com geossintéticos por meio da realização de ensaios em laboratório, monitoramento de uma obra real, e ainda por meio da elaboração de modelos numéricos devidamente calibrados. Foram realizados em laboratório ensaios de fluência convencional e fluência confinada. Para a fluência confinada foram empregados dois equipamentos distintos, sendo que as condições de carregamento e confinamento de cada ensaio foram programadas em função das características da obra real. Destaca-se que a campanha de ensaios de laboratório foi desenvolvida de forma a refletir as condições reais de campo, sendo que ensaios adicionais simulando situações de inundação e condições de compactação do solo também foram executados. Complementarmente aos ensaios de laboratório e ao monitoramento da obra foram realizadas simulações numéricas, empregando um software geotécnico, de forma a possibilitar a extrapolação de resultados e, consequentemente, a previsão do comportamento de estruturas em solo reforçado para períodos de tempo elevados.

A Figura 3.1 mostra um fluxograma contendo as atividades desenvolvidas neste trabalho, incluindo tanto os ensaios realizados em laboratório quanto as análises numéricas empregando o método dos elementos finitos.

Neste capítulo apresentam-se a descrição da obra utilizada como referência bem como o monitoramento realizado, os equipamentos de fluência utilizados nesta pesquisa, o sistema de instrumentação empregado para a realização das leituras de carga e deformações nos ensaios de laboratório, o solo e os reforços empregados, os métodos para determinação das deformações nos reforços e as premissas consideradas nas análises numéricas. 


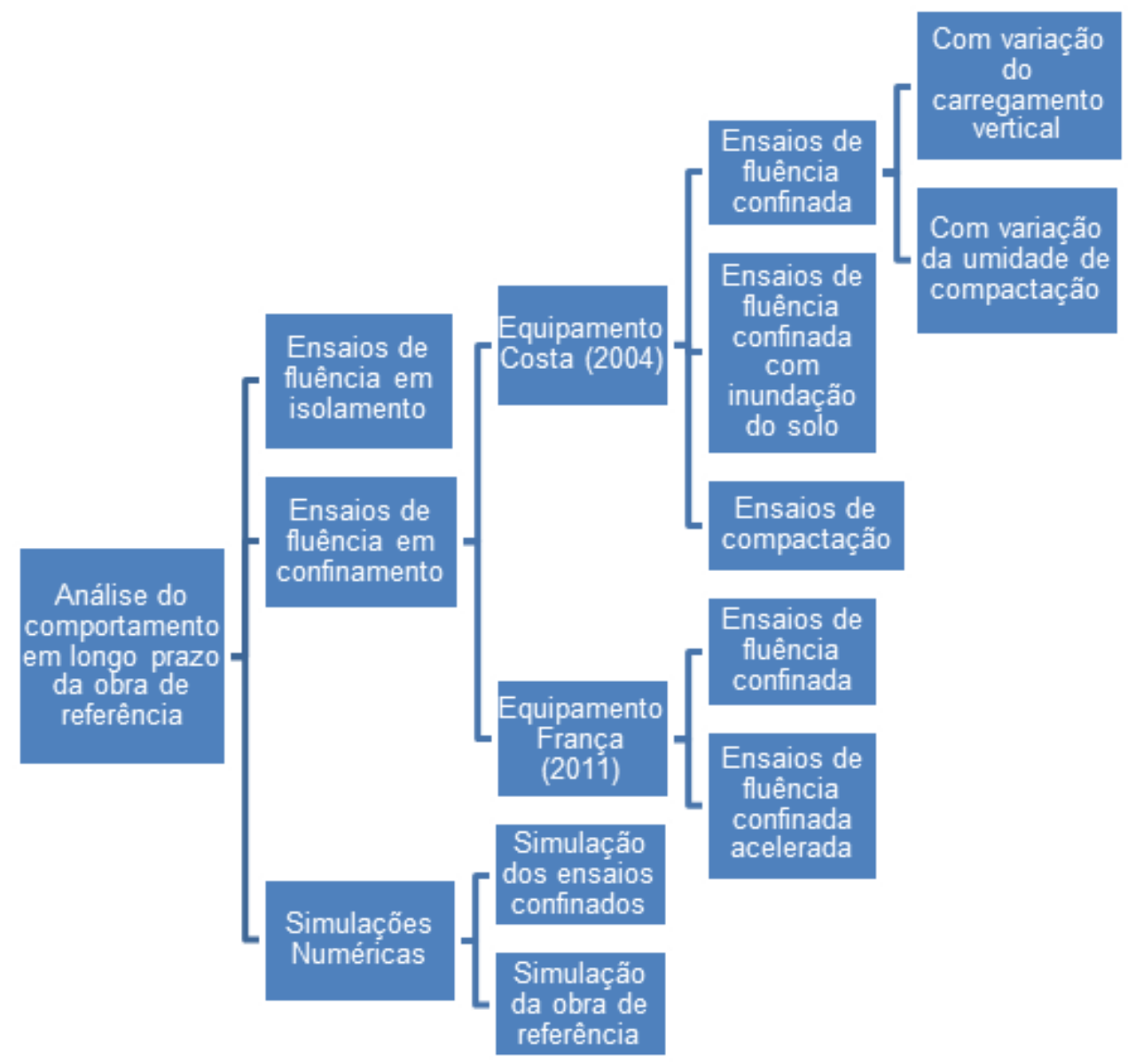

Figura 3.1 - Fluxograma de atividades desenvolvidas.

\subsection{OBRA DE REFERÊNCIA}

A obra utilizada como referência para este estudo consiste em um muro de contenção de solo reforçado com geotêxteis com a função de nivelar uma determinada área onde foi implantado um conjunto habitacional denominado Bairro Novo, situado na cidade de Campinas, no interior do estado de São Paulo. Este muro foi instrumentado desde o início de sua construção para o acompanhamento do desempenho mecânico da estrutura em função dos níveis de precipitação na região da obra e dos níveis de sucção matricial desenvolvidos no interior do maciço de solo que compõe 0 aterro da estrutura. As instrumentação e informações resultantes desta pesquisa foram apresentadas e devidamente analisadas por Portelinha (2012). 
O muro em estudo é composto por aterros com até $9 \mathrm{~m}$ de altura total, construídos com solo fino encontrado no próprio local da obra. O muro de contenção que compõe o contorno do conjunto residencial possui uma extensão aproximada de $300 \mathrm{~m}$.

Para a construção do muro foram empregados geotêxteis tecidos com resistência nominal de 50 kN/m. Entretanto, para fins comparativos, Portelinha (2012) propôs a execução de uma seção em geotêxtil não tecido com resistência à tração reduzida, com cerca de $40 \%$ da resistência do geotêxtil tecido. Para a avaliação do comportamento deste muro o autor instrumentou duas seções reforçadas, sendo uma delas situada na região construída com geotêxtil não tecido e outra situada na região construída com geotêxtil tecido. As seções instrumentadas possuíam altura aproximada de $5,4 \mathrm{~m}$ de solo reforçado, com taludes construídos em solo não reforçado, com altura de aproximadamente $3,6 \mathrm{~m}$. A instrumentação possibilitou a obtenção dos deslocamentos internos dos reforços e, por consequência, suas deformações ao longo da construção do muro. Na Figura 2.33 foi apresentada uma vista frontal da estrutura após a construção do muro reforçado em geotêxteis e durante a construção do aterro não reforçado em talude.

A decisão da utilização de solos finos locais foi o aspecto primordial para tornar a solução economicamente competitiva em relação às outras soluções disponíveis no mercado (PORTELINHA, 2012). O solo empregado na construção do aterro é composto basicamente por uma areia argilosa não plástica, cujas principais propriedades são apresentadas mais adiante.

No que concerne aos reforços, foram empregados geotêxteis tecidos com resistência nominal de $50 \mathrm{kN} / \mathrm{m}$, e geotêxteis não tecidos com gramatura de $400 \mathrm{~g} / \mathrm{m}^{2}$ e resistência nominal de $20 \mathrm{kN} / \mathrm{m}$.

Maiores detalhes contendo os ensaios de caracterização do solo local e dos geotêxteis utilizados como reforço são apresentados nos itens a seguir.

O projeto da estrutura em solo reforçado foi realizado com base nas especificações da FHWA (1998), exceto pelas recomendações referentes à quantidade de materiais finos que compõem o solo.

Sob o aspecto geométrico, o muro consiste em linhas de reforço com comprimentos de 7,0 m espaçadas a cada $0,4 \mathrm{~m}$ verticalmente. $\mathrm{O}$ muro foi construído por meio da 
técnica de envelopamento, empregando-se, na face, sacarias preenchidas com solo local compactado manualmente.

O método de projeto de tensões de serviço de Rankine, descrito por Mitchell e Villet (1987), foi utilizado no dimensionamento da estrutura, considerando o coeficiente de empuxo ativo para análises das estabilidades externa e interna.

Para a construção do muro reforçado o solo foi compactado com rolo dentado vibratório DYNAPAC® no teor de umidade ótimo (Proctor modificado), sendo que o controle de compactação da obra permitia uma faixa de aceitação de $\pm 1 \%$ em relação ao teor de umidade ótimo e $\pm 2 \%$ em relação ao grau de compactação. $O$ solo foi compactado em camadas de $20 \mathrm{~cm}$ buscando-se um grau de compactação de $98 \%$. Na região próxima a face, numa faixa aproximada de 1,0 m, a compactação foi realizada por meio de um martelo vibratório, de modo a evitar deslocamentos excessivos na face durante o processo construtivo.

O início da construção do muro em solo reforçado se deu em setembro de 2010 e teve seu fim em dezembro do mesmo ano. A obra completa, incluindo o aterro não reforçado em talude, acima do muro de contenção, foi finalizada em janeiro de 2011. A Figura 3.2 ilustra a evolução da construção da estrutura ao longo do tempo, bem como o período de leituras da instrumentação.

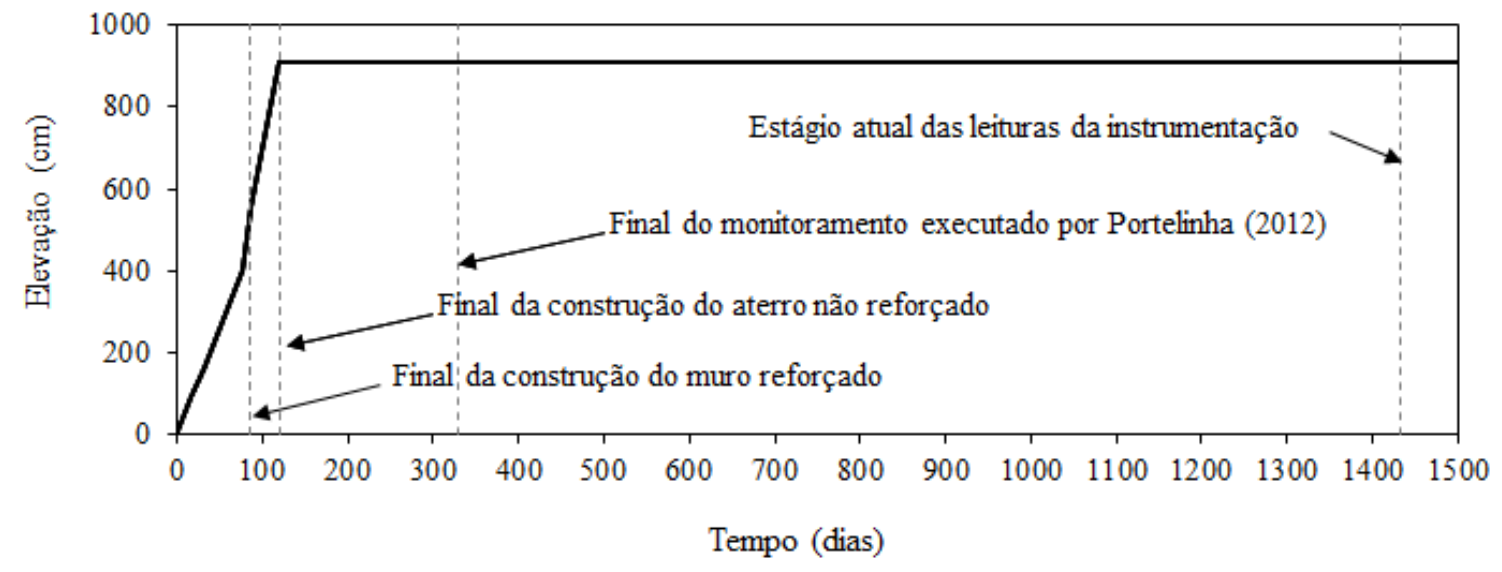

Figura 3.2 - Evolução da construção do muro em solo reforçado ao longo do tempo.

A instrumentação da estrutura para a avaliação dos deslocamentos internos dos reforços foi realizada em 3 níveis diferentes ao longo da altura do muro: E01, situada a 0,8 $\mathrm{m}$ da base do muro; E02, situada a 1,6 $\mathrm{m}$ da base do muro; e E03, situada a $5,0 \mathrm{~m}$ da base do muro (conforme mostrado na Figura 2.81). Tal instrumentação foi 
realizada por meio da utilização de extensômetros de hastes metálicas. As hastes metálicas lisas foram fixadas no solo abaixo e ao longo do comprimento do reforço em diferentes distâncias em relação à face da estrutura. Uma haste de referência foi fixada fora da zona reforçada de modo a se obter deslocamentos relativos em relação a esta referência. A Figura 3.3 mostra um detalhe com a instrumentação empregada na obra. Detalhes podem ser encontrados no trabalho de Portelinha (2012).

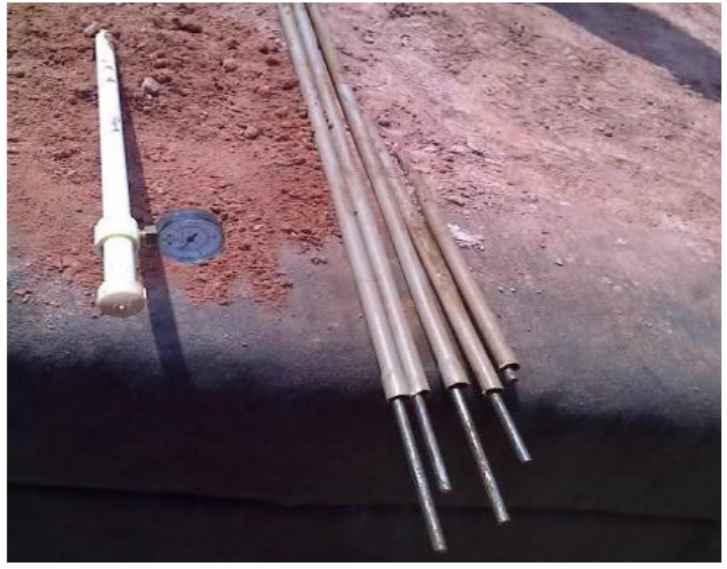

(a)

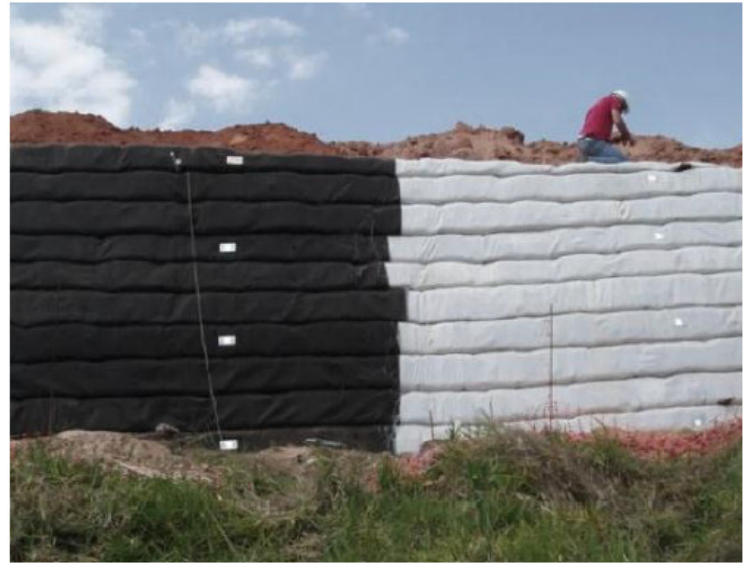

(b)

Figura 3.3 - Instrumentação: (a) hastes mecânicas e tensiômetro; (b) seções instrumentadas (PORTELINHA, 2012).

Um fato que merece destaque se refere às condições atuais da estrutura reforçada. Devido ao vandalismo no local, os instrumentos destinados à leitura de sucção matricial foram danificados e, portanto, não puderam mais ser utilizados para leituras posteriores às realizadas por Portelinha (2012). O mesmo vale para os marcos refletores, os quais foram empregados para a avaliação dos deslocamentos da face da estrutura, que foram danificados e não puderam mais ser utilizados na continuidade das leituras.

Destaca-se ainda que as leituras de deslocamentos internos posteriores às executadas por Portelinha (2012) foram realizadas apenas nos níveis de instrumentação denominados E02 e E03. O nível E01, mais próximo à base da estrutura, foi negligenciado tendo em vista que este se encontra aterrado por 
resíduos depositados pela população local, o que impossibilitou a continuidade do monitoramento.

A Figura 3.4 apresenta uma vista geral do muro de solo reforçado utilizado como referência em suas condições atuais.

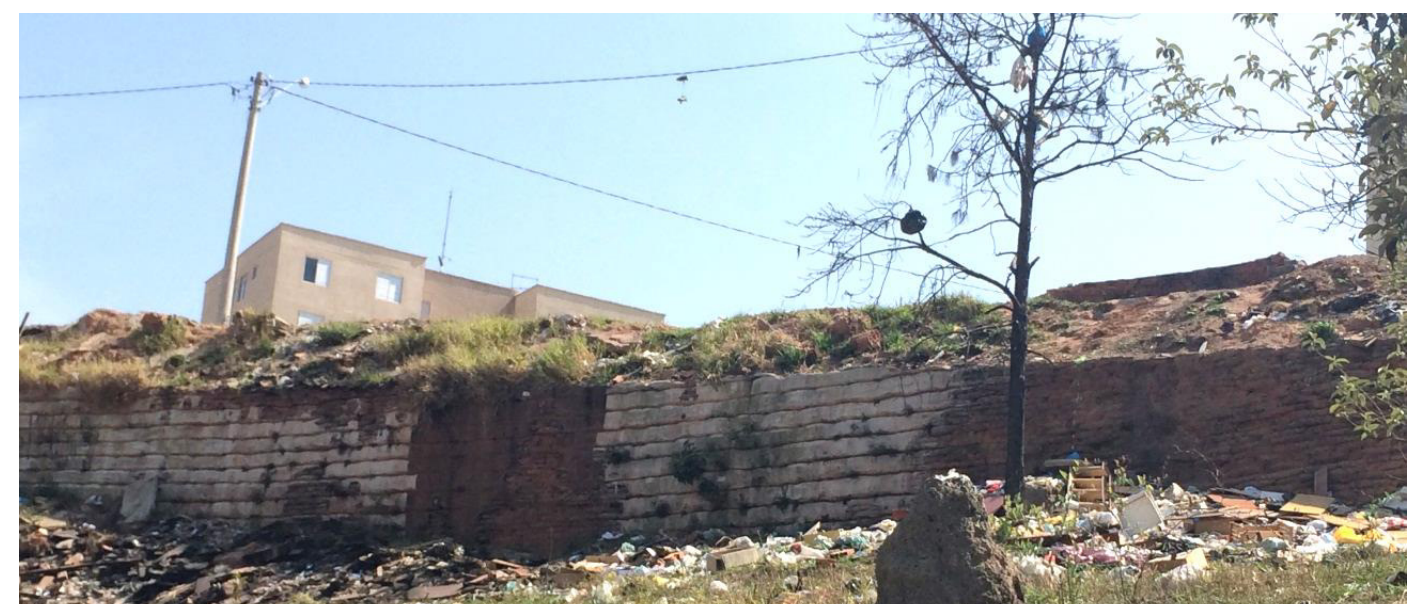

Figura 3.4 - Condições atuais do muro de solo reforçado utilizado como referência.

\subsection{SOLO}

O solo empregado na construção do aterro do muro de referência, e também nos ensaios de fluência confinada, é composto por uma areia argilosa não plástica com 40\% passante na peneira \#200, peso específico aparente seco máximo de $19,3 \mathrm{kN} / \mathrm{m}^{3}$ e teor ótimo de umidade de $11,65 \%$ (Proctor Normal). Este solo é classificado como SC de acordo com a classificação unificada.

A curva granulométrica do solo local, elaborada segundo a norma NBR 7181, e a curva de compactação pelo ensaio Proctor Normal, elaborada segundo a norma NBR 7182, são apresentadas na Figura 3.5 e na Figura 3.6, respectivamente. 


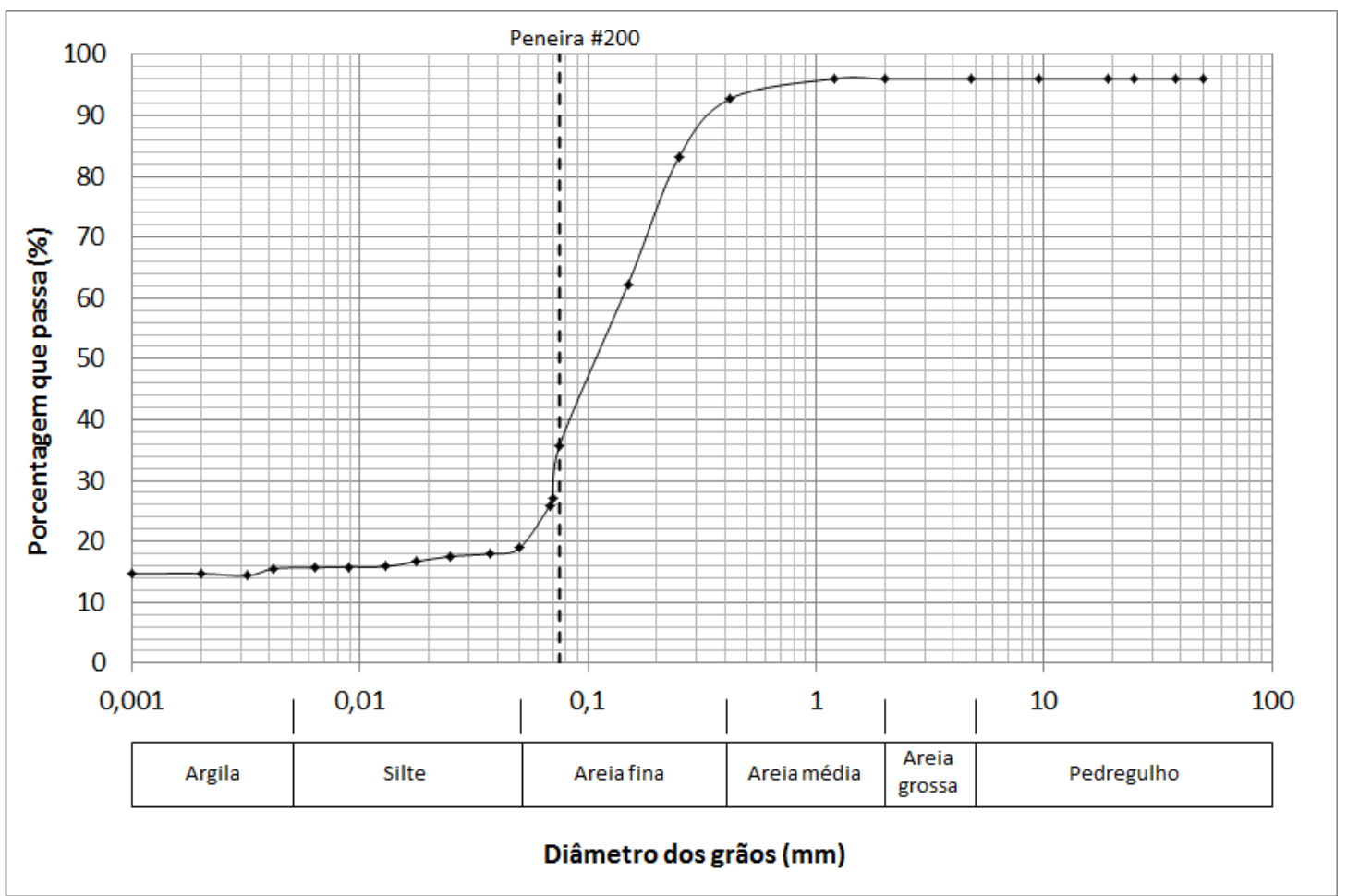

Figura 3.5 - Curva granulométrica do solo local.

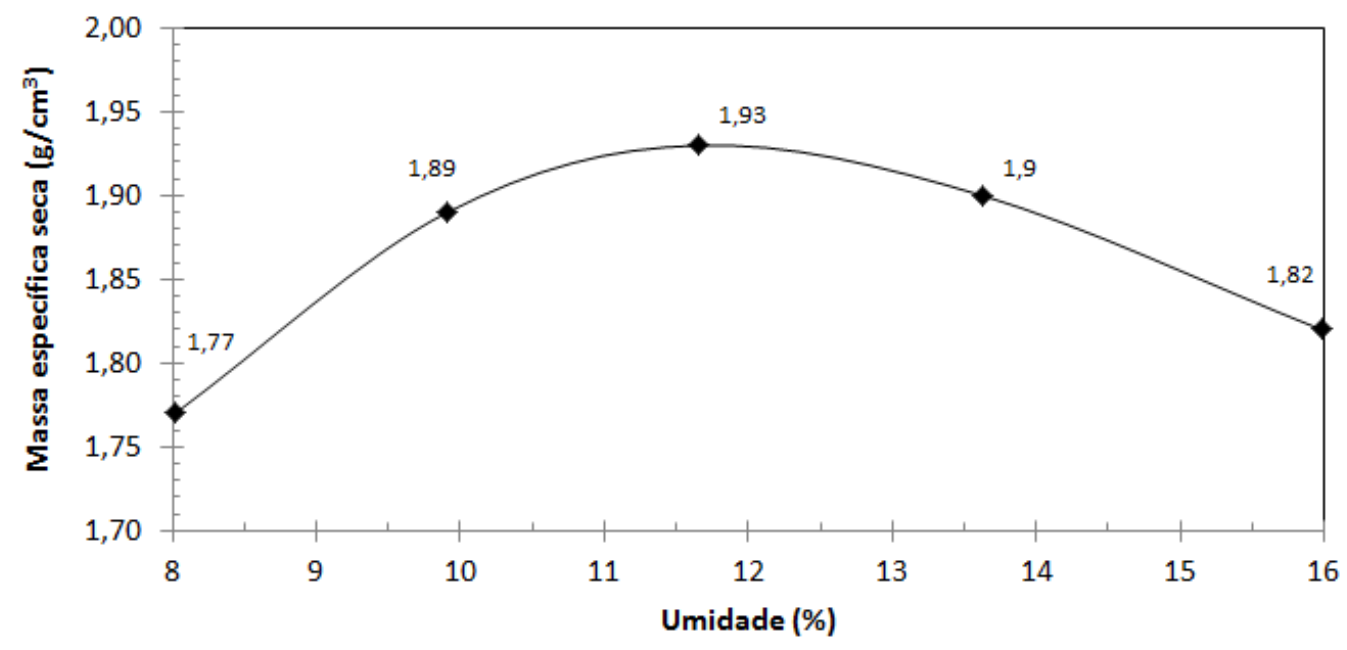

Figura 3.6 - Curva de compactação Proctor Normal.

Para a determinação dos parâmetros de resistência e deformabilidade do solo foram realizados ensaios triaxiais do tipo $\mathrm{CU}$ com corpos de prova saturados e ensaios do tipo CD com corpos de prova não saturados, compactados na umidade ótima. Os 
resultados dos ensaios triaxiais consolidados não drenados (CU), em corpos de prova saturados resultaram em um intercepto de coesão efetiva de $26 \mathrm{kPa}$ e ângulo de atrito efetivo de $35^{\circ}$ (Figura 3.7). Os ensaios consolidados drenados (CD), compactados na umidade ótima, apresentaram um intercepto de coesão de $53 \mathrm{kPa}$ e ângulo de atrito efetivo de $32,5^{\circ}$ (Figura 3.8). Destaca-se que os ensaios do tipo CU foram realizados utilizando-se o mesmo solo empregado no aterro da obra, mas com amostras retiradas de locais diferentes das empregadas para os ensaios do tipo CD.

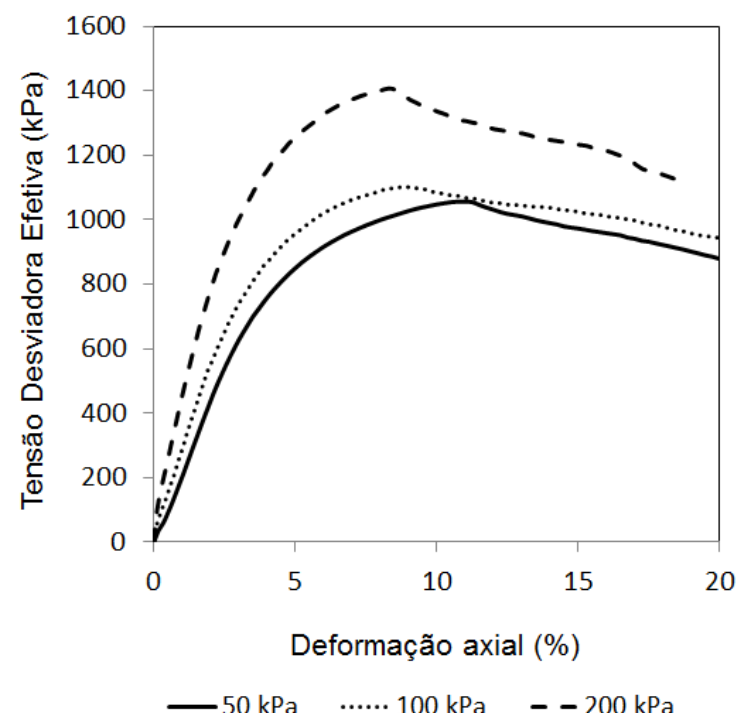

(a)

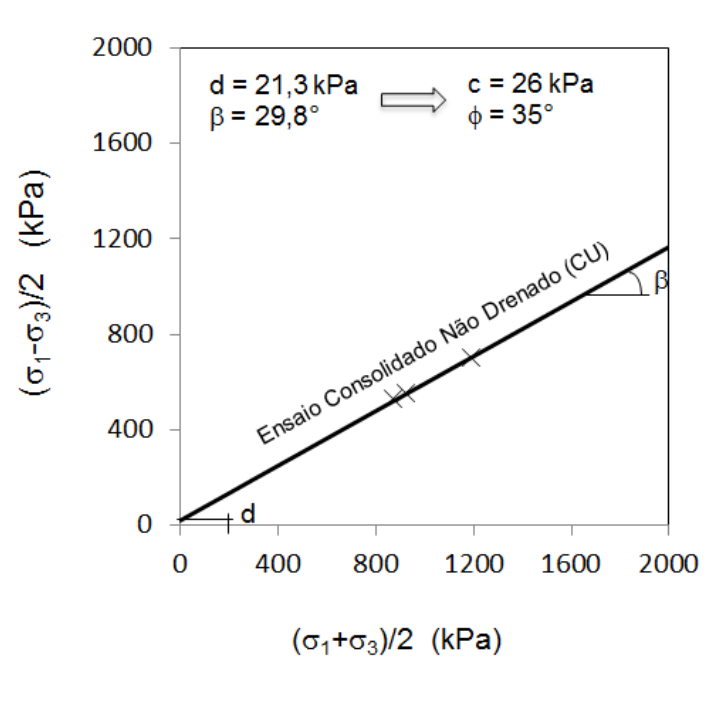

(b)

Figura 3.7 - Resultados dos ensaios de triaxiais do tipo CU para o solo local: (a) Gráfico tensãodeformação; (b) Envoltória de resistência. 


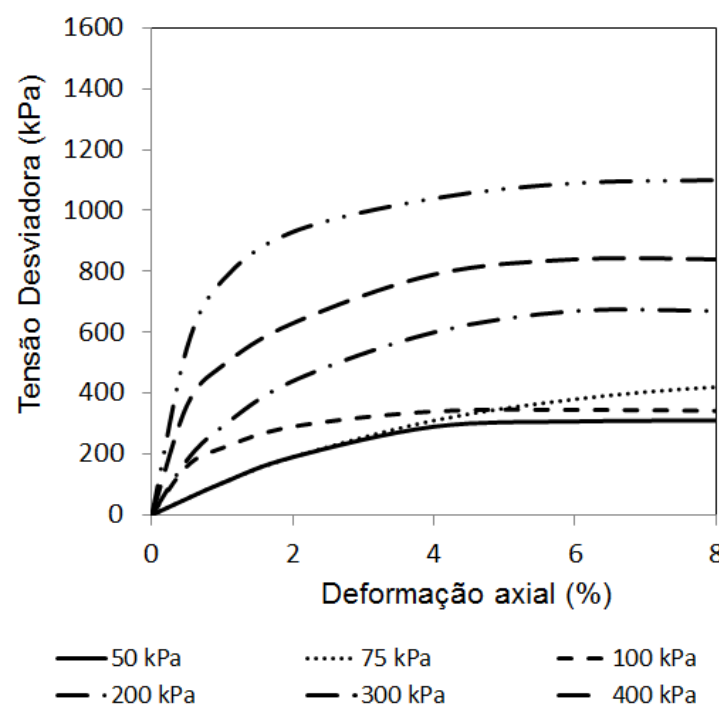

(a)

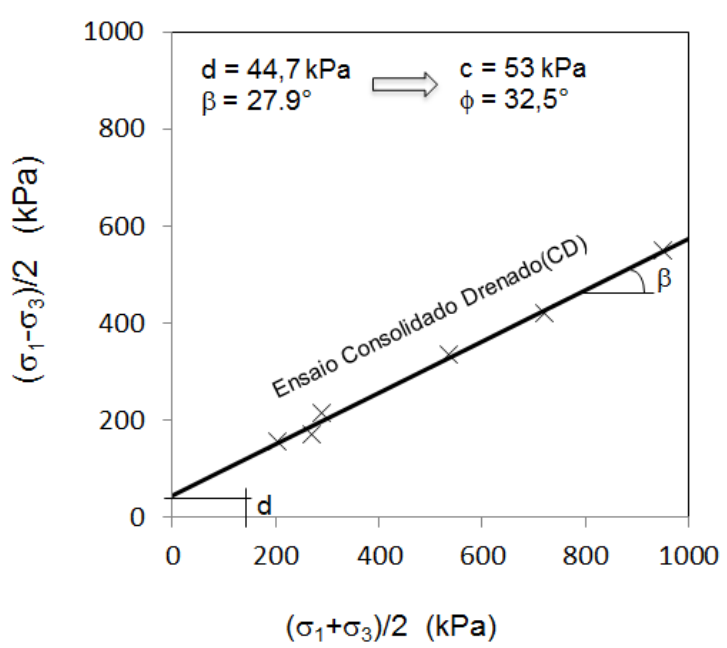

(b)

Figura 3.8 - Resultados dos ensaios de triaxiais do tipo CD para o solo local: (a) Gráfico tensãodeformação; (b) Envoltória de resistência.

A Tabela 3.1 apresenta os módulos secantes de deformabilidade dos solos obtidos nos ensaios triaxiais do tipo CU e CD para deformações de 1\%, 2\% e 5\%.

Tabela 3.1- Módulos de deformabilidade obtidos nos ensaios triaxiais do tipo CU e CD.

\begin{tabular}{ccccccc}
\hline & \multicolumn{4}{c}{ Módulo de deformabilidade do solo $\left(\mathrm{kN} / \mathrm{m}^{2}\right)$} \\
\cline { 2 - 7 } Deformação & \multicolumn{3}{c}{ Ensaios CU } & \multicolumn{3}{c}{ Ensaios CD } \\
& \multicolumn{2}{c}{ Tensão Desviadora $(\mathrm{kPa})$} & \multicolumn{2}{c}{ Tensão Desviadora $(\mathrm{kPa})$} \\
\cline { 2 - 7 } & 50 & 100 & 200 & 50 & 100 & 200 \\
\hline $1 \%$ & 3040 & 28690 & 45250 & 10710 & 22450 & 29290 \\
$2 \%$ & 10500 & 27290 & 38760 & 9450 & 14430 & 21780 \\
$5 \%$ & 15153 & 19000 & 24910 & 5950 & 6840 & 12650 \\
\hline
\end{tabular}


Com o objetivo de melhor se compreender o comportamento do solo em condições reais de trabalho, foram realizados, adicionalmente, ensaios do tipo CD com corpos de prova compactados sob diferentes teores de umidade. Foram realizados ensaios triaxiais com teores de umidade de $9 \%, 11 \%$ e $13 \%$. Por meio destes ensaios foi possível se observar a variação dos parâmetros de resistência do solo para diferentes umidades de compactação. Os resultados destas análises são mostrados na Figura 3.9.

Observa-se que a variação do intercepto de coesão do solo em função do teor de umidade se comporta como uma curva de compactação. Assim, o maior valor para este parâmetro foi obtido para o teor de umidade mais próximo do ótimo.

Comportamento semelhante foi observado para a variação do ângulo de atrito interno do solo em função do teor de umidade, ou seja, o maior ângulo de atrito foi obtido para a umidade ótima, e o menor para o solo compactado no ramo úmido.

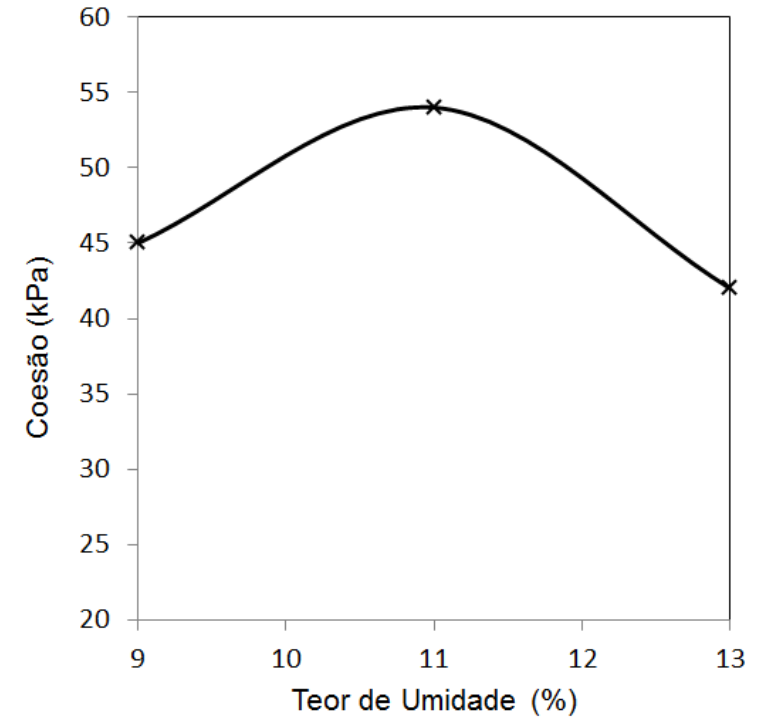

(a)

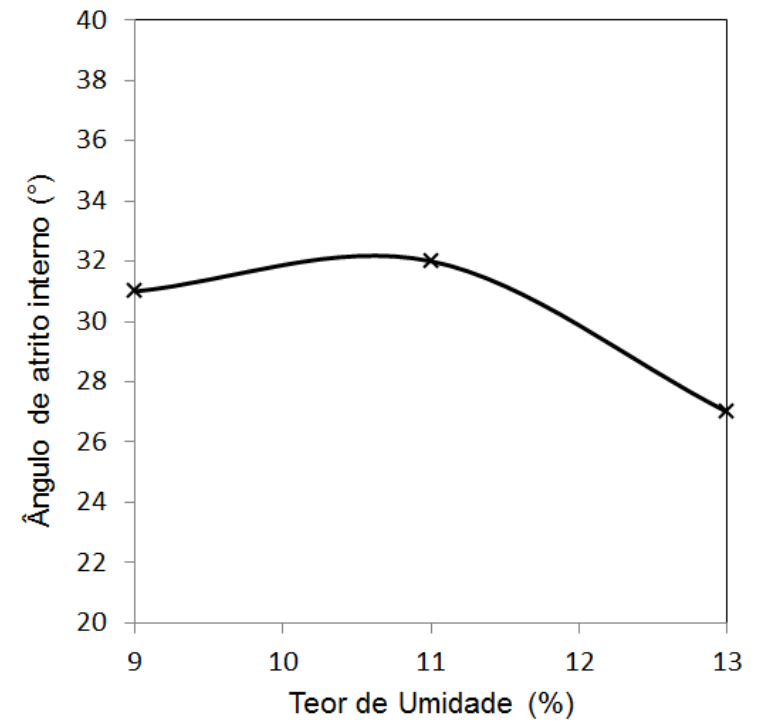

(b)

Figura 3.9 - Variação dos parâmetros de resistência do solo em função da umidade de compactação: (a) Intercepto de coesão; (b) Ângulo de atrito interno.

A Figura 3.10 apresenta a variação do módulo secante de deformabilidade do solo em função da umidade de compactação dos corpos de prova, para diferentes níveis 
de deformação axial. Os módulos de deformabilidade são apresentados para 1\%, $2 \%, 5 \%$ e $8 \%$ de deformação.

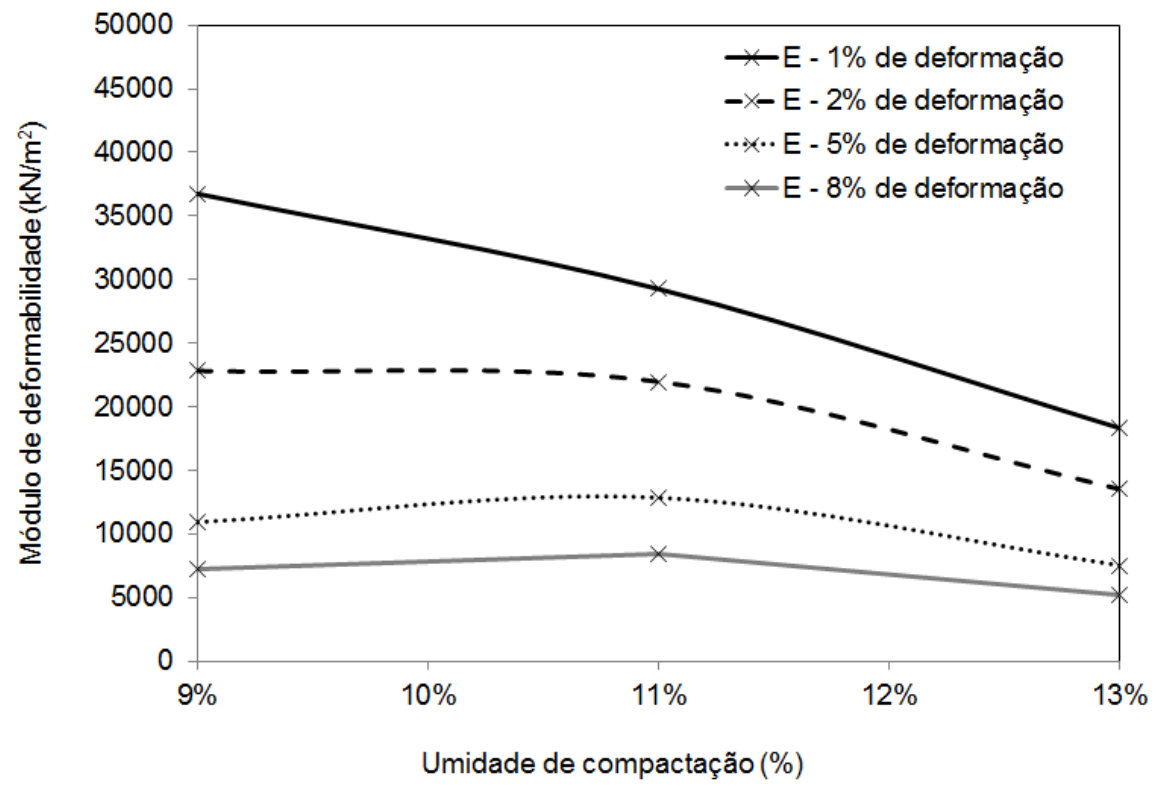

Figura 3.10 - Variação do módulo de deformabilidade em função da umidade de compactação do solo obtido por meio dos ensaios triaxiais do tipo CD.

Para uma melhor avaliação do comportamento ao longo do tempo da estrutura utilizada como referência, e para complementar as informações para a interpretação dos resultados dos ensaios de fluência confinada, foram realizados alguns ensaios de fluência com o solo local. Para a realização destes ensaios foi utilizada uma câmara de ensaios triaxiais. O solo foi submetido a diferentes combinações de carregamentos horizontais e verticais, de forma a simular as condições observadas em campo.

Os corpos de prova nos ensaios de fluência do solo foram submetidos a três condições distintas de coeficientes de empuxo. Estas condições são apresentadas na Tabela 3.2. 
Tabela 3.2- Condições de carregamento para os ensaios de fluência do solo.

\begin{tabular}{cccc}
\hline Condição & $\begin{array}{c}\text { Tensão Vertical } \\
\left(\mathrm{kN} / \mathrm{m}^{2}\right)\end{array}$ & $\begin{array}{c}\text { Tensão Horizontal } \\
\left(\mathrm{kN} / \mathrm{m}^{2}\right)\end{array}$ & $\begin{array}{c}\text { Coeficiente de } \\
\text { empuxo }\end{array}$ \\
\hline 1 & 78 & 20,3 & 0,26 \\
2 & 140 & 49,0 & 0,35 \\
3 & 190 & 121,6 & 0,64 \\
\hline
\end{tabular}

Os resultados dos ensaios de fluência sob as diferentes condições de carregamento são apresentados na Figura 3.11 .

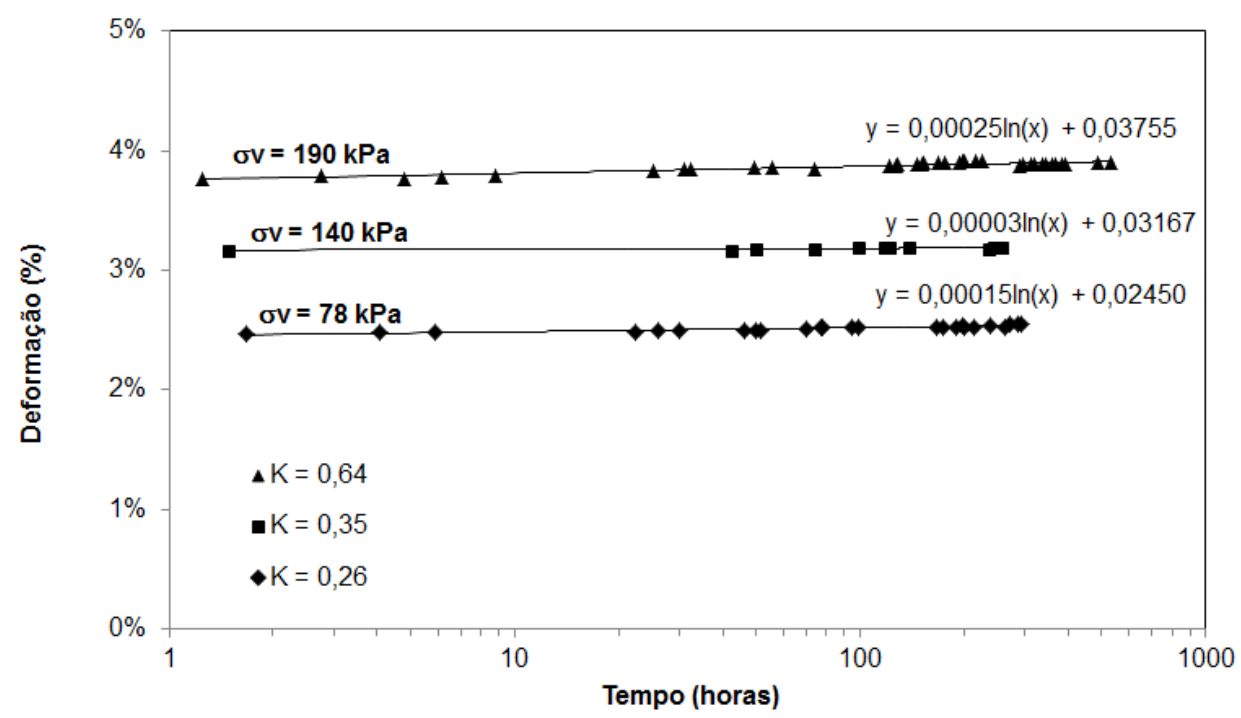

Figura 3.11 - Resultados dos ensaios de fluência realizados com o solo local.

Os resultados dos ensaios de fluência mostram que o solo sofre deformações muito pequenas ao longo tempo. O índice de fluência do solo avaliado, o qual é representado pela inclinação das curvas ajustadas em escala semi-logarítmica da Figura 3.11 , para o caso mais crítico, foi de $0,025 \%$. Para a condição simulada no nível de referência E02 da obra de referência, o índice de fluência foi ainda menor, apresentando um valor de apenas $0,003 \%$. As magnitudes dos índices de fluência apresentadas neste item foram empregadas como valores de referência para as análises numéricas que serão apresentadas mais adiante. 
Para finalizar a campanha de ensaios de caracterização do solo local foram realizados ensaios para a determinação da curva de retenção de água do solo. A curva de retenção foi determinada sob condições de secagem empregando a técnica do papel filtro. Ajustes do modelo de van Genutchen (1980), utilizando o software SWRC (versão 3.00 beta) desenvolvido por Dourado Neto; Nielsen e Hopmans (2001), foram realizados nos pontos obtidos experimentalmente. A curva de retenção de água do solo utilizado como referência nesta tese é apresentada na Figura 3.12.

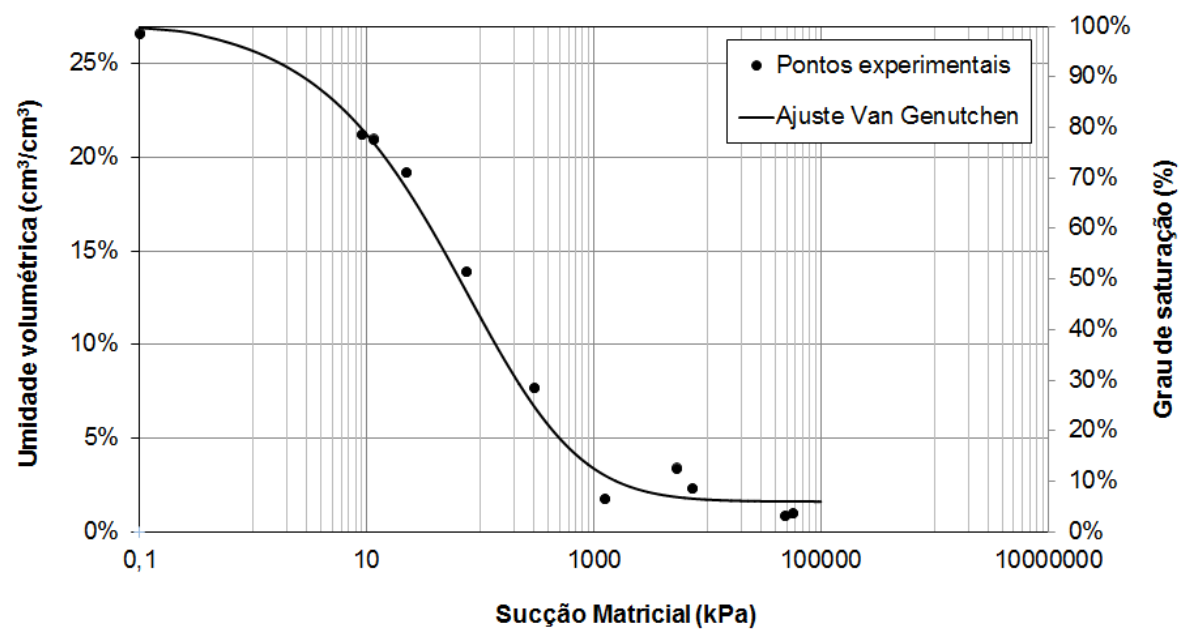

Figura 3.12 - Curva de retenção de água do solo utilizado nesta pesquisa.

\subsection{REFORÇOS}

Conforme destacado anteriormente, para a construção da estrutura reforçada foram empregados geotêxteis tecidos (GT), de polipropileno, com resistência nominal de $50 \mathrm{kN} / \mathrm{m}$, e geotêxteis não tecidos (GNT), de poliéster, com resistência nominal de $20 \mathrm{kN} / \mathrm{m}$. Estes mesmos reforços foram empregados nos ensaios de fluência confinada e em isolamento. Destaca-se que os geotêxteis tecidos utilizados nos ensaios eram do mesmo lote de fabricação dos geotêxteis utilizados na obra.

Para a realização dos ensaios de fluência (confinada e em isolamento) foram utilizadas também geogrelhas biaxiais (GG), de poliéster, com resistência nominal à tração de $40 \mathrm{kN} / \mathrm{m}$. A inclusão destes reforços nos ensaios de fluência permitiu uma 
análise mais criteriosa do comportamento ao longo do tempo de muros em solo reforçado com geossintéticos para diferentes tipos de reforços.

A resistência à tração e a deformação na ruptura dos geossintéticos empregados nesta pesquisa foram determinadas segundo a NBR 10319. Os resultados dos ensaios de tração faixa larga são apresentados na Figura 3.13. As curvas apresentadas na figura se referem aos valores médios obtidos para cada tipo de reforço.

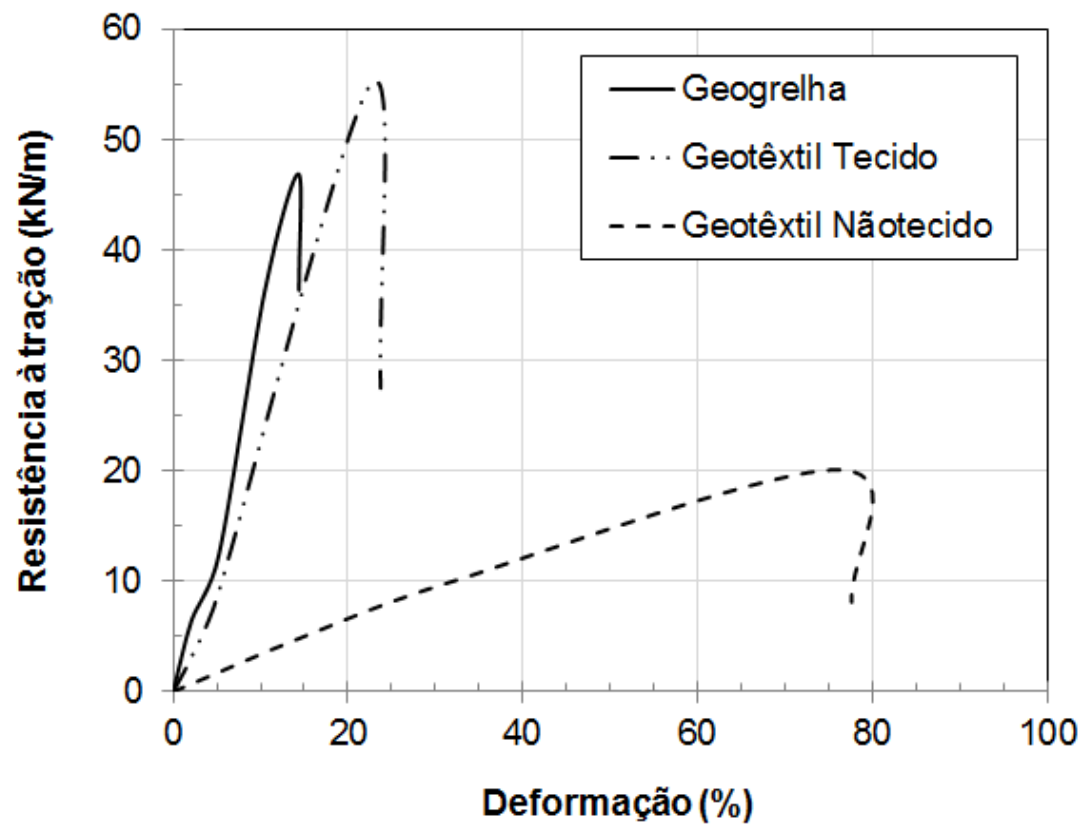

Figura 3.13 - Resultados dos ensaios de tração para os geotêxteis tecidos, não tecidos e geogrelhas.

Os valores médios das principais propriedades dos geotêxteis não tecidos, tecidos e geogrelhas, obtidos por meio dos ensaios de tração faixa larga segundo a NBR 10319, são apresentados na Tabela 3.3. 
Tabela 3.3- Propriedades mecânicas dos geotêxteis não tecidos, tecidos e geogrelhas.

\begin{tabular}{|c|c|c|c|}
\hline Propriedade & $\begin{array}{l}\text { Geotêxtil Não } \\
\text { Tecido } \\
\text { (GNT) }\end{array}$ & $\begin{array}{l}\text { Geotêxtil } \\
\text { Tecido } \\
\text { (GT) }\end{array}$ & $\begin{array}{l}\text { Geogrelha } \\
\qquad(\mathrm{GG})\end{array}$ \\
\hline $\begin{array}{c}\text { Força máxima } \\
\qquad(\mathrm{kN})\end{array}$ & 4,02 & 11,40 & 10,32 \\
\hline $\begin{array}{l}\text { Deformação máxima } \\
(\%)\end{array}$ & 76,44 & 23,95 & 14,30 \\
\hline $\begin{array}{l}\text { Força/Largura média } \\
\qquad(\mathrm{kN} / \mathrm{m})\end{array}$ & 20,10 & 55,02 & 46,91 \\
\hline $\begin{array}{l}\text { Modulo de rigidez médic } \\
\text { a } 2 \% \text { de deformação } \\
(\mathrm{kN} / \mathrm{m})\end{array}$ & 34,44 & 135,51 & 305,16 \\
\hline Tipo de Polímero & Poliéster & Polipropileno & Poliéster \\
\hline
\end{tabular}

Os resultados dos ensaios de caracterização mostraram que geotêxtil tecido apresentou maior resistência à tração do que a geogrelha. Por outro lado, a geogrelha foi o reforço que apresentou maior rigidez a $2 \%$ de deformação, seguido pelo geotêxtil tecido e pelo geotêxtil não tecido, o qual apresentou a menor rigidez.

\subsection{ENSAIOS DE FLUÊNCIA}

Neste item são apresentados os métodos de execução dos ensaios pra a avaliação do comportamento em longo prazo dos geossintéticos utilizados nesta pesquisa. Para esta avaliação foram utilizados três diferentes métodos: ensaio de fluência convencional, ensaio de fluência confinada com carregamento indireto no reforço, e ensaio de fluência confinada com carregamento direto no reforço. 


\subsubsection{Fluência em isolamento}

Para a realização de ensaios não confinados, ou ensaios em isolamento de fluência, existem algumas normas disponíveis: ISO 13431, ASTM D-5262, BS 6906 e NBR 15226. Para esta pesquisa foi adotada a norma brasileira.

Em geral, os equipamentos empregados para a realização de ensaios de fluência não confinados são considerados relativamente simples, e apesar de algumas variações do modelo básico, os equipamentos apresentam três partes principais: sistema de ancoragem, sistema para acompanhamento das deformações e sistema de aplicação de carga.

O esquema básico do equipamento para ensaios de fluência não confinada é composto por um cavalete dotado de uma garra superior para fixação do corpo de prova e aplicação do carregamento. As garras para fixação do geossintético devem possuir, no mínimo, a mesma largura do corpo de prova e impedir o seu deslizamento. Durante o ensaio, um conjunto de pesos livres submete a amostra a um esforço de tração constante, ao passo que as deformações são registradas ao longo do tempo. A Figura 3.14 mostrada a seguir ilustra um esquema geral do equipamento de ensaios.

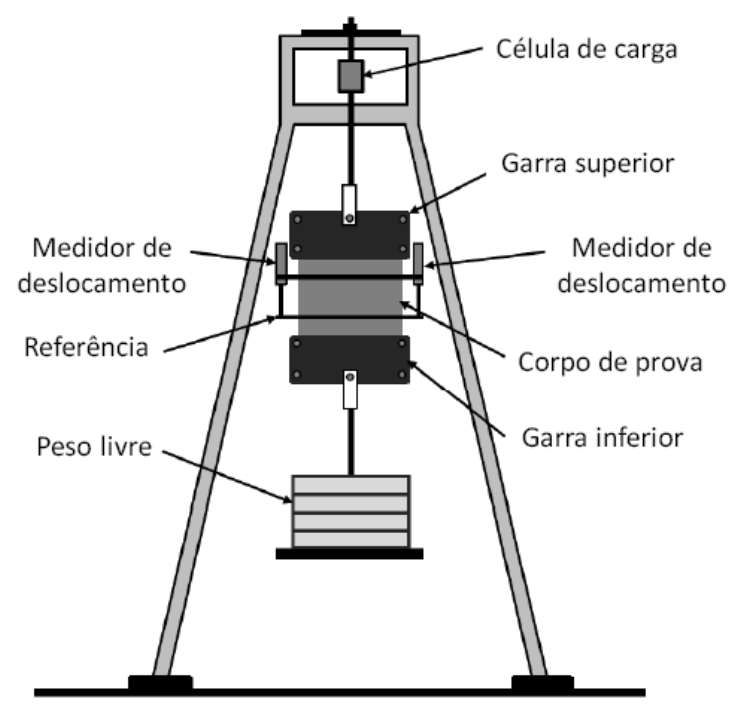

Figura 3.14 - Equipamento empregado nos ensaios de fluência não confinada (Adaptado de ASTM D-5262, 2007). 
Os ensaios de fluência em isolamento foram realizados para os geotêxteis tecidos, não tecidos e para as geogrelhas. Para ambos os geotêxteis os ensaios foram realizados empregando-se carregamentos de $2 \%, 5 \%, 10 \%$ e $20 \%$ da resistência última dos materiais. Para a geogrelha o carregamento de $20 \%$ foi negligenciado.

Os ensaios foram realizados no Laboratório de Geossintéticos do Departamento de Geotecnia da Escola de Engenharia de São Carlos.

Uma vista geral dos ensaios de fluência em isolamento para os materiais utilizados nesta pesquisa pode ser visualizada na Figura 3.15.

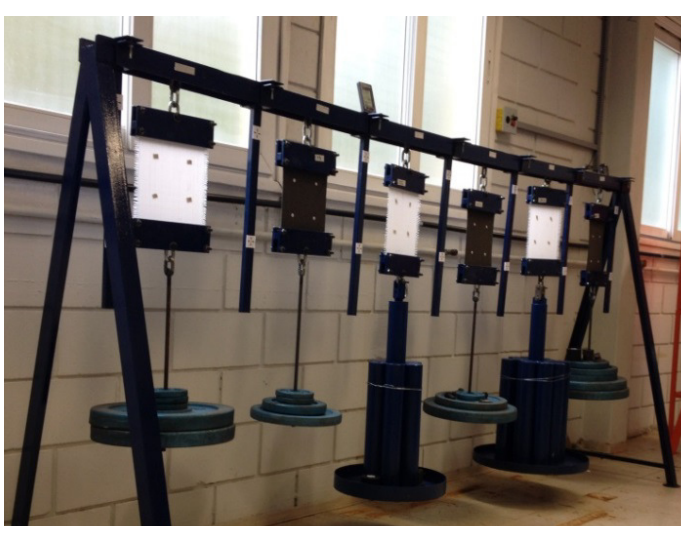

a)

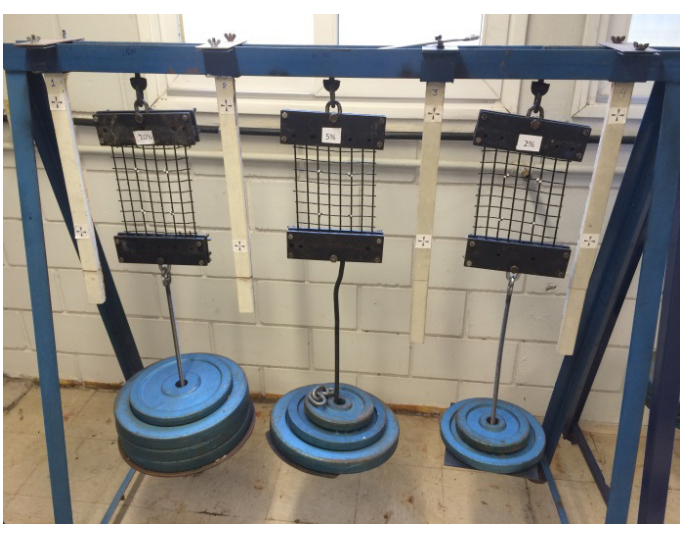

b)

Figura 3.15 - Vista geral dos ensaios de fluência não confinada em andamento para: a) geotêxteis tecidos e não tecidos; b) geogrelhas.

O programa de ensaios de fluência não confinada (em isolamento) para os três tipos de reforços avaliados é apresentado na Tabela 3.4. Esta tabela mostra, para cada um dos ensaios realizados, o tipo de reforço empregado, a relação entre a carga aplicada e a resistência última do material $\left(\mathrm{T} / \mathrm{T}_{\text {ult }}\right)$, bem como a carga absoluta aplicada aos reforços. 
Tabela 3.4- Propriedades mecânicas dos geotêxteis não tecidos, tecidos e geogrelhas.

\begin{tabular}{cccc}
\hline Ensaio & Reforço & $\begin{array}{c}\mathrm{T} / \mathrm{T}_{\text {ult }} \\
(\%)\end{array}$ & $\begin{array}{c}\text { Carga } \\
(\mathrm{kN} / \mathrm{m})\end{array}$ \\
\hline 1 & & 2 & 0,40 \\
2 & GNT & 5 & 1,00 \\
3 & & 10 & 2,00 \\
4 & & 20 & 4,00 \\
\hline 5 & \multirow{2}{*}{ GT } & 2 & 1,10 \\
6 & & 5 & 2,75 \\
7 & 10 & 5,50 \\
8 & \multirow{2}{*}{ GG } & 20 & 11,00 \\
\hline 9 & & 2 & 0,94 \\
10 & 5 & 2,35 \\
11 & & 10 & 4,70 \\
\hline
\end{tabular}

\subsubsection{Fluência confinada}

Os ensaios de fluência confinada foram realizados empregando-se dois equipamentos distintos: equipamento de interação solo-reforço desenvolvido por Costa (2004) e equipamento de fluência confinada-acelerada desenvolvido por França (2011). A descrição detalhada e a programação dos ensaios para cada um dos equipamentos são apresentadas nos itens a seguir.

\subsubsection{Ensaios realizados no equipamento de interação solo-reforço}

Este equipamento é composto basicamente por uma caixa fixa em uma mesa de apoio, um conjunto de garras para a fixação do geotêxtil, um sistema para a aplicação das tensões verticais sobre o solo e um sistema para a obtenção de deformações no reforço por meio do uso de transdutores de deslocamento à base de potenciômetro. Neste equipamento, um corpo de prova de geossintético com dimensões de $200 \times 200 \mathrm{~mm}$ é confinado entre camadas de solo de $100 \mathrm{~mm}$ de espessura cada. $O$ reforço é devidamente instrumentado permitindo a obtenção das deformações em diferentes trechos do corpo de prova.

É importante destacar que no equipamento de interação solo-reforço originalmente desenvolvido por Costa (2004), inicialmente descrito no Capítulo 2 desta tese, o 
sistema de aplicação de cargas verticais era composto por um sistema de bolsas pneumáticas, ligadas ao sistema de ar do laboratório. Entretanto, devido às limitações nos níveis máximos de carregamentos que podiam ser aplicados (por volta de $150 \mathrm{kPa}$ ), à problemas de estabilização do sistema de ar sob elevadas pressões, e à possíveis quedas no sistema durante a execução do ensaio, optou-se pelo desenvolvimento de um novo sistema de aplicação de cargas verticais. O novo sistema desenvolvido, consideravelmente mais simples que o sistema original, é composto por uma alavanca, com aproximadamente 1,20 m de comprimento, capaz de multiplicar em aproximadamente 9 vezes a carga aplicada em sua extremidade. Para garantir a verticalidade do carregamento, o novo aparato conta com um sistema de guias, que garante que o carregamento seja aplicado perpendicularmente ao maciço de solo compactado. Sobre a placa de aplicação do carregamento, existe ainda um sistema de rótulas, de forma a se obter uma melhor distribuição de tensões.

Uma representação esquemática do equipamento, incluindo as alterações no sistema de carregamento, inicialmente proposto por Costa (2004), é mostrada na Figura 3.16. Uma vista geral do equipamento modificado e o sistema de guias para garantir a verticalidade da aplicação das cargas são mostrados na Figura 3.17.

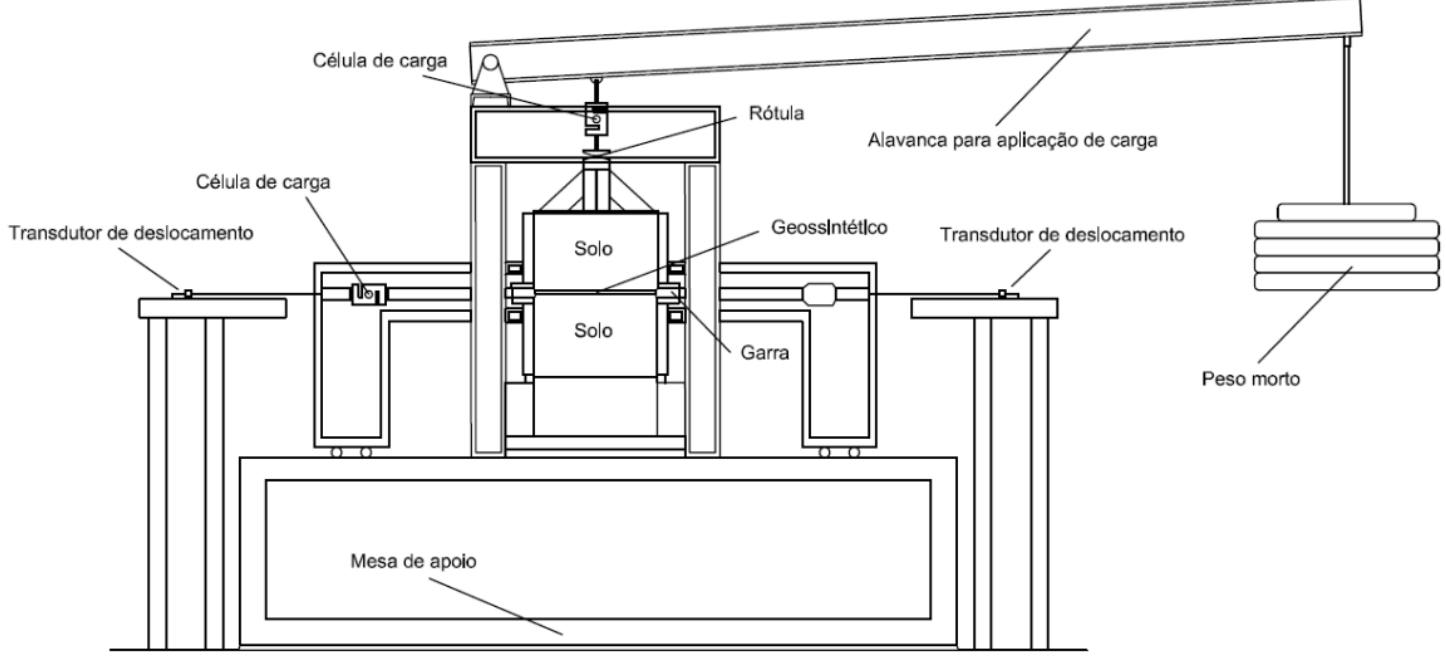

Figura 3.16 - Representação esquemática do equipamento de interação solo-reforço desenvolvido por Costa (2004), com o sistema de aplicação de cargas modificado. 
Outra modificação realizada no equipamento se refere ao sistema de instrumentação e leituras de deslocamentos internos dos reforços. Originalmente, os reforços eram instrumentados com barras metálicas e as leituras eram realizadas com o auxílio de relógios comparadores. No sistema atual, os reforços são instrumentados com fios inextensíveis ligados a um sistema de sensores de deslocamentos potenciométricos, cujas leituras são realizadas automaticamente por um sistema de aquisição de dados. Os sensores de deslocamento à base de potenciômetro possuem uma precisão de 0,001 mm, e encontram-se fixados a uma mesa posicionada em frente ao sistema de pórticos deslocáveis do equipamento.

O sistema de aquisição de dados utilizado foi o i5000 da Vishay MicroMeasurements. Trata-se de um sistema de aquisição de dados completo capaz de realizar leituras de dados de strain-gages, termopares, sensores de deslocamentos e outros tipos de transdutores. Este sistema de aquisição de dados permite a realização de até 100 leituras por segundo. Para os ensaios realizados nesta pesquisa foi empregada uma frequência de uma leitura por segundo.

Uma vista geral do equipamento de interação solo-reforço é mostrada na Figura 3.17. O sensor de deslocamento empregado nos ensaios, bem como seu posicionamento na mesa fixa em frente ao equipamento é apresentado na Figura 3.18.

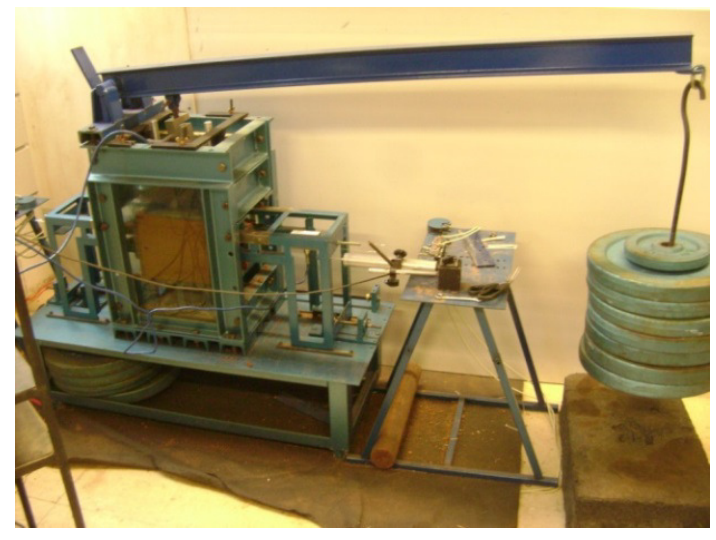

(a)

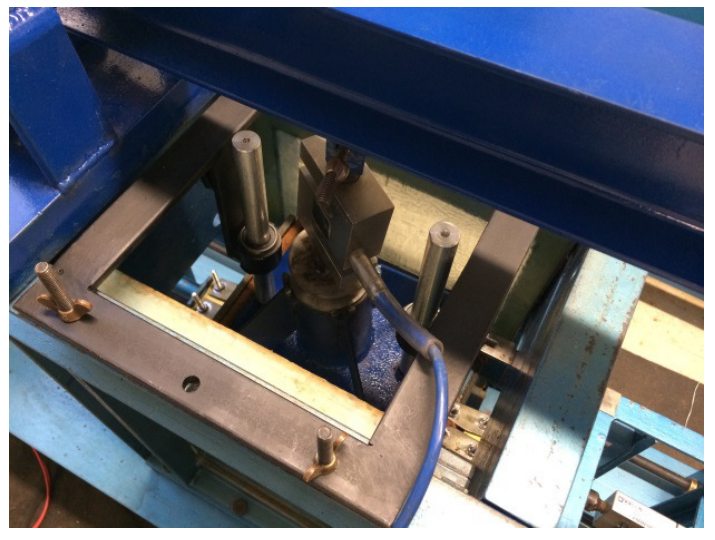

(b)

Figura 3.17 - Sistema desenvolvido para a aplicação de carregamentos verticais: a) Vista geral; b) Sistema de guias para garantir a verticalidade do carregamento. 


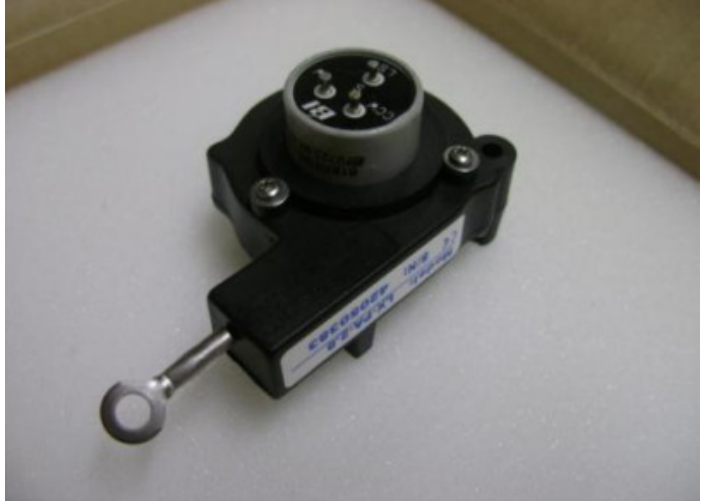

(a)

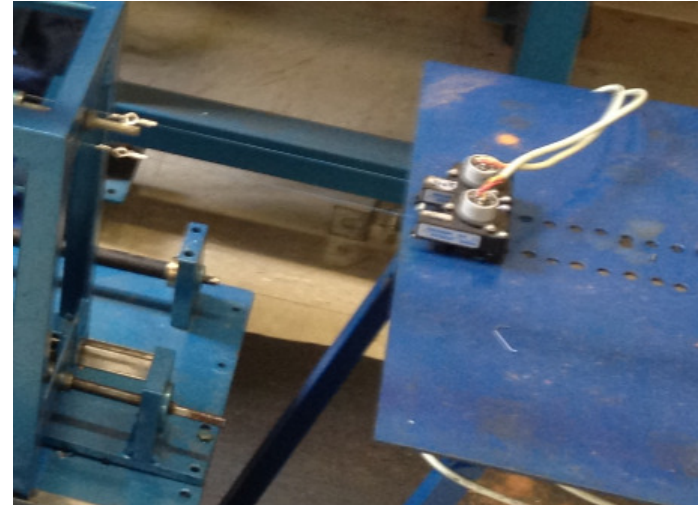

(b)

Figura 3.18 - Sistema de leitura de deslocamentos internos no reforço: a) Sensor de deslocamento potenciométrico; b) Posicionamento dos sensores na mesa fixa.

É importante destacar que a caixa apresenta um eixo de simetria, esperando-se, portanto, que os carregamentos ocorram de forma igual em ambas as paredes móveis do equipamento. É importante também salientar que a trajetória de tensões no maciço de solo é semelhante a uma condição de empuxo ativo. Neste ensaio as tensões verticais são aplicadas e mantidas constantes durante todo o período de teste, enquanto que as tensões horizontais são aliviadas por conta dos deslocamentos das paredes móveis. A Figura 3.19 ilustra a evolução do estado de tensões representado por círculos de Mohr (a) e pela trajetória das tensões (b).

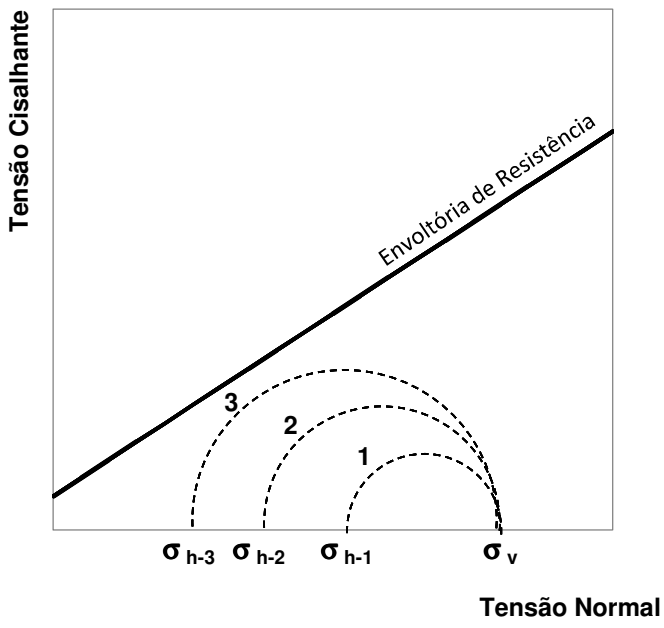

(a)

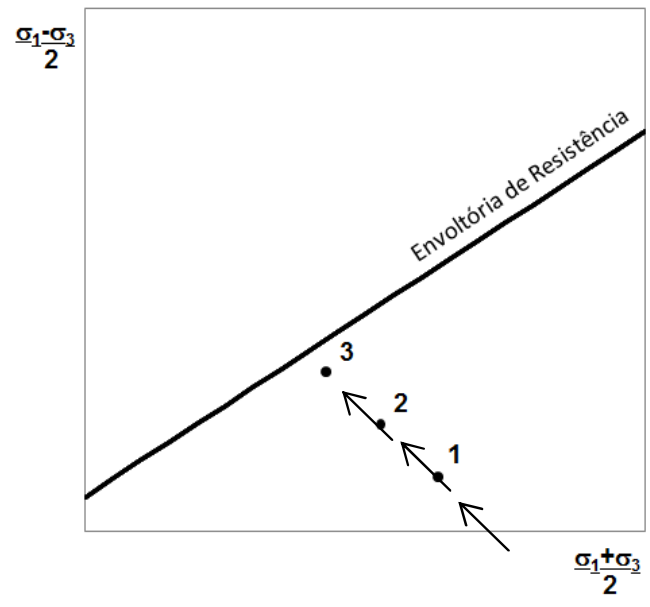

(b)

Figura 3.19 - Evolução do estado de tensões no ensaio de fluência confinada representado por: a) círculos de Mohr; b) trajetória das tensões. 
Conforme destacado anteriormente, a obtenção das deformações no reforço foi feita por meio da medida de deslocamentos de fios inextensíveis fixados ao geossintético. Quatro fios foram utilizados para acompanhar os deslocamentos de quatro pontos distintos no reforço, permitindo o registro da deformação da manta em diferentes trechos. Os deslocamentos dos fios foram registrados mediante a utilização de transdutores deslocamentos devidamente calibrados e ligados ao sistema de aquisição de dados. Adicionalmente foram registrados também os deslocamentos das faces móveis por meio do uso de transdutores de deslocamento do tipo LVDT. A Figura 3.20 ilustra o esquema geral com a disposição dos pontos instrumentados no reforço.

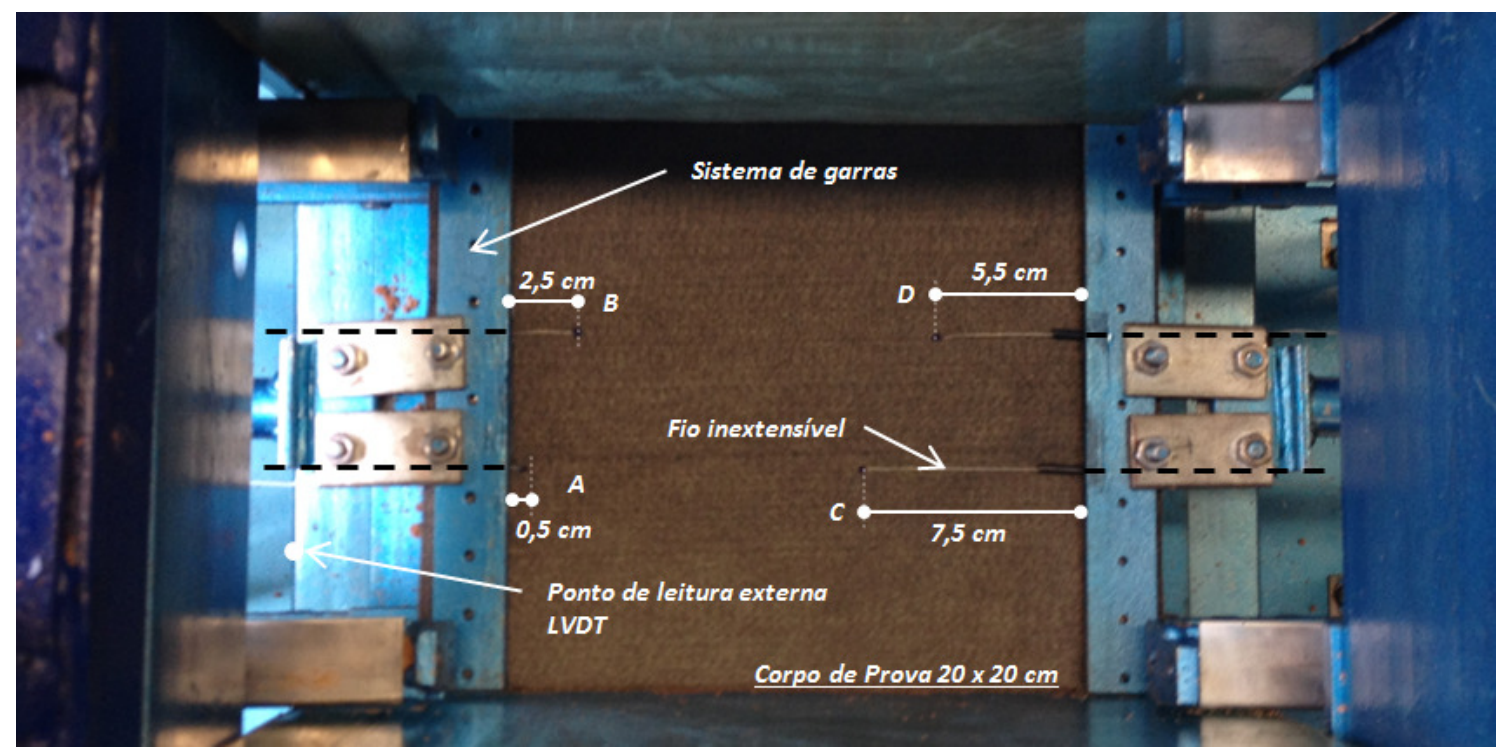

Figura 3.20 - Esquema geral de instrumentação do reforço.

Com a utilização do esquema de instrumentação proposto, foi possível a determinação das deformações no reforço em quatro pontos distintos: entre o ponto de leitura externa e o ponto $A$, entre os pontos $A$ e $B$, entre os pontos $B$ e $C$, e entre os pontos $C$ e $D$.

Destaca-se que, de forma geral, os valores das deformações foram ligeiramente superiores nas bordas em relação ao centro do reforço. Entretanto, como as diferenças entre as deformações calculadas foram muito pequenas, para as análises realizadas nesta tese foram empregados os valores médios das deformações dos quatro pontos. 
Conforme salientado anteriormente, o equipamento desenvolvido por Costa (2004) foi utilizado com o objetivo de se avaliar o comportamento em longo prazo de muros de solo reforçado com geossintéticos sob condições reais de trabalho. Para isso foi elaborado um programa de ensaios baseado na obra de referência descrita no Item 3.1.

O programa de ensaios elaborado para o equipamento de interação solo-reforço incluiu a execução de sete ensaios empregando-se geotêxteis não tecidos, sete ensaios empregando-se geotêxteis tecidos, e quatro ensaios empregando-se geogrelha como material de reforço. Todos os reforços foram ensaiados para quatro diferentes níveis de carregamento (140, 200, 300 e $400 \mathrm{kPa})$ com solo compactado com teor de umidade ótimo. Para os geotêxteis tecidos e não tecidos o ensaio com carregamento de $140 \mathrm{kPa}$ foi repetido para dois teores de umidade adicionais: um no ramo seco e um no ramo úmido.

Ainda pensando no comportamento de muros em solo reforçado submetido a diferentes condições de trabalho, como fortes chuvas, por exemplo, optou-se por realizar, adicionalmente aos ensaios de fluência confinada com variação de carregamento vertical e umidade de compactação, ensaios de fluência confinada com inundação do solo. Para tanto, os ensaios realizados com solo compactado no teor de umidade ótimo, com carregamento vertical de $140 \mathrm{kPa}$, foram repetidos para os três tipos de reforços, com a diferença que, após as 40 horas iniciais do ensaio, o solo reforçado foi submetido a uma inundação.

Para a realização da inundação do solo foi desenvolvido um sistema constituído por um recipiente elevado, com capacidade aproximada de oito litros, dotado de um sistema de mangueiras em sua base, as quais se encontravam ligadas ao maciço de solo em quatro pontos distintos. Estima-se que o maciço, para cada um dos ensaios, levou cerca de 12 horas para ficar totalmente inundado. Uma ilustração do sistema desenvolvido para inundação do solo é apresentada na Figura 3.21.

O programa de ensaios de fluência confinada para os três tipos de reforços avaliados é apresentado na

Tabela 3.5.

Ressalta-se que as sobrecargas de $140 \mathrm{kPa}$ são referentes ao carregamento médio aproximado encontrado nas camadas de reforço situadas a 1,60m de altura em relação à base do muro de referência, ou seja, se referem ao carregamento vertical esperado na linha instrumentada E02. Devido aos baixos carregamentos esperados 
nos geotêxteis situados na linha de instrumentação E03, que é a seção instrumentada mais superficial, situada a 5,0m da base do muro, não foram previstos ensaios para simular esta região. Os ensaios com sobrecargas de 200, 300 e 400 $\mathrm{kPa}$, foram definidos com o objetivo de simular muros com alturas mais elevadas, de aproximadamente, 10, 15 e 20 m de altura, respectivamente.

Tabela 3.5 - Programa de ensaios de fluência confinada para o equipamento de interação soloreforço

\begin{tabular}{|c|c|c|c|}
\hline Ensaio & Reforço & $\begin{array}{c}\text { Umidade } \\
(\%)\end{array}$ & $\begin{array}{c}\text { Sobrecarga } \\
\qquad(\mathrm{kPa})\end{array}$ \\
\hline 1 & \multirow{7}{*}{ Geotêxtil não tecido } & 8,0 & \\
\hline 2 & & $11,7^{\star}$ & 140 \\
\hline 3 & & 16,0 & \\
\hline 4 & & \multirow{3}{*}{11,7} & 200 \\
\hline 5 & & & 300 \\
\hline 6 & & & 400 \\
\hline 7 & & Inundado & 140 \\
\hline 8 & \multirow{7}{*}{ Geotêxtil tecido } & 8,0 & \\
\hline 9 & & 11,7 & 140 \\
\hline 10 & & 16,0 & \\
\hline 11 & & \multirow{3}{*}{11,7} & 200 \\
\hline 12 & & & 300 \\
\hline 13 & & & 400 \\
\hline 14 & & Inundado & 140 \\
\hline 15 & \multirow{4}{*}{ Geogrelha } & \multirow{4}{*}{11,7} & 140 \\
\hline 16 & & & 200 \\
\hline 17 & & & 300 \\
\hline 18 & & & 400 \\
\hline
\end{tabular}

*A umidade de $11,7 \%$ se refere à umidade ótima obtida nos ensaios de compactação. 


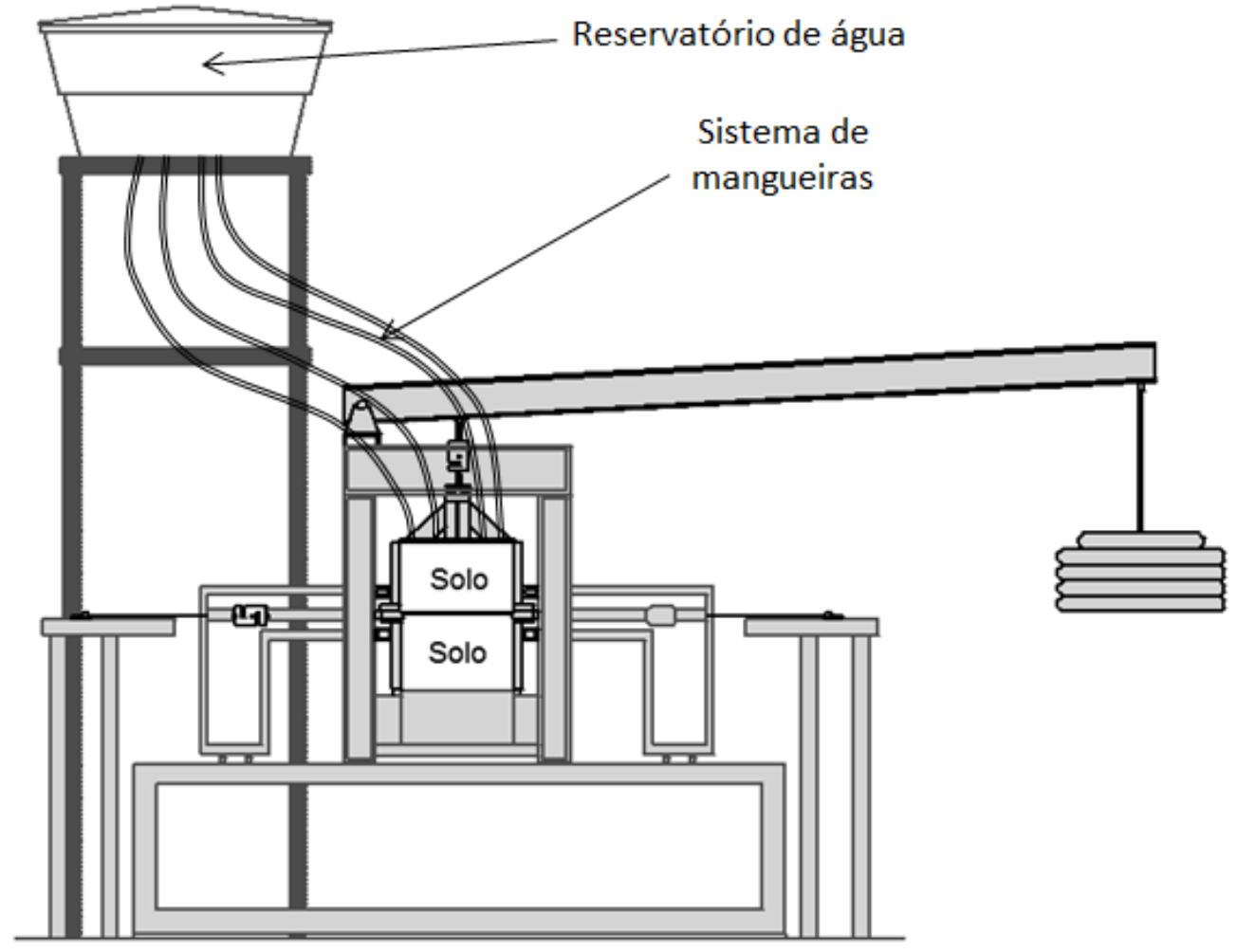

Figura 3.21 - Vista esquemática do sistema desenvolvido para a realização da inundação do solo.

Os ensaios realizados na caixa de interação solo-reforço desenvolvida por Costa (2004) foram montados compactando-se o solo em oito camadas, sendo quatro camadas situadas na porção inferior da câmara de ensaios (abaixo do reforço) e quatro camadas situadas na porção superior da câmara (acima do reforço). É importante destacar que durante o processo de compactação a movimentação das paredes laterais da câmara de ensaios foi impedida por meio do uso de um sistema de travas disponível no equipamento.

O compactador empregado para a montagem dos ensaios possuía uma massa de $4,54 \mathrm{~kg}$, com uma altura de queda de $45,72 \mathrm{~cm}$. Foram aplicados 25 golpes em cada uma das camadas executadas. Assim, a energia de compactação aplicada para a execução das camadas foi semelhante à energia de compactação dos ensaios Proctor Normal, ou seja, de aproximadamente $6 \mathrm{kgf} / \mathrm{cm}^{3}$.

Este sistema de compactação permitiu que os maciços de solo fossem executados com grau de compactação de aproximadamente $98 \%$.

O sistema de travas do equipamento, o qual impedia os deslocamentos laterais das paredes móveis durante o processo de compactação do solo, só era liberado após 
montagem completa do modelo, da preparação do sistema de instrumentação e do início da aquisição dos dados.

Todos os ensaios de fluência confinada realizados no equipamento desenvolvido por Costa (2004) tiveram uma duração de 120 horas.

Destaca-se que após o término de cada um dos ensaios executados eram realizadas medidas de umidade do solo em três pontos distintos ao longo do maciço. Observou-se que a perda de umidade do solo após as 120 horas de ensaio, para todos os ensaios realizados, foi inferior a $1 \%$.

\subsubsection{Ensaios realizados no equipamento de fluência confinada-acelerada}

O equipamento de fluência confinada e acelerada desenvolvido por França (2011) é composto por uma câmara de ensaio em que o corpo de prova de geossintético é posicionado horizontalmente entre duas camadas de solo, e o reforço é solicitado por forças de tração aplicadas por meio de garras conectadas a pesos livres. A câmara de ensaios possui um sistema que possibilita a reprodução de tensões de confinamento, por meio de uma bolsa de ar pressurizado. Além disso, conta com um sistema de resistências instaladas em seu interior, capaz de produzir temperaturas elevadas ao longo dos ensaios. Além da realização de ensaios simultaneamente confinados e acelerados, esse equipamento pode ser empregado para ensaios separadamente confinados ou acelerados, bem como, ensaios convencionais de fluência em geossintéticos.

A Figura 3.22 apresenta um esquema geral e uma fotografia do equipamento, destacando os principais elementos que compõem os sistemas responsáveis pela reprodução do confinamento do reforço em solo, pela aplicação do carregamento vertical no maciço, pela medição dos deslocamentos nos reforços, pela elevação da temperatura de ensaio e pela aquisição e registro dos dados medidos.

A câmara de ensaio do equipamento desenvolvido por França (2011) apresenta área plana quadrada com $400 \mathrm{~mm}$ de lado e altura de $200 \mathrm{~mm}$. As paredes metálicas possuem 12,5 mm de espessura. Ao longo da altura, a câmara é subdividida em dois compartimentos: superior e inferior. O compartimento superior, com 137,5 mm de altura, acomoda o solo confinante e o corpo de prova que será ensaiado. Já a parte inferior possui $50 \mathrm{~mm}$ de altura e abriga o sistema de aquecimento com 
resistências. No topo da parte superior é fixada uma tampa de reação que tem a finalidade de fornecer suporte para a bolsa inflável (a qual possui aproximadamente $30 \mathrm{~mm}$ de altura), e que é responsável pela simulação da tensão confinante no maciço.

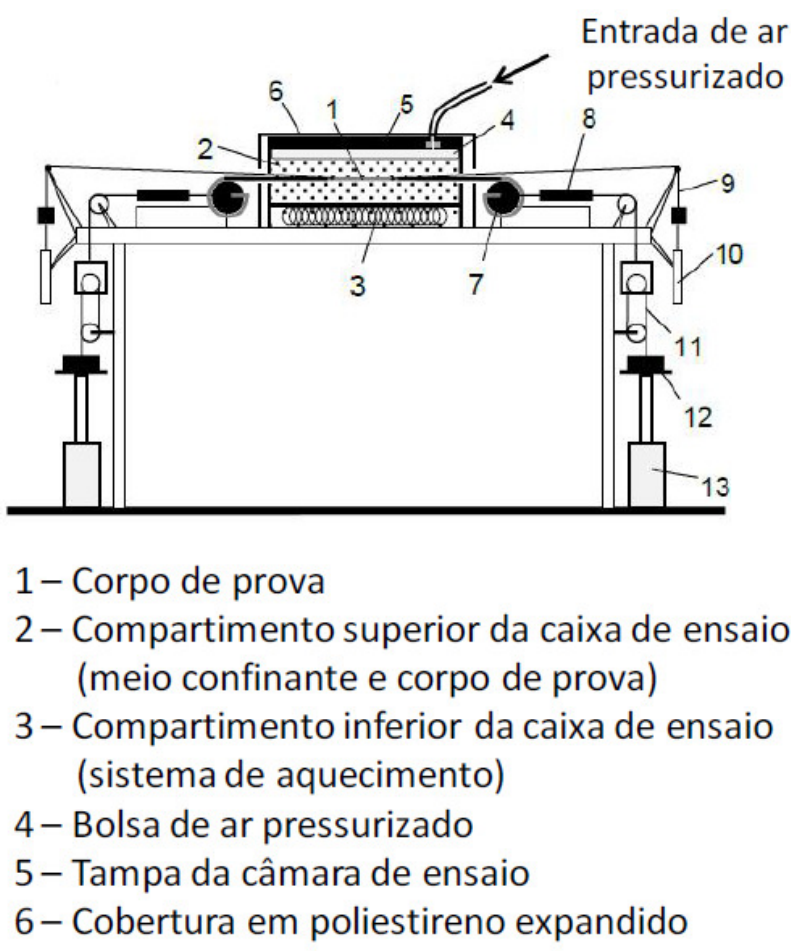

(a)

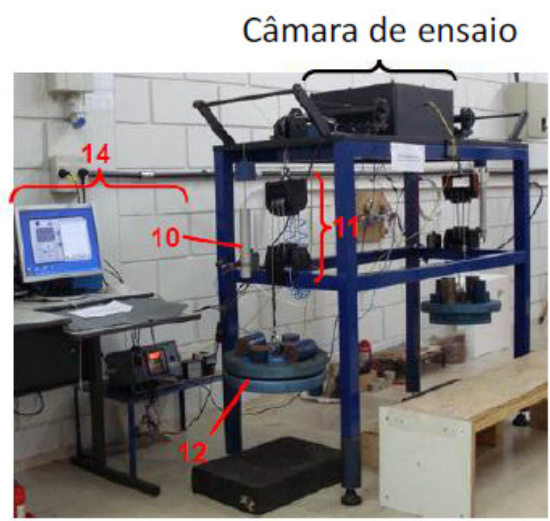

7- Garra do tipo rolete

8- Célula de carga

9 - Fio de aço inextensível

10 - Transdutor de deslocamento

11 - Conjunto de polias

12 - Peso livre

13- Macaco hidráulico

14- Sistema de aquisição de dados

(b)

Figura 3.22 - Equipamento de fluência confinada acelerada: (a) esquema geral; (b) fotografia do equipamento com ensaio em andamento (FRANÇA, 2011).

A câmara de ensaios possui duas aberturas laterais com $300 \mathrm{~mm}$ de largura por 5 $\mathrm{mm}$ de altura, que permitem o acesso do corpo de prova para a parte externa do equipamento. $\mathrm{O}$ corpo de prova é fixado por meio de garras do tipo rolete, as quais são conectadas por cabos de aço a um sistema de pesos livres. Os cabos de aço que sustentam os pesos livres passam por um conjunto de polias, capaz de multiplicar a solicitação do carregamento em aproximadamente seis vezes. A solicitação de tração é verificada continuamente por meio de células de cargas instaladas entre as garras e os cabos de aço. Os deslocamentos internos ao reforço são medidos por sensores de deslocamentos ligados por meio de fios inextensíveis a pontos conhecidos do corpo de prova. É importante destacar que os pontos instrumentados do reforço devem ficar dentro de uma faixa de interesse do corpo de 
prova, situado na região central do mesmo, que fica em contato com o solo e recebe a tensão de confinamento. O posicionamento dos pontos instrumentados situados dentro da área de interesse do ensaio é mostrado na Figura 3.23.

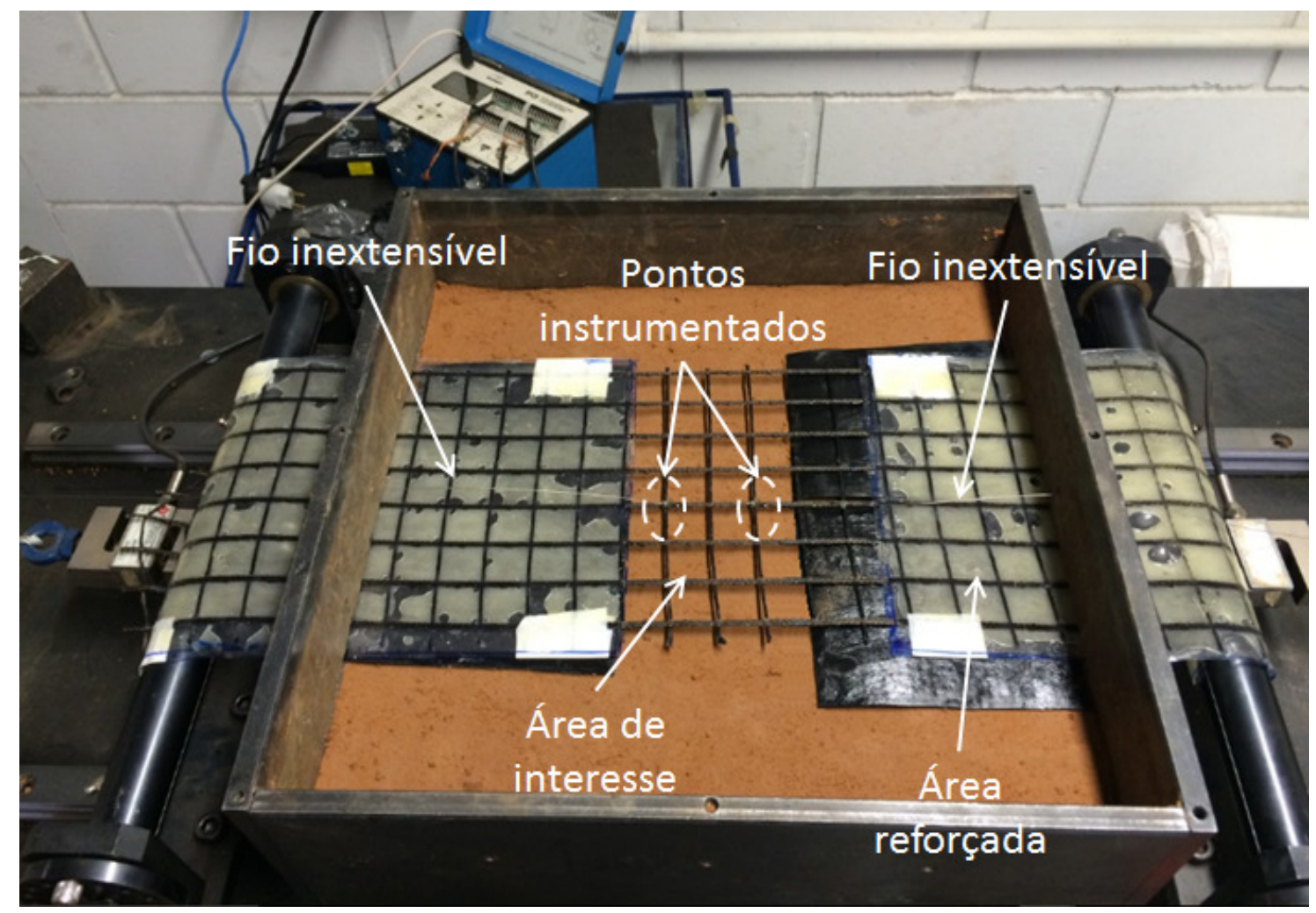

Figura 3.23 - Configuração final do corpo de prova de geossintético instrumentado.

Para facilitar a realização das leituras dos deslocamentos dos pontos instrumentados situados na região interna dos reforços, elementos metálicos (com massa de aproximadamente $1,75 \mathrm{~kg}$ ) foram fixados na extremidade dos fios inextensíveis. Desse modo, os fios inextensíveis se encontravam fixados ao reforço em uma das extremidades e fixados aos elementos metálicos na outra.

As hastes dos transdutores de deslocamento (LVDT's com curso máximo de $50 \mathrm{~mm}$ e precisão de $0,01 \mathrm{~mm}$ ) eram então colocadas em contato com os elementos metálicos, de tal forma que se registram os deslocamentos verticais dos mesmos.

A Figura 3.24 apresenta o detalhamento do sistema para a medição dos deslocamentos internos aos reforços instrumentados. 


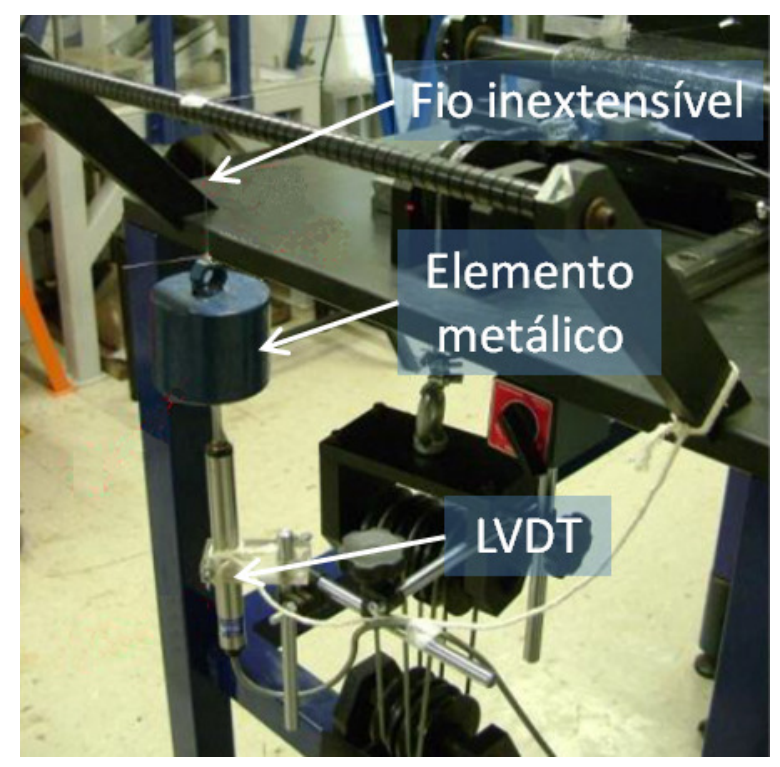

Figura 3.24 - Sistema para medição dos deslocamentos internos ao reforço.

É possível se observar que em termos de princípio de funcionamento, o equipamento desenvolvido por França (2011) difere de forma significativa quando comparado ao equipamento desenvolvido por Costa (2004). Conforme destacado anteriormente, no equipamento desenvolvido por Costa (2004), ocorre um alívio das tensões laterais durante a execução do ensaio, o que conduz a uma variação da trajetória de tensões no conjunto solo-reforço. No caso do equipamento desenvolvido por França (2011) isto não ocorre. Neste equipamento, como as paredes da câmara de ensaios são fixas, as tensões no conjunto solo-reforço permanecem constantes ao longo de todo o ensaio. Além disso, no equipamento desenvolvido por Costa (2004), a tensão horizontal aplicada no reforço é consequência da tensão vertical aplicada e da interação que ocorre entre o solo e o reforço. Para o caso do equipamento desenvolvido por França (2011) a aplicação da carga no reforço é independente da tensão vertical. Ou seja, é possível impor qualquer relação entre as tensões verticais e horizontais, mesmo que esta não seja representativa de um caso real.

Tendo em vista os aspectos mencionados, e visando uma posterior comparação entre os resultados obtidos nos diferentes equipamentos, os ensaios realizados no equipamento de fluência confinada-acelerada foram planejados de forma a se aplicar nos reforços as mesmas combinações de cargas verticais e horizontais obtidas nos ensaios realizados no equipamento desenvolvido por Costa (2004). 
Todos os ensaios foram realizados aplicando-se carregamentos verticais de $140 \mathrm{kPa}$ com o solo compactado na umidade ótima.

O programa experimental para o equipamento desenvolvido por França (2011) incluiu a execução de ensaios de fluência confinada e de ensaios de fluência confinada-acelerada. Isto permitiu a previsão das deformações para períodos de tempo superiores a 200 anos. Os ensaios confinados foram realizados com uma temperatura ambiente da ordem de $23^{\circ} \mathrm{C}$ e os ensaios acelerados foram realizados com uma temperatura imposta de $38^{\circ} \mathrm{C}$. A temperatura de $38^{\circ} \mathrm{C}$ foi selecionada em função dos resultados obtidos por França (2011), que utilizou materiais semelhantes aos empregados nessa pesquisa.

O programa de ensaios de fluência confinada para o equipamento desenvolvido por França (2011) é apresentado na Tabela 3.6.

Tabela 3.6 - Programa de ensaios de fluência confinada para o equipamento desenvolvido por França (2011).

\begin{tabular}{cccc}
\hline Ensaio & $\begin{array}{c}\text { Temperatura } \\
\left({ }^{\circ} \mathrm{C}\right)\end{array}$ & Tipo de Reforço & $\begin{array}{c}\text { Carga no reforço } \\
\mathrm{T} / \mathrm{T}_{\text {ult }}(\%)\end{array}$ \\
\hline 1 & 23 & $\begin{array}{c}\text { Geotêxtil não } \\
\text { tecido } \\
2\end{array}$ & $2,0 \%$ \\
3 & & Geotêxtil tecido & $1,6 \%$ \\
4 & Geogrelha & $1,5 \%$ \\
\hline 5 & 38 & Geotêxtil não & $2,0 \%$ \\
6 & tecido & \\
\hline & & Geotêxtil tecido & $1,6 \%$ \\
& & Geogrelha & $1,5 \%$ \\
\hline
\end{tabular}

Os ensaios realizados no equipamento desenvolvido por França (2011) foram montados compactando-se o solo em quatro camadas, sendo duas camadas situadas na porção inferior da câmara de ensaios (abaixo do reforço) e duas camadas situadas na porção superior da câmara (acima do reforço).

O compactador empregado para a montagem destes ensaios foi o mesmo utilizado para a compactação do solo utilizado na caixa desenvolvida por Costa (2004), ou seja, massa de $4,54 \mathrm{~kg}$, com uma altura de queda de $45,72 \mathrm{~cm}$. Foram utilizados 25 golpes para a compactação de cada camada, de forma a se aplicar ao solo uma 
energia de compactação de $6 \mathrm{kgf} / \mathrm{cm}^{3}$. O grau de compactação obtido, a exemplo dos ensaios realizados no equipamento desenvolvido por Costa (2004), foi da ordem de $98 \%$.

Ao término de cada um dos ensaios desenvolvidos foi realizada a medida de teor de umidade do maciço de solo. Observou-se que a redução dos teores umidade, para os ensaios confinados, foi inferior a $1 \%$. Para os ensaios confinados e acelerados, a redução dos teores de umidade foi pouco superior a $1 \%$.

Para a extrapolação dos dados obtidos nos ensaios realizados com temperatura elevada (ensaios acelerados), foi empregada a metodologia apresentada por França (2011). Esta metodologia utiliza como principal parâmetro para a avaliação do comportamento em deformação por fluência dos geossintéticos o índice de fluência T $\alpha$ obtido a partir da abordagem sugerida por Zornberg; Byler e Knudsen (2004). Dessa forma, as deformações por fluência ocorridas em temperaturas elevadas foram interpretadas como se tivessem ocorrido na temperatura de referência, mas numa escala de tempo mais extensa. Ressalta-se que a temperatura de referência empregada nesta tese foi a temperatura ambiente.

O procedimento empregado consistiu inicialmente na determinação da curva de fluência para os ensaios realizados com temperatura ambiente. Posteriormente, foi determinado, para cada um dos ensaios realizados na temperatura de referência, o

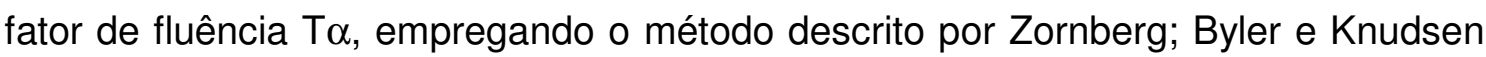
(2004). Na sequencia, foram determinadas as curvas de fluência e os parâmetros $T \alpha$ para os ensaios realizados com a temperatura elevada $\left(38^{\circ} \mathrm{C}\right)$. A partir dos parâmetros de fluência para os ensaios de referência $\left(T_{\alpha, R}\right)$ e para os ensaios com temperatura elevada $\left(T_{\alpha, i}\right)$, o fator de translação $\left(\alpha_{T}\right)$ foi determinado por meio da eq. (3.1).

$$
\alpha_{T}=10^{\operatorname{leg}\left(\frac{1}{T_{G i}}\right)-\log \left(\frac{1}{T_{W, R}}\right)}
$$

De posse dos fatores de translação para cada um dos conjuntos de reforços estudados, determinou-se o tempo fictício dos ensaios acelerados, ou seja, a duração dos ensaios caso esses fossem executados na temperatura de referência. O tempo fictício $\left(t_{R}\right)$ foi determinado pela eq. (3.2). 


$$
t_{R}=\frac{t_{1}}{\alpha_{T}}
$$

Conforme será exposto mais adiante, o emprego desta metodologia permitiu a extrapolação dos dados de deformação por fluência para períodos consideravelmente mais elevados que os tempos reais de ensaio.

\subsection{ENSAIOS DE TENSÕES INDUZIDAS POR COMPACTAÇÃO NO REFORÇO}

Conforme descrito no Item 3, no procedimento para a montagem do ensaio de fluência confinada no equipamento de interação solo-reforço, durante a compactação do solo, o movimento lateral das paredes da caixa de testes eram restringidos por um sistema de travas. Somente após a montagem completa do ensaio, e após o início da aquisição de dados, o sistema de travas era liberado, as paredes laterais começavam a se movimentar e a célula de carga lateral começava a registrar os esforços no elemento de reforço.

Com base no princípio de funcionamento deste equipamento, optou-se por realizar alguns ensaios adicionais iniciando a aquisição dos dados de carregamento no reforço durante o processo de compactação do maciço de solo. Ressalta-se que para o registro destas forças, o processo de compactação foi executado sem 0 sistema de travas acionado. Dessa forma a aquisição dos dados foi realizada simultaneamente ao início da compactação da camada superior de solo no interior da câmara de ensaios. Nesta etapa, a camada inferior de solo já estava executada e o reforço já se encontrava preso ao sistema de garras.

O procedimento para a montagem dos ensaios de compactação foi o mesmo empregado para a montagem dos ensaios de fluência confinada.

A energia de compactação empregada nos ensaios foi semelhante à energia de compactação dos ensaios Proctor Normal, ou seja, de aproximadamente $6 \mathrm{kgf} / \mathrm{cm}^{3}$. O solo na região acima do reforço foi compactado em 3 camadas, e após a execução da última camada, um carregamento de $140 \mathrm{kPa}$ foi aplicado sobre a superfície do maciço.

A execução destes ensaios permitiu a determinação da parcela de carga no reforço referente ao processo de compactação e da parcela referente ao carregamento vertical. 
Os ensaios de compactação foram realizados para os geotêxteis não tecidos, geotêxteis tecidos e geogrelhas, com o solo compactado na umidade ótima para todos os casos. O programa de ensaios de compactação é mostrado na Tabela 3.7.

Tabela 3.7 - Programa de ensaios de compactação realizados no equipamento de interação soloreforço.

\begin{tabular}{cc}
\hline Ensaio & Tipo de Reforço \\
\hline 1 & Geotêxtil não tecido \\
2 & Geotêxtil tecido \\
3 & Geogrelha \\
\hline
\end{tabular}

\subsection{MÉTODO DE CÁLCULO DAS DEFORMAÇÕES NOS REFORÇOS}

O cálculo das deformações nos reforços apresentadas nesta tese foi realizado por três métodos distintos, dependendo do ensaio em análise.

Para o caso das leituras de campo realizadas nos instrumentos instalados no muro de referência de Campinas, empregou-se o método de cálculo de deformações por ajustes sigmoidais. Resultados de análises de deformações que empregaram este tipo de ajuste foram apresentados por diversos autores (ZORNBERG et al., 1995; ZORNBERG; ARRIAGA, 2013; BENJAMIM et al., 2007; PORTELINHA et al., 2013, 2014), e se mostraram bastante eficientes na determinação da localização da deformação de pico.

Este tipo de análise consiste inicialmente em se plotar os dados de deslocamentos relativos obtidos a partir dos extensômetros e realizar um ajuste a estes dados por meio de uma curva do tipo sigmoide. A distribuição das deformações ao longo do comprimento do reforço é então calculada pela derivação dos deslocamentos relativos, empregando-se a eq. (3.3).

$$
\varepsilon=\left(\frac{1}{a+b e^{-\infty x}}\right) / d x
$$


Em que $d$ é o deslocamento medido no extensômetro, $x$ é a distância da face ao ponto de medida, e $a, b$ e $c$ são parâmetros de ajuste da curva sigmoidal determinados utilizando-se o método dos mínimos quadrados.

Para o caso dos ensaios de fluência em isolamento, a determinação das deformações nos geotêxteis e nas geogrelhas foi realizada empregando-se um software, desenvolvido no Laboratório de Geossintéticos da Escola de Engenharia de São Carlos, baseado em fotografias. O método consiste basicamente em se marcar nas fotografias os pixels das miras de referência situadas tanto no material geossintético a ser avaliado, quanto em referências externas, fixas e adjacentes a este material. O software, por sua vez, calcula automaticamente a variação dos deslocamentos relativos entre as miras internas e externas, permitindo o cálculo das deformações para aquele dado momento. Sendo assim, o método exige que uma fotografia seja tirada para cada tempo em que se deseja calcular a deformação. A precisão deste método é de $0,01 \mathrm{~mm}$.

Para o caso dos ensaios de fluência realizados sob confinamento, as deformações foram calculadas de uma forma mais simplificada. Como mostrado na Figura 3.20 do item 3.4.2, os corpos de prova foram instrumentados com fios inextensíveis, ligados a um transdutor de deslocamentos com precisão de 0,001 mm. Os fios se encontravam posicionados em 4 pontos distintos ( $A, B, C$ e D). Além disso, a face externa da caixa de ensaios contava com a presença de um LVDT, com precisão de 0,01 mm. Com esta configuração foi possível se calcular as deformações em 4 pontos distintos ao longo do reforço: entre a face móvel da caixa e o ponto $A$, entre os pontos $A$ e $B$, entre os pontos $B$ e $C$, e entre os pontos $C$ e $D$. Para cada uma das situações o cálculo foi realizado dividindo-se o deslocamento relativo entre os pontos num dado momento pela distância inicial entre os mesmos $\left(z=\Delta l / l_{\mathrm{g}}\right)$.

Ressalta-se que como as deformações foram praticamente constantes ao longo dos corpos de prova, a deformação final utilizada foi a média das deformações calculadas nos quatro pontos.

\subsection{MÉTODOS DE CÁLCULO EMPREGADOS PARA ANÁLISES DE FLUÊNCIA}

Neste trabalho foram empregados dois modelos distintos para a representação da variação das deformações ao longo do tempo: modelo de representação da equação 
logarítmica, e modelo de representação proposto por Zornberg; Byler e Knudsen (2004). Ambos os modelos permitem a determinação da susceptibilidade à fluência dos materiais, cada um com suas particularidades.

No modelo de representação logarítmica, os dados são plotados em um gráfico, com as deformações no eixo das ordenadas, e o tempo no eixo das abcissas em escala logarítmica. Uma função de ajuste, do tipo $\varepsilon=a+b \cdot \ln (t)$, é então empregada, em que " $a$ " representa a deformação inicial do reforço e " $b$ " a tendência do material a apresentar fluência.

No modelo de representação proposto por Zornberg; Byler e Knudsen (2004), os dados são plotados em um gráfico, com as deformações, descontadas da deformação inicial, no eixo das ordenadas, e a relação $\log _{10}\left(t / t_{0}\right)$ no eixo das abcissas, em que $t$ representa o tempo atual da deformação, e $t_{0}$ representa o tempo referente à deformação inicial. Aos dados ajusta-se uma reta passando pela origem representada pela equação $\varepsilon_{f}=T_{\alpha} \cdot \log _{10}\left(t / t_{0}\right)$, sendo que as deformações por fluência são caracterizadas pela inclinação da mesma, nomeada como índice de fluência $(T \alpha)$. A deformação total é dada por $\varepsilon_{t}=\varepsilon_{0}+\varepsilon_{f}$, em que $\varepsilon_{0}$ é a deformação inicial.

\subsection{SIMULAÇÕES NUMÉRICAS}

As análises numéricas apresentadas nesta pesquisa foram desenvolvidas utilizando o software geotécnico Plaxis 2D AE. O software foi empregado para simular tanto os ensaios confinados realizados no equipamento desenvolvido por Costa (2004), quanto o muro em solo reforçado construído em Campinas, o qual foi utilizado como referência neste trabalho.

Os principais objetivos das análises numéricas envolvem a compreensão dos mecanismos que governam a interação entre o solo e o reforço nos ensaios de fluência confinada, a avaliação de forma mais precisa dos mecanismos envolvidos durante o processo construtivo do muro utilizado como referência neste trabalho, além da realização da extrapolação do comportamento das estruturas, em termos de deformações, para períodos de tempo mais elevados que os períodos de leituras dos ensaios confinados e os períodos de leituras da estrutura instrumentada. 
Para a elaboração das simulações numéricas, os modelos foram devidamente calibrados em função dos ensaios de caracterização dos geossintéticos e dos solos, e também em função dos ensaios de fluência confinada e em isolamento realizados em laboratório.

O Plaxis 2D AE é um software que se baseia no Método dos Elementos Finitos (MEF) e é destinado à análises do tipo tensão-deformação para problemas geotécnicos.

Tendo em vista a natureza da obra em estudo, as análises foram realizadas considerando o estado plano de deformações. A malha de elementos finitos foi gerada empregando elementos triangulares de 15 nós. Destaca-se que tanto para as análises numéricas realizadas para simular os ensaios de fluência confinada desenvolvidos no equipamento de interação solo-reforço, quanto para as análises numéricas para simular o muro de referência, foram realizados estudos de malha, de forma a se obter um nível de refinamento adequado para cada caso.

As descrições das análises numéricas realizadas para os ensaios de fluência confinada e para a estrutura de referência são apresentadas nos itens a seguir.

\subsubsection{Simulação numérica dos ensaios de fluência confinada}

Os modelos numéricos desenvolvidos para simular os ensaios de fluência confinada realizados no equipamento desenvolvido por Costa (2004) apresentam as mesmas dimensões do aparato real.

As paredes metálicas do equipamento foram simuladas por meio do uso de elementos de placas, sendo que os parâmetros de rigidez e deformabilidade foram adotados como sendo iguais ao do aço.

Os reforços foram simulados como elementos do tipo "geogrid", que são elementos com comportamento elastoplástico, que podem ser submetidos apenas a esforços de tração. É importante destacar que os valores de rigidez dos reforços ao longo do tempo foram adotados a partir dos ensaios de fluência convencional (Figura 3.25). Como não foram realizados ensaios acelerados de fluência não confinada, os dados dos ensaios de fluência convencional foram extrapolados a partir de um ajuste de curvas simplificado, realizado no próprio Excel, para um período de 100 anos. 


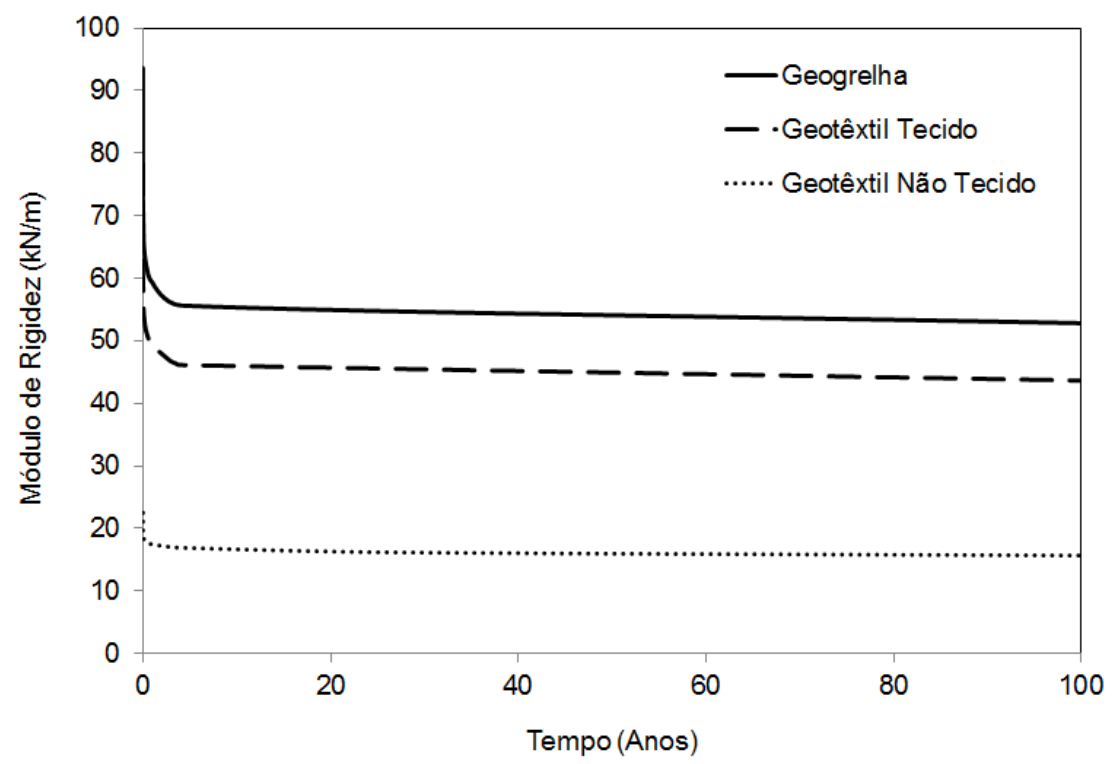

Figura 3.25 - Módulo de rigidez em função do tempo para cada tipo de reforço obtido por meio de ensaios de fluência convencional extrapolado para um período de 100 anos.

Para o solo compactado no interior da caixa de testes foi empregado o modelo denominado Soft Soil Creep, o qual apresenta as seguintes características:

- Módulo de rigidez do solo dependente do nível de carregamento;

- Distinção entre carregamento primário e solicitações de carregamento e descarregamento;

- Deformações secundárias dependentes do tempo;

- Memória de tensões de pré-adensamento;

- Critério de ruptura de Mohr-Coulomb.

Para os reforços foram adotados modelos constitutivos elastoplásticos, sem critério de ruptura. Uma vista geral do modelo numérico desenvolvido para simular os ensaios de fluência confinada no equipamento de interação solo-reforço é mostrada na Figura 3.26. 


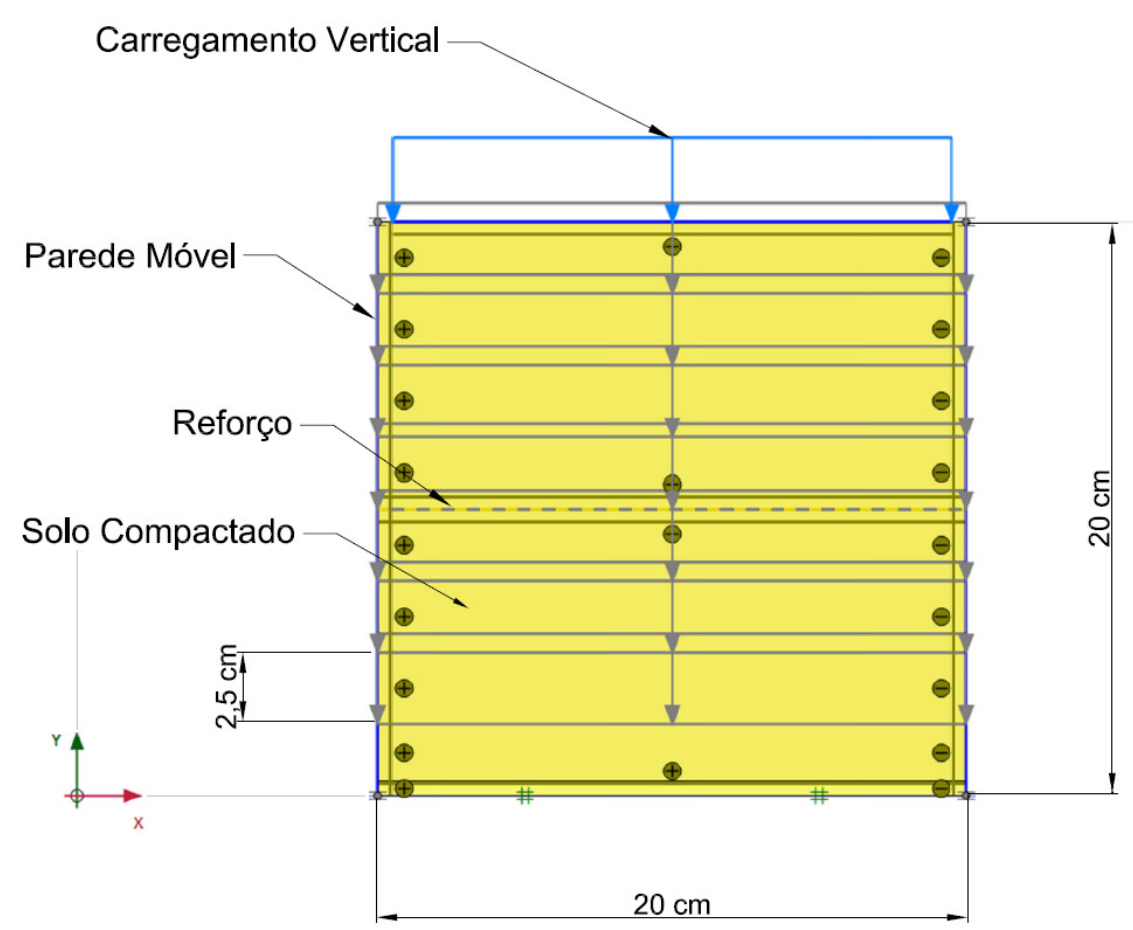

Figura 3.26 - Vista geral do modelo numérico desenvolvido para a simulação dos ensaios confinados no equipamento de interação solo-reforço.

Destaca-se que as etapas de cálculo empregadas no modelo numérico seguiram rigorosamente as etapas construtivas do modelo desenvolvido em laboratório. Inicialmente as paredes metálicas do modelo numérico encontravam-se impedidas de se deslocar lateralmente. A partir disso, o solo foi compactado em camadas de 2,5 cm, empregando para a execução de cada camada uma carga uniformemente distribuída de $150 \mathrm{kPa}$. Este carregamento representa a carga estática equivalente ao carregamento dinâmico devido à compactação do solo no laboratório. Após a execução de 4 camadas de solo compactado, o elemento de reforço foi então acionado no modelo numérico. Após o acionamento do reforço, as demais camadas foram executadas até que a caixa de testes estivesse totalmente preenchida. Após o preenchimento total da caixa com o solo compactado, o carregamento vertical referente ao ensaio de laboratório foi aplicado. Logo após a aplicação do carregamento vertical as paredes laterais da caixa foram então liberadas e possibilitadas de se deslocar lateralmente. Após a construção do modelo de acordo com o que foi executado em laboratório, e após a liberação das paredes laterais, foram criadas etapas de cálculo para cada um dos tempos em que se desejava 
saber as deformações por fluência. Em cada uma destas etapas criadas, o tempo desejado era imposto ao modelo constitutivo do solo para o cálculo das deformações por fluência no tempo desejado, e a rigidez do elemento de reforço era alterada manualmente, de acordo com a variação da rigidez apresentada na Figura 3.25. A alteração manual dos parâmetros de rigidez nos elementos de reforço se fez necessária tendo em vista que o modelo constitutivo para os reforços não engloba deformações por fluência.

Os parâmetros do solo e dos reforços empregados nas simulações numéricas dos ensaios de fluência confinada são apresentados na Tabela 3.8.

Tabela 3.8 - Parâmetros geotécnicos empregados nas análises numéricas.

\begin{tabular}{|c|c|c|c|c|}
\hline Parâmetro & Solo & $\begin{array}{l}\text { Paredes } \\
\text { laterais }\end{array}$ & Reforço & Unidade \\
\hline $\begin{array}{c}\text { Modelo do } \\
\text { Material }\end{array}$ & Soft Soil Creep & $\begin{array}{l}\text { Plate } \\
\text { Elastic }\end{array}$ & $\begin{array}{l}\text { Geogrid } \\
\text { Elastic }\end{array}$ & --- \\
\hline $\begin{array}{c}\text { Tipo de } \\
\text { Comportamento }\end{array}$ & Drenado & --- & --- & --- \\
\hline Peso Específico & 20 & 78 & --- & $\mathrm{kN} / \mathrm{m}^{3}$ \\
\hline $\begin{array}{c}\text { Módulo de } \\
\text { Deformabilidade }\end{array}$ & --- & $210 \times 10^{6}$ & --- & $\mathrm{kN} / \mathrm{m}^{2}$ \\
\hline $\begin{array}{c}\text { Módulo de } \\
\text { Rigidez }\end{array}$ & --- & --- & $\begin{array}{l}\text { Variável com o } \\
\text { tipo de reforço }\end{array}$ & $\mathrm{kN} / \mathrm{m}$ \\
\hline$\lambda$ & $1,96 \times 10^{-3}$ & --- & -- & --- \\
\hline$\kappa$ & $1,95 \times 10^{-3}$ & --- & --- & --- \\
\hline$\mu$ & $0,4 \times 10^{-3}$ & --- & --- & --- \\
\hline $\begin{array}{l}\text { Coeficiente de } \\
\text { Poisson }\end{array}$ & --- & 0,12 & --- & --- \\
\hline Coesão & 53 & --- & --- & $\mathrm{kN} / \mathrm{m}^{2}$ \\
\hline Ângulo de Atrito & 32 & --- & --- & Graus \\
\hline
\end{tabular}




\subsubsection{Simulação numérica da obra de referência}

As simulações numéricas das seções de referência da estrutura em solo reforçado de Campinas foram desenvolvidas empregando a mesma geometria sob a qual a estrutura foi construída em campo.

Para cada tipo de elemento considerado na modelagem numérica (solos e reforços) foi adotado um tipo de modelo constitutivo. Para o solo natural (solo de fundação e solo atrás da estrutura de contenção) foi empregado um modelo constitutivo elastoplástico com critério de ruptura de Mohr-Coulomb. Para o solo de aterro foi empregado o modelo denominado Soft Soil Creep, cujas principais características foram descritas no item anterior.

Para os reforços foram adotados modelos constitutivos elásticos, sem critério de ruptura.

Uma vista geral do modelo numérico desenvolvido para a simulação do muro de Campinas é mostrada na Figura 3.27.

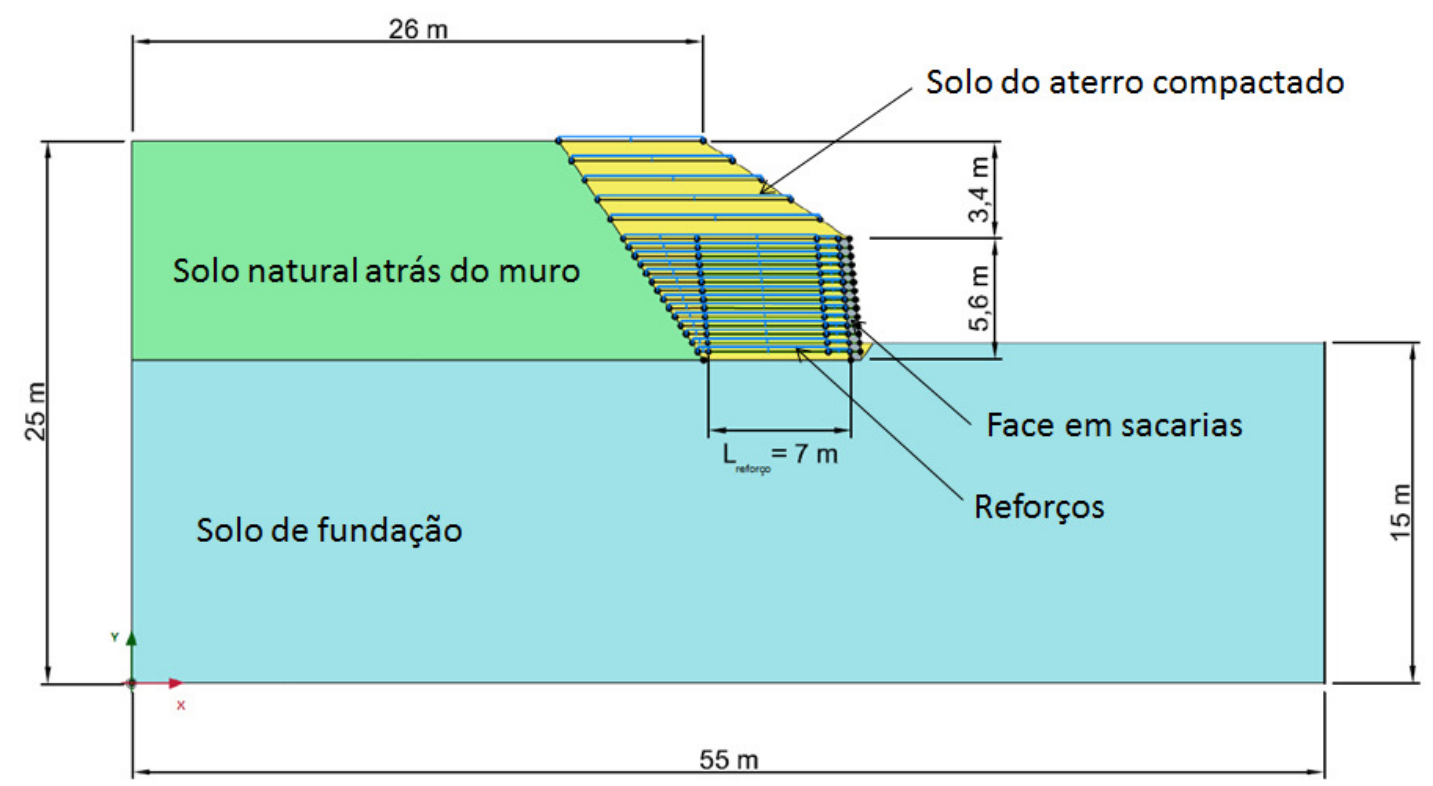

Figura 3.27 - Vista geral do modelo numérico desenvolvido para a simulação das seções instrumentadas do muro de referência de Campinas.

Conforme destacado anteriormente, os parâmetros geotécnicos foram adotados em função dos resultados obtidos na campanha de ensaios realizada em laboratório. Os 
parâmetros geotécnicos dos solos empregados nas análises são apresentados na Tabela 3.9.

Tabela 3.9 - Parâmetros geotécnicos empregados nas análises numéricas.

\begin{tabular}{|c|c|c|c|c|}
\hline Parâmetro & $\begin{array}{c}\text { Solo de } \\
\text { fundação }\end{array}$ & $\begin{array}{c}\text { Solo atrás do } \\
\text { muro }\end{array}$ & $\begin{array}{l}\text { Solo de } \\
\text { Aterro }\end{array}$ & Unidade \\
\hline $\begin{array}{l}\text { Modelo do } \\
\text { Material }\end{array}$ & Mohr-Coulomb & Mohr-Coulomb & Soft Soil Creep & --- \\
\hline $\begin{array}{c}\text { Tipo de } \\
\text { Comportamento }\end{array}$ & Drenado & Drenado & Drenado & --- \\
\hline Peso Específico & 20 & 19 & 20 & $\mathrm{kN} / \mathrm{m}^{3}$ \\
\hline $\begin{array}{c}\text { Módulo de } \\
\text { Deformabilidade }\end{array}$ & 100000 & 75000 & --- & $\mathrm{kN} / \mathrm{m}^{2}$ \\
\hline$\lambda$ & --- & --- & $9 \times 10^{-3}$ & --- \\
\hline$\kappa$ & --- & --- & $6 \times 10^{-3}$ & --- \\
\hline$\mu$ & --- & --- & $3,2 \times 10^{-4}$ & --- \\
\hline $\begin{array}{c}\text { Coeficiente de } \\
\text { Poisson }\end{array}$ & 0,35 & 0,30 & --- & --- \\
\hline Coesão & 53 & 53 & 53 & $\mathrm{kN} / \mathrm{m}^{2}$ \\
\hline Ângulo de Atrito & 32 & 35 & 32 & Graus \\
\hline
\end{tabular}

As etapas construtivas utilizadas nos modelos numéricos foram adotadas de forma a refletir com fidelidade as fases reais de construção da estrutura.

Para simular os efeitos da compactação com rolo compactador foram empregadas cargas estáticas equivalentes de $70 \mathrm{kPa}$, calculadas segundo o procedimento apresentado em Ehrlich e Becker (2009). Para a região próxima à face da estrutura de contenção foram empregados carregamentos estáticos equivalentes de $40 \mathrm{kPa}$, de forma a simular a compactação manual executada em campo.

Como já demonstrado anteriormente, o modelo constitutivo empregado para o solo de aterro incorpora o cálculo das deformações secundárias por fluência, as quais são dependentes do tempo. Para o caso dos reforços, o modelo empregado para a relação tensão-deformação foi um modelo elastoplástico, que, portanto, não 
incorpora o cálculo de deformações dependentes do tempo (deformações por fluência). Para superar esta limitação do software, foram criadas fases de cálculo adicionais, após as fases referentes ao processo construtivo do muro, para cada tempo no qual se desejava saber as deformações por fluência. Nessas etapas, o tempo desejado foi imposto ao modelo constitutivo do solo e a rigidez do elemento de reforço foi alterada manualmente de acordo com a curva de fluência em isolamento obtida em laboratório para cada tipo de reforço (Figura 3.25).

As deformações pós-construção nos reforços foram calculadas nos modelos numéricos para os mesmos períodos das leituras realizadas para a obra real. E após os períodos das leituras da obra real, o tempo foi extrapolado de forma a se obter deformações para um período de até 100 anos.

Os períodos de tempo para os quais as deformações foram calculadas são apresentados na Tabela 3.10 .

Tabela 3.10 - Períodos de tempo para os quais foram calculadas as deformações pós-construção nos reforços.

\begin{tabular}{cc}
\hline Fase Pós-Construção & Tempo (dias) \\
\hline 1 & 125 \\
2 & 239 \\
3 & 329 \\
4 & 500 \\
5 & 800 \\
6 & 1059 \\
7 & 1259 \\
8 & 1433 \\
9 & 3000 \\
10 & 5000 \\
11 & 10000 \\
12 & $876000(100$ anos $)$ \\
\hline
\end{tabular}

É importante destacar, que tanto os modelos numéricos desenvolvidos para a simulação dos ensaios de fluência confinada quanto os modelos numéricos desenvolvidos para a simulação da obra real de Campinas foram calibrados de forma a se obter a melhor correspondência possível entre os resultados calculados e os resultados obtidos em laboratório e campo. O processo de calibração dos modelos foi realizado variando-se os parâmetros de deformabilidade e fluência do solo de aterro, tomando como ponto de partida os resultados da campanha de 
ensaios realizada em laboratório e apresentados no item 3.2. Os detalhes das calibrações realizadas para os modelos numéricos desenvolvidos são apresentados mais adiante, no Capítulo 4 desta tese. 


\section{RESULTADOS DOS ENSAIOS DE LABORATÓRIO}

Os resultados obtidos a partir dos ensaios de fluência realizados em três tipos diferentes de geossintéticos são apresentados e discutidos neste Capítulo. Conforme salientado anteriormente, os ensaios de fluência foram conduzidos de forma a representar as condições de campo de um muro em solo reforçado utilizado como referência.

Os ensaios apresentados neste capítulo foram divididos em três grupos: ensaios de fluência em isolamento, ensaios de fluência confinada realizados no equipamento de interação solo-reforço desenvolvido por Costa (2004) e ensaios de fluência confinada realizados no equipamento de fluência confinada-acelerada desenvolvido por França (2011). Para cada um dos grupos de ensaios são apresentados os resultados obtidos e as análises destes resultados. Inicialmente são apresentados os resultados dos ensaios de fluência em isolamento, no qual os corpos de prova foram submetidos a quatro diferentes níveis de carregamento: $2 \%, 5 \%, 10 \%$ e $20 \%$ de suas resistências últimas. Posteriormente são apresentados os resultados dos ensaios de fluência confinada realizados no equipamento de interação solo-reforço. Nestes ensaios os corpos de prova foram testados em quatro diferentes níveis de carregamento vertical e também em três diferentes umidades de compactação. $E$ para concluir a apresentação dos resultados dos ensaios em laboratório, são apresentados os resultados dos ensaios de fluência confinada realizados no equipamento de fluência confinada-acelerada. Nestes testes os diferentes geossintéticos foram ensaiados para um carregamento vertical único e uma força de tração única, variando-se apenas a temperatura de execução do ensaio. A elevação da temperatura permitiu a extrapolação dos valores de deformação para períodos de tempo muito superiores ao tempo real de ensaio.

\subsection{ENSAIOS DE FLUÊNCIA EM ISOLAMENTO}

Os ensaios de fluência em isolamento foram realizados com o objetivo de se caracterizar as propriedades de fluência dos materiais em condição não confinada 
para que, posteriormente, estes resultados pudessem ser comparados às características dos mesmos materiais em condição confinada em solo.

Os ensaios em isolamento foram desenvolvidos empregando-se o equipamento de ensaio descrito no Item 3.4.1.

Os ensaios de fluência não confinados foram realizados conforme a ASTM D5262, tanto para os geotêxteis tecidos quanto para os não tecidos e geogrelhas. Foram empregados carregamentos de $2 \%, 5 \%, 10 \%$ e $20 \%$ da resistência última dos materiais $\left(\mathrm{T} / \mathrm{T}_{\mathrm{ult}}\right)$ para $\mathrm{o}$ caso dos geotêxteis. Para as geogrelhas 0 maior carregamento foi dispensado. Vale lembrar que as resistências últimas dos geotêxteis não tecidos, geotêxteis tecidos e geogrelhas são de 20 kN/m, 55 kN/m e $47 \mathrm{kN} / \mathrm{m}$, respectivamente. Os resultados dos ensaios realizados nos geotêxteis não tecidos, tecidos e geogrelhas são apresentados na Figura 4.1, na Figura 4.2 e na Figura 4.3, respectivamente.

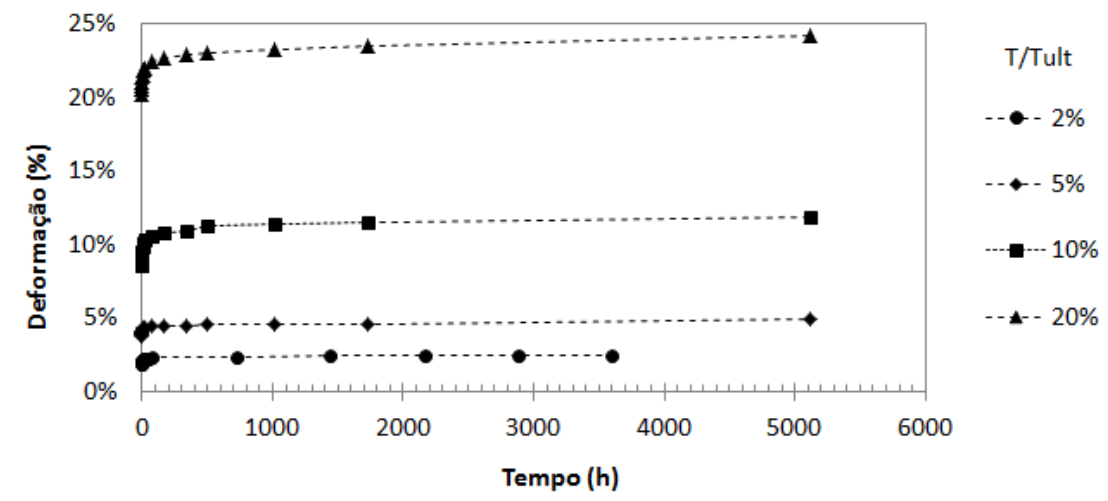

(a)

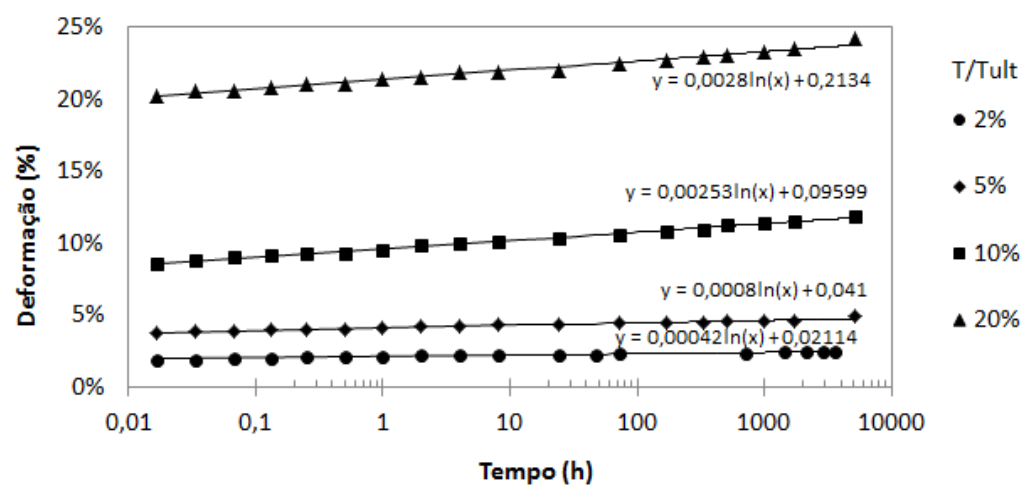

(b) 


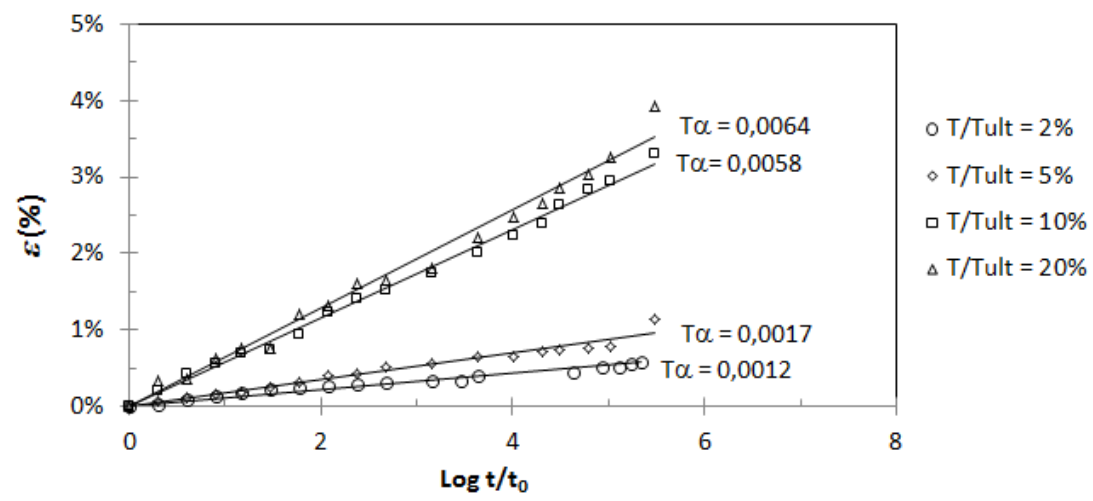

(c)

Figura 4.1 - Resultados dos ensaios de fluência em isolamento para geotêxteis não tecidos: (a) deformações em escala normal; (b) deformações em escala logarítmica; (c) deformações pelo método de Zornberg; Byler e Knudsen (2004).

Os resultados dos ensaios realizados nos geotêxteis não tecidos mostraram que as deformações no reforço são proporcionais ao carregamento aplicado, ou seja, reforços submetidos a maiores carregamentos sofrem maiores deformações (Figura 4.1a). As análises realizadas pelo método da equação logarítmica (Figura 4.1b) mostraram que, além das deformações iniciais no reforço, representadas pelo parâmetro "a", o índice de fluência do material, o qual é representado pelo parâmetro "b" da equação, também foi afetado pelo nível de carregamento ao qual o reforço foi submetido. Sendo assim, os maiores índices de fluência foram observados nos ensaios com maior carregamento. Pelo método da equação logarítmica, as deformações iniciais, para os ensaios realizados com carregamentos de $2 \%, 5 \%$, $10 \%$ e $20 \%$, foram de 2,1\%, 4,1\%, 9,6\% e 21,3\%, respectivamente. Já os índices de fluência foram de 0,04\%, 0,08\%, 0,25\% e 0,28\%, respectivamente. Esta constatação é corroborada pelas análises realizadas pelo método proposto por Zornberg; Byler e Knudsen (2004), que mostraram que os índices de fluência T $\alpha$ são crescentes com o aumento da carga aplicada (Figura 4.1c). Para os carregamentos de $2 \%, 5 \%, 10 \%$ e $20 \%$, os índices T $\alpha$ foram de 0,11\%, 0,17\%, 0,58\% e 0,64\%, respectivamente.

A Figura 4.2 apresenta os resultados dos ensaios de fluência em isolamento para os geotêxteis tecidos. 


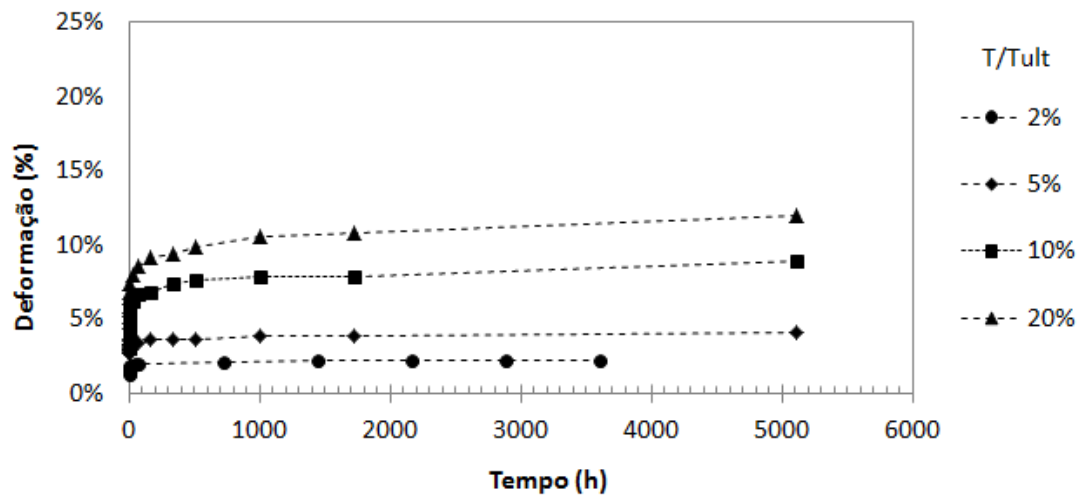

(a)

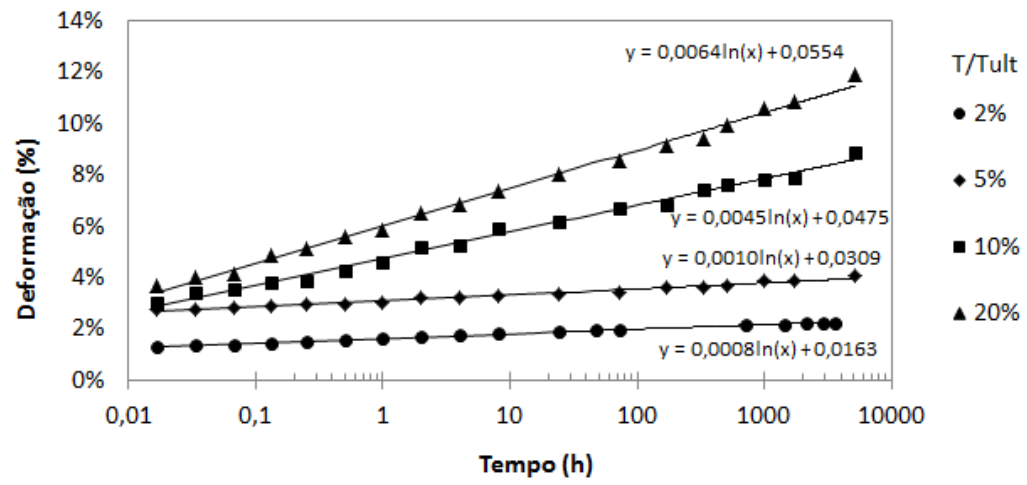

(b)

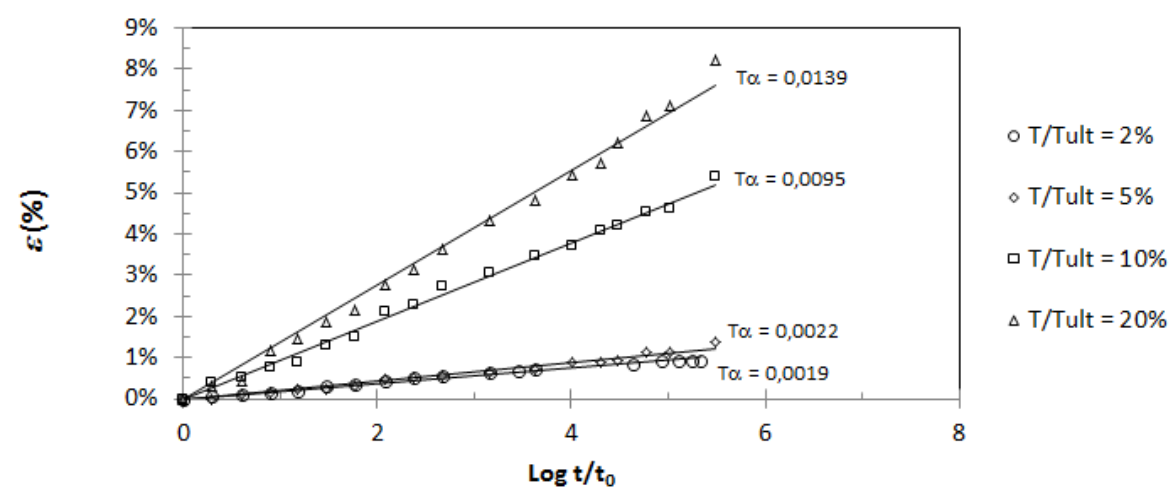

(c)

Figura 4.2 - Resultados dos ensaios de fluência em isolamento para geotêxteis tecidos: (a) deformações em escala normal; (b) deformações em escala logarítmica; (c) deformações pelo método de Zornberg; Byler e Knudsen (2004).

Como já era esperado, os resultados dos ensaios realizados nos geotêxteis tecidos mostram que os níveis de deformação para este material foram menores que os níveis de deformação observados para os geotêxteis não tecidos (Figura 4.2a). Os resultados dos ensaios analisados segundo o método da equação logarítmica 
mostraram que as deformações iniciais dos corpos de prova, representadas pelo parâmetro "a" da equação, foram de 1,6\%, 3,1\%, 4,8\% e 5,5\% para os ensaios com carregamentos de $2 \%, 5 \%, 10 \%$ e $20 \%$ da resistência última, respectivamente. Já os índices de fluência, representados pelo parâmetro "b" da equação logarítmica, foram de $0,08 \%, 0,10 \%, 0,45 \%$ e 0,64\%, respectivamente (Figura 4.2b). No que se refere aos índices de fluência determinados pelo método de Zornberg; Byler e Knudsen (2004), os valores de T $\alpha$ para os carregamentos de $2 \%, 5 \%, 10 \%$ e $20 \%$, foram de 0,19\%, 0,22\%, 0,95\% e 1,39\%, respectivamente (Figura 4.2c).

A Figura 4.3 apresenta os resultados dos ensaios de fluência em isolamento para as geogrelhas.

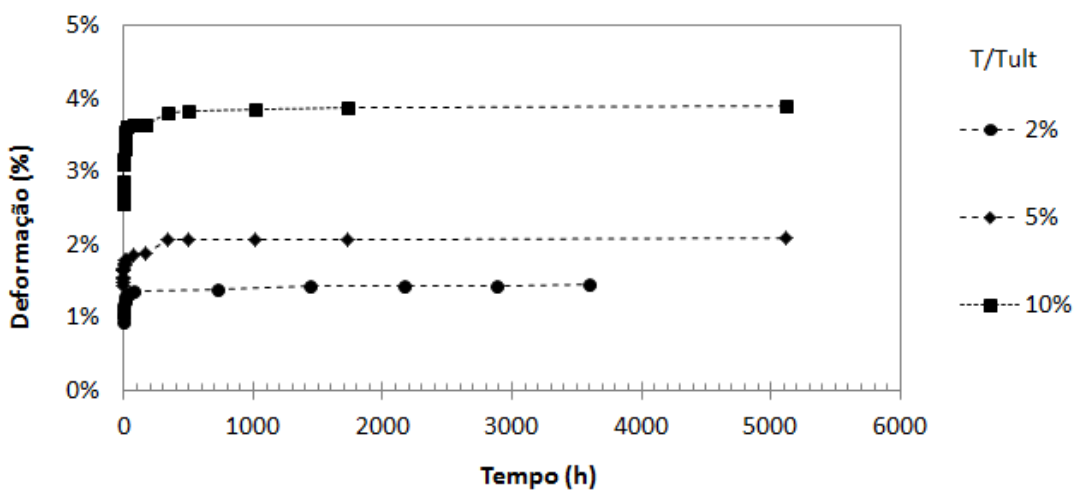

(a)

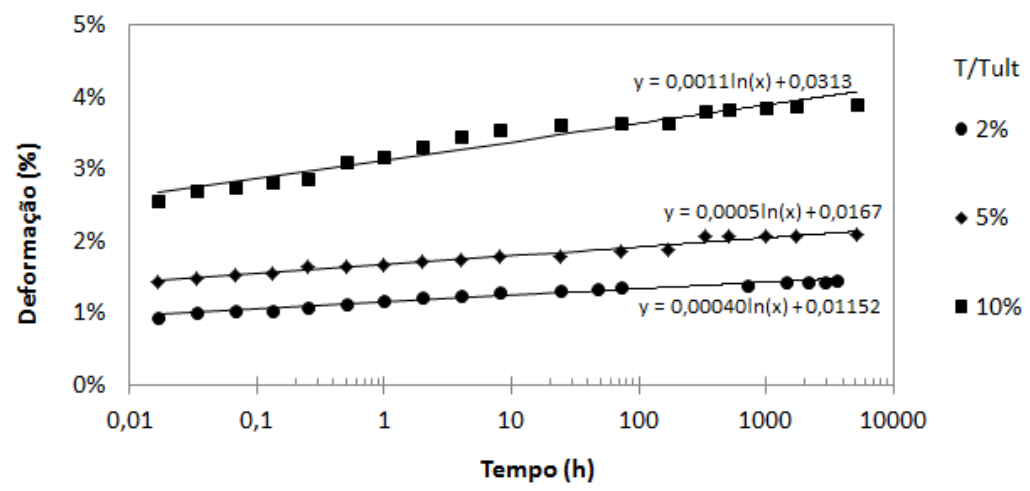

(b) 


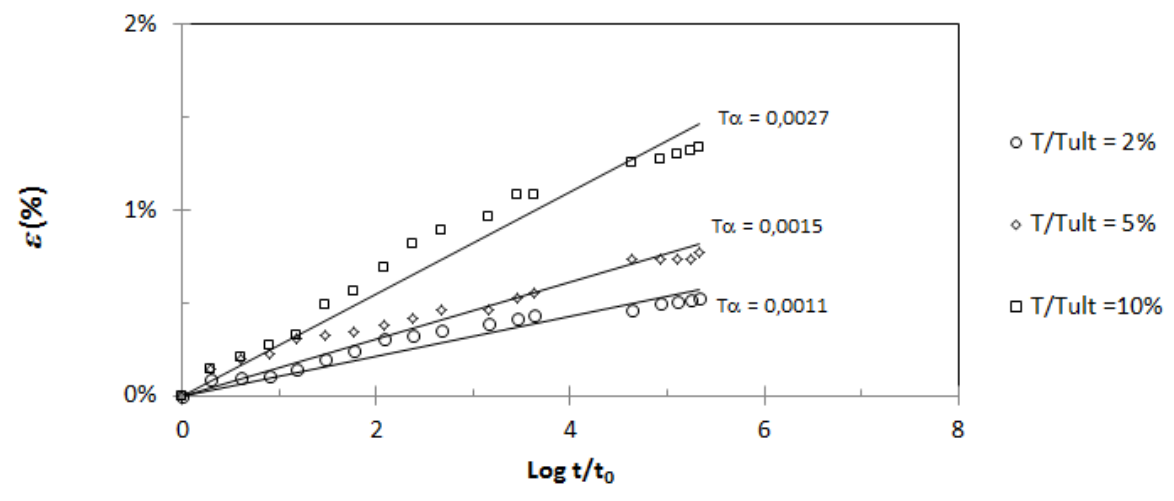

(c)

Figura 4.3 - Resultados dos ensaios de fluência em isolamento para geogrelhas: (a) deformações em escala normal; (b) deformações em escala logarítmica; (c) deformações pelo método de Zornberg; Byler e Knudsen (2004).

Os resultados dos ensaios realizados nas geogrelhas mostram que os níveis de deformação para este material foram os menores observados dentre os três materiais testados (Figura 4.3a). Os resultados dos ensaios analisados segundo o método da equação logarítmica mostraram que as deformações iniciais dos corpos de prova, representadas pelo parâmetro "a" da equação, foram de 1,2\%, 1,7\% e $3,1 \%$ para os ensaios com carregamentos de $2 \%, 5 \%$ e $10 \%$ da resistência última, respectivamente. Já os índices de fluência, representados pelo parâmetro "b" da equação, foram de $0,04 \%, 0,05 \%$ e $0,11 \%$, respectivamente (Figura $4.3 \mathrm{~b}$ ). No que se refere aos índices de fluência determinados pelo método de Zornberg; Byler e Knudsen (2004), os valores de T $\alpha$ para os carregamentos de $2 \%, 5 \%$ e $10 \%$, foram de $0,11 \%, 0,15 \%$ e $0,27 \%$, respectivamente (Figura $4.3 \mathrm{c}$ ).

Como esperado, as deformações, para todas as situações de carregamento, foram maiores para os geotêxteis não tecidos e menores para as geogrelhas. Os geotêxteis tecidos permaneceram em patamares intermediários (Figura 4.1a, Figura 4.2a e Figura 4.3a). Sob o aspecto de deformações ao longo do tempo, os geotêxteis tecidos apresentaram maiores índices de fluência, tanto pelo método da equação logarítmica (Figura 4.1b, Figura 4.2b e Figura 4.3b), quanto pelo método proposto por Zornberg; Byler e Knudsen (2004) (Figura 4.1c, Figura 4.2c e Figura 4.3c), enquanto as geogrelhas apresentaram os menores índices de fluência e os geotêxteis não tecidos apresentaram valores intermediários.

A Tabela 4.1 mostra um resumo dos resultados obtidos para fins comparativos entre os três tipos de materiais testados. 
O maior índice de fluência apresentado pelo geotêxtil tecido em comparação aos demais materiais pode ser atribuído ao tipo de polímero que compõe a estrutura do reforço. Os geotêxteis tecidos são constituídos por fibras de polipropileno enquanto os geotêxteis não tecidos e as geogrelhas são constituídos por fibras de poliéster. No que se refere à fluência dos materiais, Den Hoedt (1986) destaca que fibras de polipropileno são mais susceptíveis a esse comportamento do que fibras de poliéster. Sendo assim, embora os geotêxteis tecidos sejam mais resistentes e mais rígidos que os não tecidos, apresentam maiores tendências a se deformar ao longo do tempo.

Tabela 4.1 - Resumo das análises de fluência não confinada para os geotêxteis não tecidos, tecidos e geogrelhas por meio do método da equação logarítmica e pelo método proposto por Zornberg; Byler e Knudsen (2004).

\begin{tabular}{|c|c|c|c|c|c|}
\hline \multirow[t]{2}{*}{ Material } & \multirow{2}{*}{$\begin{array}{c}\mathrm{T} / \mathrm{T}_{\text {ult }} \\
(\%)\end{array}$} & \multicolumn{2}{|c|}{$\begin{array}{c}\text { Método da equação } \\
\text { logarítmica }\end{array}$} & \multicolumn{2}{|c|}{$\begin{array}{c}\text { Método de Zornberg; Byler e } \\
\text { Knudsen (2004) }\end{array}$} \\
\hline & & $a(\%)$ & $b(\%)$ & $\varepsilon_{0}(\%)$ & $T_{\alpha}(\%)$ \\
\hline & 2 & 2,11 & 0,04 & 1,81 & 0,12 \\
\hline Geotêxtil & 5 & 4,10 & 0,08 & 3,80 & 0,17 \\
\hline \multirow[t]{3}{*}{ Não Tecido } & 10 & 9,60 & 0,25 & 8,58 & 0,58 \\
\hline & 20 & 21,34 & 0,28 & 20,22 & 0,64 \\
\hline & 2 & 1,63 & 0,08 & 1,29 & 0,19 \\
\hline Geotêxtil & 5 & 3,09 & 0,10 & 2,43 & 0,22 \\
\hline \multirow[t]{3}{*}{ Tecido } & 10 & 4,75 & 0,45 & 2,63 & 0,95 \\
\hline & 20 & 5,54 & 0,64 & 3,21 & 1,39 \\
\hline & 2 & 1,15 & 0,04 & 0,89 & 0,11 \\
\hline \multirow[t]{2}{*}{ Geogrelha } & 5 & 1,67 & 0,05 & 1,42 & 0,15 \\
\hline & 10 & 3,13 & 0,11 & 2,55 & 0,27 \\
\hline
\end{tabular}




\subsection{ENSAIOS DE FLUÊNCIA CONFINADA REALIZADOS NO EQUIPAMENTO DE INTERAÇÃO SOLO-REFORÇO}

Apresentam-se neste item os resultados dos ensaios de fluência em confinamento realizados no equipamento de interação solo-reforço desenvolvido por Costa (2004). Destaca-se que as análises foram realizadas sob duas abordagens distintas. $\mathrm{Na}$ primeira delas avaliou-se o comportamento das deformações ao longo do tempo para diferentes carregamentos verticais, e na segunda abordagem avaliou-se o comportamento das deformações ao longo do tempo para diferentes umidades de compactação do solo.

É importante destacar que os ensaios realizados com variação de umidade foram desenvolvidos apenas para os geotêxteis tecidos e não tecidos. As geogrelhas foram empregadas apenas nos ensaios com variação de carregamentos verticais.

Os resultados dos ensaios realizados segundo essas duas abordagens são apresentados nos itens a seguir.

\subsubsection{Resultados obtidos nos ensaios confinados realizados com diferentes níveis de carregamento vertical}

Nas Figuras 4.4, 4.5 e 4.6 são apresentados os resultados dos ensaios de fluência confinada dos geotêxteis não tecidos, tecidos e geogrelhas inseridos no solo local do caso de obra relatado, para quatro diferentes níveis de carregamento vertical. Os resultados são apresentados em termos de variação da carga no reforço ao longo do tempo em escala normal (Figura 4.4a, Figura 4.5a e Figura 4.6a), variação da carga no reforço ao longo do tempo em escala semi-logarítmica (Figura 4.4b, Figura 4.5b e Figura 4.6b), variação das deformações em função do tempo plotada em escala semi-logarítmica (Figura 4.4c, Figura 4.5c e Figura 4.6c), e variação das deformações ao longo do tempo de acordo com o modelo de representação proposto por Zornberg; Byler e Knudsen (2004) (Figura 4.4d, Figura 4.5d e Figura 4.6d).

É importante lembrar que o menor carregamento vertical, de $140 \mathrm{kPa}$, empregado nos ensaios, foi utilizado com o objetivo de simular a situação real de campo correspondente ao nível de instrumentação denominado E02, conforme descrito no 
Item 3.4.2 desta tese. Os demais carregamentos, de $200 \mathrm{kPa}, 300 \mathrm{kPa}$ e $400 \mathrm{kPa}$, foram utilizados com o objetivo de simular situações de muros mais elevados.

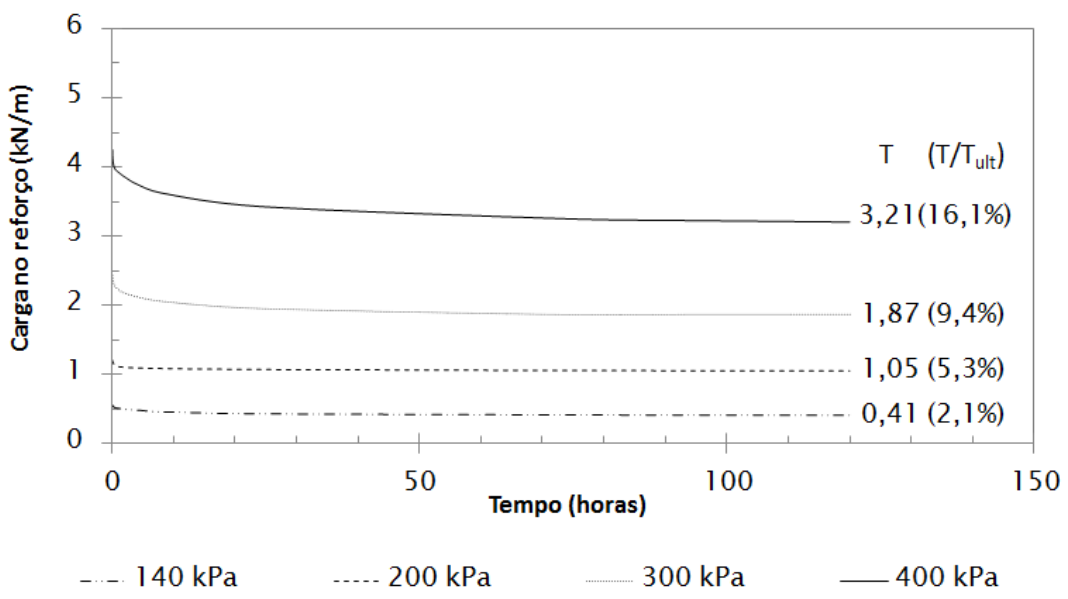

(a)

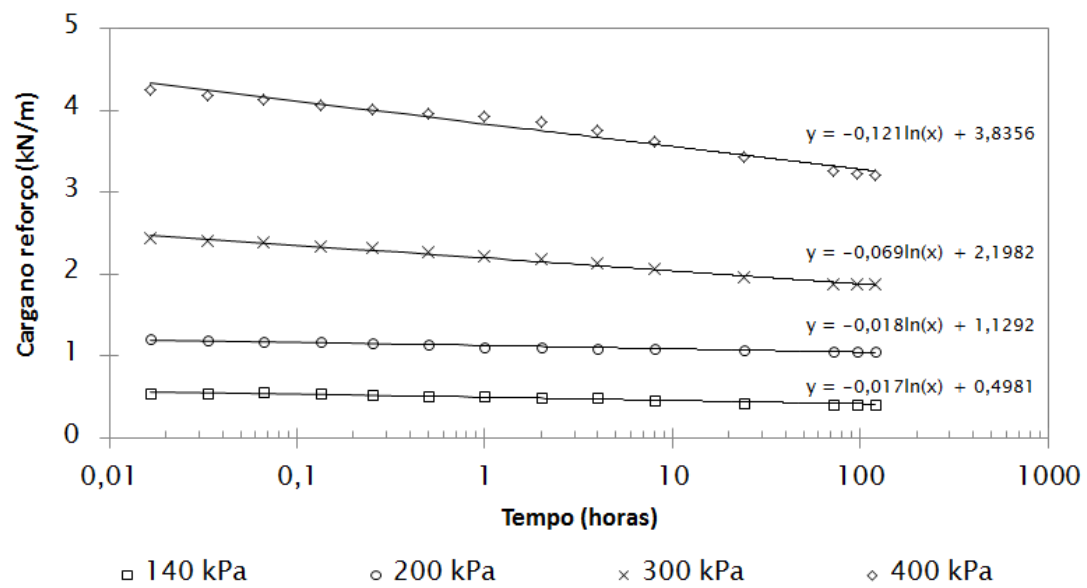

(b) 


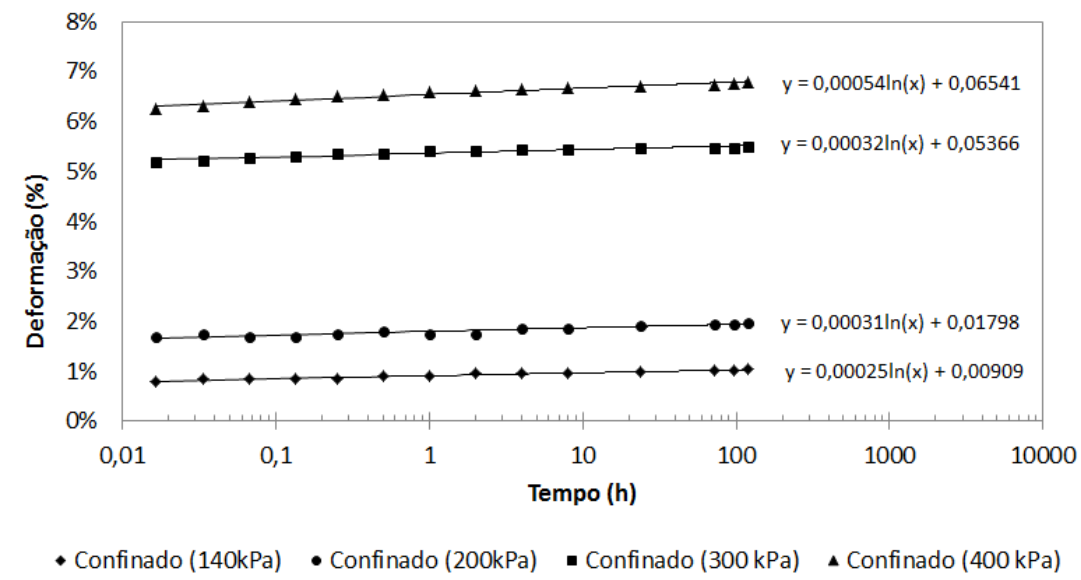

(c)

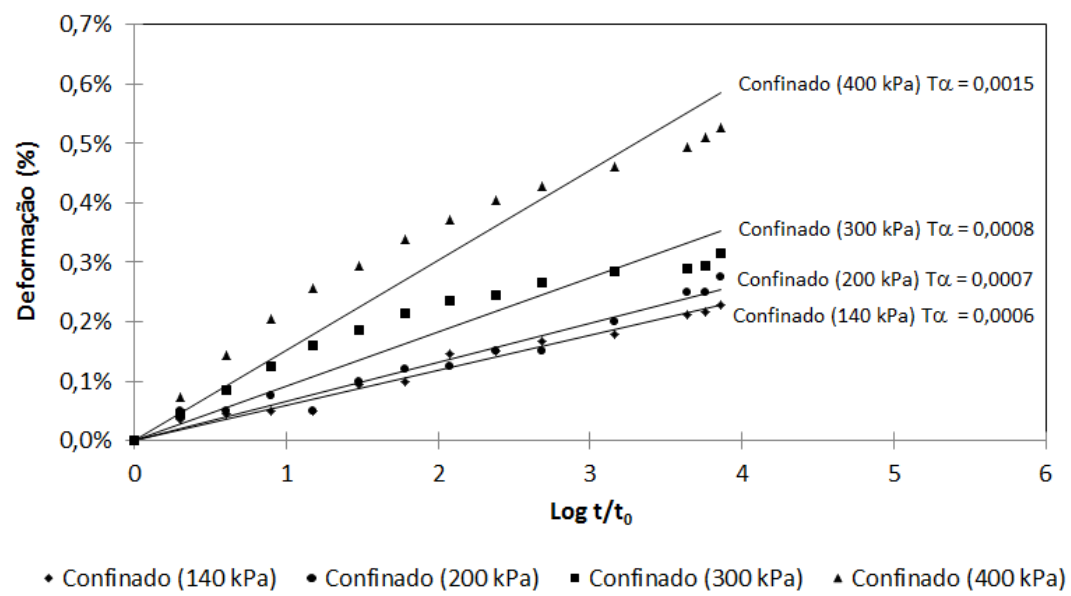

(d)

Figura 4.4 - Resultados dos ensaios de fluência confinada para geotêxteis não tecidos para diferentes carregamentos verticais: (a) Variação da carga no reforço ao longo do tempo em escala normal; (b) Variação da carga no reforço ao longo do tempo em escala semi-logarítmica; (c) Variação das deformações ao longo do tempo em escala semi-logarítmica; (d) Variação das deformações por fluência ao longo do tempo pelo método de Zornberg; Byler e Knudsen (2004). 


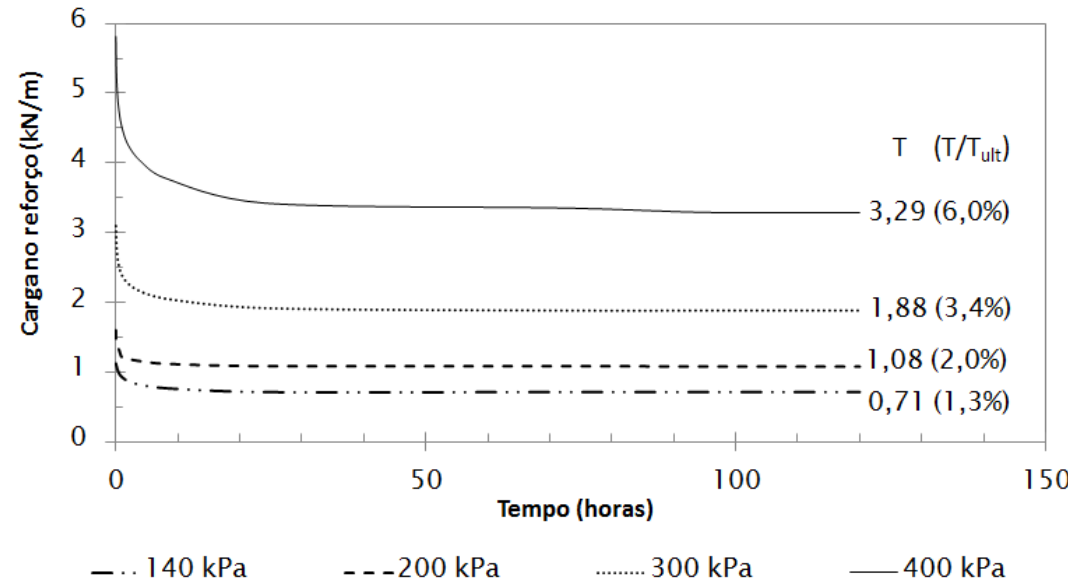

(a)

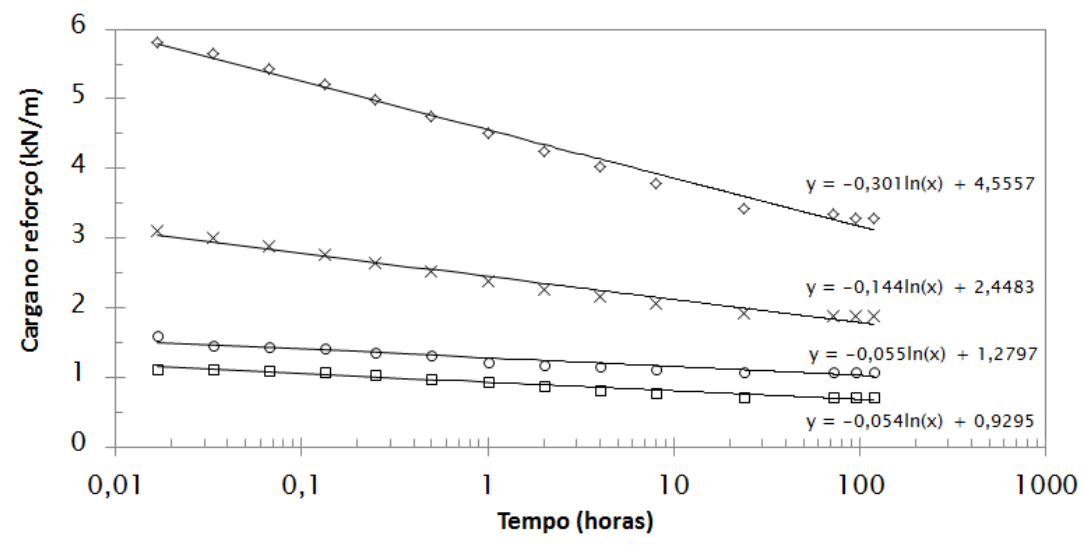
口 $140 \mathrm{kPa}$
- $200 \mathrm{kPa}$
$\times 300 \mathrm{kPa}$
$\triangle 400 \mathrm{kPa}$

(b)

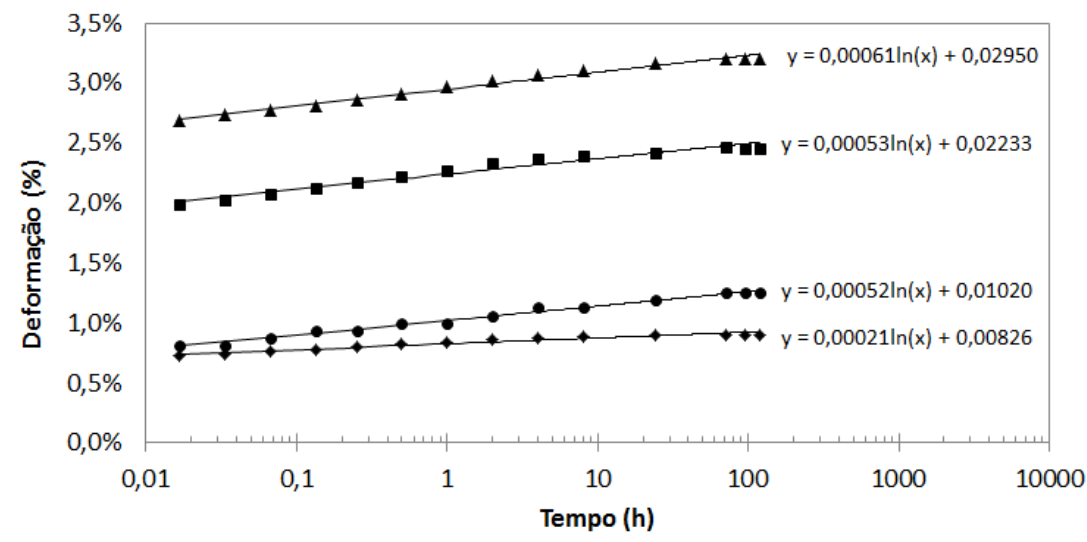

- Confinado (140 kPa) • Confinado (200 kPa) - Confinado (300 kPa) \Confinado (400 kPa)

(c) 


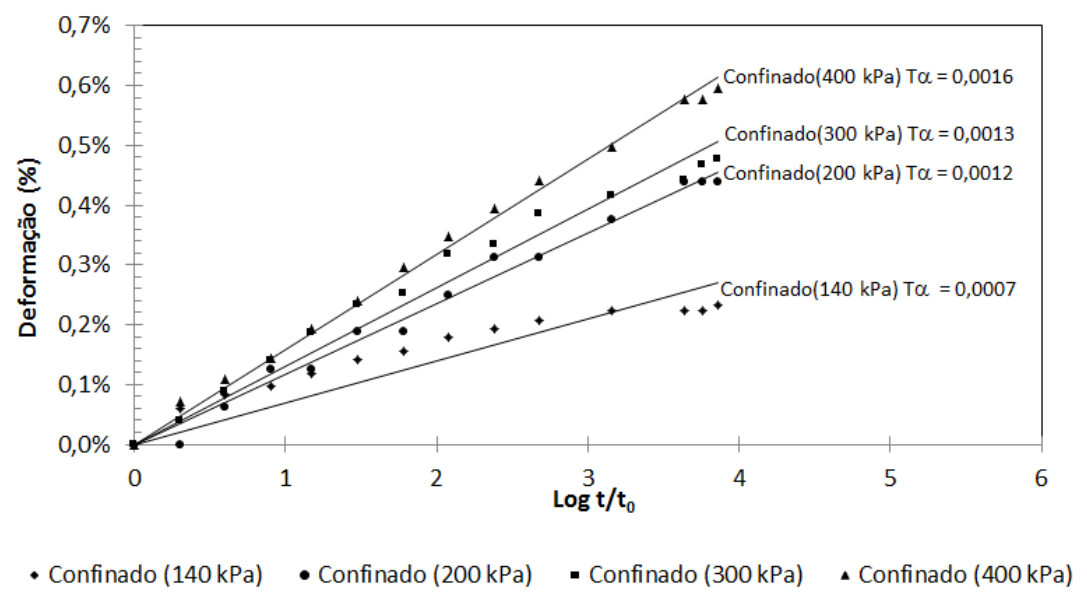

(d)

Figura 4.5 - Resultados dos ensaios de fluência confinada para geotêxteis tecidos para diferentes carregamentos verticais: (a) Variação da carga no reforço ao longo do tempo em escala normal; (b) Variação da carga no reforço ao longo do tempo em escala semi-logarítmica; (c) Variação das deformações ao longo do tempo em escala semi-logarítmica; (d) Variação das deformações por fluência ao longo do tempo pelo método de Zornberg; Byler e Knudsen (2004).

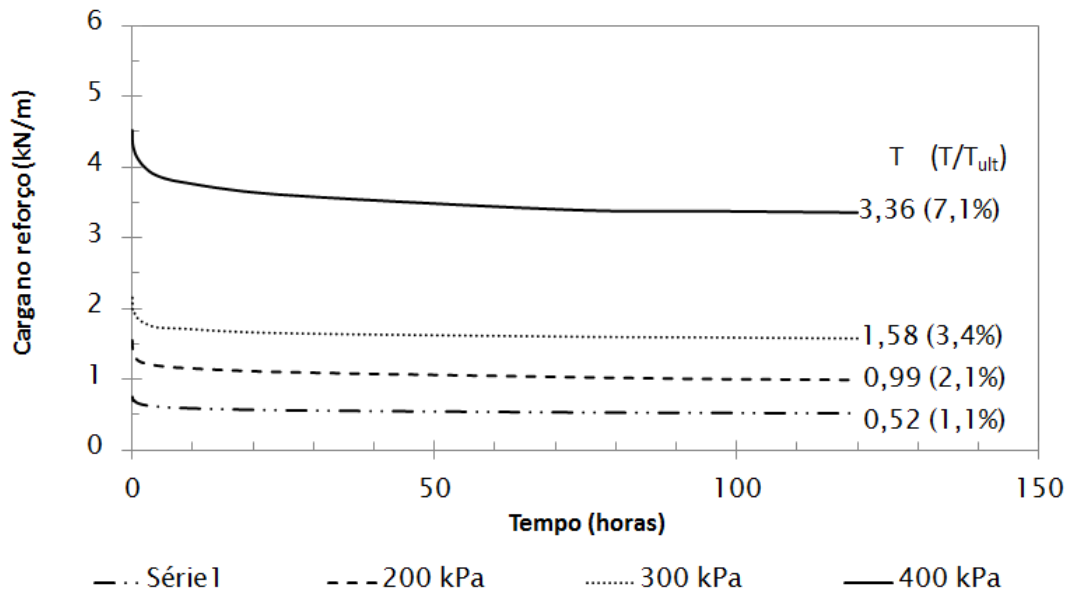

(a) 


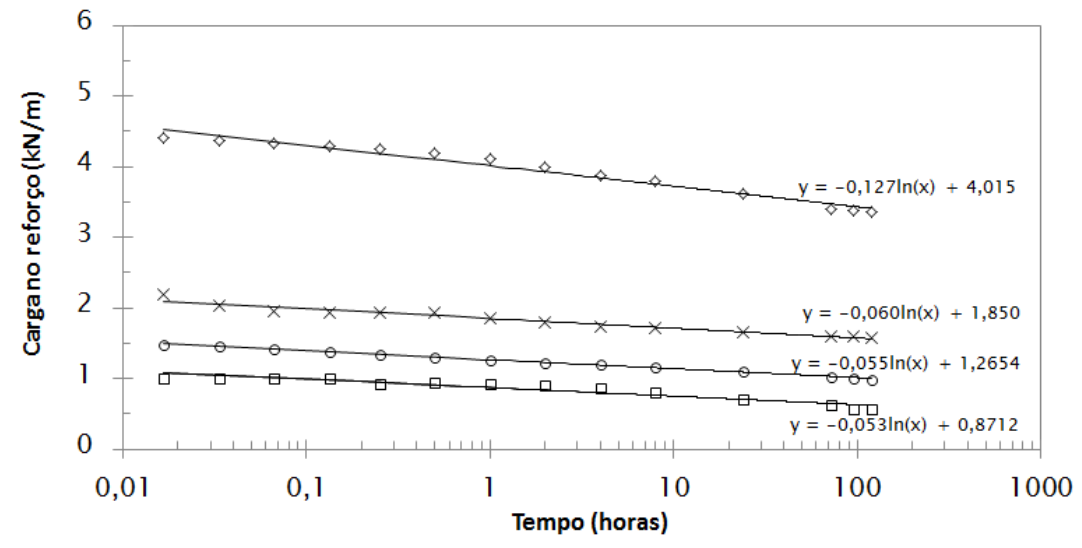
口 $140 \mathrm{kPa}$
- $200 \mathrm{kPa}$
$\times 300 \mathrm{kPa}$
$\diamond 400 \mathrm{kPa}$

(b)

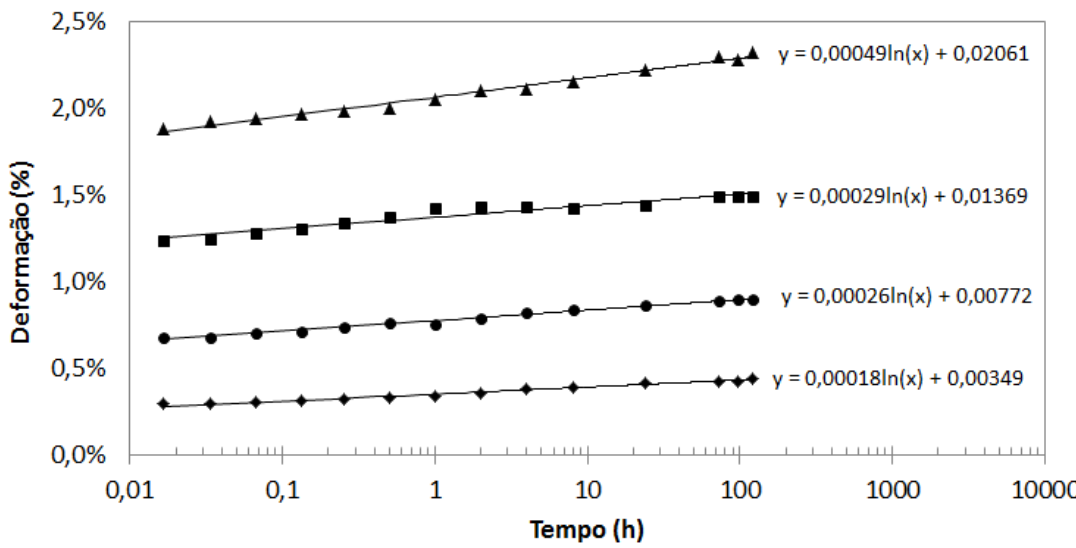

- Confinado (140 kPa) • Confinado (200 kPa) - Confinado (300 kPa) A Confinado (400 kPa)

(c) 


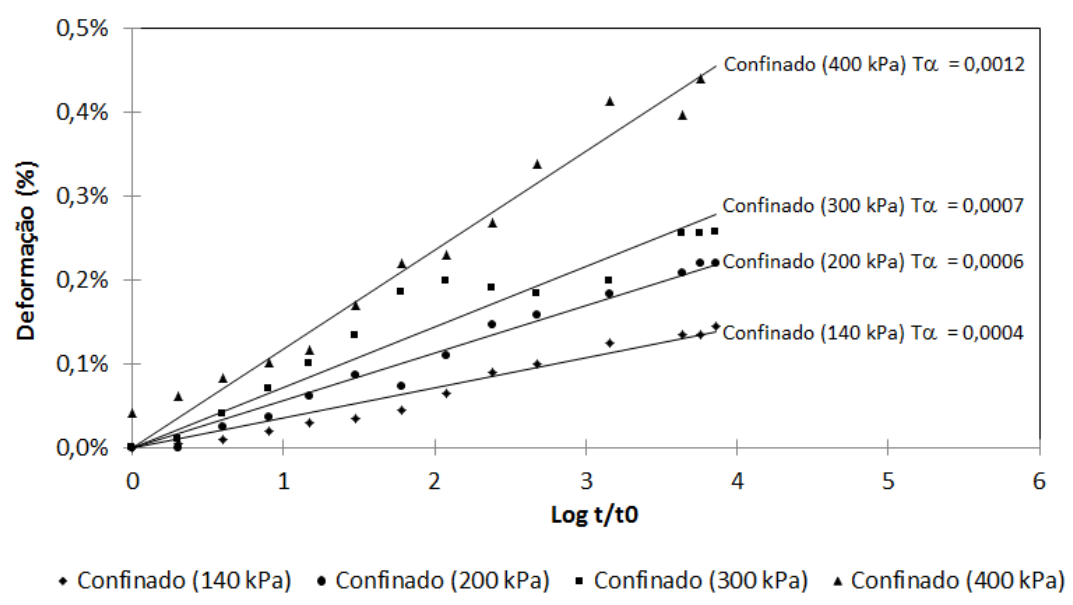

(d)

Figura 4.6 - Resultados dos ensaios de fluência confinada para geogrelhas para diferentes carregamentos verticais: (a) Variação da carga no reforço ao longo do tempo em escala normal; (b)

Variação da carga no reforço ao longo do tempo em escala logarítmica; (c) Variação das deformações ao longo do tempo em escala logarítmica; (d) Variação das deformações por fluência ao longo do tempo pelo método de Zornberg; Byler e Knudsen (2004).

Conforme se pode observar nas Figuras 4.4a, 4.5a e 4.6a, os níveis de carregamento são mais elevados no início dos ensaios e tendem a uma estabilização ao longo do tempo. Este comportamento foi observado em todos os materiais testados, sendo que em praticamente todos os casos, o tempo para a estabilização da carga é proporcional ao carregamento vertical aplicado. Nota-se que para carregamentos verticais de até $300 \mathrm{kPa}$, por volta de 15 horas de ensaio, a carga no reforço apresenta uma tendência de estabilização. Já para os ensaios com carregamentos verticais de $400 \mathrm{kPa}$, existe uma tendência para completar a mobilização de tração no reforço a partir das 30 horas. Esta tendência de estabilização está diretamente relacionada ao tempo necessário para a estabilização das deformações. Enquanto ocorrem deformações laterais, ocorrem, simultaneamente, reduções nos carregamentos horizontais. Este comportamento está relacionado à evolução das trajetórias de tensões que o maciço de solo é submetido ao longo do ensaio. Este assunto será abordado de forma mais detalhada nos itens a seguir. 
As Figuras 4.4a, 4.5a e 4.6a mostram ainda que os geotêxteis tecidos mobilizaram uma carga inicial maior que os geotêxteis não tecidos e as geogrelhas, exceto para o caso com carregamento vertical de $200 \mathrm{kPa}$, em que a geogrelha supera o geotêxtil tecido. Em relação às cargas ao final do ensaio, os geotêxteis tecidos também apresentaram cargas superiores aos demais materiais, embora os valores obtidos sejam muito semelhantes entre os geossintéticos avaliados. Este comportamento pode ser atribuído à maior rigidez do geotêxtil tecido em comparação ao não tecido. A geogrelha, apesar de mais rígida, não apresenta o maior carregamento provavelmente devido à sua geometria, que conta com uma resistência passiva do solo entre seus elementos, fazendo com que o carregamento ao longo do reforço seja ligeiramente reduzido.

As Figuras 4.4b, 4.5b e 4.6b, apresentam a variação do carregamento nos reforços ao longo do tempo plotados em escala semi-logarítmica. Os resultados mostraram, para todos os reforços avaliados, que tanto os carregamentos iniciais nos reforços, representadas pelo parâmetro "a" da equação logarítmica, quanto a tendência à redução do carregamento devido à relaxação, representadas pelo parâmetro "b" da equação, aumentam com o acréscimo de carregamento vertical.

As Figuras 4.4c, 4.5c e 4.6c, apresentam as deformações ao longo do tempo registradas nos ensaios de fluência confinada plotadas em escala semi-logarítmica. À exemplo dos resultados de relaxação observa-se que o acréscimo de carregamento vertical no maciço conduziu a maiores deformações iniciais nos reforços (parâmetro "a"), e maiores deformações por fluência (parâmetro "b"). Já as Figuras $4.4 d, 4.5 d$ e 4.6d apresentam a variação das deformações ao longo do tempo de acordo com o modelo de representação proposto por Zornberg; Byler e Knudsen (2004). Assim como observado no método da equação logarítmica, os resultados mostraram, para todos os reforços avaliados, que o parâmetro $T \alpha$, que representa as deformações por fluência, aumenta com o acréscimo de carregamento vertical.

Outra maneira de apresentar e interpretar os dados dos ensaios de fluência confinada realizados no equipamento de interação solo-reforço consiste na elaboração de curvas do tipo carga por deformação.

A Figura 4.7a mostra como as cargas e as deformações variam ao longo dos ensaios confinados realizados com geotêxteis não tecidos, a Figura $4.7 \mathrm{~b}$ se refere 
aos resultados dos ensaios realizados com geotêxteis tecidos enquanto a Figura 4.7c se refere aos ensaios com geogrelhas.

Os resultados apresentados na Figura 4.7 mostram que as trajetórias dos carregamentos nos reforços em função da deformação possuem uma forma ligeiramente curvada com a concavidade desta curva voltada para o canto inferior esquerdo dos gráficos. Isto é um indicativo de que a desaceleração das deformações é maior que a desaceleração dos carregamentos nos reforços. Com base nesta constatação, pode-se inferir que a relaxação nos reforços deve ser mais significativa nestes casos do que a fluência.

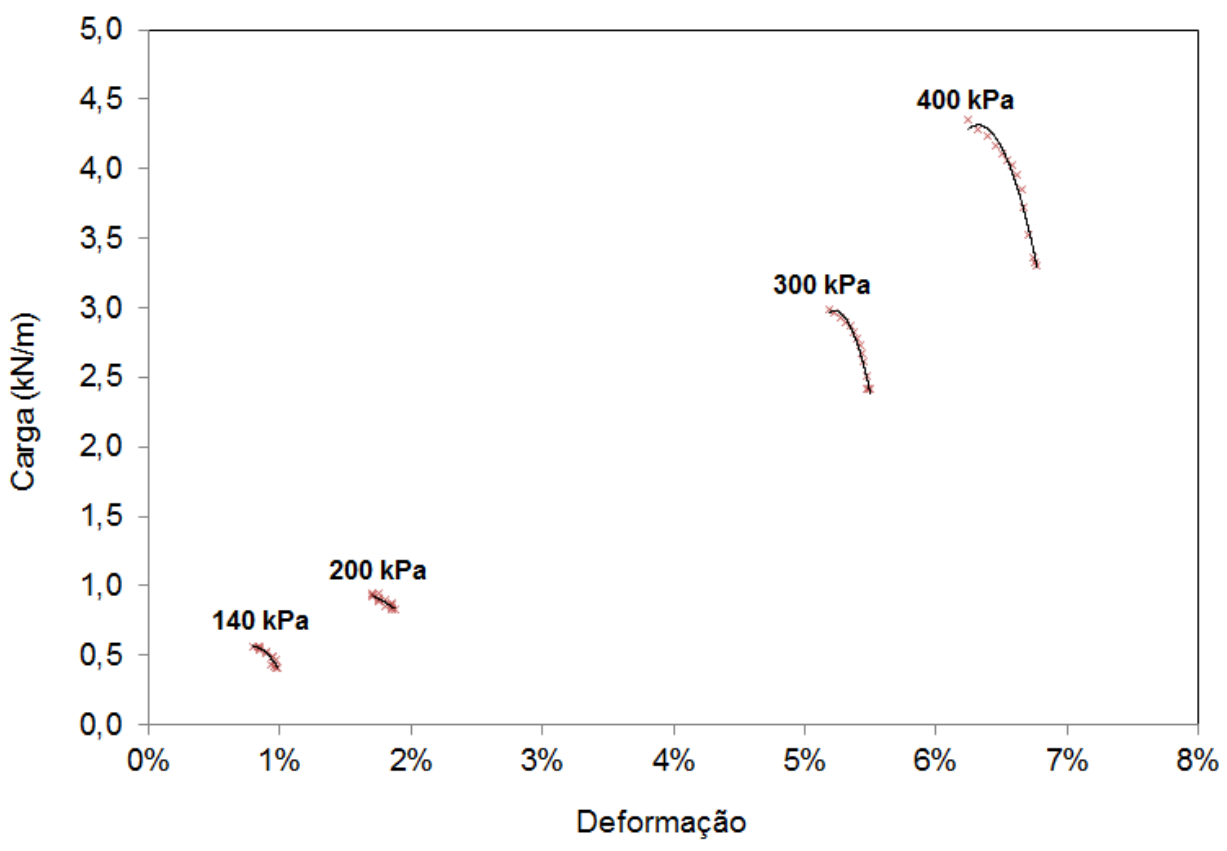

(a) 


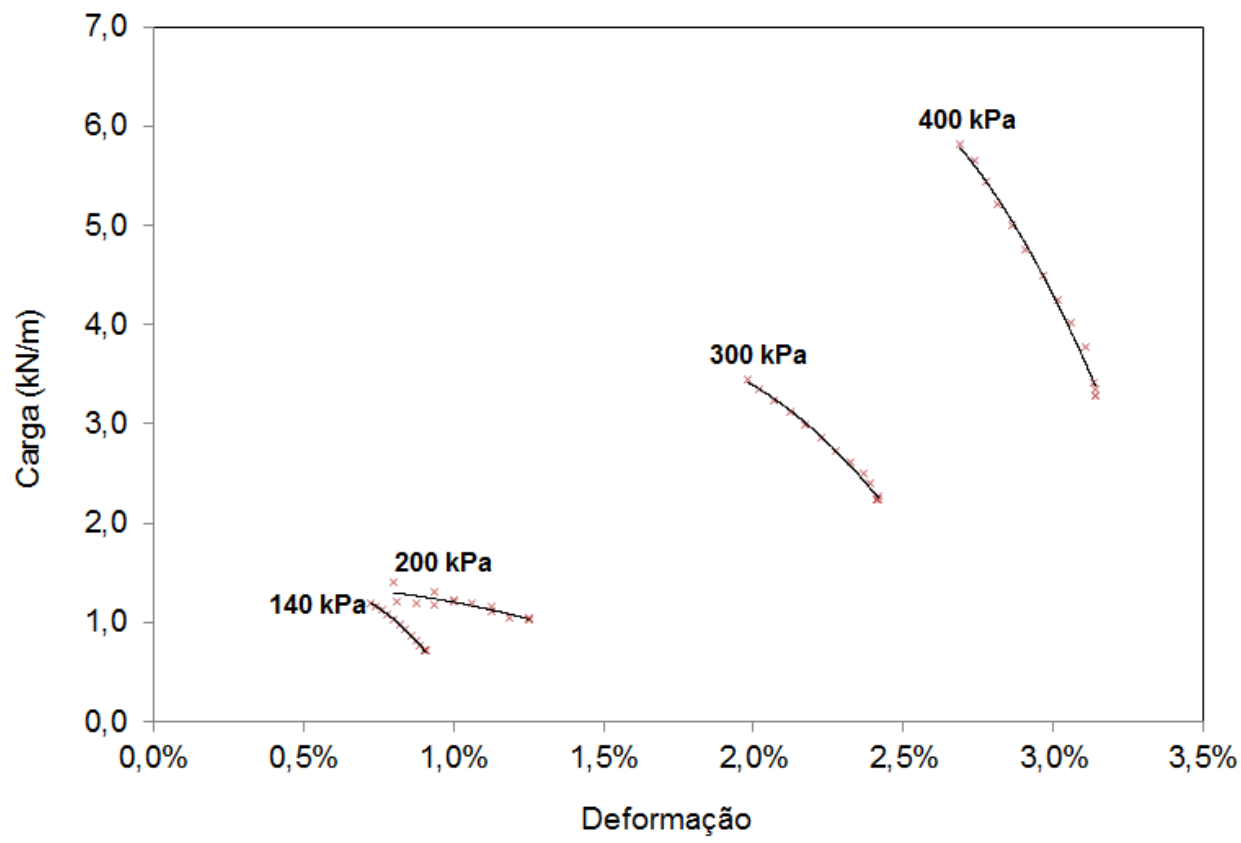

(b)

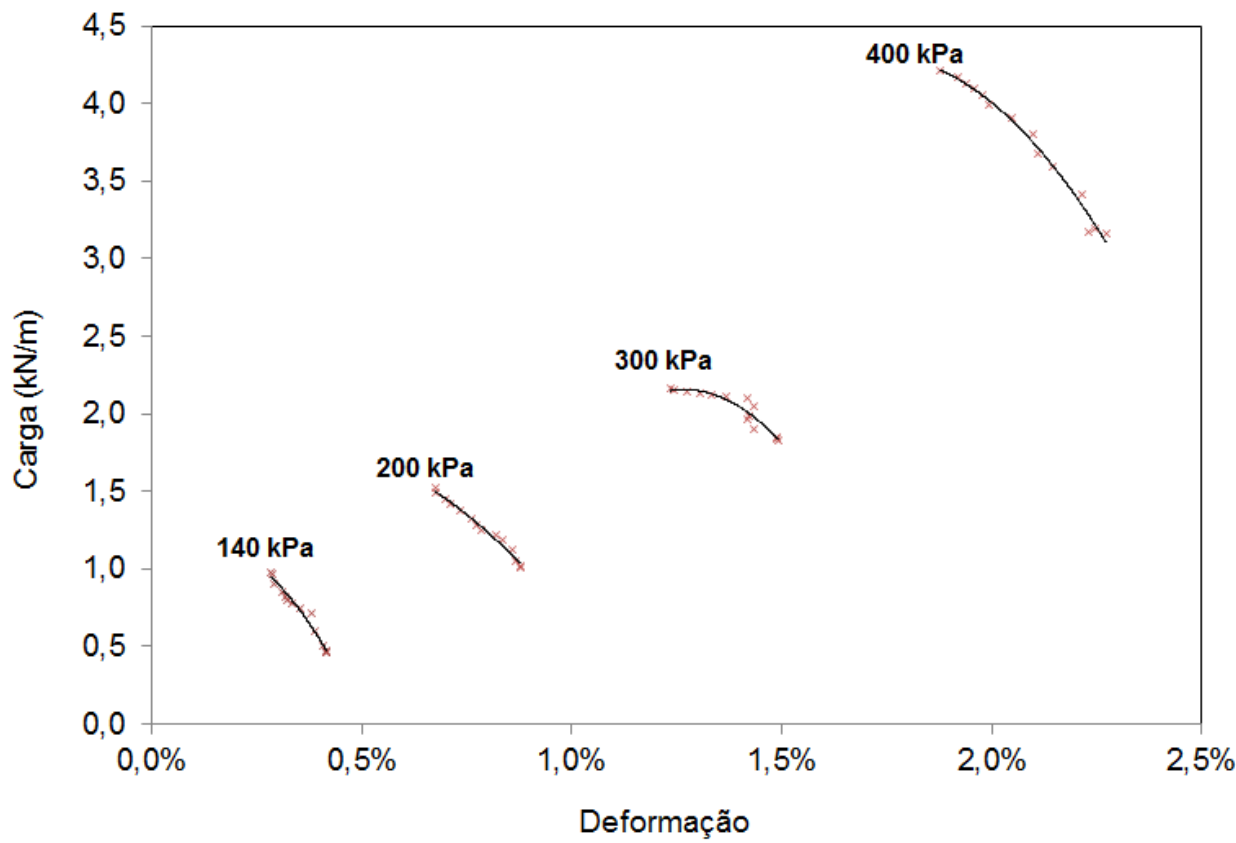

(c)

Figura 4.7 - Variação da carga nos reforços em função da deformação para os ensaios confinados realizados no equipamento desenvolvido por Costa (2004) para: (a) Geotêxteis não tecidos; (b) Geotêxteis tecidos; (c) Geogrelhas.

Os dados apresentados na Figura 4.7 corroboram os resultados mostrados nas Figuras 4.4 a 4.6, nos quais se observa que os valores do parâmetro "b", calculados para os casos da relaxação (Figuras 4.4b, 4.5b e 4.6b), apresentam magnitudes 
maiores que os valores calculados para a fluência (Figuras 4.4c, 4.5c e 4.6c), indicando que, nos ensaios realizados, a redução de carregamento ao longo do tempo por relaxação nos reforços foi maior que o aumento de deformações por fluência.

Conforme destacado anteriormente este item possui um caráter mais expositivo, sendo utilizado apenas para apresentação dos resultados dos ensaios de fluência confinada. Análises da influência do carregamento vertical e do tipo de geossintético na fluência dos materiais são apresentadas nos itens a seguir.

\subsubsection{Análise da influência do confinamento na fluência dos reforços}

Neste item são apresentadas comparações entre os resultados dos ensaios de fluência confinada realizados no equipamento de interação solo-reforço e os resultados dos ensaios de fluência em isolamento.

As Figuras 4.8 a 4.12 apresentam as comparações entre os resultados dos ensaios confinados e não confinados para os geotêxteis não tecidos, geotêxteis tecidos e geogrelhas. Nestas figuras as curvas de fluência dos ensaios confinados e não confinados são plotadas simultaneamente no mesmo gráfico. Isto possibilita a visualização da variação da posição e da inclinação das curvas em função do nível de carregamento vertical aplicado. As análises mostradas a seguir foram realizadas tanto pelo método da equação logarítmica quanto pelo método proposto por Zornberg; Byler e Knudsen (2004).

Na Figura 4.8 são apresentados os resultados dos ensaios de fluência confinada e não confinada para os geotêxteis não tecidos. Para se avaliar de forma mais precisa os efeitos do confinamento e do carregamento vertical no comportamento ao longo do tempo dos geossintéticos estudados, é importante se comparar os ensaios confinados e não confinados com os mesmos níveis de carregamento no reforço. Conforme destacado anteriormente, os ensaios em isolamento foram realizados para os carregamentos de $2 \%, 5 \%, 10 \%$ e $20 \%$ da resistência última dos materiais. Para os ensaios confinados, realizados na caixa de interação solo-reforço, os carregamentos no reforço não são impostos, e sim um resultado da interação entre o 
solo e geossintético que se encontra confinado. Sendo assim, existem alguns casos em que a comparação entre os ensaios confinados e não confinados não pode ser realizada diretamente, já que nem sempre os carregamentos resultantes nos ensaios confinados são compatíveis com os carregamentos dos ensaios em isolamento. Para os casos em que não há uma correspondência direta entre as cargas, foram realizadas interpolações a partir dos resultados dos ensaios não confinados, de forma a se obter uma curva de deformação para a carga desejada. As curvas dos ensaios em isolamento obtidas a partir de interpolação são apresentadas nos gráficos com linha pontilhada para facilitar a sua identificação.

Para o casos dos ensaios confinados realizados nos geotêxteis não tecidos, os testes com cargas verticais de $140 \mathrm{kPa}, 200 \mathrm{kPa}$ e $300 \mathrm{kPa}$, apresentaram relações $\mathrm{T} / \mathrm{T}_{\text {ult }}$ de $2,1 \%, 5,3 \%$ e $9,4 \%$, respectivamente. Devido à proximidade das cargas obtidas nestes ensaios em relação aos ensaios em isolamento, os resultados confinados foram comparados diretamente aos resultados não confinados com $2 \%$, $5 \%$ e $10 \%$ de carregamento. Já para o ensaio confinado com carga vertical de $400 \mathrm{kPa}$, a relação $\mathrm{T} / \mathrm{T}_{\text {ult }}$ obtida no reforço foi de $16,1 \%$. Não existe, portanto, um ensaio em isolamento correspondente. Os ensaios isolados com cargas mais próximas foram realizados com $10 \%$ e $20 \%$ da resistência última do material. Para este caso foi estimada uma curva de deformação ao longo do tempo, para o carregamento de $16,1 \%$, interpolada a partir das curvas com os carregamentos mais próximos. 


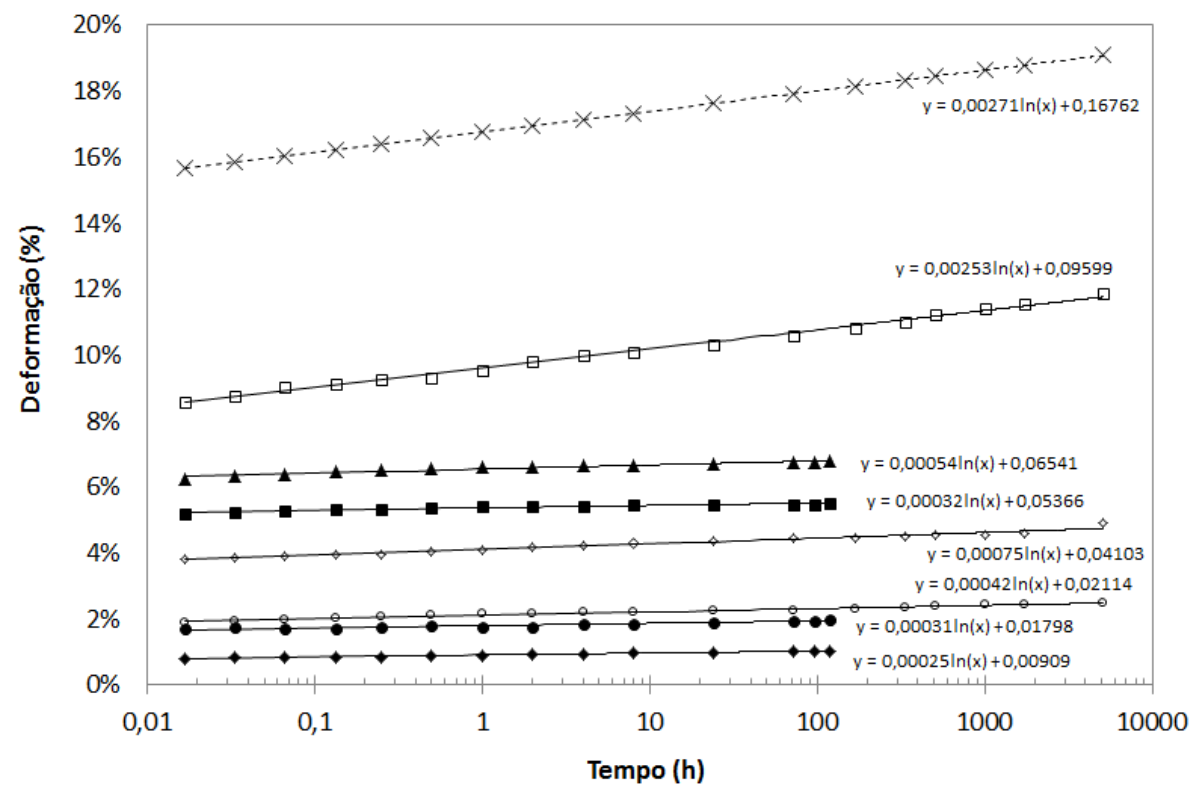

○ Não confinado (T/Tult $=2 \%)$

○ Não confinado $(T /$ Tult $=5 \%)$

$\square$ Não confinado ( $\mathrm{T} /$ Tult $=10 \%$ )

$\times$ Não Confinado $-(T /$ Tult $=16,1 \%$ )

- Confinado $(140 \mathrm{kPa}-\mathrm{T} /$ Tult $=2,1 \%)$

- Confinado $(200 \mathrm{kPa}$ - T/Tult $=5,3 \%)$

- Confinado (300 kPa - T/Tult $=9,4 \%)$

\ Confinado $(400 \mathrm{kPa}-\mathrm{T} /$ Tult $=16,1 \%)$

(a)

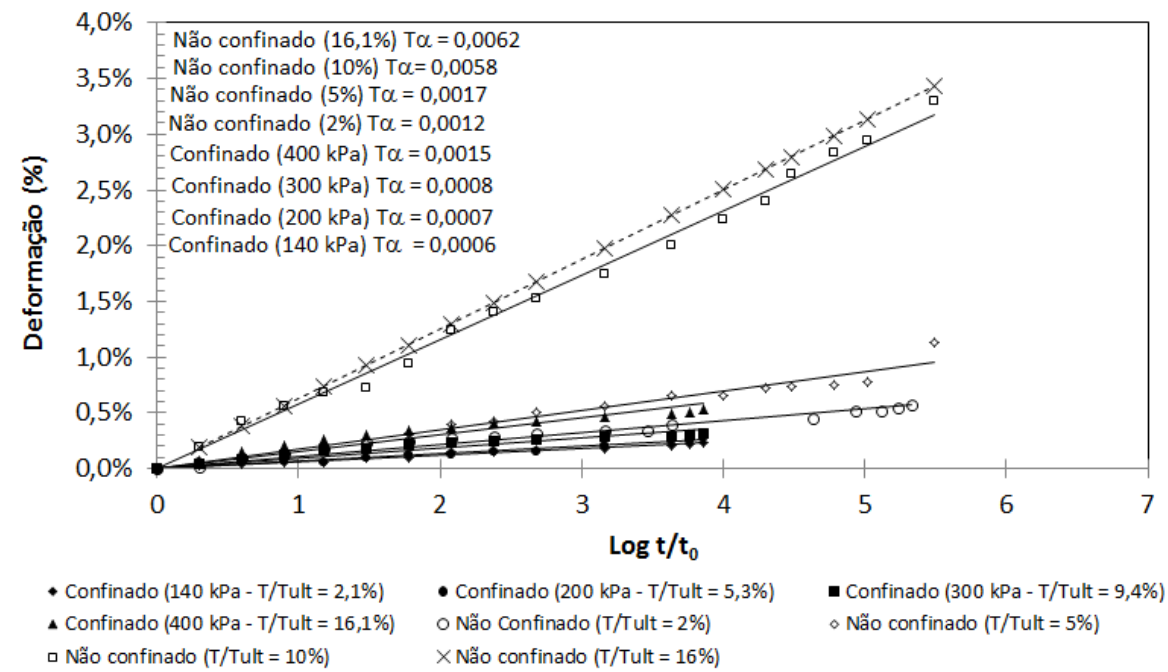

(b)

Figura 4.8 - Comparação entre os resultados dos ensaios de fluência confinada e não confinada para geotêxteis não tecidos: (a) Variação das deformações ao longo do tempo pelo método da equação logarítmica; (b) Variação das deformações por fluência ao longo do tempo pelo método de Zornberg; Byler e Knudsen (2004).

A Figura 4.8a mostra as variações das deformações ao longo do tempo, para os ensaios confinados e não confinados, pelo método da equação logarítmica. Ao se comparar os ensaios confinados entre si, observa-se que os maiores carregamentos verticais conduziram a curvas mais elevadas (com maiores valores do parâmetro "a") 
e mais inclinadas (com maiores valores do parâmetro "b"). Em outras palavras, isto significa que tanto a deformação inicial quanto a tendência à fluência do material foram influenciados pelo aumento do carregamento vertical. Ao se comparar os ensaios confinados com o seu respectivo ensaio em isolamento, observa-se que o confinamento reduziu de forma significativa os parâmetros de deformação dos reforços, tanto em relação às deformações iniciais quanto em relação à tendência à fluência.

A Figura 4.8b mostra as variações das deformações por fluência ao longo do tempo dos geotêxteis não tecidos, para os ensaios confinados e não confinados, pelo método de Zornberg; Byler e Knudsen (2004). Assim como observado nas análises realizadas pelo método da equação logarítmica, observa-se que o aumento da tensão vertical conduziu ao aumento da inclinação das curvas (parâmetro de fluência $T \alpha$ ), ou seja, maiores carregamentos verticais conduziram a maiores esforços no reforço, que por sua vez conduziram a maiores índices de fluência. Da mesma forma, ao se comparar os ensaios confinados e não confinados com o mesmo carregamento no reforço, pode-se afirmar que o confinamento reduziu de forma significativa os parâmetros de deformações nos reforços.

A Figura 4.9 apresenta uma análise comparativa entre os parâmetros de deformação e fluência obtidos nos ensaios confinados e em isolamento para os ensaios com geotêxteis não tecidos.

$\mathrm{Na}$ Figura 4.9a, o eixo vertical principal mostra a variação das deformações iniciais (parâmetro "a" da equação logarítmica) para todos os ensaios realizados e o eixo vertical secundário mostra a redução destas deformações devido ao efeito do confinamento. A Figura 4.9b é semelhante à Figura 4.9a, entretanto apresenta a variação da tendência à fluência dos geotêxteis (parâmetro "b" da curva logarítmica). As mesmas análises que foram efetivadas para os parâmetros "a" e "b" do método da equação logarítmica foram realizadas para os parâmetros $\varepsilon_{0}$ e T $\alpha$ do método proposto por Zornberg; Byler e Knudsen (2004), e são apresentadas na Figura 4.9c e Figura 4.9d, respectivamente. 


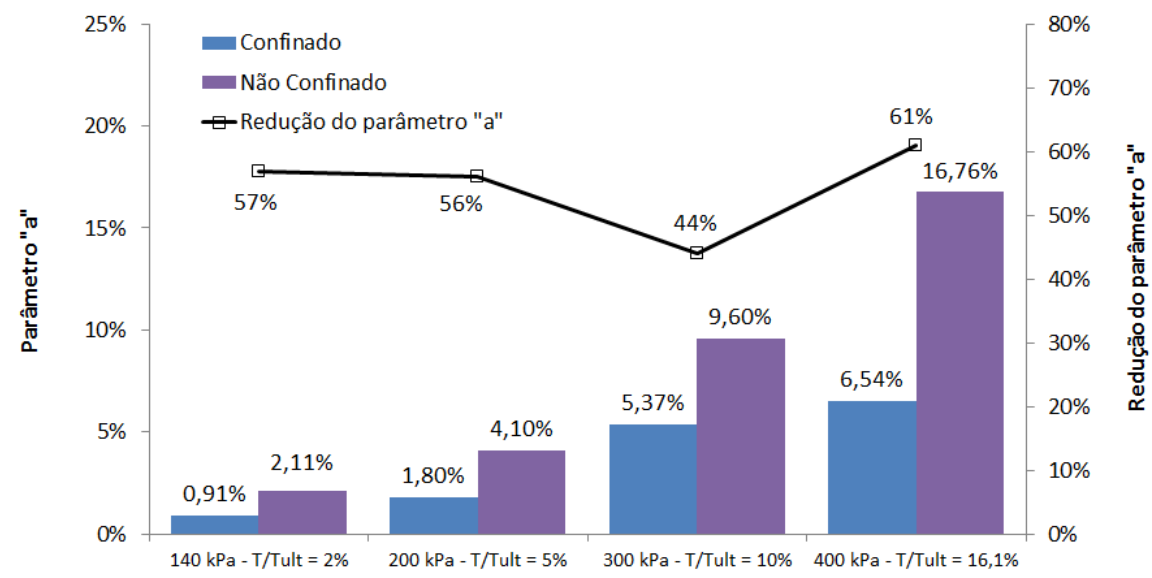

(a)

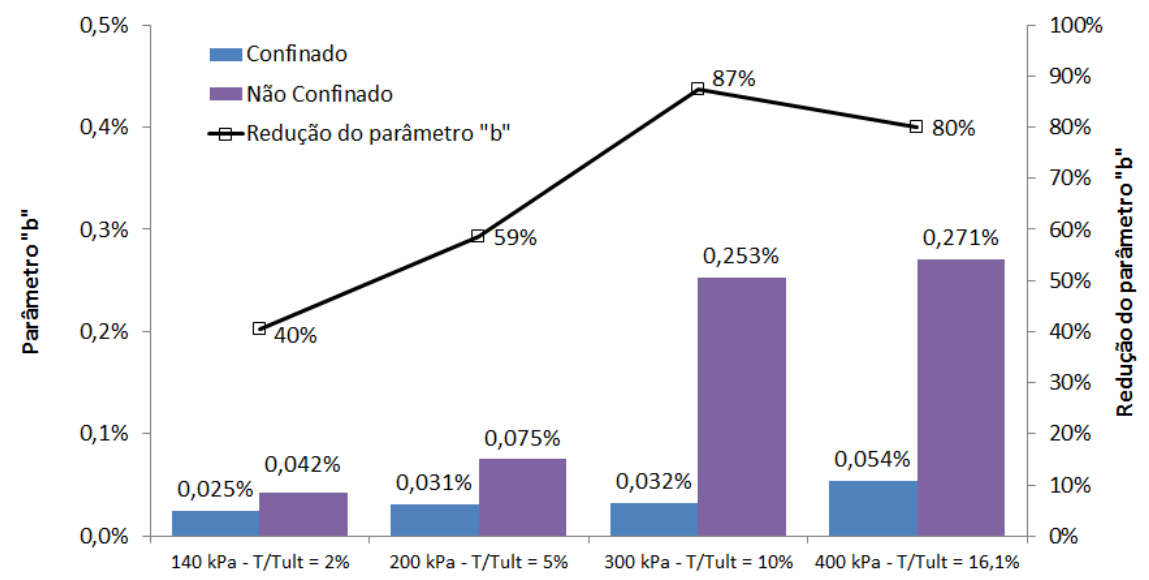

(b)

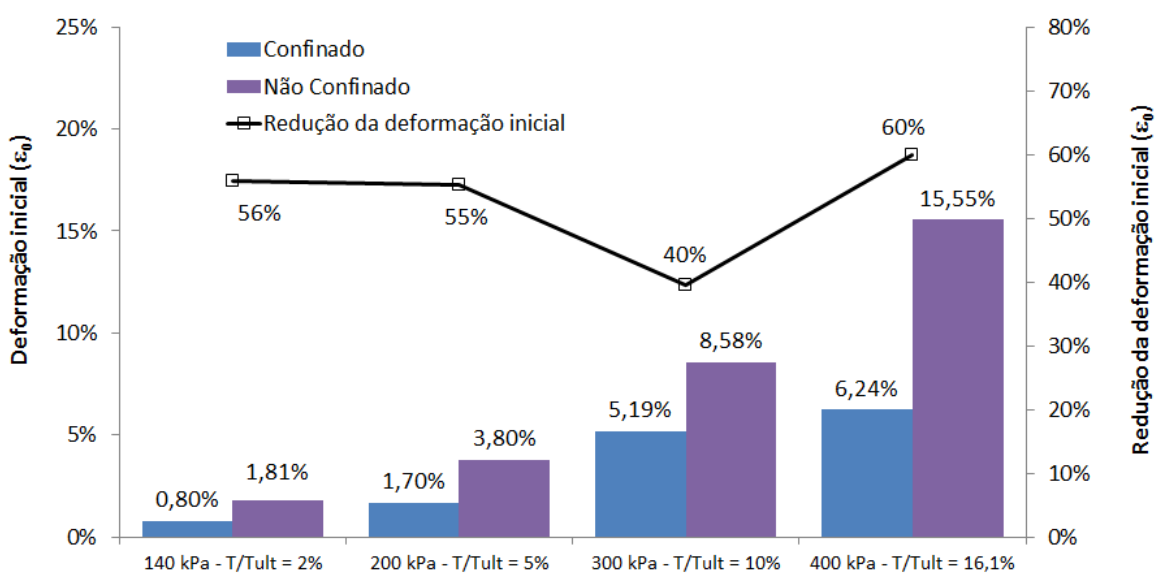

(c) 


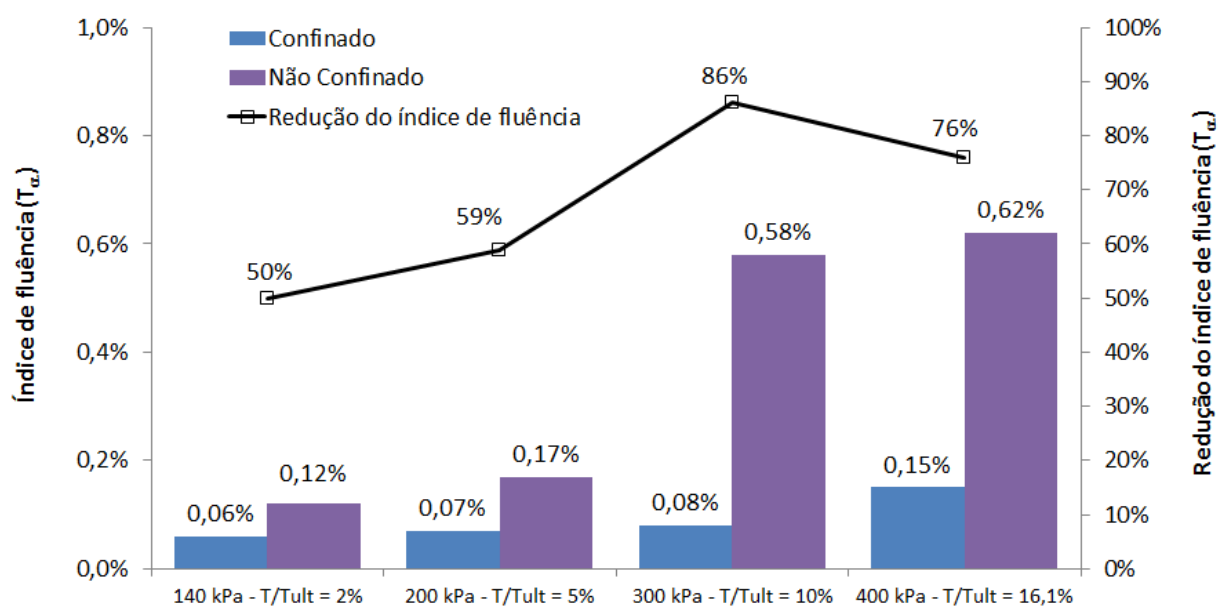

(d)

Figura 4.9 - Análise comparativa entre os resultados dos ensaios confinados e não confinados em função do nível de carregamento vertical para geotêxteis não tecidos: (a) Variação do parâmetro "a" do Método da Equação Logarítmica; (b) Variação do parâmetro "b" do Método da Equação Logarítmica;. (c) Variação do parâmetro $\varepsilon_{0}$ do Método proposto por Zornberg; Byler e Knudsen (2004);

(d) Variação do parâmetro $T_{\alpha}$ do Método proposto por Zornberg; Byler e Knudsen (2004).

Ao se comparar os resultados dos ensaios confinados com os resultados dos ensaios em isolamento, a Figura 4.9a e a Figura 4.9b revelam que, para todos os carregamentos testados, o confinamento reduziu tanto a deformação inicial dos reforços quanto a tendência à fluência dos mesmos. Nota-se que, embora ocorra a redução dos parâmetros "a" e "b" em todos os casos avaliados, não há uma relação bem definida entre o carregamento vertical e a redução dos parâmetros de deformação.

Observa-se que a maior redução do parâmetro "a" se deu no ensaio confinado com tensão vertical de 400 kPa (Figura 4.9a), e a maior redução do parâmetro "b" se deu no ensaio com tensão vertical de 300 kPa (Figura 4.9b).

As Figura 4.9c e 4.9d mostram que os parâmetros relacionados à deformação inicial $\left(\varepsilon_{0}\right)$ e ao índice de fluência $\left(T_{\alpha}\right)$ apresentaram o mesmo comportamento observado nas análises realizadas segundo o método da equação logarítmica. Ao se comparar os resultados dos ensaios confinados com os resultados dos ensaios em isolamento, observa-se que, para todos os carregamentos testados, o confinamento reduziu 
tanto a deformação inicial dos reforços quanto o índice de fluência dos mesmos. À exemplo do que foi observado pelo método da equação logarítmica, nota-se que, embora ocorra a redução dos parâmetros $\varepsilon_{0} \mathrm{e} T \alpha$ em todos os casos avaliados, não há uma relação bem definida entre o carregamento vertical e a redução dos parâmetros de deformação.

Comparando-se os resultados das análises segundo os métodos logarítmico e de Zornberg; Byler e Knudsen (2004), nota-se que há uma boa correspondência entre os resultados obtidos pelos dois métodos.

Os resultados dos ensaios confinados e não confinados realizados para os geotêxteis tecidos são mostrados na Figura 4.10.

Para a comparação entre os resultados dos ensaios confinados e não confinados realizados com geotêxteis tecidos, houve a necessidade da elaboração de algumas curvas interpoladas. Foram interpolados resultados dos ensaios em isolamento de forma a se obter curvas com relações $T / T_{\text {ult }}$ de $1,3 \%$ (para comparação com ensaio confinado com carga vertical de $140 \mathrm{kPa}$ ), 3,4\% (para comparação com ensaio confinado com carga vertical de $300 \mathrm{kPa}$ ) e $6 \%$ (para comparação com ensaio confinado com carga vertical de $400 \mathrm{kPa}$ ). $\mathrm{O}$ ensaio confinado com carregamento vertical de $200 \mathrm{kPa}$ não exigiu a interpolação de curvas, tendo em vista que a relação $T / T_{\text {ult }}$ obtida no ensaio foi de $2 \%$.

Destaca-se que as curvas obtidas por meio de interpolação mostradas nas Figuras $4.10 \mathrm{a}$ e $4.10 \mathrm{~b}$ foram plotadas com linhas pontilhadas para facilitar sua identificação. 


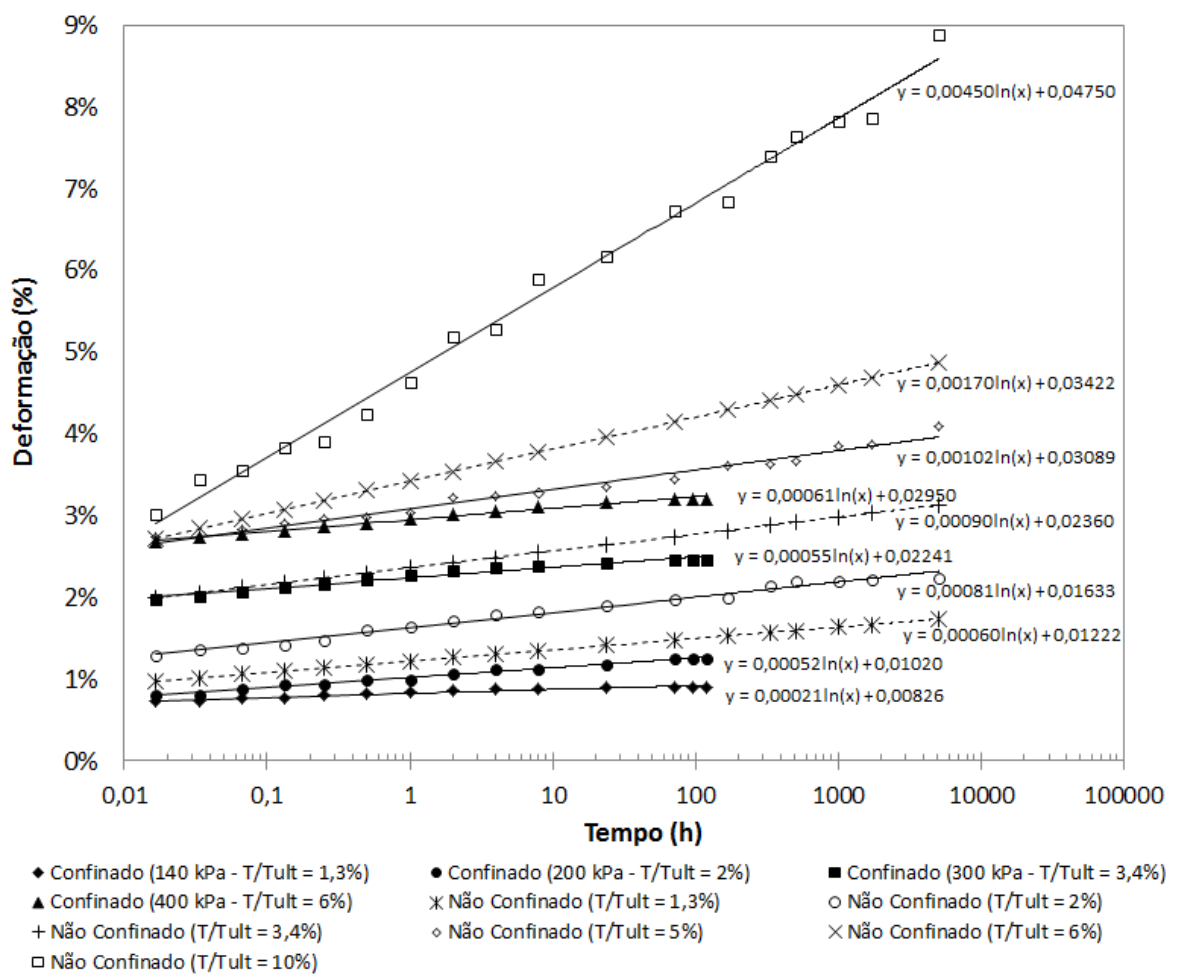

(a)

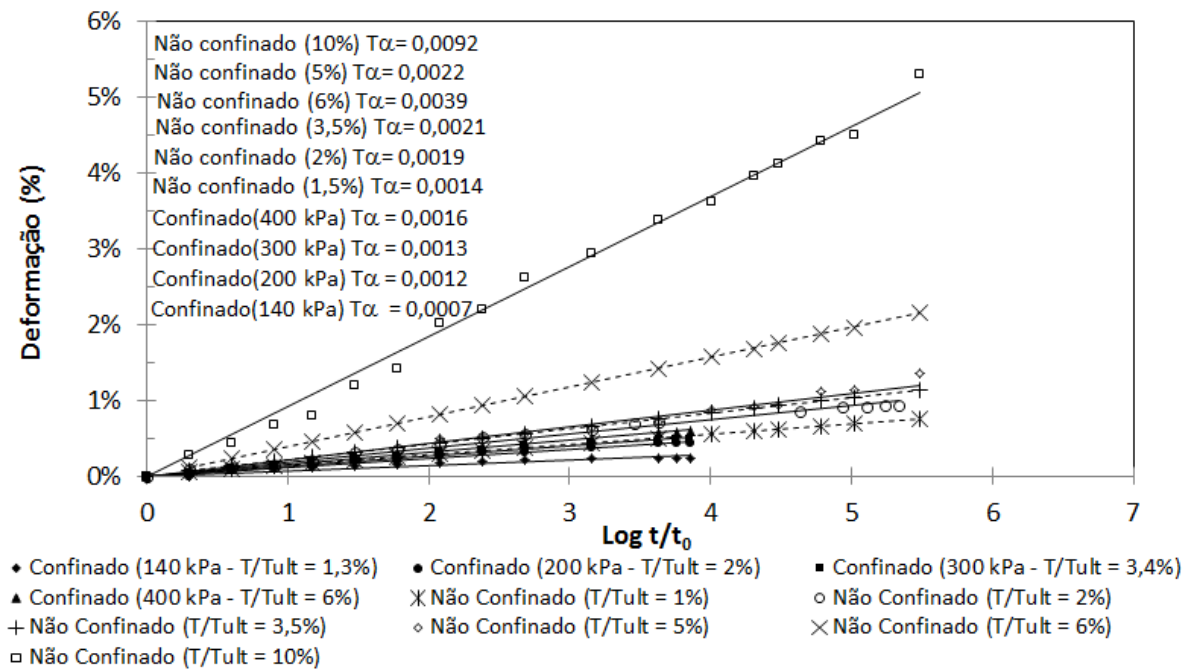

(b)

Figura 4.10 - Comparação entre os resultados dos ensaios de fluência confinada e não confinada para geotêxteis tecidos: (a) Variação das deformações ao longo do tempo pelo método da equação logarítmica; (b) Variação das deformações por fluência ao longo do tempo pelo método de Zornberg; Byler e Knudsen (2004). 
A Figura 4.10a mostra as variações das deformações ao longo do tempo, para os ensaios confinados e não confinados, pelo método da equação logarítmica para geotêxteis tecidos. Assim como notado nos resultados dos ensaios realizados com geotêxteis não tecidos, observou-se que tanto o parâmetro "a" (deformações iniciais de reforço) quanto o parâmetro "b" (inclinação da curva que representa a tendência à fluência do material) apresentaram aumento em suas magnitudes com o aumento da tensão vertical aplicada no ensaio. Além disso, ao se comparar os ensaios confinados e não confinados com mesmos carregamentos nos reforços, observou-se que o confinamento promoveu uma redução nos parâmetros relacionados às deformações. Entretanto, observa-se que estas reduções foram menos significativas quando comparadas às reduções observadas nos geotêxteis não tecidos.

A mesma tendência pode ser observada na Figura 4.10b, que apresenta os resultados dos ensaios segundo o método proposto por Zornberg; Byler e Knudsen (2004). Nota-se que a presença do confinamento promoveu uma redução do parâmetro de fluência $T \alpha$, e que o aumento da tensão vertical nos ensaios confinados conduziu ao aumento deste parâmetro.

Uma análise comparativa entre os parâmetros de deformação e fluência obtidos nos ensaios confinados e em isolamento é apresentada na Figura 4.11.

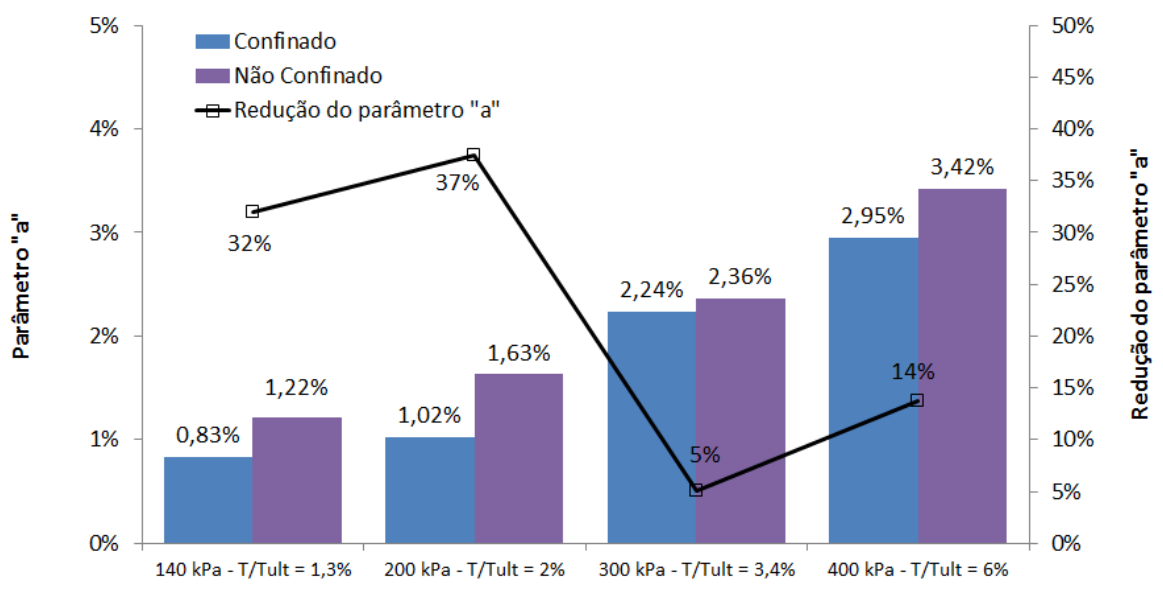

(a) 


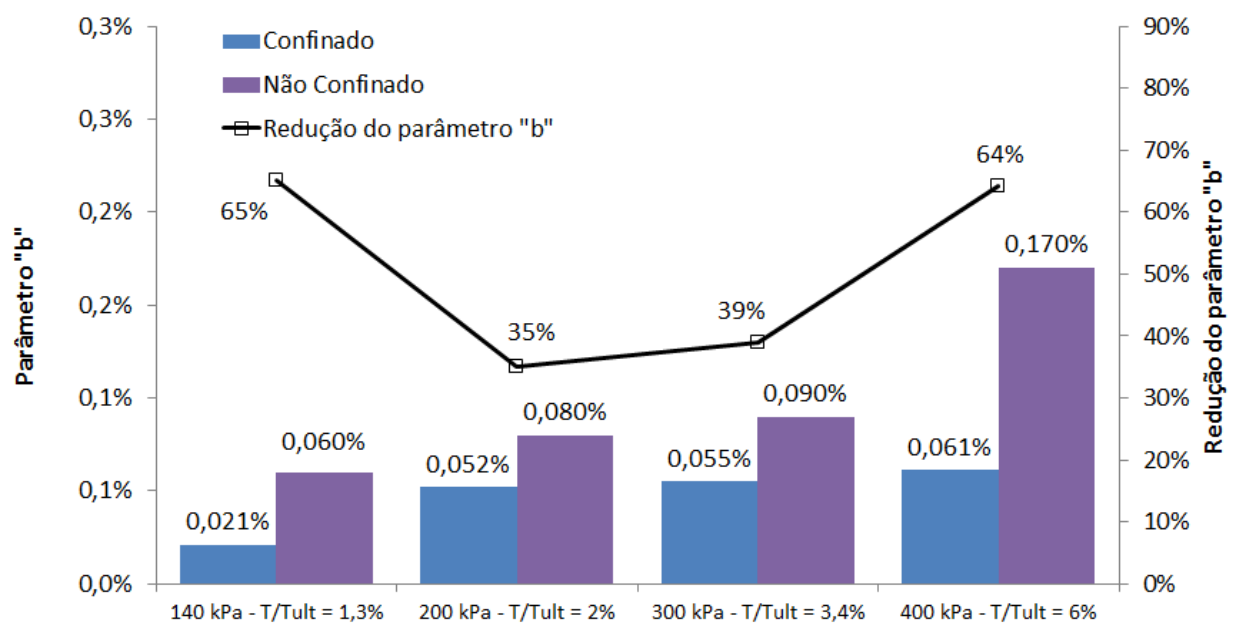

(b)

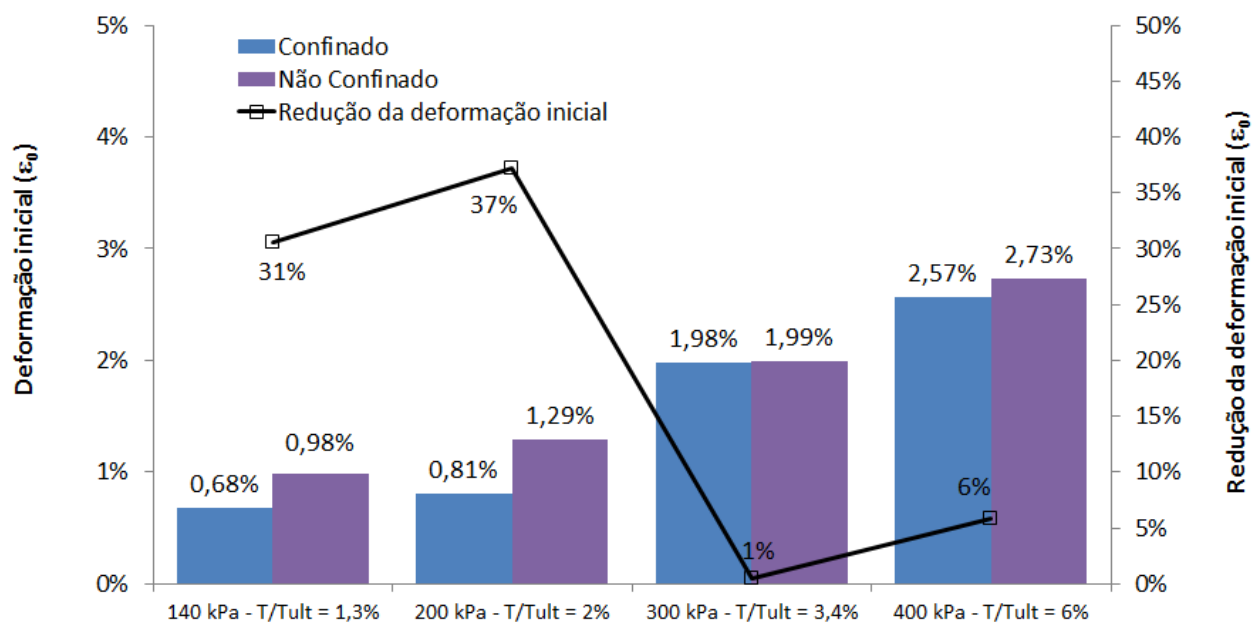

(c) 


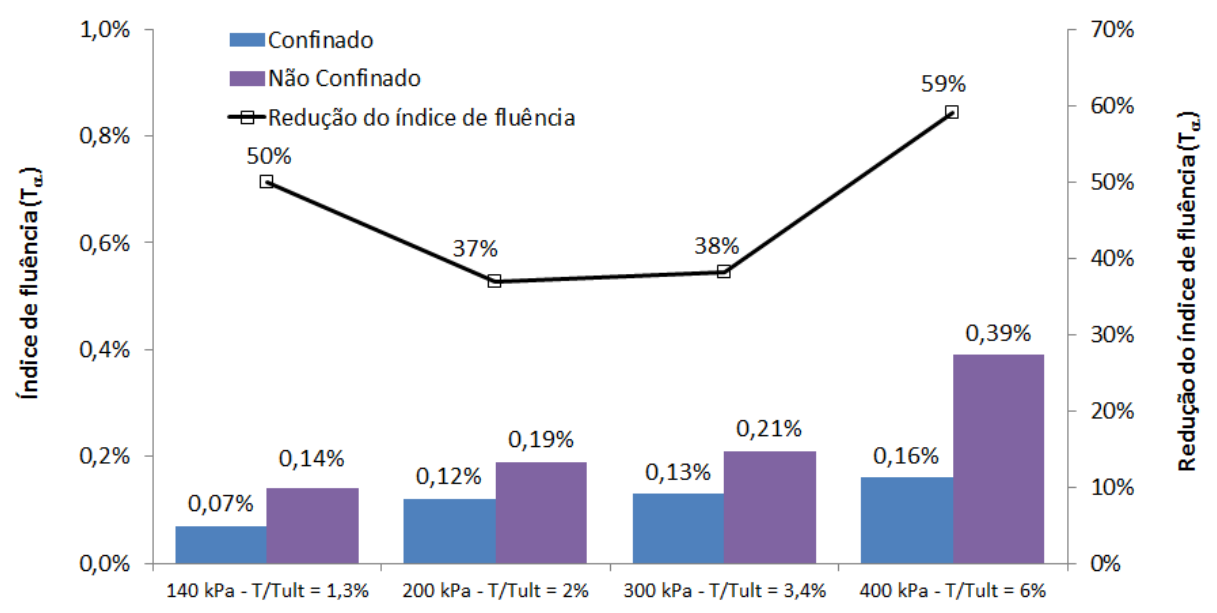

(d)

Figura 4.11 - Análise comparativa entre os resultados dos ensaios confinados e não confinados em função do nível de carregamento vertical para geotêxteis tecidos: (a) Variação do parâmetro "a" do Método da Equação Logarítmica; (b) Variação do parâmetro "b" do Método da Equação Logarítmica;. (c) Variação do parâmetro $\varepsilon_{0}$ do Método proposto por Zornberg; Byler e Knudsen (2004); (d) Variação do parâmetro T $\alpha$ do Método proposto por Zornberg; Byler e Knudsen (2004).

Conforme destacado anteriormente, a Figura 4.11 mostra que o confinamento promoveu uma redução dos parâmetros de deformação (parâmetro "a", parâmetro "b", $\varepsilon_{0}$ e T $\alpha$ ) para todos os níveis de carregamento avaliados.

A Figura 4.11a mostra que não há um padrão de comportamento bem definido da redução do parâmetro "a" em função do carregamento vertical aplicado ao ensaio. Nota-se que a maior redução do parâmetro "a" se deu no ensaio confinado com tensão vertical de $200 \mathrm{kPa}$ e a menor redução se deu para o ensaio com tensão de $300 \mathrm{kPa}$.

A não existência de um padrão de comportamento bem definido também ocorreu para a variação do parâmetro "b" em função do carregamento vertical. Observa-se que as maiores reduções do parâmetro "b" se deram para o maior e para o menor carregamento vertical (140 e $400 \mathrm{kPa}$ ), e as menores reduções ocorreram para os carregamentos verticais intermediários (200 e $300 \mathrm{kPa})$. 
As observações que foram realizadas para os parâmetros "a" e "b" do método da equação logarítmica (Figuras 4.11a e 4.11b) podem ser aplicadas também para os parâmetros $\varepsilon_{0}$ e T $\alpha$ do método proposto por Zornberg; Byler e Knudsen (2004) (Figuras $4.11 \mathrm{c}$ e d). Nota-se que em ambos os casos não há um padrão de comportamento bem definido destes parâmetros em relação à variação dos carregamentos verticais aplicados aos ensaios.

A Figura $4.11 \mathrm{c}$ mostra que a maior redução do parâmetro $\varepsilon_{0}$ se deu no ensaio confinado com tensão vertical de $200 \mathrm{kPa}$ e a menor redução se deu para o ensaio com tensão de $300 \mathrm{kPa}$.

Já a Figura 4.11d mostra que as maiores reduções do parâmetro T $\alpha$ se deram para os carregamentos verticais de 140 e $400 \mathrm{kPa}$, e as menores reduções ocorreram para os carregamentos 200 e $300 \mathrm{kPa}$.

Os resultados dos ensaios confinados e não confinados realizados para as geogrelhas são mostrados na Figura 4.12.

Assim como ocorrido para os demais reforços, a análise dos resultados para as geogrelhas também exigiu a elaboração de curvas interpoladas a partir dos resultados dos ensaios em isolamento. Os resultados dos ensaios de fluência convencional foram interpolados de forma a se obter curvas com relações $T / T_{\text {ult }}$ de 1,1\% (para comparação com ensaio confinado com carga vertical de $140 \mathrm{kPa}$ ), 3,4\% (para comparação com ensaio confinado com carga vertical de $300 \mathrm{kPa}$ ) e 7,1\% (para comparação com ensaio confinado com carga vertical de $400 \mathrm{kPa}$ ). $\mathrm{O}$ ensaio confinado com carregamento vertical de $200 \mathrm{kPa}$ não exigiu a interpolação de curvas, tendo em vista que a relação $\mathrm{T} / \mathrm{T}_{\text {ult }}$ obtida no ensaio foi de $2,1 \%$. 


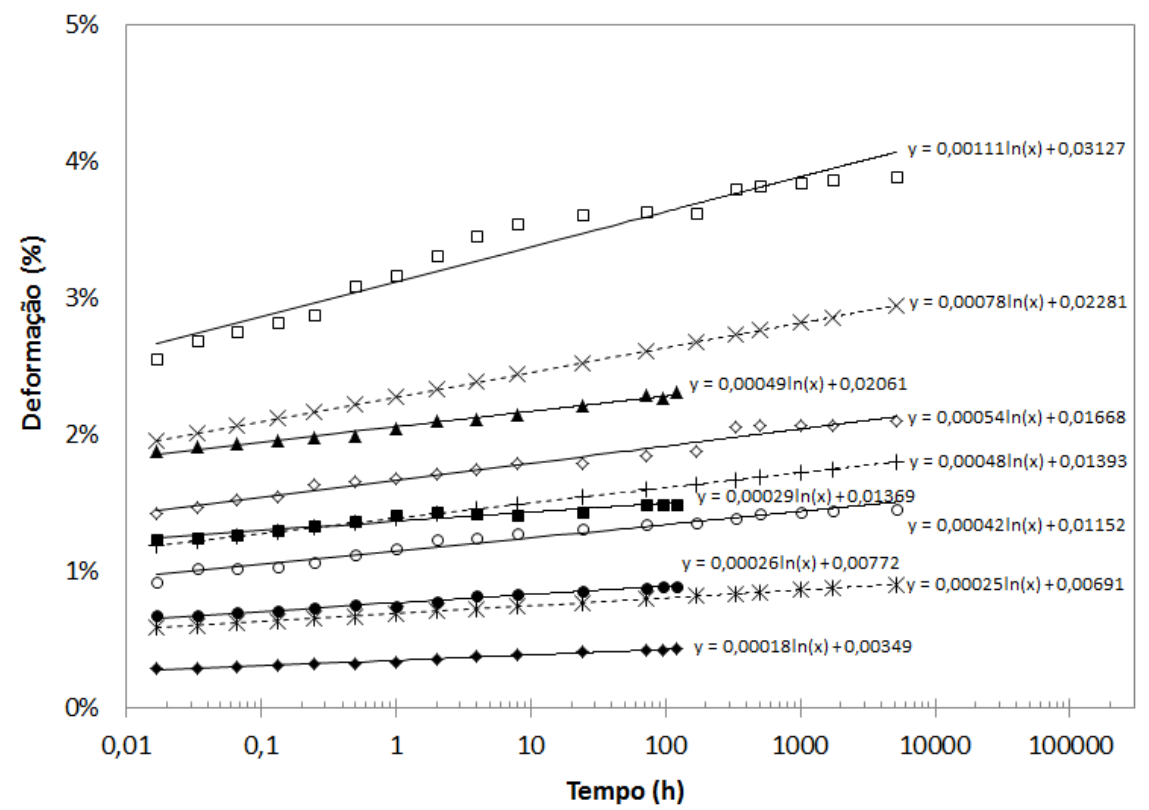

- Confinado $(140 \mathrm{kPa}-\mathrm{T} / \mathrm{Tult}=1,1 \%) \quad \bullet$ Confinado $(200 \mathrm{kPa}-\mathrm{T} / \mathrm{Tult}=2,1 \%)$

\Confinado $(400 \mathrm{kPa}-\mathrm{T} / \mathrm{Tult}=7,1 \%)$

- Não Confinado (T/Tult $=2 \%)$

- Confinado $(300 \mathrm{kPa}-\mathrm{T} / \mathrm{Tult}=3,4 \%)$

$\square$ Não Confinado (T/Tult $=10 \%)$

* Não Confinado $(T /$ Tult $=1,1 \%)$

Nă Confinado $(\mathrm{T} /$ Tult $=5 \%)$

$\times$ Não Confinado $(\mathrm{T} / \mathrm{Tult}=7,1 \%)$

(a)

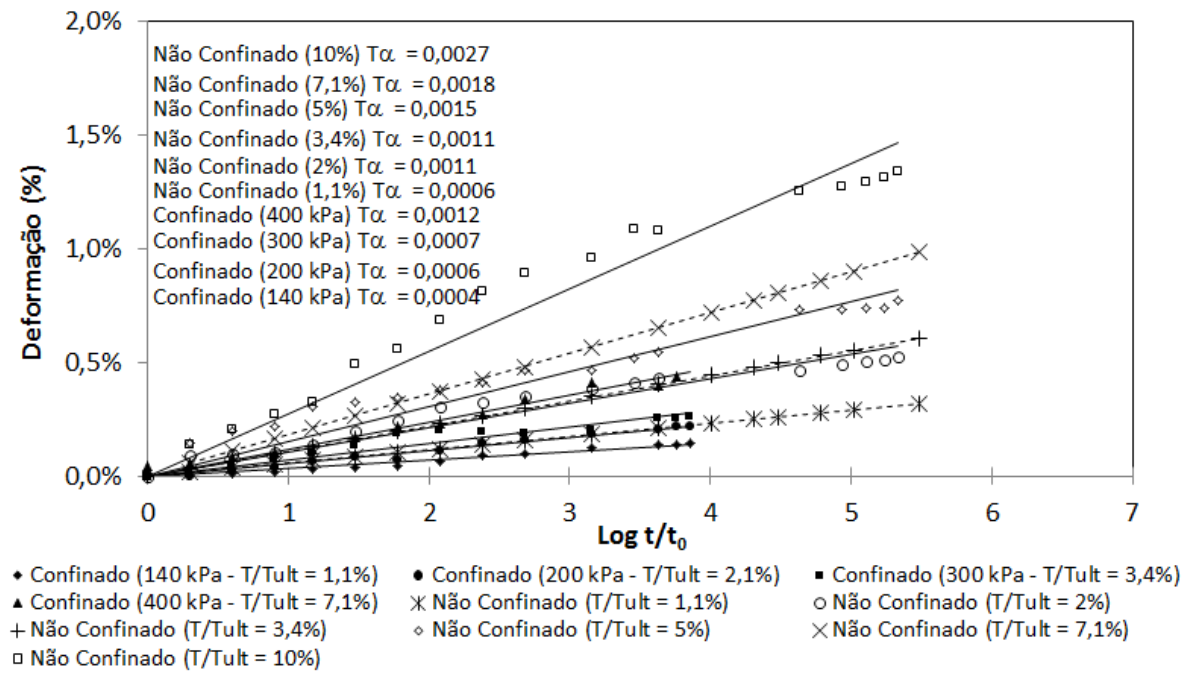

(b)

Figura 4.12 - Resultados dos ensaios de fluência confinada para geogrelhas para diferentes carregamentos verticais: (a) Variação das deformações ao longo do tempo pelo método da equação logarítmica; (b) Variação das deformações por fluência ao longo do tempo pelo método de Zornberg; Byler e Knudsen (2004). 
Assim como observado nos resultados dos ensaios realizados com os geotêxteis não tecidos e tecidos, a Figura 4.12a mostra que maiores carregamentos verticais conduziram a curvas mais elevadas e mais inclinadas, indicando que tanto a deformação inicial quanto a tendência à fluência do material foram influenciados pelo carregamento vertical aplicado no ensaio confinado. Nota-se também que, como observado nos demais tipos de reforços, o confinamento reduziu as deformações iniciais e a tendência à fluência das geogrelhas.

A mesma tendência pode ser observada na Figura 4.12b, que apresenta os resultados dos ensaios segundo o método proposto por Zornberg; Byler e Knudsen (2004). Ao se comparar os resultados dos ensaios confinados e em isolamento com as mesmas relações de $\mathrm{T} / \mathrm{T}_{\text {ult }}$, nota-se que o confinamento reduziu a tendência à fluência dos reforços. Além disso, ao se comparar os ensaios confinados entre si, observa-se que o aumento da tensão vertical aplicada nos ensaios confinados conduziu ao aumento da inclinação das curvas, representada pelo parâmetro de fluência $T \alpha$.

Uma análise comparativa entre os parâmetros de deformação inicial e fluência, obtidos nos ensaios confinados e em isolamento para geogrelhas, é apresentada Figura 4.13.

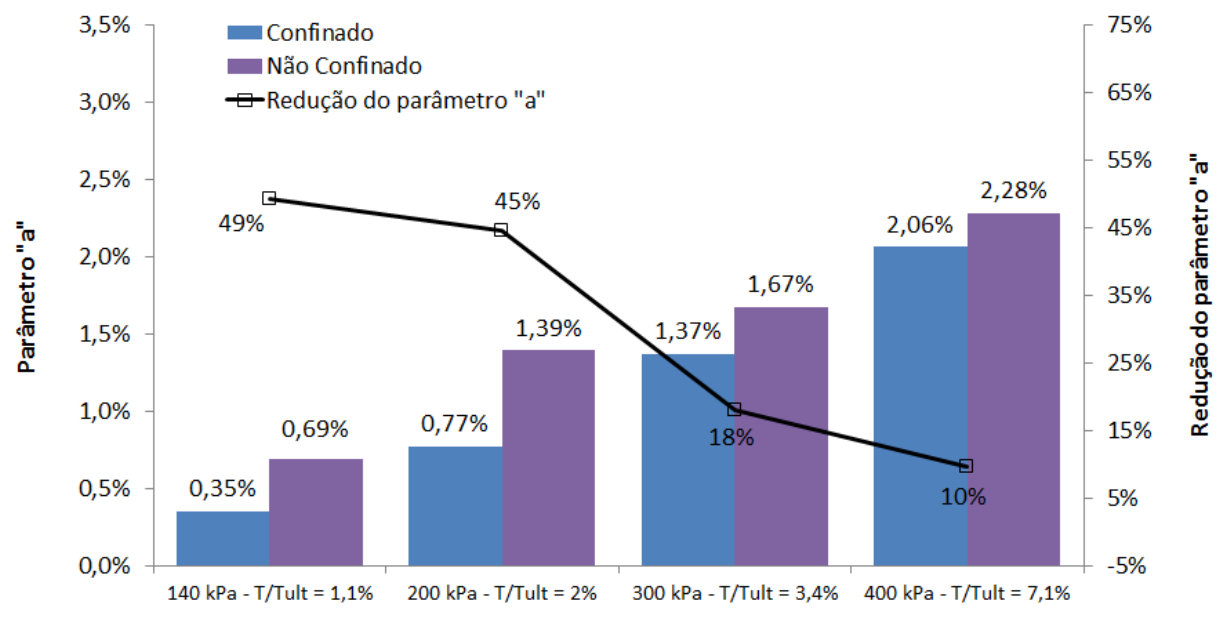

(a) 


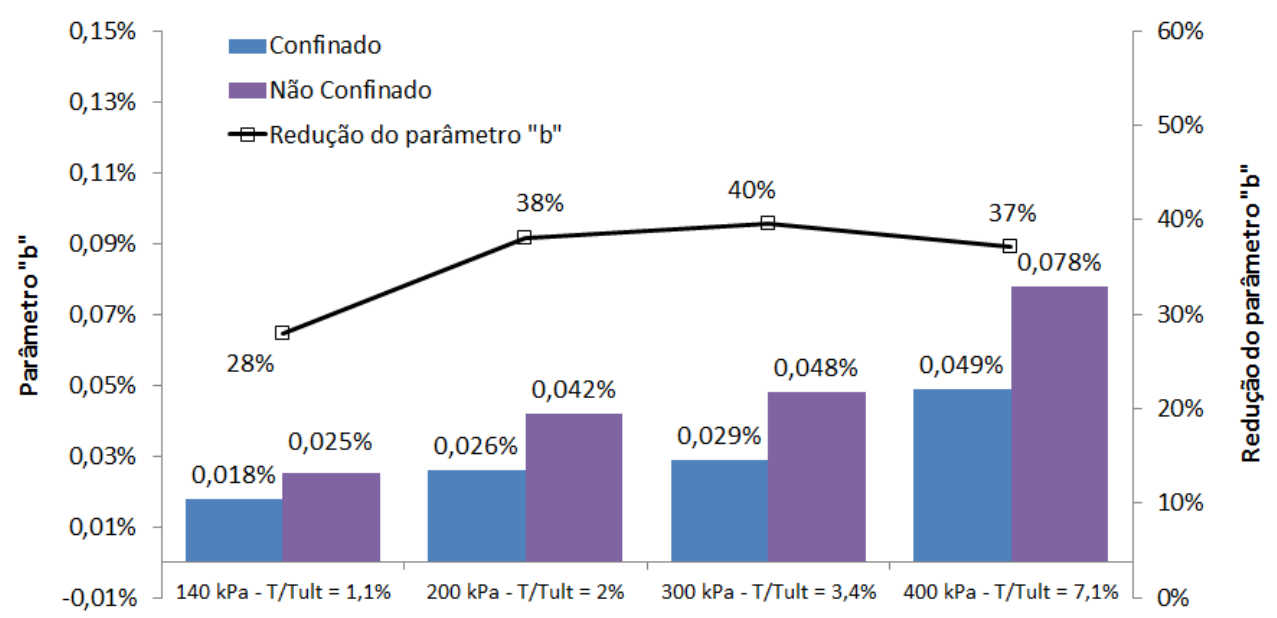

(b)

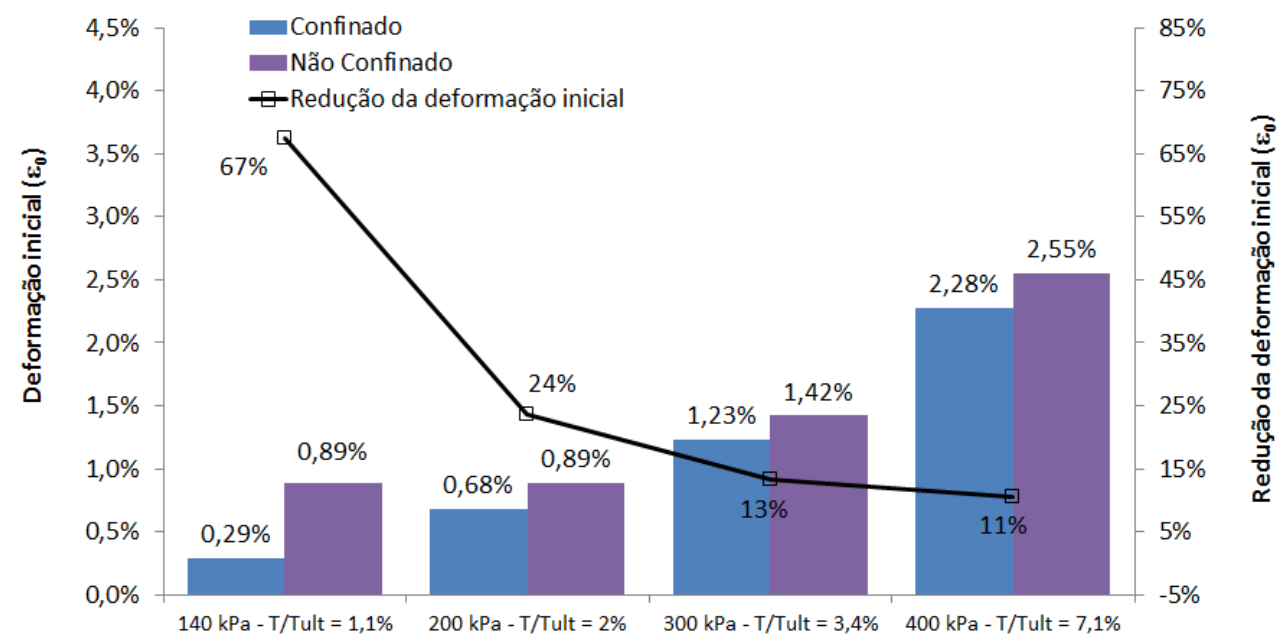

(c) 


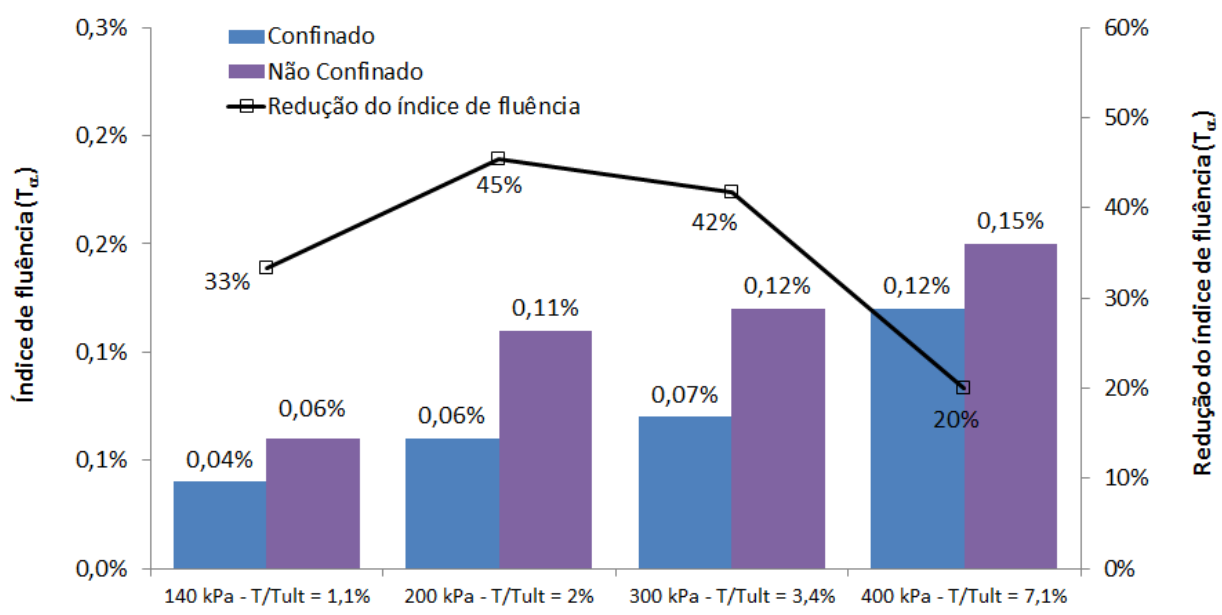

(d)

Figura 4.13 - Análise comparativa entre os resultados dos ensaios confinados e não confinados em função do nível de carregamento vertical para geogrelhas: (a) Variação do parâmetro "a" do Método

da Equação Logarítmica; (b) Variação do parâmetro "b" do Método da Equação Logarítmica;. (c) Variação do parâmetro $\varepsilon_{0}$ do Método proposto por Zornberg; Byler e Knudsen (2004); (d) Variação do parâmetro $T_{\alpha}$ do Método proposto por Zornberg; Byler e Knudsen (2004).

Assim como observado para os demais geossintéticos, a Figura 4.13 mostra que, para o caso das geogrelhas, o confinamento diminuiu tanto as deformações iniciais quanto a tendência à fluência dos reforços.

As Figura 4.13a e 4.13c mostram que, diferente do que foi observado para os geotêxteis tecidos e não tecidos, as geogrelhas apresentaram um padrão de comportamento bem definido quanto à redução do parâmetro "a" e $\varepsilon_{0}$ em função do carregamento vertical aplicado ao ensaio. Nota-se que neste caso, o aumento do confinamento conduziu à diminuição das reduções das deformações iniciais.

O mesmo não pode ser dito em relação à variação da redução dos parâmetros de fluência (parâmetro "b" e T $\alpha$ ) em função do carregamento vertical. A Figura 4.13b mostra que o aumento do carregamento vertical conduziu ao aumento da redução do parâmetro "b" até a tensão vertical de $300 \mathrm{kPa}$. Para a tensão de $400 \mathrm{kPa}$ esta tendência se inverteu. Já a Figura 4.13d mostra que o aumento do carregamento vertical conduziu ao aumento das reduções do parâmetro T $\alpha$ até a tensão vertical de 200 kPa, a partir da qual a redução do parâmetro de fluência tende a diminuir. 
Os dados de ensaios de fluência, seja ele confinado ou em isolamento, podem ser também interpretados em função da variação da rigidez do reforço ao longo tempo. Para o caso de ensaios em isolamento, a carga aplicada ao reforço é constante e as deformações variam em função do tempo. Para o caso de ensaios de fluência confinada, especificamente para os ensaios realizados no equipamento de interação solo-reforço, além das deformações, o carregamento no reforço também varia devido à relaxação, conforme demonstrado anteriormente. Esta análise, que apresenta a variação da rigidez ao longo do tempo para os ensaios confinados e não confinados, é apresentada a seguir. A Figura 4.14a mostra os resultados para o caso dos geotêxteis não tecidos, a Figura 4.14b para os geotêxteis tecidos e a Figura 4.14c para as geogrelhas.

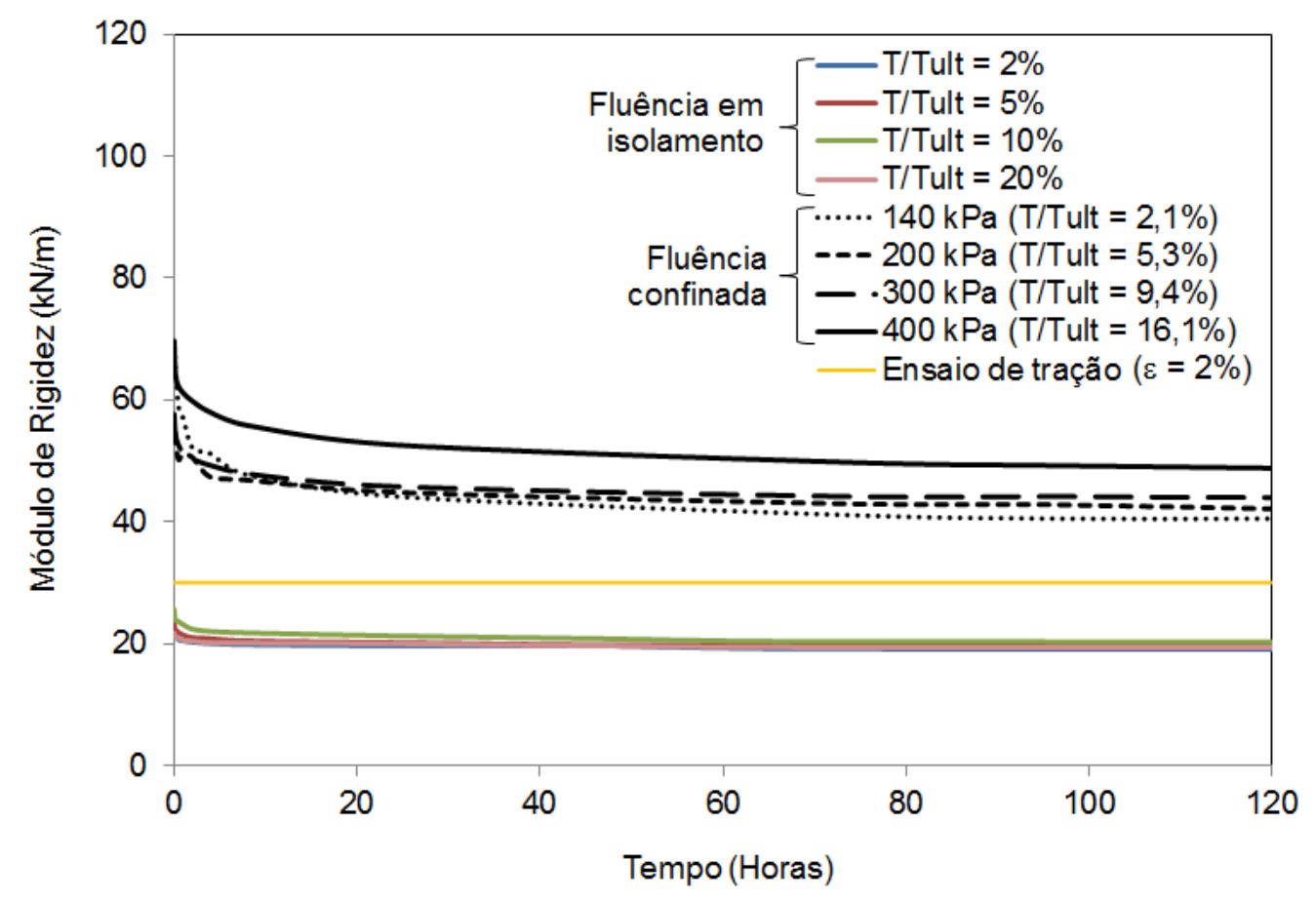

(a) 


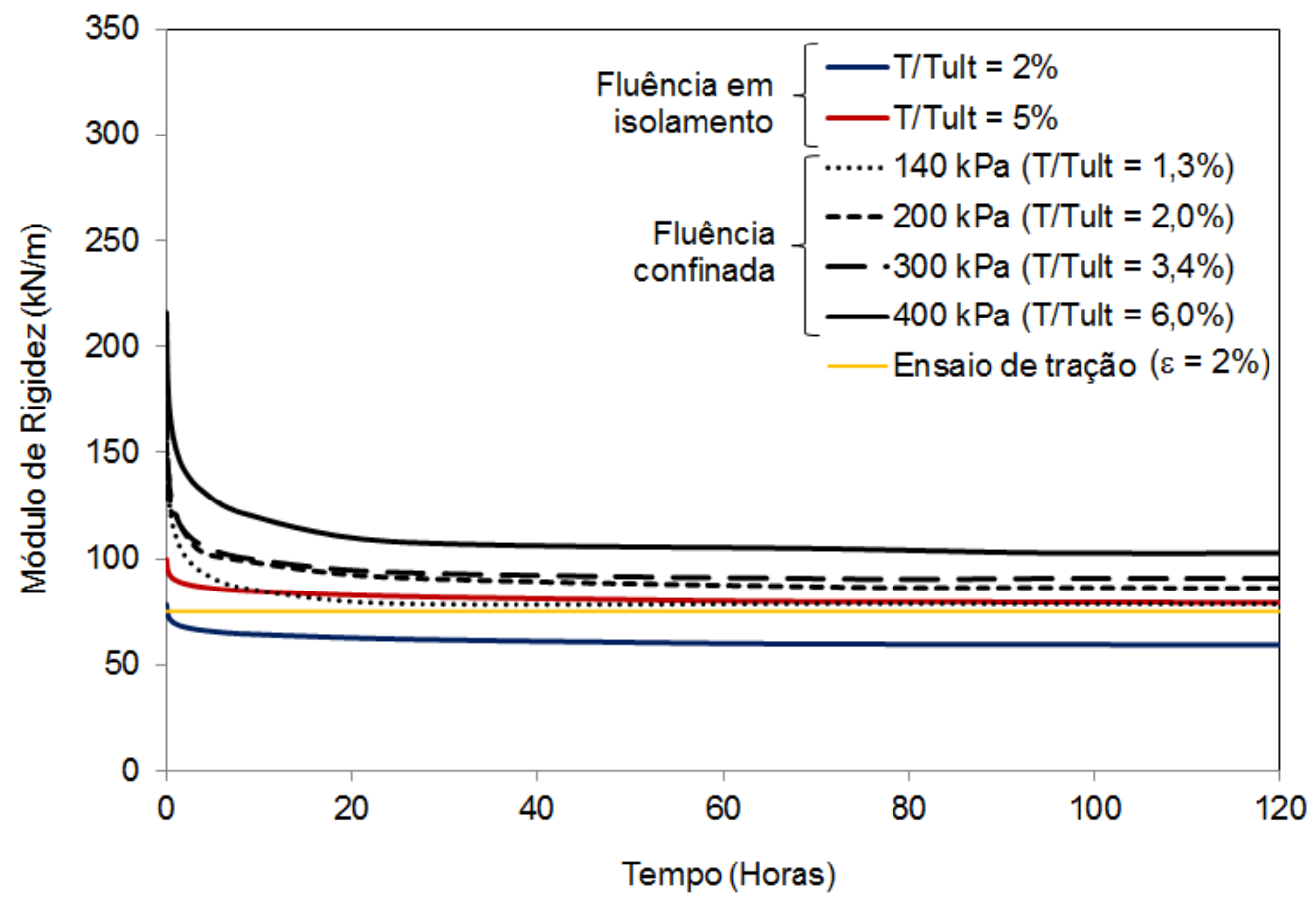

(b)

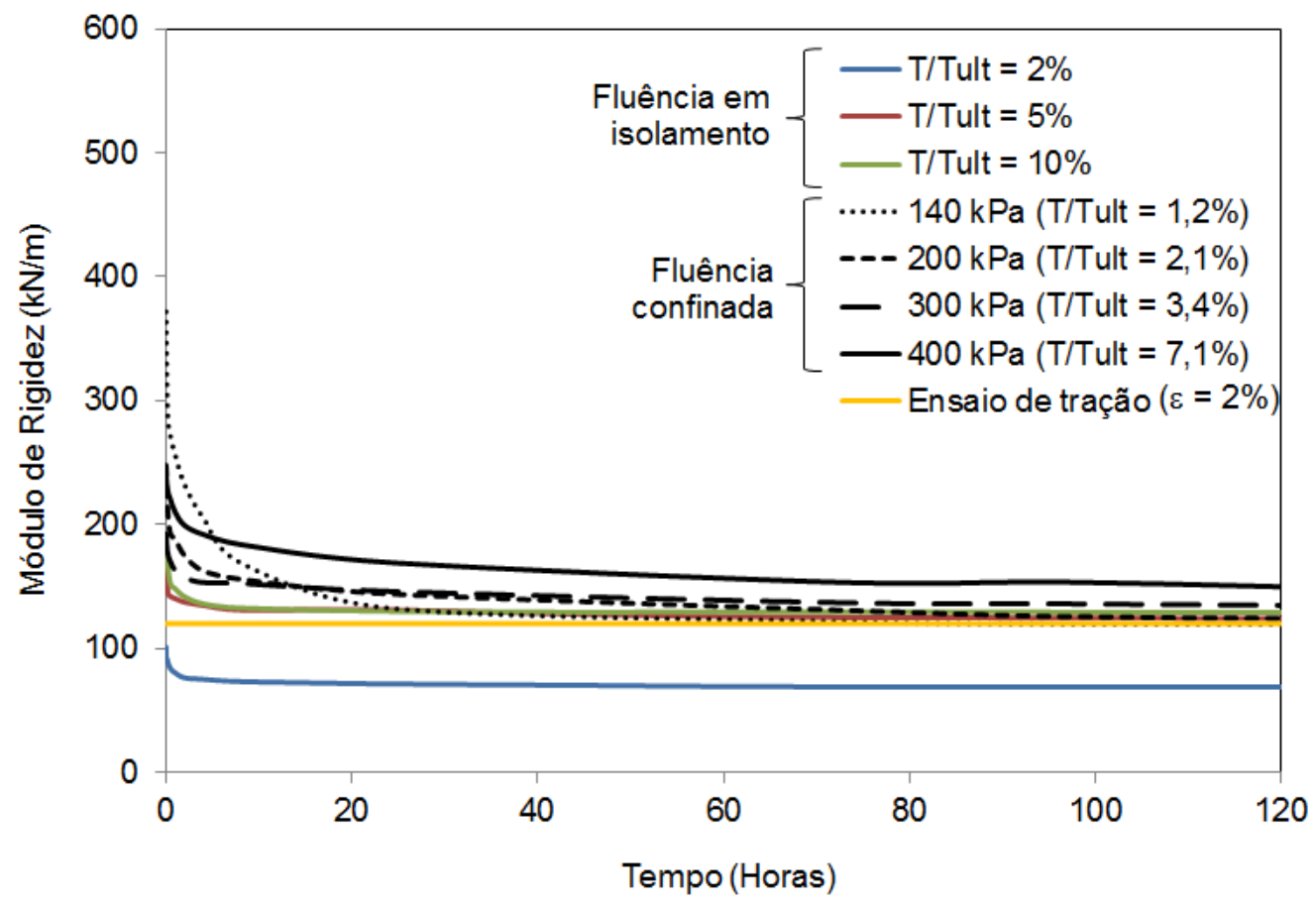

(c)

Figura 4.14 - Variação da rigidez dos reforços em função do tempo para os ensaios de fluência em isolamento, fluência confinada e ensaio de tração para: (a) Geotêxteis não tecidos; (b) Geotêxteis tecidos; (c) Geogrelhas. 
A Figura 4.14a mostra a variação da rigidez confinada ao longo do tempo para os geotêxteis não tecidos. Ao se comparar os resultados dos ensaios não confinados entre si, nota-se que a variação da rigidez é muito pequena em função do nível de carregamento aplicado, ou seja, a rigidez é praticamente a mesma para os ensaios com carregamentos de $2 \%, 5 \%, 10 \%$ e $20 \%$ da resistência última do material. Observa-se ainda, ao se comparar os resultados dos ensaios isolados com os resultados dos ensaios confinados, que o confinamento promoveu um aumento considerável de rigidez dos reforços. $\mathrm{O}$ aumento de rigidez devido ao confinamento foi da ordem de 2,5 vezes. Outro fator importante a ser observado se refere à variação da rigidez em função do nível de confinamento ao qual o reforço é submetido. Nota-se que a rigidez do conjunto solo-reforço é dependente do nível de confinamento, ou seja, maiores níveis de carregamento vertical conduziram a maiores módulos de rigidez.

A Figura 4.14b mostra que o comportamento dos geotêxteis tecidos é um pouco diferente quando comparado ao comportamento dos não tecidos. Nota-se que o nível de carregamento aplicado ao elemento nos ensaios em isolamento influenciou de maneira mais significativa na rigidez do reforço. Quanto maior o nível de carregamento aplicado, maior a rigidez observada. Nota-se também que, assim como observado para o caso dos geotêxteis não tecidos, que o confinamento influenciou na rigidez dos elementos. Entretanto essa influencia foi bem menor quando comparado aos efeitos observados no outro tipo de reforço. Para os geotêxteis tecidos o confinamento promoveu um aumento na rigidez dos reforços da ordem de 1,4 vezes. Outro fato que merece destaque é que a rigidez do conjunto solo-reforço é dependente do nível de carregamento vertical aplicado. Assim como observado para o caso dos não tecidos, maiores carregamentos verticais aplicados aos ensaios confinados levaram a maiores módulos de rigidez do conjunto soloreforço.

Em relação às geogrelhas, a Figura $4.14 \mathrm{c}$ mostra um comportamento muito semelhante aos geotêxteis tecidos. Nota-se que o nível de carregamento aplicado ao reforço nos ensaios de fluência em isolamento também influenciou de maneira significativa na rigidez do reforço. Observa-se que houve um aumento considerável na rigidez ao se elevar o carregamento de $2 \%$ para $5 \%$ da resistência última do material. Entretanto, ao se aumentar o carregamento de $5 \%$ para $10 \%$, a rigidez 
praticamente não variou. Assim como ocorreu para os geotêxteis não tecidos e tecidos, a rigidez das geogrelhas também foi afetada pelo confinamento em solo. Para as geogrelhas, o efeito do confinamento promoveu um aumento na rigidez de até 1,8 vezes em relação ao ensaio em isolamento, sendo que este valor depende do nível de carregamento vertical aplicado ao ensaio.

Conforme foi possível se observar, em todos os ensaios confinados realizados empregando-se o equipamento de interação solo-reforço, o confinamento dos reforços conduziu à diminuição das deformações inicias e da tendência à fluência, e ainda promoveu um aumento da rigidez confinada dos elementos. Além disso, observou-se que o aumento dos parâmetros relacionados à deformação inicial, à fluência e à rigidez dos materiais testados é proporcional ao acréscimo de carregamento vertical imposto ao ensaio.

Sabe-se que dentre os diversos fatores que afetam o comportamento das deformações ao longo do tempo de materiais geossintéticos, as cargas atuantes no reforço e o confinamento estão entre os mais importantes. Koerner (2005) e Simonini e Gottardi (2003) destacam que o aumento dos esforços solicitantes em reforços leva a maiores índices de fluência. Por outro lado, a presença do confinamento tende a reduzir as cargas solicitantes no elemento, e por consequência, tende a reduzir os índices de fluência. Nos ensaios realizados no equipamento de interação solo-reforço, a aplicação do carregamento vertical afeta simultaneamente o confinamento e a carga atuante no reforço. Conforme o carregamento vertical é aumentado, o reforço se torna mais confinado e, ao mesmo tempo, mais solicitado.

A partir dos resultados apresentados neste item, observou-se que, para todos os geossintéticos testados, o incremento da tensão vertical aumentou a deformação inicial e a tendência à fluência dos reforços. Isto significa que a carga no reforço exerce maior influência sobre a sobre as deformações ao longo do tempo do que o confinamento. 


\subsubsection{Análise da influência do tipo de geossintético na fluência dos reforços}

Neste item é apresentada uma análise dos efeitos do tipo de geossintético sobre o comportamento das deformações ao longo do tempo para os reforços estudados. Para facilitar as análises, para cada uma das tensões verticais aplicadas, apresentam-se, simultaneamente, os resultados dos ensaios de fluência para os três tipos de geossintéticos avaliados (Figura 4.15).

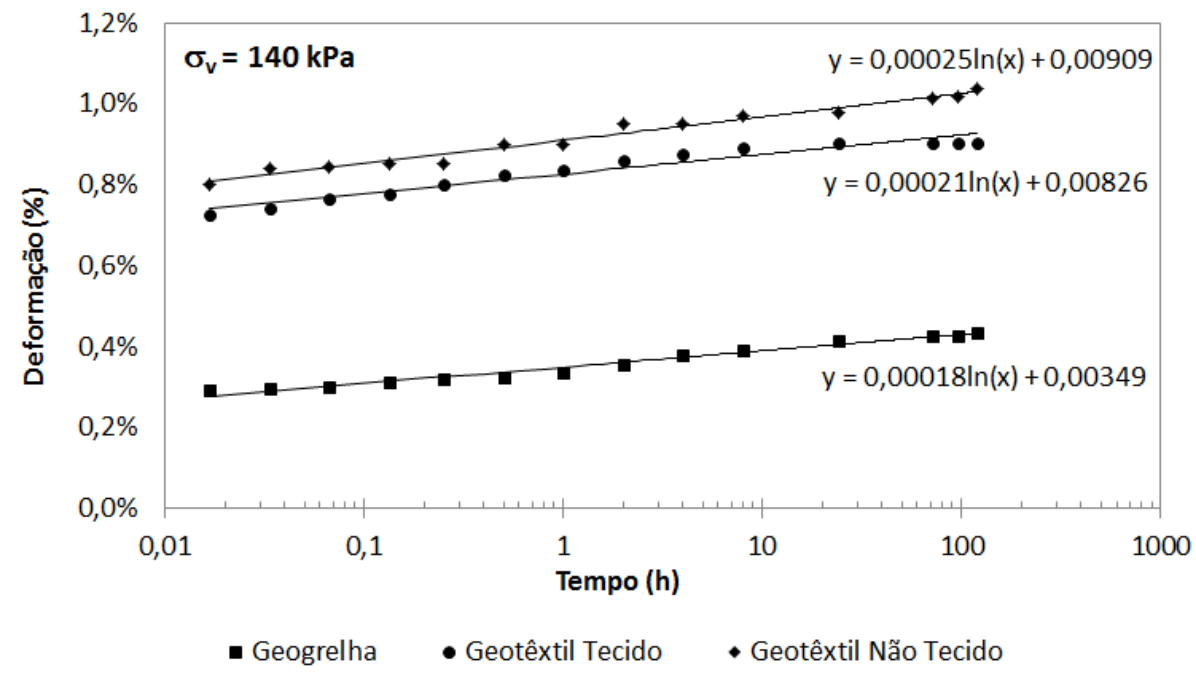

(a)

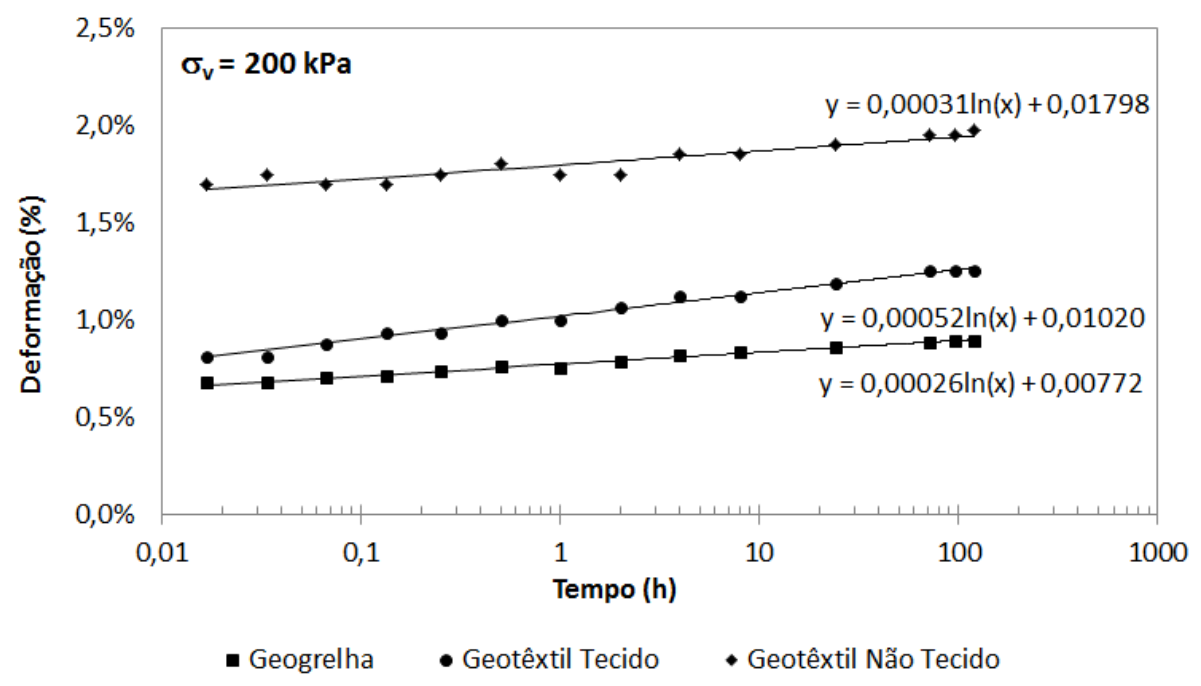

(b) 


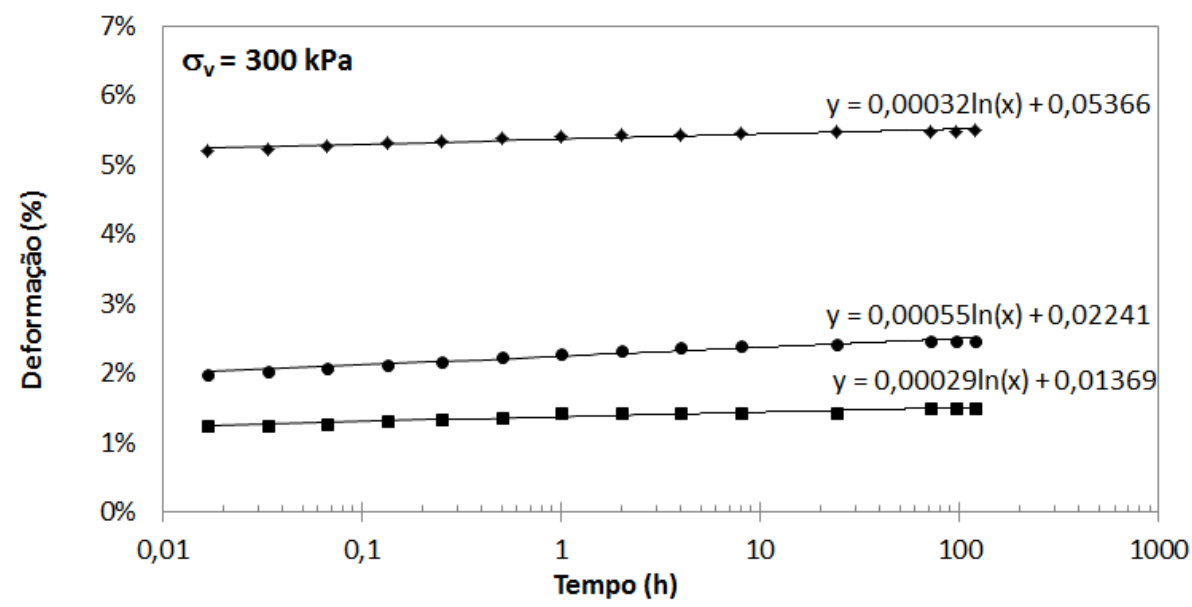

- Geogrelha • Geotêxtil Tecido • Geotêxtil Não Tecido

(c)

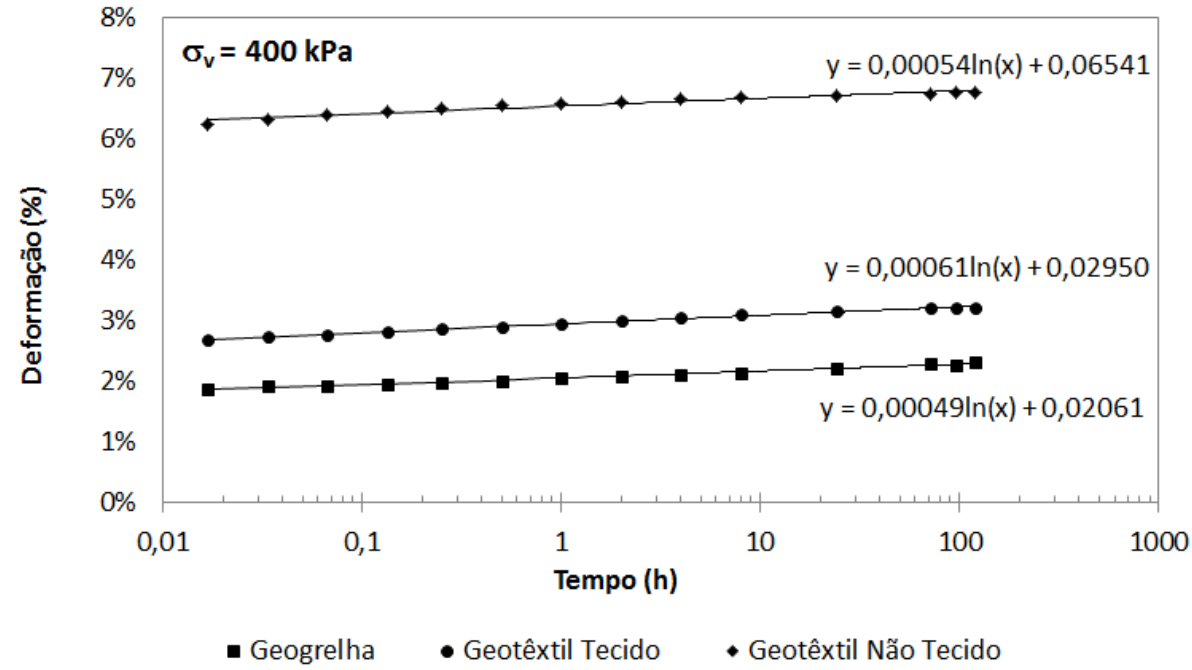

(d)

Figura 4.15 - Comparação entre os resultados dos ensaios confinados, executados no equipamento de interação solo-reforço, para cada tipo de geossintético para as seguintes tensões verticais: (a) 140 $\mathrm{kPa}$; (b) $200 \mathrm{kPa}$; (c) $300 \mathrm{kPa}$; (d) $400 \mathrm{kPa}$.

A Figura 4.15 mostra que os níveis de deformação para os geotêxteis não tecidos, para todas as tensões verticais ensaiadas, são consideravelmente maiores que os níveis de deformação para os demais geossintéticos avaliados. Por outro lado, as geogrelhas apresentaram os menores níveis de deformações, sendo que os geotêxteis tecidos permaneceram em patamares intermediários.

A Figura 4.16 mostra a variação da rigidez dos reforços ao longo do tempo para os geotêxteis não tecidos, geotêxteis tecidos e geogrelhas, para todos os níveis de carregamento aplicados nos ensaios de fluência confinada. Observa-se que os 
menores módulos de rigidez foram registrados para os geotêxteis não tecidos, os quais apresentaram uma rigidez média $\left(\mathrm{J}_{\text {méd }}\right)$ de $44 \mathrm{kN} / \mathrm{m}$. As geogrelhas foram os reforços que apresentaram os maiores módulos de rigidez confinada ( $J_{\text {méd }}$ igual a $132 \mathrm{kN} / \mathrm{m}$ ). Já o geotêxtil tecido apresentou um comportamento intermediário, com valores de rigidez situados entre os outros dois materiais $\left(J_{\text {méd }}\right.$ igual a $\left.90 \mathrm{kN} / \mathrm{m}\right)$.

Destaca-se que o valor da rigidez média $\left(J_{\text {méd }}\right)$ foi determinado como sendo a média das rigidezes obtidas ao final dos ensaios realizados com carregamentos verticais de $140,200,300$ e $400 \mathrm{kPa}$.

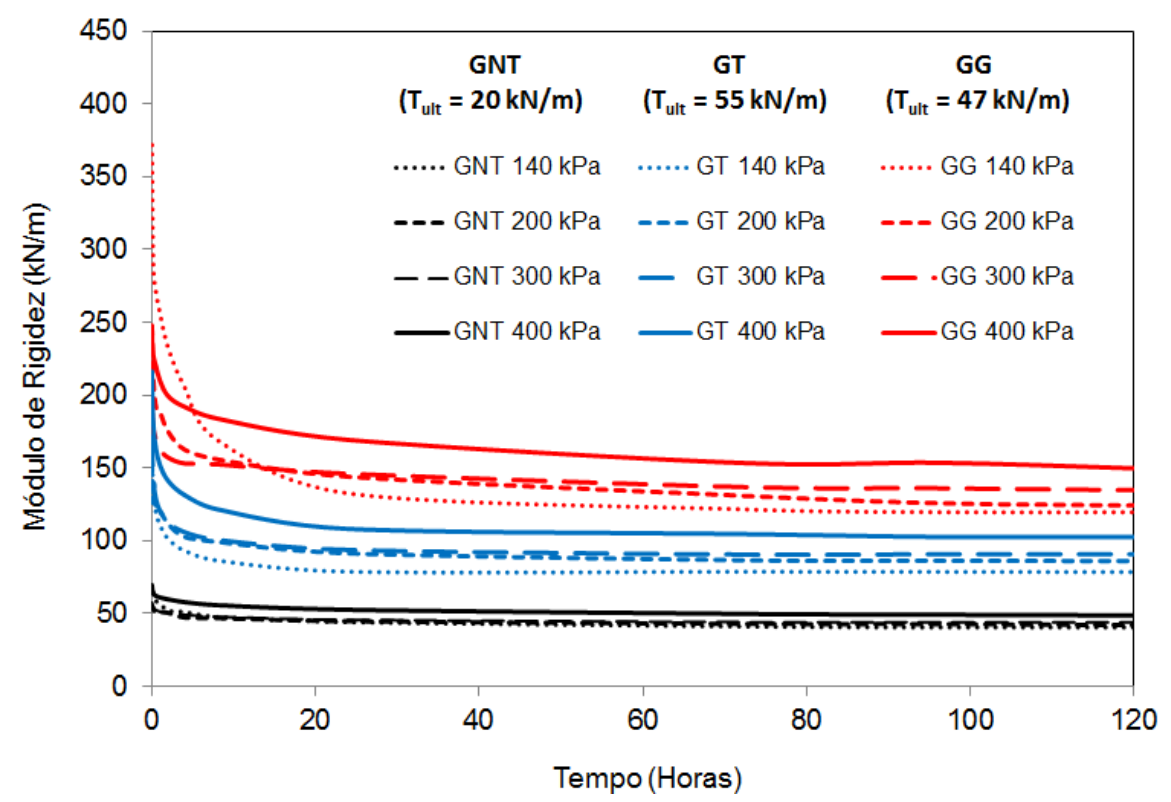

Figura 4.16 - Variação do módulo de rigidez confinado em função do tempo para os geotêxteis não tecidos, geotêxteis tecidos e geogrelhas sob diferentes níveis de carregamento vertical.

Conforme apresentado na Figura 4.15 e na Figura 4.16, observa-se que os níveis de deformação registrados nos reforços estão diretamente relacionados aos seus módulos de rigidez confinada. Os resultados indicaram que os conjuntos solo-reforço com maiores módulos de rigidez apresentam as menores deformações. Este comportamento pode ser melhor observado na Figura 4.17.

Para os geotêxteis não tecidos, que possuem um módulo de rigidez médio $\left(\mathrm{J}_{\text {méd }}\right)$ de $44 \mathrm{kN} / \mathrm{m}$, para carregamentos verticais de 140, 200, 300 e $400 \mathrm{kPa}$, foram obtidas deformações finais, ao término das 120 horas de ensaio, de 1,04\%, 1,98\%, 5,50\% e $6,77 \%$, respectivamente.

Já para o caso de geotêxteis tecidos, cujo valor de $\mathrm{J}_{\text {méd }}$ é de $90 \mathrm{kN} / \mathrm{m}$, considerando os carregamentos verticais de 140, 200, 300 e 400 kPa, foram obtidas deformações 
finais, ao término das 120 horas de ensaio, de $0,90 \%, 1,25 \%, 2,46 \%$ e $3,20 \%$, respectivamente.

E para geogrelhas, que apresentaram $J_{\text {méd }}$ de $132 \mathrm{kN} / \mathrm{m}$, considerando os carregamentos verticais de 140, 200, 300 e $400 \mathrm{kPa}$, foram obtidas deformações finais, ao término das 120 horas de ensaio, de 0,44\%, 0,90\%, 1,49\% e 2,32\%, respectivamente.

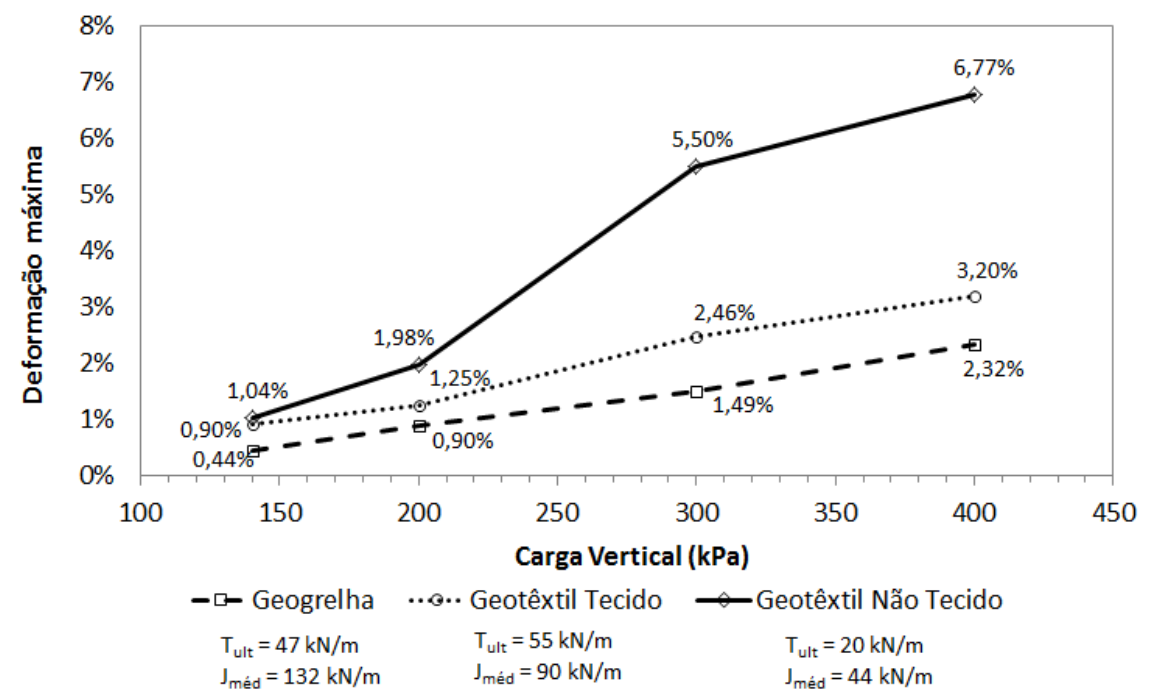

Figura 4.17 - Variação das deformações máximas em função do nível de tensão vertical aplicada para os ensaios confinados executados no equipamento de interação solo-reforço.

O mesmo comportamento observado para as deformações máximas obtidas nos reforços vale para as deformações iniciais, representada pelo parâmetro "a" do método logarítmico. Ou seja, as maiores deformações iniciais ocorreram para os geotêxteis não tecidos e as menores para as geogrelhas. Isto mostra que as deformações iniciais, assim como as deformações máximas, estão diretamente ligadas à rigidez confinada do reforço. A variação do parâmetro "a" em função do carregamento vertical aplicado pode ser vista na Figura 4.18. 


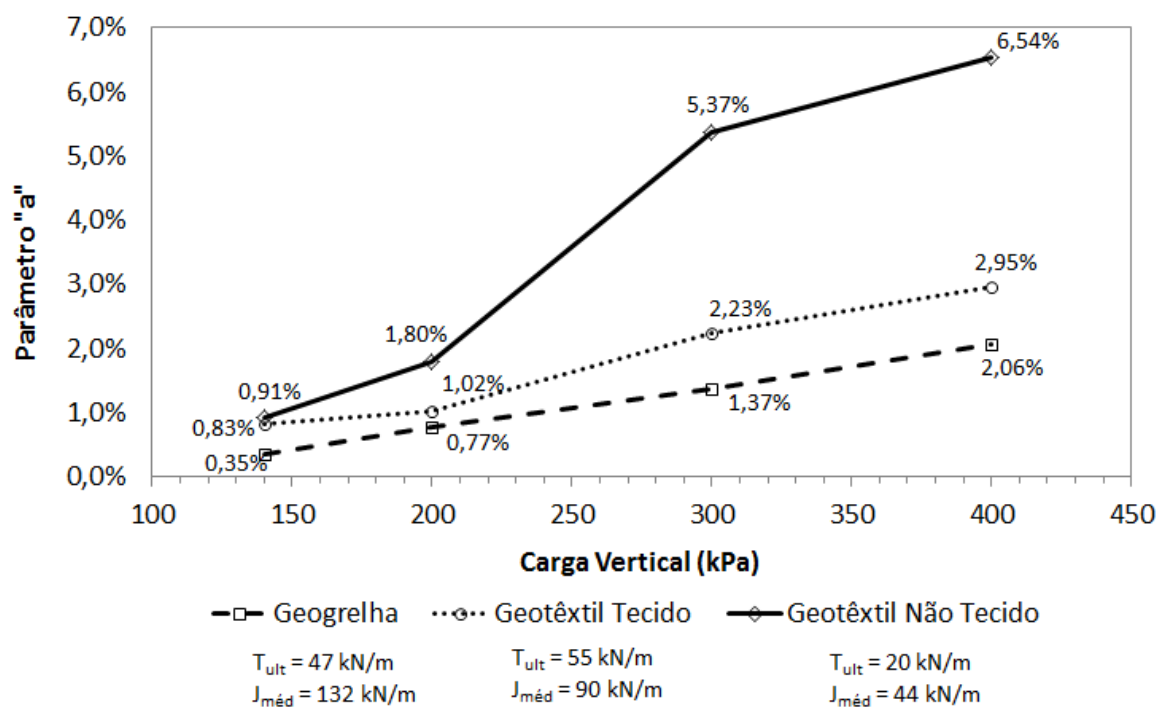

Figura 4.18 - Variação do parâmetro "a" em função do nível de tensão vertical aplicada para os ensaios confinados executados no equipamento de interação solo-reforço.

A Figura 4.19 mostra a variação do parâmetro "b", que representa a tendência à fluência do material, em função do nível de tensão vertical aplicado ao ensaio. Observa-se que os valores do parâmetro "b", de forma geral, foram maiores para os geotêxteis tecidos, e menores para as geogrelhas. Os geotêxteis não tecidos ficaram em patamares intermediários. Este comportamento foi observado para todos os casos, exceto para o ensaio com carregamento de $140 \mathrm{kPa}$, no qual o geotêxtil tecido apresentou resultados intermediários e o maior índice de fluência se deu para o geotêxtil não tecido. Apesar dessa diferença observada entre os diferentes tipos de materiais, nota-se que os índices de fluência são muito baixos, podendo ser considerados praticamente semelhantes para todos os materiais testados. Isso é um indicativo de que a fluência praticamente não ocorre para tais níveis de carregamento. 


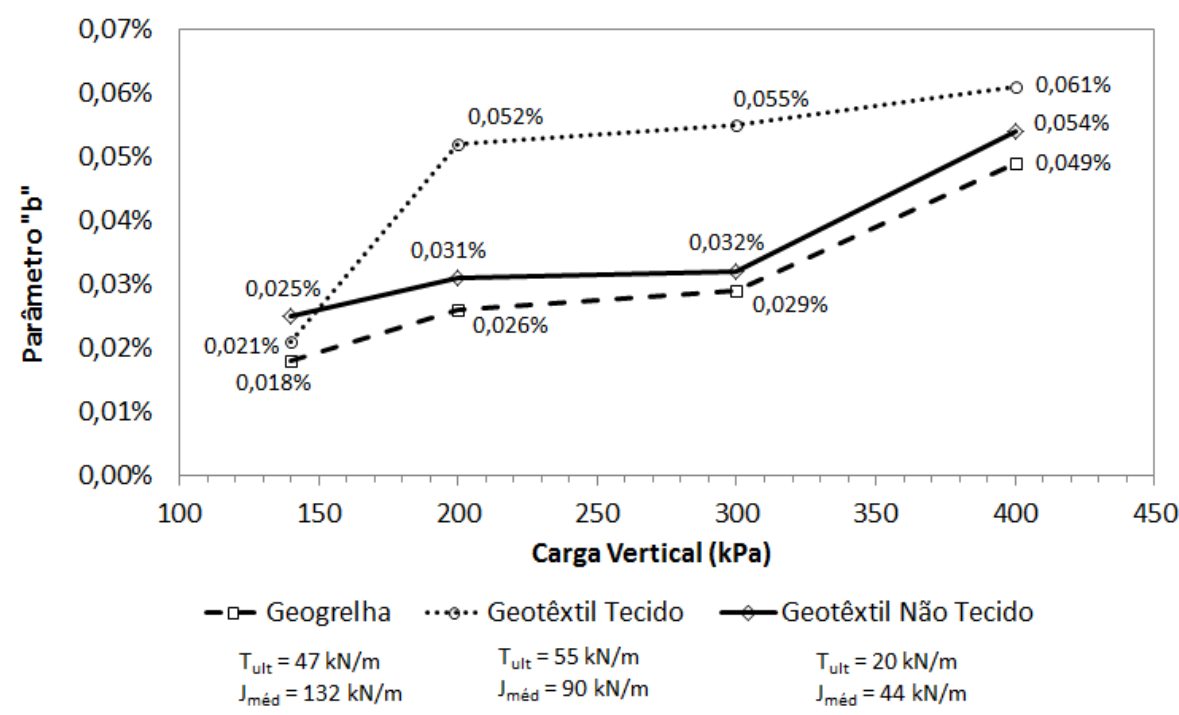

Figura 4.19 - Variação do parâmetro "b" em função do nível de tensão vertical aplicada para os ensaios confinados executados no equipamento de interação solo-reforço.

A Figura 4.20 mostra a variação do parâmetro T $\alpha$, que representa 0 índice de fluência do material pelo método de Zornberg; Byler e Knudsen (2004), em função do nível de tensão vertical aplicado ao ensaio. Nota-se que, assim como observado para o método da equação logarítmica, os níveis de fluência são demasiadamente baixos, indicando também que para os níveis de tensão e confinamento aos quais os materiais estão submetidos, a fluência é praticamente inexistente. No que se refere ao comportamento em relação ao tipo de geossintético, os geotêxteis tecidos se mostram mais susceptíveis à fluência que os demais tipos de reforço, comportamento semelhante ao observado pelo método da equação logarítmica. Conforme destacado anteriormente, este fato está relacionado ao tipo de polímero que compõe o material, já que materiais compostos por polipropileno são mais susceptíveis à fluência que materiais compostos por poliéster. 


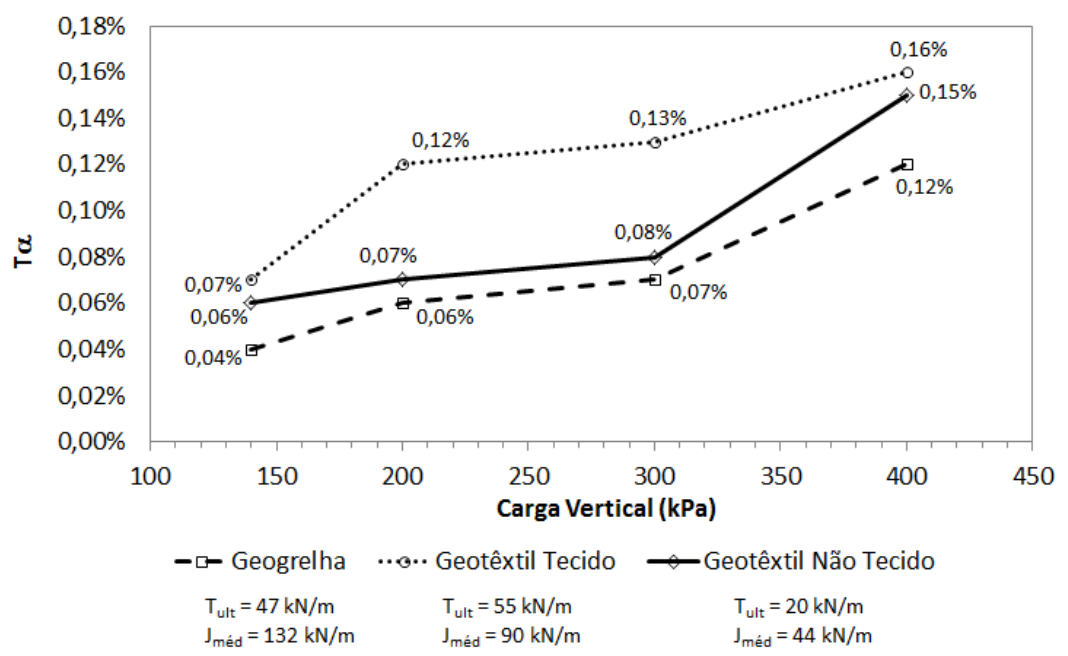

Figura 4.20 - Variação do parâmetro $T_{\alpha}$ em função do nível de tensão vertical aplicada para os ensaios confinados executados no equipamento de interação solo-reforço.

Outro aspecto importante a ser avaliado se refere aos carregamentos que atuam nos reforços durantes os ensaios confinados no equipamento desenvolvido por Costa (2004). Conforme destacado anteriormente, nestes ensaios as cargas que atuam nos reforços não são impostas, elas são resultado da interação solo-reforço e variam em função do carregamento vertical aplicado. Portanto, no início de cada ensaio, não se sabe ao certo qual o carregamento que irá atuar nos elementos confinados. Para facilitar a análise dos resultados, a Tabela 4.2 mostra, para cada um dos ensaios confinados, a porcentagem de carga no reforço em relação à sua resistência máxima à tração $\left(\mathrm{T} / \mathrm{T}_{\mathrm{ult}}\right)$, bem com o valor medido das cargas nos reforços após a sua estabilização.

Tabela 4.2 - Valores de cargas estabilizadas para os ensaios de fluência confinada.

\begin{tabular}{ccccccc}
\hline \multirow{2}{*}{$\begin{array}{c}\text { Carregamento } \\
\text { vertical }\end{array}$} & \multicolumn{3}{c}{ Carga no reforço após estabilização } \\
$(\mathrm{kN} / \mathrm{m})$ & $\mathrm{G}$ & \multicolumn{3}{c}{$\mathrm{T} / \mathrm{T}_{\text {ult }}$} \\
\cline { 2 - 7 }$(\mathrm{kPa})$ & $\mathrm{GNT}$ & $\mathrm{GT}$ & $\mathrm{GG}$ & $\mathrm{GNT}$ & $\mathrm{GT}$ & $\mathrm{GG}$ \\
& $\mathrm{T}_{\text {ult }}$ & $\mathrm{T}_{\text {ult }}$ & $\mathrm{T}_{\text {ult }}$ & $\mathrm{T}_{\text {ult }}$ & $\mathrm{T}_{\text {ult }}$ & $\mathrm{T}_{\text {ult }}$ \\
& $20 \mathrm{kN} / \mathrm{m}$ & $55 \mathrm{kN} / \mathrm{m}$ & $47 \mathrm{kN} / \mathrm{m}$ & $20 \mathrm{kN} / \mathrm{m}$ & $55 \mathrm{kN} / \mathrm{m}$ & $47 \mathrm{kN} / \mathrm{m}$ \\
\hline 140 & 0,41 & 0,71 & 0,52 & 2,1 & 1,3 & 1,1 \\
200 & 1,05 & 1,08 & 0,99 & 5,3 & 2,0 & 2,1 \\
300 & 1,87 & 1,88 & 1,58 & 9,4 & 3,4 & 3,4 \\
400 & 3,21 & 3,29 & 3,36 & 16,1 & 6,0 & 7,1 \\
\hline
\end{tabular}


Os dados apresentados na Tabela 4.2 mostram que os carregamentos que atuam nos reforços são muito semelhantes para os ensaios com mesma tensão vertical. Entretanto a relação $T / T_{\text {ult se }}$ mostrou maior para os reforços em geotêxteis não tecidos, e muito semelhantes entre os reforços em geotêxteis tecidos e geogrelhas. Este fato ocorre em função das resistências últimas dos geotêxteis tecidos e geogrelhas serem muito próximas e a resistência última do geotêxtil não tecido ser bem menor.

A Figura 4.21 mostra a variação do carregamento vertical que chega ao reforço, representado pela relação $\mathrm{T} / \mathrm{T}_{\text {ult, }}$ em função do carregamento vertical aplicado.

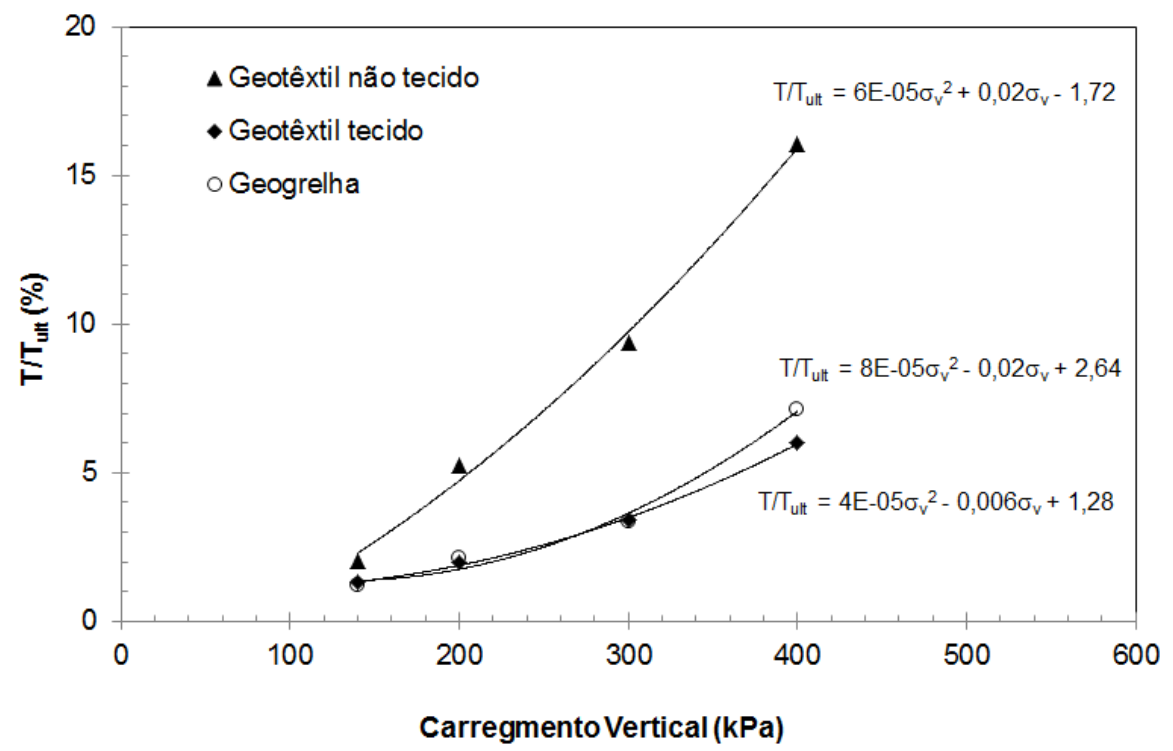

Figura 4.21 - Variação da relação $\mathrm{T} / \mathrm{T}_{\text {ult }}$ em função do carregamento vertical para diferentes tipos de reforço.

Pode-se notar que os níveis de carga que chegam aos reforços aumentam com o acréscimo de carregamento vertical. Conforme mostrado na Figura 4.21, a tendência de crescimento da carga que atinge o reforço em função do carregamento vertical é bem representada por uma curva com ajuste polinomial. Para o ensaio com tensão vertical de $140 \mathrm{kPa}$, que simula os prováveis carregamentos atuantes no muro de referência de Campinas, na seção instrumentada intermediária, denominada E02, as porcentagens de carga que chegam aos reforços em relação à suas resistências 
últimas, são de 2,1\%, 1,3\% e 1,1\%, para os casos com geotêxtil não tecido, tecido e geogrelha, respectivamente.

Para os demais carregamentos verticais, em todos os materiais avaliados, observase que a porcentagem de carga que chega ao reforço também é relativamente baixa. Para o caso de maior tensão vertical (400 kPa, que representa um muro teórico com aproximadamente $20 \mathrm{~m}$ de altura), a relação $\mathrm{T} / \mathrm{T}_{\text {ult }}$ é de $16,1 \%$ para o caso com geotêxtil não tecido, de $6,0 \%$ para o tecido e $7,1 \%$ para a geogrelha.

\subsubsection{Resultados $\mathrm{e}$ análises dos ensaios confinados realizados com diferentes umidades de compactação}

Neste item são apresentados os resultados dos ensaios de fluência confinada para os geotêxteis tecidos e não tecidos inseridos no solo local do caso de obra relatado, para três diferentes umidades de compactação. Conforme descrito anteriormente, foram selecionadas três diferentes umidades ao longo da curva de compactação (Figura 4.22): umidade de $8 \%$ (situada no ramo seco da curva), 11,7\% (umidade ótima) e $16 \%$ (situada no ramo úmido). É importante destacar que todos os ensaios foram realizados sob o mesmo carregamento vertical, de $140 \mathrm{kPa}$, que representa o provável carregamento atuante na linha de instrumentação E02 da obra de referência de Campinas.

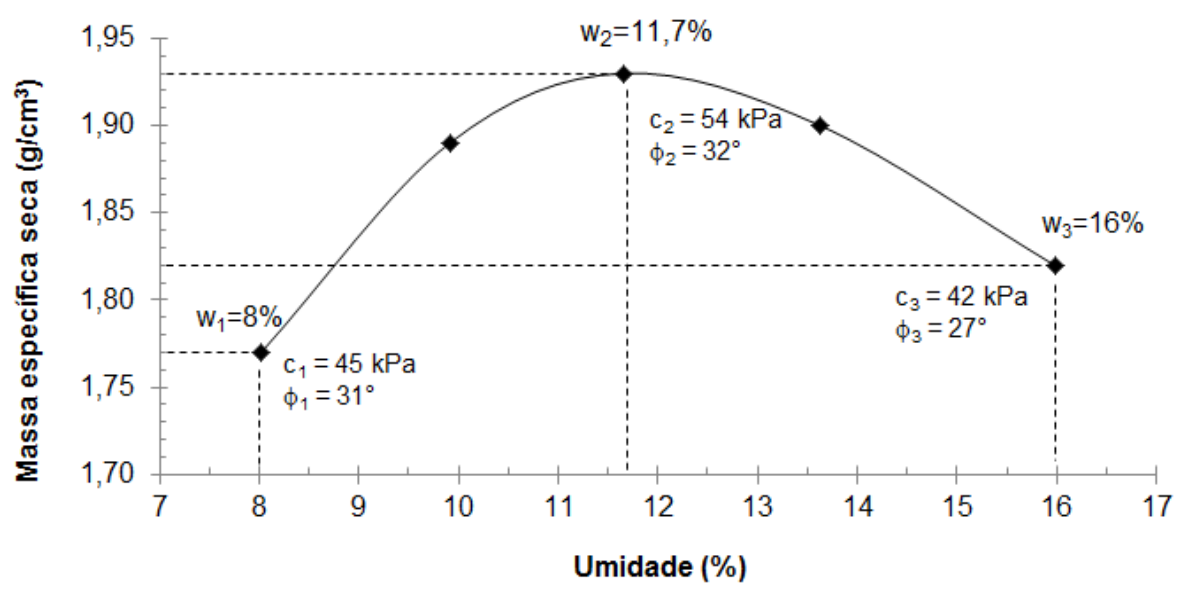

Figura 4.22 - Umidades de compactação utilizadas nos ensaios. 
Os resultados para os geotêxteis não tecidos são apresentados na Figura 4.23 e para os geotêxteis tecidos na Figura 4.24.

Os resultados são apresentados em termos de variação da carga no reforço ao longo do tempo (Figura 4.23a e Figura 4.24a), variação das deformações em função do tempo plotada em escala semi-logarítmica (Figura 4.23b e Figura 4.24b), variação das deformações ao longo do tempo de acordo com o modelo de representação proposto por Zornberg; Byler e Knudsen (2004) (Figura 4.23c e Figura 4.24c), variação do módulo de rigidez confinada ao longo do tempo (Figura 4.23d e Figura 4.24d), e variação das cargas nos reforços em função das deformações (Figura 4.23e e Figura 4.24e).

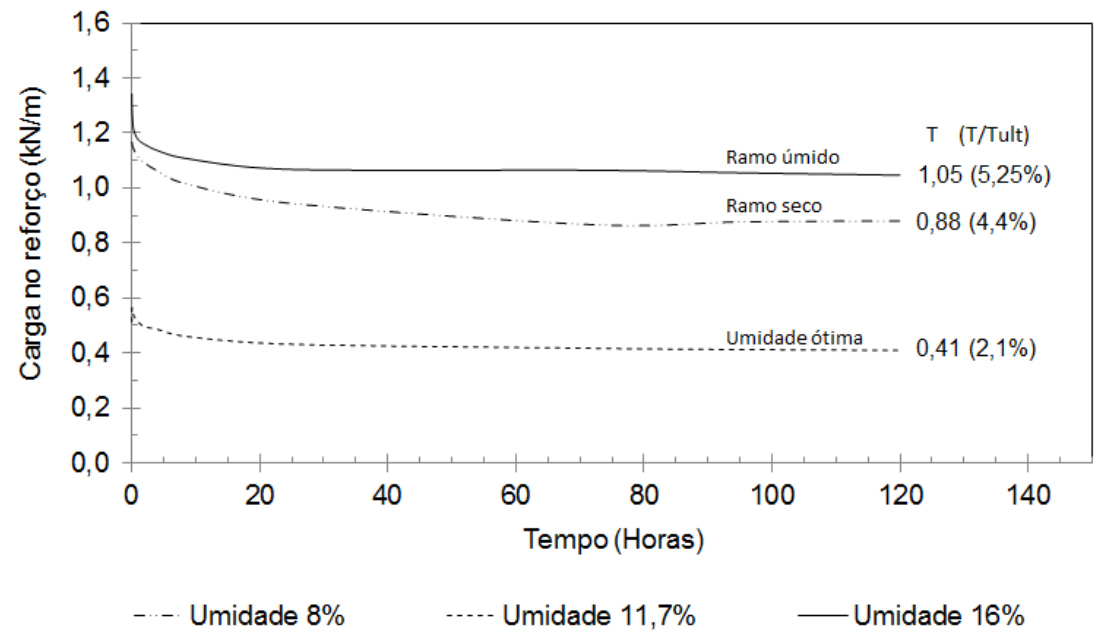

(a)

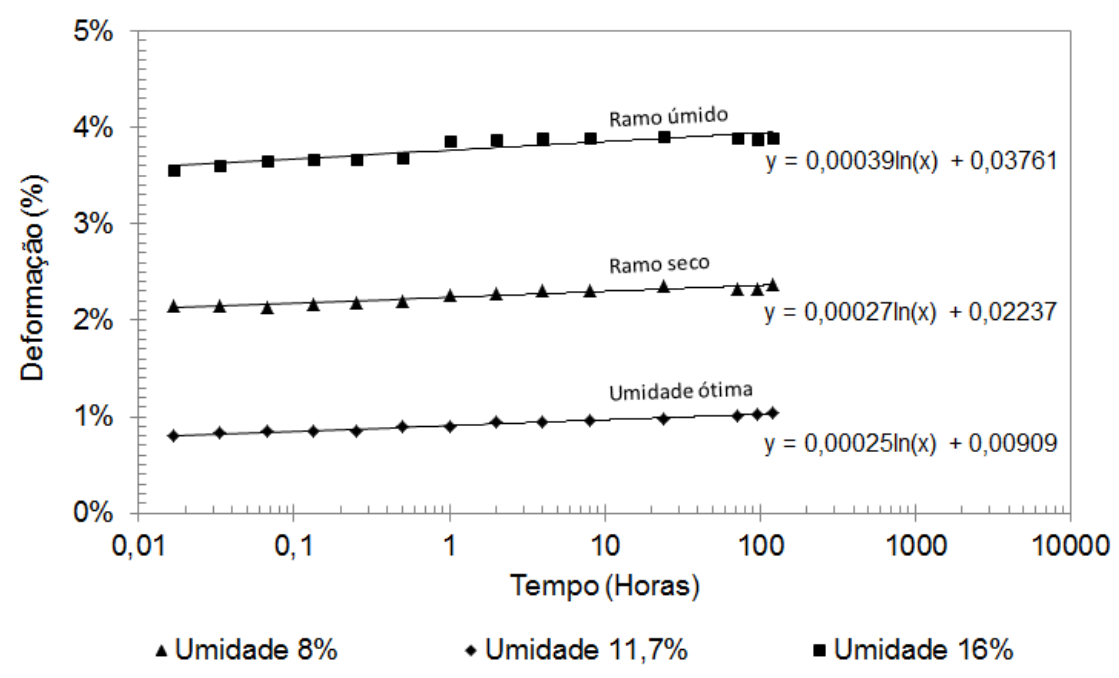

(b) 


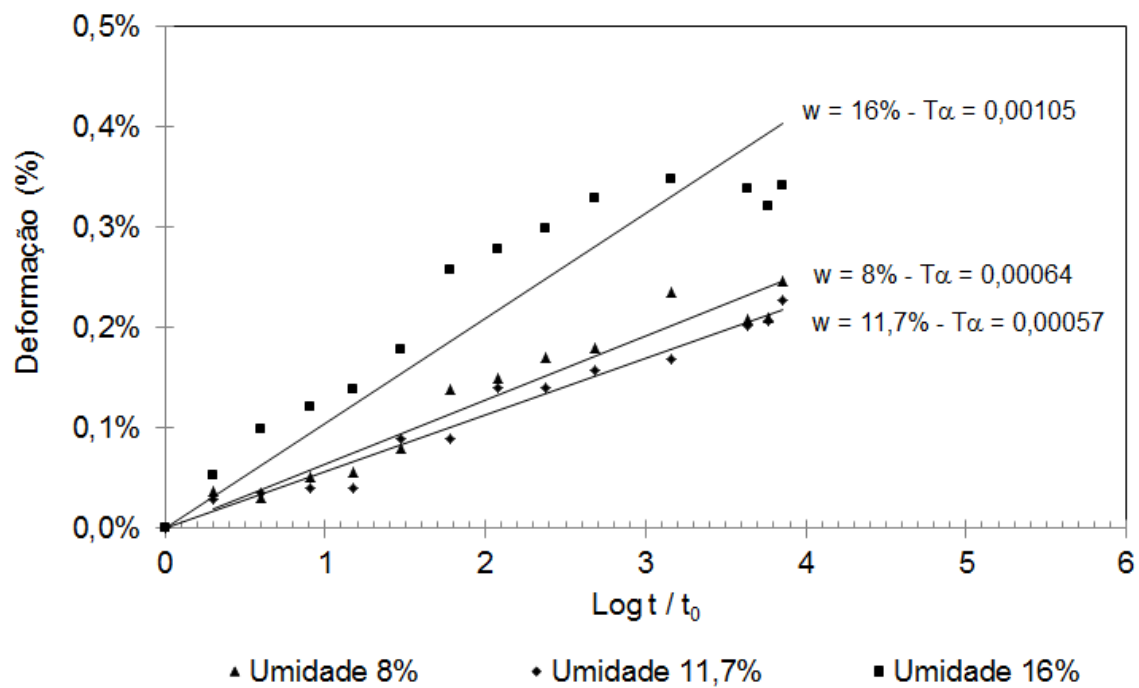

(c)

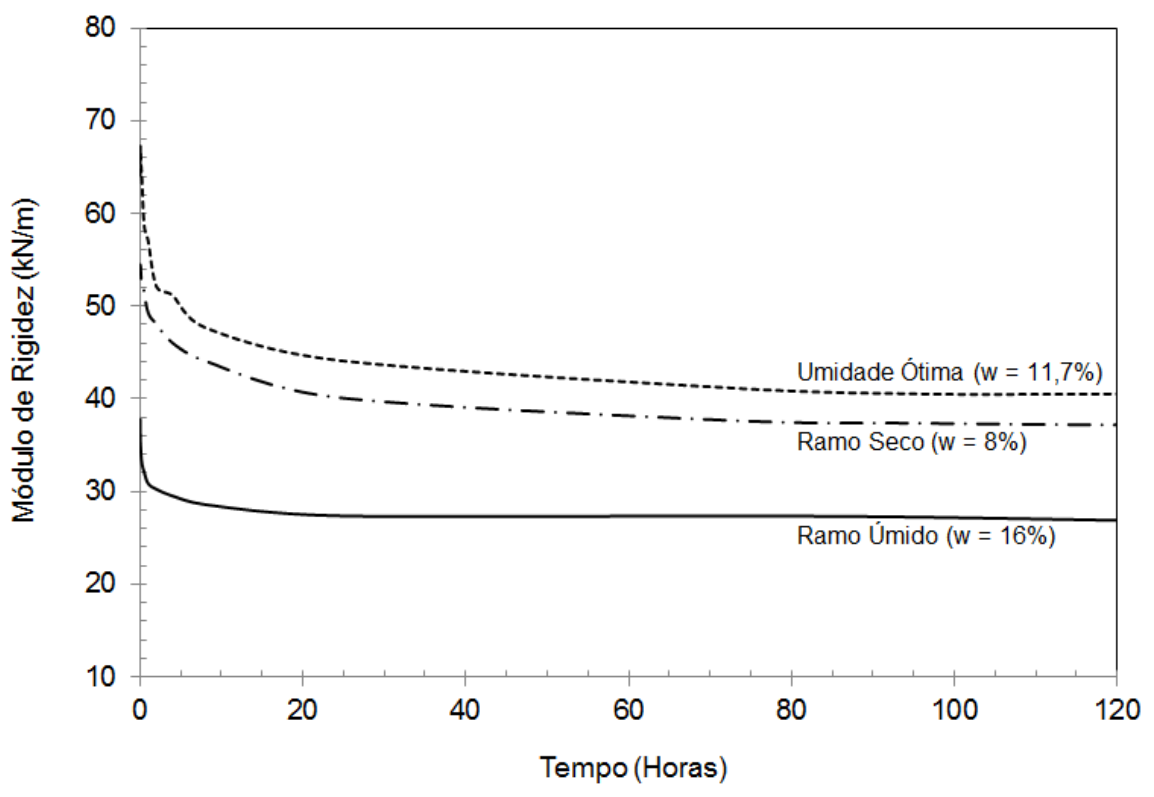

(d) 


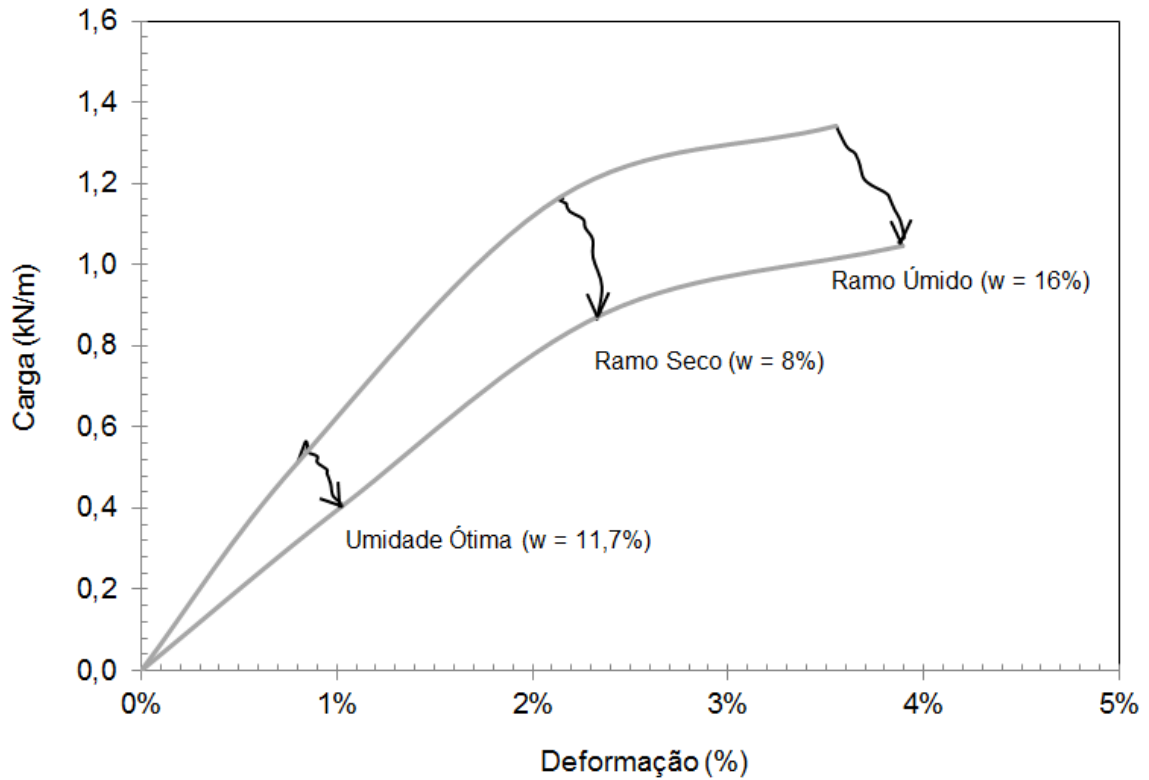

(e)

Figura 4.23 - Resultados dos ensaios de fluência confinada para geotêxteis não tecidos para diferentes umidades de compactação do solo: (a) Variação da carga no reforço ao longo do tempo; (b) Variação das deformações ao longo do tempo pelo método da equação logarítmica; (c) Variação das deformações por fluência ao longo do tempo pelo método de Zornberg; Byler e Knudsen (2004);

(d) Variação do módulo de rigidez ao longo do tempo; (e) Trajetórias dos carregamentos e deformações para as diferentes umidades de compactação.

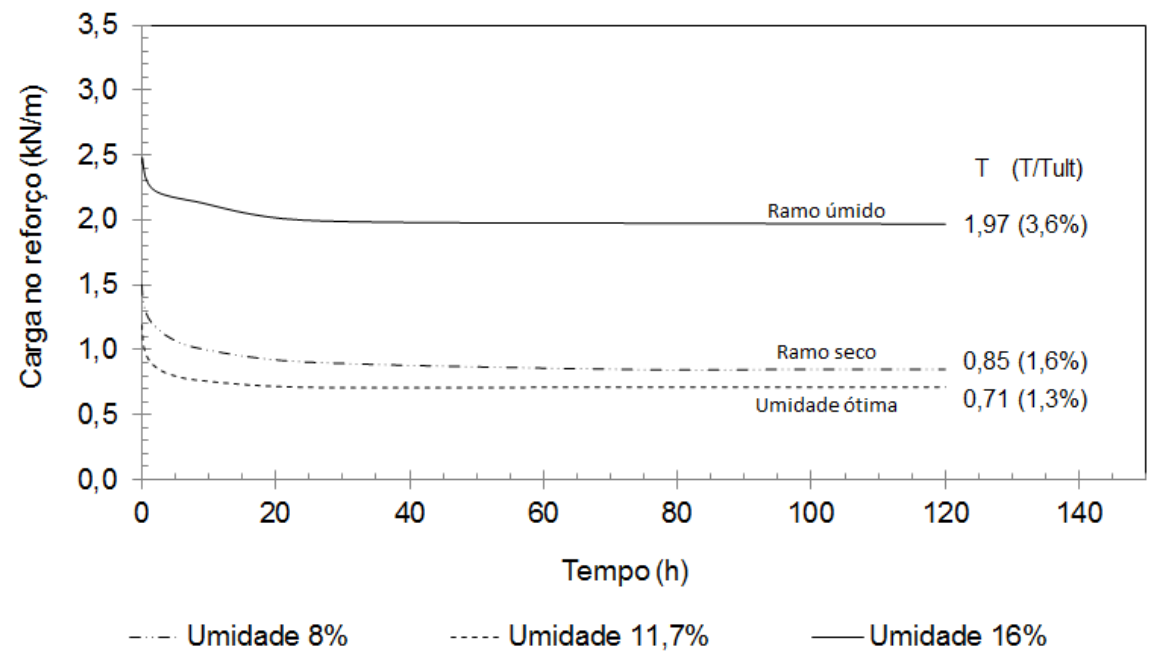

(a) 


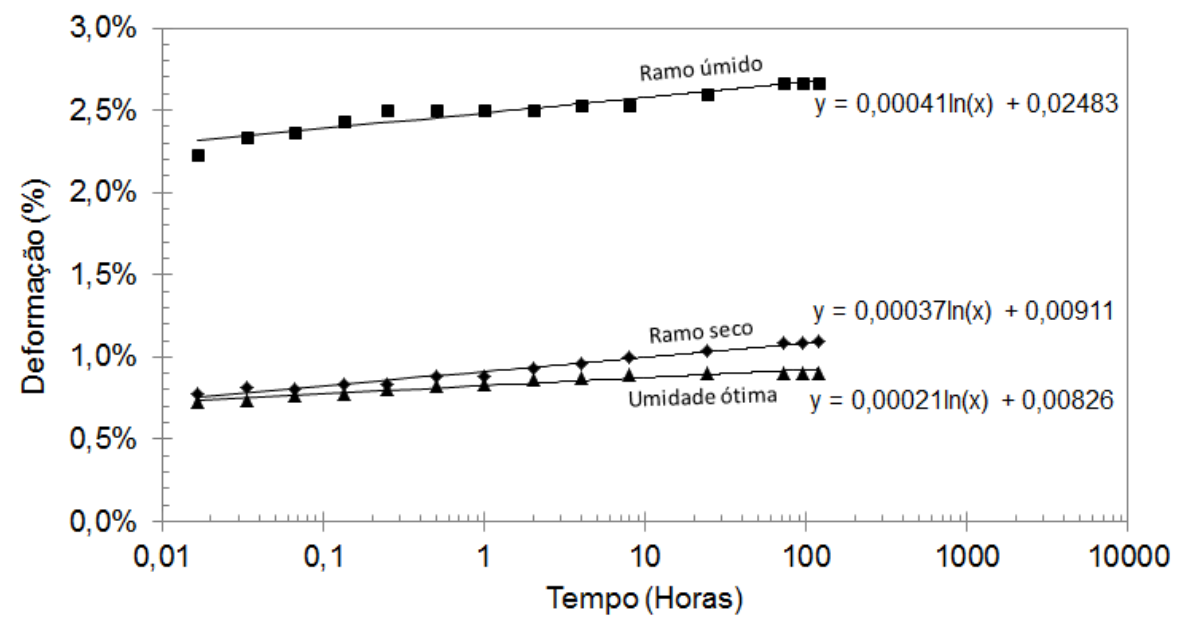

- Umidade $8 \%$ ॥ Umidade $11,7 \%$ - Umidade $16 \%$

(b)

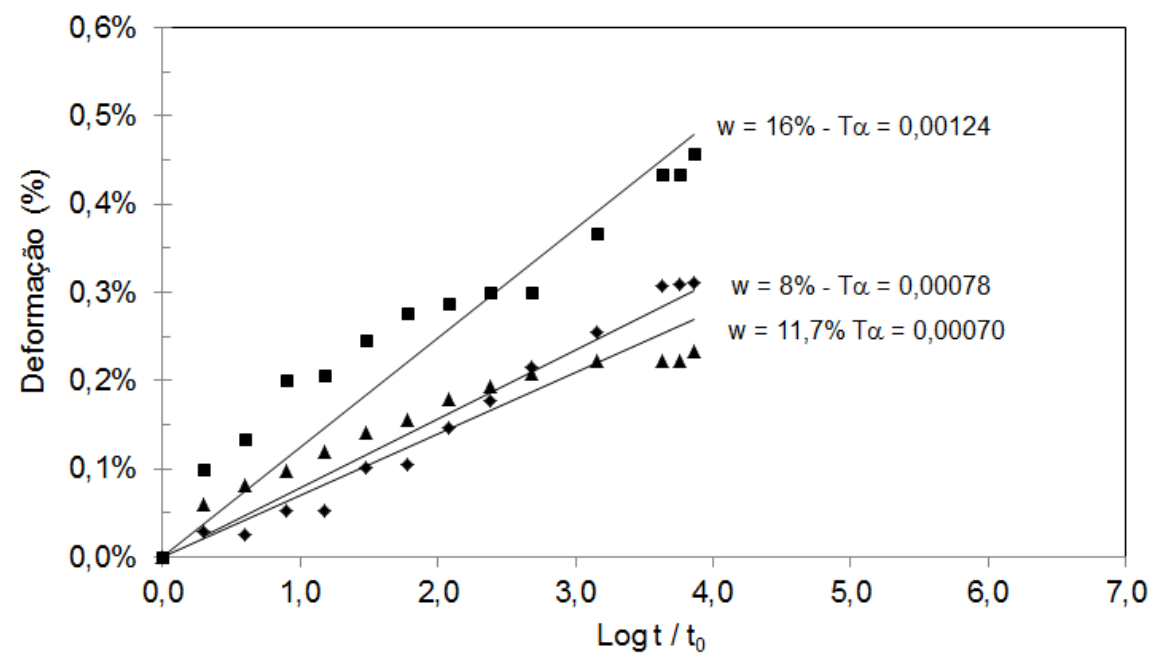

- $140 \mathrm{kPa}(\mathrm{w}=8 \%) \quad$ ॥ $140 \mathrm{kPa}(\mathrm{w}=11,7 \%) \quad$ - $140 \mathrm{kPa}(\mathrm{w}=16 \%)$

(c) 


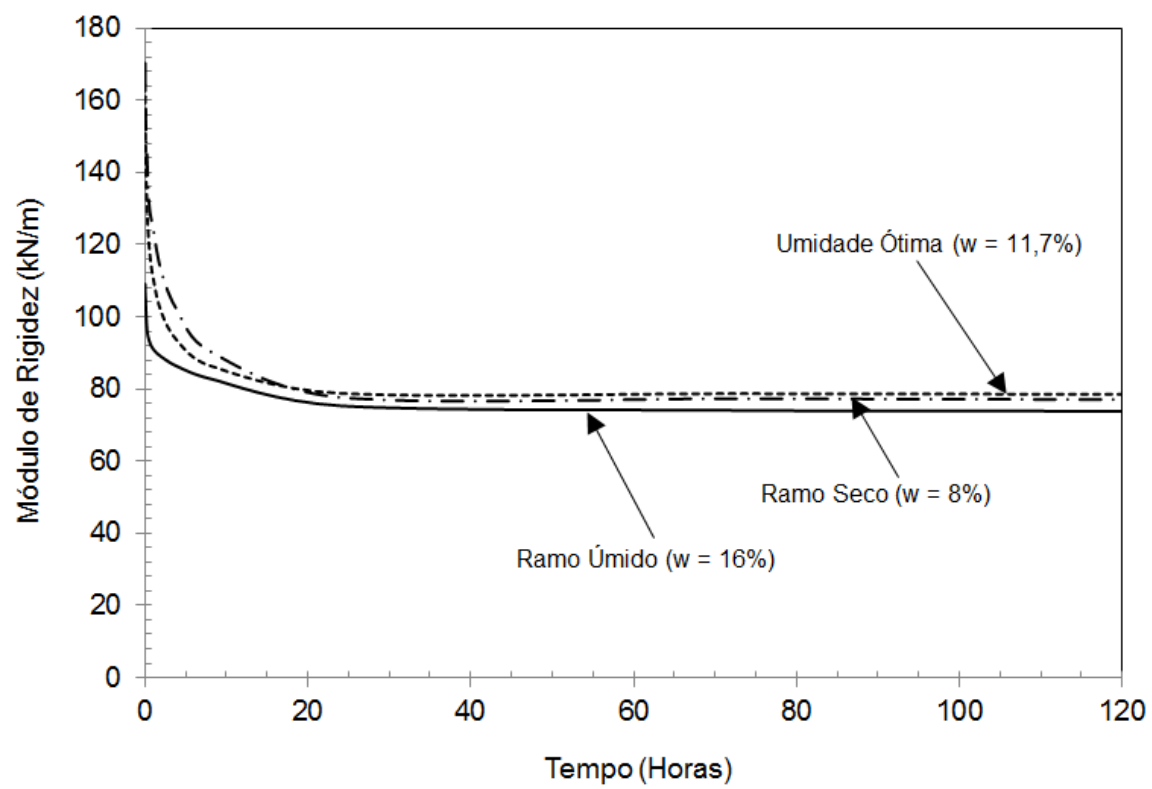

(d)

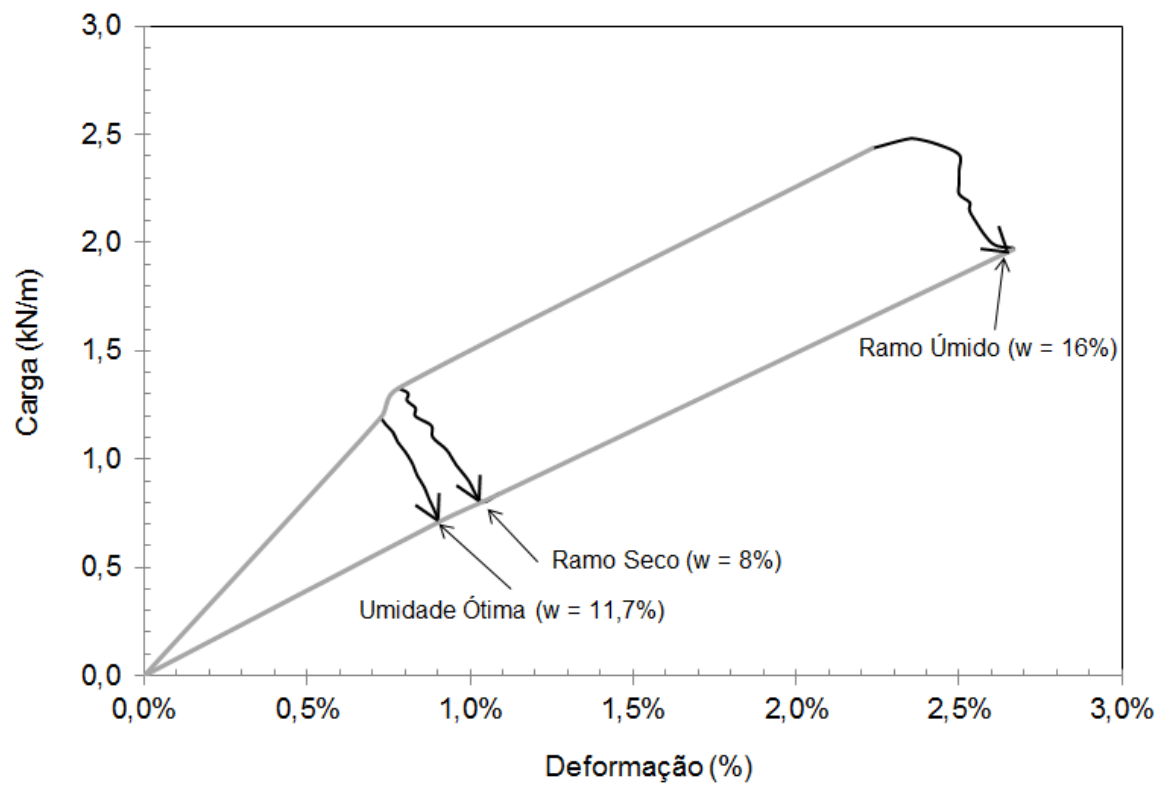

(e)

Figura 4.24 - Resultados dos ensaios de fluência confinada para geotêxteis tecidos para diferentes umidades de compactação do solo: (a) Variação da carga no reforço ao longo do tempo; (b) Variação das deformações ao longo do tempo pelo método da equação logarítmica; (c) Variação das deformações por fluência ao longo do tempo pelo método de Zornberg; Byler e Knudsen (2004); (d) Variação do módulo de rigidez ao longo do tempo; (e) Trajetórias dos carregamentos e deformações para as diferentes umidades de compactação. 
Conforme se pode observar na Figura 4.23a e na Figura 4.24a, os níveis de carregamento são mais elevados no início dos ensaios e tendem a uma estabilização ao longo do tempo. Este comportamento foi observado tanto para os geotêxteis tecidos quanto para os geotêxteis não tecidos, sendo que para as situações com maior e menor umidade, a estabilização é ligeiramente mais lenta.

Observa-se ainda que os carregamentos nos reforços foram maiores para os solos compactados na umidade mais elevada e menores para os solos compactados na umidade ótima.

$\mathrm{Na}$ Figura 4.23b e na Figura 4.24b observa-se que os níveis de deformações iniciais, representados pelo parâmetro "a" do método logarítmico, foram mais elevados para os ensaios realizados com solos compactados com maior umidade. O melhor comportamento foi observado para os solos compactados na umidade ótima, enquanto que os ensaios realizados com solo compactado no ramo seco apresentaram deformações em níveis intermediários.

O mesmo comportamento foi observado para a fluência, representado pelo parâmetro "b" do método logarítmico. Assim, o parâmetro "b" com maior magnitude foi observado para o ensaio com solo compactado no ramo úmido, enquanto o ensaio com solo compactado na umidade ótima apresentou o parâmetro "b" com menor magnitude, e o ensaio com solo compactado no ramo seco permaneceu em níveis intermediários.

A Figura 4.23c e Figura 4.24c mostram as deformações ao longo do tempo segundo o método proposto por Zornberg; Byler e Knudsen (2004). Observa-se que o parâmetro $T \alpha$, que representa o índice de fluência dos materiais, é maior para os ensaios realizados com solo compactado no ramo úmido. Observa-se ainda que o índice de fluência foi menor para o solo compactado na umidade ótima, enquanto que o solo compactado no ramo seco apresentou índices intermediários. Estes resultados corroboram os resultados observados segundo as análises realizadas pelo método logarítmico.

$\mathrm{Na}$ Figura 4.23d e Figura 4.24d são apresentadas as variações dos módulos de rigidez ao longo do tempo para as diferentes condições de umidade de compactação dos solos, para o caso dos geotêxteis não tecidos e tecidos, respectivamente.

Para o caso dos geotêxteis não tecidos (Figura 4.23d), observa-se que a rigidez confinada dos reforços variou de forma significativa para as diferentes umidades de compactação. Nota-se que a maior rigidez foi observada para o caso com o solo 
compactado no teor de umidade ótimo, o qual apresentou uma rigidez final $\left(\mathrm{J}_{\text {final }}\right)$, após 120 horas de ensaio, de $41 \mathrm{kN} / \mathrm{m}$. Para o ensaio em que o solo foi compactado no teor de umidade situado no ramo seco, o $\mathrm{J}_{\text {final }}$ foi de $37 \mathrm{kN} / \mathrm{m}$. O menor valor de $J_{\text {final }}$ foi observado para o ensaio cujo solo foi compactado no ramo úmido. Para este caso a rigidez final registrada no ensaio foi de $27 \mathrm{kN} / \mathrm{m}$. Estes resultados vão de encontro ao que foi observado nas variações de cargas e deformações nos reforços ao longo do tempo.

Para o caso dos geotêxteis tecidos (Figura 4.24d), observa-se que a variação da rigidez confinada dos reforços foi pouco afetada pela umidade de compactação do solo. Assim como ocorrido para o caso dos geotêxteis não tecidos, a maior rigidez final $\left(\mathrm{J}_{\text {final }}\right)$ após 120 horas de ensaio foi observada para o ensaio cujo solo foi compactado na umidade ótima. O menor valor de $J_{\text {final }}$ foi observado para o caso com solo compactado no ramo úmido, enquanto que o ensaio realizado com solo compactado com teor de umidade situado no ramo seco apresentou resultados intermediários. Apesar de o comportamento ter sido semelhante ao que foi observado nos ensaios realizados com geotêxteis não tecidos, observa-se que a variação da rigidez entre o melhor e pior caso foi inferior a $5 \%$.

$\mathrm{Na}$ Figura 4.23e e Figura 4.24e foram mostradas as trajetórias das cargas nos reforços em função das deformações, para os geotêxteis não tecidos e tecidos, respectivamente. Observa-se que para ambos os casos, as menores cargas e deformações ocorreram para os ensaios em que o solo foi compactado na umidade ótima. Por outro lado, os maiores carregamentos nos reforços e, consequentemente, maiores deformações, foram observadas para os casos em que o solo foi compactado na maior umidade. Os resultados mostram ainda que, para todos os casos, a trajetória dos carregamentos apresenta uma leve curvatura com a concavidade voltada para o canto inferior esquerdo do gráfico, indicando que as deformações apresentam uma tendência de se estabilizar em uma taxa maior que os carregamentos. Isto é um indicativo de que a relaxação ocorreu de forma mais intensa que a fluência nos ensaios realizados.

Para melhor visualização dos resultados obtidos nos ensaios de fluência confinada com variação de umidade de compactação, a Figura 4.25, a Figura 4.26, a Figura 4.27 e a Figura 4.28 foram elaboradas.

A Figura 4.25 mostra a variação da deformação máxima obtida nos ensaios em função da umidade de compactação. Assim como já havia sido constatado 
anteriormente, a figura mostra que, para ambos os materiais, as deformações foram menores para os casos em que o solo foi compactado na umidade ótima e maiores para os casos em que o solo foi compactado no ramo úmido. Para os casos em que o solo foi compactado no ramo seco, as deformações permaneceram em patamares intermediários.

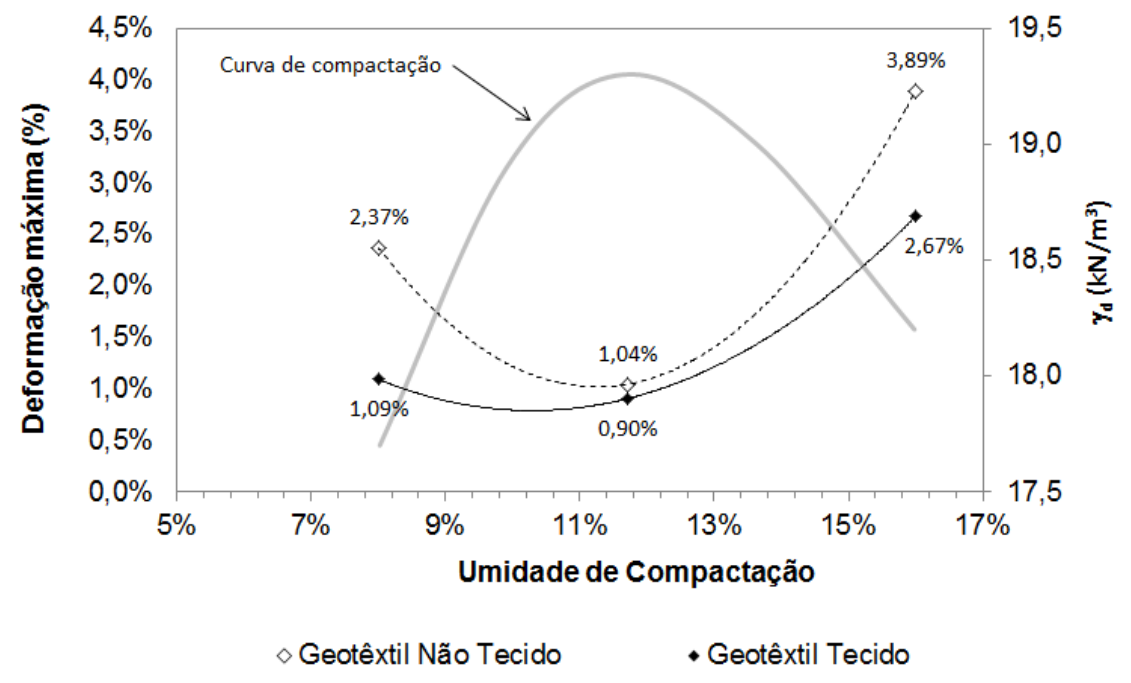

Figura 4.25 - Variação da deformação máxima em função da umidade de compactação para os ensaios confinados executados no equipamento desenvolvido por Costa (2004).

As mesmas observações realizadas para as deformações máximas são também válidas para as deformações iniciais, representadas pelo parâmetro "a" do método da equação logarítmica. A variação do parâmetro "a" em função da umidade de compactação é apresentada na Figura 4.26. 


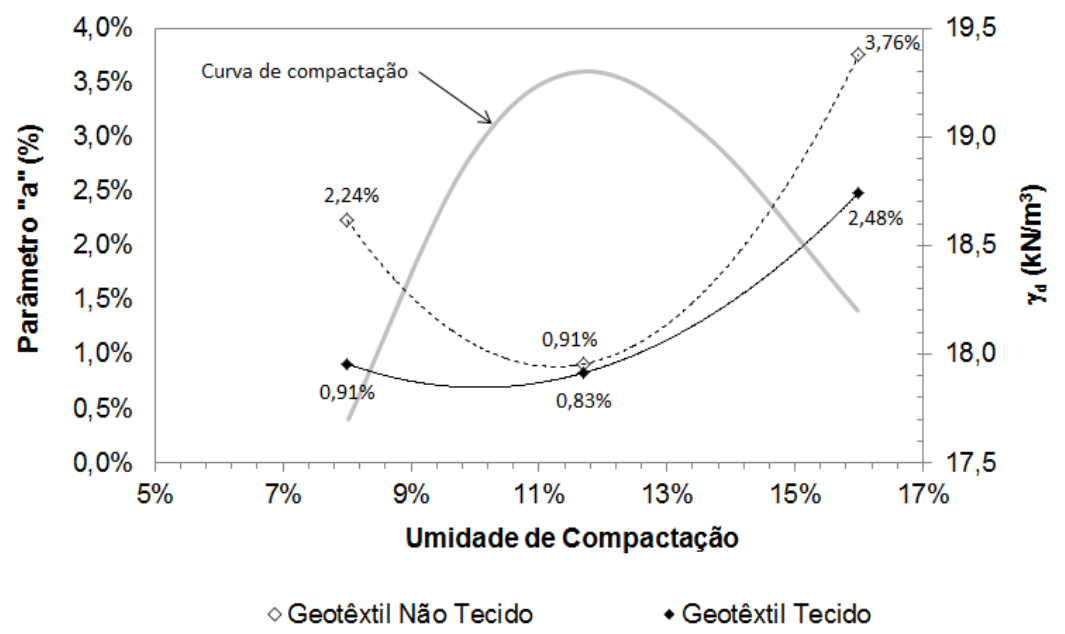

Figura 4.26 - Variação do parâmetro "a" em função da umidade de compactação para os ensaios confinados executados no equipamento desenvolvido por Costa (2004).

Observa-se ainda que, pela análise do método logarítmico, para ambos os geotêxteis avaliados, os índices de fluência, representados pelo parâmetro "b", foram menores para os casos em que o solo foi compactado na umidade ótima. Por outro lado, os solos compactados no ramo úmido conduziram a índices de fluência mais elevados. A variação do parâmetro "b" em função da umidade de compactação é apresentada na Figura 4.27.

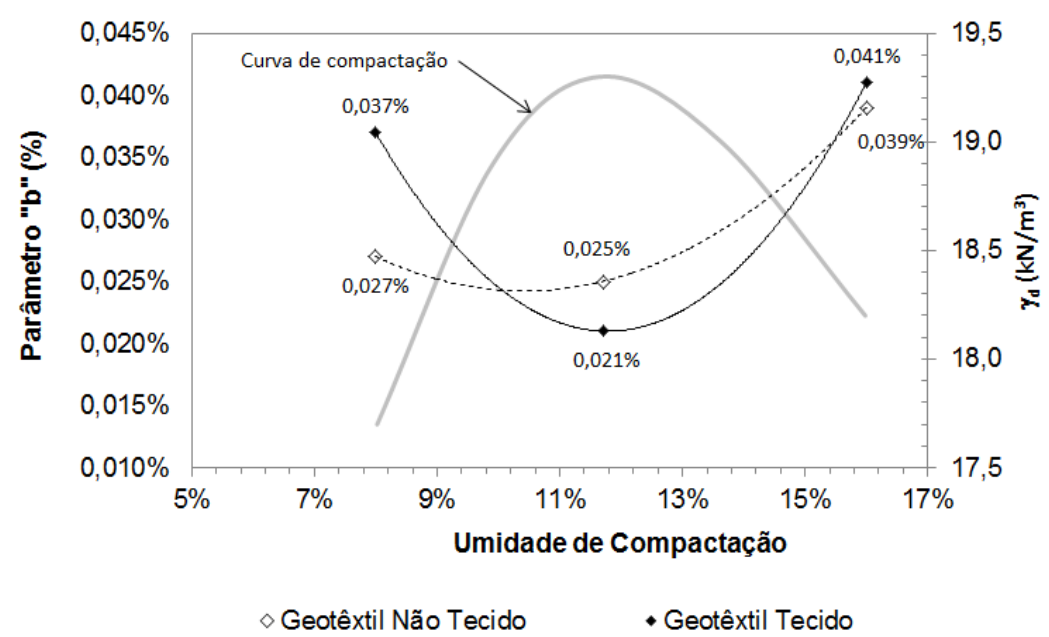

Figura 4.27 - Variação do parâmetro "b" em função da umidade de compactação para os ensaios confinados executados no equipamento desenvolvido por Costa (2004). 
Ainda com relação aos índices de fluência, observa-se que os valores registrados nos ensaios, para todas as condições de umidades, são muito baixos, podendo ser considerados semelhantes para ambos os materiais e para todas as umidades de compactação. Isso mostra que a fluência praticamente não ocorre para a condição confinada, mesmo com a variação da umidade de compactação do solo.

Com relação à variação do índice de fluência, considerando-se o método proposto por Zornberg; Byler e Knudsen (2004), em função da umidade de compactação, observa-se que os menores índices foram observados para os casos em que o solo foi compactado na umidade ótima. Para os casos em que o solo foi compactado no ramo úmido, os índices de fluência foram os mais elevados. Já para o caso de compactação no ramo seco, os índices de fluência permaneceram em patamares intermediários. A variação do parâmetro T $\alpha$ em função da umidade de compactação é mostrada na Figura 4.28.

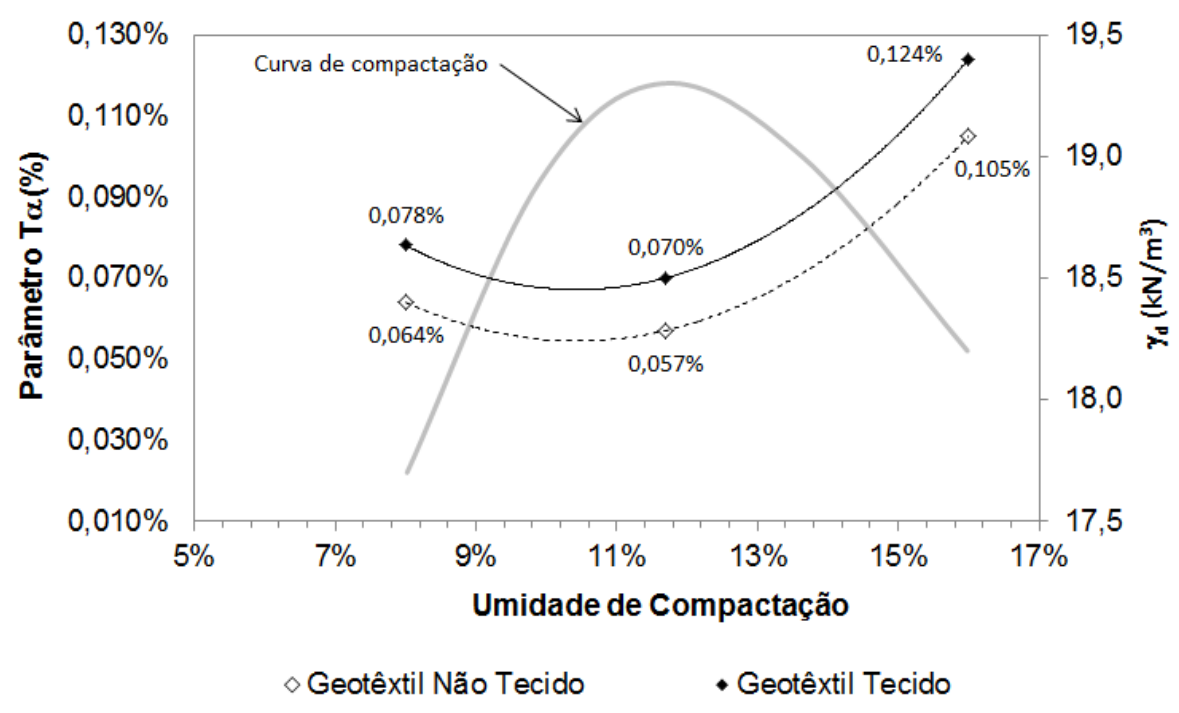

Figura 4.28 - Variação do parâmetro T $\alpha$ em função da umidade de compactação para os ensaios confinados executados no equipamento desenvolvido por Costa (2004).

A Figura 4.29 mostra a variação do módulo de rigidez confinada em função do teor de umidade de compactação do solo. Observa-se que o módulo de rigidez do conjunto solo-reforço apresentou maiores valores para os casos em que o solo foi compactado na umidade ótima. Assim como observado para os demais parâmetros avaliados, os piores resultados foram obtidos para as situações em que o solo foi compactado no ramo úmido. É importante destacar ainda que para o caso dos 
geotêxteis tecidos, a variação dos módulos de rigidez em função da umidade de compactação do solo foi muito pouco significativa.

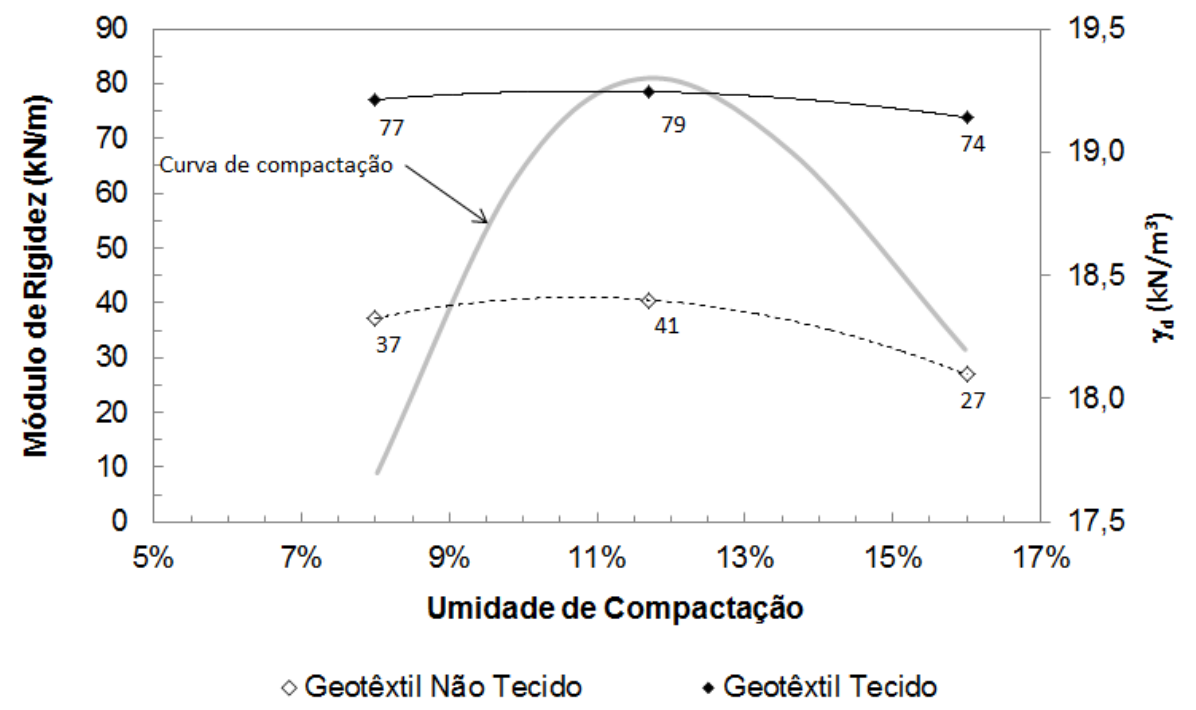

Figura 4.29 - Variação do módulo de rigidez confinado em função da umidade de compactação para os ensaios confinados executados no equipamento desenvolvido por Costa (2004).

Outro aspecto importante a ser avaliado, se refere ao nível de carregamento que atinge os reforços para as diferentes umidades de compactação testadas. A Tabela 4.3 mostra, para cada um dos ensaios confinados, a porcentagem de carga no reforço em relação à sua resistência máxima à tração $\left(\mathrm{T} / \mathrm{T}_{\text {ult }}\right)$, bem com o valor medido das cargas nos reforços após a sua estabilização.

Tabela 4.3 - Valores de cargas ao final dos ensaios de fluência confinada.

\begin{tabular}{ccccc}
\hline & \multicolumn{2}{c}{$\begin{array}{c}\text { Carga no reforço ao final do } \\
\text { ensaio } \\
\text { Umidade do solo } \\
(\%)\end{array}$} & \multicolumn{2}{c}{$\begin{array}{c}\text { T/T } / \mathrm{m}) \\
(\%)\end{array}$} \\
\cline { 2 - 5 } & $\begin{array}{c}\mathrm{GNT} \\
\mathrm{T}_{\text {ult }}=20 \mathrm{kN} / \mathrm{m}\end{array}$ & $\mathrm{T}_{\text {ult }}=55 \mathrm{kN} / \mathrm{m}$ & $\mathrm{T}_{\text {ult }}=20 \mathrm{kN} / \mathrm{m}$ & $\mathrm{T}_{\text {ult }}=55 \mathrm{kN} / \mathrm{m}$ \\
\hline $8,0 \%$ & 0,88 & 0,85 & 4,4 & 1,6 \\
$11,7 \%$ & 0,41 & 0,71 & 2,1 & 1,3 \\
$16,0 \%$ & 1,05 & 1,97 & 5,3 & 3,6 \\
\hline
\end{tabular}


A Figura 4.30 mostra a variação do carregamento vertical que chega ao reforço, representado pela relação $\mathrm{T} / \mathrm{T}_{\text {ult, }}$ em função da umidade de compactação do solo.

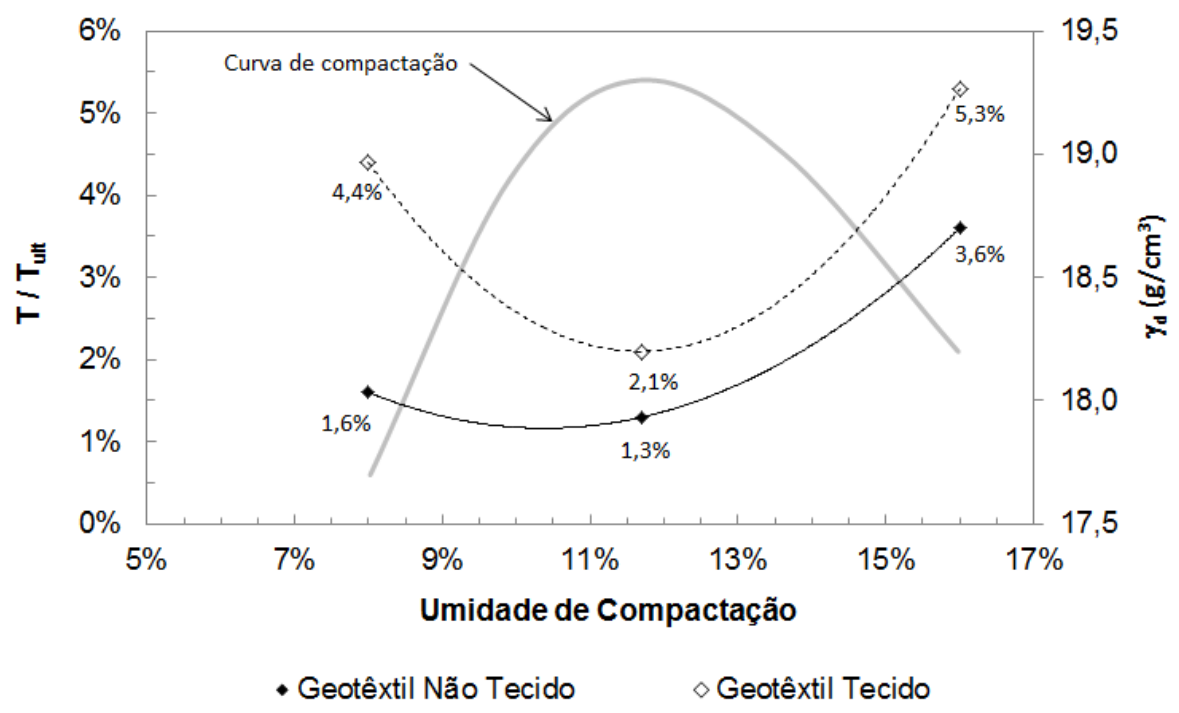

Figura 4.30 - Variação da relação $\mathrm{T} / \mathrm{T}_{\text {ult }}$ em função da umidade de compactação do solo.

Como se pode observar na Figura 4.30, existe uma tendência de decréscimo na solicitação do reforço ( $T / T_{\text {ult }}$ ) com o aumento da umidade de compactação do solo. Esta tendência ocorre até que a umidade ótima seja atingida. Após a umidade ótima o comportamento se inverte, sendo que a solicitação no reforço tende a aumentar com 0 acréscimo da umidade. Este comportamento ocorre para ambos os geotêxteis.

A partir dos resultados mostrados neste item, nota-se que as curvas de variação dos parâmetros de deformação dos reforços (parâmetros "a", "b" e $T_{\alpha}$ ), dos módulos de rigidez confinada e das cargas atuantes nos reforços ( $T / T_{\text {ult }}$ ) em função do teor de umidade sob o qual o solo foi compactado, apresentam uma relação direta com a curva de compactação do mesmo. A curva de compactação do solo utilizado nos ensaios foi apresentada no eixo secundário de todos os gráficos mostrados para facilitar a comparação dos dados. Isto indica que os esforços mobilizados e as deformações registradas nos reforços são proporcionais ao grau de compactação em que se encontra o maciço. Em outras palavras, quanto mais bem compactado o solo se encontrar, menores serão os esforços e as deformações nos reforços. Isto explica o fato dos ensaios compactados na umidade ótima apresentarem os 
menores esforços solicitantes, e, por consequência, os menores índices de deformação e fluência.

\subsubsection{Resultados e análises dos ensaios confinados com inundação}

Buscando entender o comportamento de muros em solo reforçado sob diferentes condições de trabalho, foram realizados, adicionalmente aos ensaios de fluência confinada com variação de carregamento vertical e variação da umidade de compactação, ensaios de fluência confinada com inundação do solo. Foram realizados três ensaios de fluência confinada, na caixa de ensaios desenvolvida por Costa (2004), aplicando-se uma inundação ao solo após aproximadamente 40 horas de ensaio.

Os ensaios foram realizados para os três tipos de reforços (geotêxteis não tecidos, geotêxteis tecidos e geogrelhas), com o solo inicialmente compactado na umidade ótima, e com carregamento vertical de $140 \mathrm{kPa}$.

O sistema para inundação do solo era constituído por um recipiente elevado, com capacidade aproximada de oito litros, dotado de um sistema de mangueiras em sua base, as quais se encontravam ligadas ao maciço de solo em quatro pontos distintos. Estima-se que o maciço, para cada um dos ensaios, levou cerca de 12 horas para ficar totalmente inundado.

Os resultados dos ensaios inundados são apresentados a seguir para o geotêxtil não tecido (Figura 4.31), geotêxtil tecido (Figura 4.32) e geogrelha (Figura 4.33).

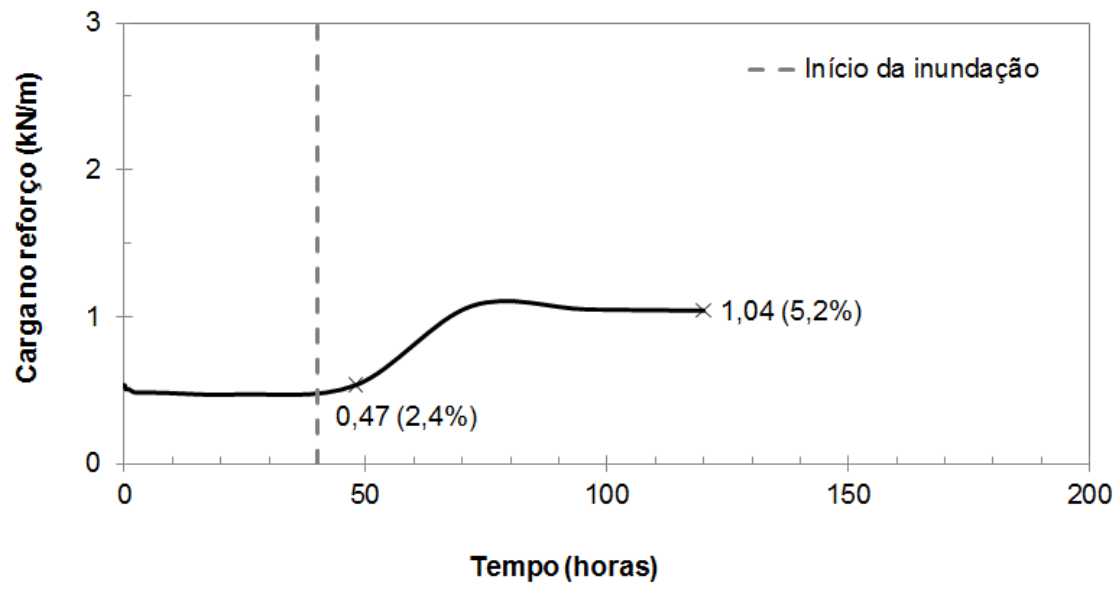

(a) 


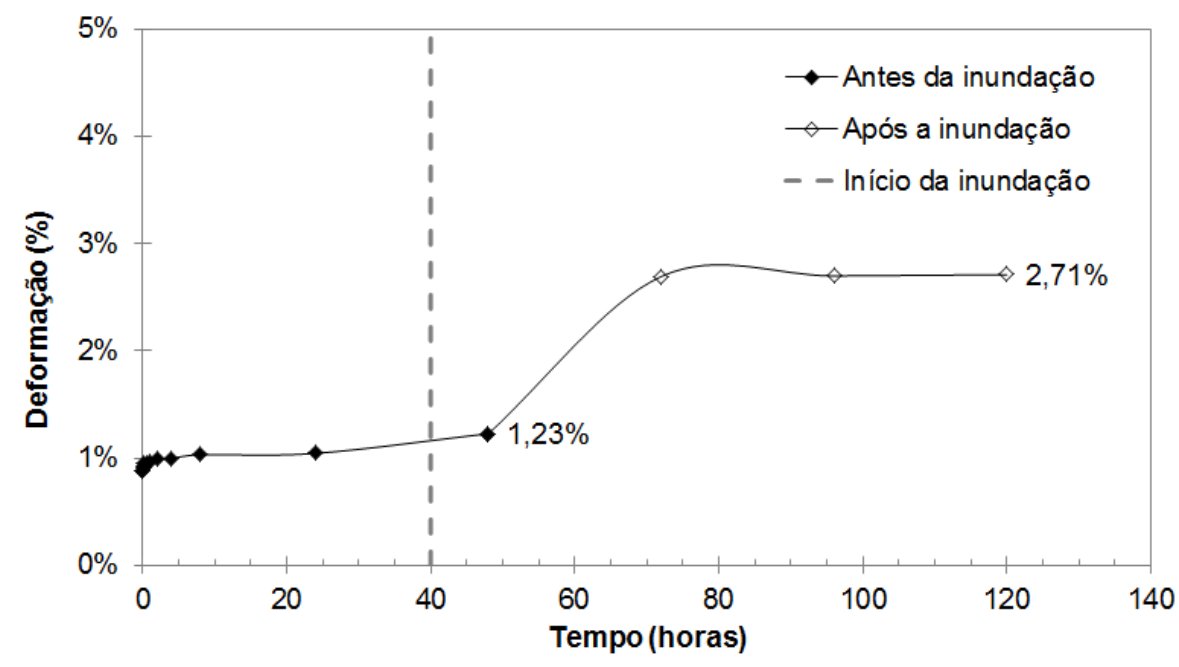

(b)

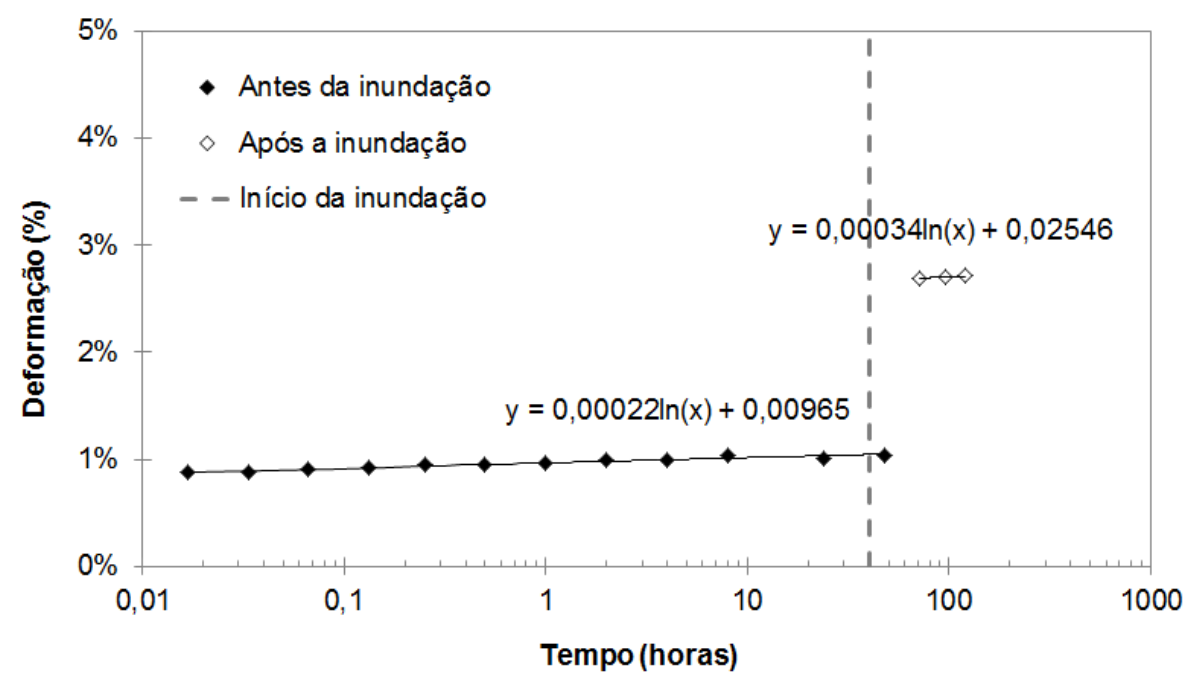

(c) 


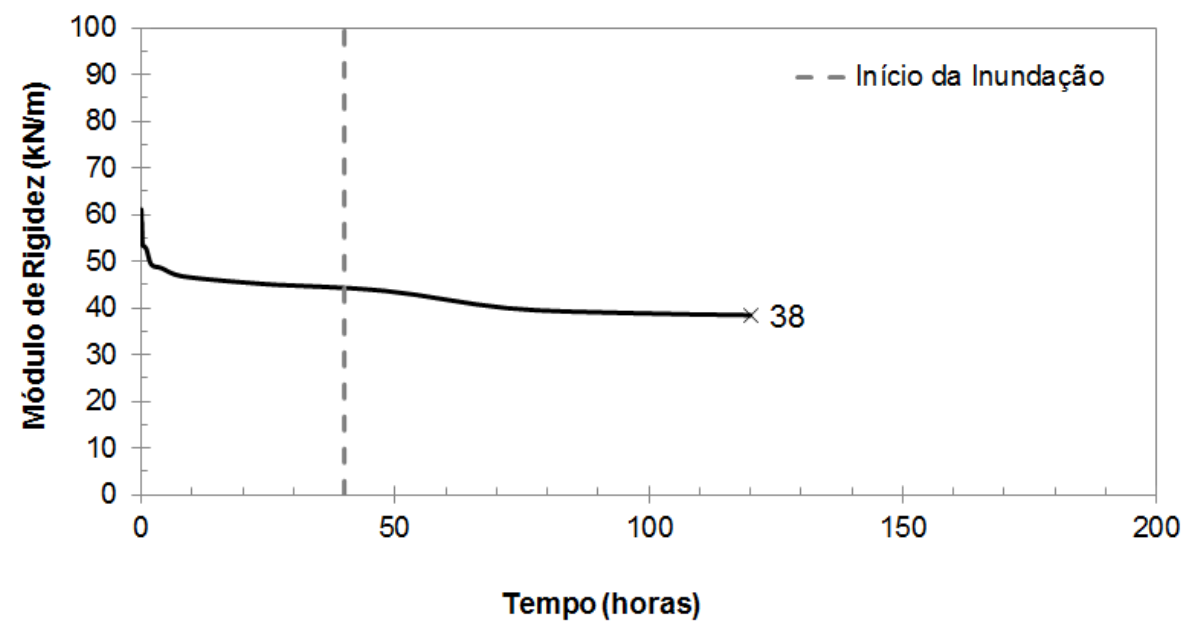

(d)

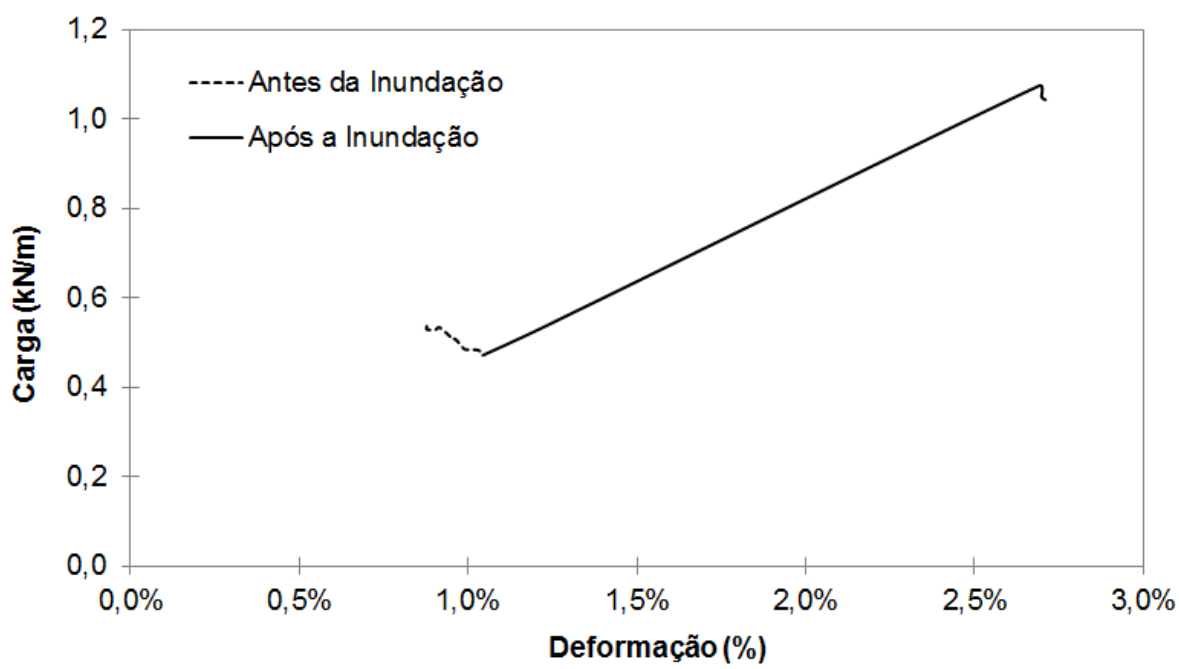

(e)

Figura 4.31 - Resultados dos ensaios de fluência confinada com inundação para geotêxteis não tecidos: (a) Variação da carga no reforço ao longo do tempo; (b) Variação das deformações ao longo do tempo em escala normal; (c) Variação das deformações ao longo do tempo em escala logarítmica;

(d) Variação do módulo de rigidez confinada ao longo do tempo; (e) Trajetória das cargas e deformações no reforço.

A Figura 4.31a mostra que após a inundação do solo no ensaio realizado com geotêxtil não tecido ocorreu um aumento no carregamento do reforço de aproximadamente $90 \%$. O carregamento aumentou de $0,47 \mathrm{kN} / \mathrm{m}(2,4 \%$ da carga última) para 1,04 kN/m (5,2\% da carga última).

Já na Figura 4.31b, que mostra a variação das deformações ao longo do tempo em escala normal, pode-se observar que as deformações mais que dobraram após a 
inundação, assim como observado para os carregamentos. Entretanto, após a ocorrência da inundação, as deformações se estabilizaram e permaneceram praticamente constantes.

$\mathrm{Na}$ Figura 4.31c, que mostra a variação das deformações ao longo do tempo em escala logarítmica, observa-se que o parâmetro "b", relacionado à tendência à fluência dos materiais aumentou em torno de 1,5 vezes. Mesmo com este aumento, o valor do parâmetro "b" ainda é menor que o valor obtido para os ensaios não confinados, podendo ser considerado muito baixo mesmo após a inundação.

Em relação à variação da rigidez confinada ao longo do tempo, a Figura 4.31d mostra que a inundação praticamente não afetou este parâmetro. Observa-se que após o início do processo de inundação o módulo de rigidez sofreu uma variação pouco significativa, indicando que a taxa de aumento das deformações e dos carregamentos nos reforços foi muito semelhante.

A Figura 4.31e mostra a variação da trajetória das cargas e deformações no reforço durante a execução do ensaio confinado inundado. Nota-se que após o início do processo de inundação, tanto as cargas quanto as deformações sofrem um aumento considerável em suas magnitudes até atingirem um valor máximo, momento no qual o solo se encontra totalmente inundado. A partir desse momento a trajetória das cargas no reforço volta a ter um comportamento semelhante ao observado antes da inundação.

Os resultados dos ensaios de fluência confinada com inundação que utilizaram geotêxtil tecido como reforço são apresentados na Figura 4.32. 


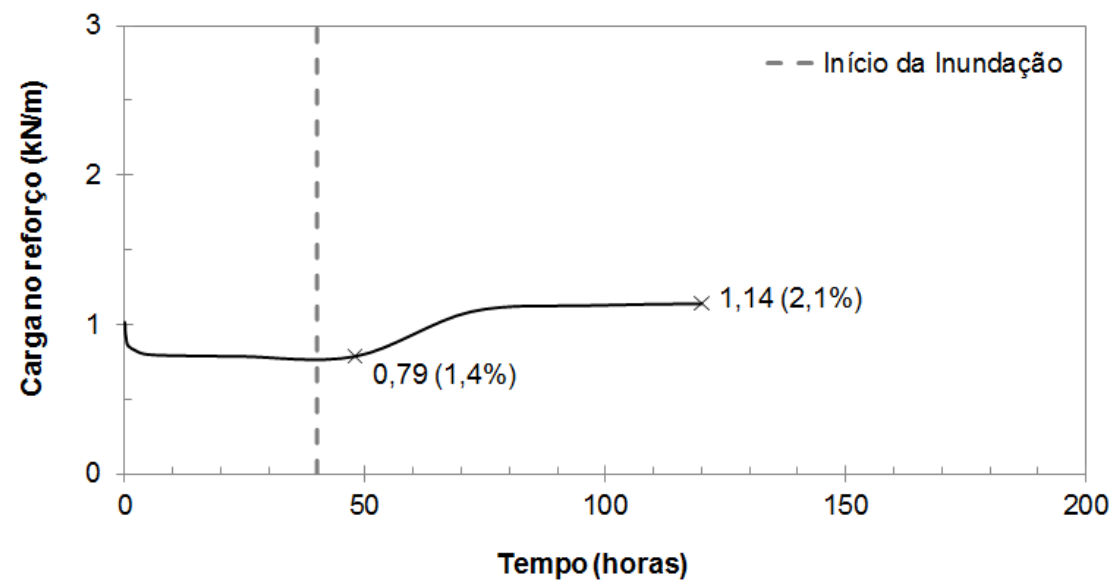

(a)

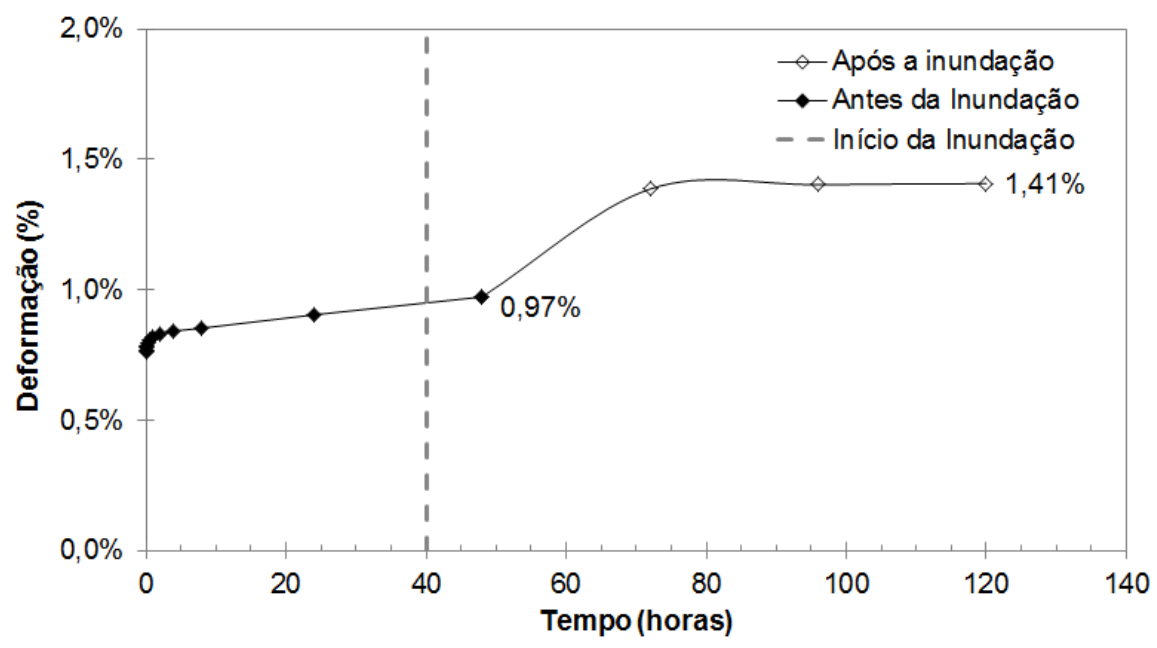

(b)

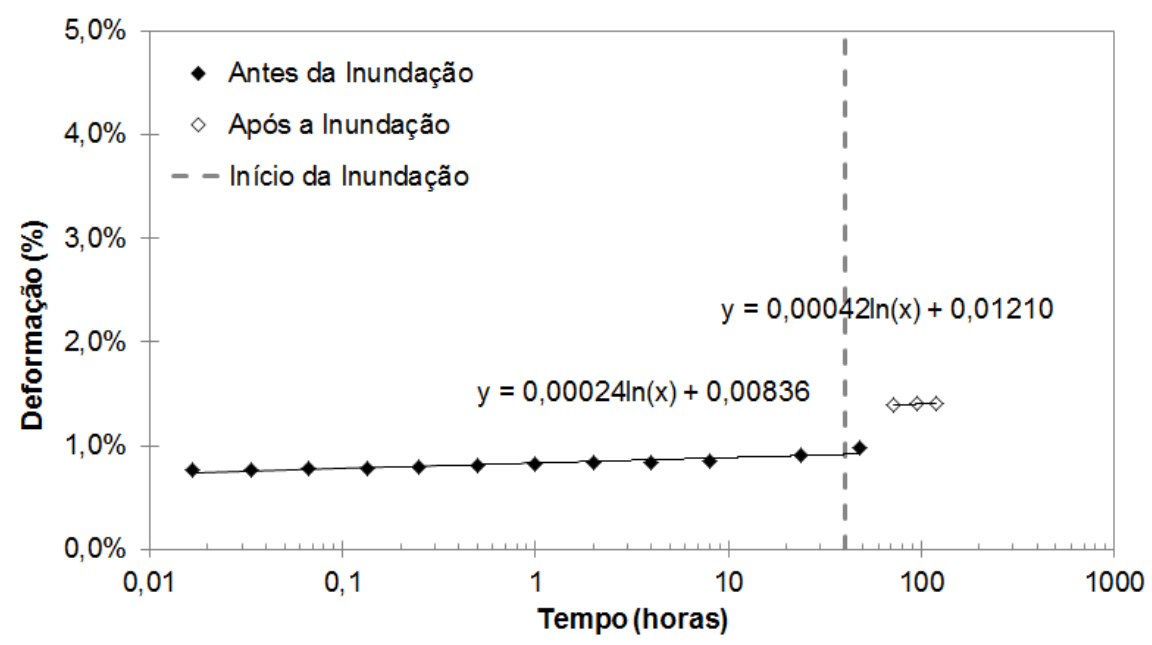

(c) 


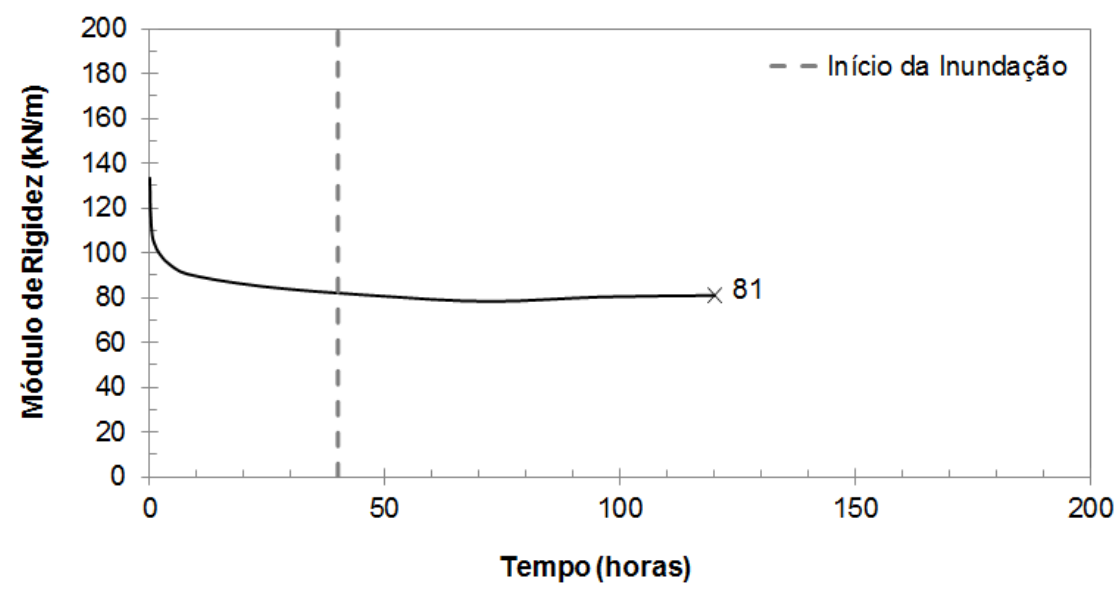

(d)

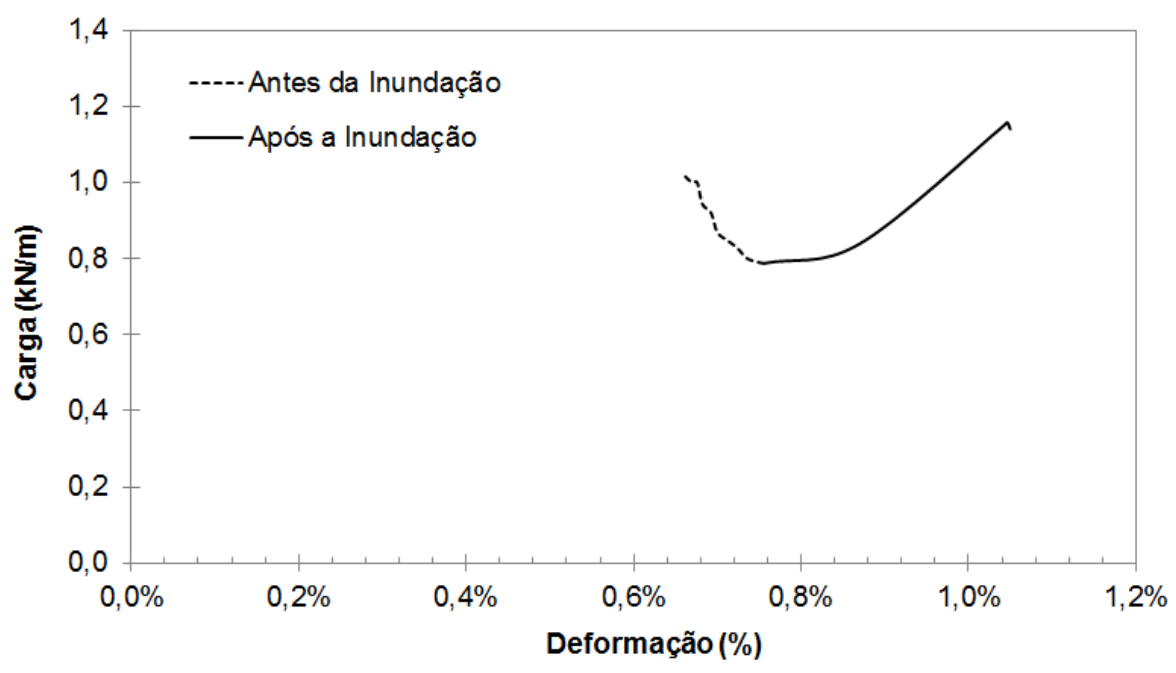

(e)

Figura 4.32 - Resultados dos ensaios de fluência confinada com inundação para geotêxteis tecidos:

(a) Variação da carga no reforço ao longo do tempo; (b) Variação das deformações ao longo do tempo em escala normal; (c) Variação das deformações ao longo do tempo em escala logarítmica; (d) Variação do módulo de rigidez confinada ao longo do tempo; (e) Trajetória das cargas e deformações no reforço.

A Figura 4.32a mostra que, para o caso de geotêxteis tecidos, após a inundação do solo ocorreu um aumento no carregamento do reforço de aproximadamente $44 \%$. $O$ carregamento aumentou de $0,79 \mathrm{kN} / \mathrm{m}(1,4 \%$ da carga última) para $1,14 \mathrm{kN} / \mathrm{m}(2,1 \%$ da carga última).

Já na Figura 4.32b, que mostra a variação das deformações ao longo do tempo em escala normal, pode-se observar que as deformações aumentaram em cerca de 45\% após a inundação, assim como observado para os carregamentos no reforço. 
Entretanto, após a ocorrência da inundação, as deformações se estabilizaram e permaneceram praticamente constantes.

$\mathrm{Na}$ Figura 4.32c, que mostra a variação das deformações ao longo do tempo em escala logarítmica, observa-se que o parâmetro "b" aumentou em torno de 1,6 vezes. Mesmo com este aumento, o valor do parâmetro "b" pode ser considerado muito baixo mesmo após a inundação.

Por meio da Figura 4.32d é possível se observar que, a exemplo do que foi registrado para os ensaios realizados com geotêxteis não tecidos, a rigidez confinada dos geotêxteis tecidos não sofreu alteração devido ao processo de inundação do solo. Isto indica que as cargas nos reforços sofreram acréscimos proporcionais aos aumentos de deformação após a inundação.

Em relação à trajetória das cargas e deformações no reforço ao longo do ensaio realizado com geotêxtil tecido (Figura 4.32e), nota-se que o comportamento é muito semelhante ao observado para o caso do geotêxtil não tecido. Observa-se que o processo de inundação do maciço gerou um acréscimo considerável na carga e na deformação do reforço, retomando a trajetória inicial dos carregamentos após o término da inundação. Observa-se que apesar do comportamento semelhante entre os dois tipos de geotêxteis, os acréscimos de cargas e deformações foram consideravelmente maiores para o caso dos não tecidos.

Os resultados dos ensaios inundados realizados com geogrelhas são mostrados na Figura 4.33. 


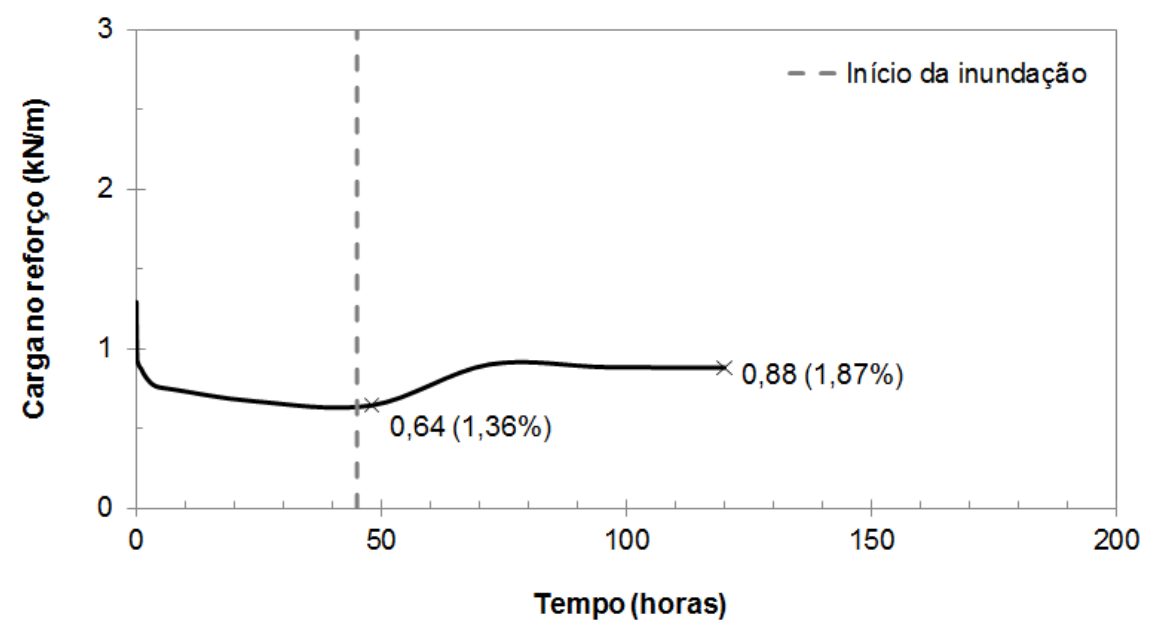

(a)

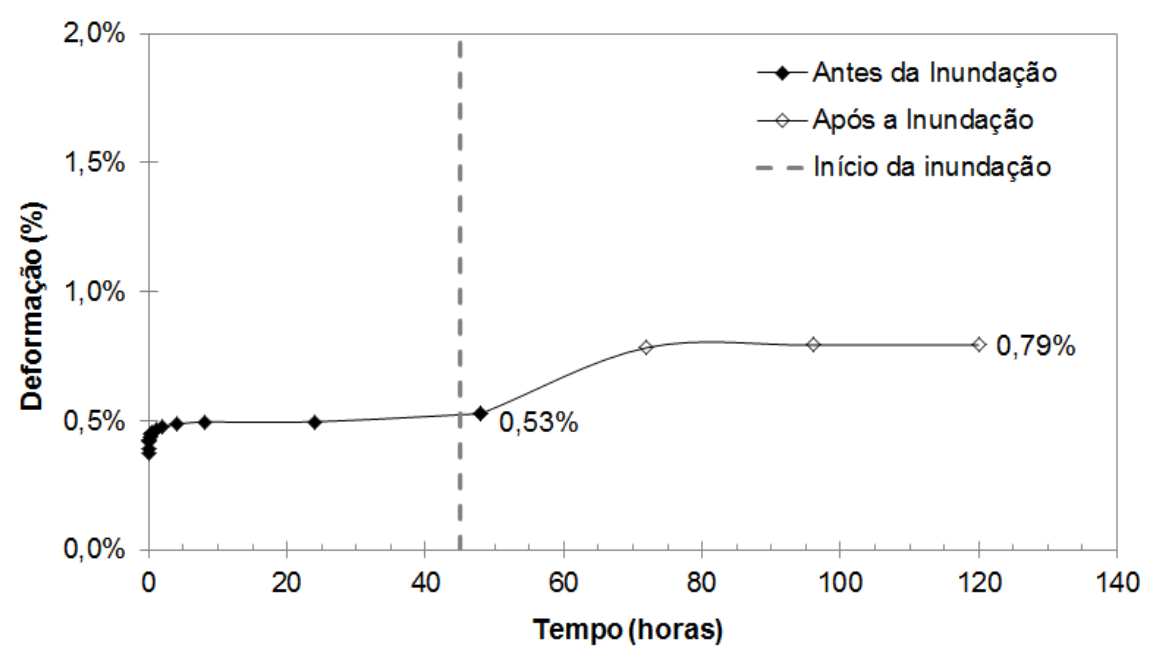

(b)

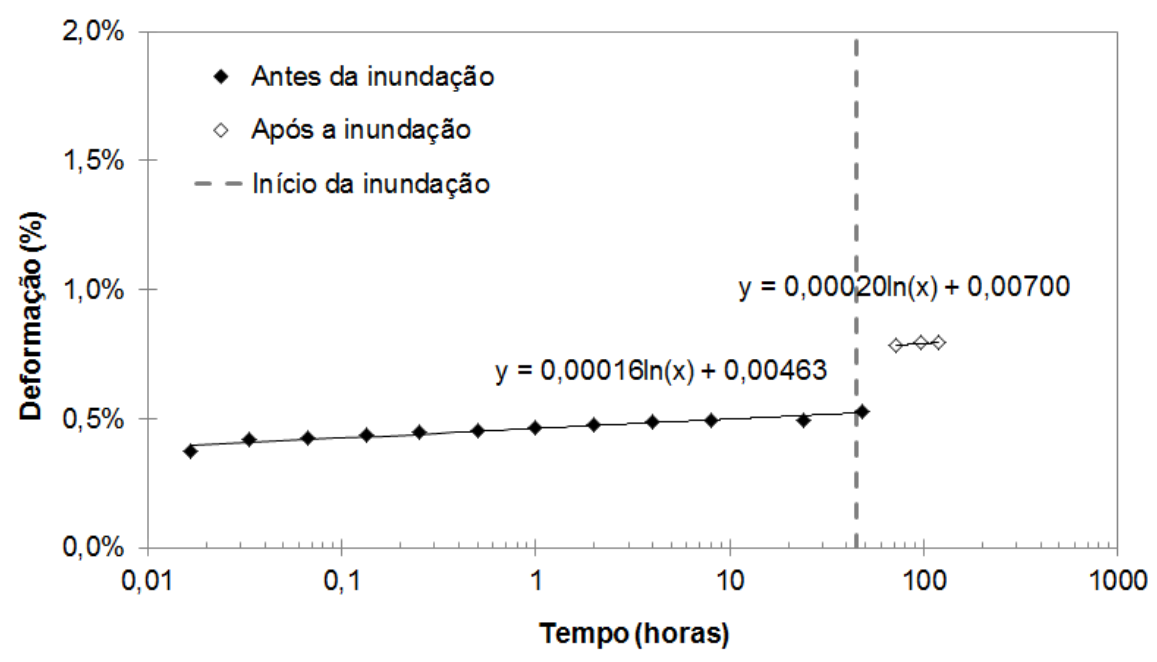

(c) 


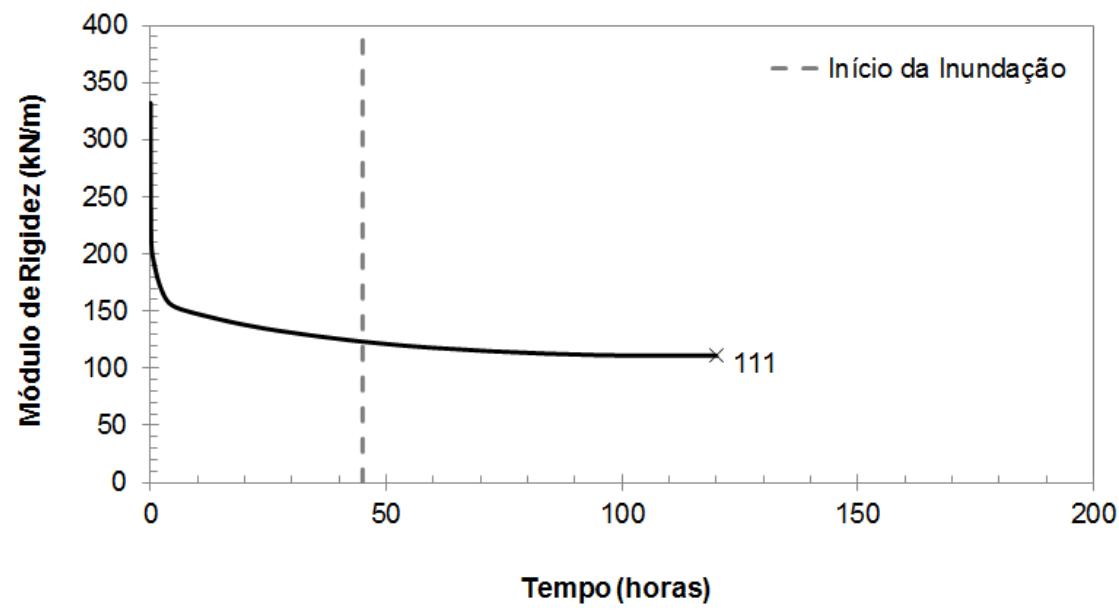

(d)

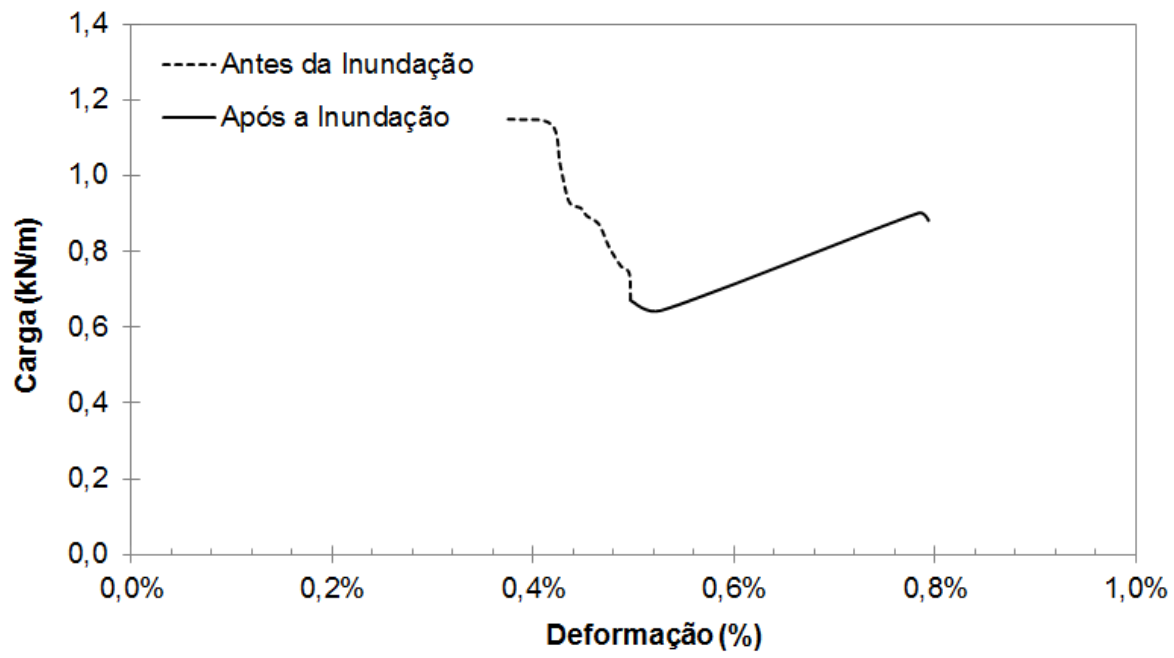

(e)

Figura 4.33 - Resultados dos ensaios de fluência confinada com inundação para geogrelhas: (a) Variação da carga no reforço ao longo do tempo; (b) Variação das deformações ao longo do tempo em escala normal; (c) Variação das deformações ao longo do tempo em escala logarítmica; (d) Variação do módulo de rigidez confinada ao longo do tempo; (e) Trajetória das cargas e deformações no reforço.

A Figura 4.33a mostra que, para o caso de geogrelhas, após a inundação do solo ocorreu um aumento no carregamento do reforço de aproximadamente $40 \%$. O carregamento aumentou de $0,66 \mathrm{kN} / \mathrm{m}(1,4 \%$ da carga última) para $0,88 \mathrm{kN} / \mathrm{m}(1,9 \%$ da carga última).

Já na Figura 4.33b, que mostra a variação das deformações ao longo do tempo em escala normal, pode-se observar que as deformações aumentaram em cerca de 
$50 \%$ após a inundação, assim como observado para os carregamentos. Entretanto, após a ocorrência da inundação, as deformações se estabilizaram e permaneceram praticamente constantes.

$\mathrm{Na}$ Figura 4.33c, que mostra a variação das deformações ao longo do tempo em escala logarítmica, observa-se que o parâmetro "b" aumentou em torno de 1,25 vezes após a inundação.

A Figura $4.33 \mathrm{~d}$ mostra que a rigidez confinada do reforço foi pouco afetada pela inundação, assim como ocorrido para os demais reforços.

Por fim, a Figura 4.33e mostra que a trajetória das cargas e deformações ao longo do ensaio inundado realizado com geogrelha apresentou comportamento semelhante aos demais tipos de reforço. Em relação à magnitude das cargas e deformações, os resultados dos ensaios realizados com geogrelhas se aproximaram dos resultados dos ensaios realizados com geotêxteis tecidos.

Os resultados dos ensaios com inundação mostraram que para todos os geossintéticos testados ocorreram aumentos consideráveis nas cargas atuantes nos reforços e, por consequência, nos parâmetros relacionados à deformação instantânea e ao índice de fluência dos mesmos.

Os resultados mostraram que os maiores acréscimos de deformação ocorreram para o solo reforçado com geotêxtil não tecido, indicando que, para este tipo de reforço, a inundação deve atuar de forma mais intensa nos parâmetros de resistência de interface entre o solo e o reforço. Provavelmente a inundação do solo diminuiu de forma significativa a impregnação do reforço com solo local. Portanto, é de se esperar que para muros em solo reforçado com geotêxteis não tecidos as variações de umidade por infiltração, elevação de nível freático ou contribuições subsuperficiais decorrentes de deficiência de drenagem podem causar deformações importantes.

Para os demais reforços, apesar do acréscimo nas cargas e deformações ter sido relativamente elevado, os valores absolutos continuam baixos, indicando que mesmo com o processo de inundação, o desempenho da estrutura deve continuar sendo satisfatório.

É importante destacar que o aumento de carga observado nos reforços ensaiados pode ser atribuído à diminuição da resistência do solo devido à inundação. Com a entrada de água no solo, ocorre uma redução na resistência do mesmo devido à 
diminuição dos efeitos da sucção e, por consequência, ocorrem maiores deformações laterais na caixa de ensaios e os reforços são mais solicitados.

\subsubsection{Resultados e análises dos ensaios de tensões induzidas por compactação no reforço}

Adicionalmente aos ensaios de fluência confinada, foram realizados três ensaios de tensões induzidas por compactação no reforço, também chamados aqui de ensaios de compactação, na caixa de interação solo-reforço desenvolvida por Costa (2004). Tais ensaios foram realizados com o objetivo de estimar a parcela de forças que atuam no reforço devido à compactação do solo.

Conforme descrito no item 3.4.2.1 desta tese, no procedimento para a montagem do ensaio de fluência confinada na caixa de interação solo-reforço, durante a compactação do solo, os movimentos laterais das paredes da caixa de testes são restringidos por um sistema de travas. Somente após a montagem completa do ensaio, e após o início da aquisição de dados, o sistema de travas é liberado e as paredes laterais começam a se movimentar.

Nos ensaios de compactação aqui apresentados, as paredes laterais não foram travadas durante o processo de compactação do solo. Isto permitiu a aquisição dos dados referentes às forças que atuam no reforço durante todo o processo de compactação.

Como destacado no item 3.5, foram realizados três ensaios de compactação para diferentes geossintéticos: geotêxtil não tecido, geotêxtil tecido e geogrelha.

A energia de compactação empregada nos ensaios foi semelhante à energia de compactação dos ensaios Proctor Normal, ou seja, de aproximadamente $6 \mathrm{kgf} / \mathrm{cm}^{3}$. O solo na região acima do reforço foi compactado em 4 camadas, e após a execução da última camada, um carregamento de $140 \mathrm{kPa}$ foi aplicado sobre a superfície do maciço.

É importante destacar que, como a quantidade de ensaios de compactação foi muito pequena, a realização de análises quantitativas referentes ao efeito da compactação no carregamento dos reforços fica relativamente limitada. Entretanto, análises com caráter qualitativo elucidam bem o comportamento para cada tipo de reforço. 
Ressalta-se que as deformações nos reforços não foram registradas durante os ensaios de compactação. Foram realizados testes preliminares com a aquisição dos deslocamentos internos do reforço e os resultados não foram satisfatórios, e, portanto, não foram empregadas nas análises aqui apresentadas.

Os resultados dos ensaios de compactação podem ser observados na Figura 4.34.

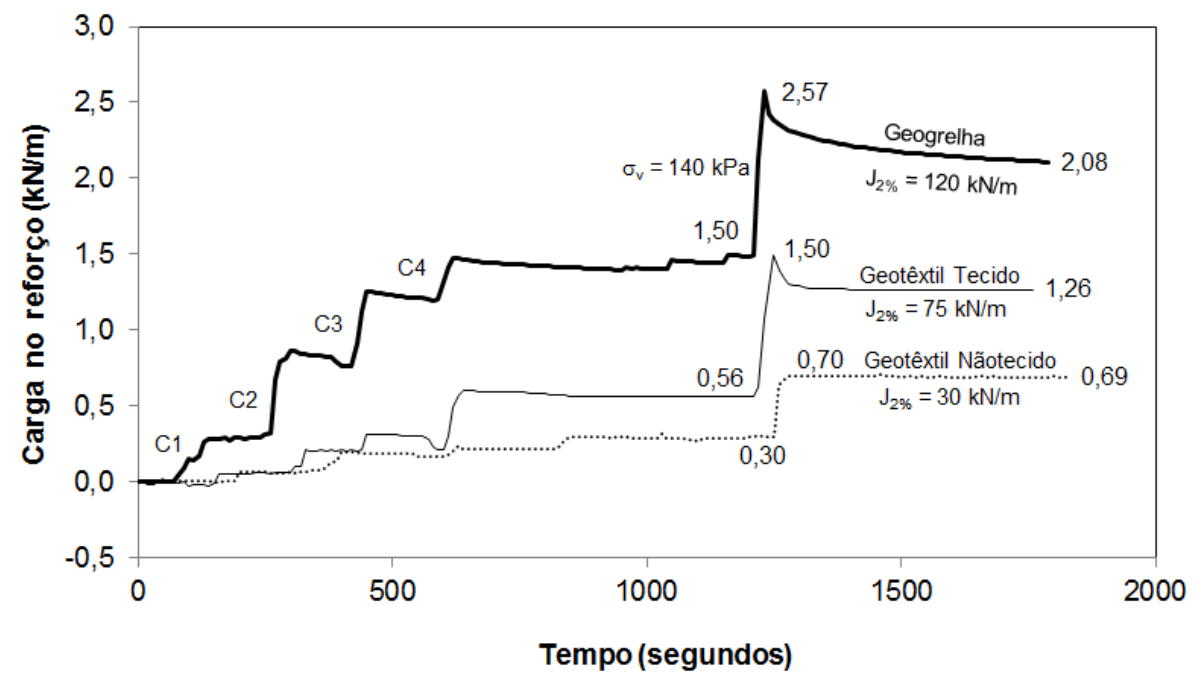

Figura 4.34 - Resultados dos ensaios de compactação realizados para geotêxtil não tecido, geotêxtil tecido e geogrelha.

A Figura 4.34 mostra que durante a execução de cada uma das camadas (C1, C2, C3 e C4), para todos os tipos de geossintéticos testados, ocorre um acúmulo de carga no reforço devido ao processo de compactação. Observa-se que este acúmulo de carga é menor para o geotêxtil não tecido e maior para a geogrelha, enquanto o geotêxtil tecido apresentou resultados intermediários. Por esta razão, pode-se afirmar que o acúmulo de carga no reforço durante o processo de compactação é proporcional à rigidez do reforço, ou seja, reforços mais rígidos acumulam maior carga durante o processo de compactação.

Observa-se ainda que os acúmulos de carga devidos apenas à aplicação do carregamento vertical de $140 \mathrm{kPa}$, para todo os reforços testados, são compatíveis com os carregamentos observados nos ensaios confinados apresentados no item 4.2.1.

Outra forma de se apresentar os resultados dos ensaios de compactação é mostrada na Figura 4.35. Nesta Figura as cargas atuantes nos reforços são plotadas em função do número de golpes acumulado para cada uma das camadas 
compactadas. Quanto maior a inclinação da reta ajustada, maior é o acumulo de cargas devido à compactação. Assim como constatado anteriormente, o geotêxtil não tecido, que possui a menor rigidez, apresentou a reta com inclinação mais abatida, e, portanto, o menor acúmulo de cargas. Já a geogrelha, que é o material mais rígido, apresentou a reta com maior inclinação, e, portanto, com maior acúmulo de carregamento no reforço. O geotêxtil tecido apresentou resultados intermediários.

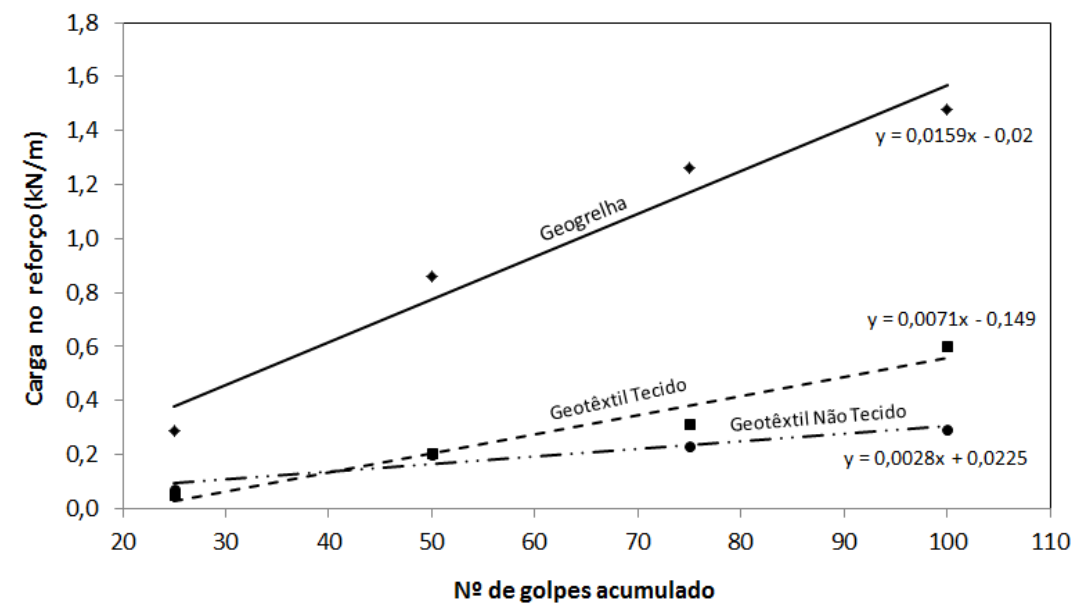

Figura 4.35 - Variação da carga no reforço em função do número de golpes acumulado para cada tipo de reforço.

Outro aspecto a ser observado se refere aos carregamentos obtidos nos reforços após a compactação comparados aos carregamentos nos reforços sem o efeito da compactação. Vale lembrar que os ensaios confinados foram realizados sem considerar o acréscimo de cargas no reforço devido à compactação. Isto porque durante a montagem dos ensaios, as paredes laterais se encontravam impedidas de se movimentarem lateralmente pelo sistema de travas.

A Tabela 4.4 mostra uma comparação entre os carregamentos estabilizados nos reforços durante a execução dos ensaios de fluência confinada, com os carregamentos estabilizados obtidos nos ensaios de compactação, após a aplicação do carregamento vertical de $140 \mathrm{kPa}$. 
Tabela 4.4 - Valores dos carregamentos nos reforços sem e com os efeitos da compactação.

\begin{tabular}{|c|c|c|c|}
\hline \multirow[b]{2}{*}{ Tipo de Reforço } & \multicolumn{2}{|c|}{ Carga no reforço $(\mathrm{kN} / \mathrm{m})$} & \multirow{2}{*}{$\begin{array}{c}\text { Acréscimo de } \\
\text { carregamento } \\
\text { devido à } \\
\text { compactação }\end{array}$} \\
\hline & $\begin{array}{l}\text { Sem Efeitos da } \\
\text { Compactação }\end{array}$ & $\begin{array}{l}\text { Com Efeitos da } \\
\text { Compactação }\end{array}$ & \\
\hline Geotêxtil Não tecido & 0,41 & 0,69 & $68 \%$ \\
\hline Geotêxtil Tecido & 0,71 & 1,26 & $77 \%$ \\
\hline Geogrelha & 0,52 & 2,08 & $300 \%$ \\
\hline
\end{tabular}

Confirmando as informações apresentadas anteriormente, a Tabela 4.4 mostra que os maiores acréscimos de carga ocorreram na geogrelha e os menores no geotêxtil não tecido. Observa-se que o acúmulo de carga devido à compactação foi muito superior para o caso da geogrelha. Este fato talvez seja explicado pela geometria do material, que apresenta aberturas entre seus elementos, permitindo o contato solosolo, e facilitando o travamento do material no meio em que ele se encontra inserido. Observa-se ainda que a não consideração das cargas adicionais devidos ao efeito da compactação nos ensaios confinados é a provável explicação para as diferenças obtidas entre os resultados dos ensaios de fluência confinada e os resultados das leituras realizadas em campo na obra de referência.

\subsubsection{Análise numérica dos ensaios confinados}

Com o objetivo de se melhor compreender o mecanismo que governa a interação entre o solo e o reforço no equipamento desenvolvido por Costa (2004), foram realizadas análises numéricas empregando-se o software geotécnico Plaxis 2D AE. Além de auxiliar na compreensão dos mecanismos atuantes no maciço de solo durante a execução dos ensaios, as simulações numéricas permitiram também uma extrapolação dos dados para tempos maiores do que aqueles realizados na prática. O modelo numérico desenvolvido possui as mesmas dimensões do ensaio real. As paredes do modelo foram simuladas como elementos de placa, com parâmetros de 
deformabilidade e rigidez do aço. Os reforços foram simulados como elementos do tipo "geogrid", que são elementos com comportamento elastoplástico, que podem ser submetidos apenas a esforços de tração. Os valores de rigidez empregados nos reforços foram determinados a partir dos ensaios de fluência não confinada. $O$ modelo constitutivo empregado para o solo foi o "soft soil creep". Conforme destacado anteriormente este modelo constitutivo considera o efeito do tempo no cálculo das deformações. Foram empregados elementos de interface para simular o contato entre solo e o reforço e o solo e a parede. Os efeitos da compactação foram considerados por meio do emprego de cargas distribuídas equivalentes. A determinação das cargas de compactação, os parâmetros geotécnicos e estruturais empregados, a metodologia adotada nas etapas construtivas, bem com os demais detalhes da modelagem numérica foram apresentados de forma detalhada no item 3.8 desta tese.

A Figura 4.36 mostra o modelo numérico desenvolvido no software Plaxis 2D que representa os ensaios confinados realizados no equipamento desenvolvido por Costa (2004).

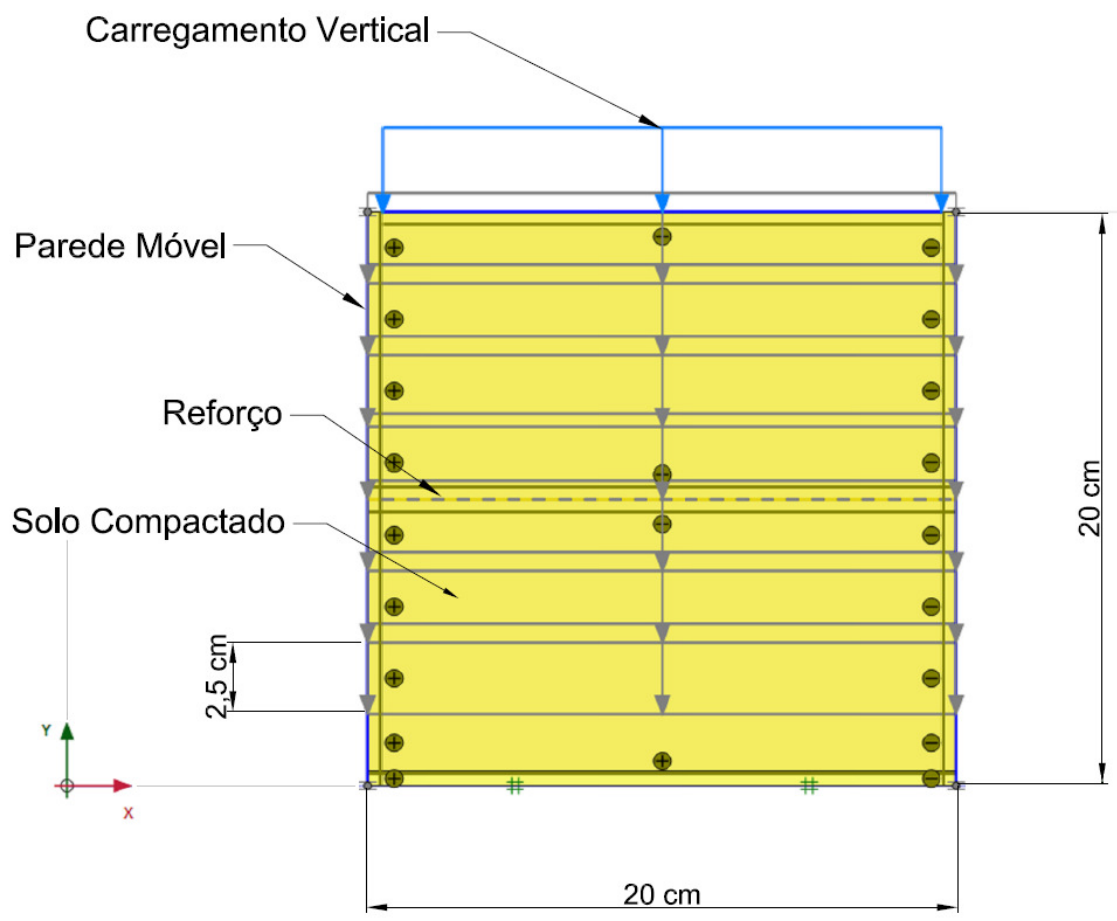

Figura 4.36 - Vista geral do modelo numérico desenvolvido para a simulação dos ensaios confinados na caixa de testes desenvolvida por Costa (2004). 
Conforme destacado anteriormente, os parâmetros geotécnicos de resistência e deformabilidade empregados nas análises foram obtidos a partir de ensaios triaxiais realizados em laboratório. A calibração do modelo foi realizada de forma a se obter o melhor ajuste possível entre os resultados dos ensaios de laboratório e os resultados das análises numéricas.

Os parâmetros de deformabilidade referentes ao modelo constitutivo empregado (parâmetros $\lambda$ e $\kappa$ ) foram adotados inicialmente em função do módulo de deformabilidade o qual foi determinado em função dos ensaios triaxiais do tipo $C D$, executados com o solo compactado na umidade ótima, cujos resultados foram apresentados no Capítulo 3. A partir dos valores iniciais, os parâmetros de deformabilidade foram variados até se obter uma convergência entre os níveis de deformação calculados e os níveis de deformação registrados no ensaio instrumentado para um tempo imediatamente após a liberação das paredes móveis. Após a obtenção desta convergência, os modelos foram calibrados em função do parâmetro de fluência $(\mu)$, cujo valor inicial foi determinado em função dos ensaios de fluência do solo apresentados também no Capítulo 3. Assim como foi realizado para os parâmetros de deformabilidade, o parâmetro referente à fluência do modelo numérico foi variado até que houvesse uma boa concordância entre os resultados calculados e os resultados lidos ao longo do tempo do ensaio.

Apenas com caráter ilustrativo, a Figura 4.37 e a Figura 4.38 apresentam, respectivamente, os deslocamentos e as tensões horizontais obtidos nas simulações numéricas para geotêxteis não tecidos, após 120 horas de ensaio. 


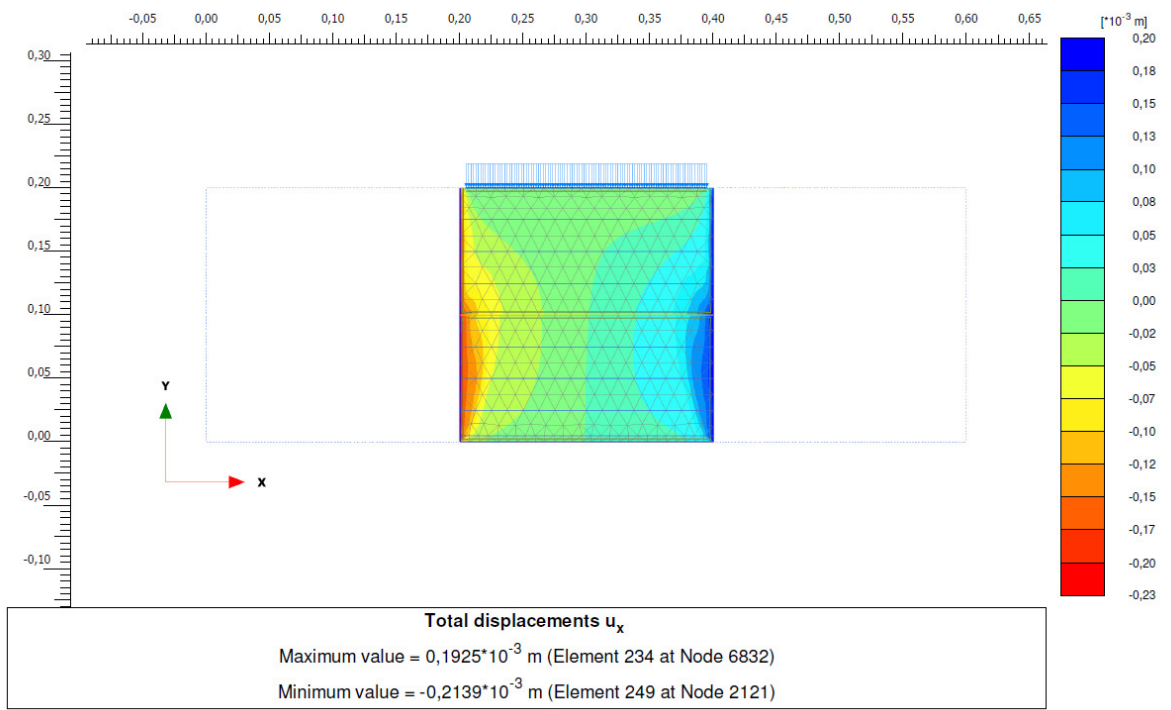

Figura 4.37 - Deslocamentos horizontais obtidos no modelo numérico para simulação do ensaio confinado na caixa de testes desenvolvida por Costa (2004) com geotêxtil não tecido.

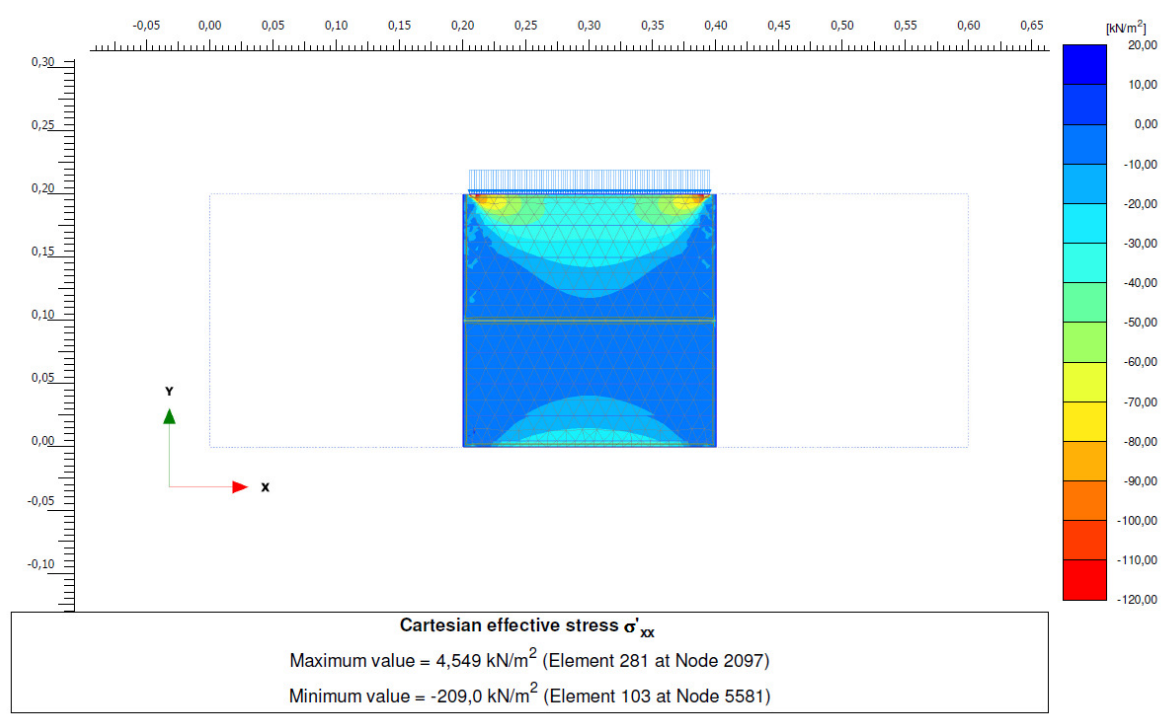

Figura 4.38 - Tensões horizontais obtidas no modelo numérico para simulação do ensaio confinado na caixa de testes desenvolvida por Costa (2004) com geotêxtil não tecido.

Os ajustes obtidos nos modelos numéricos para os geotêxteis não tecidos, geotêxteis tecidos e geogrelhas são mostrados na Figura 4.39, na Figura 4.40, e na Figura 4.41, respectivamente. 


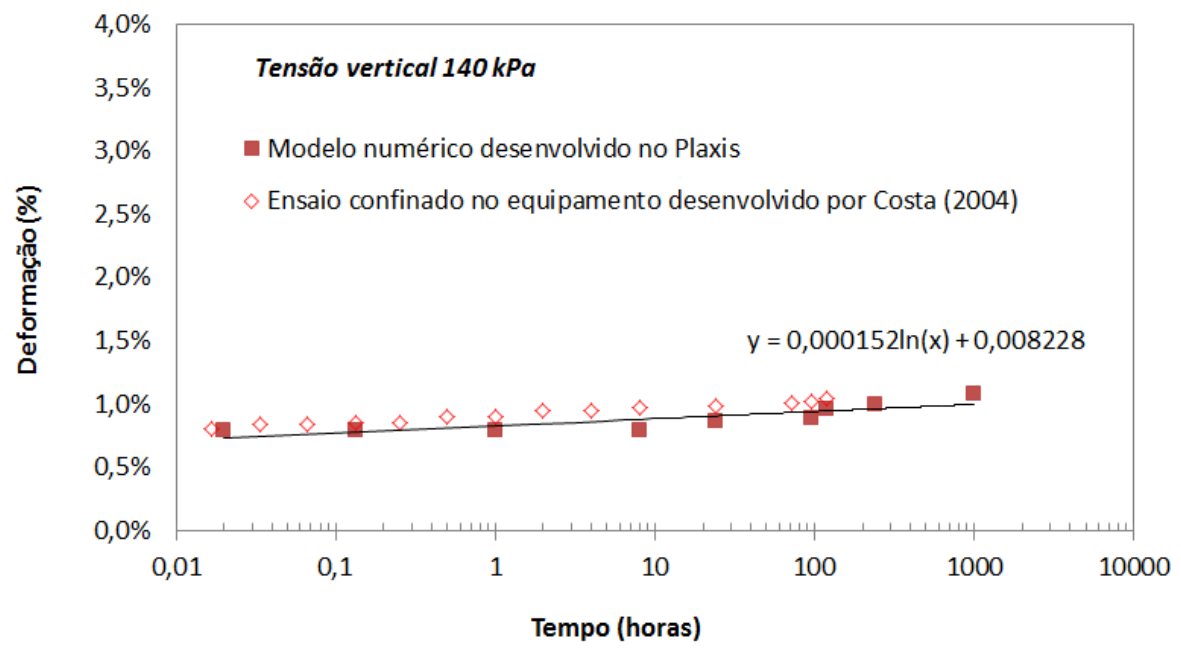

(a)

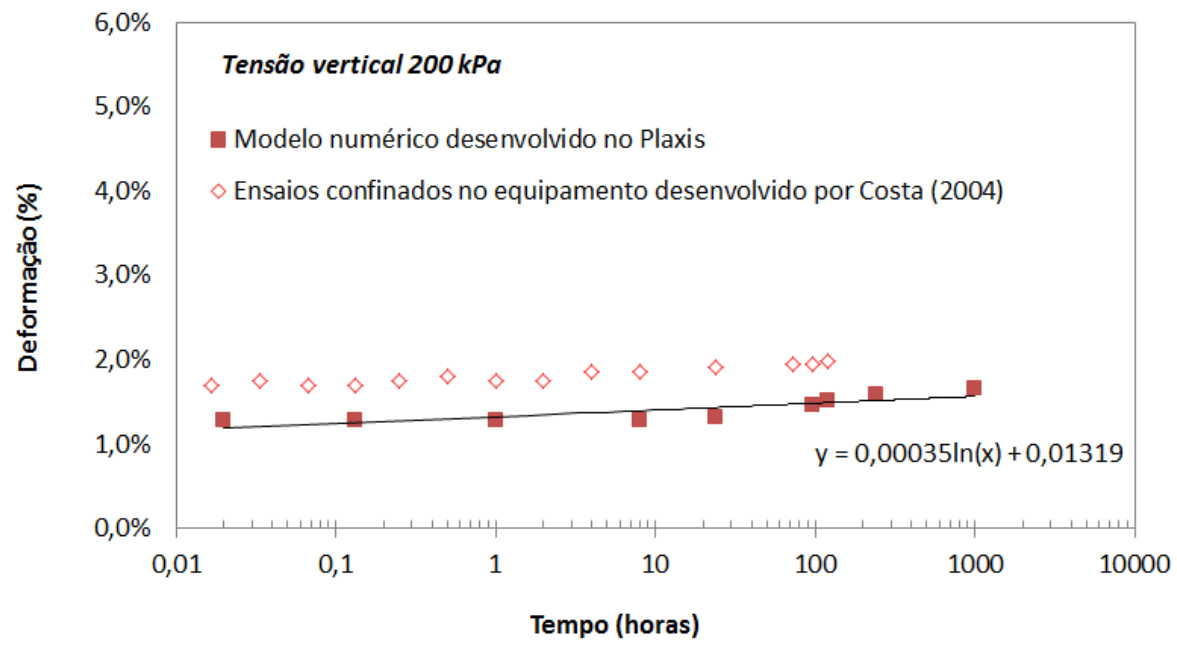

(b)

Figura 4.39 - Resultados do modelo calibrado para o caso dos geotêxteis não tecidos. 


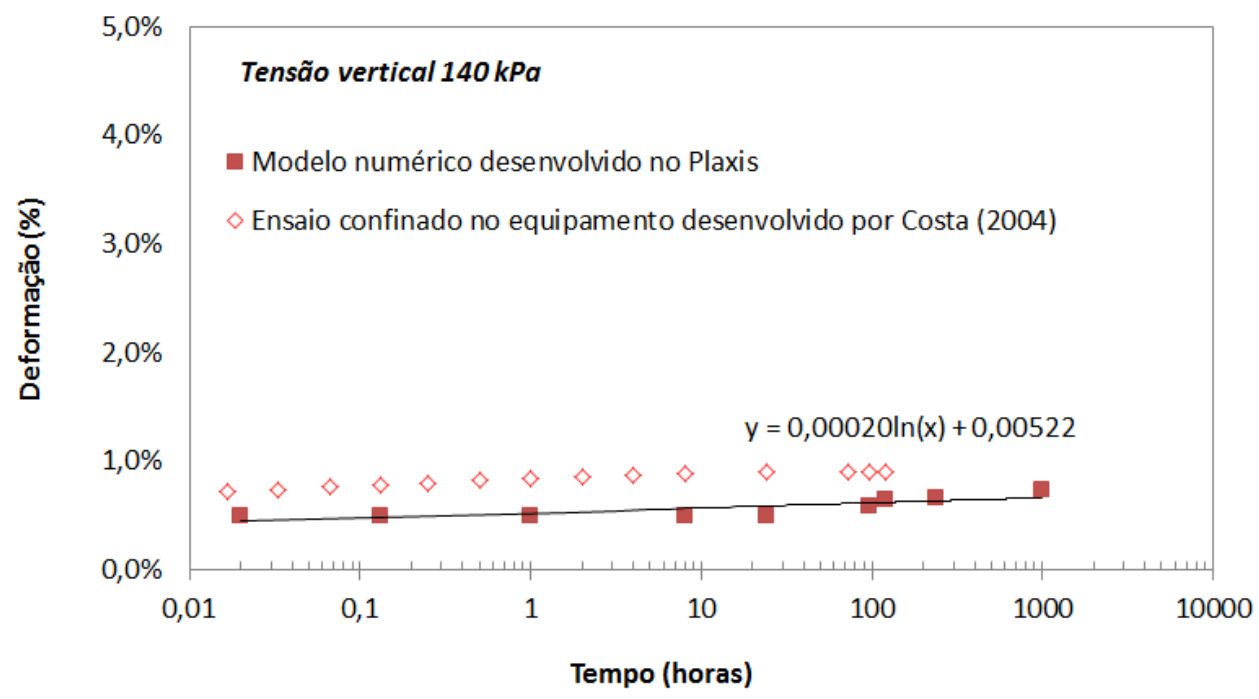

(a)

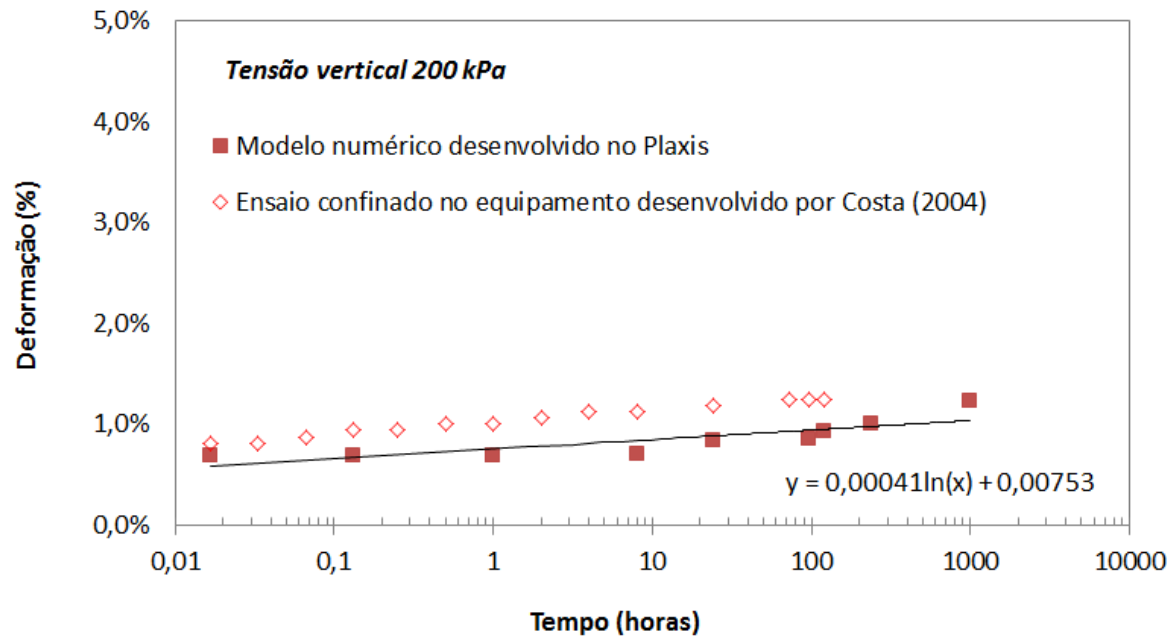

(b)

Figura 4.40 - Resultados do modelo calibrado para o caso dos geotêxteis tecidos. 


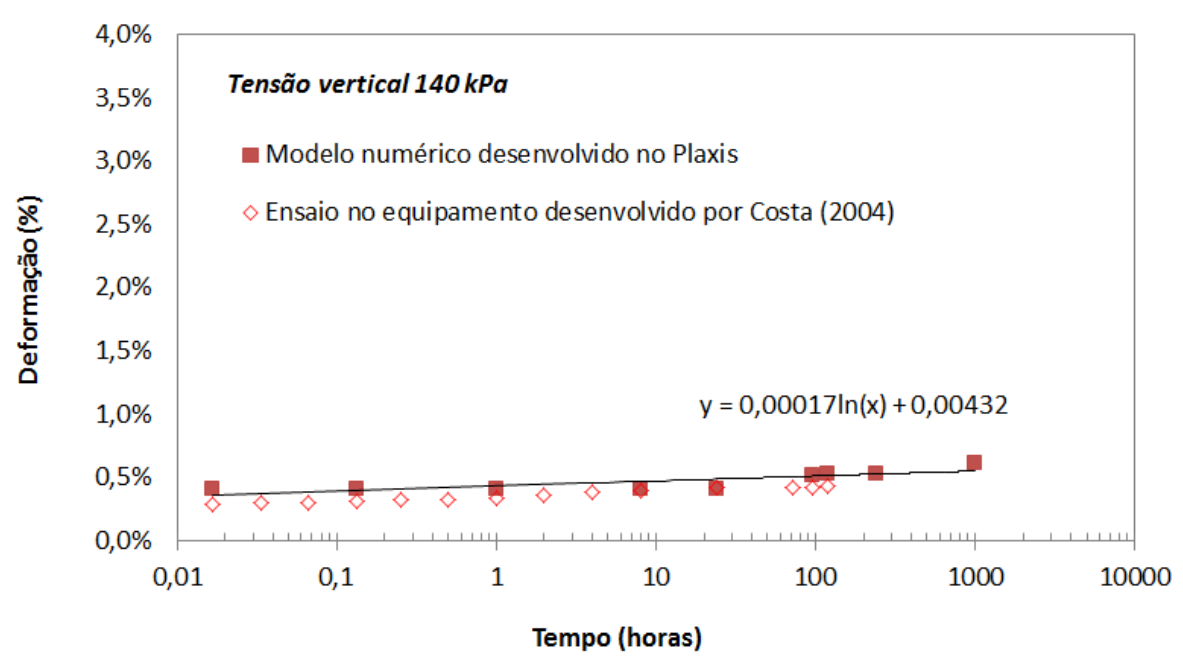

(a)

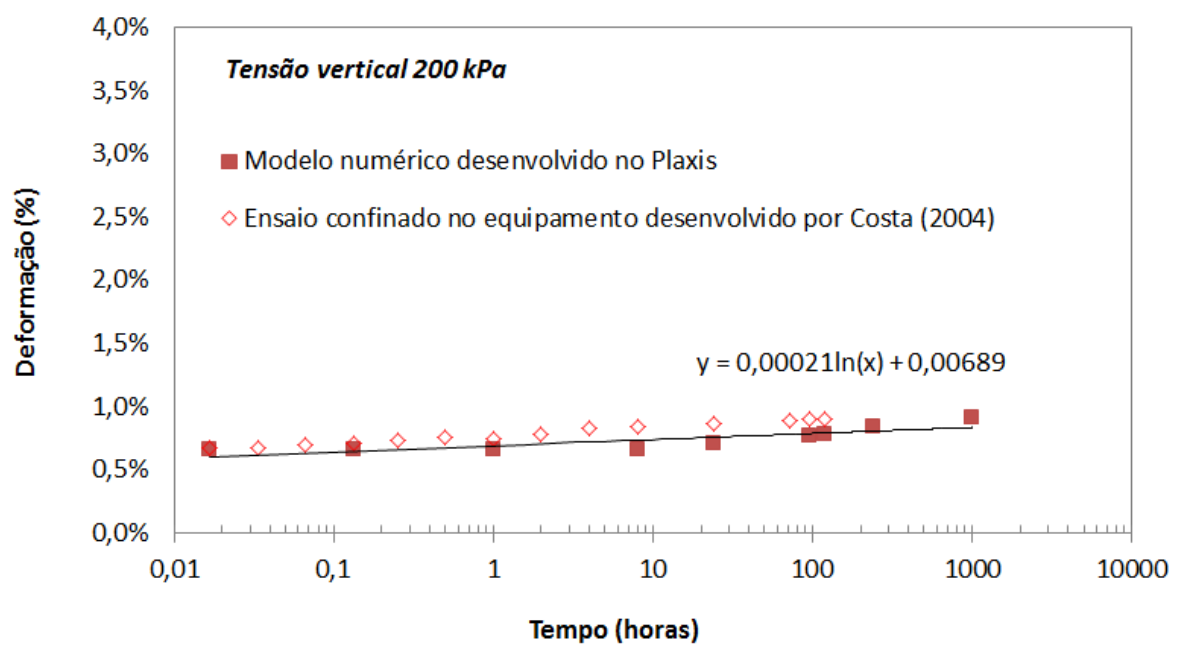

(b)

Figura 4.41 - Resultados do modelo calibrado para o caso das geogrelhas.

As Figuras mostram que houve um bom ajuste entre os resultados obtidos nos ensaios confinados e os resultados da modelagem numérica. Nota-se que os melhores ajustes ocorreram para o ensaio com geotêxtil não tecido com menor carregamento e para os ensaios com geogrelhas. A curva que apresentou maior diferença foi a curva referente ao ensaio com geotêxtil não tecido submetido a um carregamento vertical de $200 \mathrm{kPa}$.

As pequenas diferenças observadas entre os resultados dos ensaios realizados em laboratório e os resultados da modelagem computacional, provavelmente estão associadas ao parâmetro de redução de resistência de interface entre o solo e o reforço $\left(R_{\text {inter }}\right)$ empregado nas modelagens numéricas. Para todos os tipos de 
reforço foi empregado um valor único de 0,8 para este parâmetro. Possivelmente este valor é adequado para os ensaios em geogrelha, mas deve ser elevado para o caso dos geotêxteis. Caso fossem adotados menores valores para a redução da resistência de interface para os geotêxteis, os reforços iriam se deformar mais na modelagem computacional, e iria ocorrer uma aproximação entre as curvas obtidas em laboratório e as curvas obtidas nos modelos numéricos.

A adoção de diferentes valores para o parâmetro $R_{\text {inter }}$ se justifica pelas características físicas e geométricas dos diferentes tipos de reforço. A geogrelha, por ser um elemento vazado, permite um contato solo-solo quando o material se encontra confinado. Este tipo de contato permite um melhor travamento do reforço no maciço, e, portanto, estima-se que o parâmetro de redução para a resistência de interface seja elevado, possivelmente próximo da unidade. Para o caso dos geotêxteis o contato solo-solo não ocorre. Assim, a resistência de interface entre o solo e o reforço é menor para os geotêxteis do que para as geogrelhas. Para o caso dos geotêxteis tecidos, que são materiais que possuem fibras alinhadas, praticamente não ocorre o imbricamento do solo no reforço, e, portanto, a resistência de interface é baixa. Já para o caso dos geotêxteis não tecidos, cujas fibras se encontram dispostas de forma aleatória e sem alinhamento entre as mesmas, 0 imbricamento do solo no reforço ocorre, fato este que conduz a um aumento da resistência de interface entre o solo e o reforço. Dessa forma, é de se esperar que a resistência de interface entre o solo e o reforço para os geotêxteis não tecidos, apresente valores intermediários entre a geogrelhas e o geotêxteis tecidos.

Além do fator de redução da resistência de interface, as diferenças observadas entre os resultados numéricos e os de laboratório, podem também estar relacionados à possíveis folgas entre as peças que compõem o equipamento, que podem ter gerado deslocamentos ligeiramente maiores que os previstos. Adicionalmente, pode ter ocorrido algum tipo de problema durante a montagem dos ensaios, como deficiências no controle de compactação do maciço por exemplo.

É importante destacar que não foram realizadas calibrações dos modelos numéricos para os casos com carregamentos de $300 \mathrm{kPa}$ e $400 \mathrm{kPa}$. Isto se deve ao fato de que, para estes carregamentos, o solo sofre ruptura. A partir do momento em que o solo sofre uma ruptura generalizada, o software automaticamente interrompe os cálculos. A ruptura do solo para carregamentos superiores a $200 \mathrm{kPa}$ foi constatada também nos ensaios confinados realizados em laboratório. 
Conforme apresentado nas Figura 4.39 a Figura 4.41, a utilização do modelo numérico permitiu a extrapolação dos valores de deformações para um período de 1000 horas e tensões verticais de até 200 kPa. A relação entre os parâmetros "a" e "b" e a tensão vertical aplicada ao ensaio de fluência confinada é apresentada na Figura 4.42.

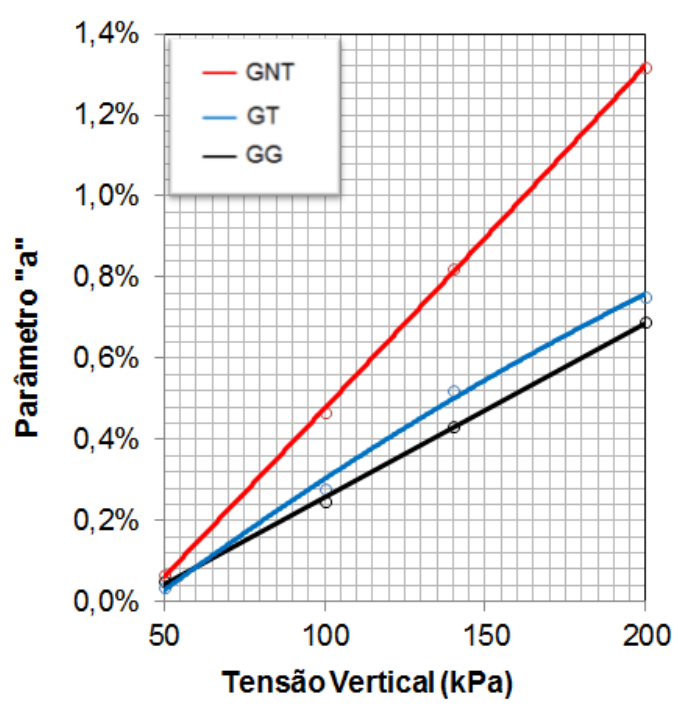

(a)

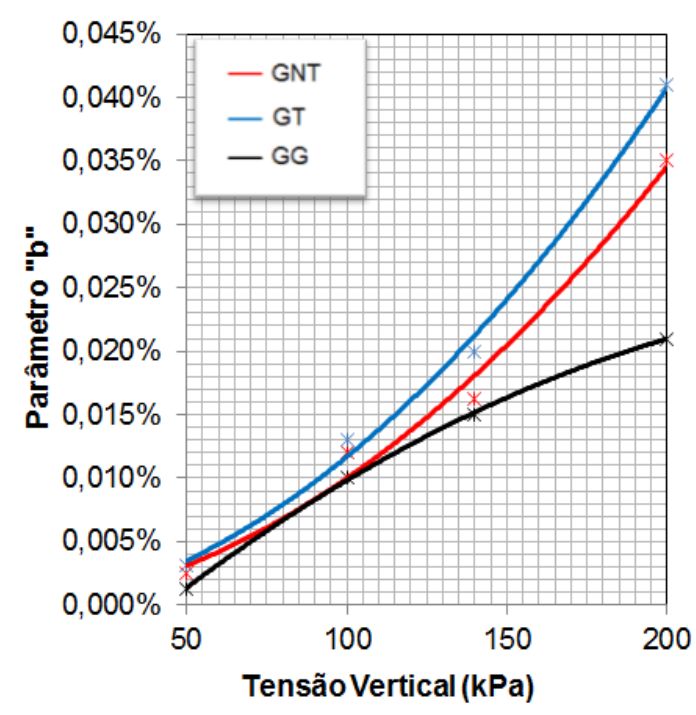

(b)

Figura 4.42 - Gráficos obtidos na modelagem computacional para a correlação entre a tensão vertical aplicada no ensaio confinado e: (a) Parâmetro "a"; (b) Parâmetro "b".

As trajetórias de tensões para as simulações numéricas dos ensaios com geotêxteis não tecidos, geotêxteis tecidos e geogrelhas são apresentadas nas Figuras 4.43, 4.4 e 4.45 , respectivamente.

Ressalta-se que as trajetórias de tensões foram calculadas para um ponto situado na região central das paredes laterais da caixa de ensaios simulada no modelo numérico. 


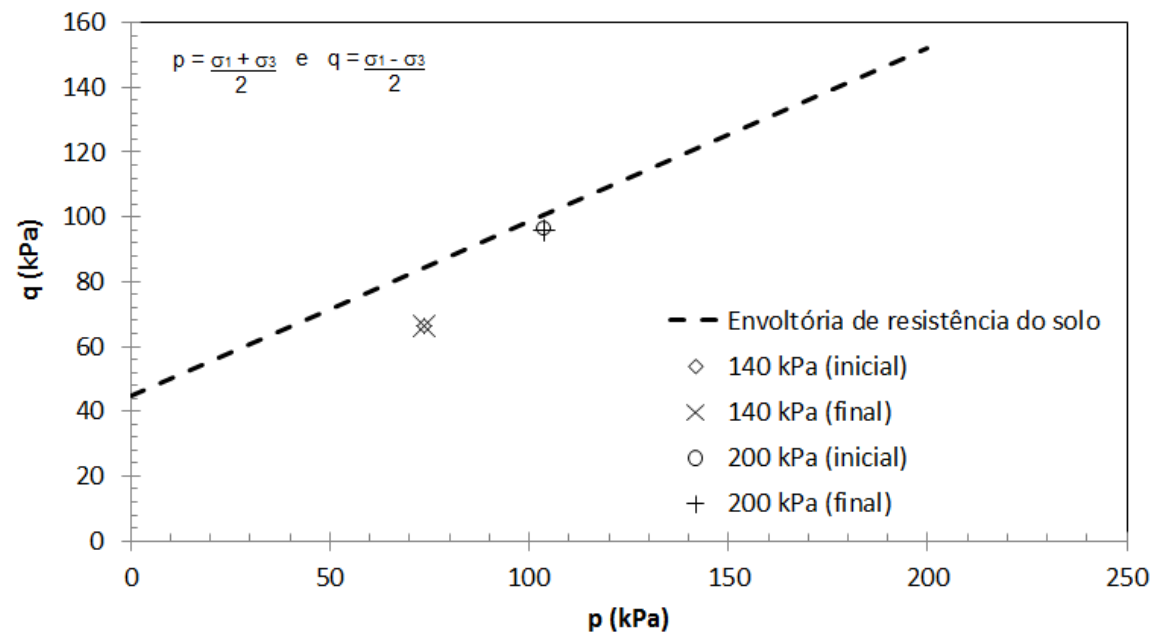

Figura 4.43 - Trajetória de tensões na região central das paredes da caixa de testes calculada a partir da simulação numérica do ensaio com geotêxtil não tecido.

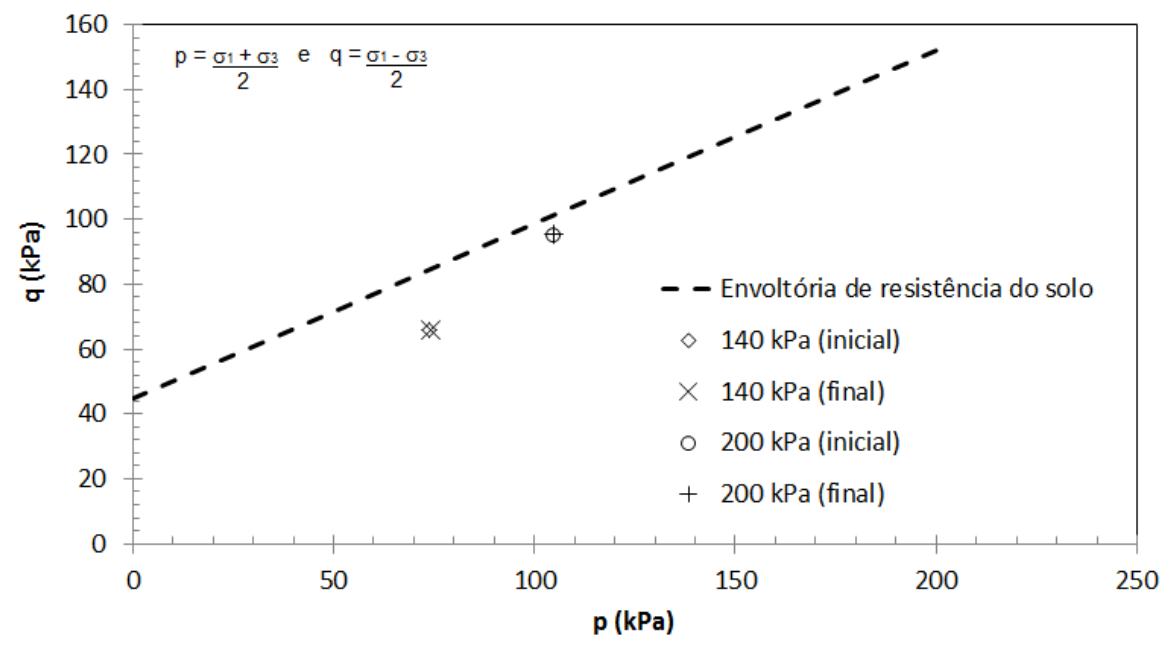

Figura 4.44 - Trajetória de tensões na região central das paredes da caixa de testes calculada a partir da simulação numérica do ensaio com geotêxtil tecido. 


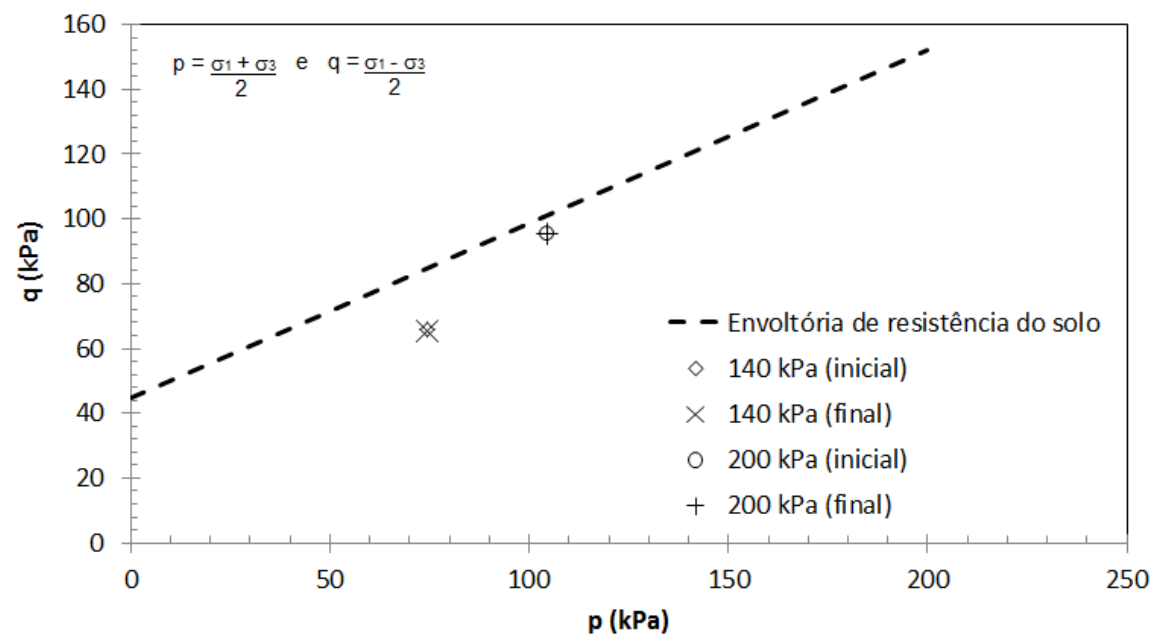

Figura 4.45 - Trajetória de tensões na região central das paredes da caixa de testes calculada a partir da simulação numérica do ensaio com geogrelha.

Para todos os casos, a situação inicial se refere ao tempo zero, ou seja, logo após o início do ensaio, e a situação final se refere a um tempo de 120 horas, conforme realizado nos ensaios de laboratório.

Observa-se que para todos os reforços avaliados, e para todos os carregamentos verticais considerados, a trajetória de tensões permanece praticamente inalterada. Isto se deve ao fato de que, no modelo numérico, os carregamentos horizontais praticamente não se alteram com o tempo. Nos ensaios reais, conforme já discutido anteriormente, após a liberação das paredes no início do ensaio, os carregamentos no reforço apresentam uma tendência de redução, até que o equilíbrio de tensões e deformações entre o solo e o reforço seja estabelecido. Este processo de compatibilização de deformações não ocorre no modelo numérico, daí as diferenças entre as trajetórias de tensões reais e as trajetórias de tensões simuladas no software Plaxis. As análises das trajetórias de tensões para os ensaios confinados são apresentadas no Item 4.2.6.

Outro fator importante que pode ser investigado por meio das análises numéricas se refere à distribuição das deformações e dos carregamentos ao longo dos reforços (Figura 4.46). 


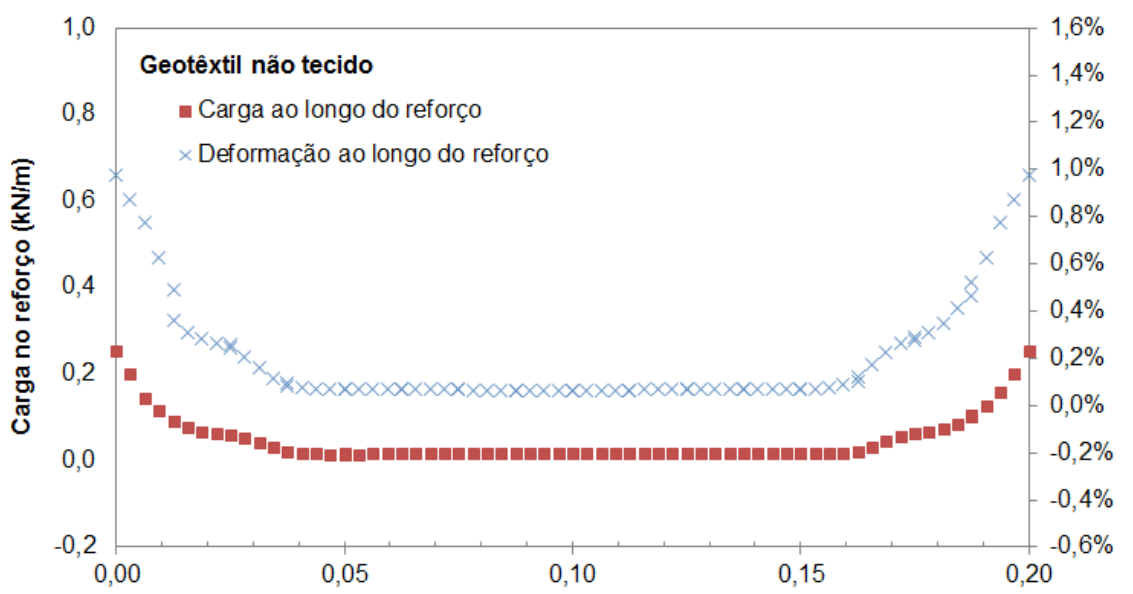

Comprimento do reforço (m)

(a)

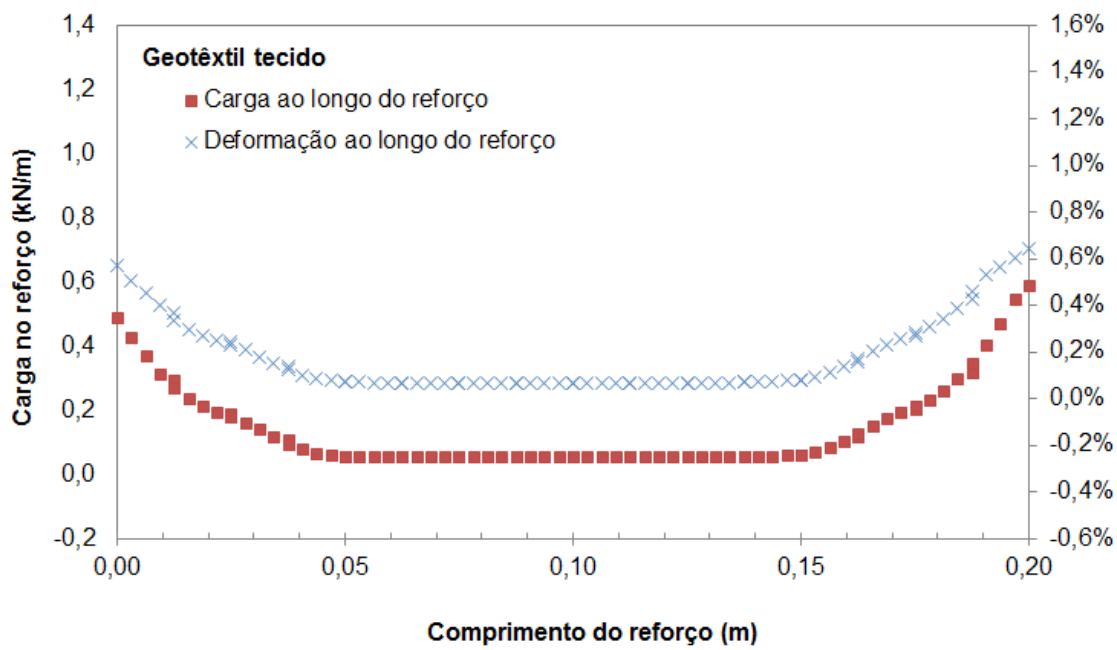

(b) 


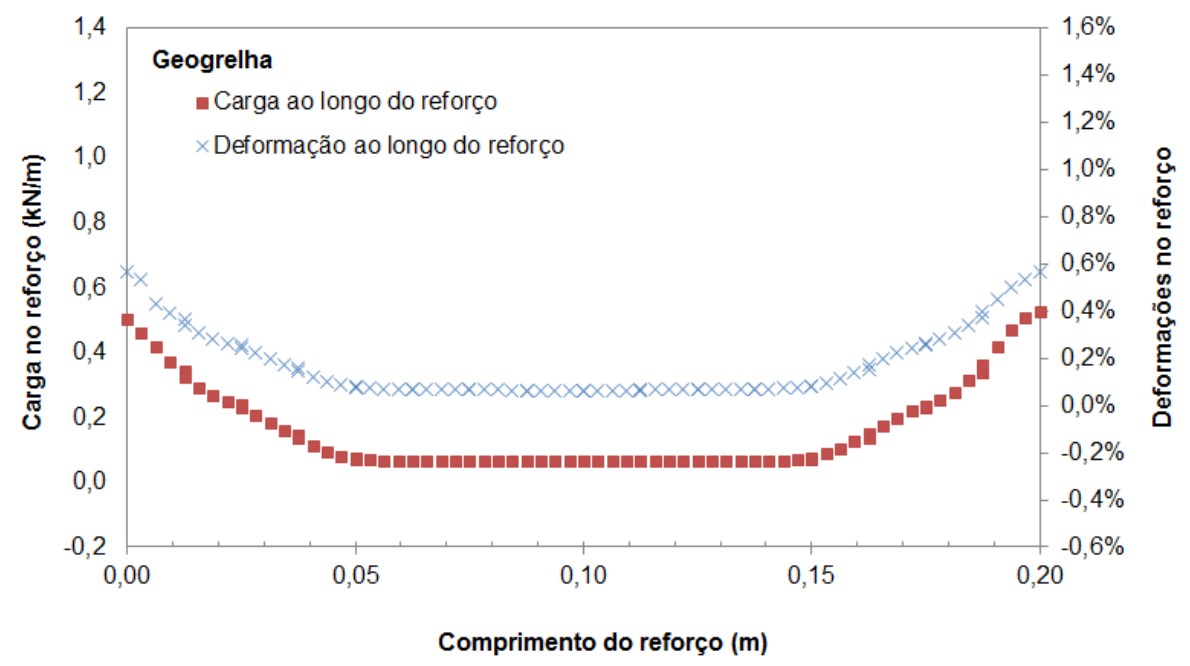

(c)

Figura 4.46 - Variação dos carregamentos e das deformações ao longo dos reforços para: a) Geotêxteis não tecidos; b) Geotêxteis tecidos; c) Geogrelhas.

Observa-se que, para todos os tipos de geossintéticos simulados no modelo numérico, a variação das deformações e das cargas não é constante ao longo do reforço. Tanto o carregamento quanto as deformações são maiores próximos à extremidade do reforço e vão diminuindo em direção ao centro. Esses resultados vão de encontro ao que foi observado nas leituras dos ensaios de laboratório. Entretanto, cabe ressaltar que, conforme descrito no Capítulo 2 desta tese, a variação das deformações ao longo do reforço instrumentado nos ensaios realizados no equipamento desenvolvido por Costa (2004) foi relativamente pequena. A tendência de redução das deformações em direção ao centro do reforço também foi constatada, entretanto esta redução foi significativamente menor quando comparada aos resultados numéricos.

A modelagem numérica permitiu também a determinação do coeficiente de empuxo ativo para o solo reforçado, denominado neste texto de $\mathrm{K}_{\mathrm{a}, \mathrm{r}} \mathrm{O}$ valor deste parâmetro foi calculado como a relação entre a tensão horizontal média obtida nas paredes do modelo numérico e a tensão vertical aplicada. Os valores dos coeficientes de empuxo reforçados calculados segundo os modelos numéricos propostos são apresentados na Tabela 4.5. 
Tabela 4.5 - Valores de $\mathrm{K}_{\mathrm{a}, \mathrm{r}}$ obtidos por meio das análises numéricas.

\begin{tabular}{cccc}
\hline \multirow{2}{*}{ Tensão Vertical } & \multicolumn{3}{c}{ Tipo de reforço } \\
\cline { 2 - 4 } & Geotêxtil não tecido & Geotêxtil tecido & Geogrelha \\
\hline $140 \mathrm{kPa}$ & 0,045 & 0,053 & 0,055 \\
\hline $200 \mathrm{kPa}$ & 0,044 & 0,051 & 0,057 \\
\hline
\end{tabular}

Observa-se que, para todos os reforços analisados, o valor do coeficiente de empuxo varia muito pouco com o aumento da tensão vertical. Observa-se ainda que os menores valores de $\mathrm{K}_{\mathrm{a}, \mathrm{r}}$ foram obtidos para os geotêxteis não tecidos, e os maiores valores para as geogrelhas.

\subsubsection{Análise do estado de tensões do maciço nos ensaios confinados}

Conforme destacado no item 3.4.2.1 desta tese a trajetória de tensões no maciço de solo ao longo dos ensaios de fluência confinada é semelhante a uma condição de empuxo ativo. Neste ensaio as tensões verticais são aplicadas e mantidas constantes durante todo o período de teste, enquanto que as tensões horizontais são aliviadas por conta dos deslocamentos das paredes móveis.

Com o registro das tensões verticais que atuam sobre o maciço de solo compactado, e ainda com o registro das cargas horizontais que atuam no reforço, é possível se determinar as trajetórias de tensões ao longo do tempo para os ensaios confinados. É possível ainda se determinar a relação entre as tensões horizontais e verticais ao longo do ensaio.

As Figuras 4.47, 4.48 e 4.49 apresentam as trajetórias de tensões para os ensaios realizados com geotêxteis não tecidos, geotêxteis tecidos e geogrelhas, respectivamente. 


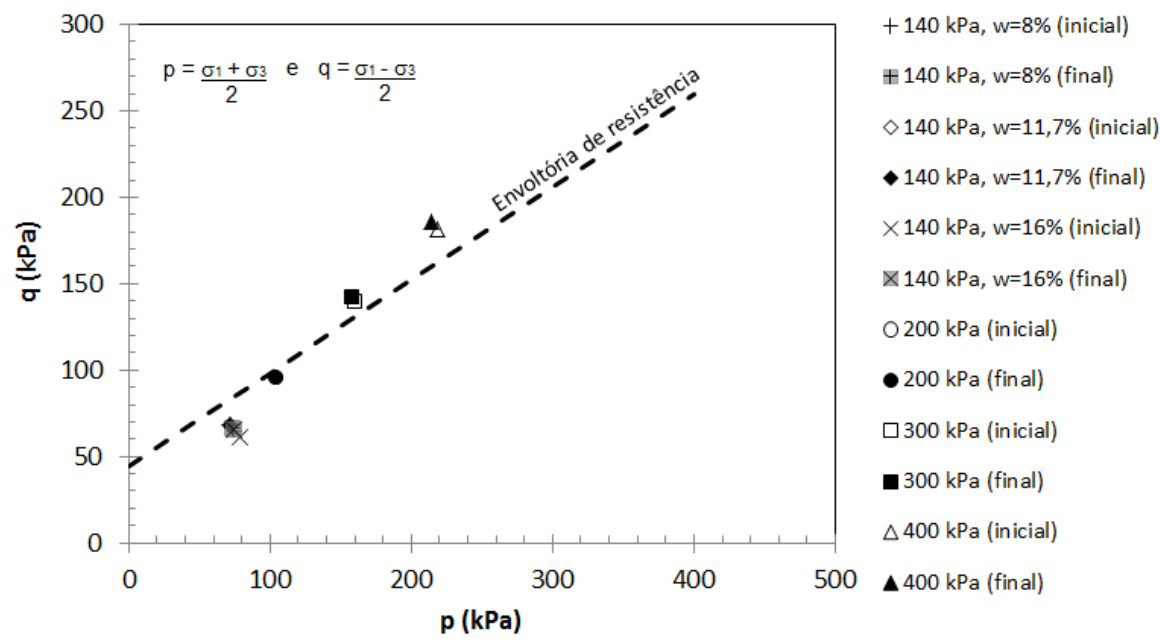

Figura 4.47 - Trajetória de tensões nos ensaios de fluência confinada de geotêxteis não tecidos.

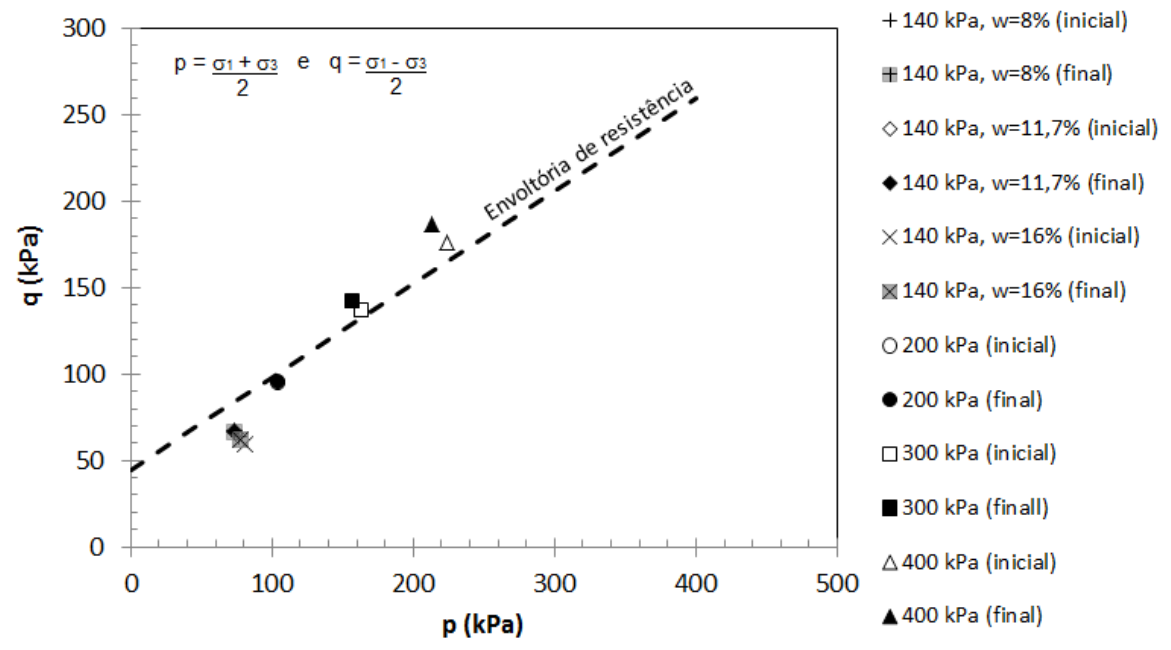

Figura 4.48 - Trajetória de tensões nos ensaios de fluência confinada de geotêxteis tecidos. 


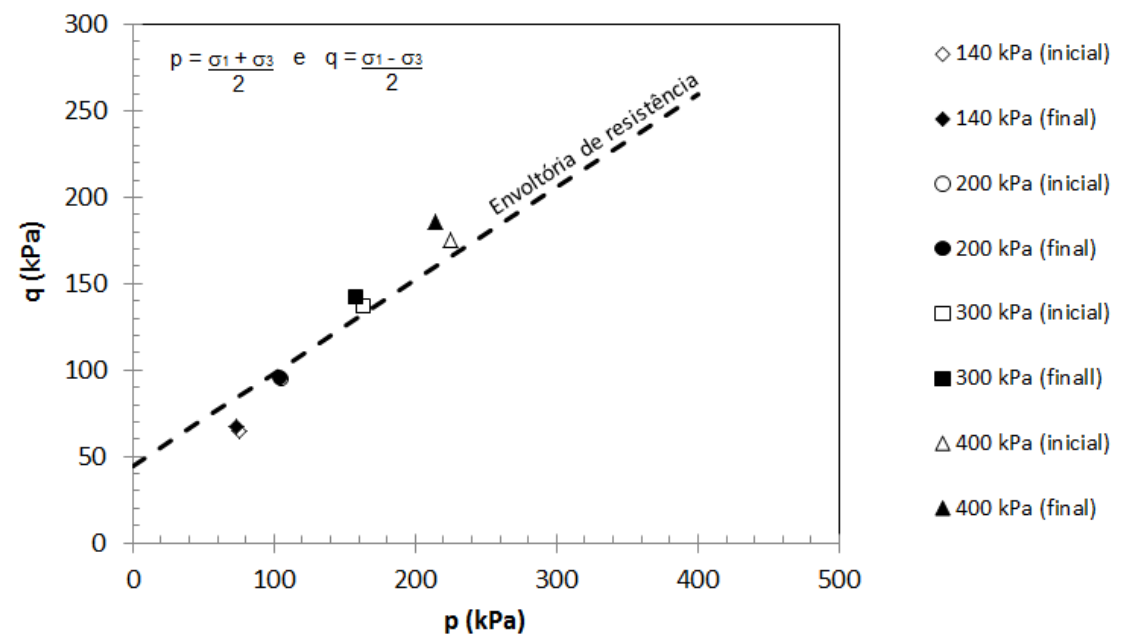

Figura 4.49 - Trajetória de tensões nos ensaios de fluência confinada de geogrelhas.

Observa-se que para os carregamentos verticais de $140 \mathrm{kPa}$ e $200 \mathrm{kPa}$, para todos os materiais testados, as tensões encontram-se abaixo da envoltória de resistência. Para os demais carregamentos, as tensões encontram-se acima da envoltória de resistência. Isto indica que para cargas superiores a $200 \mathrm{kPa}$ o solo se plastifica devido à ruptura do maciço. É importante lembrar que a envoltória de resistência se refere aos resultados dos ensaios triaxiais consolidados drenados (CD), realizados em corpos de prova compactados na umidade ótima, ou seja, na mesma condição de compactação sob a qual os ensaios confinados foram realizados. A plastificação do maciço de solo para cargas superiores a $200 \mathrm{kPa}$ também foi verificada nas simulações numéricas apresentadas no item 4.2.5.

Observa-se ainda que, para todos os casos avaliados, a trajetória de tensões tende a se deslocar para a diagonal superior esquerda do gráfico, indicando que há uma redução das tensões horizontais ao longo da execução dos ensaios.

Conforme salientado anteriormente, a redução de tensões nas paredes da caixa de testes ocorre devido à movimentação lateral da mesma após a liberação das travas. Enquanto ocorre a movimentação lateral das paredes, ocorre, consequentemente, uma redução dos carregamentos laterais. Esta redução das tensões ocorre até que o equilíbrio de tensões e deformações entre o solo e o reforço seja estabelecido. A partir do momento em que ocorre esta compatibilização, as cargas no reforço e nas paredes da caixa de testes passam a ser praticamente constantes. 
As Figuras 4.50, 4.51 e 4.52, apresentam a relação entre as tensões horizontais e verticais nos ensaios confinados e ainda a variação do coeficiente de empuxo ativo do solo reforçado $K_{a, r}$, para os diferentes carregamentos verticais, para os ensaios realizados com geotêxteis não tecidos, geotêxteis tecidos, e geogrelhas, respectivamente. Nestas figuras são apresentados os coeficientes de empuxo ativo reais, calculados por meio das tensões horizontais e verticais medidas ao longo dos ensaios, e os coeficientes de empuxo ativo teóricos, calculados pelo método de Rankine, considerando a coesão do solo, por meio da Equação 4.1:

$$
K_{a}=\frac{1-\operatorname{sen} \phi^{\prime}}{1+\operatorname{sen} \phi^{\prime}}-\frac{2 \cdot c^{\prime} \cdot \cos \phi^{\prime}}{\sigma_{V}^{\prime} \cdot\left(1+\operatorname{sen} \phi^{\prime}\right)}
$$

Ressalta-se que os cálculos foram realizados apenas para os ensaios com solo compactado na umidade ótima.

É importante destacar que o coeficiente de empuxo ativo teórico se refere à relação entre as tensões horizontais e verticais para o caso de solos não reforçados. Já o coeficiente de empuxo ativo reforçado, denominado neste texto de $\mathrm{K}_{\mathrm{a}, \mathrm{r}}$, se refere à relação entre as tensões horizontais e verticais calculada para o ensaio confinado, cujo maciço de solo encontra-se reforçado com materiais geossintéticos. Sendo assim, a comparação entre o coeficiente de empuxo teórico e o coeficiente de empuxo reforçado calculado, tem o objetivo de mostrar a melhoria que a utilização de reforços no solo promove sob o aspecto de tensões horizontais. 


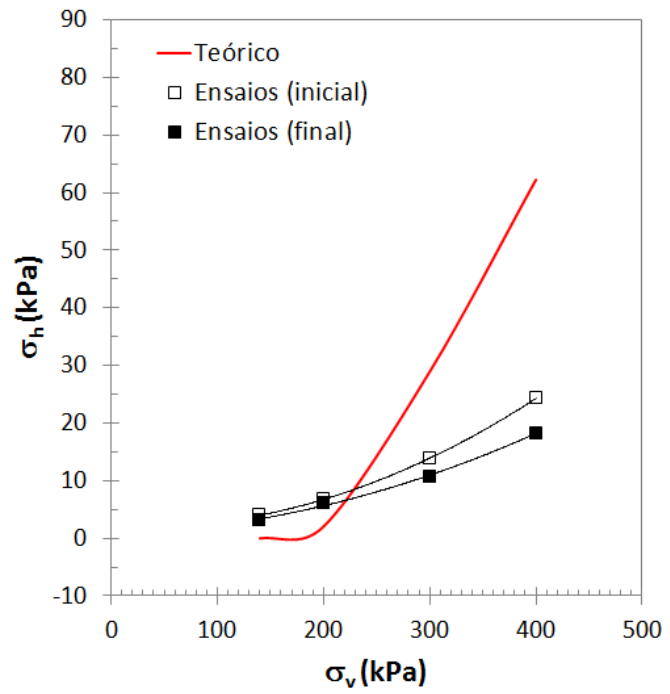

(a)

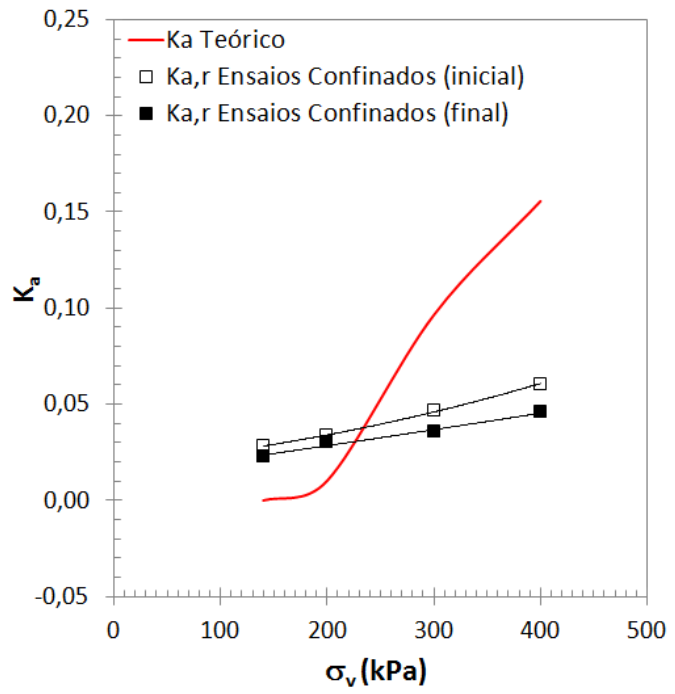

(b)

Figura 4.50 - Estado de tensões no maciço nos ensaios confinados de geotêxteis não tecidos: (a) Tensões horizontais $x$ verticais; (b) variação do coeficiente de empuxo ativo $\left(k_{\mathrm{a}}\right)$ para diferentes tensões verticais.

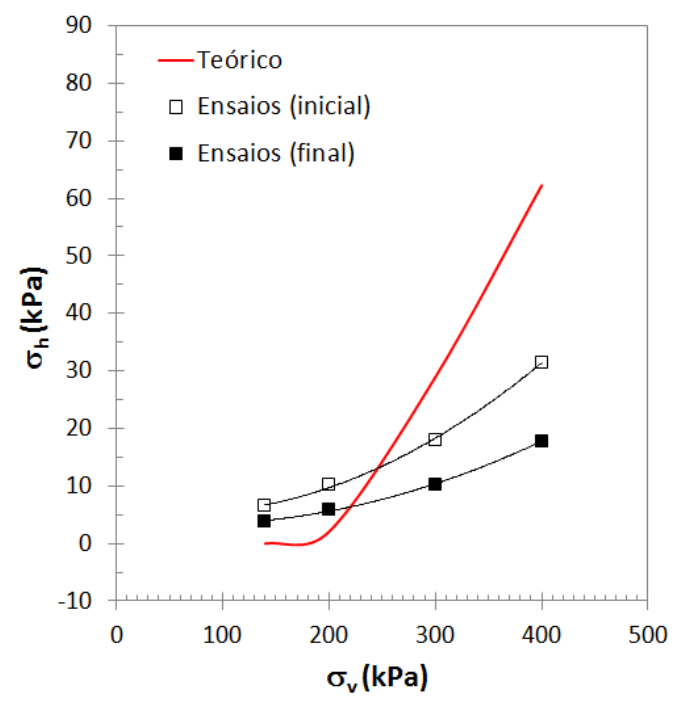

(a)

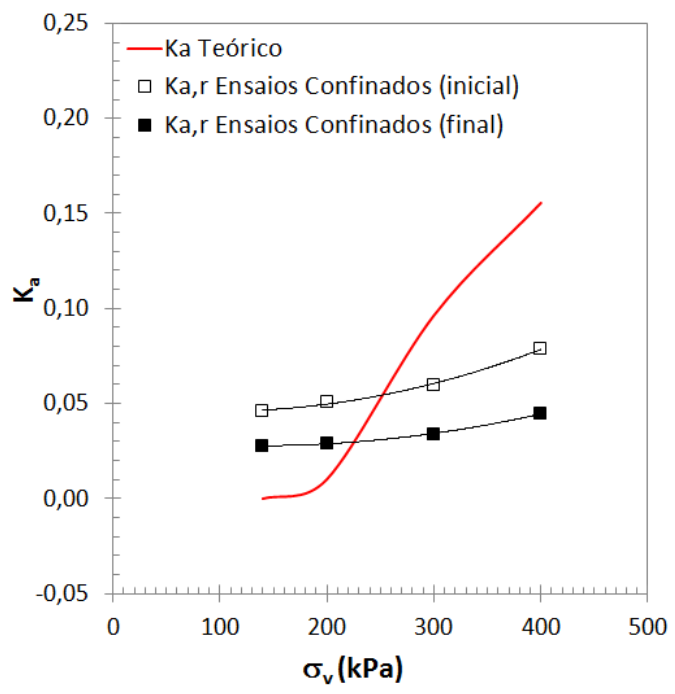

(b)

Figura 4.51 - Estado de tensões no maciço nos ensaios confinados de geotêxteis tecidos: (a) Tensões horizontais x verticais; (b) variação do coeficiente de empuxo ativo $\left(k_{a}\right)$ para diferentes tensões verticais. 


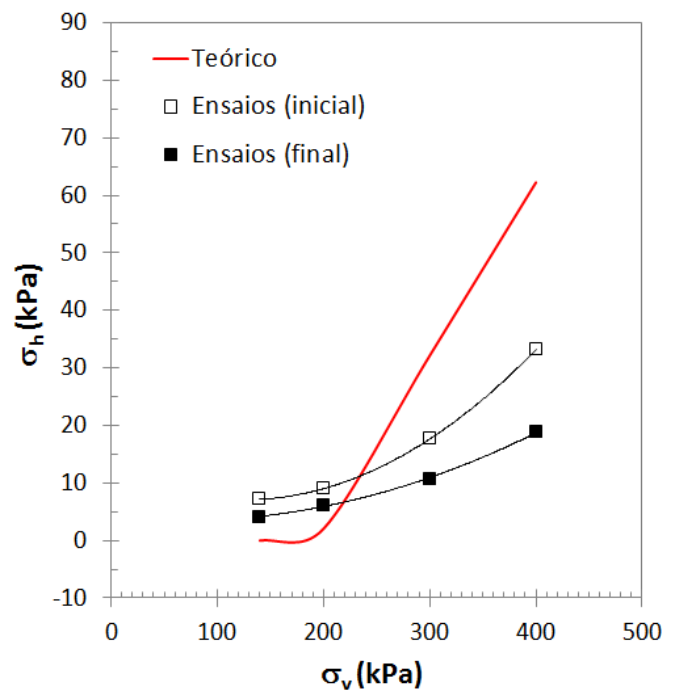

(a)

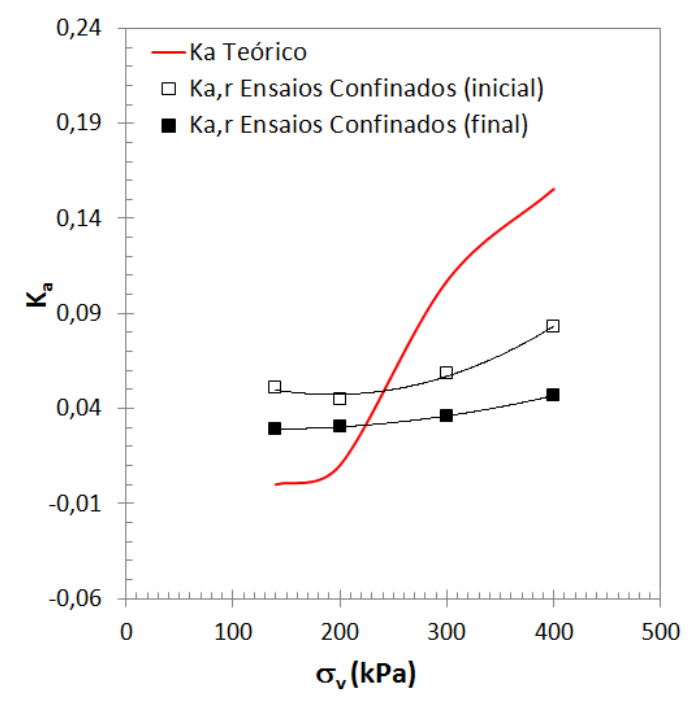

(b)

Figura 4.52 - Estado de tensões no maciço nos ensaios confinados de geogrelhas: (a) Tensões horizontais $x$ verticais; (b) variação do coeficiente de empuxo ativo $\left(k_{a}\right)$ para diferentes tensões verticais.

Observa-se que, para todos os casos, os valores teóricos do coeficiente de empuxo ativo $\left(K_{a}\right)$ e da tensão horizontal foram menores que os valores reais registrados nos ensaios com carregamentos verticais de $140 \mathrm{kPa}$ e $200 \mathrm{kPa}$. Para carregamentos verticais acima de $200 \mathrm{kPa}$ este comportamento se inverte, e o valores registrados nos ensaios passam a ser menores que os valores teóricos. As Figuras 4.50, $4.51 \mathrm{e}$ 4.52 mostram ainda que, quanto menor a tensão vertical aplicada nos ensaios confinados, mais os resultados teóricos e práticos se aproximam. Para os casos dos carregamentos verticais de $140 \mathrm{kPa}$ e $200 \mathrm{kPa}$, os valores das tensões horizontais e dos coeficientes de empuxo iniciais para solos reforçados, calculados por meio dos ensaios confinados, são muito próximos aos valores dos coeficiente de empuxo teóricos para solo não reforçados. Conforme o carregamento vertical é aumentado, a diferença entre os valores dos coeficientes de empuxo reforçados e não reforçados aumenta.

A Figura 4.53 mostra uma comparação entre os coeficientes de empuxo reforçados, na situação final de ensaio, obtidos para cada um dos tipos de reforços utilizados. Observa-se que as curvas de variação dos coeficientes em função do carregamento vertical apresentam uma forma muito parecida entre os reforços considerados. Notase que os valores dos coeficientes de empuxo reforçados são muitos próximos entre si, exceto para o caso de menor carregamento vertical em que o coeficiente de 
empuxo reforçado para o geotêxtil não tecido apresentou valor menor quando comparado ao geotêxtil tecido e à geogrelha.

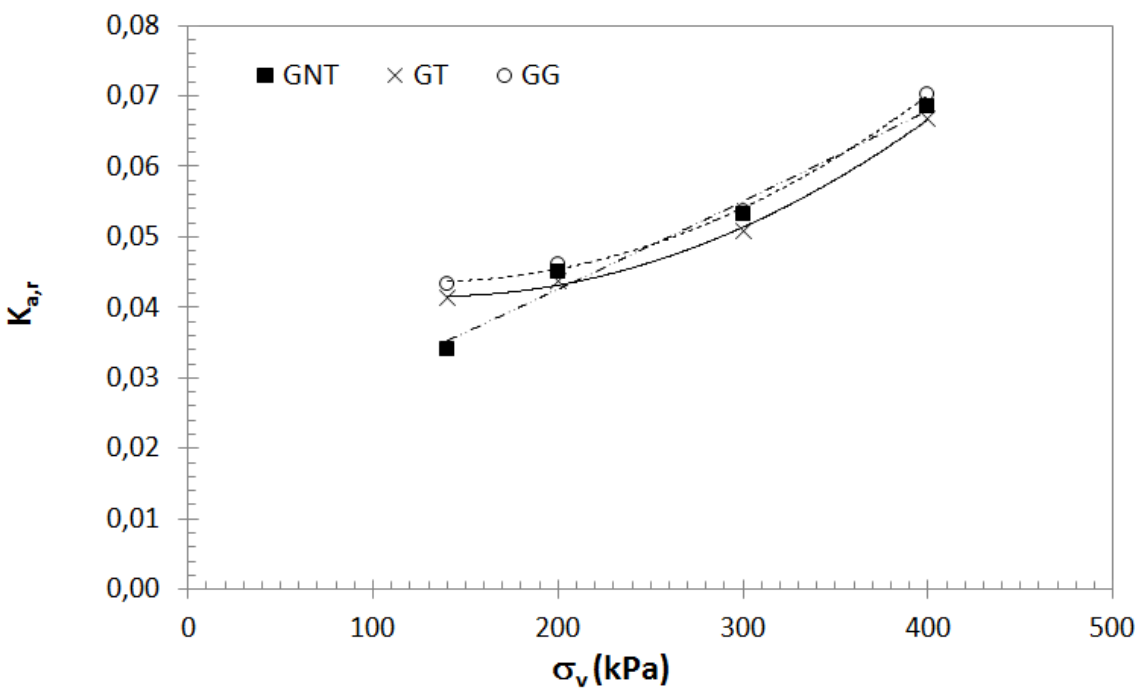

Figura 4.53 - Comparação entre os coeficientes de empuxo reforçados $\left(\mathrm{K}_{\mathrm{a}, \mathrm{r}}\right)$ ao final do ensaio para os diferentes reforços testados.

Este item apresentou as trajetórias de tensões dos ensaios de fluência confinada bem como a variação dos coeficientes de empuxo dos solos reforçados em função dos carregamentos verticais aplicados. De forma geral observa-se que os carregamentos horizontais medidos nos ensaios confinados foram muito baixos. Pode-se notar que para o caso mais crítico, referente ao ensaio confinado realizado com geogrelha e carregamento vertical de $400 \mathrm{kPa}$, o coeficiente de empuxo do solo reforçado foi de aproximadamente 0,07 . Para os demais tipos de reforços e carregamentos, foram observados coeficientes de empuxo ainda menores, comprovando o bom desempenho dos solos reforçados com materiais geossintéticos.

\subsubsection{Análise conjunta dos resultados dos ensaios de fluência}

Neste item são apresentadas análises conjuntas dos ensaios confinados e não confinados. Os ensaios confinados incluem tanto os resultados dos ensaios com variação de carregamento vertical quanto os ensaios com variação da umidade de compactação, incluindo os ensaios realizados com inundação. As Figuras 4.54, 4.55 
e 4.56 mostram a variação do parâmetro "a", do parâmetro " $b$ " e do módulo de rigidez em função da relação $\mathrm{T} / \mathrm{T}_{\text {ult, }}$ para os geotêxteis não tecidos, geotêxteis tecidos e geogrelhas, respectivamente.

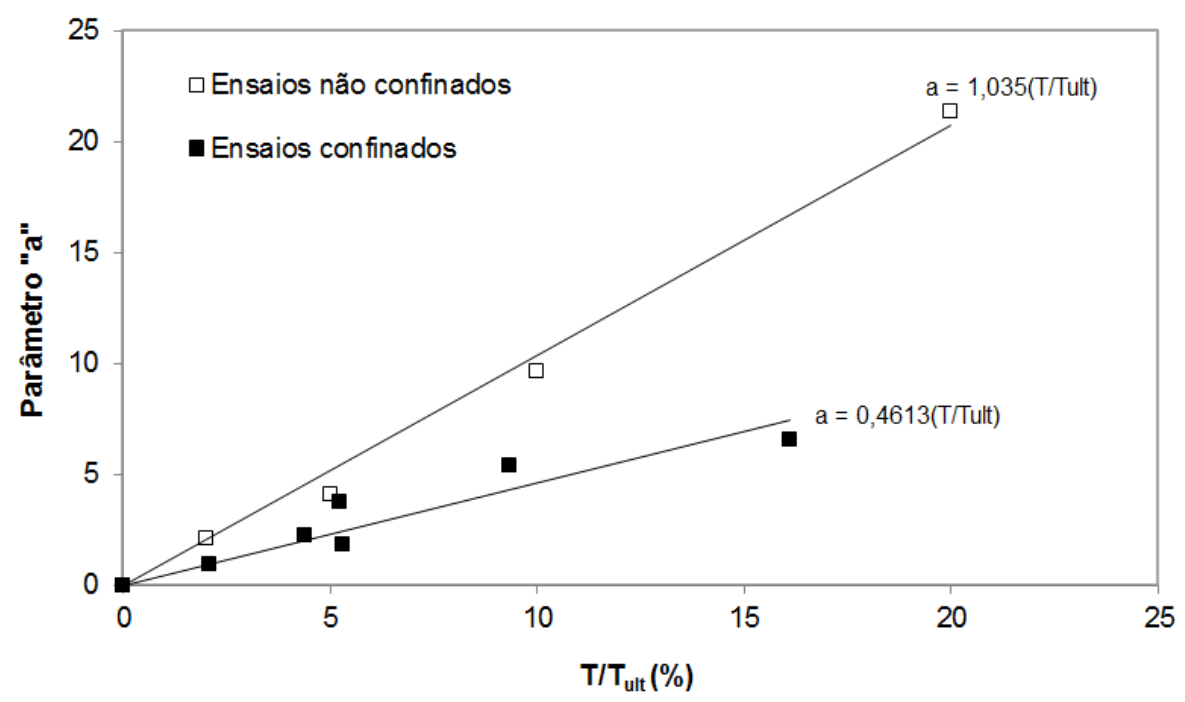

(a)

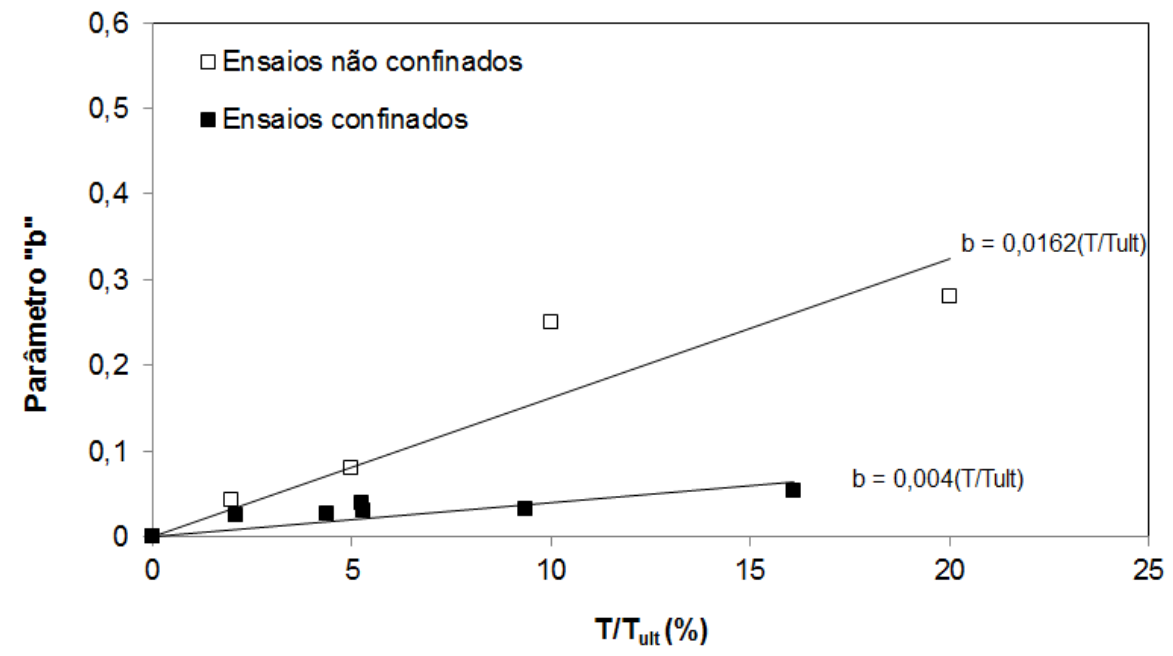

(b) 


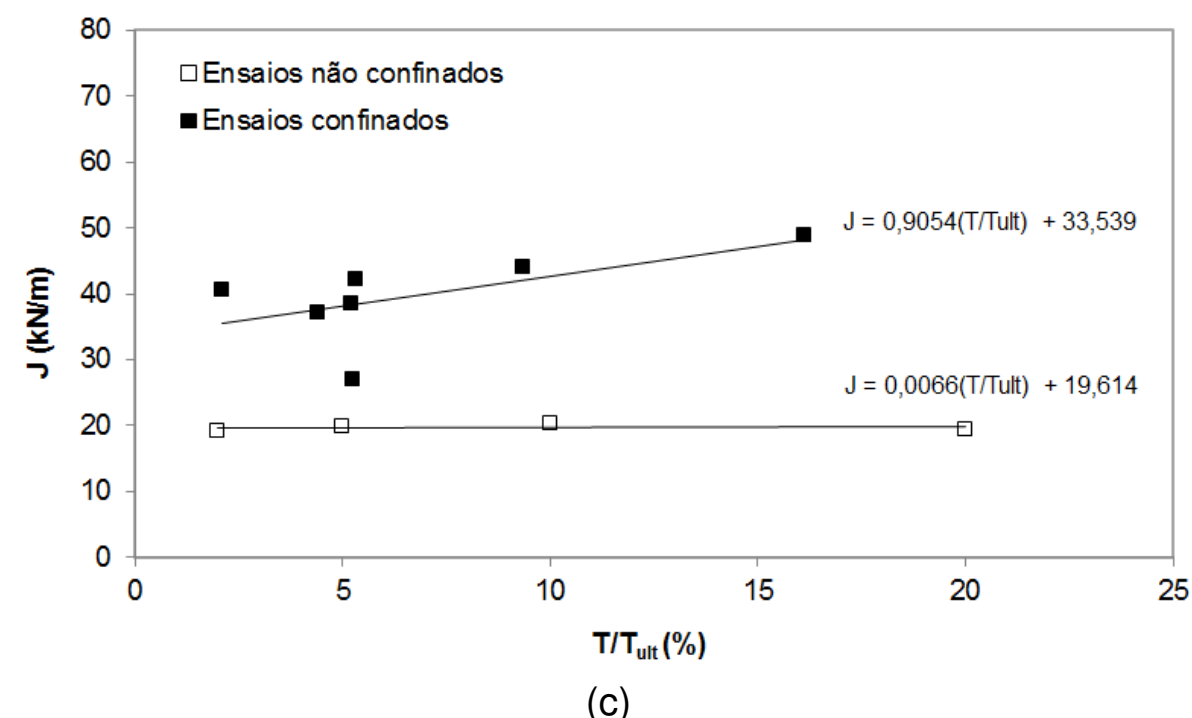

Figura 4.54 - Variação dos parâmetros de deformação e rigidez em função de $T / T_{\text {ult }}$ para os geotêxteis não tecidos: (a) variação do parâmetro "a" da equação logarítmica; (b) Variação do parâmetro "b" da equação logarítmica; (c) Variação do módulo de rigidez

As Figuras 4.54a, b e c mostram que a variação dos parâmetros de ajuste da equação logarítmica ( $a$ e $b$ ) e a variação do módulo de rigidez em função da relação $\mathrm{T} / \mathrm{T}_{\mathrm{ult}}$, apresentam comportamentos distintos para os ensaios confinados e não confinados. Observa-se que os parâmetros "a" e "b" são menores para os ensaios confinados. Já o módulo de rigidez é menor para os ensaios em isolamento.

Este comportamento vai de encontro a diversos relatos encontrados na bibliografia. Msouti et al. (1997) indicam que em geotêxteis não tecidos a estricção do material é reduzida pelo efeito do confinamento em solo, restringindo a movimentação das fibras. Segundo Costa (2004), a estricção do geotêxtil pode ser reduzida devido ao atrito solo-reforço na direção perpendicular à solicitação, devido ao aumento do atrito entre as fibras em função da tensão normal aplicada, ou ainda devido a uma possível impregnação de solo na manta, diminuindo a possibilidade de deslizamento entre as fibras. Comportamento semelhante a este foi observado também por Koerner (2012) e Wu e Hong (1994).

As variações dos parâmetros de deformação e rigidez em função de $T / T_{\text {ult }}$ para os geotêxteis tecidos são apresentas na Figura 4.55. 


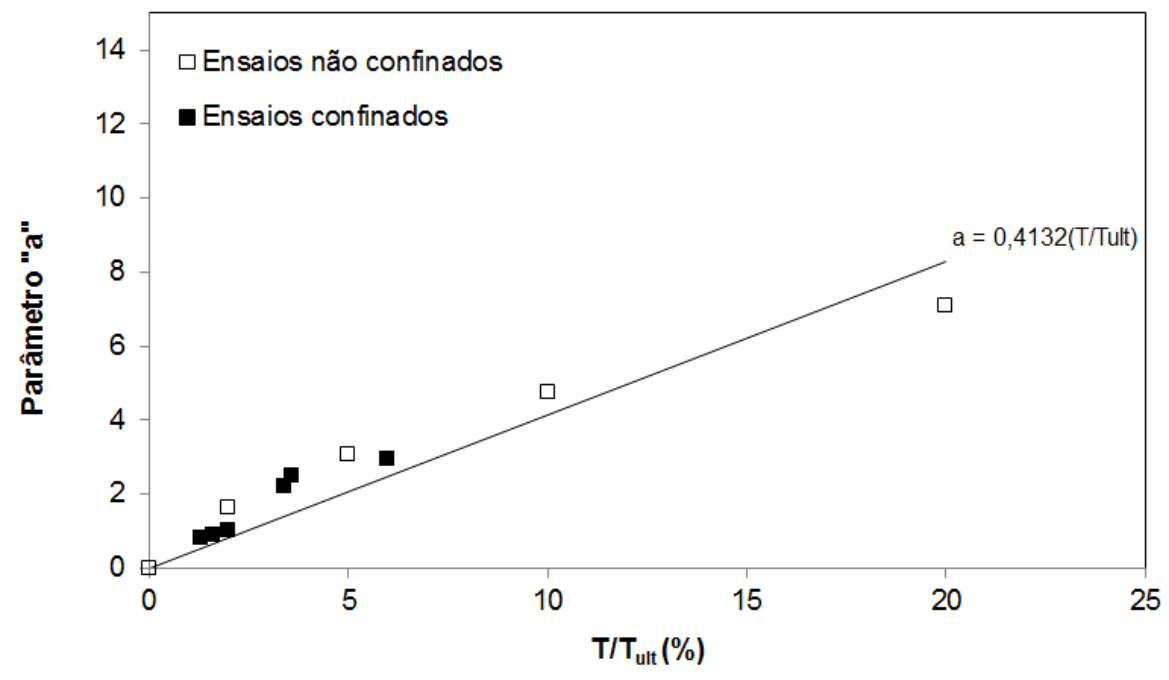

(a)

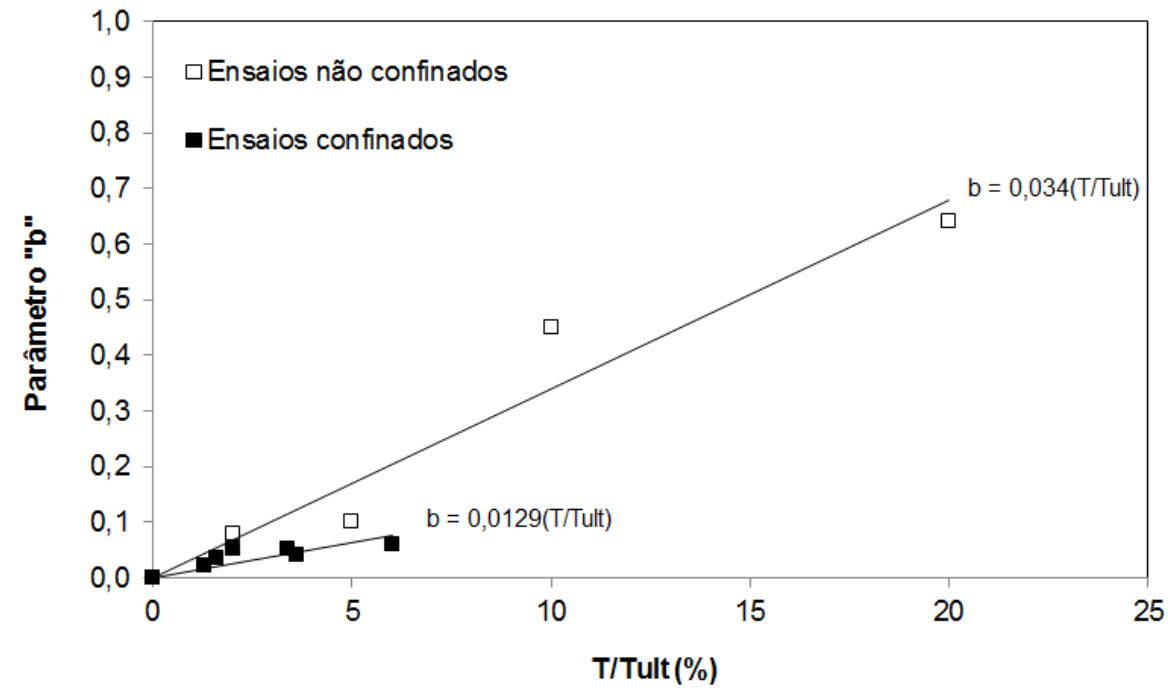

(b) 


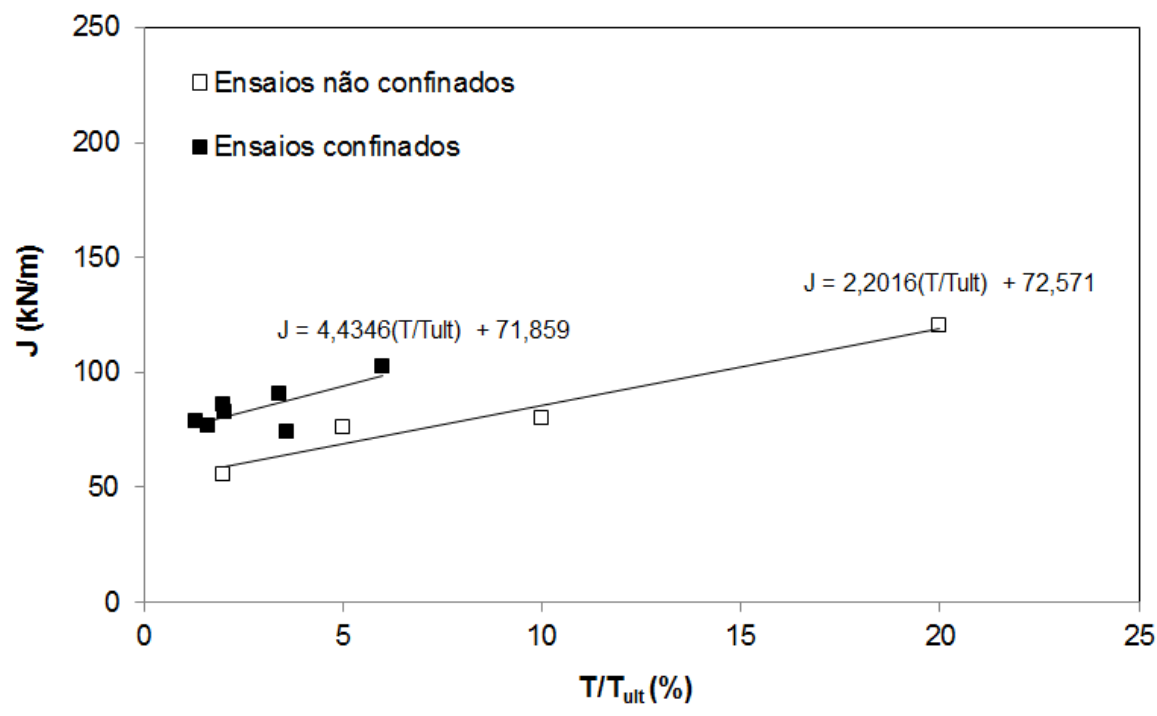

(c)

Figura 4.55 - Variação dos parâmetros de deformação e rigidez em função de $T / T_{\text {ult }}$ para os geotêxteis tecidos: (a) variação do parâmetro "a" da equação logarítmica; (b) Variação do parâmetro "b" da equação logarítmica; (c) Variação do módulo de rigidez.

A Figura 4.55a mostra que a variação parâmetro "a" da equação logarítmica em função da relação $T / T_{\text {ult }}$ para os ensaios confinados e não confinados com geotêxteis tecidos podem ser representados por um único ajuste de curva. Isto indica que o confinamento não exerceu influência ou exerceu uma influencia muito pouco significativa sobre as deformações iniciais dos reforços.

Por outro lado, o confinamento exerceu uma influência sobre o parâmetro "b", que se refere à tendência à fluência do reforço. A Figura $4.55 \mathrm{~b}$ mostra que os ensaios confinados e isolados não podem ser representados por uma curva única. Nota-se ainda que a influência do confinamento na fluência dos reforços foi consideravelmente menor para os geotêxteis tecidos em relação aos não tecidos.

As mesmas observações realizadas para o parâmetro "b" são válidas para a variação do módulo de rigidez em função do carregamento (Figura 4.55c). Nota-se que a presença do confinamento conduziu ao aumento dos módulos de rigidez dos geotêxteis tecidos, embora este aumento não seja tão pronunciado quanto o observado para os geotêxteis não tecidos.

Este comportamento também vai de encontro a relatos encontrados na bibliografia. Alguns autores destacam que os geotêxteis tecidos, ao contrario dos não tecidos, tem demostrado pouca ou nenhuma diferença em seu comportamento de fluência 
por efeito do confinamento (LEVACHER et al., 1994; KOERNER, 2012; MSOUTI et al., 1997).

As variações dos parâmetros de deformação e rigidez em função de $T / T_{\text {ult }}$ para as geogrelhas são apresentas na Figura 4.56.

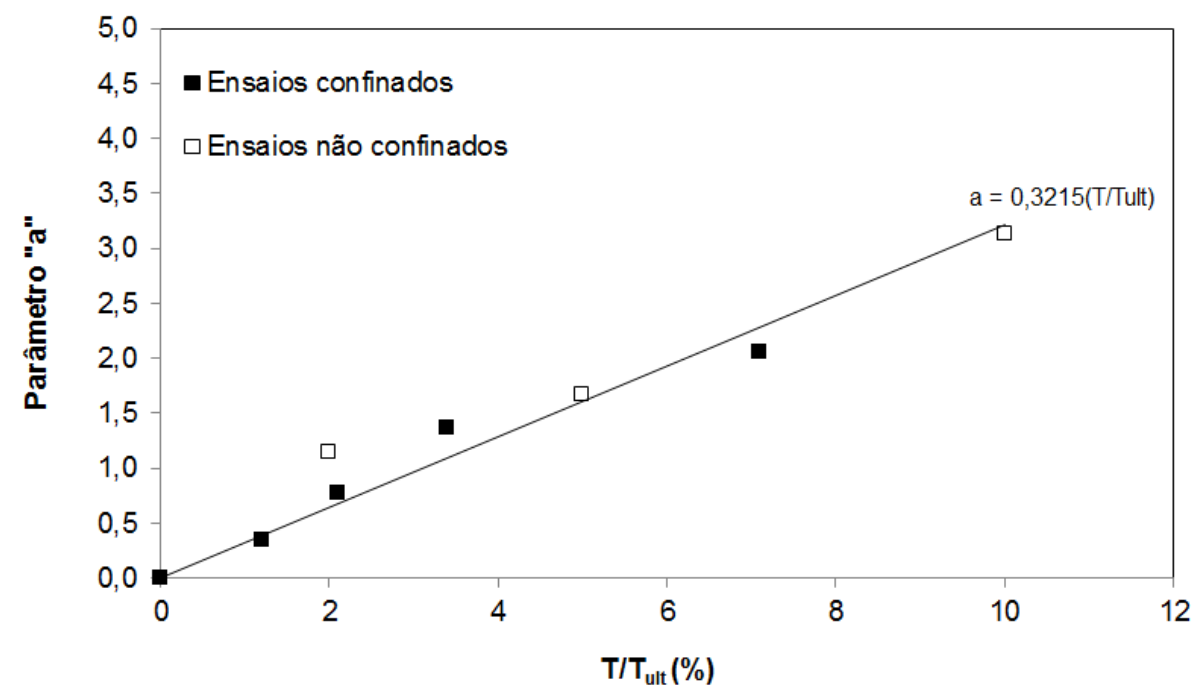

(a)

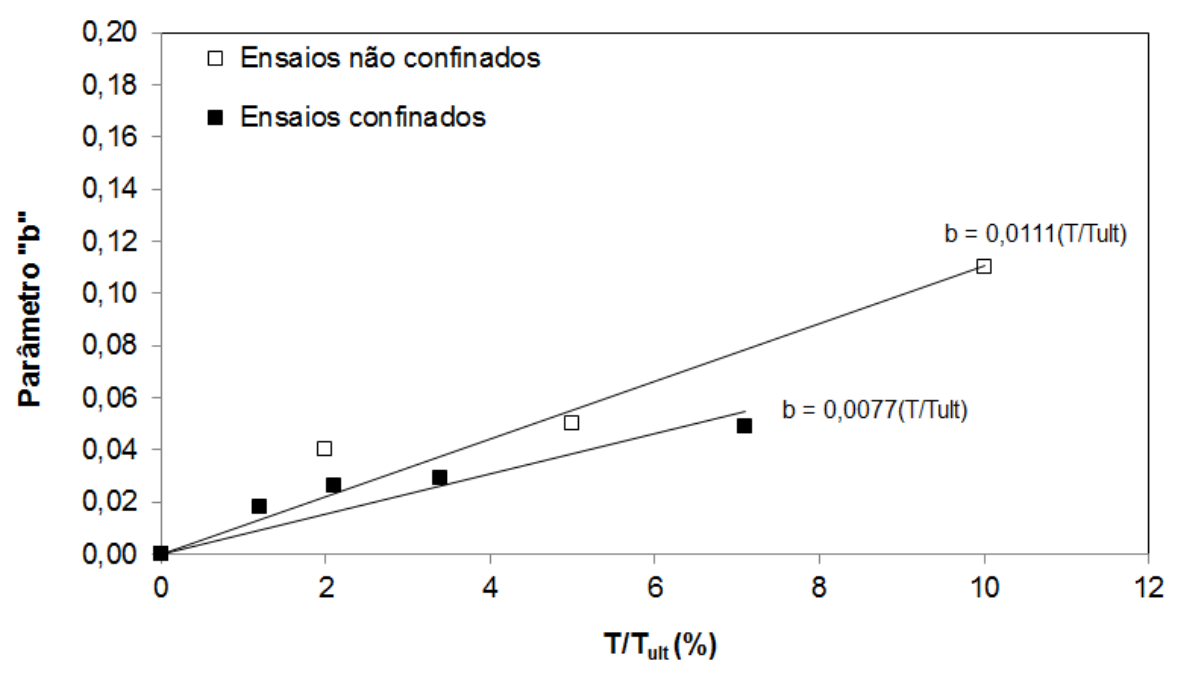

(b) 


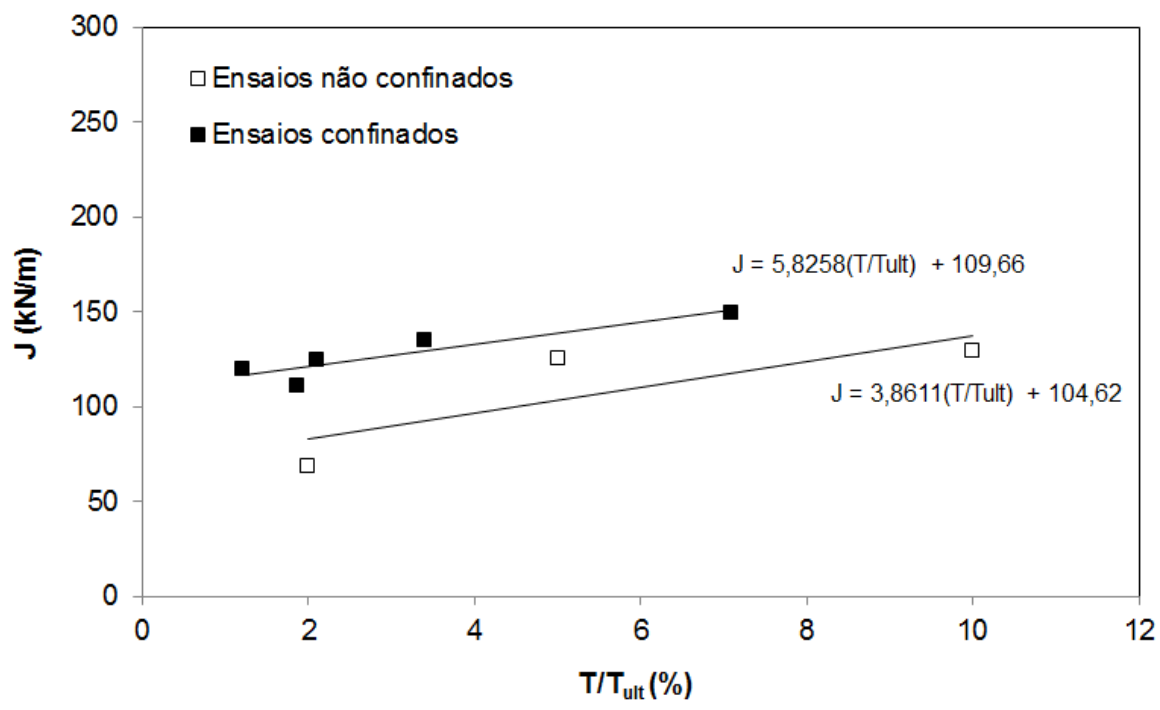

(c)

Figura 4.56 - Variação dos parâmetros de deformação e rigidez em função de $T / T_{\text {ult }}$ para as geogrelhas: (a) variação do parâmetro "a" da equação logarítmica; (b) Variação do parâmetro "b" da equação logarítmica; (c) Variação do módulo de rigidez.

A Figura 4.56 mostra que o comportamento das geogrelhas foi muito semelhante ao comportamento observado para os geotêxteis tecidos. Nota-se que as deformações iniciais, representadas pelo parâmetro "a", não foram afetadas pelo efeito do confinamento (Figura 4.56a). Já a tendência à fluência dos reforços, representados pelo parâmetro "b", e o módulo de rigidez (J), foram influenciados de maneira pouco significativa pelo confinamento em solo (Figuras $4.56 \mathrm{~b}$ e c).

De forma geral, os resultados dos ensaios confinados realizados no equipamento de interação solo-reforço desenvolvido por Costa (2004) mostraram que o confinamento influenciou tanto na deformação inicial quanto na tendência à fluência do reforço para o caso dos geotêxteis não tecidos. Para o caso dos geotêxteis tecidos e geogrelhas o confinamento influenciou apenas na tendência à fluência dos materiais, enquanto as deformações iniciais aparentemente não foram afetadas. Estes resultados corroboram as informações encontradas na bibliografia apresentadas por Kamiji (2006), França (2011) e Avesani (2013).

A Figura 4.57 mostra a variação dos parâmetros "a" e "b" da equação logarítmica em função da solicitação no reforço ( $T / T_{\text {ult }}$ ) obtida nos ensaios de fluência confinada realizados com geotêxteis não tecidos de polipropileno e poliéster, apresentados por 
Kamiji (2006). Destaca-se que os ensaios realizados por Kamiji (2006) foram realizados empregando o equipamento de interação desenvolvido por Costa (2004).
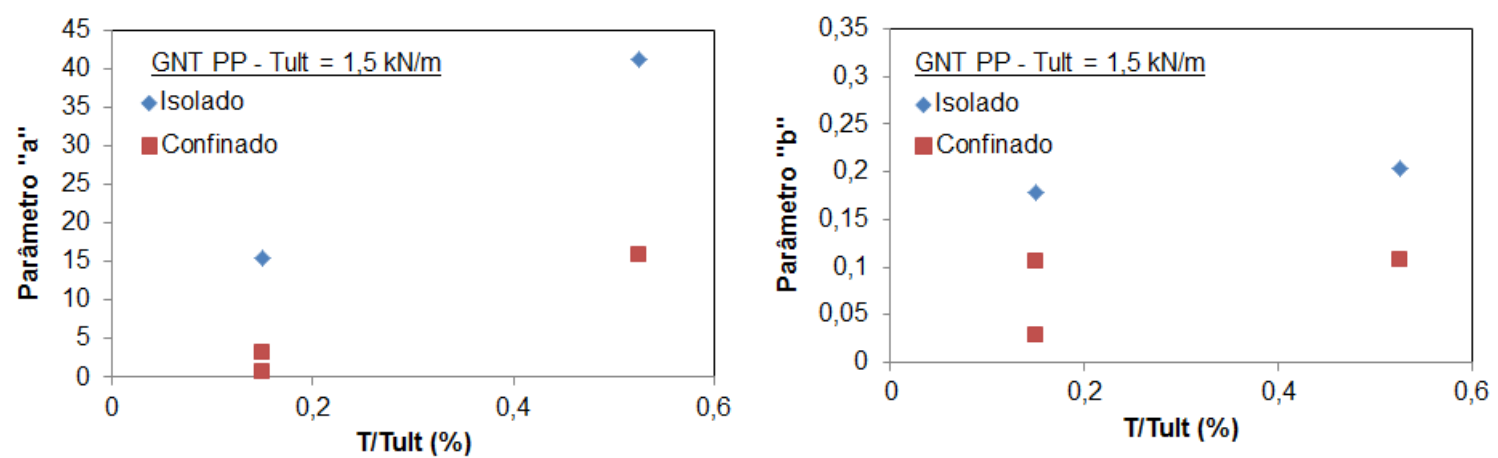

(a)
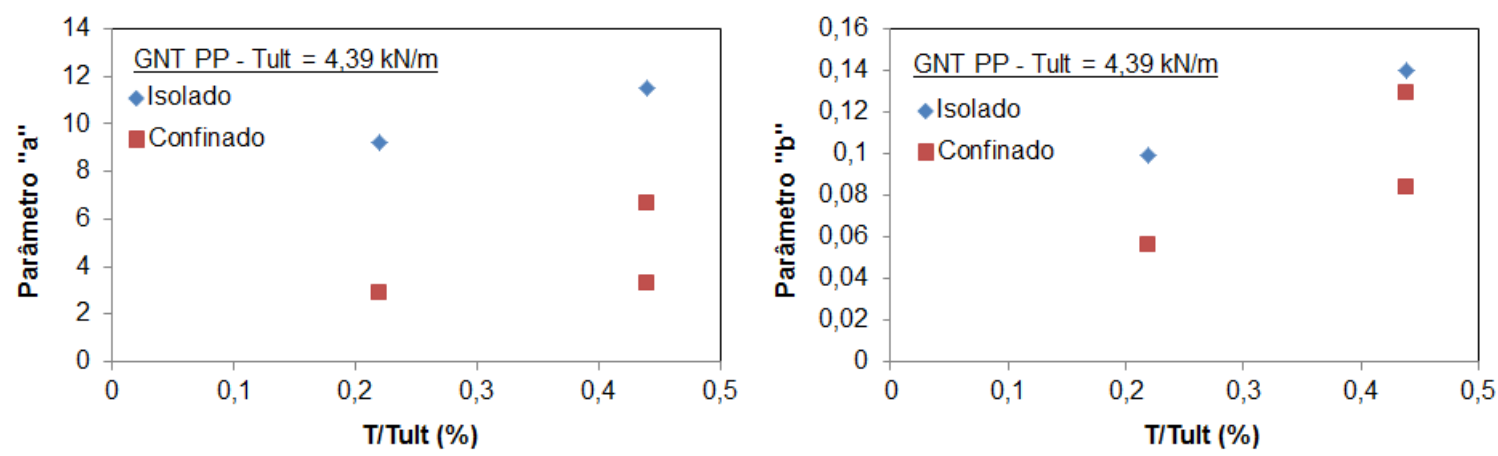

(b)
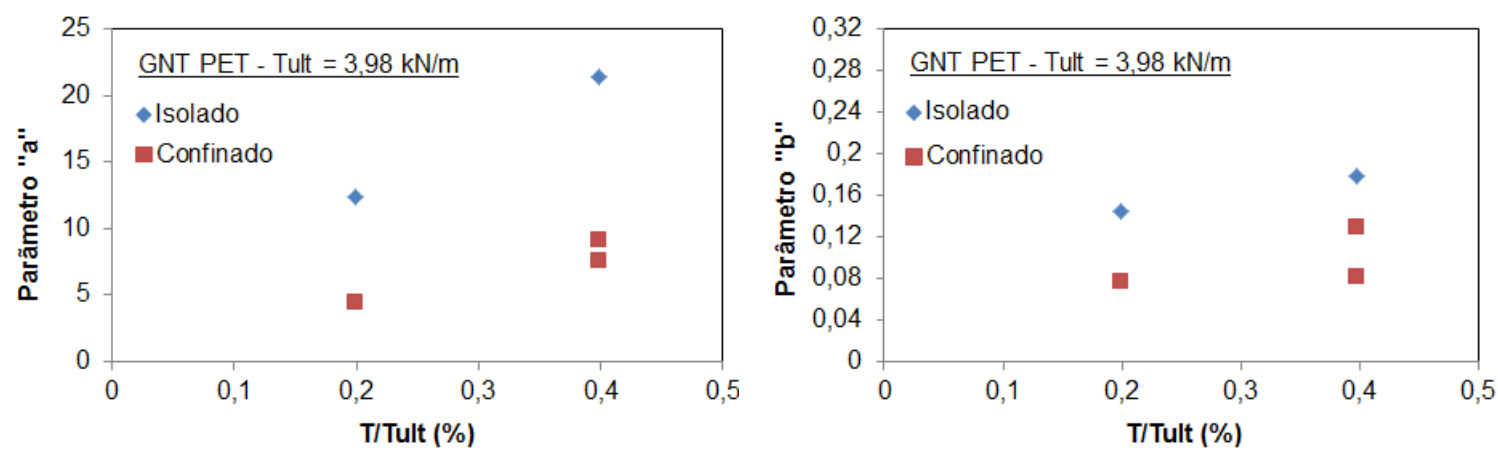

(c)

Figura 4.57 - Dados de variação dos parâmetros "a" e "b" em função de $T / T_{\text {ult }}$ apresentados por Kamiji (2006) para: (a) geotêxtil não tecido de polipropileno com resistência de 1,5 kN/m; (b) geotêxtil não tecido de polipropileno com resistência de $4,39 \mathrm{kN} / \mathrm{m}$; (c) geotêxtil não tecido de poliéster com resistência de $3,98 \mathrm{kN} / \mathrm{m}$.

A Figura 4.58, por sua vez, mostra a variação dos parâmetros $\varepsilon_{0}$ e T $\alpha$ do método de Zornberg; Byler e Knudsen (2004) em função da relação $T / T_{\text {ult }}$ obtida a partir dos resultados dos ensaios de fluência confinada realizados com geotêxteis não tecidos 
de poliéster, geogrelhas de poliéster e geotêxteis tecidos de polipropileno, apresentados por França (2011).
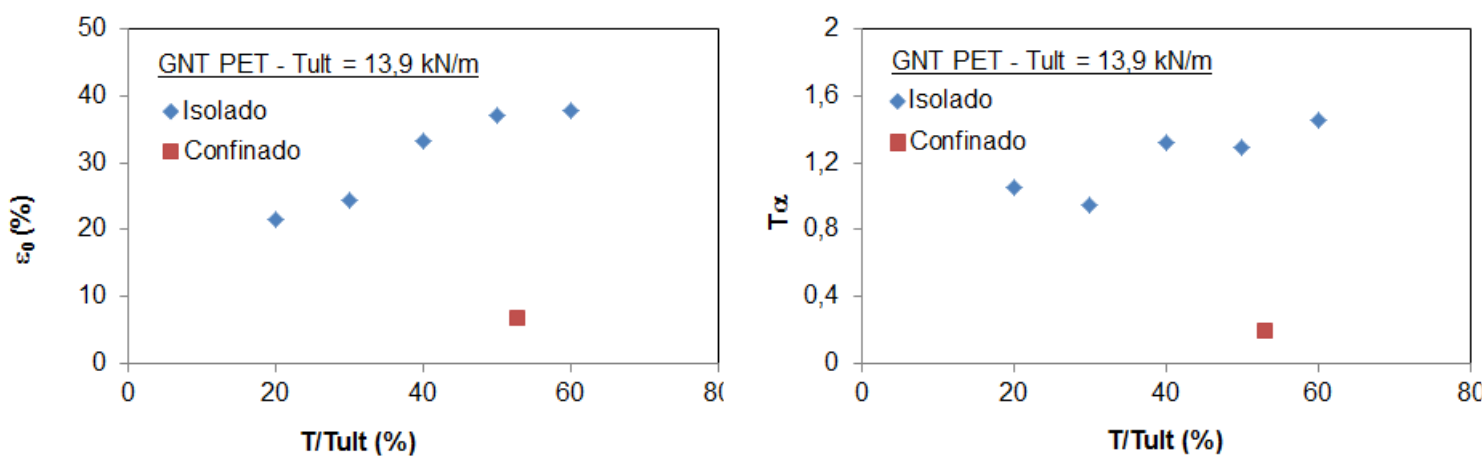

(a)
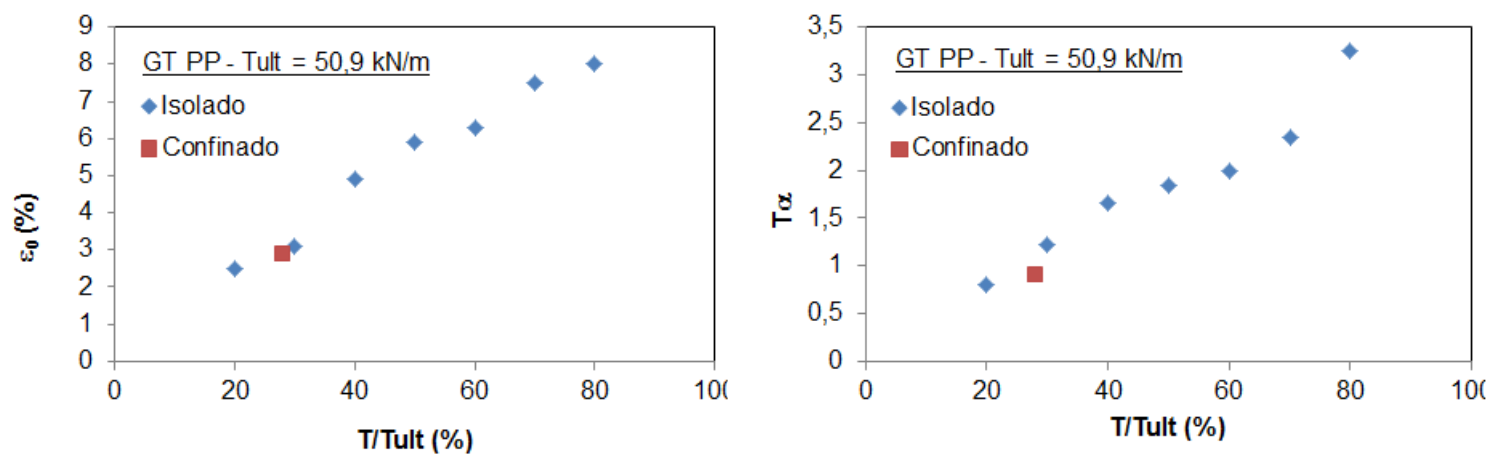

(b)
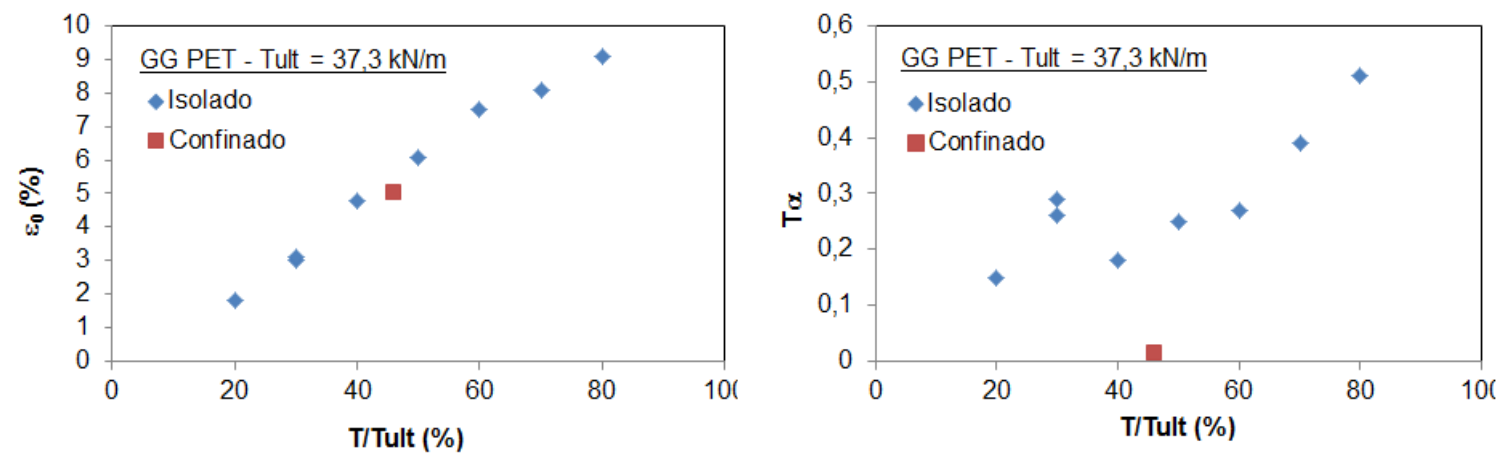

(c)

Figura 4.58 - Dados de variação dos parâmetros $\varepsilon_{0}$ e $T \alpha$ em função de $T / T_{\text {ult }}$ apresentados por França (2011) para: (a) geotêxtil não tecido de poliéster com resistência de $13,9 \mathrm{kN} / \mathrm{m}$; (b) geotêxtil tecido de polipropileno com resistência de $50,9 \mathrm{kN} / \mathrm{m}$; (c) geogrelha de poliéster com resistência de $37,3 \mathrm{kN} / \mathrm{m}$.

Já a Figura 4.59 mostra a variação dos parâmetros de deformação "a" e "b" em função do carregamento no reforço para geotêxteis não tecidos e tecidos de poliéster a partir dos ensaios de fluência confinada publicados por Avesani (2013). 

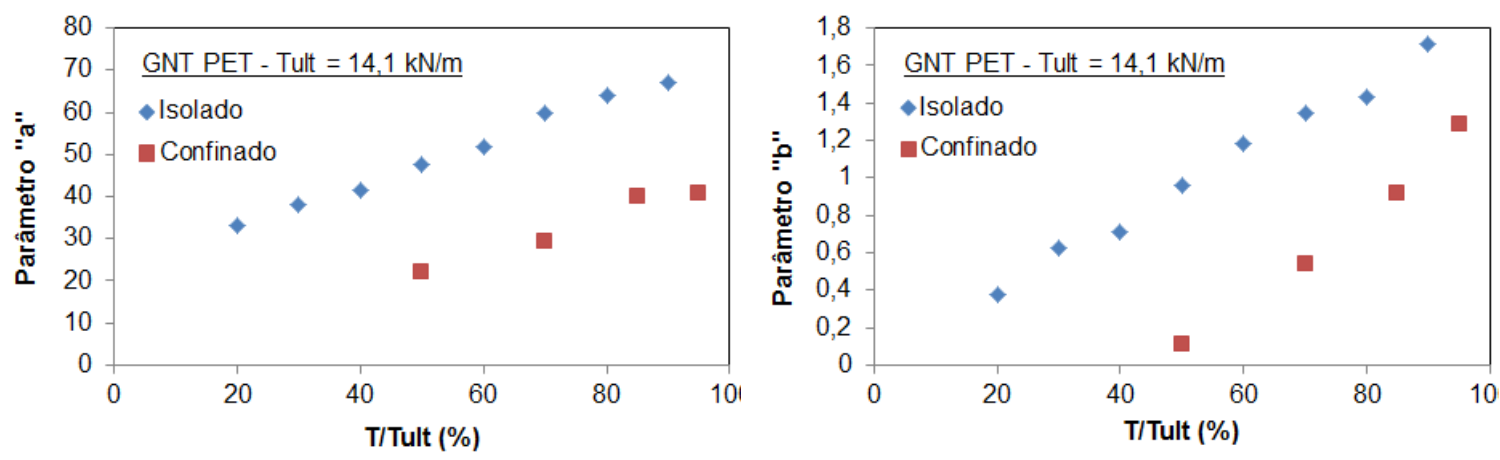

(a)
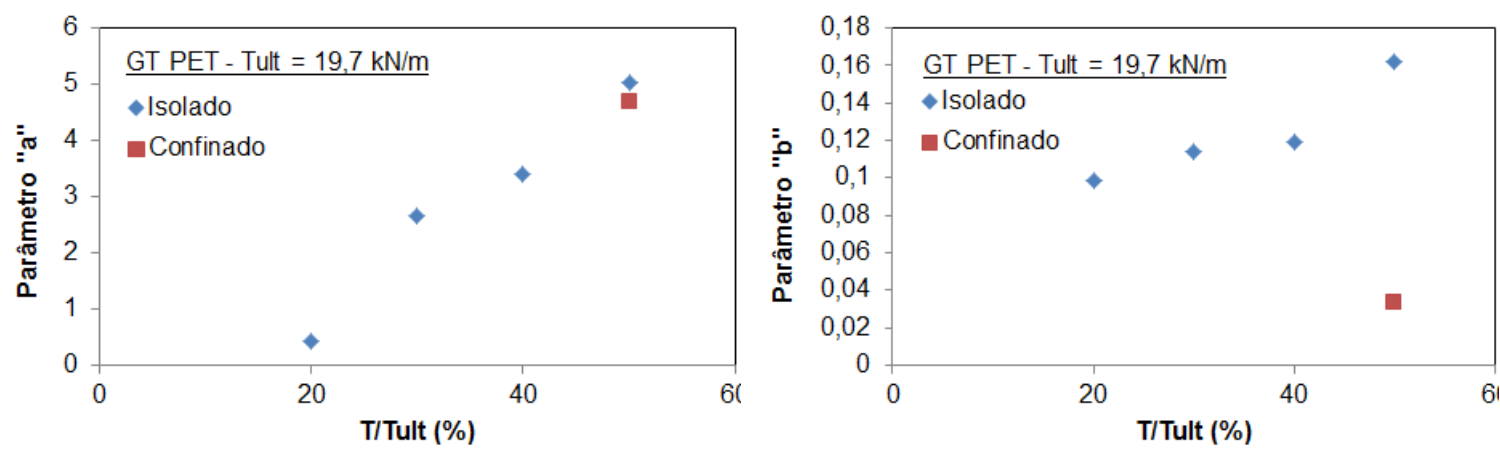

(b)

Figura 4.59 - Dados de variação dos parâmetros "a" e "b" em função de $T / T_{\text {ult }}$ apresentados por Avesani (2013) para: (a) geotêxtil não tecido de poliéster com resistência de 14,1 kN/m; (b) geotêxtil tecido de poliéster com resistência de $19,7 \mathrm{kN} / \mathrm{m}$.

As Figuras 4.57 a 4.59 mostram que para os geotêxteis não tecidos existe uma clara influencia do confinamento nos parâmetros relacionados à deformação inicial e tendência à fluência do reforço. Já para os geotêxteis tecidos e geogrelhas a deformação inicial foi influenciada de maneira pouco intensa pela presença do confinamento, enquanto que os parâmetros de fluência sofreram uma variação considerável.

Em função dos resultados obtidos nos ensaios de fluência confinada realizados no equipamento desenvolvido por Costa (2004) (Figura 4.54 a Figura 4.56) e das informações encontradas na bibliografia (Figura 4.57 a Figura 4.59), pode-se assumir que os parâmetros de deformação "a" e "b" e, consequentemente, a rigidez dos reforços, são dependentes do nível de confinamento sob o qual o reforço se encontra. A partir dessa premissa foram definidas equações genéricas de ajuste para a determinação da rigidez inicial dos reforços confinados e também do parâmetro que representa a tendência à redução da rigidez ao longo do tempo em função do nível de confinamento sob o qual o reforço encontra-se submetido. 
A variação da rigidez dos reforços em função do tempo é representada pela Equação 4.2.

$$
J(t)=J(1 h)+V_{J} \cdot \ln (t)
$$

Em que $J(1 h)$ representa a rigidez inicial do reforço para uma hora de ensaio, $V_{J}$ representa a tendência à redução da rigidez ao longo do tempo, e $t$ é o tempo. A função de ajuste para o parâmetro $\mathrm{J}(1 \mathrm{~h})$ é representada pela Equação 4.3.

$$
J(1 h)=J\left(1 h_{\text {isolamento }}\right)+\Delta J\left[1-\exp \left(-\alpha_{J} \cdot \sigma_{V}\right)\right]
$$

Em que:

$J\left(1 h_{\text {isolamento }}\right)$ - rigidez inicial do ensaio de fluência em isolamento;

$\Delta \mathrm{J}$ - parâmetro que representa a variação da rigidez inicial;

$\alpha_{J}$ - parâmetro de ajuste de forma da curva;

$\sigma_{v}-$ tensão de confinamento (tensão normal no reforço).

A função de ajuste para o parâmetro $V_{J}$ é representada pela Equação 4.4.

$$
V_{J}=V_{J, \text { isolamento }}+\Delta V_{J}\left[1-\exp \left(-\alpha_{V} \cdot \sigma_{V}\right)\right]
$$

Em que:

$\mathrm{V}_{\mathrm{J}, \text { isolamento }}$ - parâmetro que representa a tendência à redução da rigidez do ensaio de fluência em isolamento;

$\Delta \mathrm{V}_{\mathrm{J}}$ - parâmetro que representa a variação da tendência à redução da rigidez;

$\alpha_{V}$ - parâmetro de ajuste de forma da curva;

$\sigma_{v}-$ tensão de confinamento (tensão normal no reforço).

As curvas ajustadas para cada um dos reforços são mostradas na Figura 4.60. 


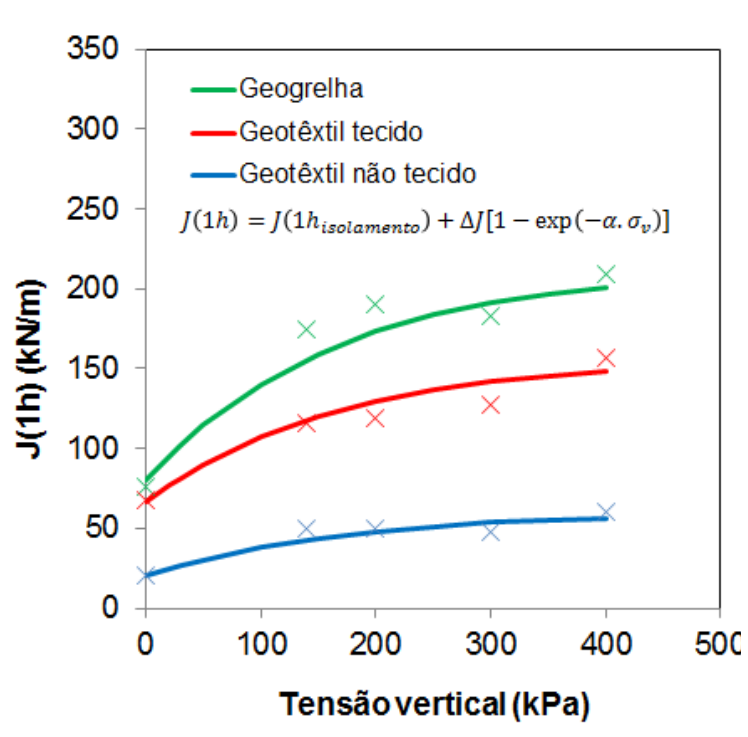

(a)

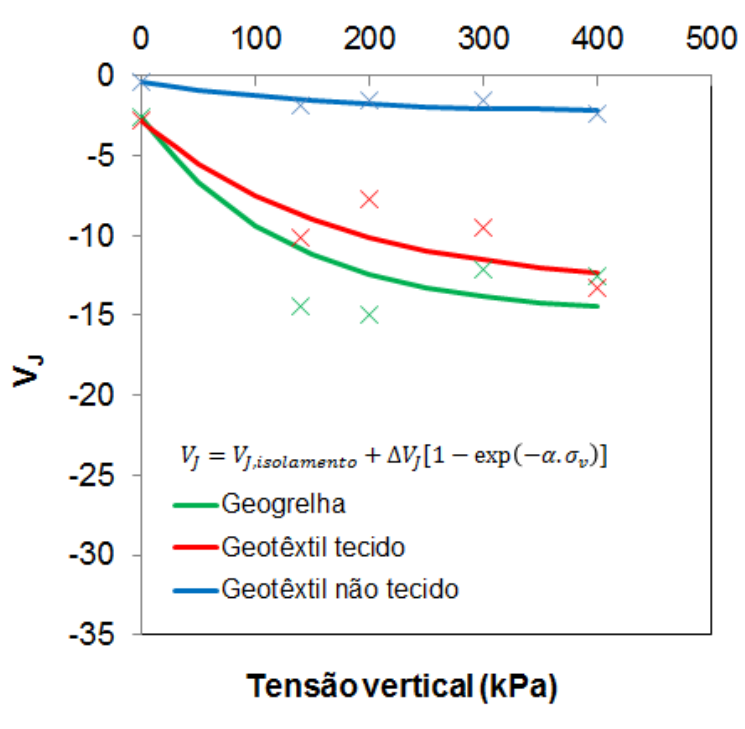

(b)

Figura 4.60 - Curvas de ajuste para cada tipo de reforço ensaiado para os parâmetros: (a) J(1h); (b) $V_{J}$.

Os parâmetros de ajuste para as funções representadas pelas Equações 4.3 e 4.4 são mostrados na Tabela 4.6.

Tabela 4.6 - Parâmetros de ajuste para as Equações de $J(1 h)$ e $V_{J}$.

\begin{tabular}{ccccc}
\hline \multirow{2}{*}{ Tipo de } & \multicolumn{4}{c}{ Parâmetro de ajuste } \\
\cline { 2 - 5 } Reforço & \multicolumn{3}{c}{$\mathrm{J}(1 \mathrm{~h})$} & \multicolumn{3}{c}{$\mathrm{V}_{\mathrm{J}}$} \\
\cline { 2 - 5 } & $\Delta \mathrm{J}$ & $\alpha_{J}$ & $\Delta \mathrm{V}_{\mathrm{J}}$ & $\alpha_{V}$ \\
\hline GNT & 40,33 & 0,006 & $-1,95$ & 0,006 \\
GT & 89,42 & 0,006 & $-10,47$ & 0,004 \\
GG & 133,24 & 0,006 & $-12,33$ & 0,008 \\
\hline
\end{tabular}

Em função das curvas de ajuste mostradas na Figura 4.60 e dos parâmetros apresentados na Tabela 4.6, é possível afirmar que as Equações 4.2, 4.3 e 4.4 podem ser utilizadas como um modelo analítico para a previsão do comportamento ao longo do tempo de reforços confinados a partir do resultado de ensaios em isolamento. 


\subsection{ENSAIOS DE FLUÊNCIA REALIZADOS NO EQUIPAMENTO DE FLUÊNCIA CONFINADA-ACELERADA}

Apresentam-se neste item os resultados dos ensaios de fluência em confinamento realizados no equipamento de fluência confinada-acelerada desenvolvido por França (2011).

Destaca-se que as análises foram realizadas sob duas abordagens distintas. $\mathrm{Na}$ primeira delas foram realizados ensaios sob temperatura ambiente $\left(23^{\circ} \mathrm{C}\right)$, para um carregamento vertical de $140 \mathrm{kPa}$, com solo compactado na umidade ótima e para três diferentes tipos de reforço: geotêxtil não tecido, geotêxtil tecido e geogrelha. Os carregamentos impostos nos reforços foram aproximadamente os mesmos carregamentos obtidos nos ensaios executados na caixa desenvolvida por Costa (2004), ou seja, com relações de $\mathrm{T} / \mathrm{T}_{\text {ult }}$ de $2 \%$ para os geotêxteis não tecidos, $1,6 \%$ para os geotêxteis tecidos e 1,5\% para as geogrelhas. Na segunda abordagem foram realizados os mesmo ensaios da campanha anterior, porém acelerados, ou seja, com uma temperatura maior que a temperatura ambiente da sala de ensaios. Para este caso foi utilizada uma temperatura de $38^{\circ} \mathrm{C}$. A realização dos ensaios acelerados com tal temperatura permitiu a previsão das deformações para períodos consideravelmente mais elevados que o tempo de execução do ensaio propriamente dito, chegando até 621 anos para o caso das geogrelhas. O método de extrapolação dos dados por meio do uso de ensaios acelerados foi apresentado no Capítulo 3 desta tese.

Cabe destacar ainda que, ao final dos ensaios acelerados, realizados sob temperatura de $38^{\circ} \mathrm{C}$, a perda de umidade de solo foi inferior a $1 \%$. Assim, considera-se que a variação de umidade não influenciou nos resultados dos ensaios.

\subsubsection{Resultados dos ensaios}

Os resultados dos ensaios realizados segundo as abordagens descritas acima são apresentados na Figura 4.61 (geotêxteis não tecidos), Figura 4.62 (geotêxteis tecidos) e Figura 4.63 (geogrelhas). 


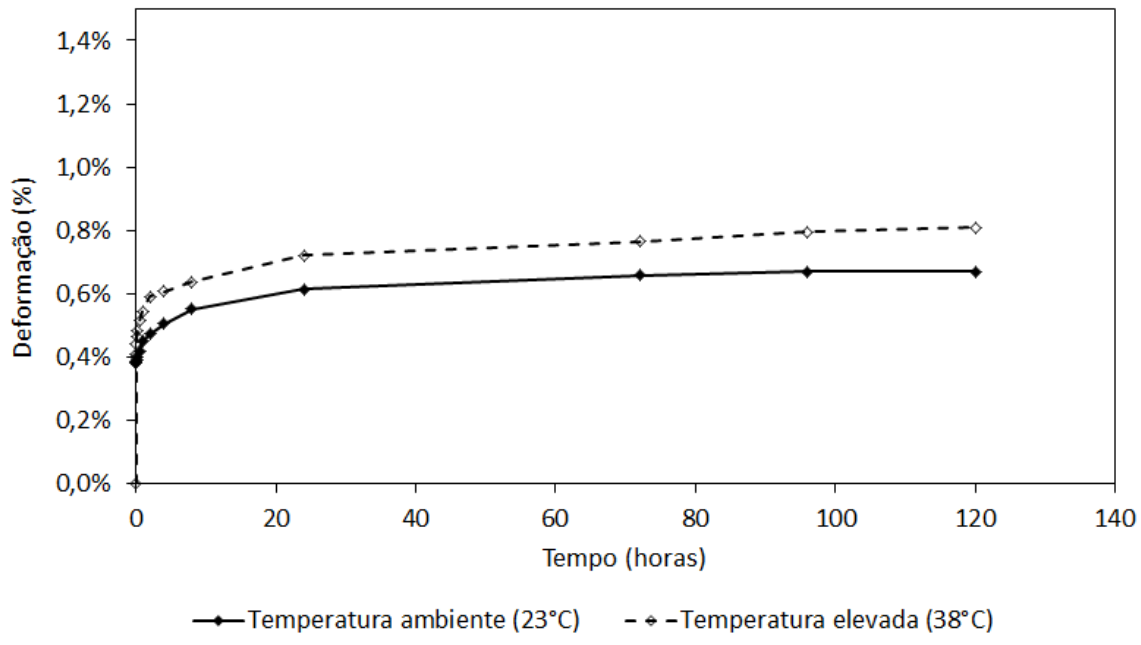

(a)

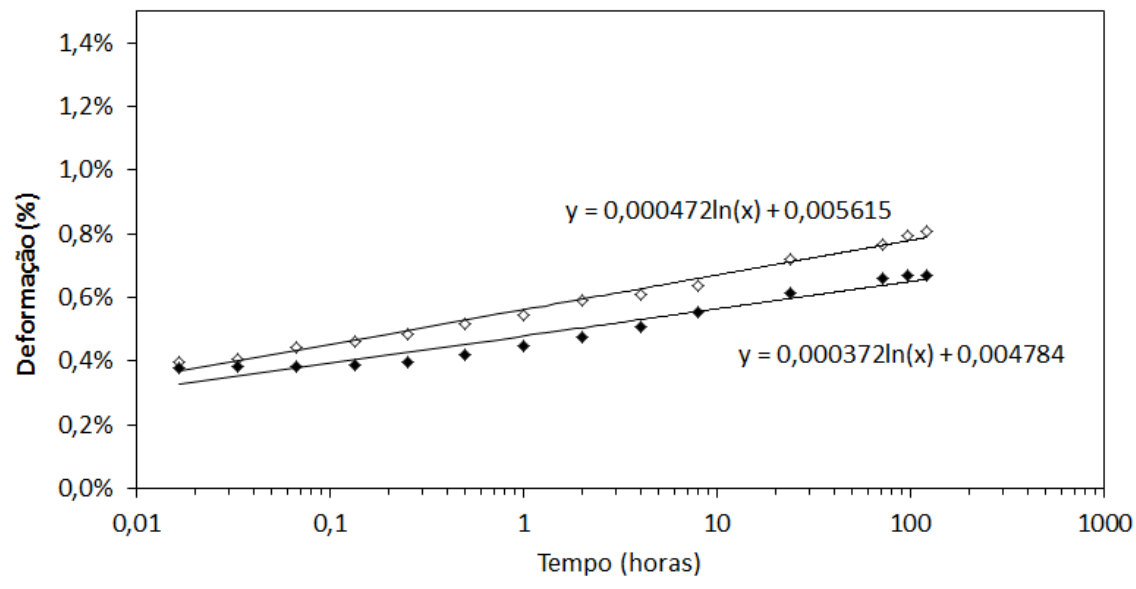

- Temperatura ambiente $\left(23^{\circ} \mathrm{C}\right) \quad \diamond$ Temperatura elevada $\left(38^{\circ} \mathrm{C}\right)$

(b)

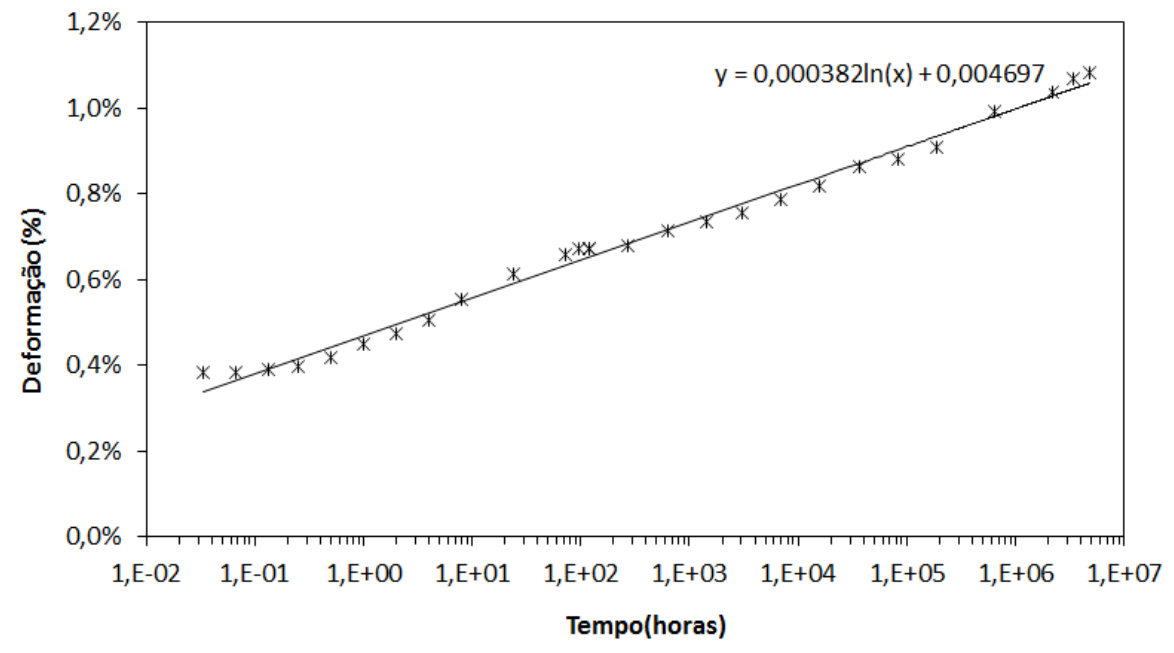

(c) 


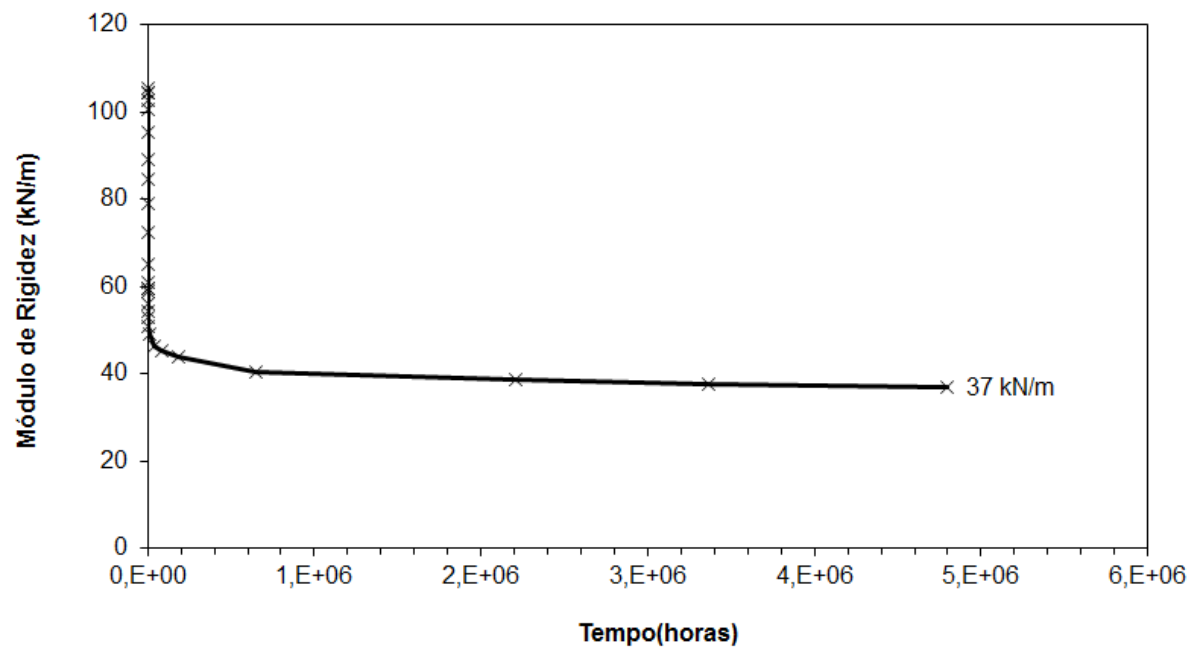

(d)

Figura 4.61 - Resultados dos ensaios de fluência confinada executados no equipamento de fluência confinada-acelerada para geotêxteis não tecidos, para duas temperaturas diferentes: (a) Variação das deformações ao longo do tempo; (b) Variação das deformações ao longo do tempo pelo método da equação logarítmica; (c) Variação das deformações ao longo do tempo extrapolado - Curva Mestra;

(d) Variação da rigidez confinada ao longo do tempo.

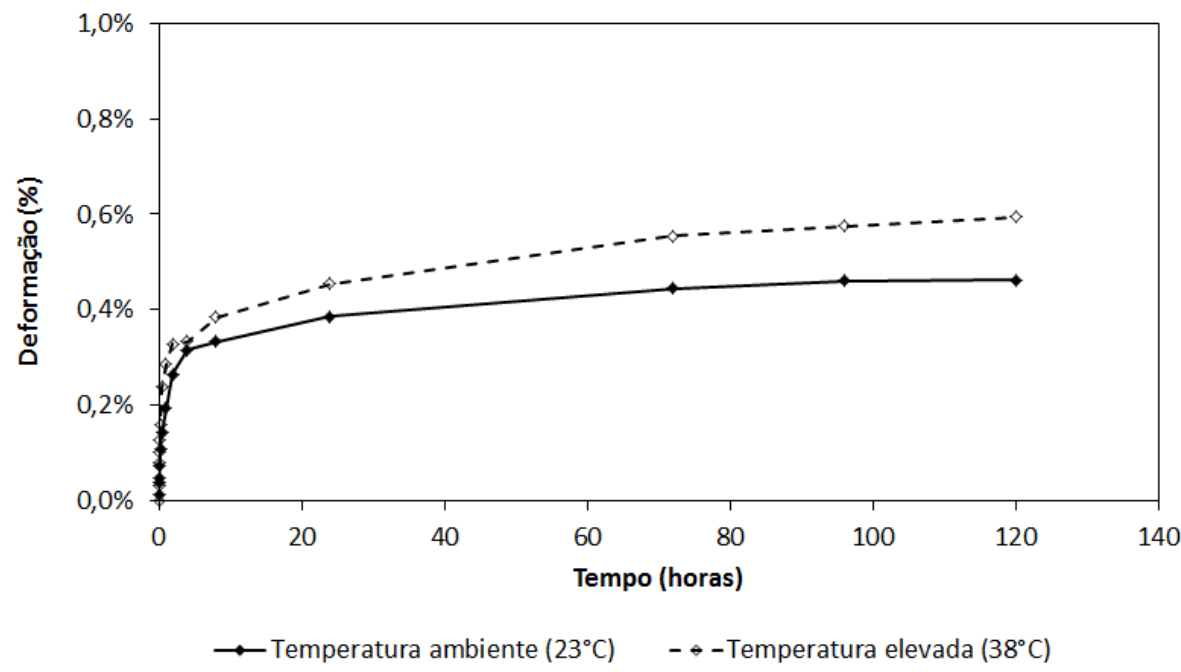

(a) 


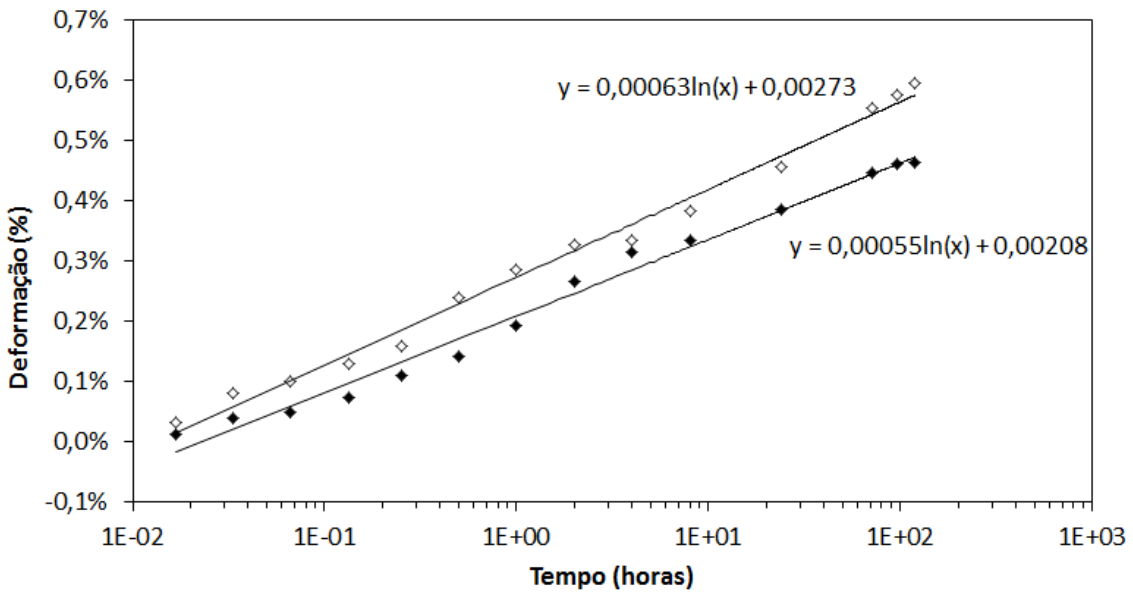

- Temperatura ambiente $\left(23^{\circ} \mathrm{C}\right) \quad \diamond$ Temperatura elevada $\left(38^{\circ} \mathrm{C}\right)$

(b)

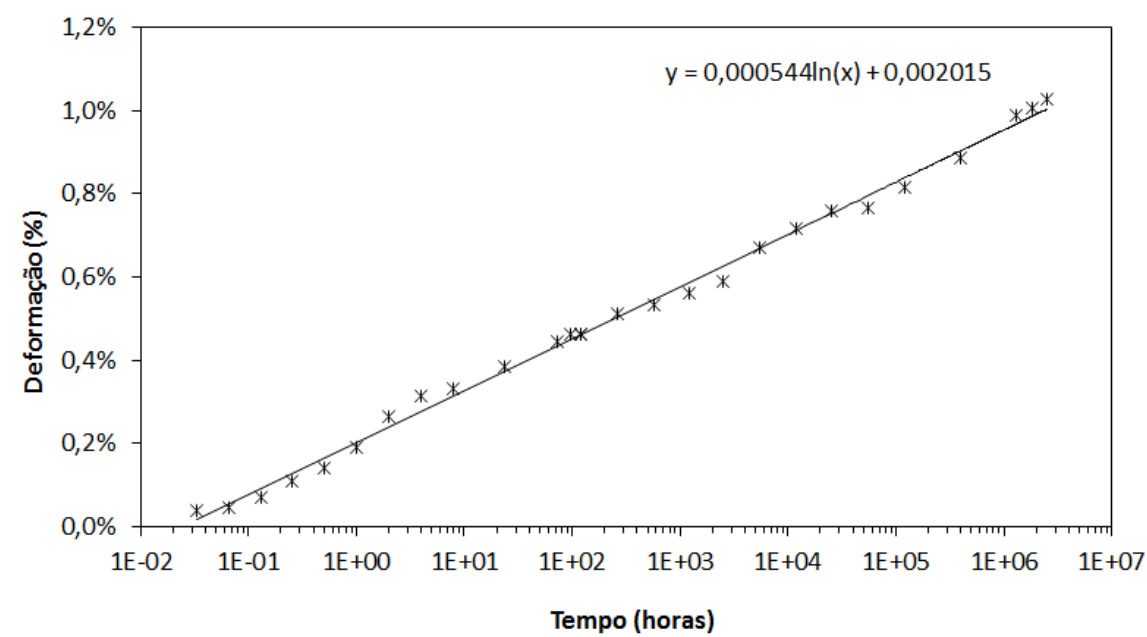

(c) 


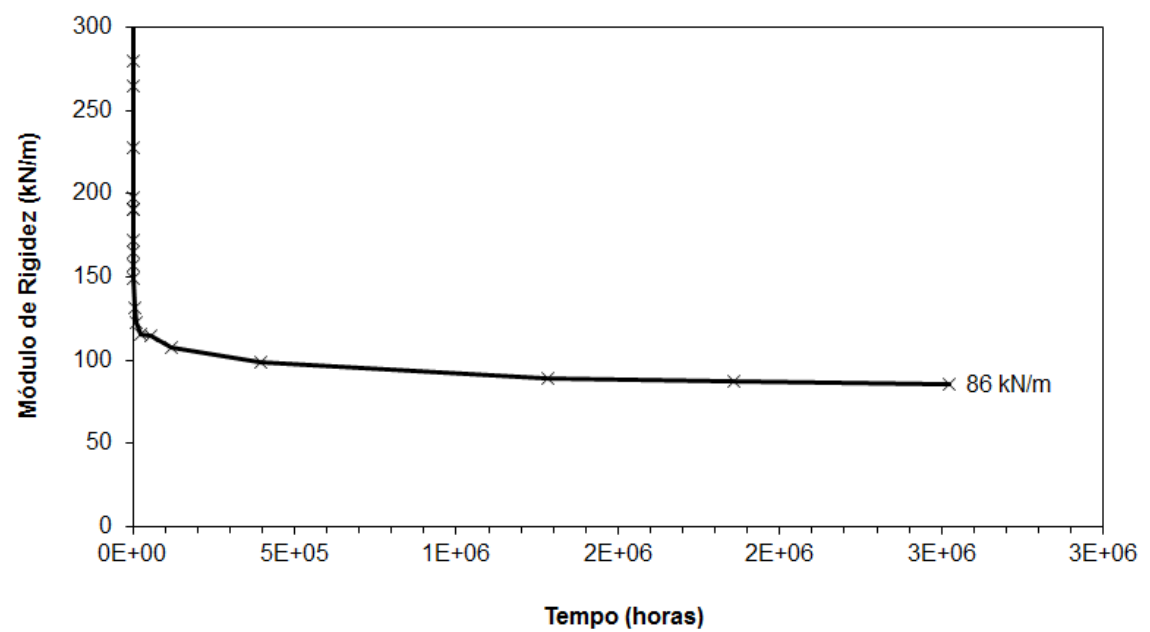

(d)

Figura 4.62 - Resultados dos ensaios de fluência confinada executados no equipamento de fluência confinada-acelerada para geotêxteis tecidos, para duas temperaturas diferentes: (a) Variação das deformações ao longo do tempo; (b) Variação das deformações ao longo do tempo pelo método da equação logarítmica; (c) Variação das deformações ao longo do tempo extrapolado - Curva Mestra;

(d) Variação da rigidez confinada ao longo do tempo.

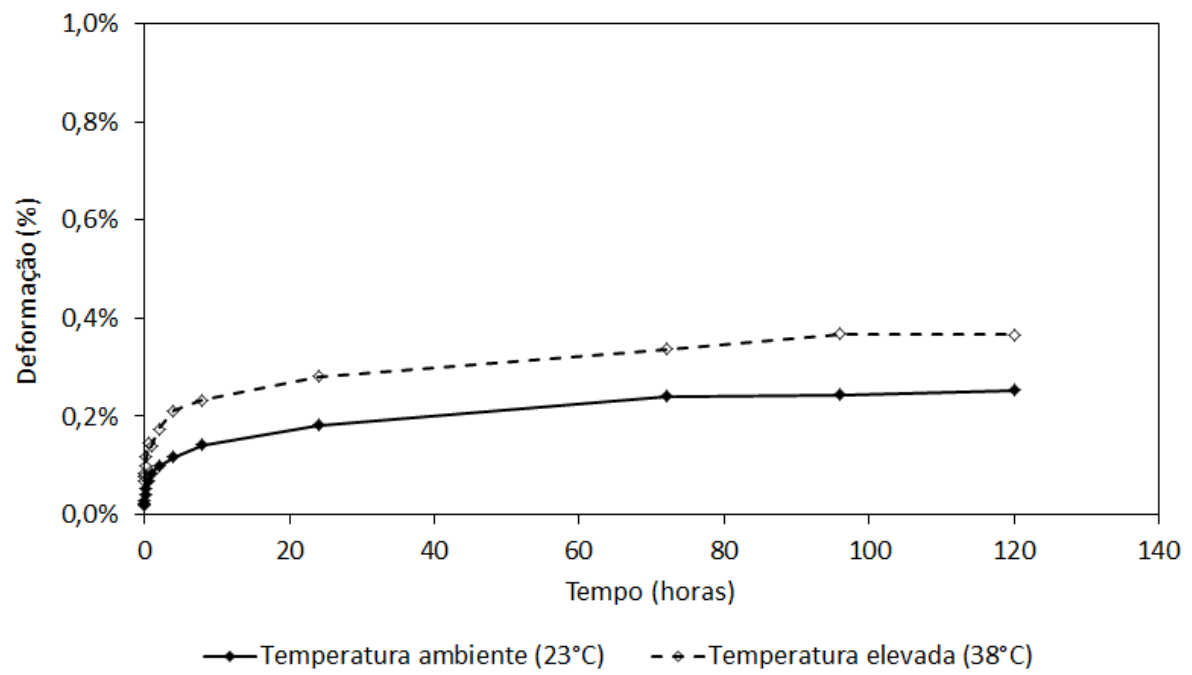

(a) 


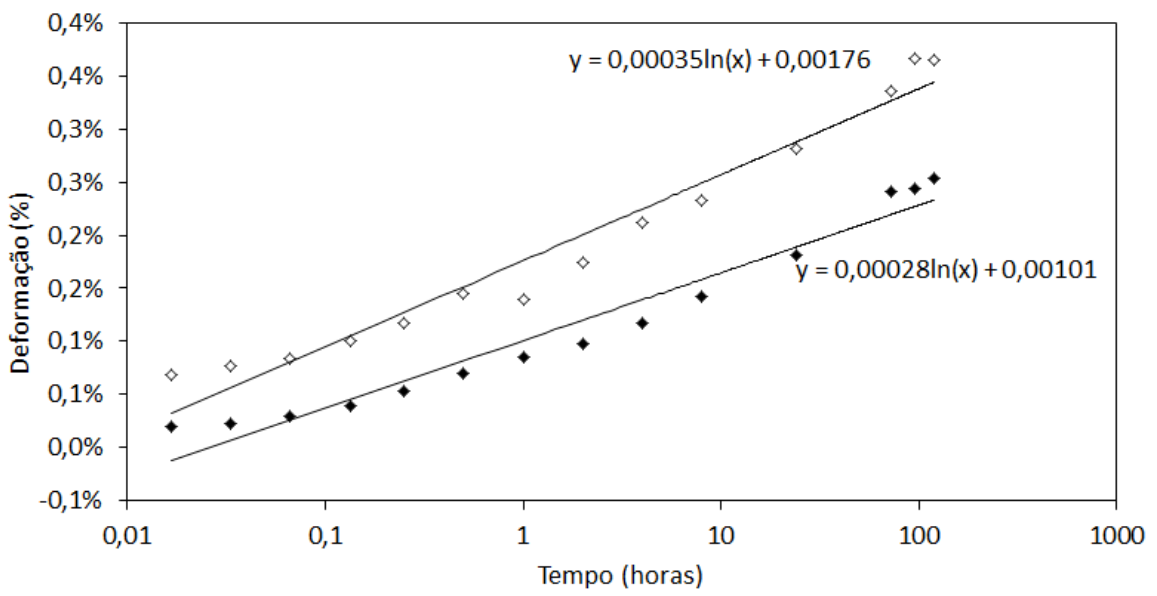

- Temperatura ambiente $\left(23^{\circ} \mathrm{C}\right) \quad \diamond$ Temperatura elevada $\left(38^{\circ} \mathrm{C}\right)$

(b)

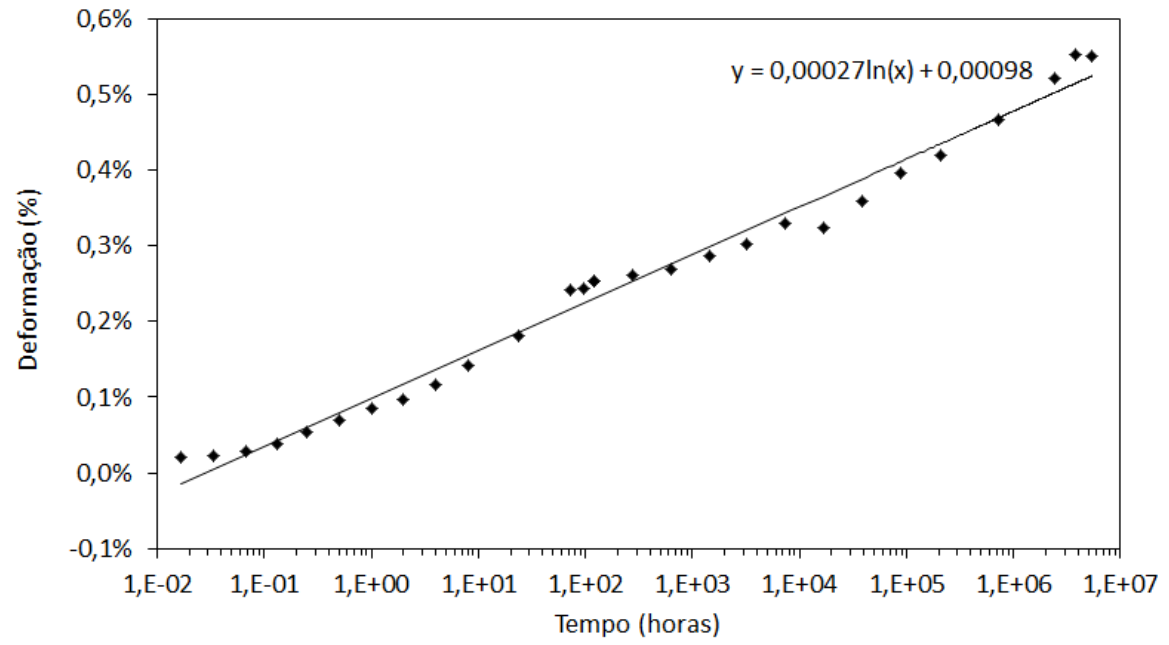

(c) 


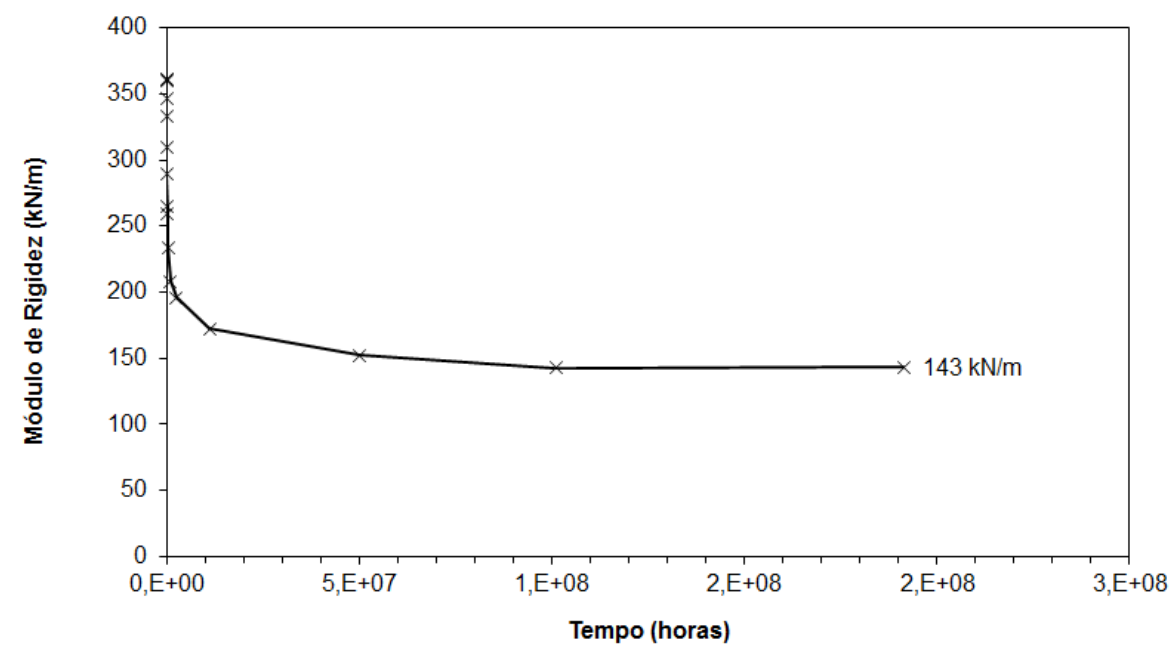

(d)

Figura 4.63 - Resultados dos ensaios de fluência confinada executados no equipamento de fluência confinada-acelerada para geogrelha, para duas temperaturas diferentes: (a) Variação das deformações ao longo do tempo; (b) Variação das deformações ao longo do tempo pelo método da equação logarítmica; (c) Variação das deformações ao longo do tempo extrapolado - Curva Mestra;

(d) Variação da rigidez confinada ao longo do tempo.

As Figuras 4.61a, 4.62a e 4.63a mostram que para todos os geossintéticos avaliados, as deformações foram mais elevadas para as maiores temperaturas.

Com relação aos níveis de deformação, observa-se que os maiores valores ocorreram para os geotêxteis não tecidos, seguidos pelos geotêxteis tecidos e por último pelas geogrelhas. Estes resultados vão de encontro aos resultados obtidos nos ensaios realizados no equipamento de interação solo-reforço desenvolvido por Costa (2004).

No que se refere às análises dos resultados pelo método da equação logarítmica, as Figuras 4.61b, 4.62b e 4.63b, mostram que os valores do parâmetro "a", que se relaciona às deformações iniciais do material, foram maiores para os geotêxteis não tecidos e menores para as geogrelhas, enquanto os geotêxteis tecidos permaneceram em patamares intermediários. Já com relação ao parâmetro "b", que se relaciona à fluência do material, os menores valores foram observados para as geogrelhas e os maiores valores para os geotêxteis tecidos. Para este caso os geotêxteis não tecidos ficaram em patamares intermediários. Este comportamento foi observado tanto para os ensaios realizados com temperatura ambiente $\left(23^{\circ} \mathrm{C}\right)$, quanto para os ensaios acelerados, realizados com temperatura elevada $\left(38^{\circ} \mathrm{C}\right)$. 
Como já era esperado, observa-se que o aumento da temperatura conduz a valores maiores dos parâmetros "a" e "b".

Já as Figuras 4.61c, 4.62c e 4.63c, que apresentam as deformações para um tempo extrapolado (curvas mestras), confirmam o comportamento mostrado nas demais figuras, ou seja, os valores do parâmetro "a", relacionado às deformações iniciais, foram maiores para os geotêxteis não tecidos, seguidos pelos geotêxteis tecidos e pelas geogrelhas, e o parâmetro "b", relacionado à fluência do material, foi maior para o geotêxtil tecido, seguido pelo geotêxtil não tecido e pela geogrelha. É importante destacar que os ensaios confinados, os quais foram executados com 120 horas de duração, permitiram a extrapolação para diferentes tempos dependendo do tipo de material avaliado. Para o caso dos geotêxteis não tecidos foi possível extrapolar os dados para um período de 548 anos. Para os geotêxteis tecidos a extrapolação foi realizada para 288 anos, e para as geogrelhas o fator de translação possibilitou a extrapolação para um período de 621 anos.

As Figuras 4.61d, 4.62d e 4.63d apresentam a variação do módulo de rigidez confinado para o caso dos geotêxteis não tecidos, geotêxteis tecidos e geogrelhas, respectivamente. Os resultados vão de encontro ao que foi observado nos ensaios em isolamento e também nos ensaios confinados realizados no equipamento de interação solo-reforço. Observa-se que os maiores valores de rigidez confinada foram observados para as geogrelhas, seguido pelos geotêxteis tecidos e por último pelos geotêxteis não tecidos. Vale destacar que os valores de rigidez confinada foram calculados em função da curva mestra.

\subsubsection{Análise da influência do confinamento na fluência dos reforços para os ensaios confinados}

Neste item são apresentadas comparações entre os resultados dos ensaios de fluência confinada realizados no equipamento de fluência confinada-acelerada desenvolvido por França (2011) e os resultados dos ensaios de fluência em isolamento. 
É importante lembrar que as cargas aplicadas aos reforços nos ensaios confinados na caixa de testes de fluência confinada-acelerada foram aproximadamente as mesmas cargas registradas nos ensaios confinados executados na caixa de interação solo-reforço, ou seja, carga de $2 \%$ da resistência última para os geotêxteis não tecidos $(0,40 \mathrm{kN} / \mathrm{m}), 1,6 \%$ para os geotêxteis tecidos $(0,88 \mathrm{kN} / \mathrm{m})$ e $1,5 \%$ para as geogrelhas $(0,71 \mathrm{kN} / \mathrm{m})$. Nota-se que as cargas empregadas para os geotêxteis tecidos e geogrelhas foram levemente superiores aos valores das cargas registradas nos ensaios realizados na caixa de interação solo-reforço desenvolvida por Costa (2004). Esta pequena diferença se deve às dificuldades em se ajustar com precisão as cargas nos ensaios realizados na caixa de fluência confinada-acelerada desenvolvida por França (2011).

As Figuras 4.64, 4.65 e 4.66 apresentam as comparações entre os resultados dos ensaios confinados e não confinados para os geotêxteis não tecidos, geotêxteis tecidos e geogrelhas, respectivamente.

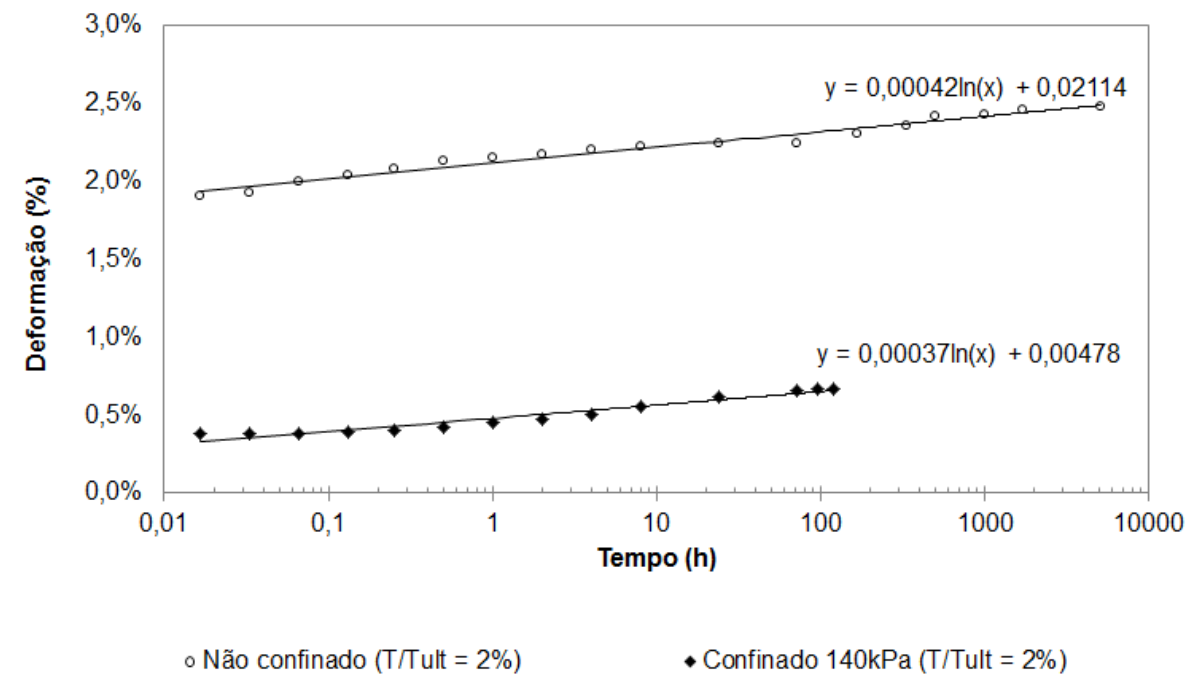

(a) 


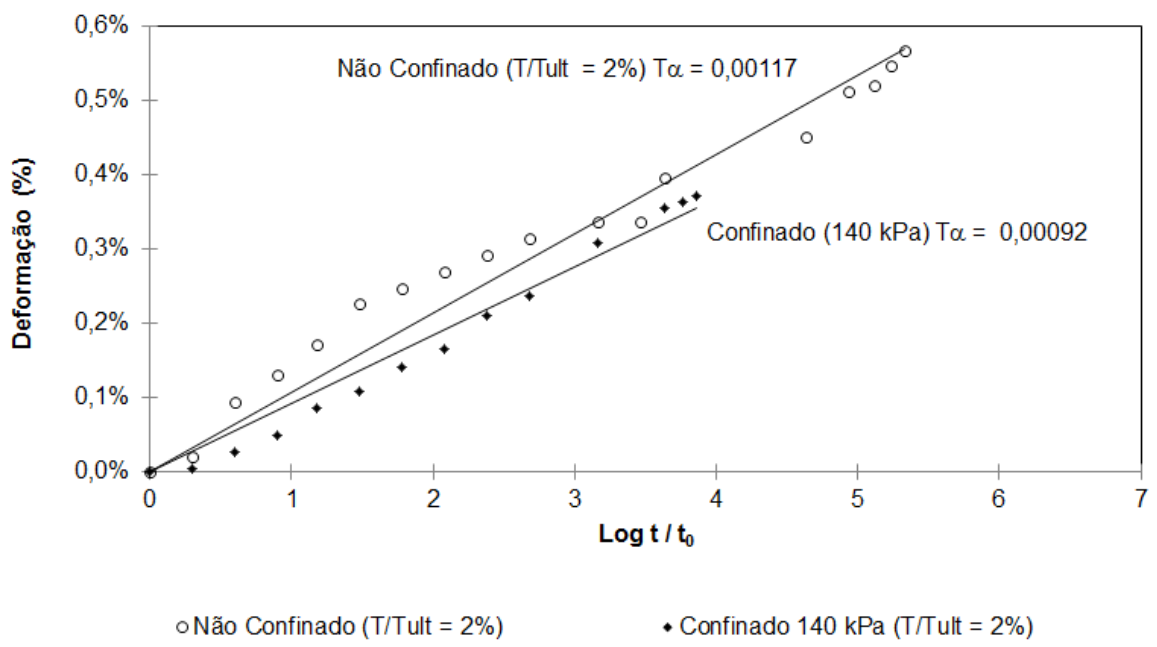

(b)

Figura 4.64 - Comparação entre os resultados dos ensaios confinados, executados no equipamento de fluência confinada-acelerada, e resultados dos ensaios não confinados, para geotêxteis não tecidos: (a) Variação das deformações ao longo do tempo pelo método da equação logarítmica; (b) Variação das deformações por fluência ao longo do tempo pelo método de Zornberg; Byler e Knudsen (2004).

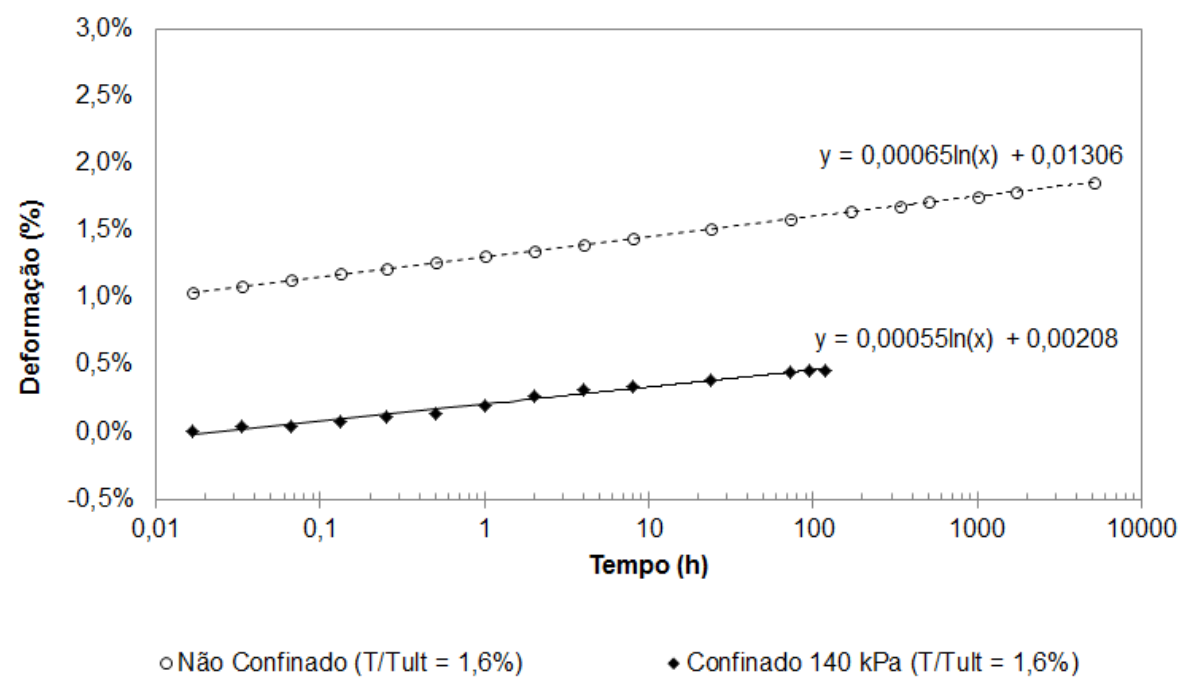

(a) 


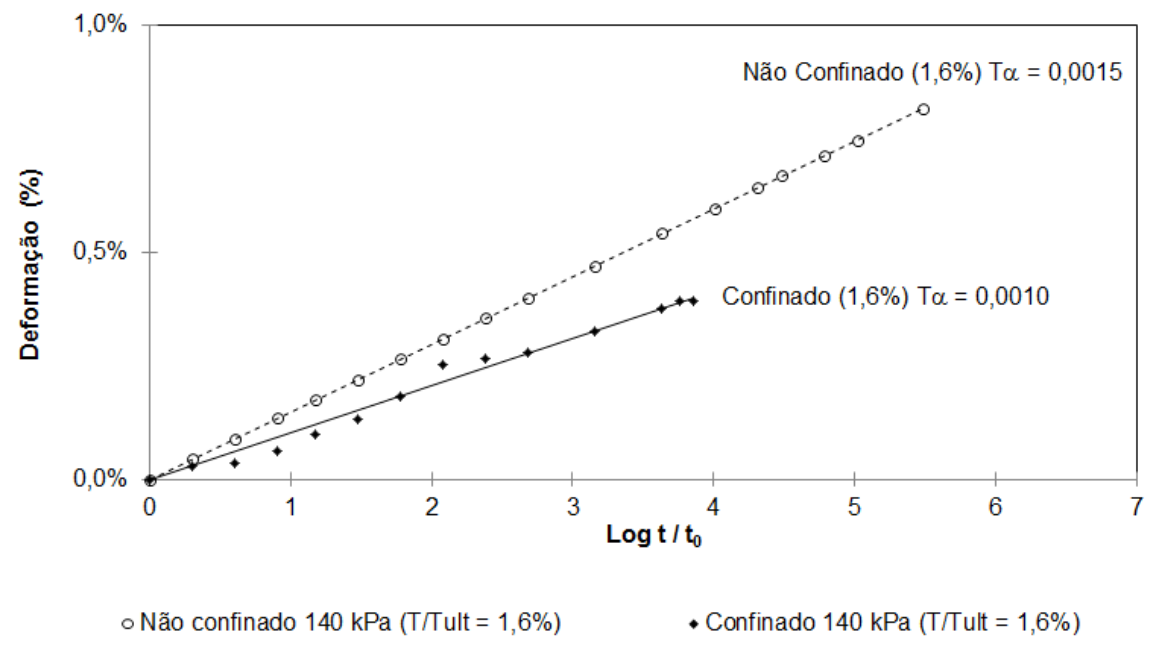

(b)

Figura 4.65 - Comparação entre os resultados dos ensaios confinados, executados no equipamento de fluência confinada-acelerada, e resultados dos ensaios não confinados, para geotêxteis tecidos: (a) Variação das deformações ao longo do tempo pelo método da equação logarítmica; (b) Variação das deformações por fluência ao longo do tempo pelo método de Zornberg; Byler e Knudsen (2004).

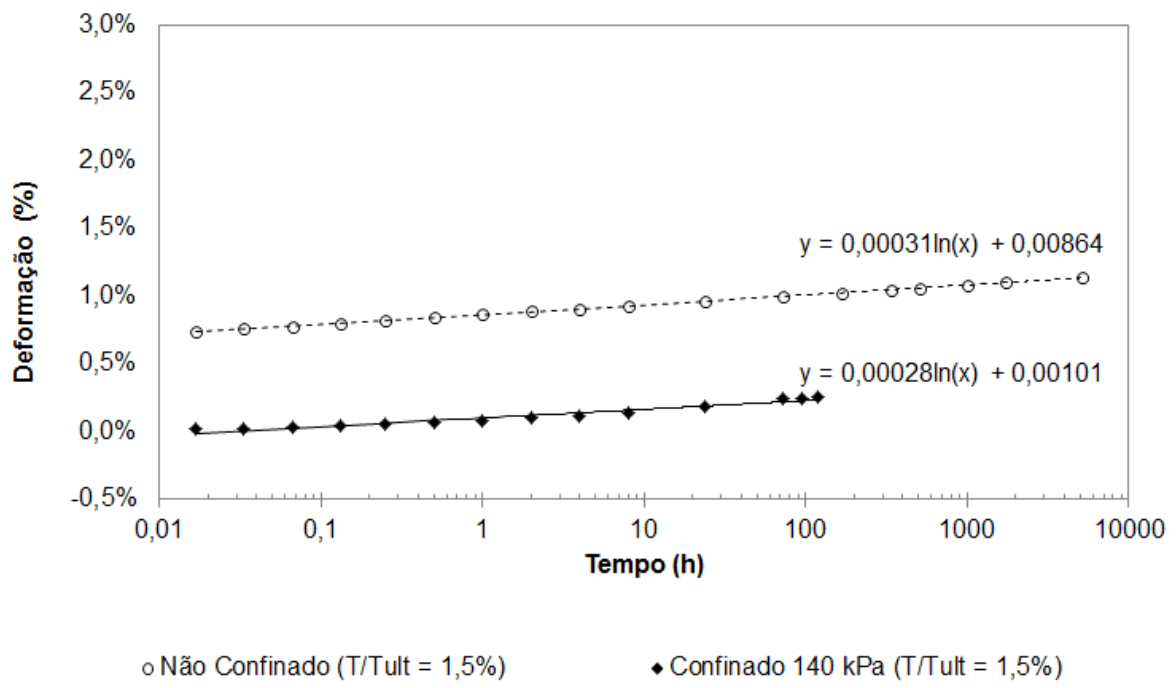

(a) 


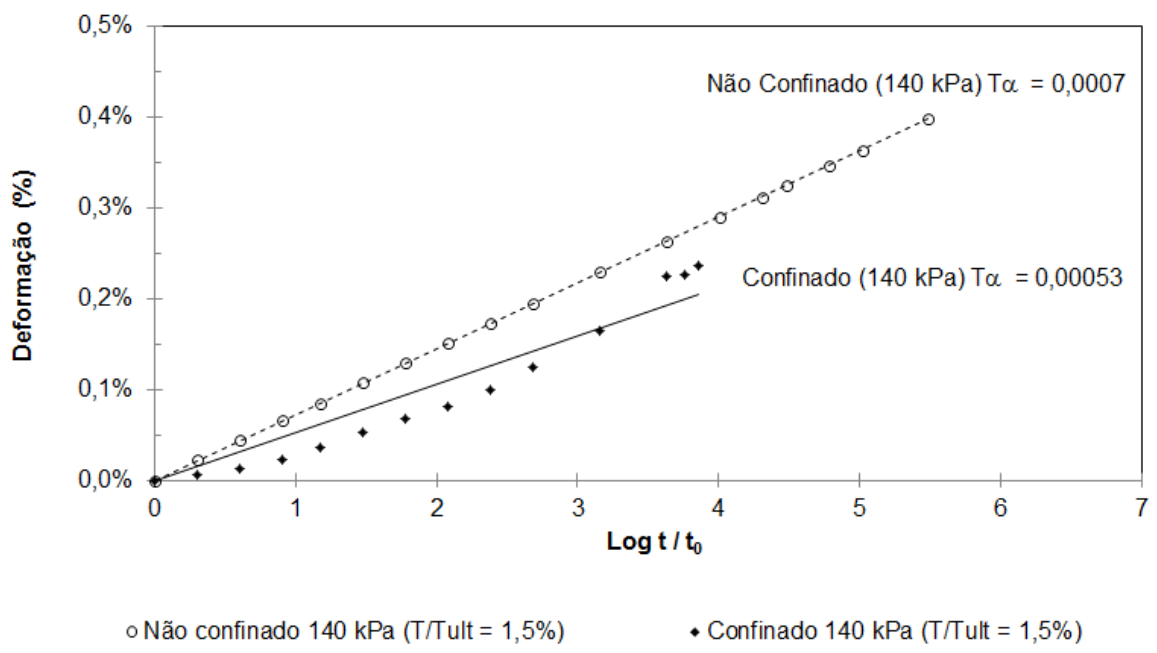

(b)

Figura 4.66 - Comparação entre os resultados dos ensaios confinados, executados no equipamento de fluência confinada-acelerada, e resultados dos ensaios não confinados, para geogrelhas: (a)

Variação das deformações ao longo do tempo pelo método da equação logarítmica; (b) Variação das deformações por fluência ao longo do tempo pelo método de Zornberg; Byler e Knudsen (2004).

A Figura 4.64a mostra que, para o caso dos geotêxteis não tecidos, o confinamento promoveu reduções tanto no parâmetro "a", que representa as deformações iniciais do material, como no parâmetro "b", que representa a tendência à fluência do reforço. Observa-se que o parâmetro "a" foi reduzido em aproximadamente $77 \%$, enquanto que o parâmetro "b" foi reduzido em aproximadamente $12 \%$. Já as deformações ao longo do tempo pelo método proposto por Zornberg; Byler e Knudsen (2004) (Figura 4.64b), mostram que o confinamento promoveu uma redução do fator de fluência $(T \alpha)$ de aproximadamente $21 \%$.

Assim como observado no caso dos geotêxteis não tecidos, o confinamento também promoveu reduções no parâmetro "a" (relacionado às deformações iniciais do material) e no parâmetro "b" (referente a tendência à fluência do reforço) para o caso dos geotêxteis tecidos (Figura 4.65a). Observa-se que o parâmetro "a" foi reduzido em aproximadamente $84 \%$, enquanto que o parâmetro "b" foi reduzido em aproximadamente $15 \%$ devido aos efeitos do confinamento. Os resultados apresentados na Figura 4.65b, a qual apresenta as deformações ao longo do tempo pelo método proposto por Zornberg; Byler e Knudsen (2004), confirmam as 
tendências observadas no método da equação logarítmica. Os dados analisados por este método mostram que o fator de fluência $T \alpha$ foi reduzido em aproximadamente $33 \%$.

O confinamento também promoveu reduções nos parâmetros relacionados às deformações iniciais (parâmetro "a") e índices de fluência (parâmetros "b" e T $\alpha$ ) para os ensaios realizados com geogrelhas. A Figura 4.66a mostra que as reduções do parâmetro "a" devido ao confinamento foram da ordem de $88 \%$, enquanto que as reduções do parâmetro "b" foram da ordem de $10 \%$. Pelo método proposto por Zornberg; Byler e Knudsen (2004) (Figura 4.66b), observa-se que a redução do fator de fluência $T \alpha$ foi de aproximadamente $25 \%$.

\subsection{COMPARAÇÃO ENTRE OS RESULTADOS OBTIDOS NO EQUIPAMENTO DE INTERAÇÃO SOLO-REFORÇO E NO EQUIPAMENTO DE FLUÊNCIA CONFINADA-ACELERADA}

Neste item apresta-se uma comparação entre os resultados obtidos nos ensaios confinados realizados nos equipamentos de interação solo-reforço e fluência confinada-acelerada desenvolvidos por Costa (2004) e França (2011), respectivamente.

Conforme descrito anteriormente, os equipamentos, apesar de desenvolvidos para o mesmo fim, apresentam princípios de funcionamento bem distintos. No equipamento de interação solo-reforço, um carregamento vertical é aplicado no topo do maciço, solicitando o solo, que por sua vez, desloca-se lateralmente (devido à presença de paredes móveis no equipamento), e transfere o carregamento ao reforço. Ou seja, o reforço é solicitado de forma indireta, por meio da interação solo-geossintético.

Já no equipamento de fluência confinada-acelerada, o solo se encontra confinado em uma caixa com paredes fixas. Um carregamento vertical é aplicado ao maciço de forma a simular a condição de confinamento desejada. Já os reforços são solicitados de forma direta por meio de pesos ligados às extremidades do geossintético.

É importante destacar que o carregamento aplicado no reforço para os ensaios realizados na caixa de fluência confinada-acelerada, foram os mesmos 
carregamentos obtidos previamente nos ensaios realizados no equipamento de interação solo-reforço, após 120 horas de ensaio. Ressalta-se que devido às dificuldades em se ajustar a carga com precisão no equipamento desenvolvido por França (2011), os carregamentos para estes ensaios foram ligeiramente diferentes, sendo que esta pequena diferença pode ser considerada desprezível.

Os resultados dos ensaios obtidos em ambos os equipamentos são apresentados na Figura 4.67 para os geotêxteis não tecidos, na Figura 4.68 para os geotêxteis tecidos e na Figura 4.69 para as geogrelhas. Os resultados são mostrados em termos de parâmetros de deformação pelo método da equação logarítmica e pelo método de Zornberg; Byler e Knudsen (2004), em termos de variação da deformação ao longo do tempo e em termos de variação da deformação em função do carregamento no reforço.

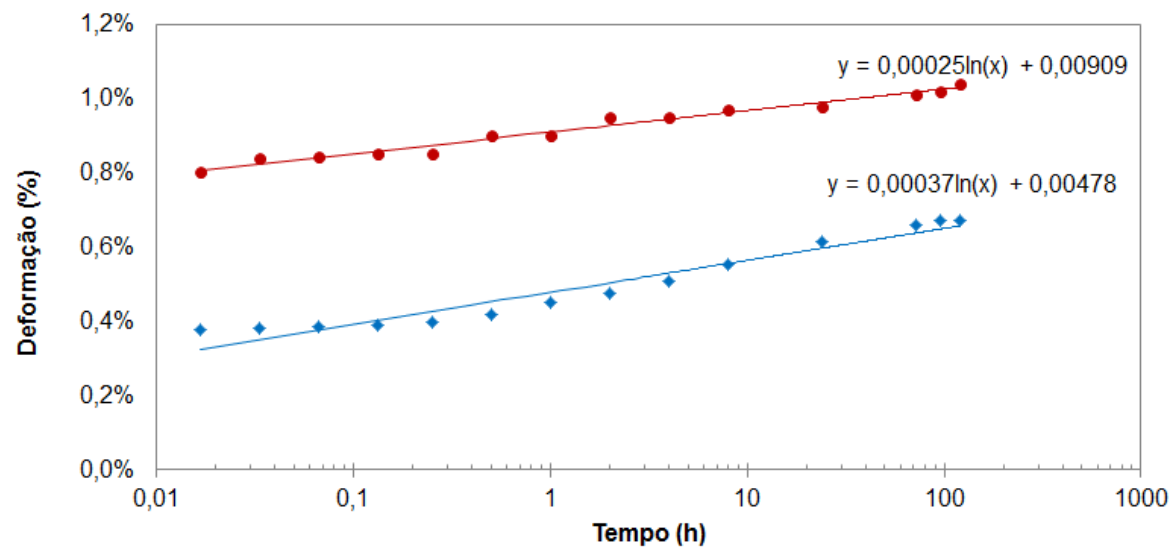

- Equipamento de interação solo-reforço • Equipamento de fluência confinada-acelerada

(a) 


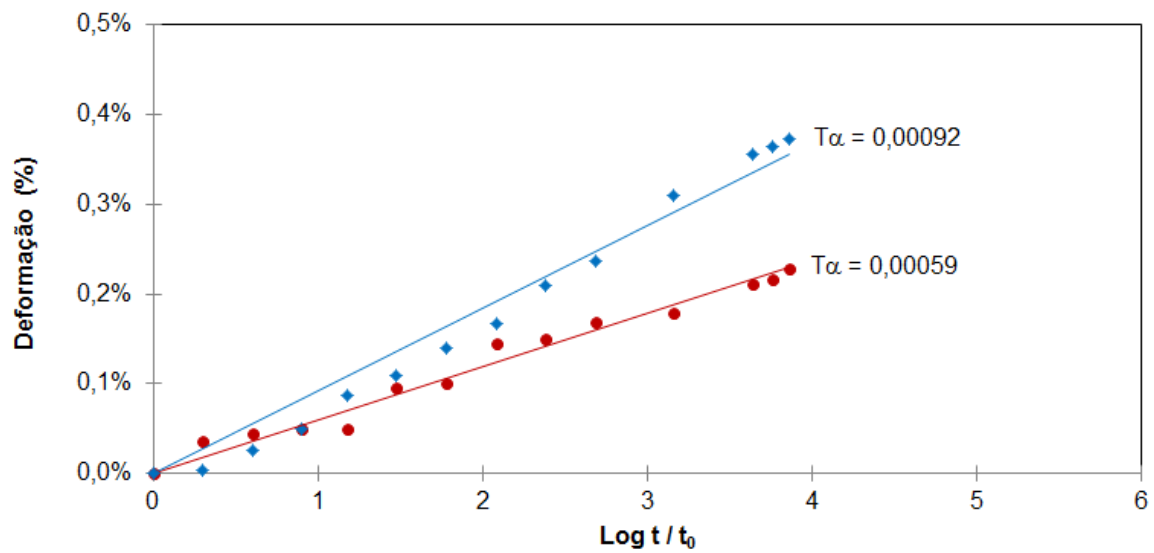

- Equipamento de interação solo-reforço • Equipamento de fluência confinada-acelerada

(b)

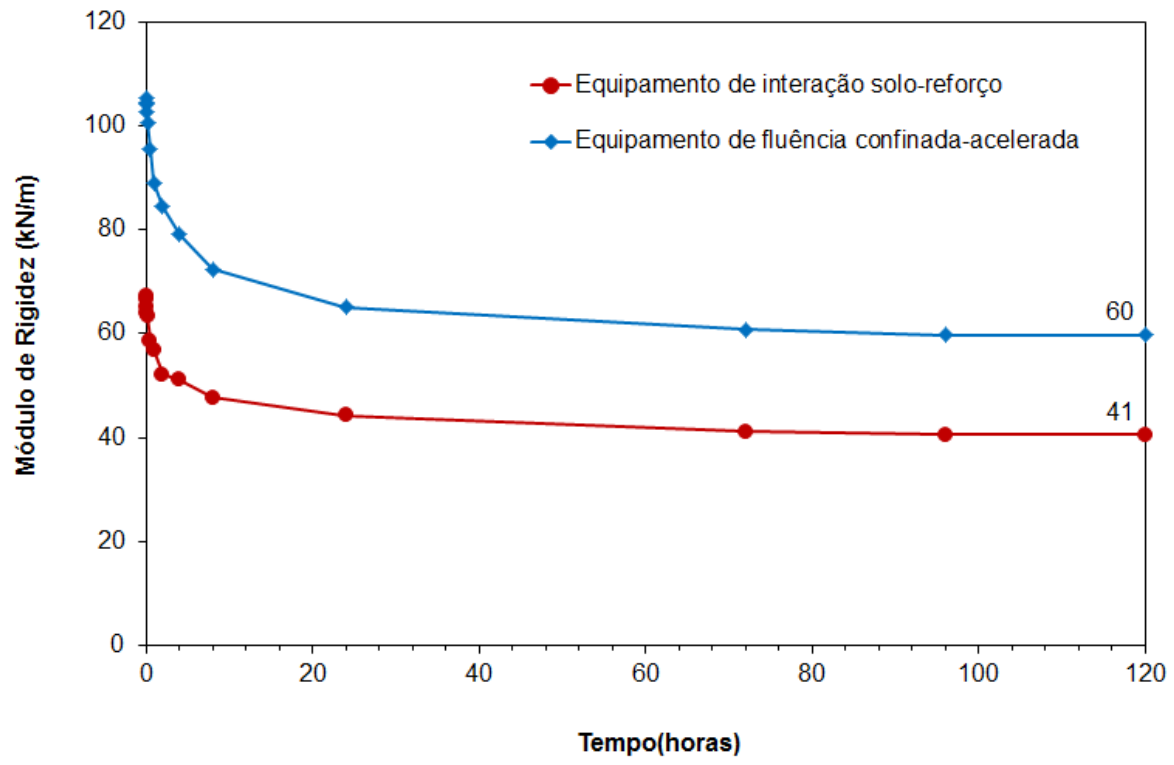

(c) 


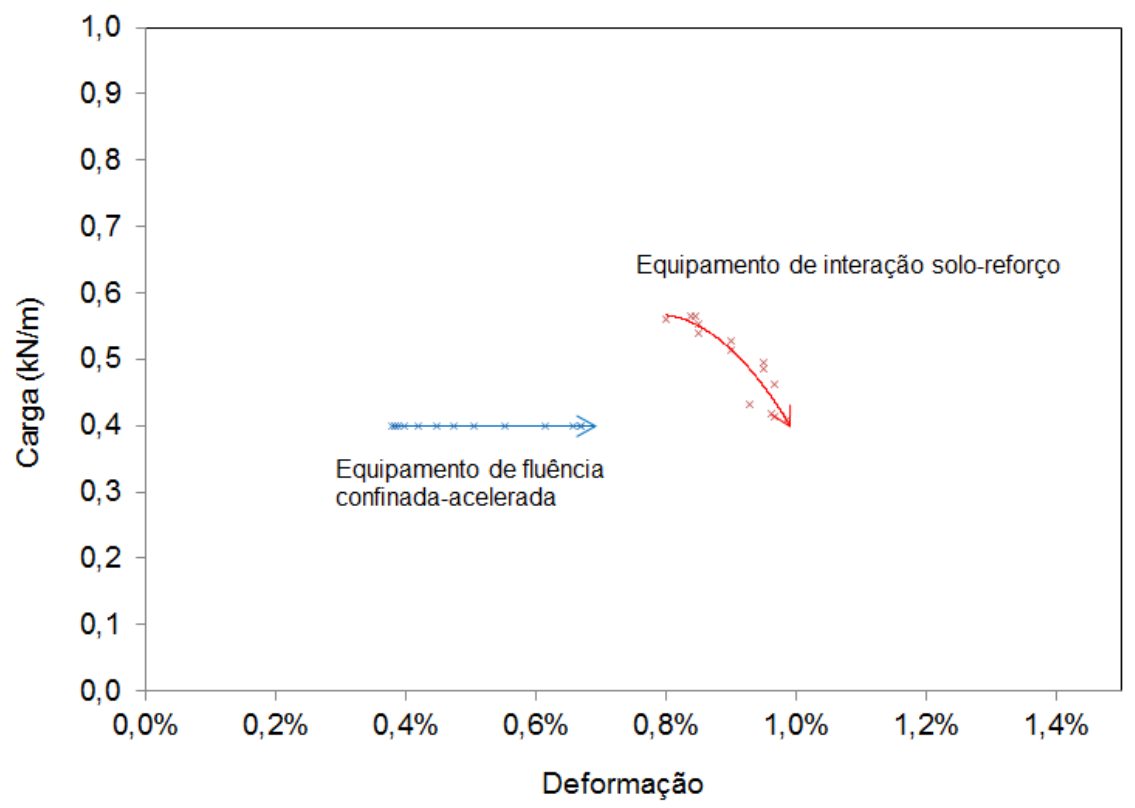

(d)

Figura 4.67 - Comparação entre os resultados obtidos nos ensaios confinados executados nos equipamentos de interação solo-reforço e fluência confinada-acelerada para geotêxteis não tecidos: (a) Método logarítmico; (b) Método de Zornberg; Byler e Knudsen (2004); (c) Variação do módulo de rigidez ao longo do tempo; (d) Variação da deformação em função da carga.

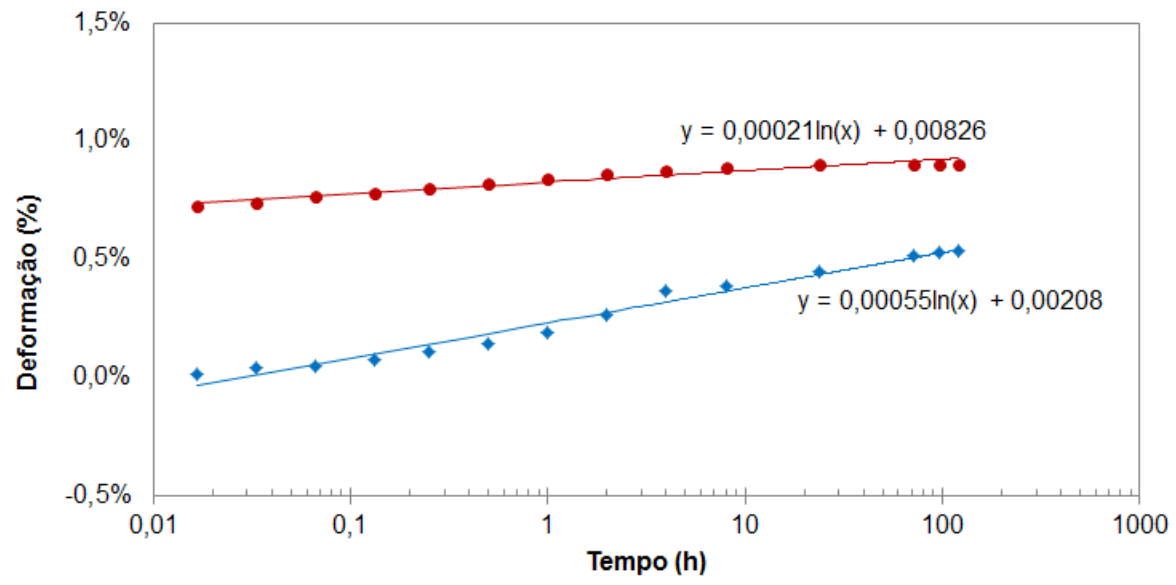

- Equipamento de interação solo-reforço • Equipamento de fluência confinada-acelerada

(a) 


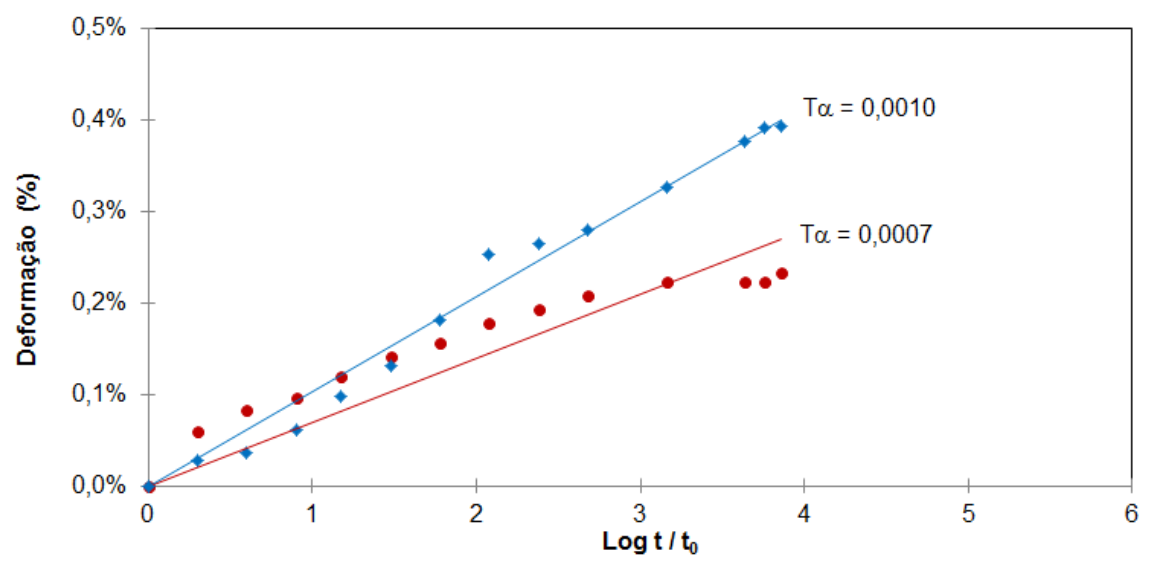

• Equipamento de interação solo-reforço • Equipamento de fluência confinada-acelerada

(b)

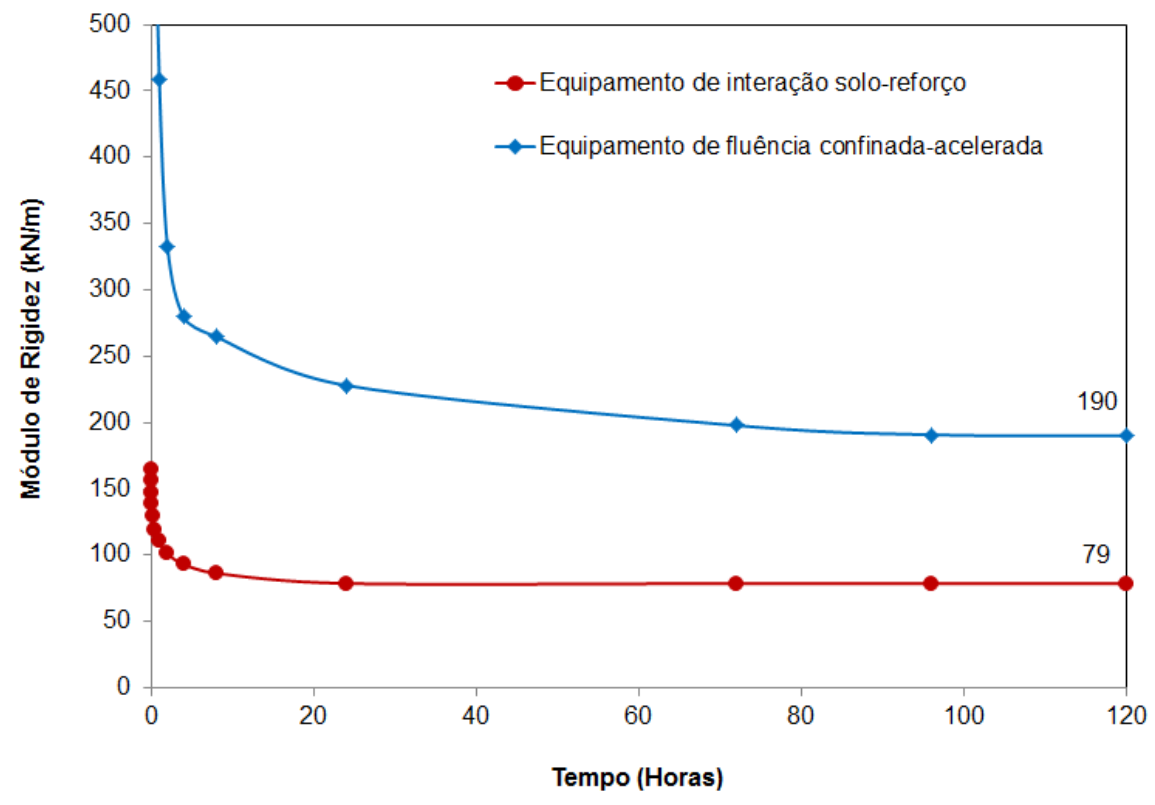

(c) 


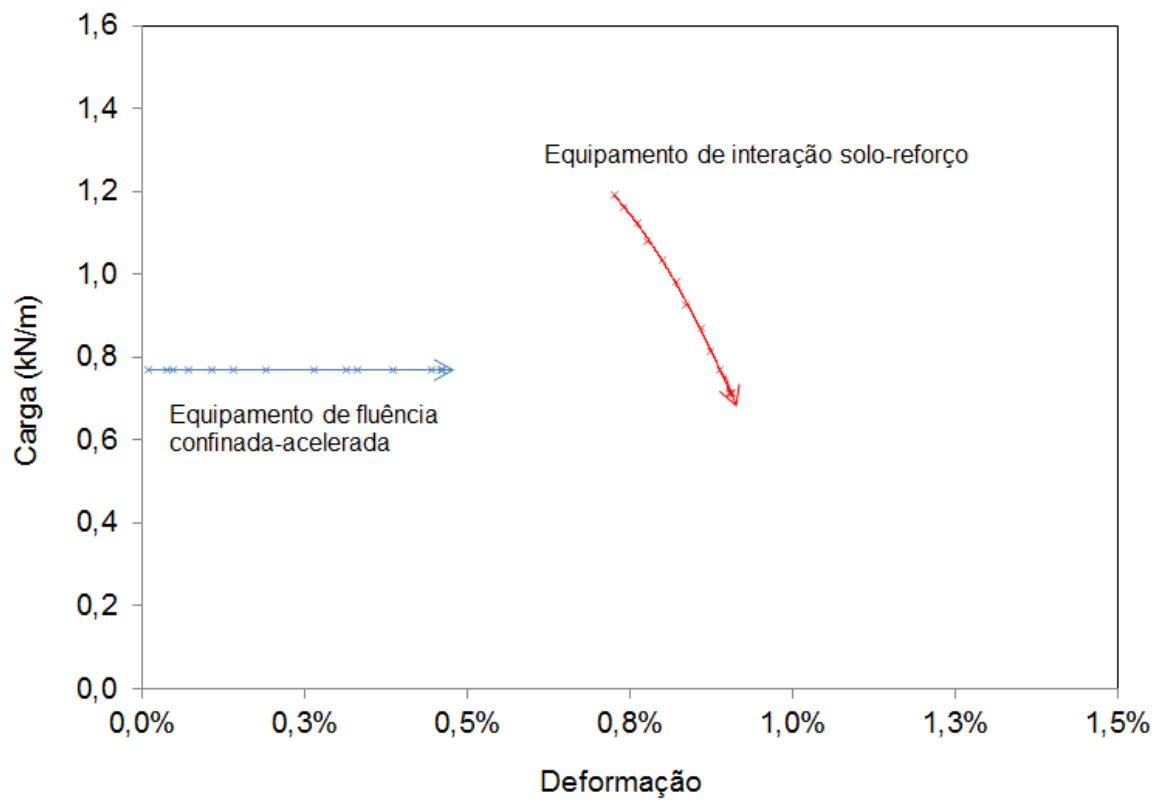

(d)

Figura 4.68 - Comparação entre os resultados obtidos nos ensaios confinados executados nos equipamentos de interação solo-reforço e fluência confinada-acelerada para geotêxteis tecidos: (a) Método logarítmico; (b) Método de Zornberg; Byler e Knudsen (2004); (c) Variação do módulo de rigidez ao longo do tempo; (d) Variação da deformação em função da carga.

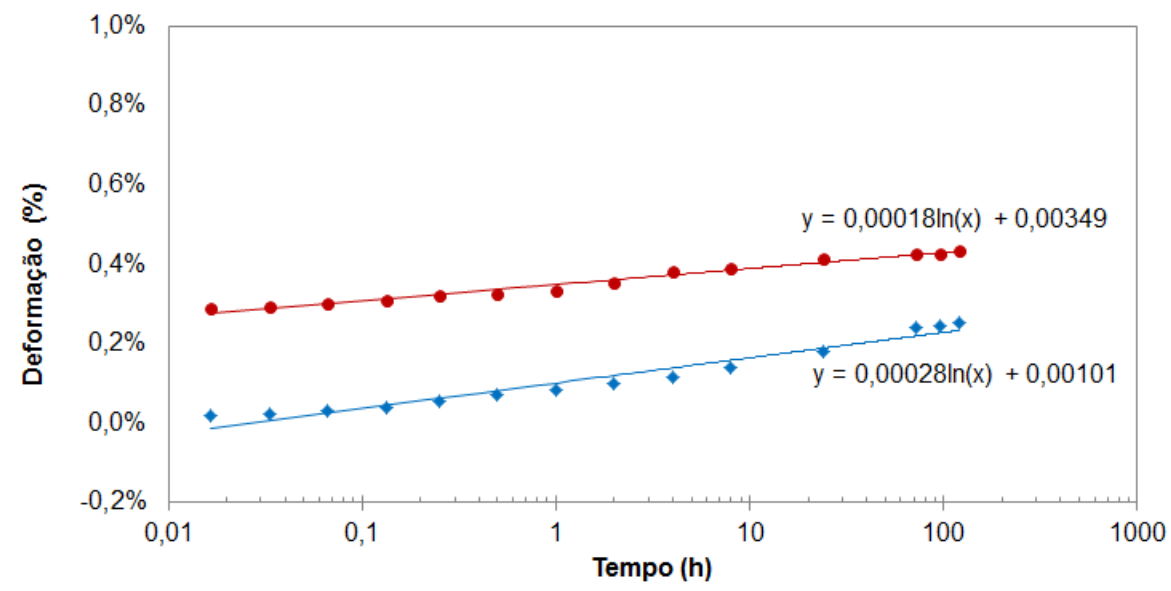

- Equipamento de interação solo-reforço • Equipamento de fluência confinada-acelerada

(a) 


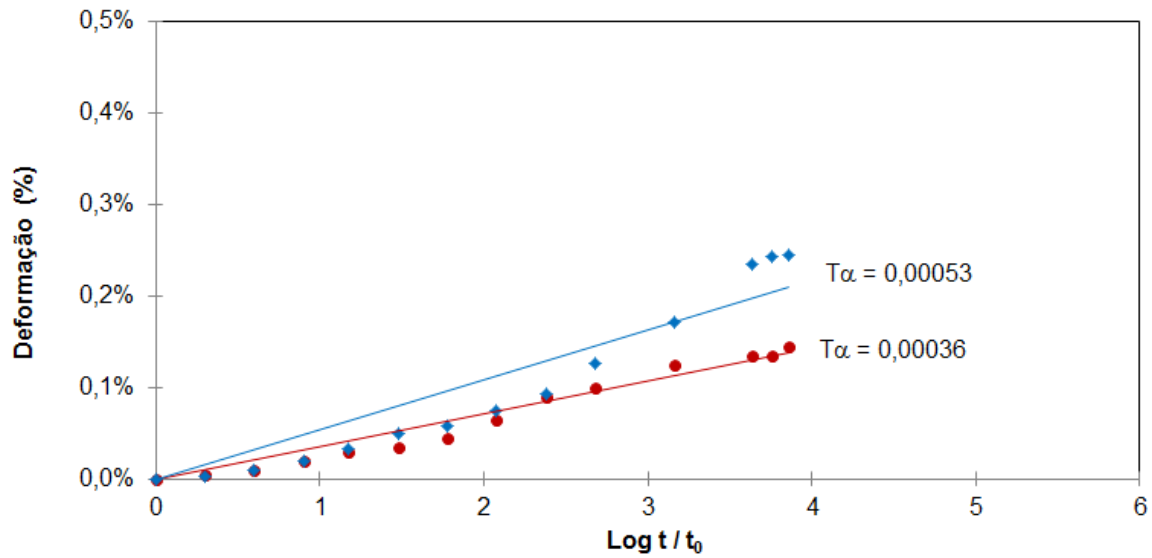

- Equipamento de interação solo-reforço • Equipamento de fluência confinada-acelerada

(b)

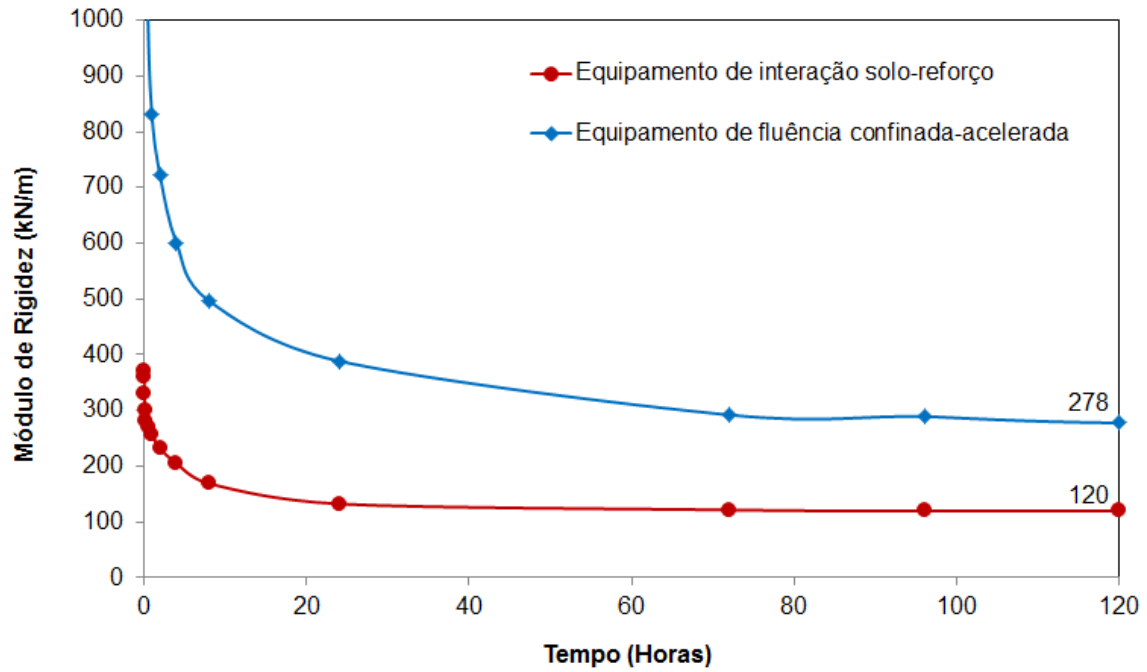

(c) 


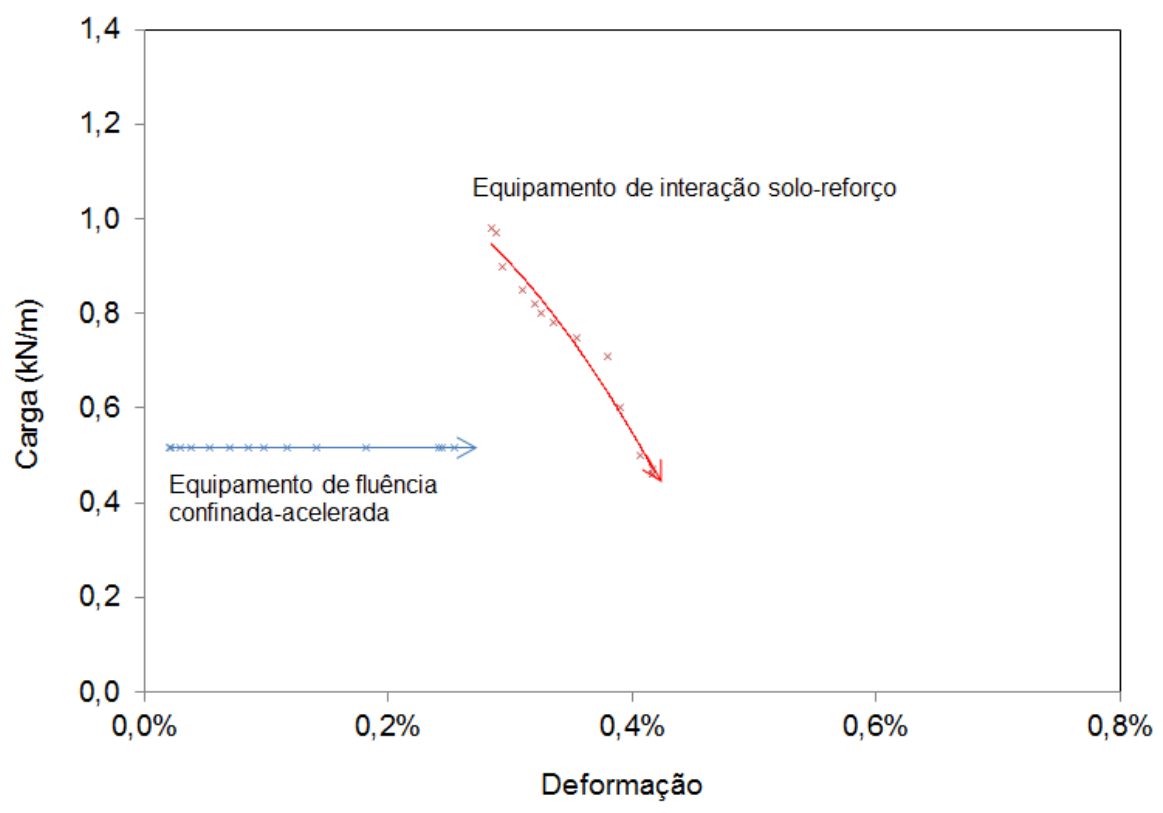

(d)

Figura 4.69 - Comparação entre os resultados obtidos nos ensaios confinados executados nos equipamentos de interação solo-reforço e fluência confinada-acelerada para geogrelhas: (a) Método logarítmico; (b) Método de Zornberg; Byler e Knudsen (2004); (c) Variação do módulo de rigidez ao longo do tempo; (d) Variação da deformação em função da carga.

A Figura 4.67a mostra que o parâmetro "a", que se relaciona às deformações iniciais do reforço, para o caso dos geotêxteis não tecidos, foi de $0,91 \%$ para o ensaio realizado no equipamento de interação solo-reforço e de $0,48 \%$ para o ensaio realizado no equipamento fluência confinada-acelerada. Já o parâmetro "b", que se relaciona à tendência à fluência do material, foi de $0,025 \%$ para o ensaio realizado no equipamento de interação solo-reforço e de $0,037 \%$ para o ensaio realizado no equipamento de fluência confinada-acelerada.

Observa-se que a deformação inicial foi da ordem de 1,9 vezes maior para o ensaio realizado no equipamento de interação solo-reforço. Por outro lado, a tendência à fluência do material se mostrou maior para o ensaio realizado no equipamento de fluência confinada-acelerada em cerca de 1,5 vezes.

Um comportamento muito semelhante foi observado para os geotêxteis tecidos (Figura 4.68a) e para as geogrelhas (Figura 4.69a). Para os geotêxteis tecidos, o parâmetro "a" obtido no equipamento de interação solo-reforço foi de $0,83 \%$, ou seja, aproximadamente 4 vezes maior quando comparado ao parâmetro "a" obtido no 
equipamento de fluência confinada-acelerada, que foi de $0,21 \%$. Já o parâmetro "b" foi de $0,021 \%$ para o equipamento interação, valor este aproximadamente 2,6 vezes menor que o encontrado no equipamento de fluência confinada-acelerada, que foi de 0,055\%.

Para o caso das geogrelhas, no equipamento de interação solo-reforço, o parâmetro "a" foi de 0,35\% e o parâmetro "b" 0,018\%. Já no outro equipamento, o parâmetro "a" foi de $0,10 \%$ e o parâmetro "b" $0,028 \%$. Assim, o parâmetro "a" foi 3,5 vezes maior para o equipamento de interação solo-reforço, enquanto que o parâmetro "b" foi 1,5 vezes maior para o equipamento de fluência confinada-acelerada.

As Figuras 4.67b, 4.68b e 4.69b mostram que, para todos os geossintéticos avaliados, o parâmetro T $\alpha$, que se relaciona com as deformações por fluência sofridas pelo material pelo método de Zornberg; Byler e Knudsen (2004), foi maior para os ensaios realizados na caixa de fluência confinada-acelerada. Para os geotêxteis não tecidos o parâmetro T $\alpha$ obtido no equipamento França (2011) foi 1,55 vezes maior do que no equipamento desenvolvido por Costa (2004), enquanto que para os geotêxteis tecidos a diferença foi de 1,43 vezes e para as geogrelhas foi de 1,47 vezes.

Ao se comparar os resultados dos ensaios entre os equipamentos de interação soloreforço de Costa (2004) e de fluência confinada-acelerada de França (2011) em termos de variação do módulo de rigidez confinada ao longo do tempo (Figura 4.67c, Figura 4.68c e Figura 4.69c), observa-se que, para todos os reforços testados, os valores dos módulos de rigidez foram maiores para os ensaios realizados no equipamento de França (2011). Este fato se mostra condizente com os resultados apresentados nas demais figuras, tendo em vista que para carregamentos semelhantes aplicados em ambos os equipamentos, os níveis de deformação observados no equipamento desenvolvido por França (2011) foram consideravelmente menores.

Em termos de variação das deformações em função do carregamento nos reforços, as Figuras 4.67d, 4.68d e 4.69d mostram que os ensaios realizados no equipamento de interação solo-reforço apresentam uma relação carga $x$ deformação que possuem uma forma levemente curvada, com a concavidade desta curva voltada para o canto inferior esquerdo do gráfico. Já a trajetórias das deformações em função do carregamento no reforço para os ensaios realizados na caixa de fluência 
confinada-acelerada se apresentam em forma de uma reta horizontal, já que os carregamentos para este caso não variam ao longo de todo o ensaio.

Conforme destacado anteriormente os ensaios foram realizados em equipamentos distintos, porém com condições semelhantes de carregamento e umidade de compactação do solo.

Os resultados dos ensaios mostraram que, em todos os casos testados, os parâmetros referentes à deformação inicial do reforço foram maiores para os ensaios realizados na caixa de interação solo-reforço. Os resultados mostraram também que, para todos os casos testados, os maiores parâmetros de fluência ocorreram para os ensaios realizados no equipamento de fluência confinadaacelerada.

Este fato pode ser explicado pelo princípio de funcionamento de cada um dos equipamentos. No equipamento de interação solo-reforço, uma carga vertical solicita o maciço de solo, que por sua vez se desloca lateralmente e solicita o reforço por meio da interação solo-geossintético. Neste caso o reforço é solicitado por um carregamento que varia até que o conjunto entre em equilíbrio, ou seja, ocorre simultaneamente um aumento das deformações e um decréscimo de carga nos reforços ao longo do tempo. Já no equipamento de fluência confinada-acelerada, o reforço é solicitado diretamente por meio de pesos que se encontram presos às extremidades do reforço. Neste equipamento o geossintético é solicitado por uma carga constante ao longo de todo o ensaio, e em nenhum momento o equilíbrio entre solo e reforço é atingido. Isto explica os maiores fatores de fluência observados nos ensaios realizados no equipamento de fluência confinada-acelerada desenvolvido por França (2011).

Destaca-se ainda que o fato das paredes da caixa desenvolvida por França (2011) serem fixas implica numa menor deformação lateral dos reforços, já que as paredes impedem a movimentação do solo lateralmente. $O$ oposto ocorre na caixa de interação solo-reforço desenvolvida por Costa (2004). O fato das paredes serem móveis implica numa deformação lateral do solo, que por sua vez carrega o reforço e faz com que os mesmos se deformem livremente até que o equilíbrio seja estabelecido. Isto provavelmente explica os maiores níveis de deformações observadas no equipamento desenvolvido por Costa (2004). Além disso, o nível de carregamento nos reforços no início dos ensaios realizados no equipamento de interação solo-reforço é consideravelmente mais elevado que o nível de 
carregamento horizontal aplicado nos reforços no equipamento de fluência confinada-acelerada. Isso faz com que o equipamento de interação solo-reforço apresente deformações iniciais mais elevadas.

A Figura 4.70 mostra, de maneira esquemática, o comportamento típico observado em cada um dos equipamentos avaliados. A Figura 4.70a ilustra a trajetória das cargas em função da deformação observada para ambos os equipamentos. Para o caso do equipamento de interação solo-reforço desenvolvido por Costa (2004), a trajetória das cargas apresenta uma concavidade voltada para o canto inferior esquerdo do gráfico. Isto indica que a desaceleração das deformações ocorre de forma mais intensa do que a desaceleração do carregamento no reforço, mostrando que, para os casos avaliados, a relaxação é mais expressiva do que a fluência. Para o caso do equipamento de fluência confinada-acelerada desenvolvido por França (2011), a trajetória de fluência é uma reta horizontal. Isto indica que o carregamento no reforço é constante ao longo de todo o ensaio, e em momento algum ocorre a relaxação do reforço. Este mesmo comportamento pode ser observado na Figura $4.70 \mathrm{~b}$, que apresenta o carregamento ao longo do tempo para ambos os ensaios.

A Figura 4.70c mostra o comportamento típico observado para ambos os ensaios em termos de deformações ao longo do tempo. De forma geral, os ensaios realizados no equipamento desenvolvido por França (2011) apresentaram menores deformações iniciais e maiores índices de fluência.

Como os carregamentos impostos aos ensaios executados no equipamento desenvolvido por França (2011) foram aproximadamente os mesmos carregamentos que foram obtidos nos ensaios executados no equipamento de Costa (2004), e os níveis de deformações obtidos no equipamento França (2011) foram tipicamente menores, conclui-se que os módulos de rigidez confinada são tipicamente maiores para os ensaios realizados no equipamento de França (2011), conforme mostrado na Figura 4.70d. 


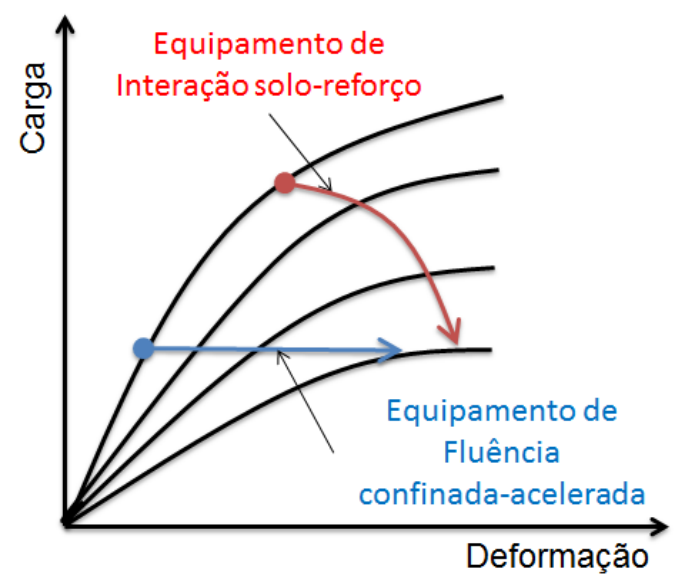

(a)

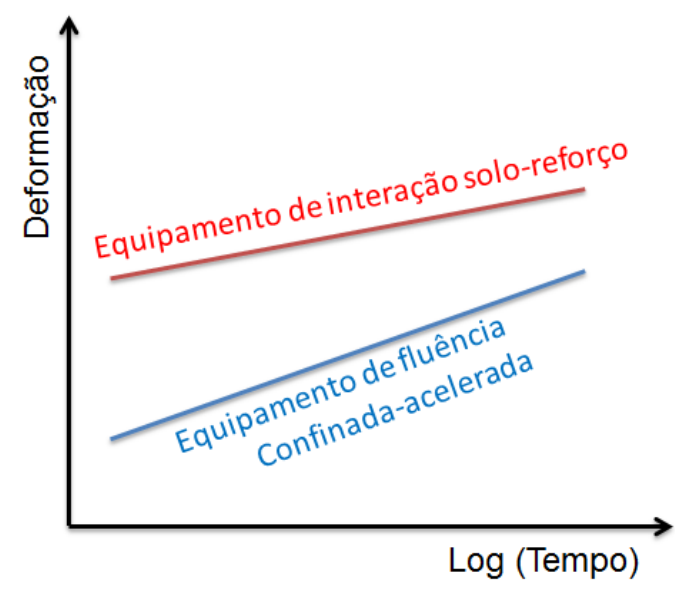

(c)

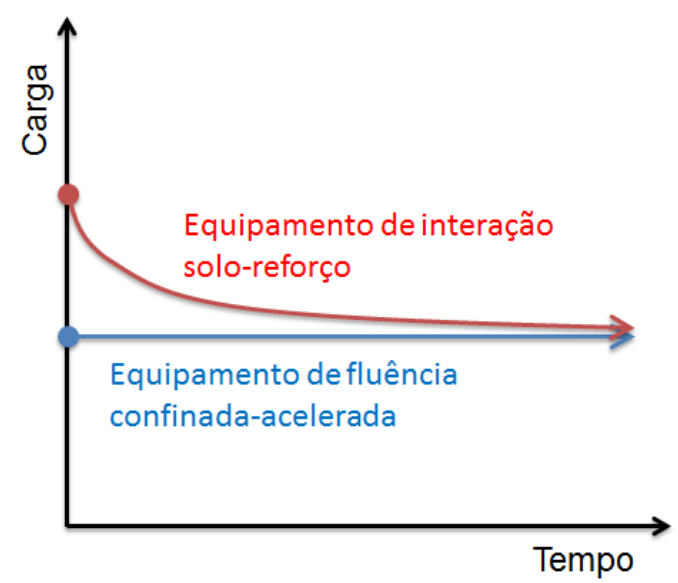

(b)

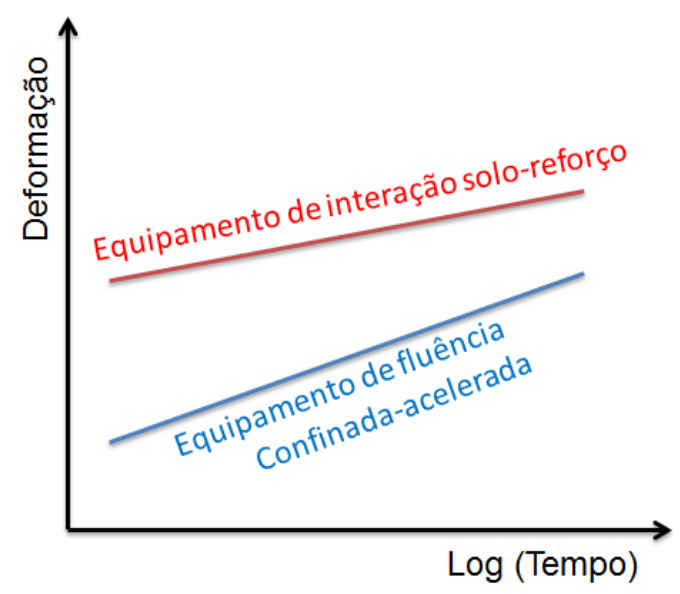

(d)

Figura 4.70 - Comparação entre os comportamentos típicos observados nos equipamentos de interação solo-reforço e fluência confinada-acelerada.

Com base nos resultados obtidos nos ensaios de fluência confinada realizados em ambos os equipamentos, pode-se afirmar que o equipamento de fluência confinadaacelerada desenvolvido por França (2011) é um equipamento para a execução de ensaios de fluência confinada propriamente dito. O equipamento permite a aplicação de qualquer combinação entre a tensão vertical e o carregamento no reforço, mesmo que esta combinação não seja realista. A comparação direta entre esse ensaio e o ensaio de fluência em isolamento, reflete a influência do confinamento em termos teóricos. Por outro lado, o equipamento desenvolvido por Costa (2004) reproduz a interação entre o reforço e solo em uma condição semelhante ao de um 
muro real construído em solo reforçado. O equipamento não permite a aplicação de carregamentos no reforço de forma direta. $\mathrm{O}$ carregamento no reforço é resultado do carregamento vertical aplicado e da interação entre o solo e o reforço. O mecanismo de funcionamento desse tipo de equipamento é mais realista já que está sujeito, simultaneamente, aos fenômenos de fluência e relaxação.

É importante destacar também que as deformações ao longo do tempo obtidas no equipamento de interação solo-reforço desenvolvido por Costa (2004) são dependentes das características de fluência do solo confinante. Para casos em que são empregados solos com taxas de fluência menores que as dos reforços, o solo tende a restringir o desenvolvimento das deformações no geossintético. Este foi o caso dos resultados apresentados nesta tese. Por outro lado, segundo Wu e Helwany (1996), quando são utilizados solos com taxas de fluência maiores que as dos reforços, as deformações ao longo do tempo nos materiais confinados tendem a ser aumentadas. Este tipo de comportamento não ocorre nos ensaios realizados no equipamento de fluência confinada-acelerada desenvolvido por França (2011), já que as paredes da câmara de ensaios são fixas.

No equipamento de interação solo-reforço, deslocamentos relativos entre o solo e o geossintético confinado não são esperados, já que as deformações ao longo do tempo ocorrem em função da interação entre os materiais empregados no ensaio. Por outro lado, no equipamento de fluência confinada-acelerada, deslocamentos relativos entre o solo e o reforço são esperados, já que as paredes da câmara de ensaios impedem o deslocamento lateral do solo, mas não restringem o movimento do reforço.

Outro fator importante a respeito dos mecanismos de funcionamento dos equipamentos se refere à possível plastificação do solo confinante. No equipamento de fluência confinada-acelerada, independente do carregamento vertical imposto, o solo não sofre plastificação, tendo em vista que o estado de tensões não varia ao longo do ensaio. Já no equipamento de interação solo-reforço ocorre um alívio de tensões laterais ao longo do teste. Dependendo do carregamento vertical aplicado ao ensaio, o solo envolvente pode sofrer plastificação, e partir desse momento os reforços passam a sofrer um acréscimo nos carregamentos de forma não linear. Este comportamento é condizente com situações reais de muros construídos em solos reforçados com geossintéticos. 
Em vista dos resultados dos ensaios de fluência confinada apresentados neste trabalho, pode-se dizer que o equipamento de fluência confinada-acelerada apresentado por França (2011) é mais adequado para a verificação dos efeitos do confinamento sobre o comportamento ao longo do tempo de geossintéticos. Este tipo de equipamento, apesar de não representar de forma realista os mecanismos desenvolvidos em uma obra real de solos reforçados com geossintéticos, possui a capacidade de isolar os efeitos do confinamento em solo, além de possibilitar a execução de ensaios acelerados. Já no equipamento de interação solo-reforço desenvolvido por Costa (2004), os efeitos do confinamento não podem ser isolados. Neste tipo de equipamento ocorrem simultaneamente os efeitos da fluência e da relaxação, e, portanto, as análises do efeito do confinamento de forma isolada ficam comprometidas. Pode-se afirmar que este equipamento é mais indicado para a previsão das deformações ao longo do tempo de estruturas reais do que para análises do efeito do confinamento.

As análises referentes ao desempenho dos equipamentos em comparação aos resultados obtidos na instrumentação da obra real de Campinas são apresentadas mais adiante no Capítulo 5 (Item 5.2) desta tese.

\subsection{SUMÁRIO DO CAPÍTULO 4}

Neste capítulo foram apresentados os resultados dos ensaios fluência confinada e isolada realizados em laboratório empregando três diferentes geossintéticos: geotêxteis não tecidos, geotêxteis tecidos e geogrelhas. Os ensaios de fluência em confinamento foram realizados empregando dois equipamentos distintos: equipamento de interação solo-reforço desenvolvido por Costa (2004), e equipamento de fluência confinada-acelerada desenvolvido por França (2011). As condições de carregamentos empregadas nos ensaios foram baseadas nas características do muro em solo reforçado de Campinas, utilizado como referência neste trabalho. Para complementar os resultados dos ensaios de laboratório, modelagens computacionais foram também realizadas.

Os resultados dos ensaios de fluência isolada e confinada em conjunto com os resultados das análises numéricas apresentadas neste item permitiram concluir que: 
- Os ensaios de fluência confinada realizados no equipamento de interação solo-reforço desenvolvido por Costa (2004) mostraram que os parâmetros referentes às deformações iniciais (parâmetros "a" e $\varepsilon_{0}$ )

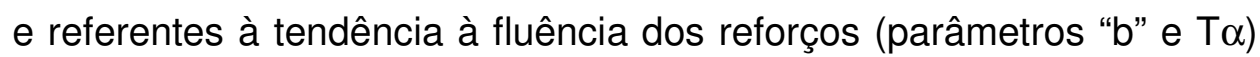
foram reduzidos devido à presença do confinamento para os geotêxteis não tecidos, geotêxteis tecidos e geogrelhas, para todos os níveis de carregamento testados $(140,200,300$ e $400 \mathrm{kPa})$;

- Para todos os reforços avaliados (geotêxtil tecido, geotêxtil não tecido e geogrelha), observou-se que maiores níveis de carregamentos verticais aplicados ao ensaio confinado conduziram a maiores níveis de deformações, de parâmetros de fluência e de cargas nos reforços. Em todos os casos, as curvas do tipo carga-deformação obtidas para os diferentes tipos de reforço apresentaram uma forma curvada, com a concavidade da curva voltada para o canto inferior esquerdo do gráfico. Isto indica que a desaceleração das deformações nos reforços foi maior que a desaceleração das cargas, permitindo concluir que, nos ensaios realizados no equipamento desenvolvido por Costa (2004), a relaxação ocorreu de forma mais intensa do que a fluência;

- Para o caso dos geotêxteis não tecidos (GNT) o confinamento em solo promoveu o aumento da rigidez do reforço em aproximadamente 2,5 vezes. Para os geotêxteis tecidos (GT) o aumento da rigidez em função do confinamento foi da ordem de 1,4 vezes. Já para o caso das geogrelhas (GG) o acréscimo foi da ordem de 1,8 vezes. Tais resultados mostram que os geotêxteis não tecidos sofreram maior influência pelo confinamento que os demais tipos de reforço;

- Com relação ao tipo de material, os resultados mostraram que tanto as deformações iniciais quanto as deformações totais foram maiores para os geotêxteis não tecidos e menores para as geogrelhas, com os geotêxteis tecidos apresentando resultados intermediários. Em termos de fluência (parâmetro "b" e T $\alpha$ ), os resultados mostraram que os maiores valores foram obtidos para os geotêxteis tecidos e os menores para geogrelhas, com os geotêxteis não tecidos apresentando 
resultados intermediários. Estes resultados vão de encontro com dados encontrados na bibliografia e são explicados em função do tipo de polímero que compõe o material;

- No que se refere aos níveis de carregamento mobilizados nos reforços, os ensaios realizados no equipamento de interação solo-reforço mostraram que, para todos os níveis de carregamento testados, os esforços obtidos para os diferentes tipos de reforços foram muito semelhantes. Em relação às cargas mobilizadas nos reforços normalizadas pela resistência última dos materiais $\left(\mathrm{T} / \mathrm{T}_{\text {ult }}\right)$, os geotêxteis tecidos foram os que apresentaram as maiores magnitudes. Já os geotêxteis tecidos e geogrelhas apresentaram valores muito parecidos entre si;

- Os resultados dos ensaios confinados mostraram que a relaxação nos reforços, assim como a fluência, é dependente do nível de carregamento vertical aplicado ao ensaio, ou seja, a carga inicial no reforço e a tendência à redução da carga por relaxação são mais elevadas para carregamentos verticais maiores. Os resultados mostraram que os maiores índices de relaxação foram observados para os geotêxteis tecidos e os menores para os geotêxteis não tecidos. As geogrelhas apresentaram resultados intermediários;

- Os ensaios realizados com diferentes umidades de compactação no equipamento de interação solo-reforço mostraram que o melhor desempenho do conjunto solo-reforço foi obtido para os ensaios realizados com o maciço compactado na umidade ótima. As maiores deformações iniciais e índices de fluência foram obtidos para os ensaios com solo compactado com teor de umidade situado no ramo úmido. Os ensaios com solo compactado com teor de umidade situado no ramo seco apresentaram resultados intermediários. Estes resultados permitiram concluir que o comportamento do conjunto soloreforço em termos de deformações instantâneas e fluência estão diretamente relacionados ao grau de compactação em que o solo se encontra; 
- Os resultados dos ensaios confinados inundados mostraram que os acréscimos de carga nos reforços, decorrentes do processo de inundação, foram semelhantes aos acréscimos de deformação. Em termos de comportamento, isto indica que, apesar dos aumentos expressivos nos carregamentos e deformações (cerca de 100\% para GNT, $45 \%$ para GT e $50 \%$ para GG) a rigidez confinada dos reforços praticamente não se alterou;

- Os ensaios de compactação realizados no equipamento desenvolvido por Costa (2004) mostraram que o processo de compactação promoveu um acréscimo de carga nos reforços. O acréscimo de carga no reforço devido aos efeitos da compactação foi de $68 \%$ para os geotêxteis não tecidos, $77 \%$ para os geotêxteis tecidos e $300 \%$ para as geogrelhas. Os resultados permitiram concluir que os acréscimos de carregamento estão associados à rigidez do geossintético e também às propriedades de interface solo-reforço;

- As modelagens computacionais realizadas para os ensaios confinados empregando o equipamento de interação solo-reforço permitiram a extrapolação dos resultados dos ensaios de laboratório para períodos de tempo de até 1000 horas. Assim, é possível realizar a previsão do comportamento de ensaios de fluência confinada a partir dos resultados de ensaios de fluência em isolamento empregando os gráficos mostrados na Figura 4.42;

- As análises referentes à variação do estado de tensões ao longo dos ensaios realizados no equipamento de interação solo-reforço mostraram que a trajetória de tensões se desloca em direção à diagonal superior esquerda dos gráficos, indicando que há uma redução das tensões horizontais ao longo da execução dos ensaios com carregamento vertical constante;

- A análise conjunta dos resultados dos ensaios em isolamento e dos ensaios confinados no equipamento de interação solo-reforço mostrou que o confinamento em solo afetou de maneira significativa tanto a deformação inicial quanto a tendência à fluência dos geotêxteis não 
tecidos. Para os geotêxteis tecidos e geogrelhas apenas a tendência à fluência sofreu influência significativa pelo confinamento. Estes resultados corroboraram os dados encontrados na bibliografia publicados por Kamiji (2006), França (2011) e Avesani (2013);

- A partir das informações apresentadas na análise conjunta dos dados, foi possível se determinar um modelo analítico para a previsão do comportamento ao longo do tempo de reforços. A partir deste modelo é possível determinar a variação do módulo de rigidez confinada ao longo do tempo tendo como dados de entrada os resultados de ensaios não confinados. O modelo proposto para a previsão de comportamento é apresentado nas Equações 4.2, 4.3 e 4.4;

- Os ensaios de fluência confinada realizados no equipamento de fluência confinada-acelerada desenvolvido por França (2011) mostraram que, a exemplo do que foi observado para o equipamento de interação solo-reforço desenvolvido por Costa (2004), tanto as deformações iniciais quanto os índices de fluência foram reduzidos devido à presença do confinamento em solo;

- Os ensaios confinados-acelerados realizados no equipamento desenvolvido por França (2011) permitiram a extrapolação das deformações para um período de 584 anos para os geotêxteis não tecidos, 288 anos para os tecidos e 621 anos para a geogrelhas. As deformações máximas obtidas para os tempos extrapolados foram da ordem de $1 \%$ para os geotêxteis não tecidos e tecidos e da ordem de $0,5 \%$ para as geogrelhas;

- As comparações entre os resultados obtidos nos dois tipos de equipamentos para a avaliação da fluência confinada mostraram que os níveis de deformação foram maiores para os ensaios realizados no equipamento de interação solo-reforço. Por outro lado, os maiores índices de fluência foram obtidos para os ensaios realizados no equipamento de fluência confinada-acelerada. Este fato é explicado pelo princípio de funcionamento de cada um dos equipamentos. No equipamento de interação o carregamento no reforço no início do 
ensaio é consideravelmente maior que o carregamento no equipamento de fluência confinada-acelerada. Isto explica as maiores deformações no primeiro equipamento. Além disso, no equipamento de Costa (2004) o carregamento no reforço sofre um decréscimo ao longo do ensaio, devido à relaxação do conjunto solo-reforço. No equipamento de França (2011), a força no elemento confinado é constante ao longo de todo o ensaio. Sendo assim, o equipamento de Costa (2004) sofre simultaneamente os efeitos da fluência e da relaxação, enquanto o equipamento de França (2011) está sujeito somente à fluência. Este fato explica os menores índices de fluência obtidos nos ensaios realizados no equipamento de Costa (2004);

- Os resultados dos ensaios obtidos em ambos os equipamentos permitiram concluir que o equipamento desenvolvido por França (2011) é um equipamento para a execução de ensaios de fluência confinada propriamente dito. A comparação direta entre esse ensaio e o ensaio de fluência não confinada, reflete a influência do confinamento em termos teóricos. Por outro lado, o equipamento desenvolvido por Costa (2004) reproduz a interação entre o reforço e solo em uma condição semelhante ao de um muro real construído em solo reforçado.

- Os resultados dos ensaios obtidos em ambos os equipamentos permitiram concluir que o equipamento de fluência confinada-acelerada apresentado por França (2011) é mais adequado para a verificação dos efeitos do confinamento sobre o comportamento ao longo do tempo de geossintéticos. Este tipo de equipamento, apesar de não representar de forma realista os mecanismos desenvolvidos em uma obra real de solos reforçados com geossintéticos, possui a capacidade de isolar os efeitos do confinamento em solo, além de possibilitar a execução de ensaios acelerados;

- O equipamento de interação solo-reforço desenvolvido por Costa (2004) é mais indicado para a previsão das deformações ao longo do tempo de estruturas reais, tendo em vista que representa de maneira mais realista os mecanismos desenvolvidos em estruturas de solo reforçado com geossintéticos. 


\section{RESULTADOS DA OBRA INSTRUMENTADA}

Este Capítulo apresenta os resultados e análises do monitoramento do muro em solo reforçado, construído na cidade de Campinas, utilizado como referência para este trabalho.

Conforme destacado no Capítulo 3 desta tese, mais especificamente no item 3.1, a obra consiste em um muro de contenção de solo reforçado com geotêxteis com a função de nivelar uma determinada área onde foi implantado um conjunto habitacional. Este muro foi instrumentado desde o início de sua construção para o acompanhamento do desempenho mecânico da estrutura em função dos níveis de precipitação na região da obra e dos níveis de sucção matricial desenvolvidos no interior do maciço de solo que compõe o aterro da estrutura. As informações resultantes desta instrumentação foram apresentadas por Portelinha (2012).

É importante lembrar que o muro em estudo é composto por aterros com até $9 \mathrm{~m}$ de altura, sendo que, da altura total, aproximadamente $5,6 \mathrm{~m}$ foi construído em solo reforçado, e aproximadamente 3,4 $\mathrm{m}$ em talude não reforçado. Para a construção do aterro foi empregado um solo fino encontrado no próprio local da obra.

Conforme apresentado no Capítulo 3, o final da construção do aterro reforçado se deu com 86 dias, e a obra total, incluindo o aterro não reforçado em talude sobre a estrutura reforçada, se deu com 120 dias.

Nos itens a seguir são apresentados os resultados das leituras nos instrumentos situados nas elevações de 0,8 m (E01), 1,60 m (E02) e 5,0 m (E03), lembrando que as elevações possuem como referência (nível 0) o pé do muro (Figura 5.1).

Neste capítulo os dados obtidos a partir das leituras dos instrumentos do muro são comparados aos dados obtidos nos ensaios de fluência confinada realizados em laboratório.

Destaca-se que os resultados das leituras de campo são analisados segundo duas abordagens distintas: por modelos numéricos, utilizando o Método dos Elementos Finitos (MEF), e pelo modelo analítico proposto no Item 4.2.7 apresentado no Capítulo 4 desta tese. 
Trincheira de drenagem

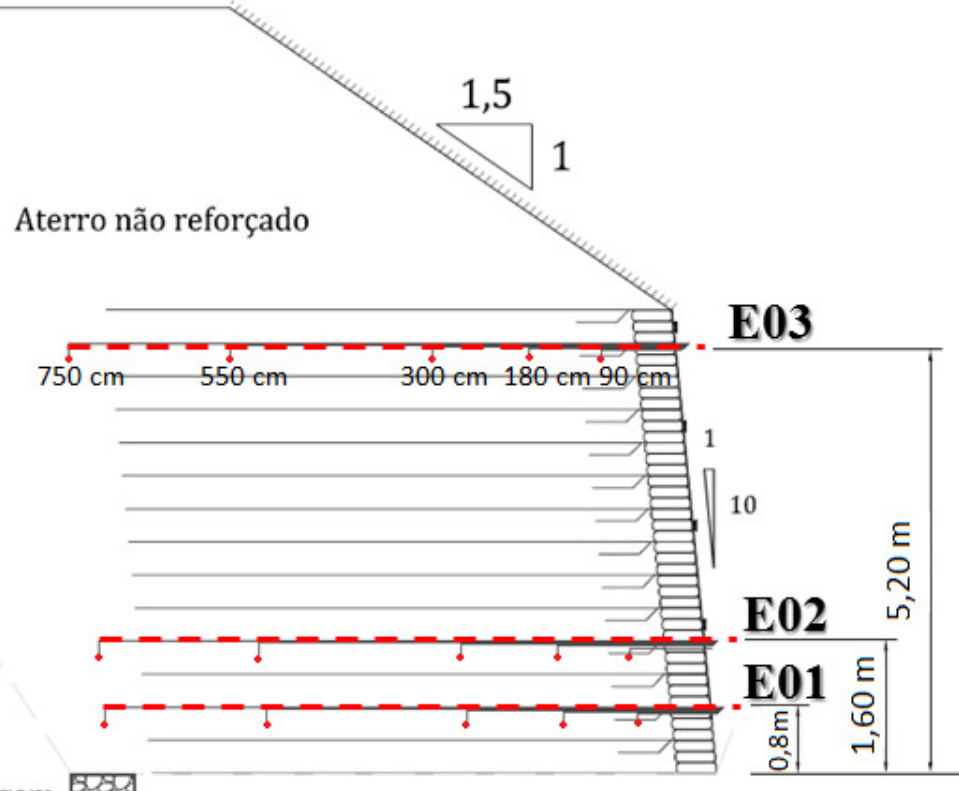

Figura 5.1 - Posicionamento dos níveis de leitura E01, E02 e E03 ao longo da seção instrumentada.

\subsection{RESULTADOS OBTIDOS NAS LEITURAS DOS INSTRUMENTOS}

Na Figura 5.2 e Figura 5.3 são apresentados os principais resultados das leituras dos instrumentos instalados nas seções de geotêxteis não tecidos e tecidos, respectivamente.

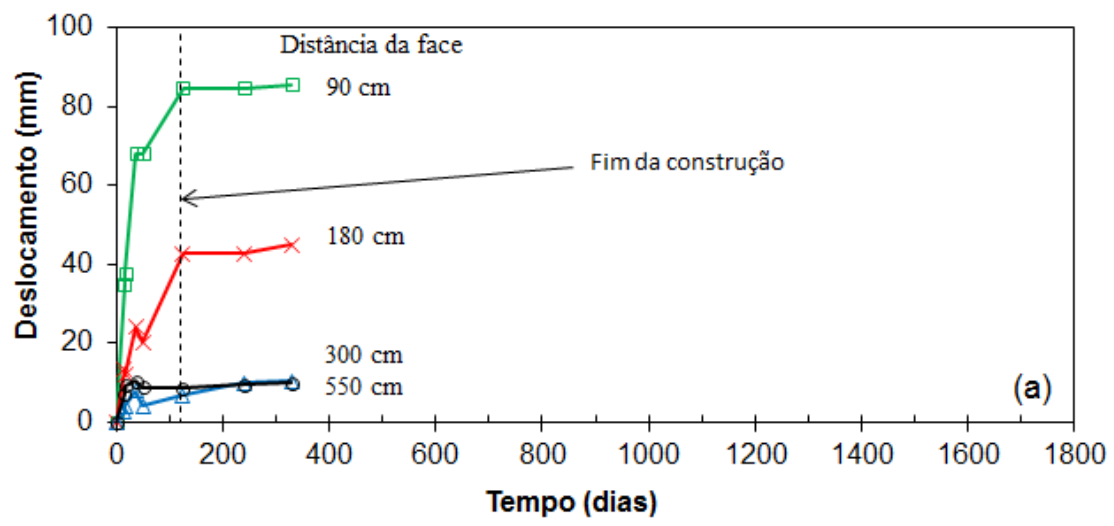



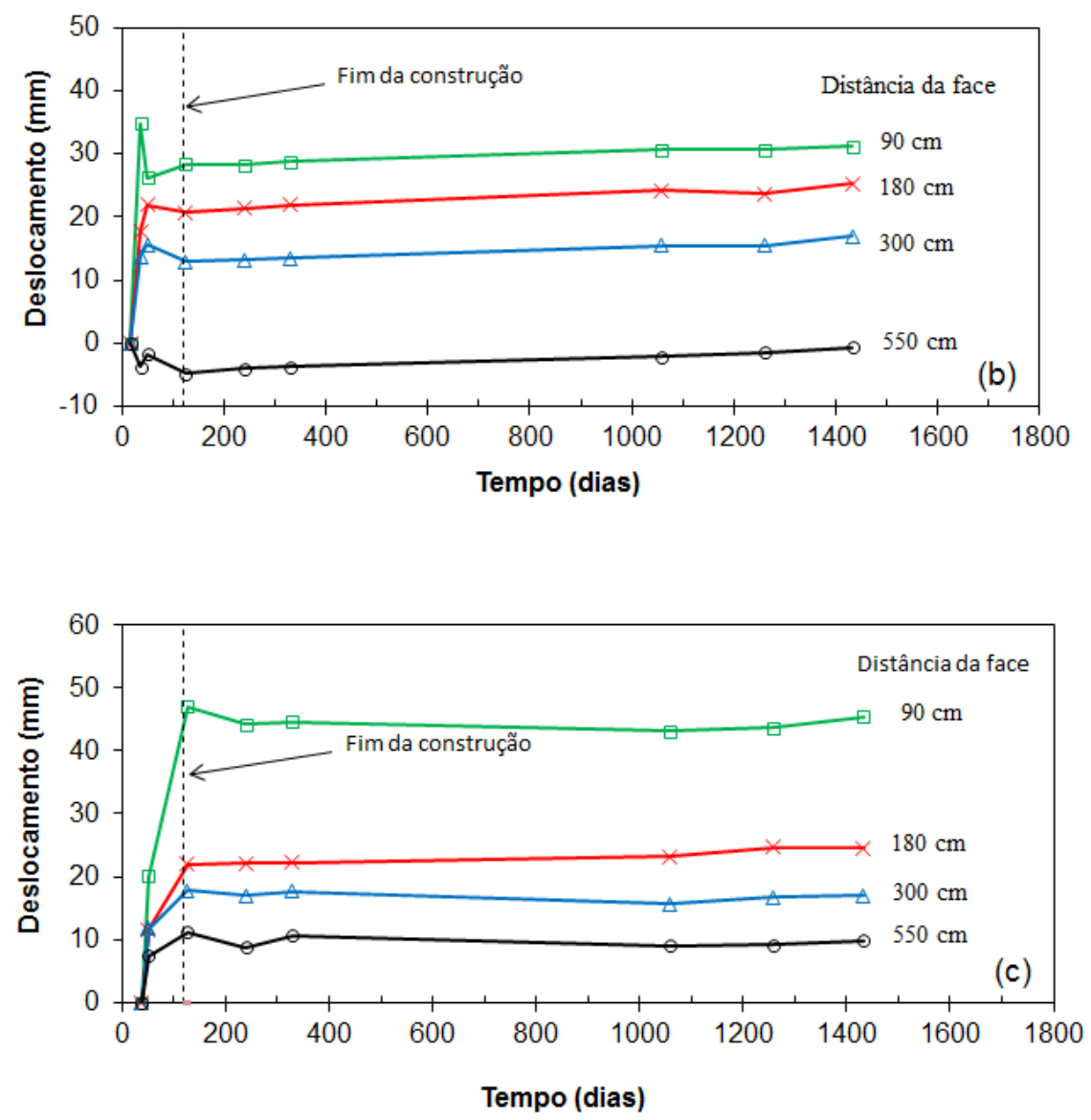

Figura 5.2 - Deslocamentos internos para a seção em geotêxteis não tecidos na elevação: (a) 0,8 m (E01); (b) 1,6 m (E02); (c) 5,2 m (E03).

Como se pode observar na Figura 5.2, para a seção em geotêxteis não tecidos, os maiores deslocamentos foram observados nos pontos mais próximos à face da estrutura. Observa-se que os valores de deslocamentos diminuem ao longo do comprimento do reforço. A Figura 5.2 mostra também que os maiores níveis de deslocamentos foram atingidos na linha de monitoramento E01, de menor elevação. Observa-se ainda que, para a linha instrumentada de maior elevação (E03), os deslocamentos no ponto mais próximo à face foram relativamente altos quando comparados com os deslocamentos da linha intermediaria (E02). Nos demais pontos ao longo dos reforços, os deslocamentos registrados nos níveis E02 e E03 foram muito semelhantes. Os maiores deslocamentos próximo à face para o nível instrumentado E03 provavelmente podem ser atribuídos à fatores externos de obra, 
tendo em vista que este nível se encontra muito próximo ao topo do muro e, portanto, mais susceptível aos efeitos dos agentes externos.
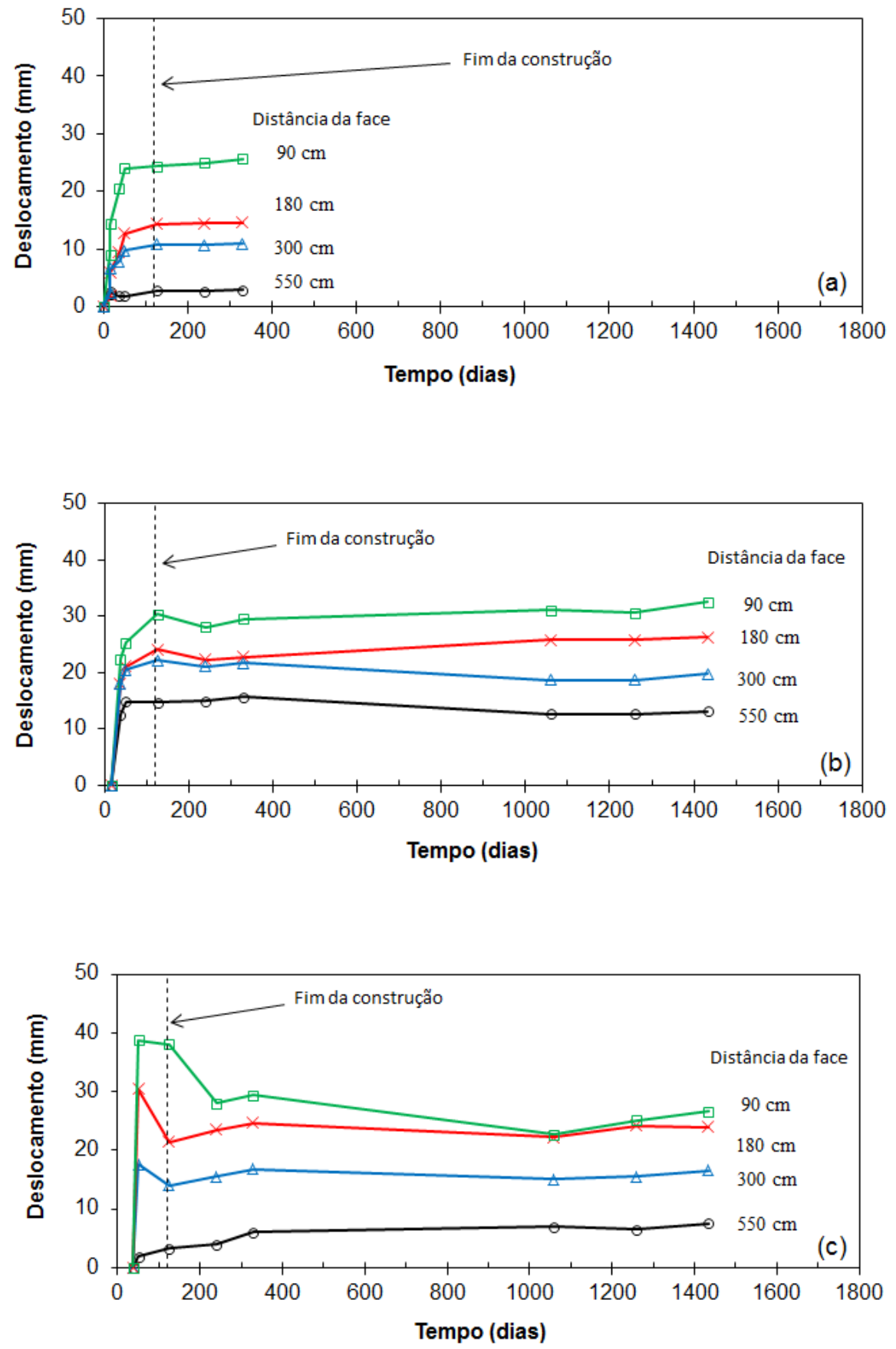

Figura 5.3 - Deslocamentos internos para a seção em geotêxteis tecidos na elevação: (a) $0.8 \mathrm{~m}$ (E01); (b) $1.6 \mathrm{~m}$ (E02); (c) $5.2 \mathrm{~m} \mathrm{(E03).}$ 
Para a seção em geotêxteis tecidos, a Figura 5.3 mostra que os maiores deslocamentos também ocorreram nos pontos mais próximos à face da estrutura. Entretanto, diferentemente do observado para a seção em geotêxteis não tecidos, os maiores deslocamentos ocorreram na linha instrumentada mais próxima ao topo da estrutura, denominada linha de instrumentação E03.

Teoricamente, seriam esperados deslocamentos mais elevados na linha instrumentada de menor elevação, tendo em vista que a cobertura de solo é maior, sendo esta região, portanto, sujeita a maiores empuxos de solo. Entretanto, nas camadas mais elevadas, mesmo com o empuxo de solo menor, existe a maior susceptibilidade a deslocamentos devido às ações externas. A geometria do muro (Figura 5.1), com sobrecarga em talude, somado aos carregamentos externos de equipamentos de compactação e caminhões que trafegam nessa região, provavelmente favorecem a ocorrência de deslocamentos mais elevados nas regiões mais altas do aterro reforçado.

As Figuras 5.4 a 5.9 apresentam, para cada linha instrumentada, para ambos os geotêxteis empregados na obra, os deslocamentos relativos em relação à face, a distribuição das deformações ao longo dos reforços calculadas a partir de um ajuste sigmoidal (descrito no item 3.6 desta tese), e ainda a evolução das deformações máximas nos reforços em função do tempo.

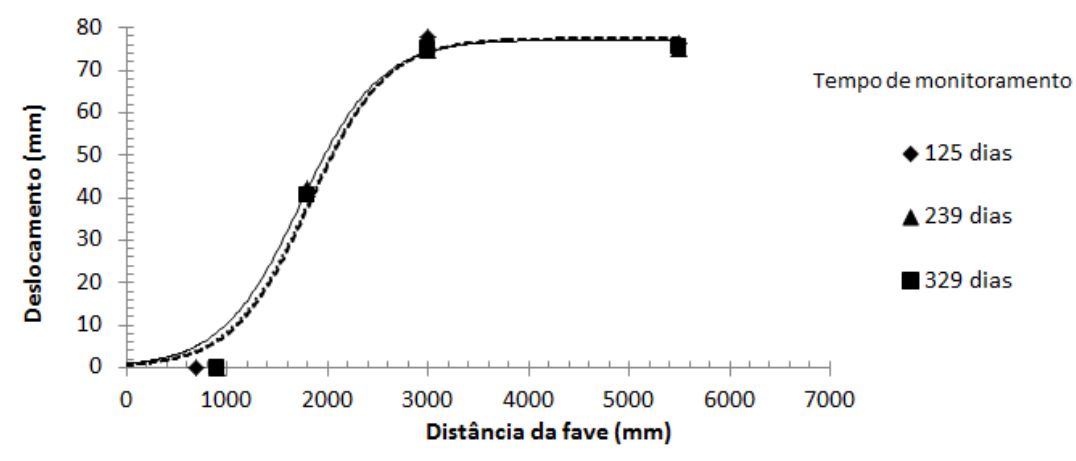

(a) 


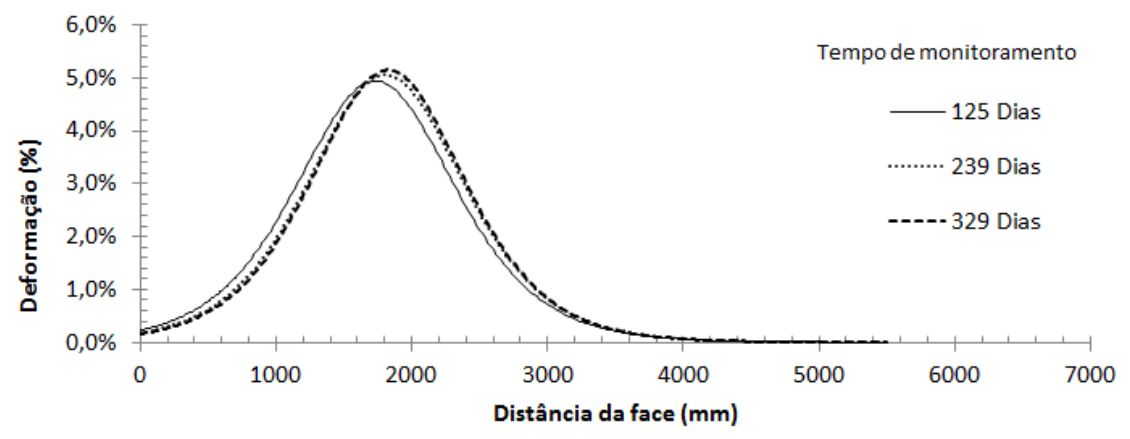

(b)

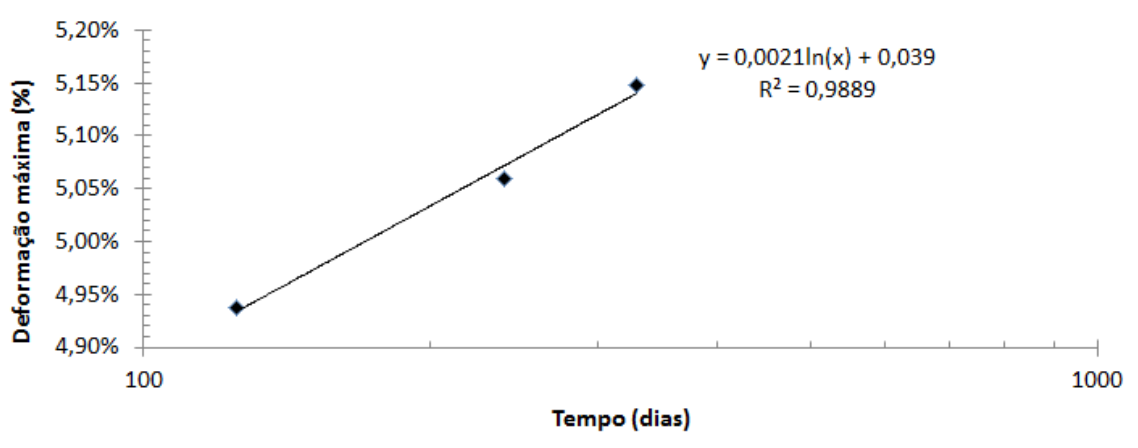

(c)

Figura 5.4 - Resultados das leituras de deslocamentos internos na seção em geotêxtil não tecido, elevação 0,8 m (E01): (a) deslocamentos relativos; (b) curvas sigmoides de deformação; (c) deformações máximas ao longo do tempo.

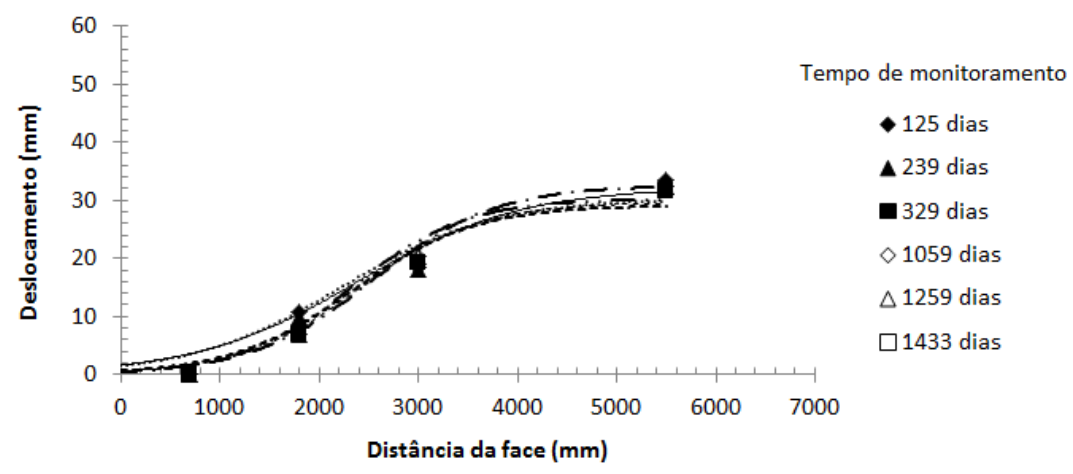

(a) 


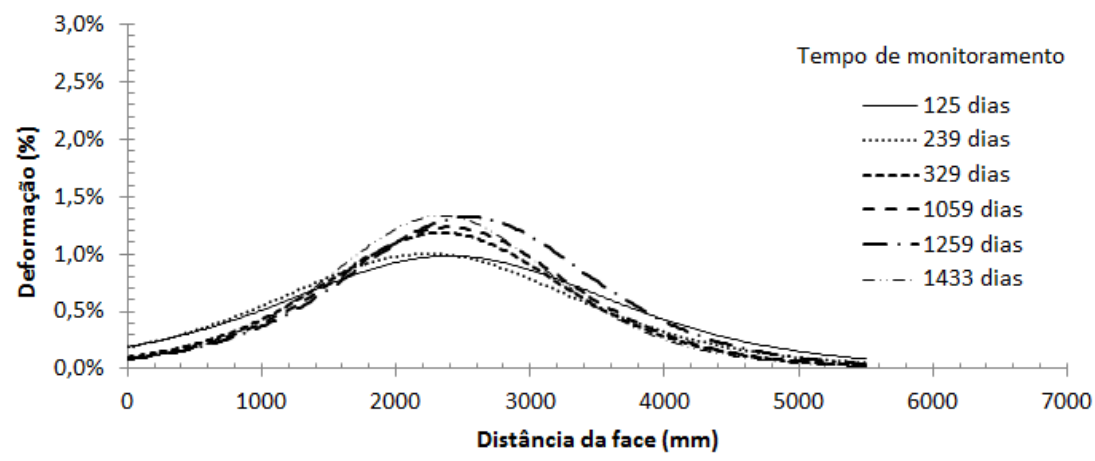

(b)

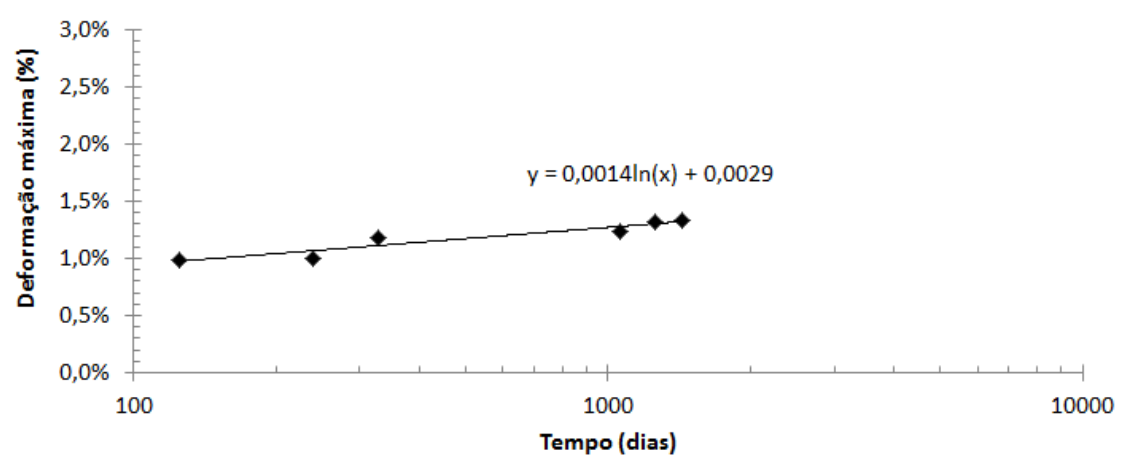

(c)

Figura 5.5 - Resultados das leituras de deslocamentos internos na seção em geotêxtil não tecido, elevação 1,6 m (E02): (a) deslocamentos relativos; (b) curvas sigmoides de deformação; (c) deformações máximas ao longo do tempo.

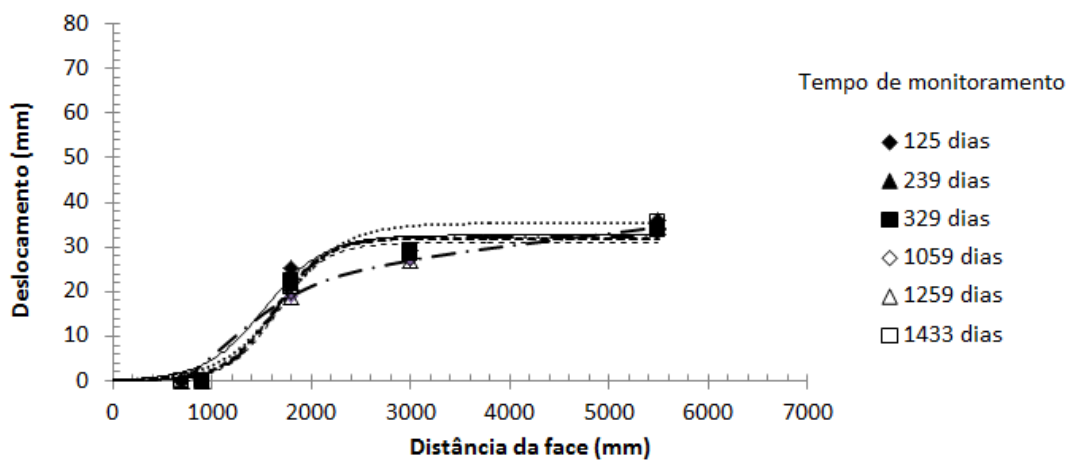

(a) 


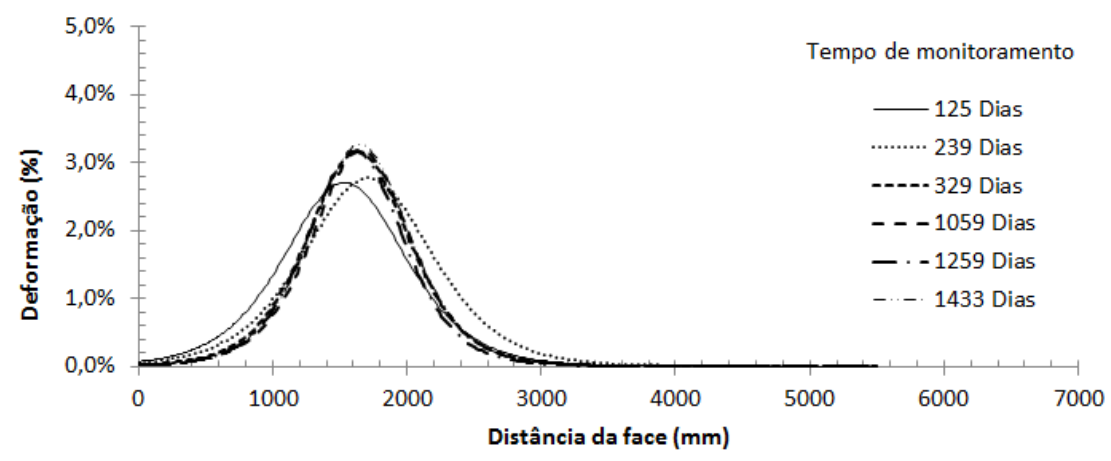

(b)

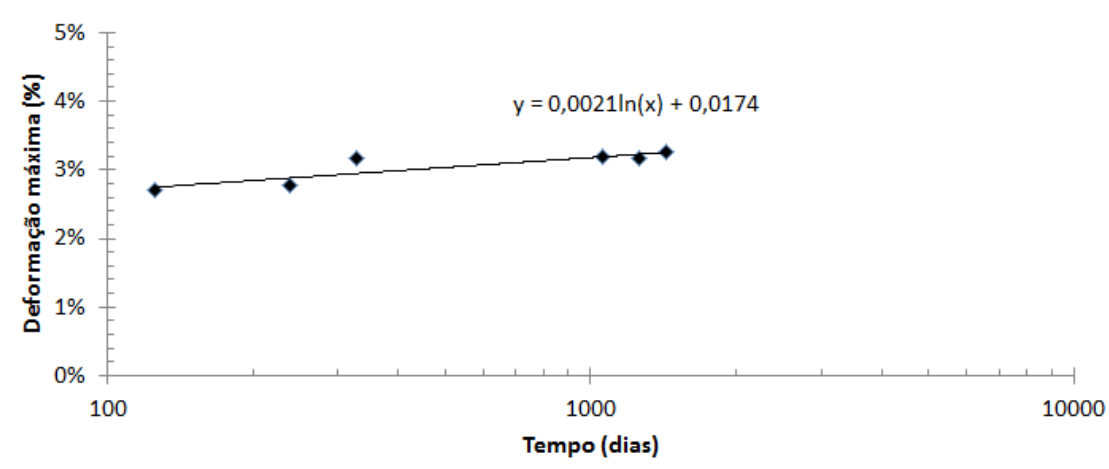

(c)

Figura 5.6 - Resultados das leituras de deslocamentos internos na seção em geotêxtil não tecido, elevação 5,2 m (E03): (a) deslocamentos relativos; (b) curvas sigmoides de deformação; (c) deformações máximas ao longo do tempo.

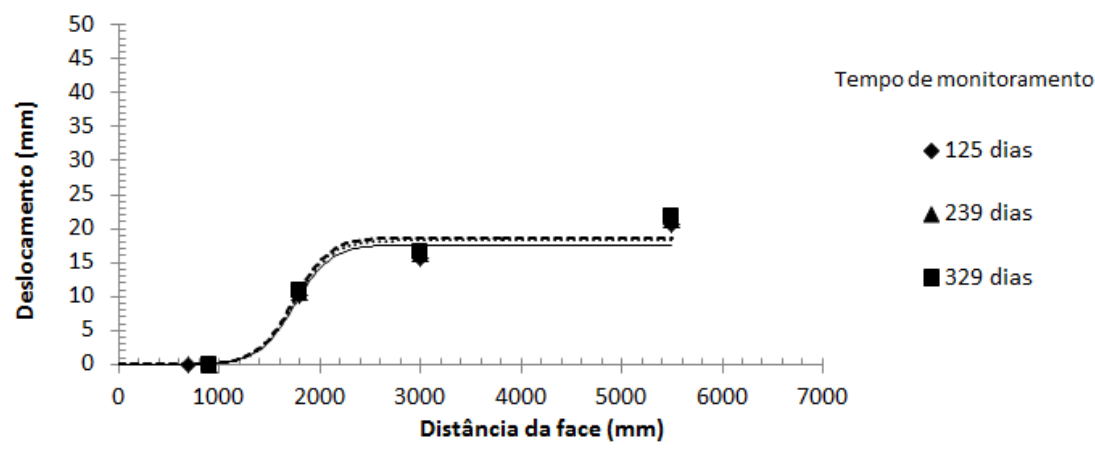

(a) 


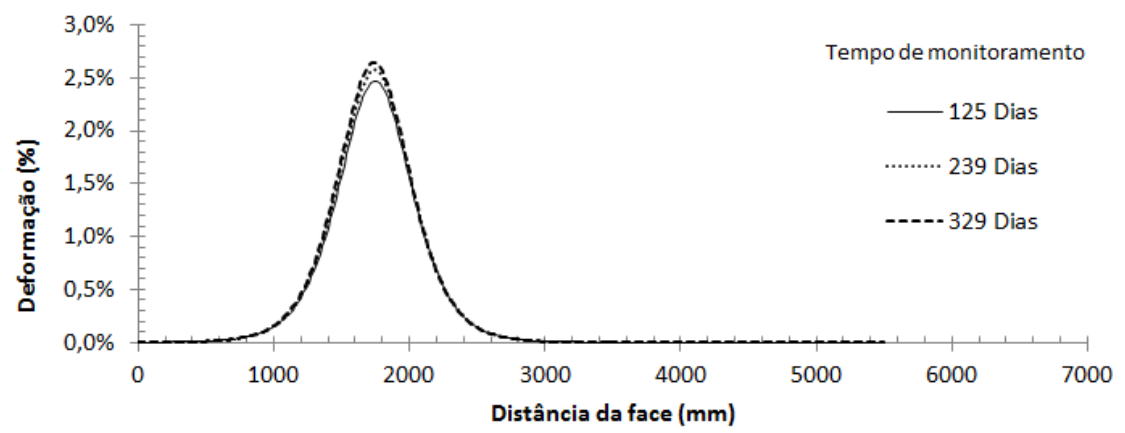

(b)

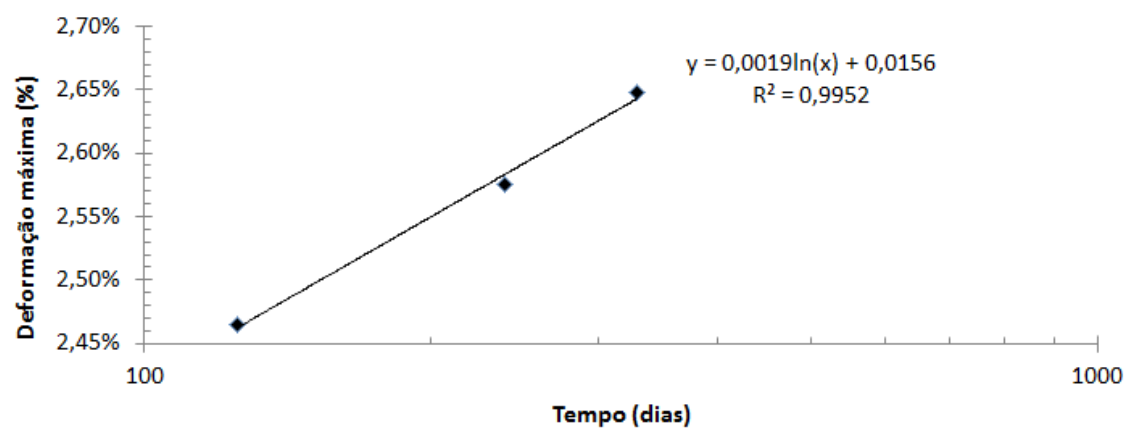

(c)

Figura 5.7 - Resultados das leituras de deslocamentos internos na seção em geotêxtil tecido, elevação 0,8 m (E01): (a) deslocamentos relativos; (b) curvas sigmoides de deformação; (c) deformações máximas ao longo do tempo.

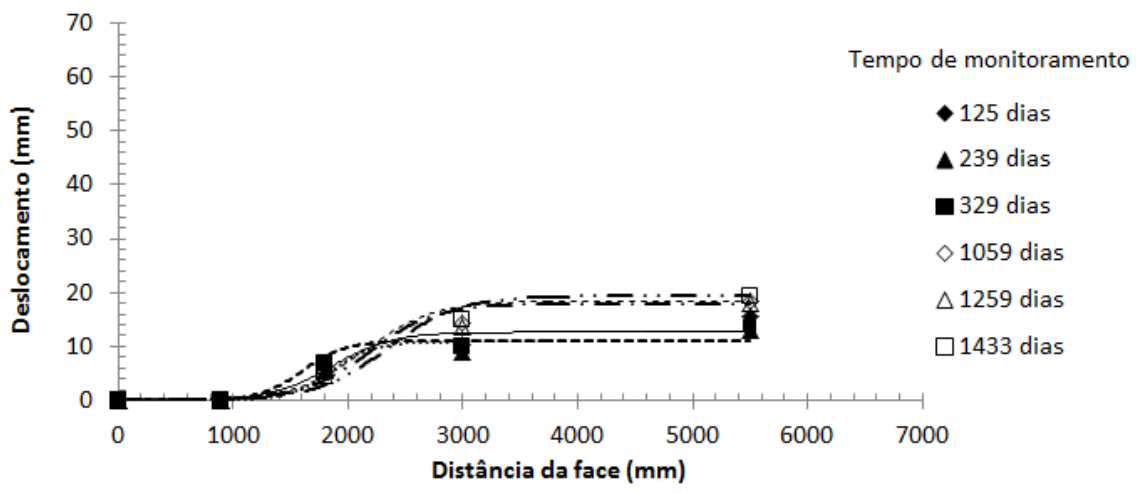

(a) 


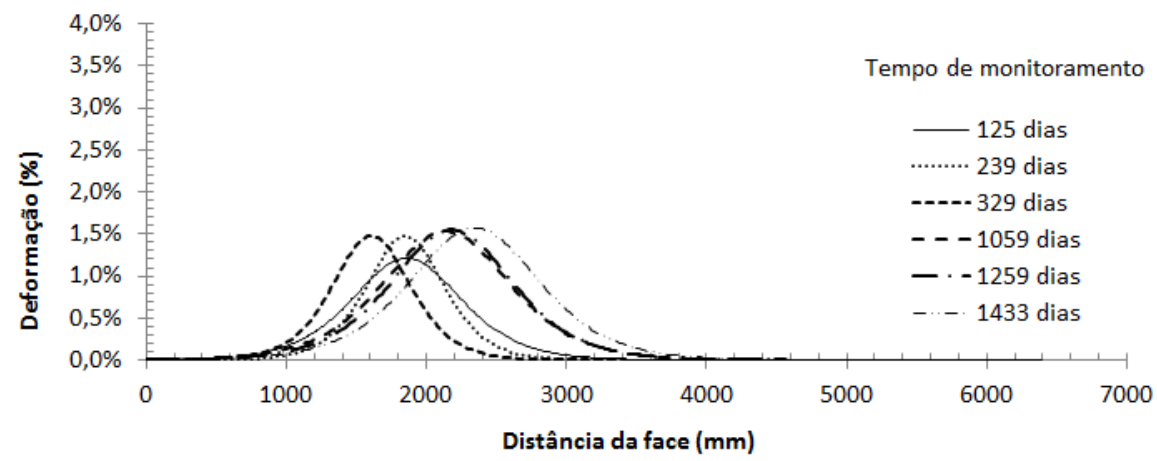

(b)

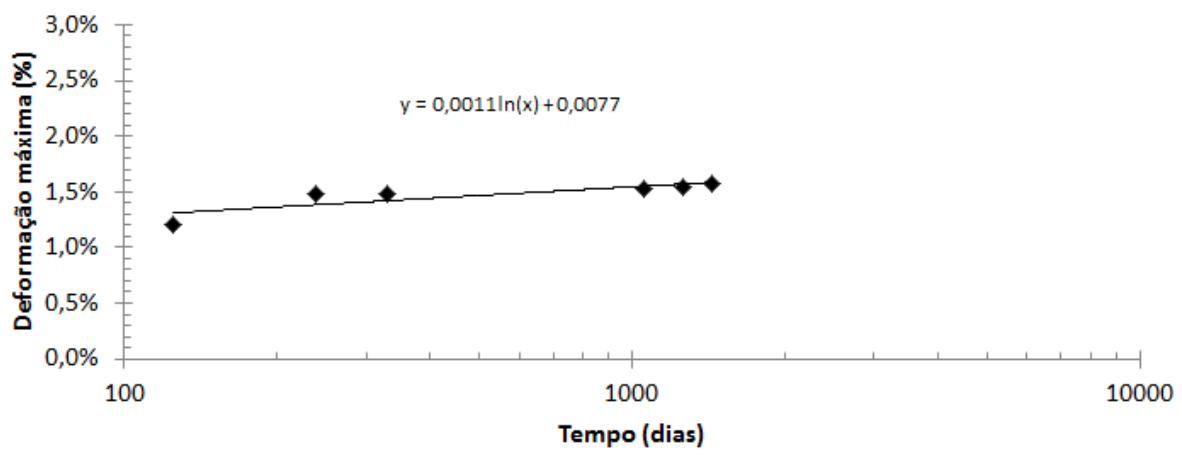

(c)

Figura 5.8 - Resultados das leituras de deslocamentos internos na seção em geotêxtil tecido, elevação 1,6 m (E02): (a) deslocamentos relativos; (b) curvas sigmoides de deformação; (c) deformações máximas ao longo do tempo.

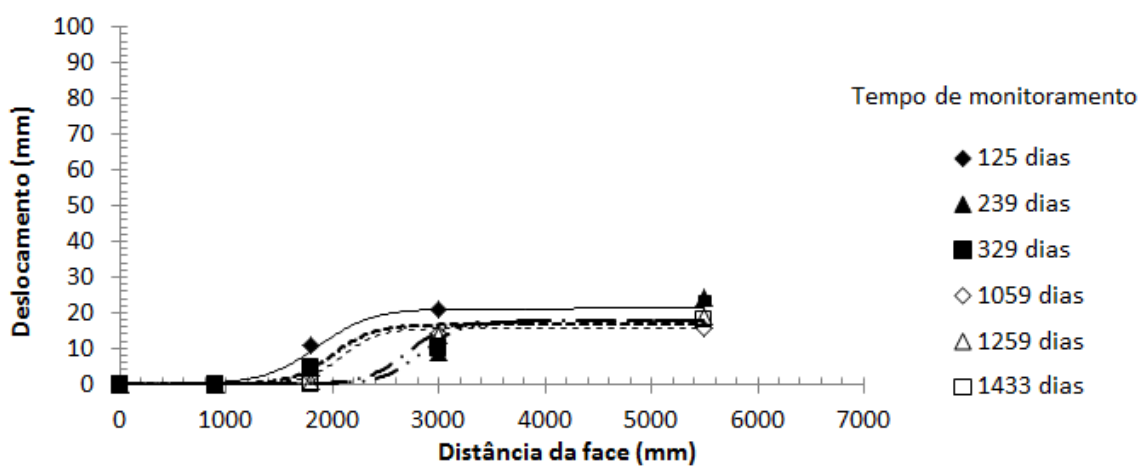

(a) 


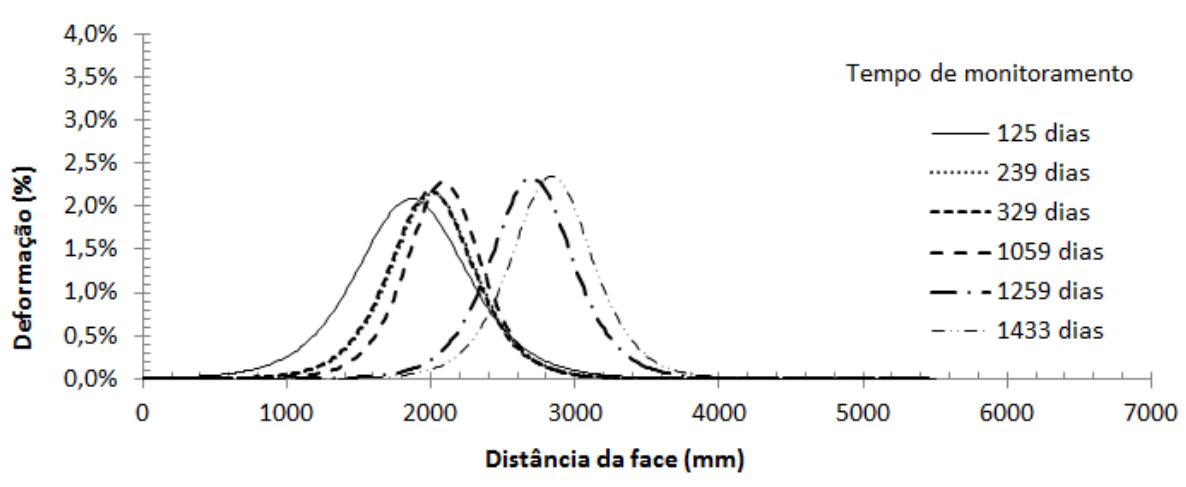

(b)

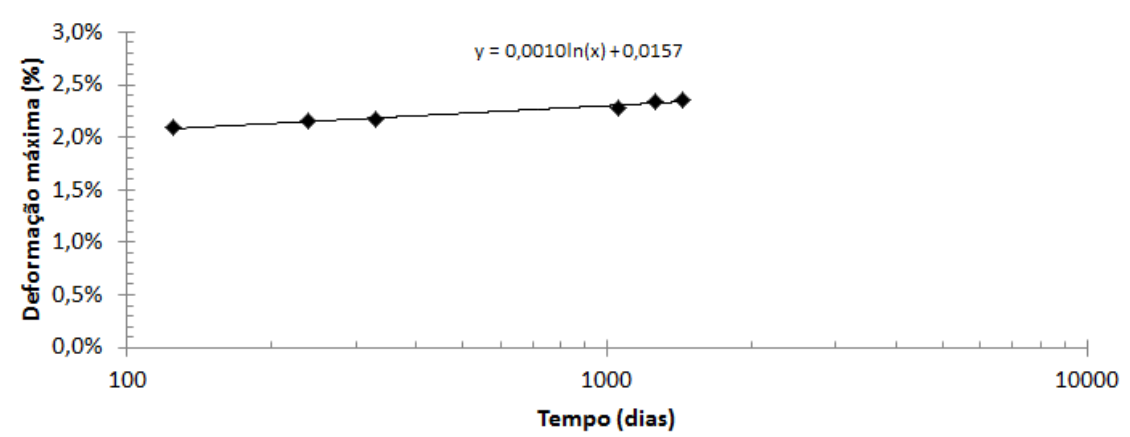

(c)

Figura 5.9 - Resultados das leituras de deslocamentos internos na seção em geotêxtil tecido, elevação 5,2 m (E03): (a) deslocamentos relativos; (b) curvas sigmoides de deformação; (c) deformações máximas ao longo do tempo.

A partir das Figuras 5.4, 5.5, e 5.6, observa-se que as deformações máximas, para a seção em geotêxtil não tecido, foram da ordem de $5 \%$ para linha instrumentada mais baixa (E01), pouco superiores a 1\% para a linha instrumentada intermediária (E02), e pouco superiores a 3\% para a linha de instrumentação mais elevada (E03). Conforme destacado anteriormente, era de se esperar que a camada intermediária apresentasse maiores deformações nos reforços em relação à camada superior, tendo em vista que nessa região os empuxos de solo são maiores. Entretanto, devido à geometria do carregamento do muro em forma de talude, a decomposição das forças atuantes favorece a ocorrência dos deslocamentos horizontais nas camadas mais superiores.

Sob o ponto de vista de evolução das deformações ao longo do tempo (Figura 5.4c, Figura 5.5c e Figura 5.6c), observa-se que as inclinações das retas de ajuste para as linhas E01 (mais baixa) e E03 (mais elevada) são semelhantes entre si, e 
maiores do que a inclinação da reta de ajuste para a linha E02 (intermediária). Isto indica que existe uma maior tendência à fluência das camadas superior e inferior em relação à camada intermediária.

Nas Figuras 5.7, 5.8 e 5.9, que se referem à seção de geotêxtil tecido, pode-se notar que as deformações máximas foram próximas a 2,7\% para a linha instrumentada E01, pouco superiores a 1,5\% para a linha instrumentada E02 e pouco superiores a 2,3\% para a linha E03. Sob o aspecto de evolução de deformações ao longo do tempo, as retas de ajuste para as seções mais alta (E03) e intermediária (E02) apresentaram inclinações praticamente iguais, indicando que para ambos os casos a tendência à fluência é a mesma. Já pra a seção mais baixa (E01) a inclinação da reta de ajuste foi ligeiramente maior.

É importante ressaltar que, tanto para a seção instrumentada em geotêxtil tecido, quanto para a seção instrumentada em geotêxtil não tecido, as variações de deformações ao longo do tempo foram muito pequenas. Isto indica que os índices de fluência para os geotêxteis empregados como reforço, para este caso de obra específico, foram muito baixos.

Um fato que merece destaque a partir das observações realizadas nos dados registrados em campo se refere à distribuição das deformações nos reforços ao longo da altura da estrutura de contenção. Ao se observar os resultados da seção em geotêxtil não tecido (Figura 5.4, Figura 5.5, e Figura 5.6) e da seção em geotêxtil tecido (Figura 5.7, Figura 5.8 e Figura 5.9), nota-se que as maiores deformações foram observadas na base da estrutura para a seção em geotêxtil não tecido e no topo da estrutura para a seção em geotêxtil tecido. Em ambas as seções as menores deformações ocorreram na região central. Esta distribuição é bem diferente do que geralmente tem se observado em estruturas em solo reforçado. Geralmente, as maiores deformações ocorrem no terço inferior da estrutura (BENJAMIM, 2006). Segundo Bathurst el al. (2008) esta distribuição geralmente assume uma forma trapezoidal. A Figura 5.10 mostra uma comparação entre a distribuição das deformações registradas em campo para a obra de referência e a previsão destas distribuições pelo método k-stiffness, proposto por Bathurst et al. (2008), e pelo método proposto por Ehrlich e Mitchell (1994), que considera o efeito da compactação no cálculo das cargas nos reforços.

Destaca-se que a previsão das deformações foi realizada empregando os parâmetros do solo obtidos por meio dos ensaios triaxiais, cujos resultados foram 
mostrados no Capítulo 3 (Figura 3.8), e os parâmetros de rigidez do reforço obtidos por meio dos ensaios de fluência confinada, cujos resultados foram mostrados no Capítulo 4 (Figura 4.14).

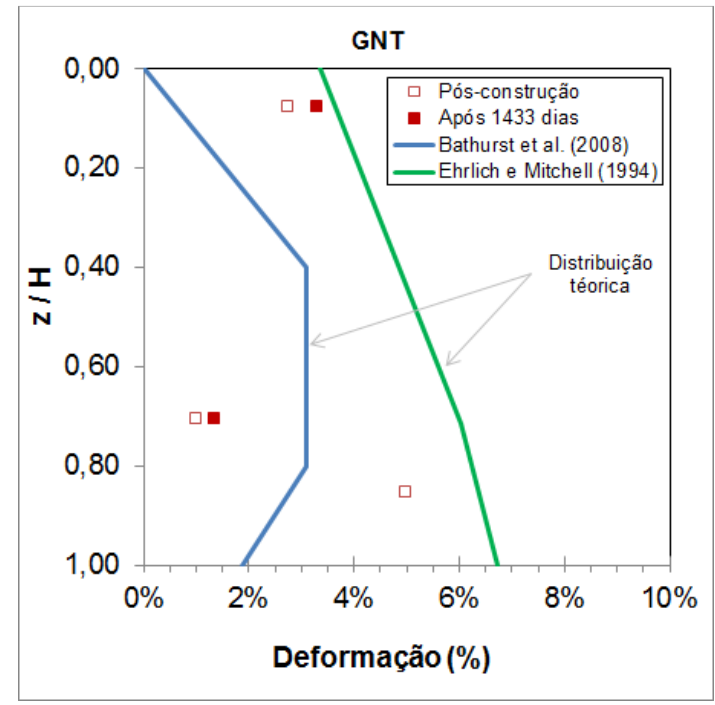

(a)

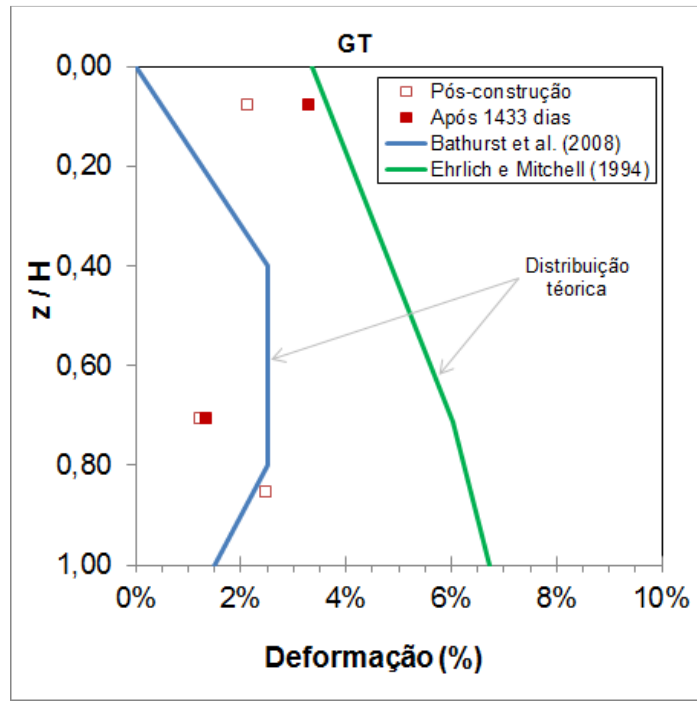

(b)

Figura 5.10 - Distribuição das deformações medidas e teóricas no muro de referência de Campinas para a seção em: (a) geotêxtil não tecido; (b) geotêxtil tecido.

A Figura 5.10 mostra que, para a seção em geotêxtil não tecido, as deformações na base e no topo da estrutura foram condizentes com a distribuição de deformações obtida pelo método proposto por Ehrlich e Mitchell (1994). Entretanto, para a região central da estrutura, as deformações registradas apresentaram magnitudes mais próximas aos valores obtidos pelo método proposto por Bathurst et al. (2008). Para o caso da seção em geotêxtil tecido, as deformações registradas na região central e na base do muro foram próximas aos valores determinados pelo método de Bathurst et al. (2008), enquanto que a deformação no topo da estrutura apresentou valor próximo ao encontrado pelo método de Ehrlich e Mitchell (1994). Observa-se que ambos os modelos de previsão de comportamento apresentaram valores com magnitudes condizentes com os registrados em campo. Entretanto, a forma de distribuição das deformações observadas campo não foi bem representada por nenhum dos modelos considerados.

Nas Figuras 5.11 e 5.12 são apresentadas as superfícies de ruptura estimadas para as seções em geotêxtil não tecido e geotêxtil tecido, respectivamente. Nestas 
Figuras são apresentadas as distribuições de deformações ao longo dos geotêxteis nas seções instrumentadas.

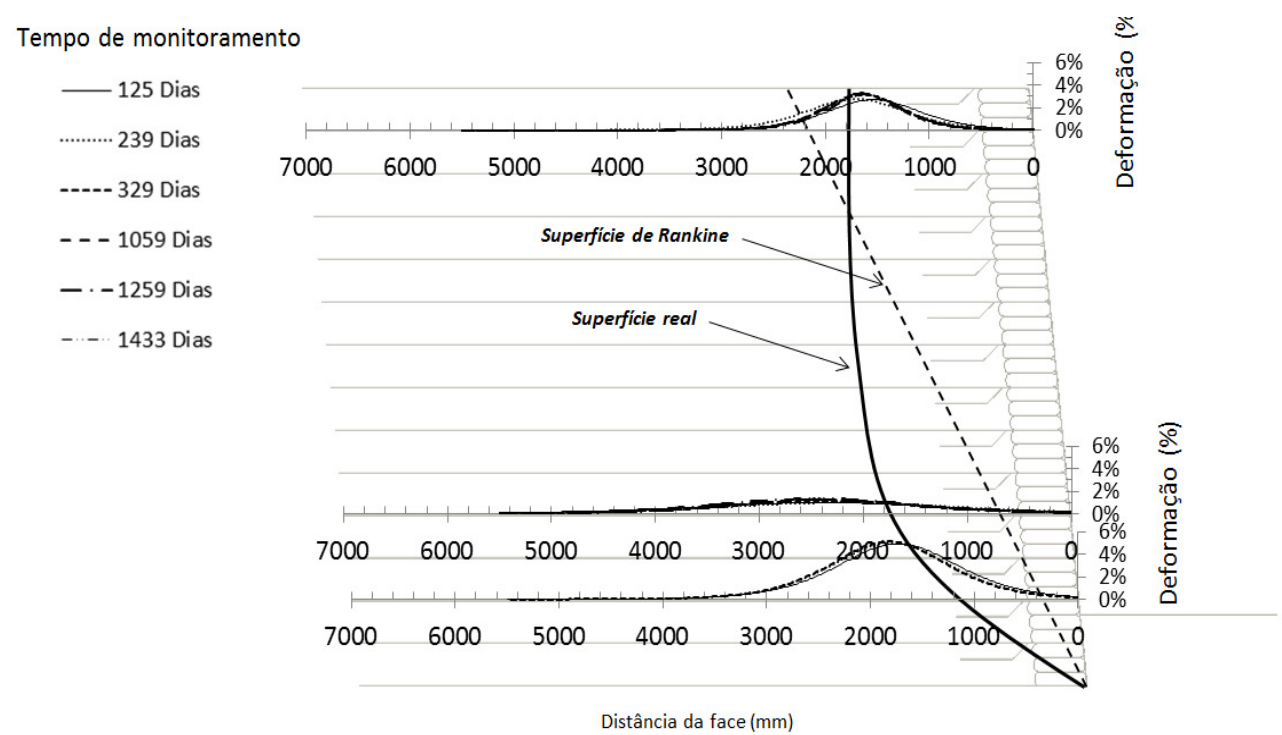

Figura 5.11 - Distribuição das deformações ao longo do comprimento dos reforços da seção de geotêxteis não tecidos (linhas E01, E02 e E03).

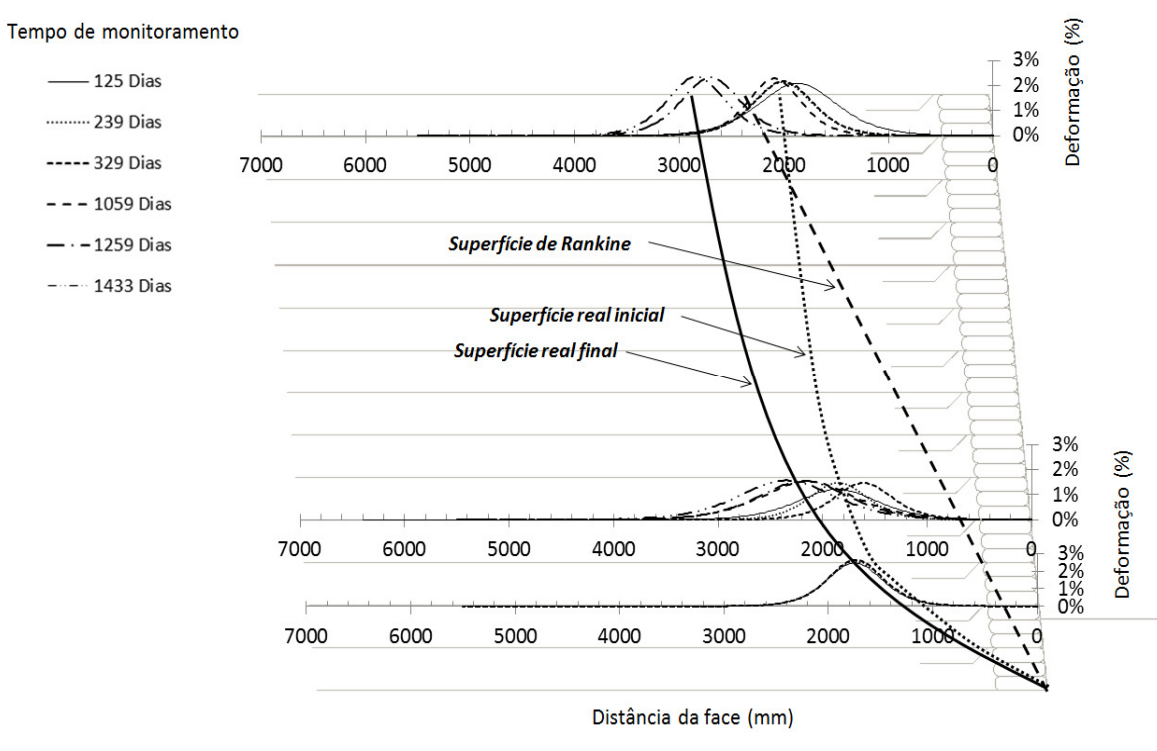

Figura 5.12 - Distribuição das deformações ao longo do comprimento dos reforços da seção de geotêxteis tecidos (linhas E01, E02 e E03). 
Como se pode observar, a superfície potencial de ruptura não se deslocou ao longo do tempo para a seção reforçada em geotêxteis não tecidos. Por outro lado, para o caso da seção reforçada em geotêxteis tecidos, ocorreu um deslocamento da superfície de ruptura em direção ao interior do maciço. Teoricamente esse deslocamento não era esperado, conforme será mostrado mais adiante nas modelagens computacionais realizadas. Por essa razão, provavelmente 0 deslocamento da superfície de ruptura tenha se dado em função de algum problema relacionado ao processo construtivo do muro, como por exemplo, a não homogeneidade da compactação das camadas. Outro problema que pode ter levado ao deslocamento da superfície ao longo do tempo pode estar associado à problemas nas leituras realizadas, ou ainda à algum tipo de dano que o sistema de instrumentação possa ter sofrido, tendo em vista que este não se encontra protegido de ações antrópicas.

\subsection{COMPARAÇÃO ENTRE OS RESULTADOS DE FLUÊNCIA OBTIDOS EM CAMPO E LABORATÓRIO}

Para a validação dos resultados dos ensaios de laboratório é necessário que se faça a comparação com os resultados obtidos nas leituras de campo, realizadas no muro de referência de Campinas. Neste item, os resultados dos ensaios de campo serão comparados com resultados dos ensaios de fluência confinada realizados em laboratório. Inicialmente os resultados de campo serão comparados aos resultados dos ensaios de fluência confinada realizados com o equipamento de interação soloreforço desenvolvido por Costa (2004). Logo na sequência os resultados das leituras de campo serão comparados aos resultados dos ensaios de fluência confinadaacelerada realizados no equipamento desenvolvido por França (2011).

As Figuras 5.13 e 5.14 apresentam, para os geotêxteis não tecidos e tecidos, respectivamente, os resultados, plotados em um único gráfico, dos ensaios de fluência confinada, realizados em laboratório com o equipamento de interação soloreforço, e os resultados das análises de fluência realizadas para a estrutura real. 


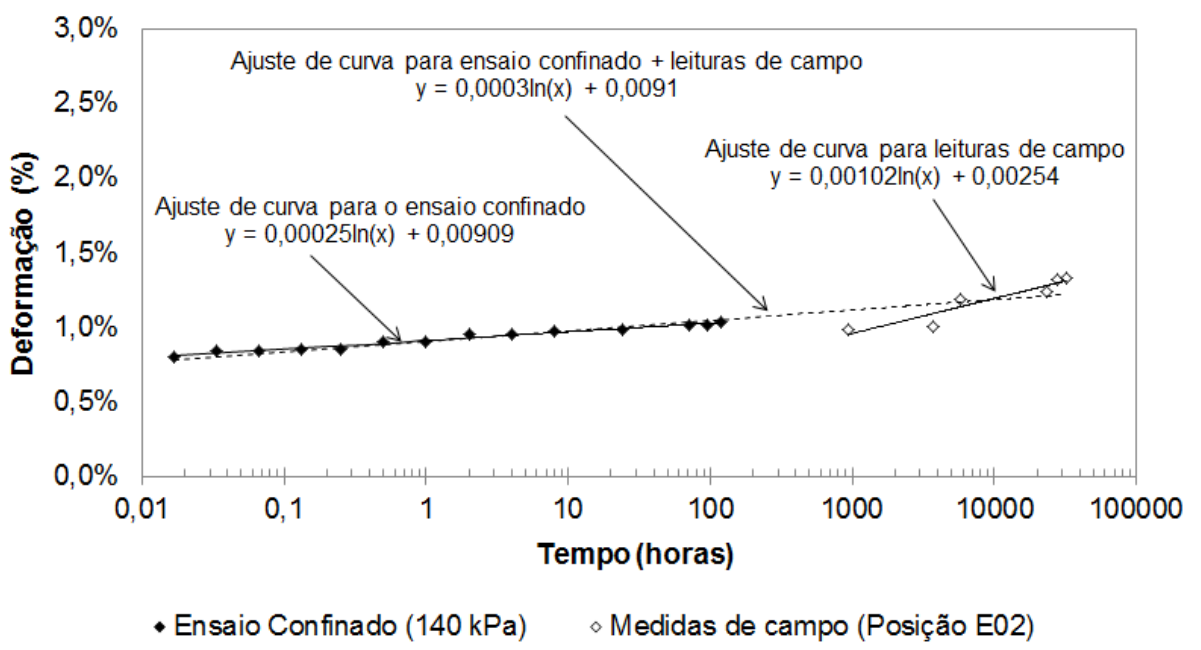

(a)

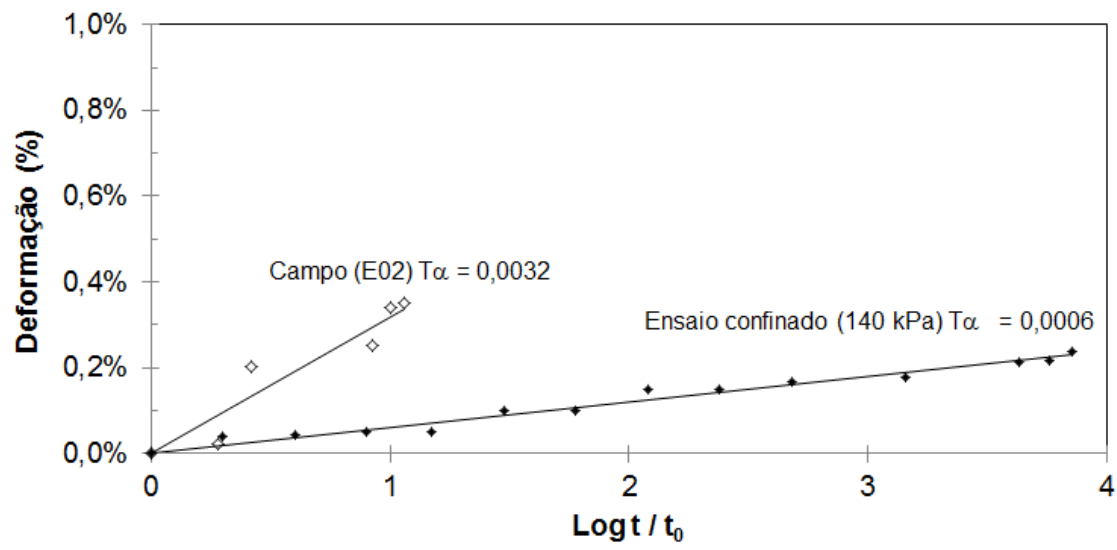

- Ensaio confinado (140 kPa) • Leitura de campo (posição E02)

(b)

Figura 5.13 Comparação entre os resultados dos ensaios de fluência em laboratório utilizando o equipamento de interação solo-reforço desenvolvido por Costa (2004) e os resultados de campo, para geotêxteis não tecidos pelos métodos: (a) da curva logarítmica; (b) de Zornberg; Byler e Knudsen (2004). 


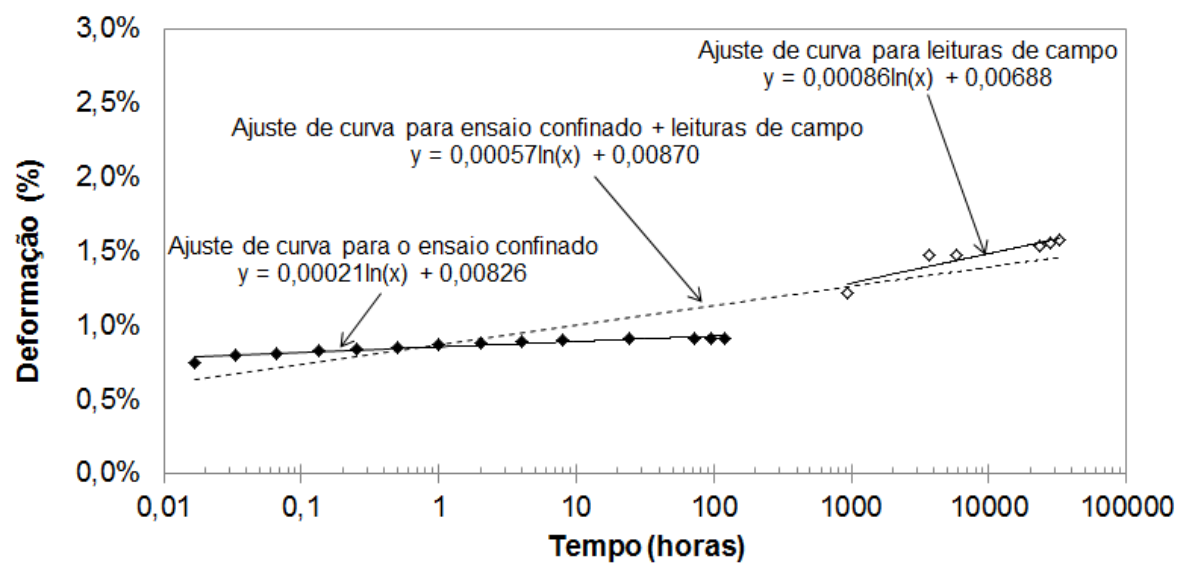

- Ensaio Confinado (140 kPa) • Medida de campo (posição E02)

(a)

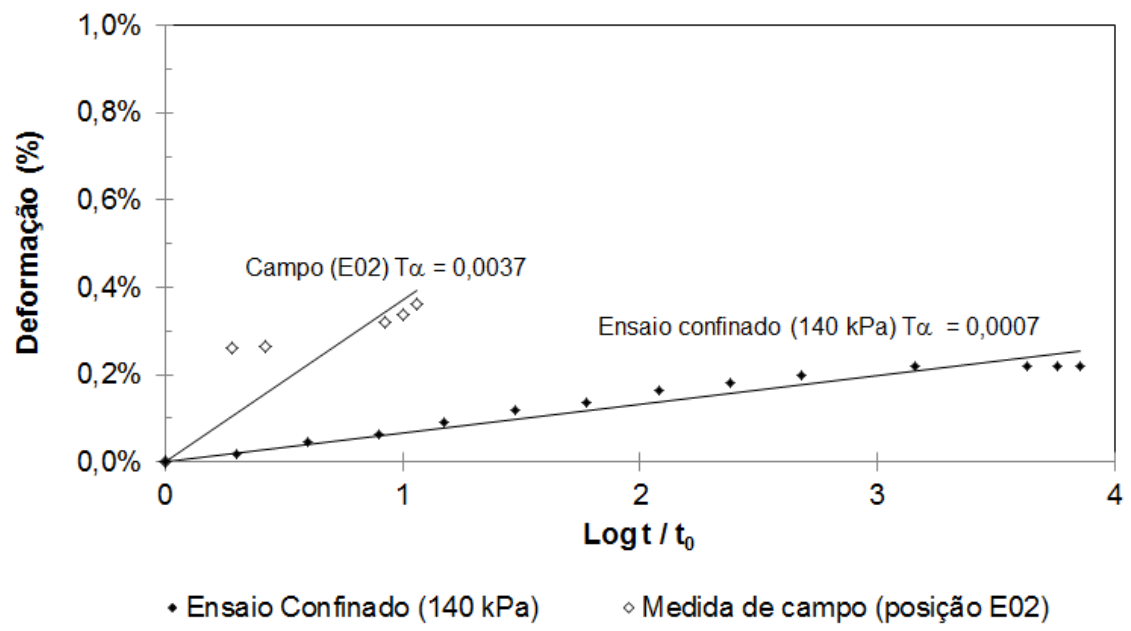

(b)

Figura 5.14 - Comparação entre os resultados dos ensaios de fluência em laboratório utilizando o equipamento de interação solo-reforço desenvolvido por Costa (2004) e os resultados de campo, para geotêxteis tecidos pelos métodos: (a) da curva logarítmica; (b) de Zornberg; Byler e Knudsen (2004).

As Figuras 5.13 e 5.14 mostram que, tanto para o caso de geotêxteis não tecidos quanto para o caso de geotêxteis tecidos, os níveis de deformações obtidos foram semelhantes ao se comparar os ensaios de laboratório com os resultados das leituras de campo. Entretanto, sob o aspecto de fluência, observa-se que os resultados de laboratório são subestimados. Para o caso de geotêxteis não tecidos, os parâmetros de fluência, "b" pelo método da equação logarítmica e To pelo método de Zornberg; Byler e Knudsen (2004) são subestimados em 
aproximadamente 5,5 vezes pelos ensaios de laboratório. Já para o caso de geotêxteis tecidos, os parâmetros de fluência são subestimados em aproximadamente 4,1 vezes (parâmetro "b") e aproximadamente 5,3 vezes (parâmetro $T \alpha$ ) pelos ensaios laboratório.

É importante lembrar que os ensaios de fluência confinada e os resultados de campo, encontram-se em tempos diferentes, e, portanto, a comparação direta entre os resultados deve ser realizada com cautela.

Um fator que possivelmente contribuiu para que os parâmetros de fluência tenham sido diferentes entre os resultados de campo e laboratório se refere ao processo de montagem dos ensaios de fluência confinada. Conforme foi apresentado anteriormente, nos ensaios confinados o solo foi compactado no interior da caixa de interação solo-reforço restringindo a movimentação lateral das paredes. Dessa forma, durante o processo de montagem dos ensaios, os esforços de compactação do solo não foram transferidos ao reforço, fazendo com que o mesmo tivesse uma carga reduzida ao início do registro das deformações. Conforme já discutido anteriormente, menores carregamentos no reforço conduzem à menores índices de fluência. Talvez, se os ensaios de fluência confinada tivessem sido executados com as paredes laterais liberadas durante o processo de compactação, os índices de fluência obtidos em laboratório fossem mais próximos dos obtidos em campo.

As Figuras 5.15 e 5.16 apresentam, para os geotêxteis não tecidos e tecidos, respectivamente, os resultados, plotados em um único gráfico, dos ensaios de fluência confinada, realizados em laboratório com o equipamento de fluência confinada-acelerada desenvolvido por França (2011), e os resultados das análises de fluência realizadas para a estrutura real. 


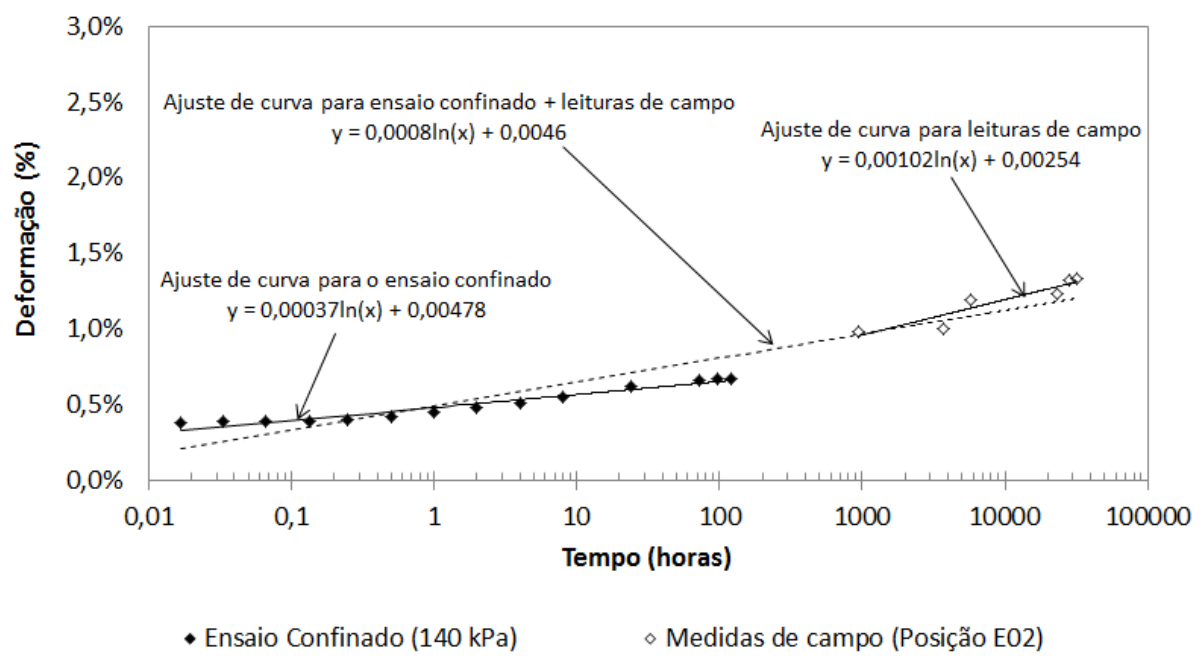

(a)

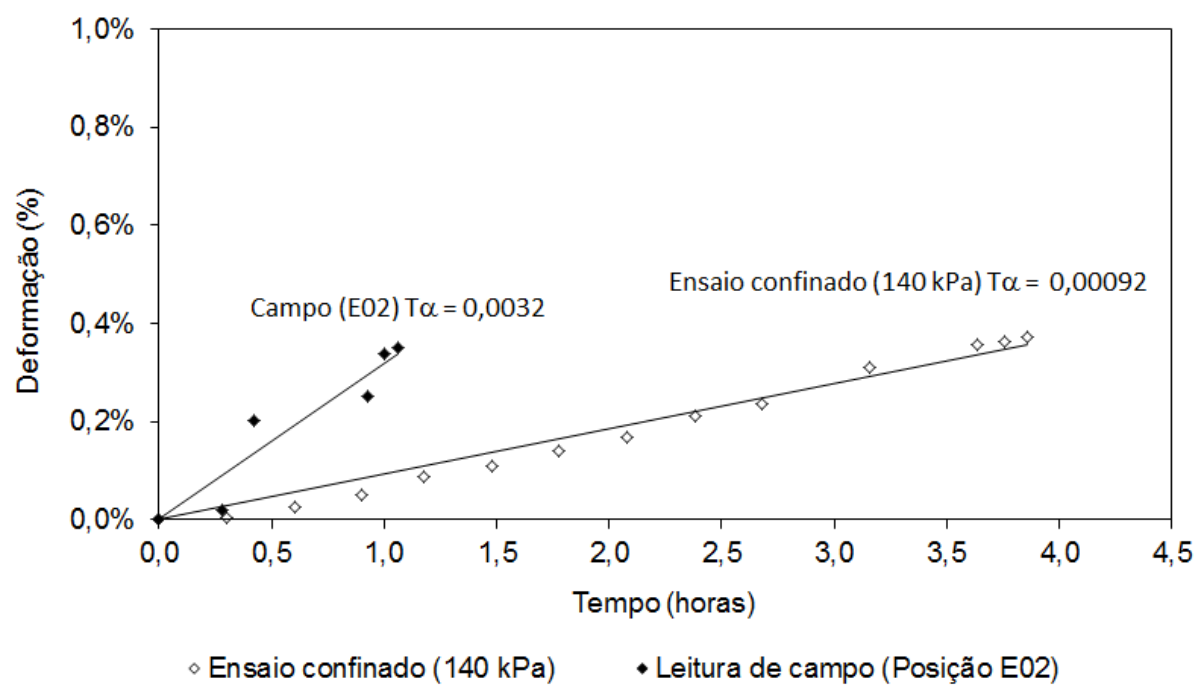

(b)

Figura 5.15 - Comparação entre os resultados dos ensaios de fluência em laboratório utilizando o equipamento de fluência confinada-acelerada desenvolvido por França (2011) e os resultados de campo, para geotêxteis não tecidos pelos métodos: (a) da curva logarítmica; (b) de Zornberg; Byler e Knudsen (2004). 


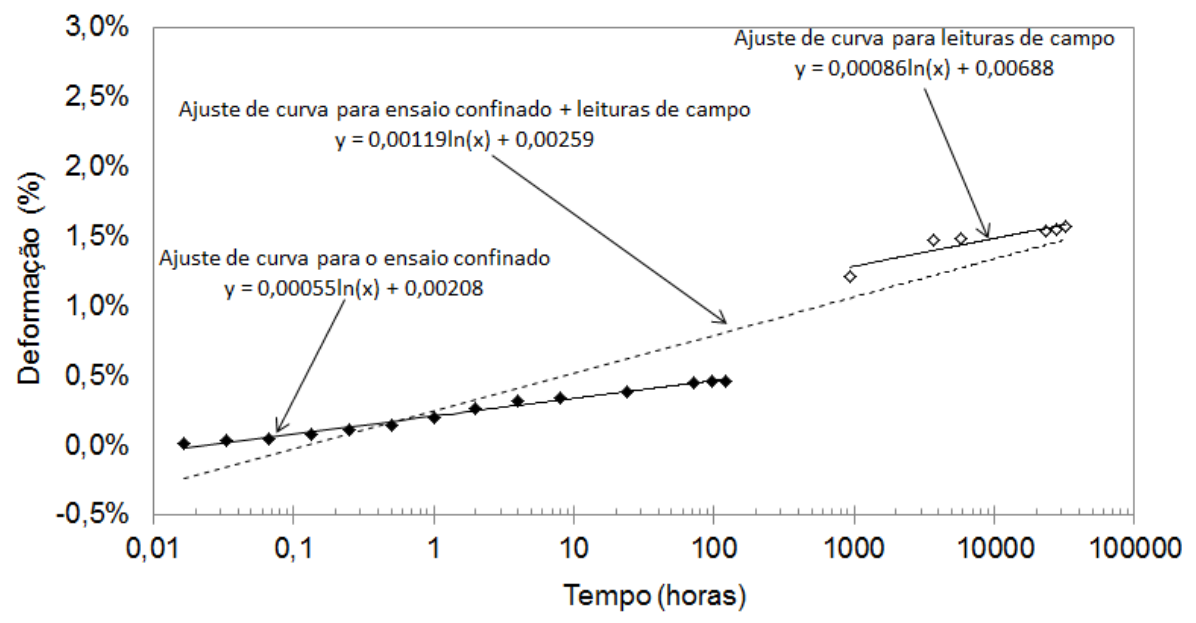

- Ensaio Confinado (140 kPa) • Medida de campo (posição E02)

(a)

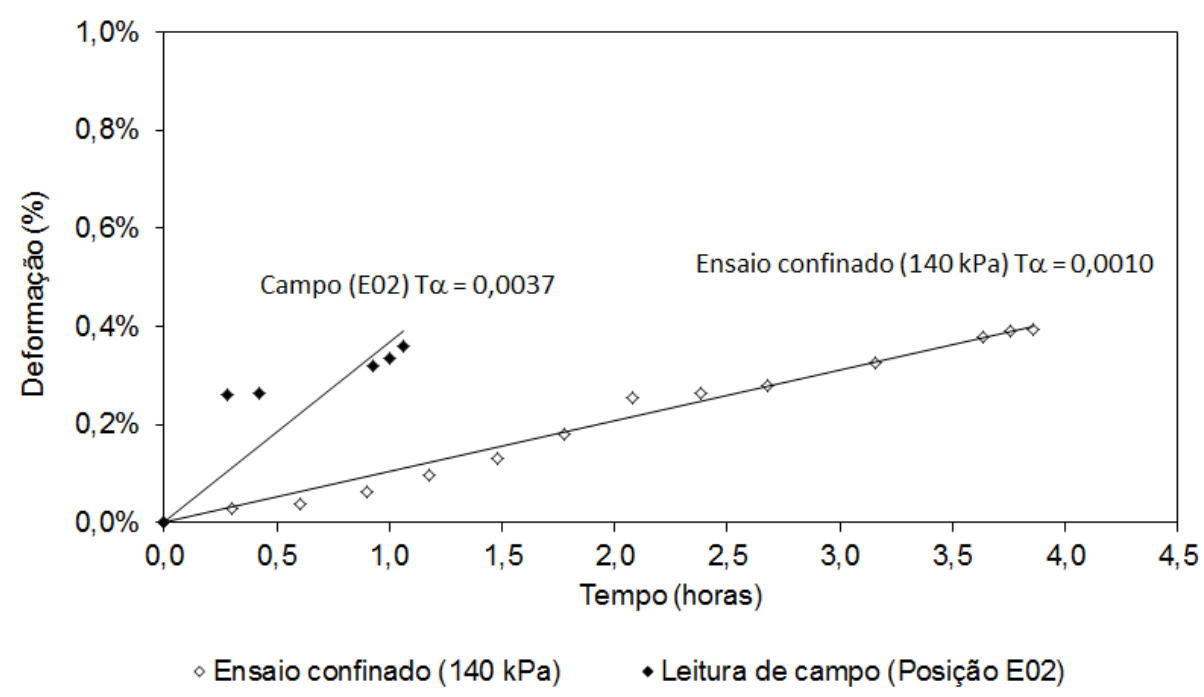

(b)

Figura 5.16 - Comparação entre os resultados dos ensaios de fluência em laboratório utilizando o equipamento de fluência confinada-acelerada desenvolvido por França (2011) e os resultados de campo, para geotêxteis tecidos pelos métodos: (a) da curva logarítmica; (b) de Zornberg; Byler e Knudsen (2004).

As Figuras 5.15 e 5.16 mostram que, tanto para o caso de geotêxteis não tecidos quanto para o caso de geotêxteis tecidos, os níveis de deformações dos ensaios de fluência confinada foram ligeiramente inferiores aos níveis de deformação registrados a partir das leituras de campo. O mesmo ocorre sob a ótica da fluência, ou seja, os parâmetros de fluência dos ensaios de laboratório foram subestimados em relação aos obtidos em campo. Para o caso de geotêxteis não tecidos, os parâmetros de fluência "b" pelo método da equação logarítmica e T $\alpha$ pelo método de 
Zornberg; Byler e Knudsen (2004) foram subestimados em aproximadamente 2,8 e 3,5 vezes pelos ensaios de laboratório, respectivamente. Já para o caso de geotêxteis tecidos, os parâmetros de fluência foram subestimados em aproximadamente 1,6 vezes (parâmetro "b") e aproximadamente 3,7 vezes (parâmetro $T \alpha$ ) pelos ensaios laboratório.

Assim como destacado anteriormente, é importante lembrar que os ensaios de fluência confinada e os resultados de campo, encontram-se em tempos diferentes, e, portanto, a comparação direta entre os resultados deve ser realizada com cautela.

Os resultados das Figuras 5.15 e 5.16 mostram também que apesar de existir uma diferença entre os índices de fluência obtidos em laboratório e em campo, os resultados entre as duas abordagens não são tão discrepantes, já que existe certo paralelismo entre as curvas obtidas. É possível observar que as principais diferenças, tanto para o caso dos geotêxteis não tecidos quanto para o caso dos tecidos, estão relacionadas à deformação inicial. Aparentemente, a deformação inicial em campo é consideravelmente maior quando comparada à deformação inicial dos ensaios de laboratório, já que a curva de campo parece estar transladada em relação à de laboratório. Isto é um indicativo que as diferenças entre as curvas estejam relacionadas principalmente em relação às deformações iniciais registradas em campo, que podem ter apresentado maior magnitude devido à passagem de equipamentos pesados durante a compactação do solo ou ainda devido a folgas existentes nos reforços durante a execução da obra.

Por meio das Figuras 5.13 a 5.16 observa-se que os ajustes das curvas para os ensaios de laboratório são consideravelmente melhores quando comparados aos ajustes dos resultados de campo. Isto ocorre, pois nos testes de laboratório as condições são controladas, e poucas variáveis influenciam nos resultados durante a execução dos ensaios. Isso não ocorre em campo, sendo que a estrutura está a todo o momento sujeita a influência de variáveis externas, como a variação climática e variações antrópicas severas. Além disso, o ajuste da curva para as deformações do muro compreende um período de tempo muito elevado. Neste período as deformações dependentes do tempo passam por diversas variações. Talvez a forma mais correta de avaliação fosse realizar o ajuste de diversas curvas ao longo do tempo, e não de apenas uma curva. Dessa forma seria possível representar, de maneira mais realista, as acelerações e desacelerações das deformações ao longo de todo o período de leituras, as quais podem ocorrer pela ação de diversos fatores 
externos, como variação de temperatura, passagem e estacionamento de veículos pesados, ou ainda variações drásticas de umidade do solo devido a fortes chuvas.

Os gráficos comparativos entre os resultados de campo e os resultados dos ensaios confinados realizados empregando-se os equipamentos de interação solo-reforço e fluência confinada-acelerada mostram um melhor ajuste dos dados para os geotêxteis não tecidos. Os dados referentes ao reforço em geotêxtil tecido não apresentam um ajuste tão bom quanto o observado para o outro material.

Observa-se ainda que os resultados obtidos no equipamento de interação soloreforço apresentaram níveis de deformação mais próximos aos observados em campo, entretanto, apresentaram parâmetros de fluência consideravelmente menores. Por outro lado, os resultados obtidos no equipamento desenvolvido por França (2011) apresentaram níveis de deformação consideravelmente inferiores aos observados nas leituras de campo, entretanto, apresentaram parâmetros de fluência mais condizentes com a situação real.

\subsection{MODELAGEM COMPUTACIONAL DO MURO DE REFERÊNCIA}

Com o objetivo de melhor se compreender os mecanismos envolvidos no processo construtivo do muro em solo reforçado com geossintéticos de Campinas, o qual foi utilizado como referência neste trabalho, foram realizadas análises numéricas empregando-se o software geotécnico Plaxis 2D AE. Além de auxiliar na compreensão dos mecanismos de interação solo-reforço durante o processo construtivo e ao longo da vida útil da obra, a modelagem computacional permitiu também uma extrapolação dos dados para tempos maiores do que o atual tempo de construção do muro.

É importante lembrar que o modelo constitutivo utilizado para o solo foi o "soft soil creep model", o qual considera o efeito do tempo no cálculo das deformações. O modelo constitutivo do solo foi calibrado em função dos parâmetros de resistência, deformabilidade e fluência do solo, obtidos em ensaios triaxiais realizados em laboratório. Já os parâmetros de rigidez e deformação ao longo do tempo para os reforços foram determinados em função dos ensaios de fluência convencional. Os 
parâmetros do solo obtidos após a calibração do modelo empregados na modelagem computacional foram apresentados na Tabela 3.9 do Capítulo 3 desta tese. Já os parâmetros referentes à rigidez e fluência dos reforços foram apresentados na Figura 3.26.

As Figuras 5.18 e 5.19 mostram as calibrações realizadas para os modelos numéricos referentes às seções em geotêxtil não tecido e geotêxtil tecido respectivamente. Destaca-se que as calibrações dos modelos foram realizadas tomando-se como base os resultados obtidos nas leituras dos instrumentos instalados na seção E02 da obra de referência.

Os parâmetros de deformabilidade referentes ao modelo constitutivo empregado (parâmetros $\lambda$ e $\kappa$ ) foram adotados inicialmente em função do módulo de deformabilidade médio obtido para o solo de aterro. Este módulo foi determinado em função do ensaios triaxiais do tipo CD, executados com o solo compactado na umidade ótima, cujos resultados foram apresentados no Capítulo 3. A partir dos valores iniciais, os parâmetros foram variados até se obter uma convergência entre os níveis de deformação calculados e os níveis de deformação lidos na seção instrumentada de referência para um tempo imediatamente após o término da construção do muro. Após a obtenção desta convergência, os modelos foram calibrados em função do parâmetro de fluência $(\mu)$, cujo valor inicial foi determinado em função dos ensaios de fluência do solo apresentados também no Capítulo 3. Assim como foi realizado para os parâmetros de deformabilidade, o parâmetro referente à fluência do modelo numérico foi variado até que houvesse uma boa concordância entre os resultados calculados e os resultados lidos ao longo do tempo para a obra real.

Os parâmetros de fluência dos reforços foram determinados em função dos ensaios de fluência não confinada realizados em laboratório para estes materiais (Figura 5.17). Destaca-se que, em função da não realização dos ensaios de fluência não confinada acelerada, os dados foram extrapolados de maneira simples, por meio do uso de ajustes do próprio Excel, para um período de 100 anos. 


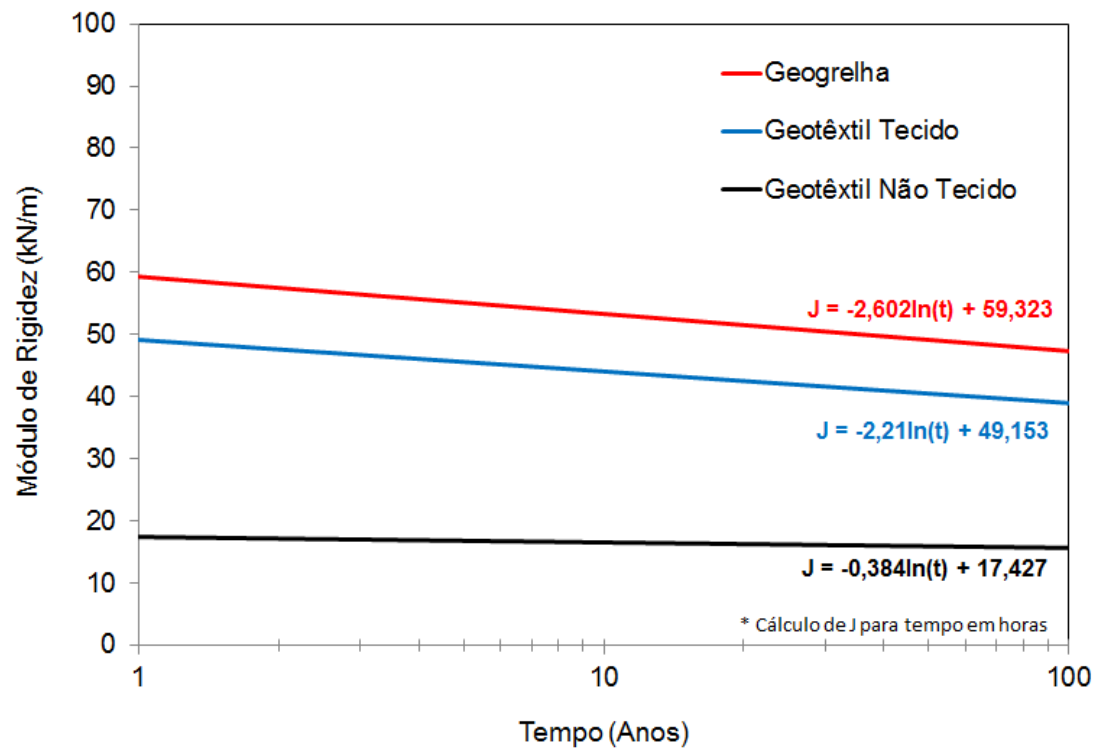

Figura 5.17 - Módulos de rigidez em função do tempo adotados para os diferentes reforços nas modelagens computacionais.

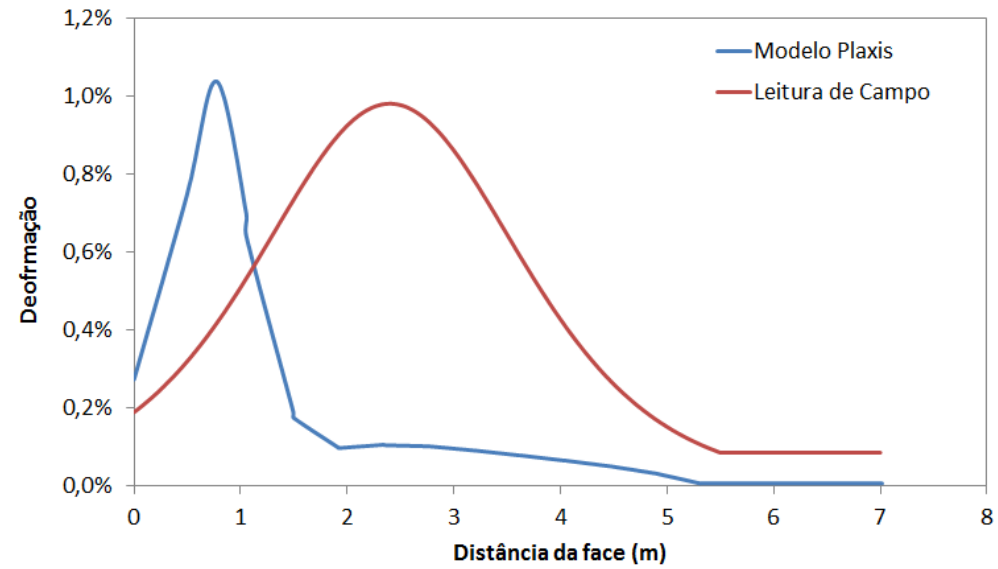

(a) 


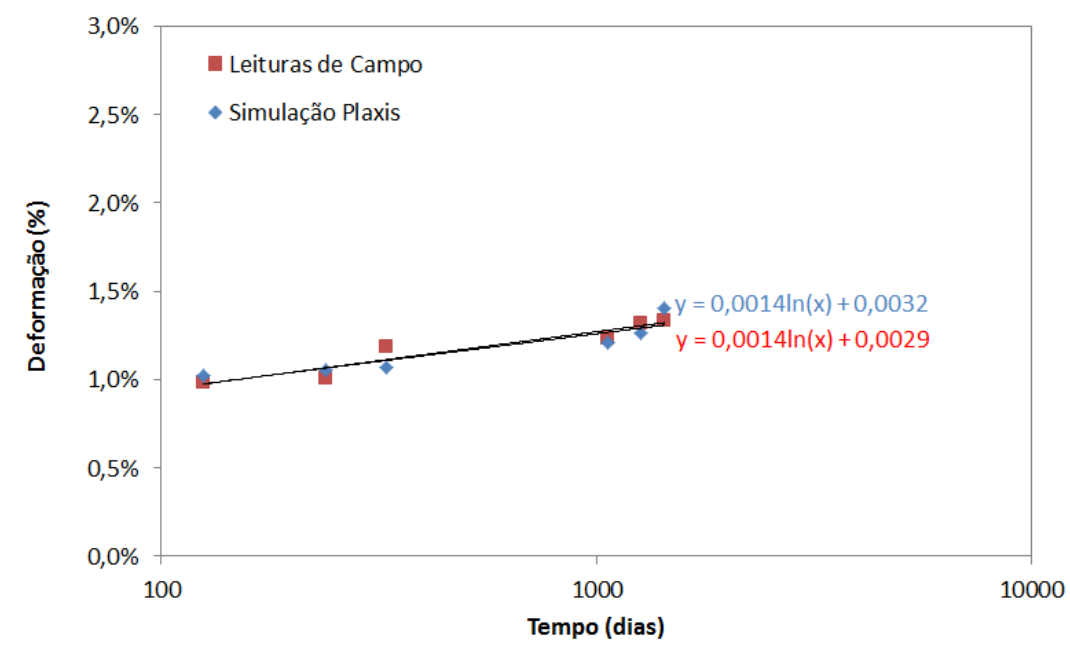

(b)

Figura 5.18 - Calibração do modelo numérico para a seção em solo reforçado com geotêxtil não tecido: (a) Comparação entre as deformações lidas na instrumentação e as deformações previstas no modelo numérico para a seção E02; (b) Ajuste das deformações pelo método da equação logarítmica para os resultados da instrumentação de campo e para os resultados obtidos no modelo numérico.

A Figura 5.18a mostra que, para os geotêxteis não tecidos, os níveis de deformações obtidos no modelo numérico foram muito próximos aos obtidos nas leituras dos instrumentos. Apesar da semelhança entre os níveis de deformação, observa-se que a posição do pico, local onde ocorre a deformação máxima no reforço, foi ligeiramente diferente entre os valores registrados nos instrumentos e os previstos no modelo numérico. O pico de deformação previsto no modelo numérico se encontra deslocado em direção à face, a aproximadamente $1 \mathrm{~m}$ do paramento. Já o pico de deformação registrado nos instrumentos se encontra a aproximadamente $2,5 \mathrm{~m}$ da face.

Já a Figura 5.18b mostra que a variação das deformações ao longo do tempo foi praticamente igual entre os resultados do modelo numérico e os resultados das leituras de campo. Conforme se pode observar, o parâmetro "a" da equação logarítmica, que se relaciona às deformações iniciais do reforço, apresenta uma diferença de apenas $10 \%$ entre os resultados lidos e os resultados previstos. No que se refere ao parâmetro "b" da equação logarítmica, o qual se relaciona com a tendência à fluência dos reforços, nota-se que os valores previstos e registrados foram iguais. 


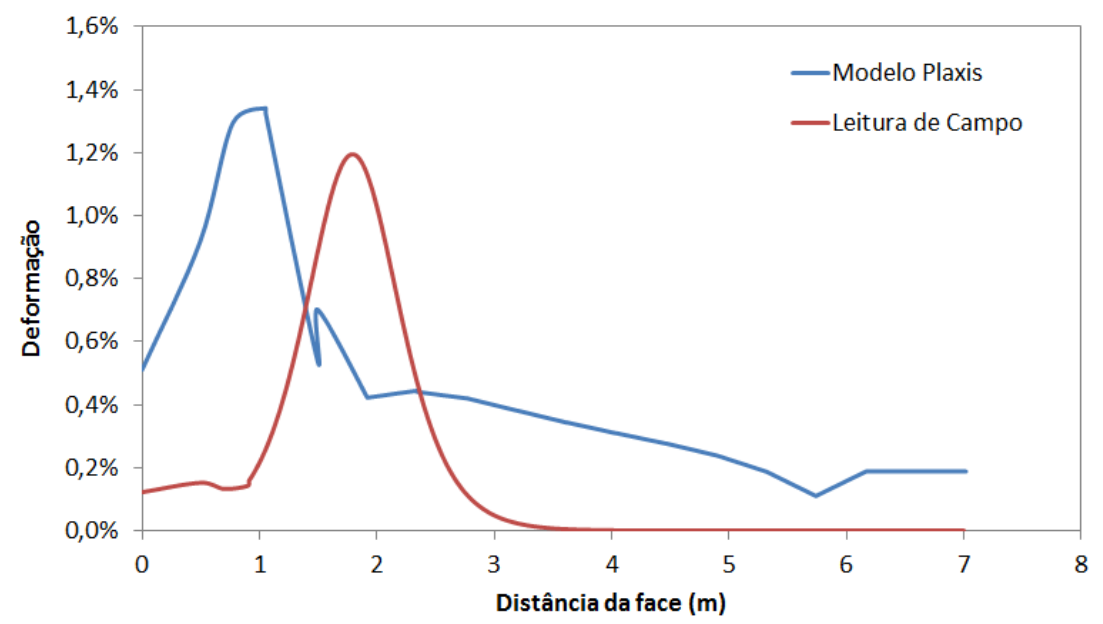

(a)

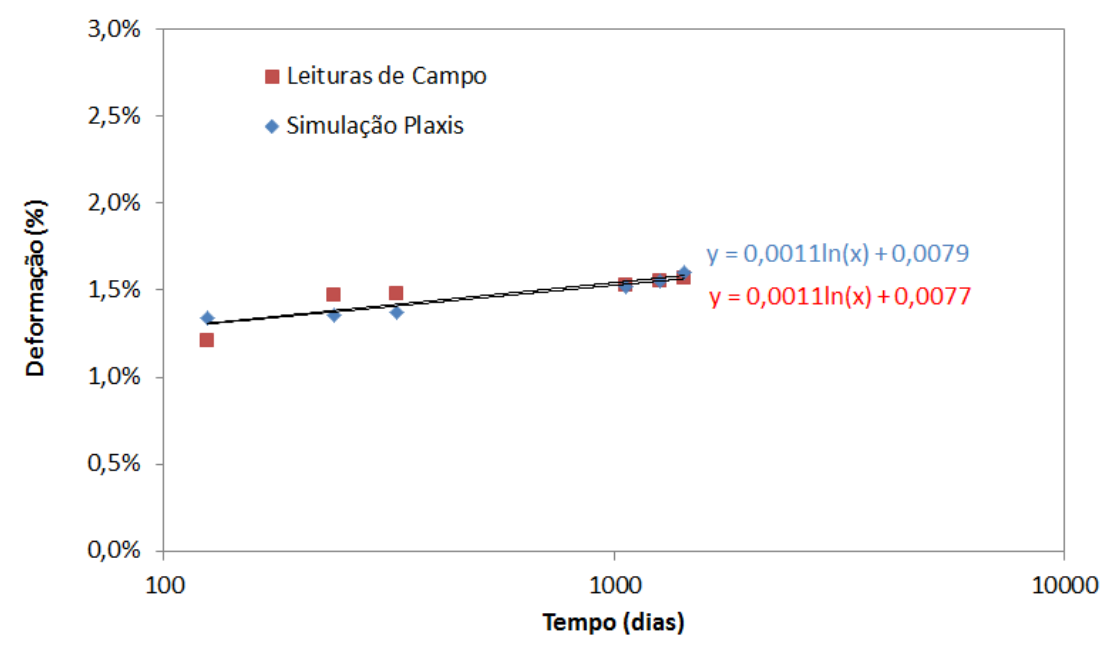

(b)

Figura 5.19 - Calibração do modelo numérico para a seção em solo reforçado com geotêxtil tecido:

(a) Comparação entre as deformações lidas na instrumentação e as deformações previstas no modelo numérico para a seção E02; (b) Ajuste das deformações pelo método da equação logarítmica para os resultados da instrumentação de campo e para os resultados obtidos no modelo numérico.

As mesmas observações feitas para o caso da seção reforçada com geotêxteis não tecidos valem para o caso da seção reforçada com geotêxteis tecidos. A Figura 5.19a mostra que os níveis de deformação para o reforço situado na posição E02 foram muitos semelhantes ao se comprar os resultados registrados pela instrumentação e os resultados previstos por meio das simulações numéricas. Assim como se observou para os geotêxteis não tecidos, nota-se que o pico de deformação previsto no modelo numérico se encontra mais próximo à face do que o pico de deformação registrado na instrumentação da obra real. $\mathrm{Na}$ previsão de comportamento empregando-se a simulação numérica, o pico de deformação 
ocorreu a aproximadamente 1,0 $\mathrm{m}$ da face. Para o caso das leituras de deformação realizadas por meio de instrumentos, o pico de deformação se encontra a aproximadamente $2,0 \mathrm{~m}$ da face.

No que se refere à variação de deformações ao longo do tempo, observa-se que os valores registrados na instrumentação e os valores previstos numericamente foram muito semelhantes (Figura 5.19b). Observa-se que o parâmetro "a" da equação logarítmica, previsto nas análises numéricas, foi apenas $2 \%$ superior ao valor registrado pela instrumentação. Com relação ao parâmetro "b", o valor previsto numericamente foi igual ao registrado na seção instrumentada.

As Figuras 5.20 e 5.21 apresentam alguns dos principais resultados obtidos nas simulações numéricas para as seções em solo reforçado com geotêxteis não tecidos e geotêxteis tecidos, respectivamente, para um período de tempo imediatamente após o término da construção da obra.

A Figura 5.20a mostra a malha deformada para a seção em geotêxteis não tecidos. Os deslocamentos estão aumentados em 20 vezes para facilitar a visualização. Observa-se que os maiores deslocamentos ocorrem no topo do aterro não reforçado, e que os deslocamentos na face do muro ocorrem em maior magnitude no terço inferior do mesmo. A Figura 5.20b, que mostra os deslocamentos horizontais obtidos no modelo, confirma os fatos observados anteriormente, ou seja, os maiores deslocamentos ocorrem no topo do aterro não reforçado e os maiores deslocamentos na face ocorrem no terço inferior.

Já Figura 5.20c apresenta as tensões horizontais obtidas no modelo numérico. Observa-se que as tensões horizontais ao longo face do aterro reforçado são praticamente nulas. Observa-se ainda que, quanto mais próximo do pé do muro, mais próximo da face as tensões horizontais se manifestam. Para alturas maiores do muro as tensões horizontais tendem a se afastar da face, indicando um provável local da superfície de ruptura.

A Figura 5.20d mostra o histórico dos pontos de plastificação do maciço ao longo de sua construção. Observa-se que apenas uma pequena região no pé do muro sofreu plastificação, sendo que a forma desta região plastificada é coincidente com o local das tensões horizontais apresentadas na Figura 5.20c. Para casos em que o muro se encontra em situações mais críticas de estabilidade, provavelmente esta região plastificada iria se estender até o topo do maciço, podendo levar a estrutura toda ao colapso. 


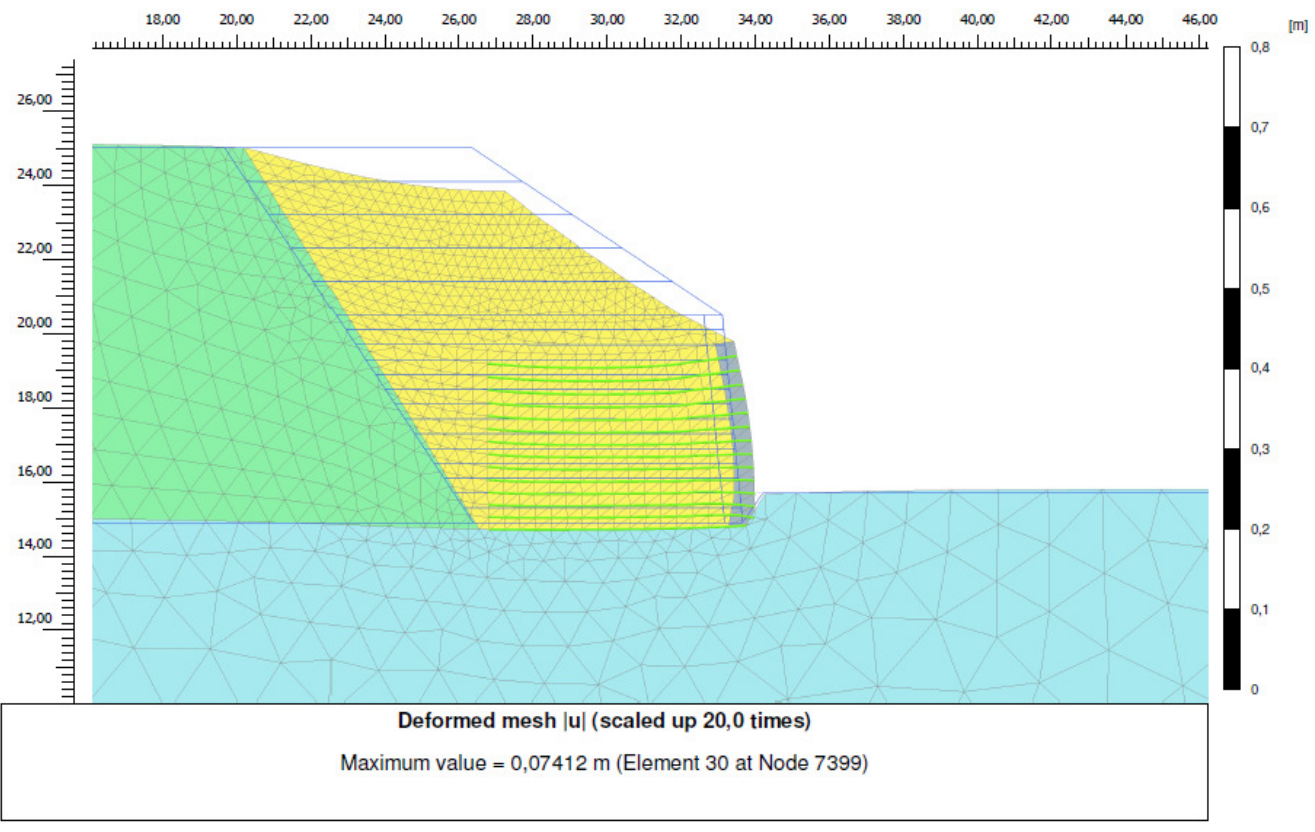

(a)

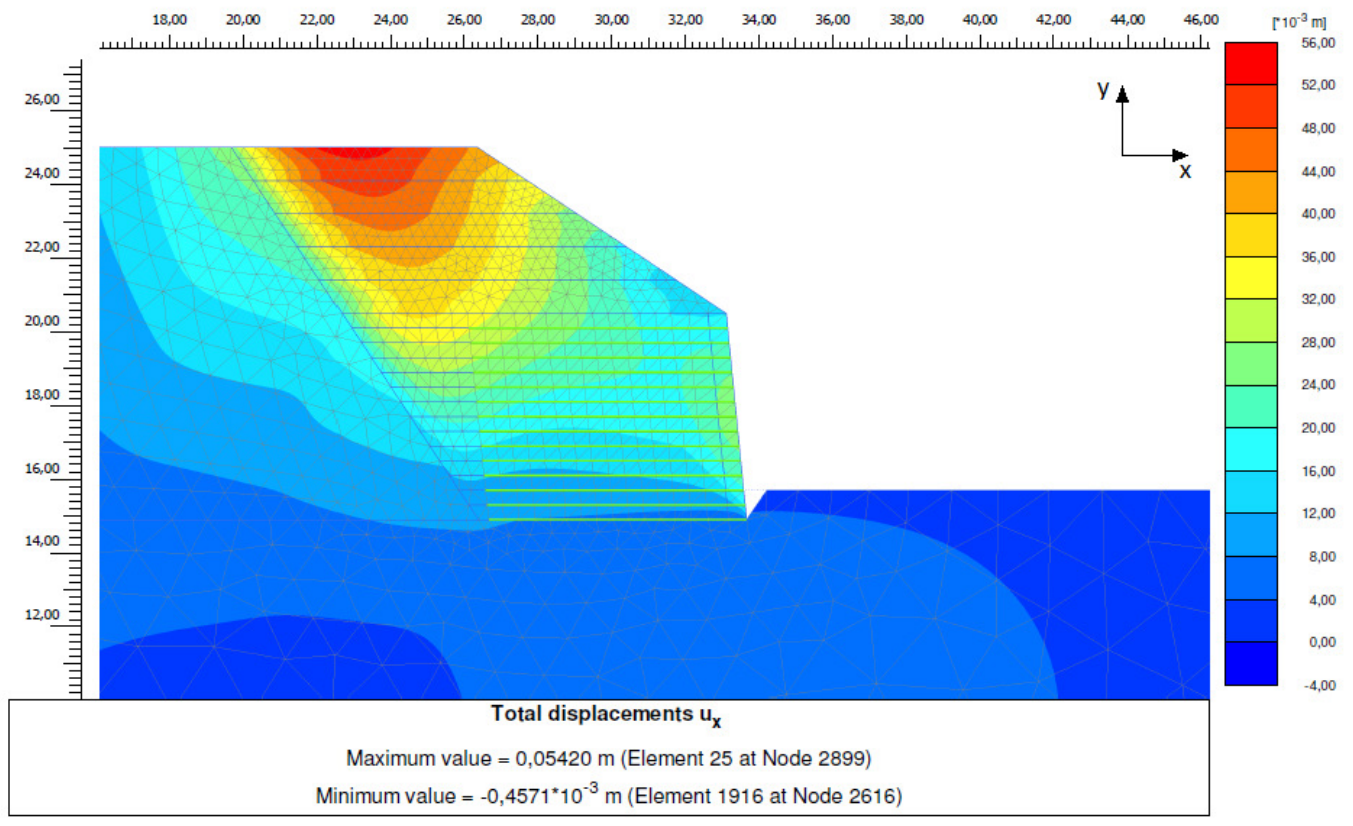

(b) 


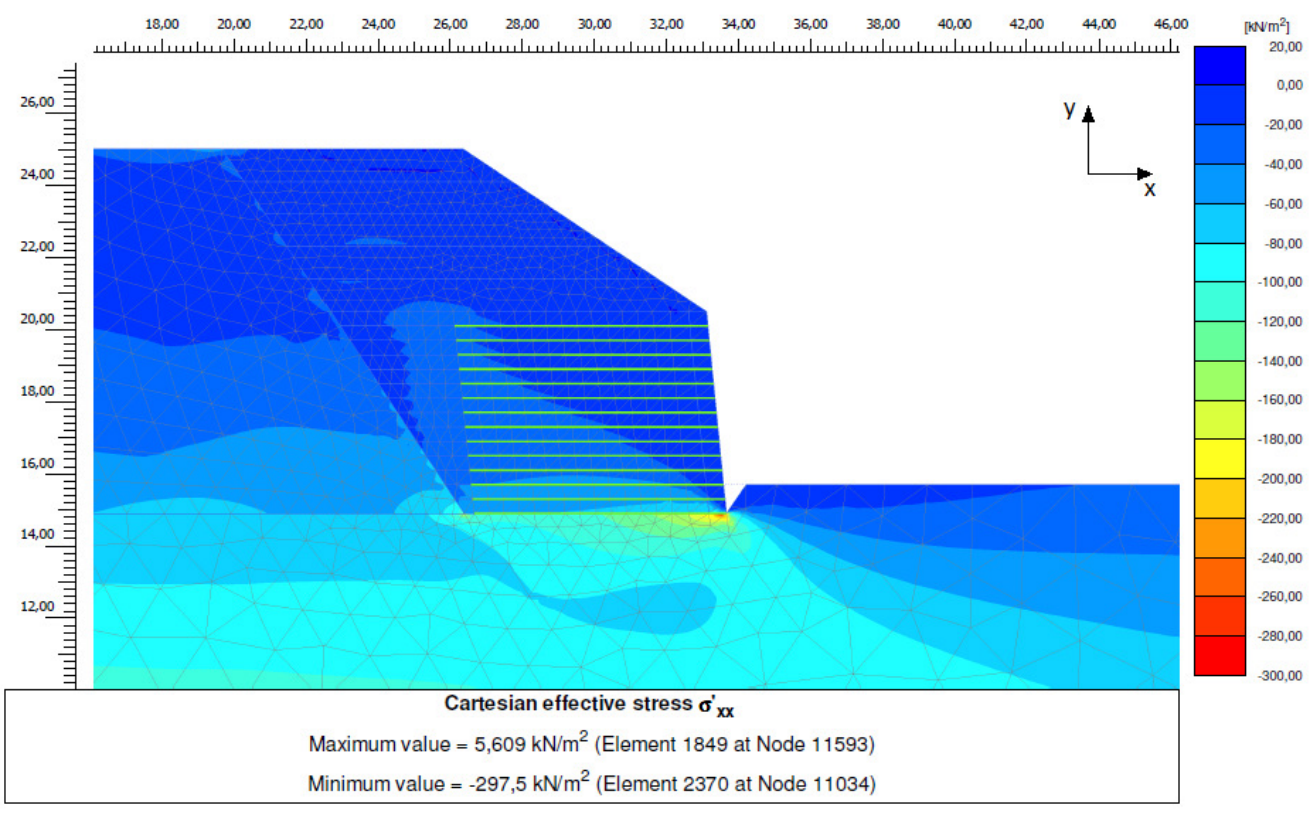

(c)

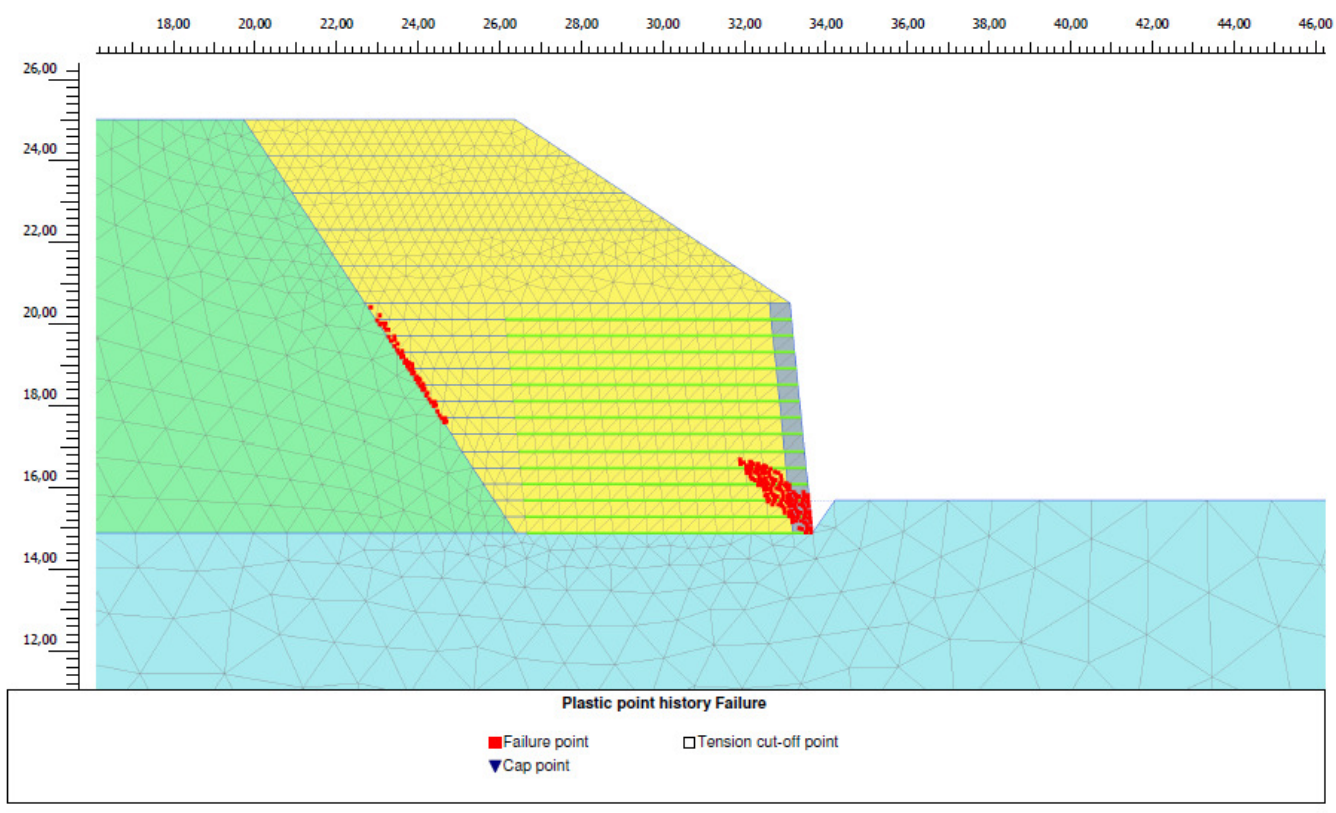

(d)

Figura 5.20 - Resultados da simulação numérica para a seção em geotêxtil não tecido para um tempo imediatamente após o término da construção do muro: (a) Malha deformada; (b) Deslocamentos horizontais; (c) Tensões efetivas horizontais; (d) Histórico de plastificação do aterro reforçado.

A Figura 5.21 mostra os principais resultados obtidos para a seção reforçada com geotêxteis tecidos, também para um período de tempo imediatamente após o término da construção da obra. Nota-se que o comportamento observado para esta 
seção é muito semelhante ao comportamento apresentado anteriormente para a seção em geotêxtil não tecido, sendo que as principais diferenças se referem apenas à magnitude das tensões e das deformações.

A Figura 5.21a mostra a malha deformada para a seção em geotêxteis tecidos. Assim como observado anteriormente, nota-se que os maiores deslocamentos ocorrem no topo do aterro não reforçado, e que as deformações na face do muro ocorrem em maior magnitude no terço inferior da mesma. A Figura 5.21b, que mostra os deslocamentos horizontais obtidos no modelo, confirma os fatos observados anteriormente.

Já Figura 5.21c apresenta as tensões horizontais obtidas no modelo numérico. Assim como destacado para seção em geotêxtil não tecido, nota-se que as tensões horizontais ao longo da face do aterro reforçado são praticamente nulas, e que quanto mais próximo ao pé do muro, mais próximo da face as tensões horizontais aparecem. Nas regiões mais elevadas do muro as tensões horizontais tendem a se afastar da face.

A Figura 5.21d mostra o histórico dos pontos de plastificação do maciço ao longo de sua construção. Observa-se que apenas uma pequena região no pé do muro sofreu plastificação, sendo que a forma desta região plastificada é praticamente coincidente com o local das tensões horizontais apresentadas na Figura 5.21c. Comparando-se as seções reforçadas com geotêxteis não tecidos e tecidos entre si, observa-se que a última apresenta uma região plastificada ligeiramente menor quando comparada com a primeira. Além disso, a região plastificada da seção em geotêxtil tecido apresenta, aparentemente, uma inclinação maior em relação ao plano horizontal, indicando que a sua provável superfície de ruptura passa mais próxima à face da estrutura. 


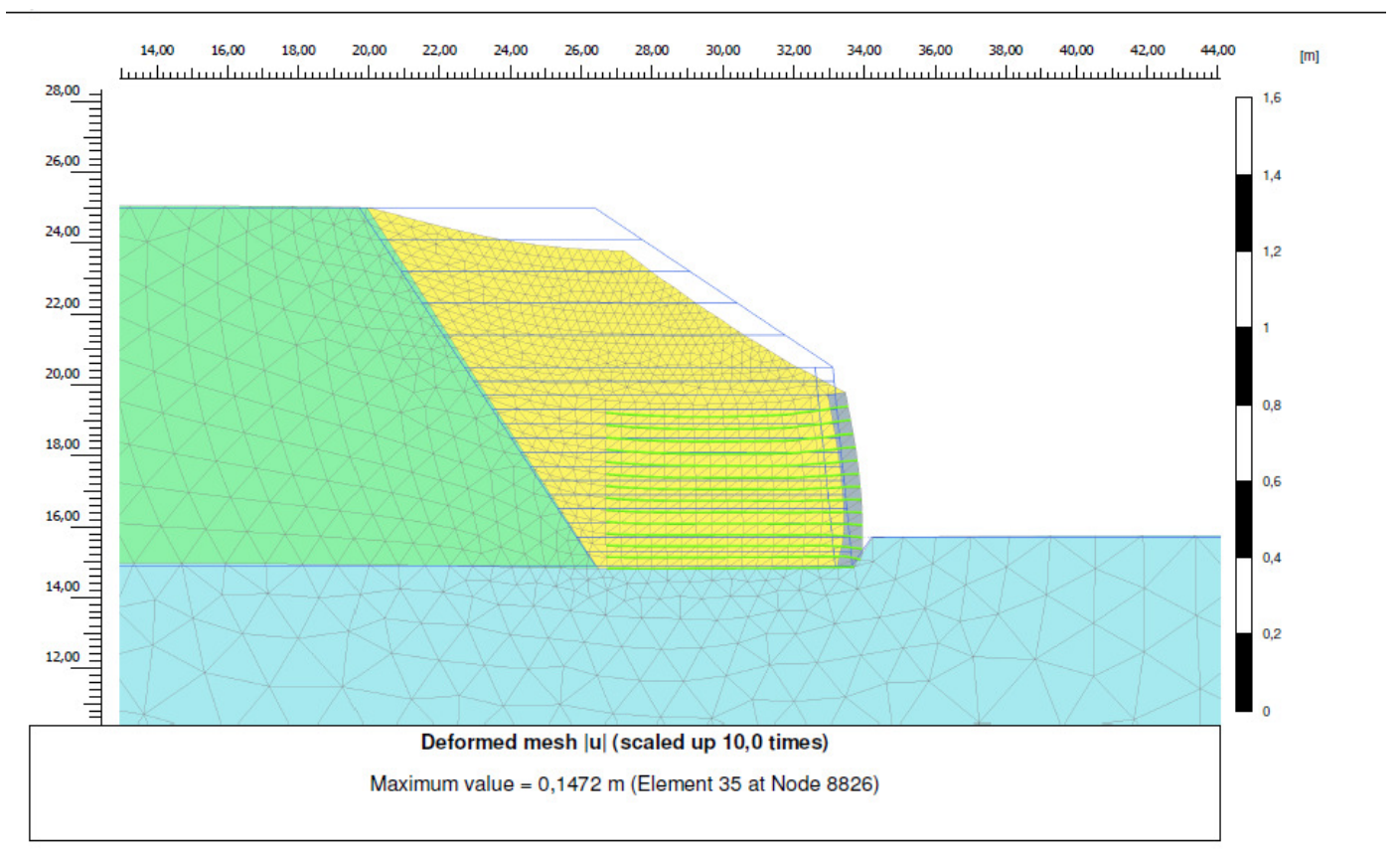

(a)

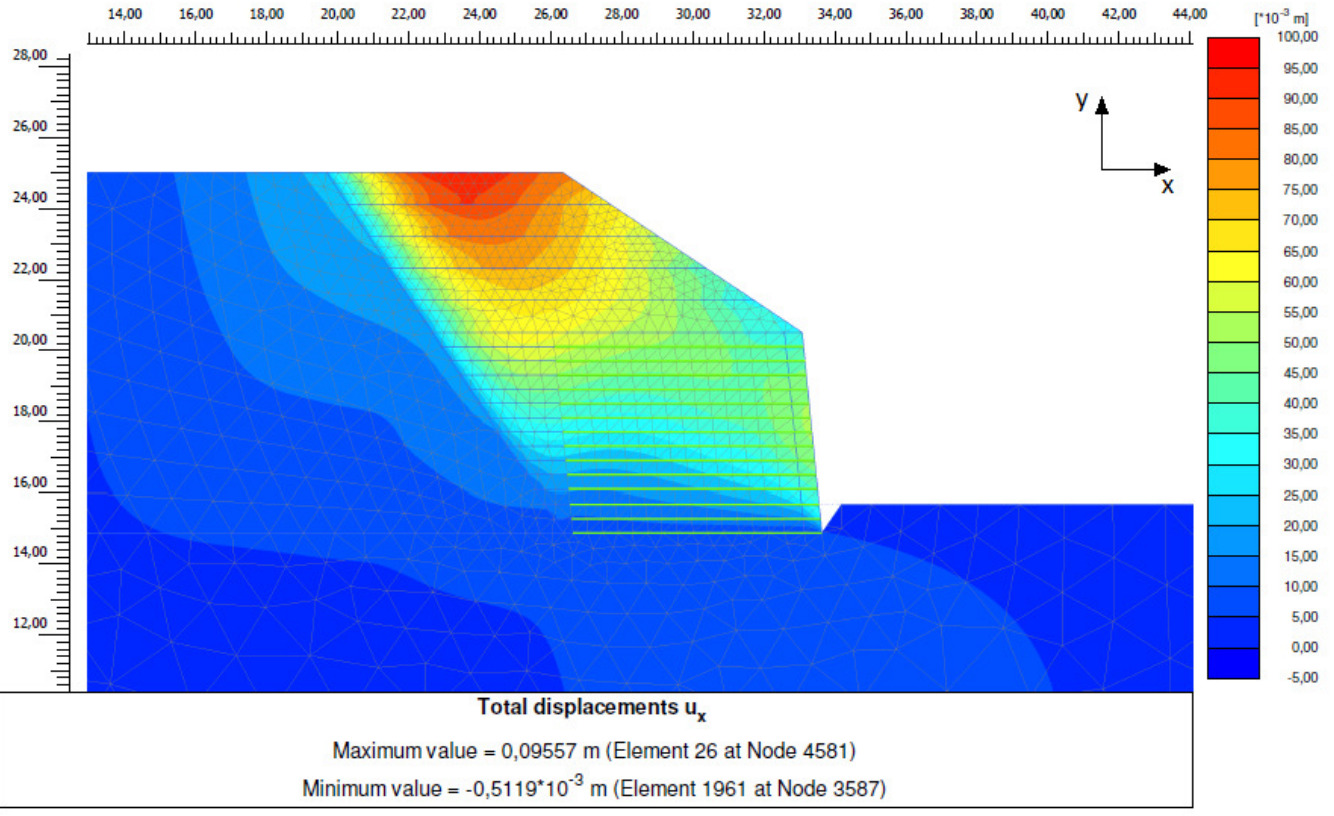

(b) 


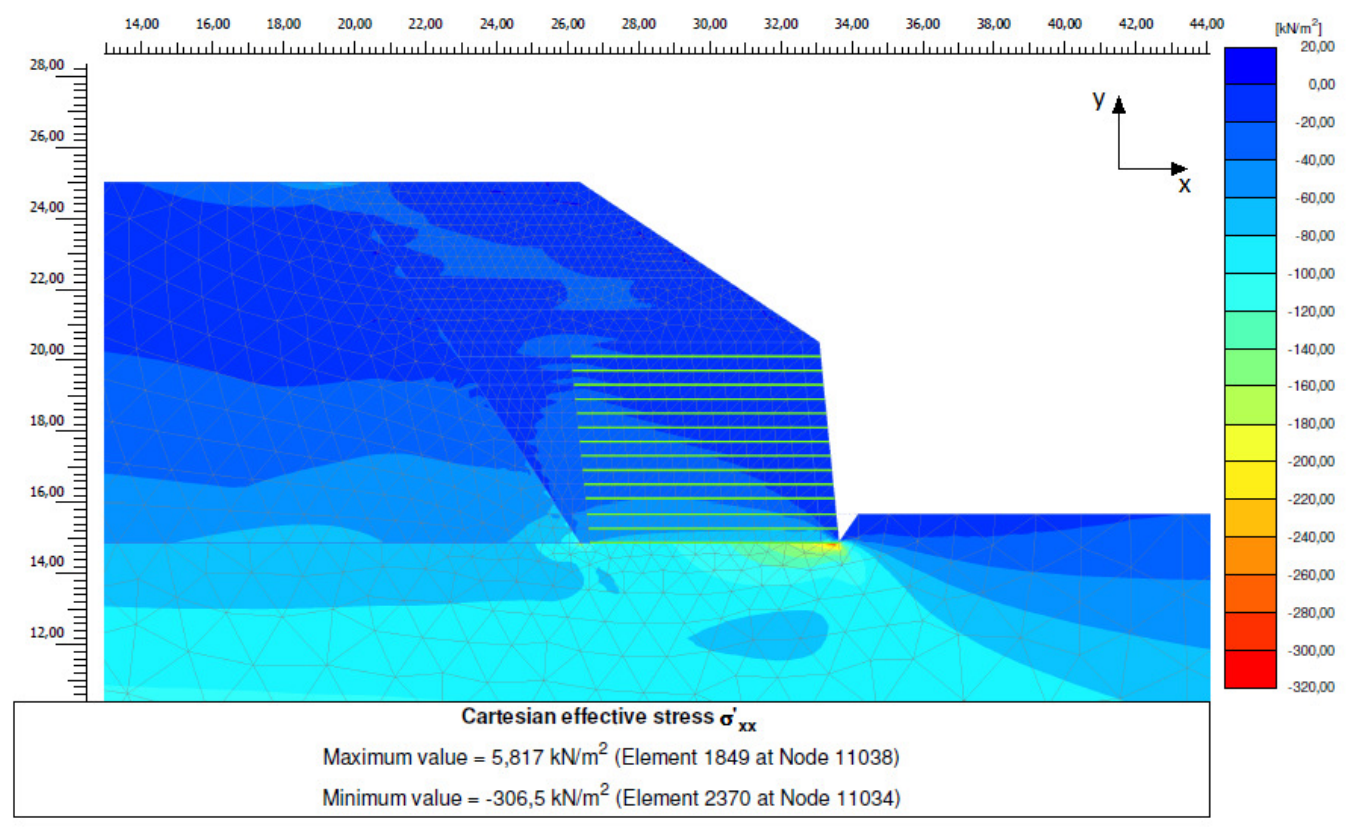

(c)

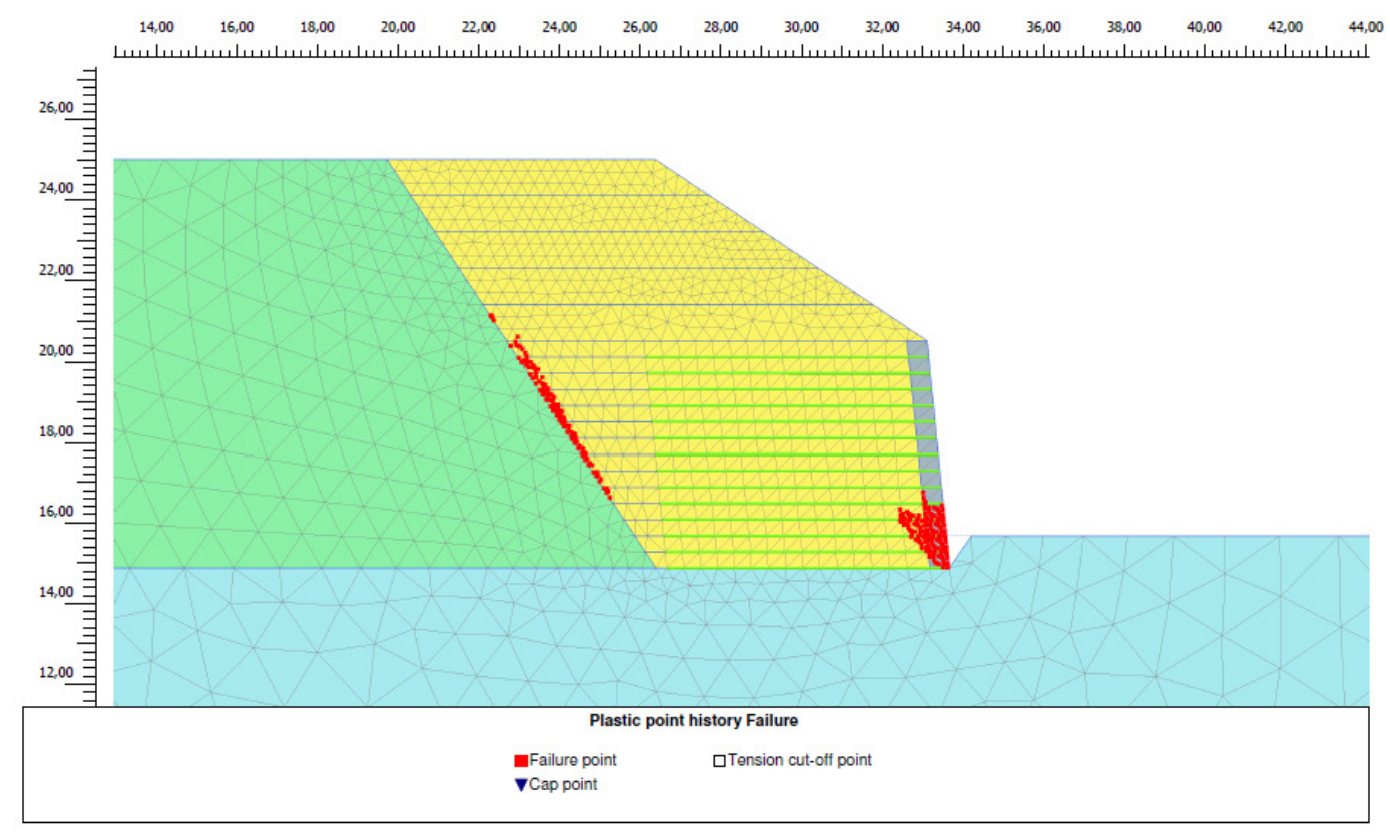

(d)

Figura 5.21 - Resultados da simulação numérica para a seção em geotêxtil tecido para um tempo imediatamente após o término da construção do muro: (a) Malha deformada; (b) Deslocamentos horizontais; (c) Tensões efetivas horizontais; (d) Histórico de plastificação do aterro reforçado.

A partir do modelo numérico calibrado foi possível realizar extrapolações do comportamento para períodos de tempo bem mais elevados que o tempo atual da obra. Conforme destacado anteriormente, a extrapolação dos parâmetros de rigidez 
foi realizada por meio da curva apresentada na Figura 5.17. Já a extrapolação do tempo para as deformações no maciço foi realizada aplicando-se o tempo desejado no modelo constitutivo do solo. A Figura 5.22 e a Figura 5.23 apresentam a extrapolação das deformações para um período de tempo de 36500 dias, equivalente a 100 anos, para a seção instrumentada E02.

A Figura 5.22a mostra a variação das deformações ao longo do reforço para diferentes períodos de tempo. Nota-se que as deformações máximas no reforço são da ordem de $1 \%$ para o período imediatamente após o término da construção. Após 100 anos de obra, a previsão é que o reforço se deforme por volta de $3 \%$.

A Figura 5.22b mostra a variação das deformações ao longo do tempo, também para um período máximo de 100 anos, com o eixo das abscissas em escala logarítmica. Observa-se que o comportamento das deformações ao longo dos anos não pode ser descrito por um ajuste de curvas único. Nota-se que ao longo do tempo ocorre uma tendência de variação da inclinação da curva, indicando que o parâmetro de ajuste "b" da equação logarítmica, o qual está relacionado à tendência à fluência do material, tende a aumentar ao longo do tempo. Este mesmo comportamento foi observado nas análises apresentadas no item 5.2, que trata dos resultados obtidos na instrumentação de campo. Conforme se observa na Figura 5.22b, as deformações ao longo do tempo para um período de 100 são mais bem representadas por 3 ajustes de curvas ao longo tempo. Para o período mais crítico (de 1433 dias a 36500 dias), o parâmetro "b", segundo as previsões com o uso do modelo numérico, é de 0,0059 , ou seja, aproximadamente 14 vezes maior que o parâmetro "b" obtido por meio dos ensaios em isolamento e aproximadamente 28 vezes maior que o parâmetro "b" obtido no ensaio confinado com 120 horas de duração. 


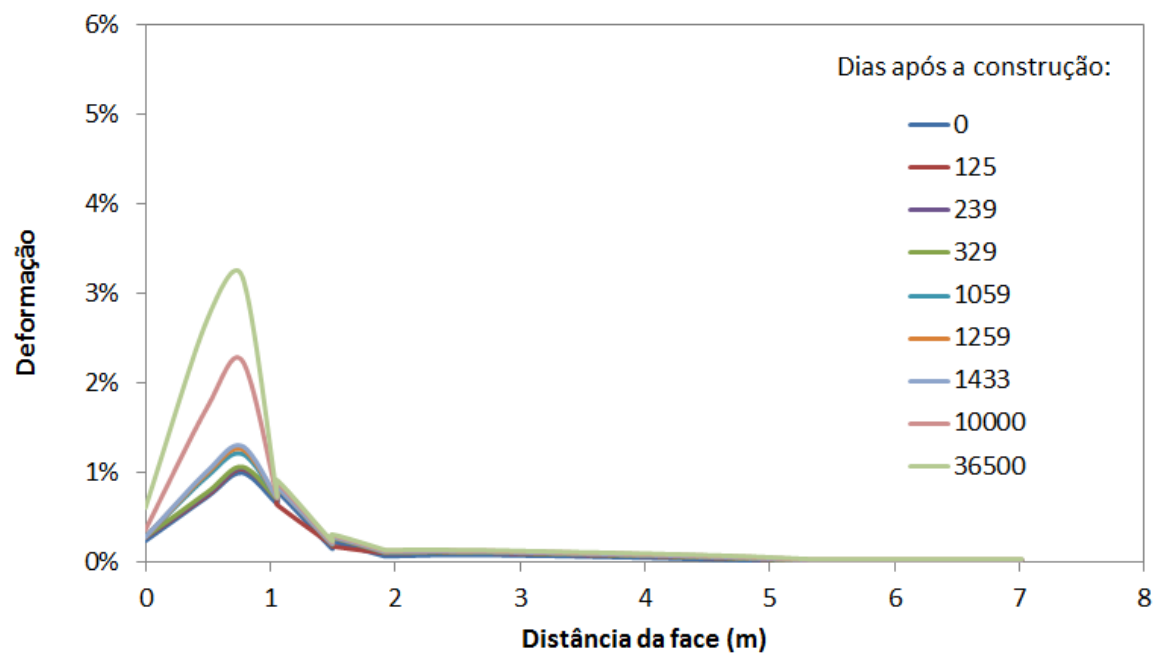

(a)

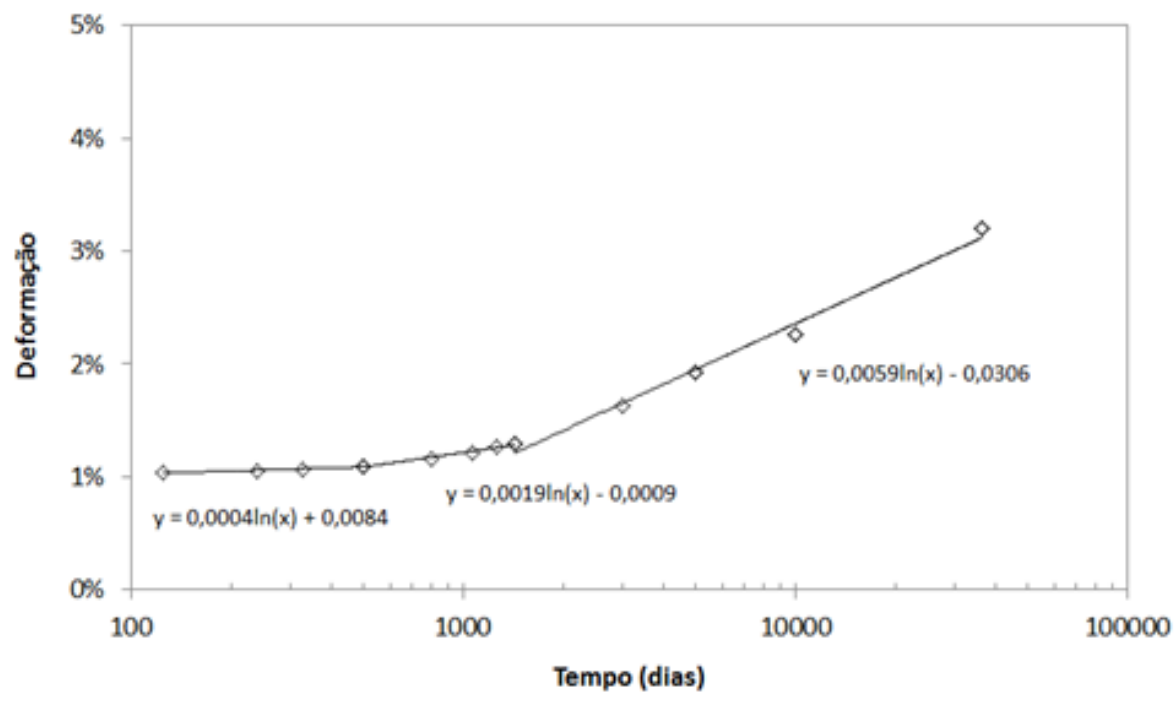

(b)

Figura 5.22 - Extrapolação dos resultados do modelo numérico para um período máximo de 100 anos para a seção em geotêxtil não tecido, seção instrumentada E02: (a) Variação das deformações ao longo do reforço para diferentes tempos; (b) Variação das deformações máximas ao longo do tempo.

As mesmas análises realizadas para os geotêxteis não tecidos foram também realizadas para a seção em geotêxtil tecido (Figura 5.23).

A Figura 5.23a mostra a variação das deformações ao longo do reforço tecido para diferentes períodos de tempo. Nota-se que as deformações máximas no reforço são da ordem de 1,2\% para o período imediatamente após o término da construção. Após 100 anos de obra, a previsão é que o reforço se deforme por volta de 4\%. 
Assim como foi observado para os reforços não tecidos, nota-se que as deformações dos geotêxteis tecidos plotadas ao longo do tempo, em escala logarítmica, não podem ser representadas por apenas um ajuste de curvas (Figura 5.23b). Nota-se que as deformações ao longo do tempo são mais bem representadas pelo ajuste de 2 curvas distintas. A Figura 5.23b mostra que para o caso mais crítico (período de 3000 a 36500 dias), o parâmetro "b" de ajuste da curva logarítmica é de 0,0645 , ou seja, aproximadamente 8 vezes maior que o parâmetro "b" obtido nos ensaios em isolamento, e aproximadamente 30 vezes maior que o parâmetro "b" obtido nos ensaios confinados com 120 horas de duração.

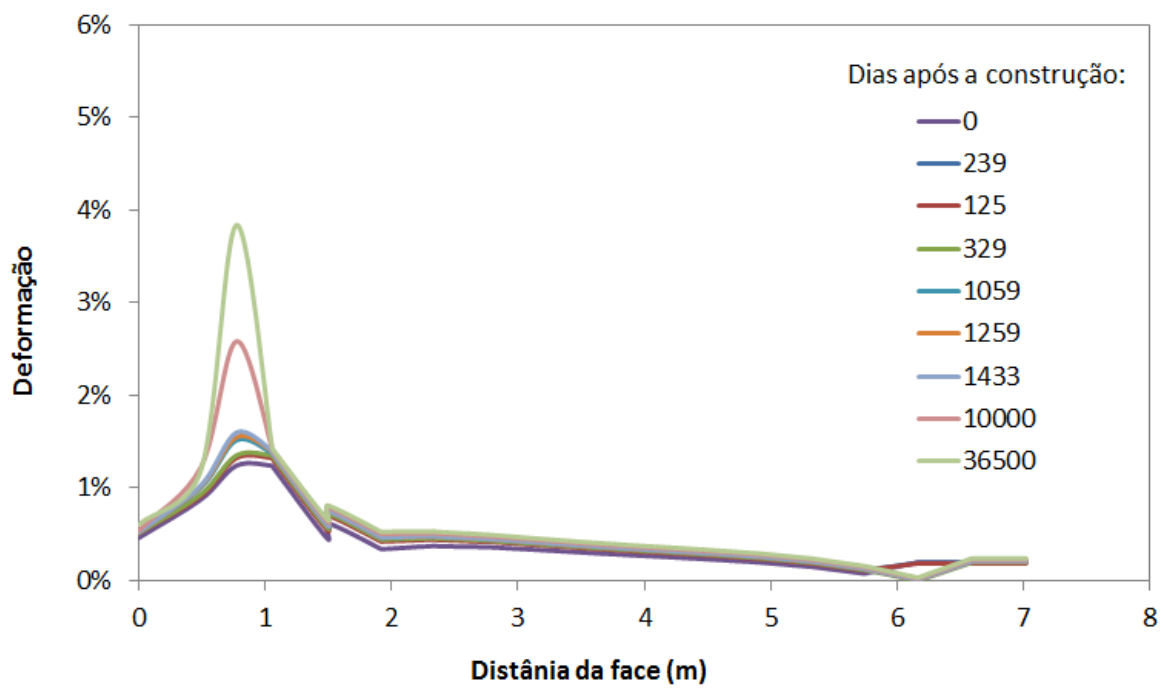

(a) 


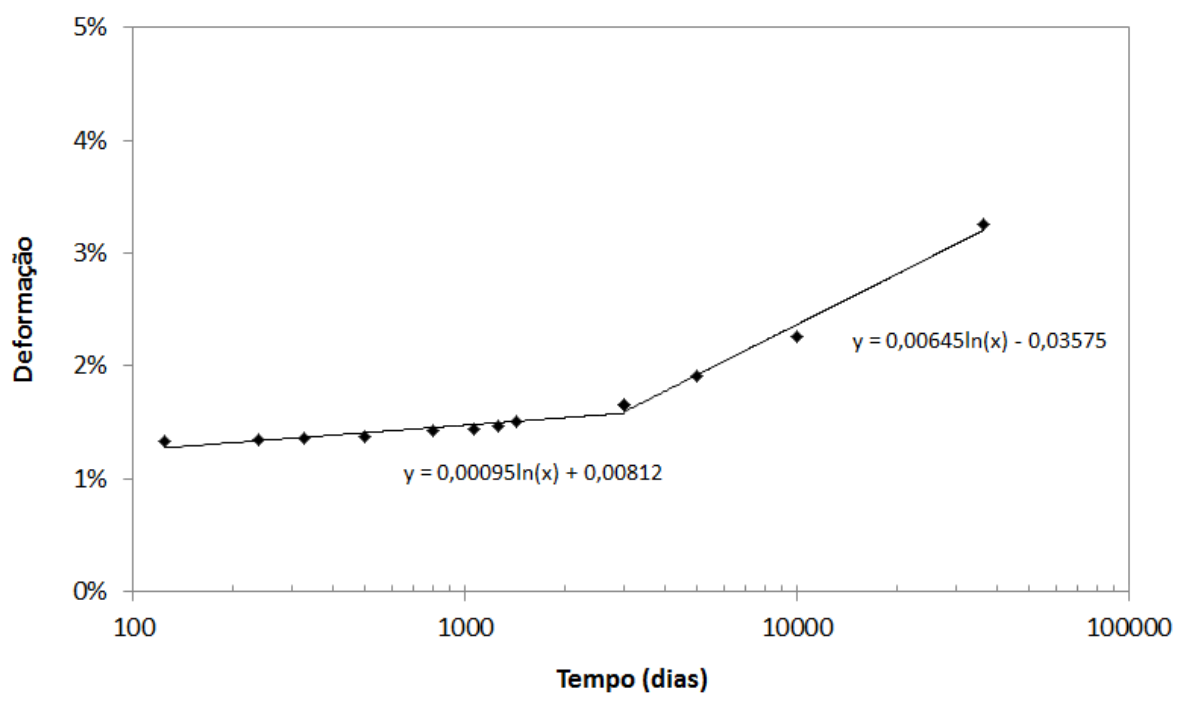

(b)

Figura 5.23 - Extrapolação dos resultados do modelo numérico para um período máximo de 100 anos para a seção em geotêxtil tecido, seção instrumentada E02: (a) Variação das deformações ao longo do reforço para diferentes tempos; (b) Variação das deformações máximas ao longo do tempo.

Além da extrapolação para períodos mais elevados de tempo, o modelo numérico desenvolvido permite a extrapolação dos resultados para outros tipos de reforços. No caso aqui apresentado os resultados foram extrapolados para as geogrelhas. As simulações numéricas para geogrelhas foram realizadas empregando-se os parâmetros geotécnicos utilizados na calibração da seção em geotêxtil tecido.

Os resultados da extrapolação para o caso das geogrelhas são apresentados na Figura 5.24.

Observa-se na Figura 5.24a que as deformações máximas ao longo do reforço ocorrem a aproximadamente 1,0 $\mathrm{m}$ da face. Nota-se que o nível de deformação é crescente com o tempo, atingindo um valor de aproximadamente 2,3\% após um período de 100 anos.

Assim como observado para os demais tipos de reforços (geotêxteis não tecidos e tecidos), a variação das deformações máximas nos reforços ao longo do tempo (Figura 5.24b), não pode ser representada por uma única curva de ajuste. Para o caso das geogrelhas as deformações ao longo do tempo são mais bem representadas pelo ajuste de duas curvas distintas. O primeiro ajuste representa um período de tempo situado entre 125 e 3000 dias, e o segundo ajuste representa um período de tempo entre 3000 e 36500 dias. 


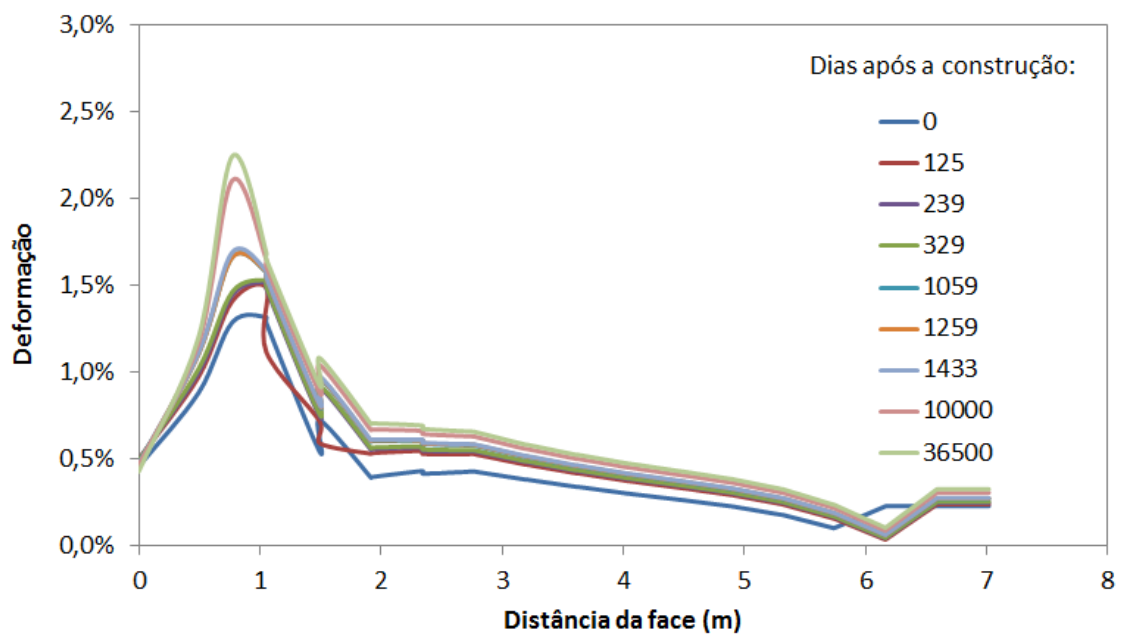

(a)

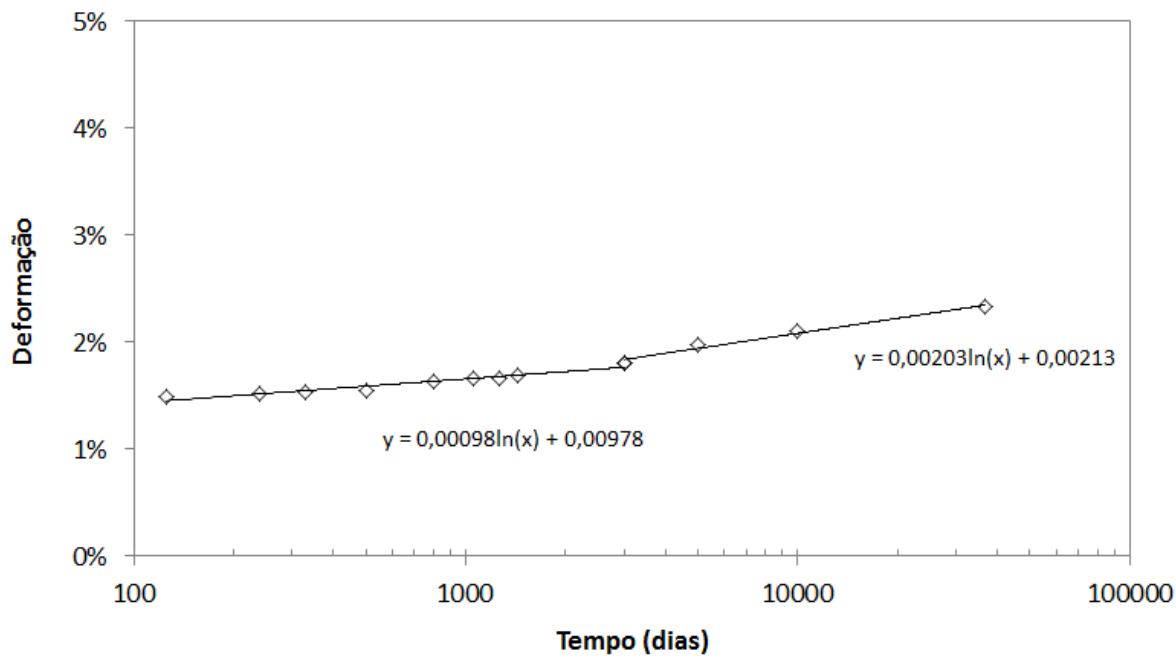

(b)

Figura 5.24 - Extrapolação dos resultados do modelo numérico utilizando geogrelhas como reforço, para um período de 100 anos, para a quinta linha de reforço: (a) Variação das deformações ao longo do reforço para diferentes tempos; (b) Variação das deformações máximas ao longo do tempo.

Pode-se notar que dentre os tipos de reforços simulados por meio do emprego do Método dos Elementos Finitos (MEF), os reforços em geogrelha foram os que apresentaram as menores deformações para o tempo padrão de 100 anos. Isto se deve ao fato do reforço ser o mais rígido entre os utilizados, o que confere à obra as menores deformações iniciais, além de possuir o menor índice de fluência, o que proporciona à obra as menores deformações ao longo do tempo.

As maiores deformações após o período de 100 anos foram observadas para o modelo numérico que empregou o geotêxtil tecido como reforço, enquanto a seção 
com geotêxteis não tecidos apresentou níveis de deformações com valores intermediários.

O fato da seção em geotêxteis tecidos apresentar os maiores níveis de deformação ao longo do tempo está associado ao tipo de polímero que compõe o reforço, conforme destacado no Capítulo 2 desta tese.

A partir dos modelos numéricos calibrados em função da linha instrumentada E02 (instalada na quinta linha de reforços), é possível estimar os níveis de deformação e a variação das deformações ao longo do tempo para os demais reforços.

A Figura 5.25 apresenta uma estimativa da variação das deformações ao longo do tempo para as linhas de reforços $n^{\circ} 3,5,7,9$ e 11, para as seções em geotêxteis não tecidos, geotêxteis tecidos e geogrelhas.

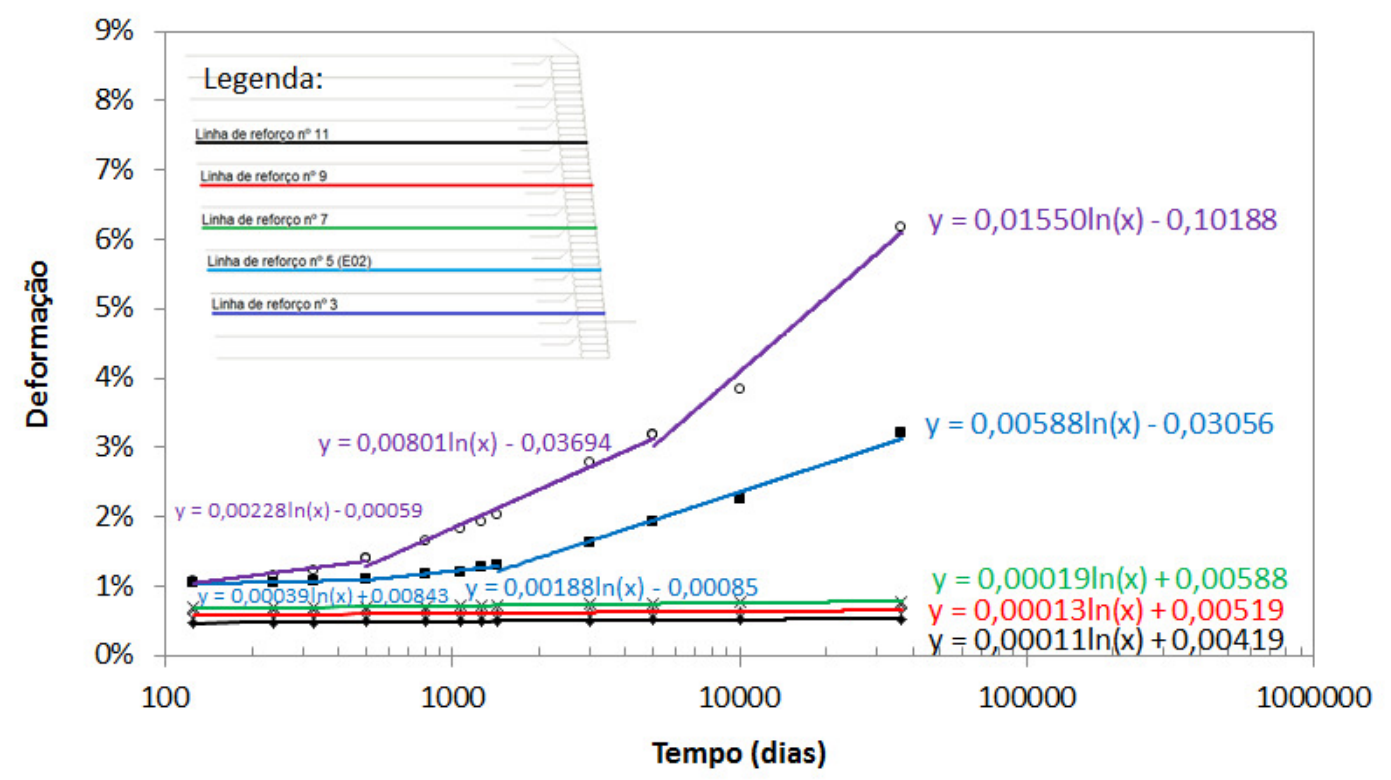

(a) 


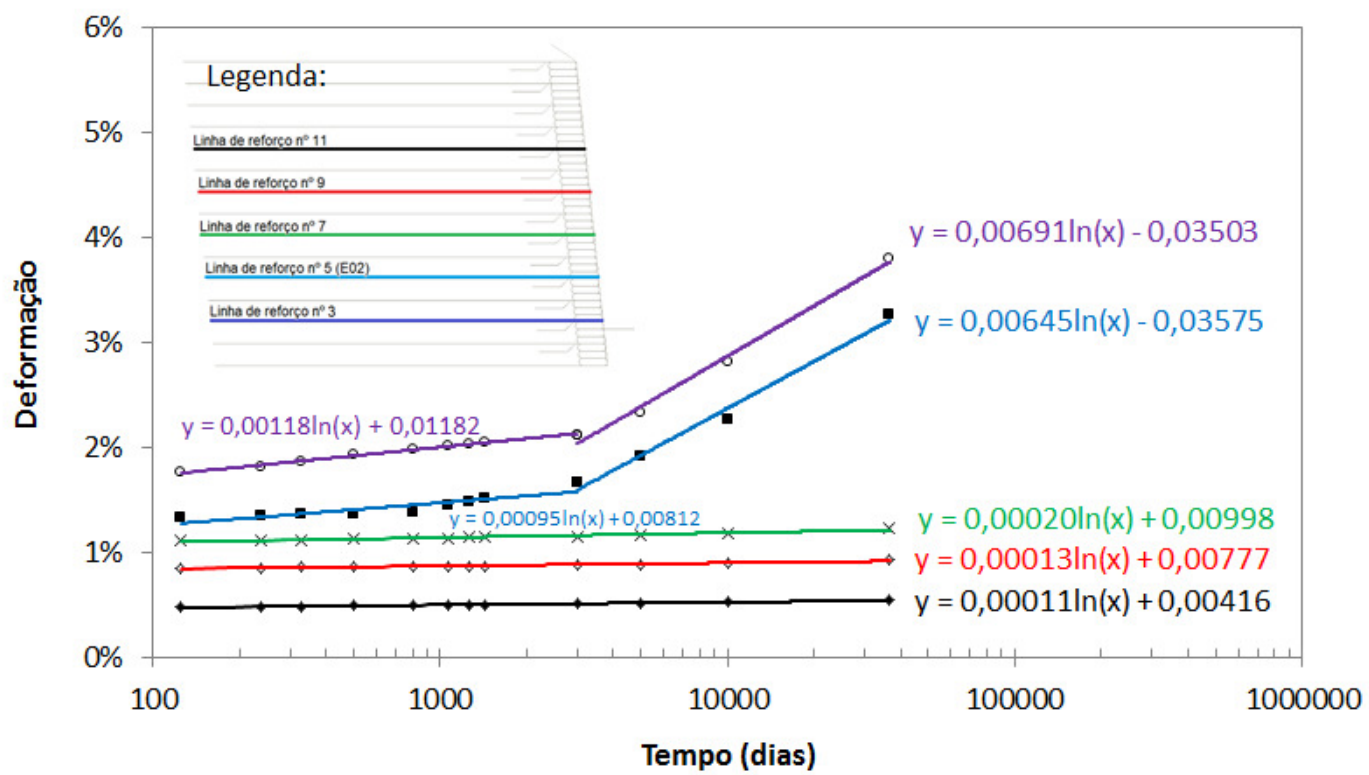

(b)

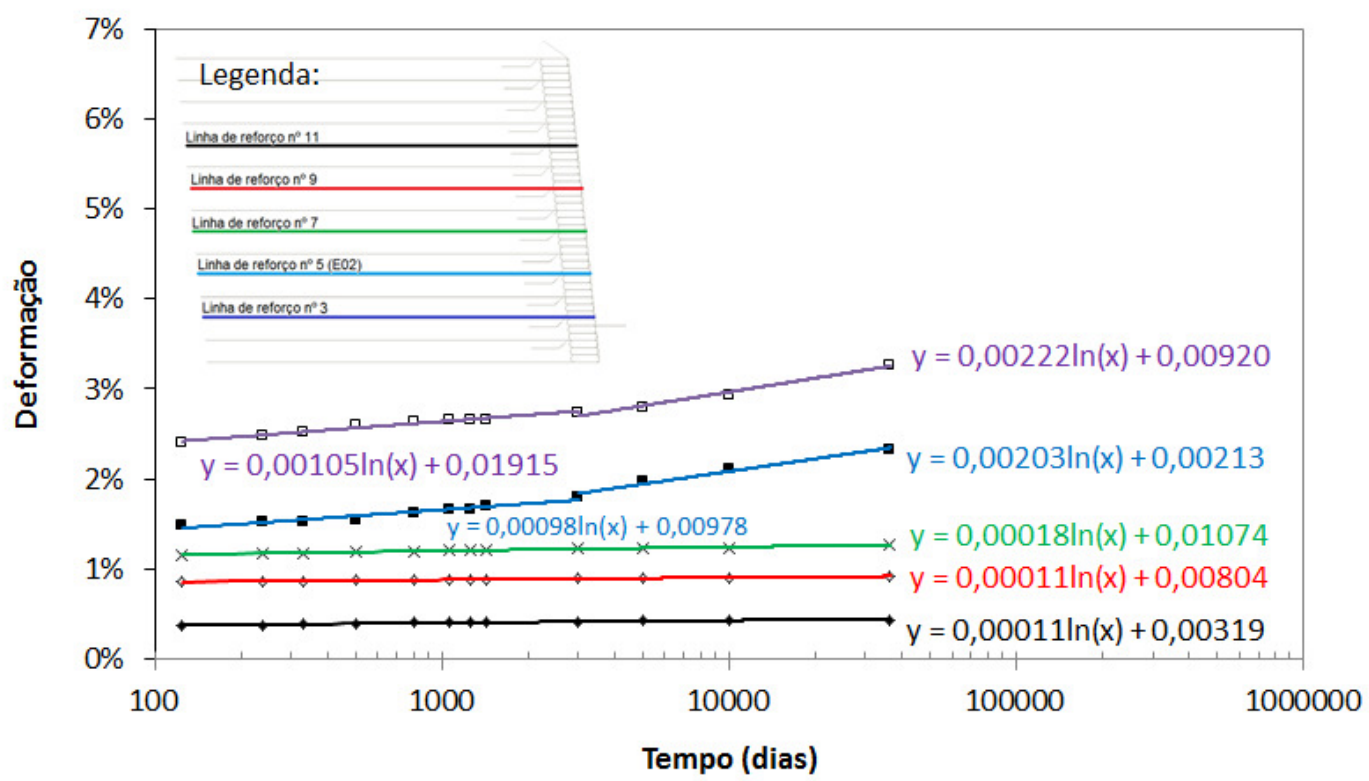

(c)

Figura 5.25 - Estimativa da variação das deformações ao longo do tempo para as linhas de reforços $n^{\circ} 3,5,7,9$ e 11 para os modelos numéricos de solos reforçados com: (a) Geotêxteis não tecidos; (b) Geotêxteis tecidos; (c) Geogrelhas.

Observa-se que, para todos os geossintéticos em análise, as maiores deformações e maiores níveis e fluência ocorrem nos reforços com maiores alturas de cobertura de solo, e, consequentemente, maiores carregamentos horizontais. Pode-se notar ainda que para as linhas de reforços $n^{\circ} 7,9$ e 11, a variação das deformações ao 
longo do tempo pode ser ajustada por uma curva única. Para o caso das linhas de reforços no 3 e 5 existe a necessidade de fazer o ajuste das curvas por meio do uso de três segmentos para o caso dos geotêxteis não tecidos, e dois segmentos para os geotêxteis tecidos e geogrelhas. Este fato pode ser explicado devido à plastificação do solo que ocorre na região próxima ao pé do muro. Conforme mostrado na Figura 5.20d e na Figura 5.21d, as linhas de reforços 3 e 5 encontramse dentro da região plastificada. As demais camadas encontram-se fora desta região, e portanto apresentam deformações compatíveis com os dados de entrada de fluência do solo e do reforço, os quais são representados por um ajuste único de deformações ao longo do tempo em escala semi-logarítmica.

A Tabela 5.1 mostra uma comparação geral dos parâmetros de deformação inicial "a" e taxa de fluência "b" determinados por meio dos ensaios de laboratório, das leituras de campo da obra instrumentada e das análises computacionais utilizando o Método dos Elementos Finitos (MEF).

Tabela 5.1 - Comparação geral dos parâmetros "a" e "b" obtidos a partir de diferentes abordagens.

\begin{tabular}{ccccccc}
\hline & & \multicolumn{5}{c}{ Laboratório } \\
\cline { 3 - 5 } Reforço & Parâmetro & $\begin{array}{c}\text { Fluência } \\
\text { Isolada }\end{array}$ & $\begin{array}{c}\text { Fluência } \\
\text { Confinada } \\
\text { Costa } \\
(2004)\end{array}$ & $\begin{array}{c}\text { Fluência } \\
\text { Confinada } \\
\text { França } \\
(2011)\end{array}$ & Campo & MEF \\
\hline \multirow{2}{*}{ GNT } & a & $2,11 \%$ & $0,91 \%$ & $0,05 \%$ & $0,25 \%$ & $0,12 \%$ \\
& b & $0,042 \%$ & $0,025 \%$ & $0,037 \%$ & $0,102 \%$ & $0,115 \%$ \\
GT & a & $1,63 \%$ & $0,83 \%$ & $0,21 \%$ & $0,69 \%$ & $0,81 \%$ \\
& b & $0,081 \%$ & $0,021 \%$ & $0,055 \%$ & $0,086 \%$ & $0,069 \%$ \\
\hline
\end{tabular}

Observa-se que as deformações iniciais nos reforços (parâmetro "a"), foram maiores para os ensaios em isolamento. Esse comportamento já era esperado, tendo em vista que o confinamento tende a reduzir as deformações iniciais de elementos confinados. Por outro lado, observa-se que as taxas de fluência, representadas pelo parâmetro "b", foram maiores para as leituras de campo e para a previsão utilizando o MEF. Conforme destacado anteriormente, a região onde se encontra instalada a seção instrumentada E02, apresenta plastificação do solo. A partir do momento em que o solo que confina o reforço sofre plastificação, ocorre uma redistribuição não 
linear das tensões nessa região, e o reforço passa a receber carregamentos mais elevados.

A Tabela 5.2 apresenta as taxas de fluência nas linhas instrumentadas E01, E02 e E03, obtidas por meio das leituras de campo, do MEF e dos ensaios de fluência em isolamento realizados em laboratório. Destaca-se que os resultados dos parâmetros "b" dos ensaios de fluência em isolamento foram obtidos por meio de interpolação de curvas para as relações $\mathrm{T} /$ Tult correspondentes aos carregamentos de cada uma das linhas instrumentadas.

Tabela 5.2 - Comparação entre as taxas de fluência obtidas em campo, MEF e laboratório, para todos os níveis instrumentados.

\begin{tabular}{|c|c|c|c|c|c|c|}
\hline \multirow{3}{*}{$\begin{array}{c}\text { Nível de } \\
\text { Instrumentação }\end{array}$} & \multicolumn{6}{|c|}{ Parâmetro $b$} \\
\hline & \multicolumn{3}{|c|}{ GNT } & \multicolumn{3}{|c|}{ GT } \\
\hline & Campo & MEF & $\begin{array}{c}\text { Laboratório } \\
\text { Fluência } \\
\text { Isolada }\end{array}$ & Campo & MEF & $\begin{array}{c}\text { Laboratório } \\
\text { Fluência } \\
\text { Isolada }\end{array}$ \\
\hline E01 & $0,110 \%$ & $0,801 \%$ & $0,043 \%$ & $0,096 \%$ & $0,118 \%$ & $0,090 \%$ \\
\hline E02 & $0,102 \%$ & $0,102 \%$ & $0,027 \%$ & $0,086 \%$ & $0,086 \%$ & $0,083 \%$ \\
\hline E03 & $0,150 \%$ & $<0,011 \%$ & $0,023 \%$ & $0,074 \%$ & $<0,011 \%$ & $0,023 \%$ \\
\hline
\end{tabular}

Pode-se observar que, para as linhas instrumentadas inferiores (E01 e E02), houve um bom ajuste entre os resultados obtidos nas leituras de campo e os resultados das análises numéricas. Para a linha instrumentada E03 a taxa de fluência registrada em campo foi significativamente maior do que a prevista no MEF. Observa-se que em todas as linhas instrumentadas as deformações de campo foram maiores que as deformações dos ensaios de fluência em isolamento. Conforme destacado anteriormente, tal comportamento era esperado para as linhas instrumentadas inferiores (E01 e E02), as quais se encontram dentro da zona plastificada. Esse comportamento não era esperado para a seção instrumentada E03, que teoricamente, encontra-se bem afastada da região de plastificação. Entretanto, ao longo das visitas realizadas ao local da obra, foi possível se observar uma série de fatores externos que podem ter provocado tal comportamento. Em um determinado período pós-construtivo, foram executadas pequenas edificações sobre o topo do talude. Essas edificações não foram permanentes, já que foram demolidas pouco tempo após suas construções. A presença destas edificações pode ter gerado 
sobrecargas na crista do talude, as quais podem ter sido responsáveis pelos deslocamentos não previstos na região do topo do muro. Além disso, existe a possibilidade das construções terem sido executadas utilizando brocas como elementos de fundação. Caso isto tenha ocorrido, certamente o reforço foi danificado nas camadas mais superficiais. Além disso, as condições atuais da face do muro são muito críticas. A região na frente da estrutura é utilizada atualmente como depósito de resíduos pela população local. Periodicamente os resíduos são incinerados ao ar livre. Este processo acabou danificando a face da estrutura em diversos pontos, sendo que em alguns locais a face envelopada não existe mais, tendo sido totalmente consumida pelo fogo. Somando-se a isso, pode-se também considerar a possibilidade de danos de instalação nos reforços durante a execução da estrutura de contenção.

A Figura 5.26 mostra as cargas nos reforços obtidas nos modelos numéricos dos muros em solo reforçado com geotêxteis não tecidos, geotêxteis tecidos e geogrelhas, para duas situações distintas: situação pós-construção e situação após um período de tempo de 100 anos. Nota-se que, em todos os casos, independente do tipo de reforço, as potenciais superfícies de ruptura são muito semelhantes. Observa-se ainda que os modelos numéricos não apresentaram uma tendência de variação da posição da superfície potencial de ruptura ao longo do tempo, diferente dos resultados que foram observados em campo.

A Figura 5.26a mostra que, para o caso dos geotêxteis não tecidos, a variação das cargas nos reforços a partir do período pós construtivo para um período de 100 anos foi consideravelmente grande. As forças máximas no reforço foram de $0,4 \mathrm{kN} / \mathrm{m}$ para $1,9 \mathrm{kN} / \mathrm{m}$, ou seja, houve uma aumento de quase 5 vezes na magnitude dos esforços.

Já a Figura 5.26b e Figura 5.26c mostram que, para os casos dos geotêxteis tecidos e geogrelhas, respectivamente, as variações das cargas máximas do período pós construtivo para o período de 100 anos de construção foram relativamente pequenas. Para o caso dos geotêxteis tecidos o acréscimo de carga foi da ordem de $10 \%$, enquanto que para o caso das geogrelhas este acréscimo foi da ordem de $20 \%$. 

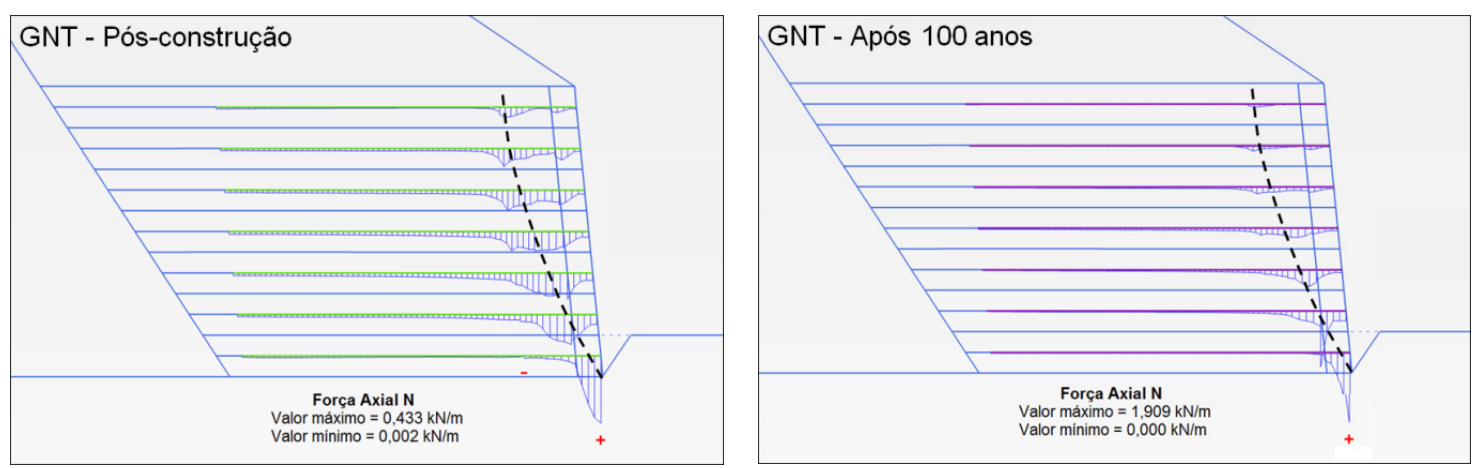

(a)
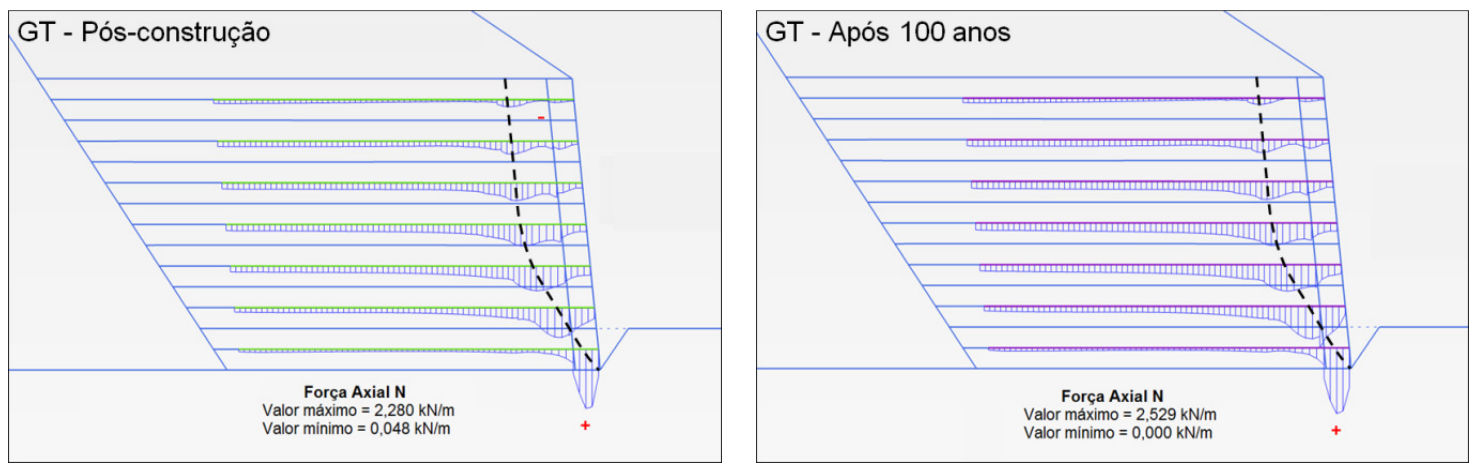

(b)
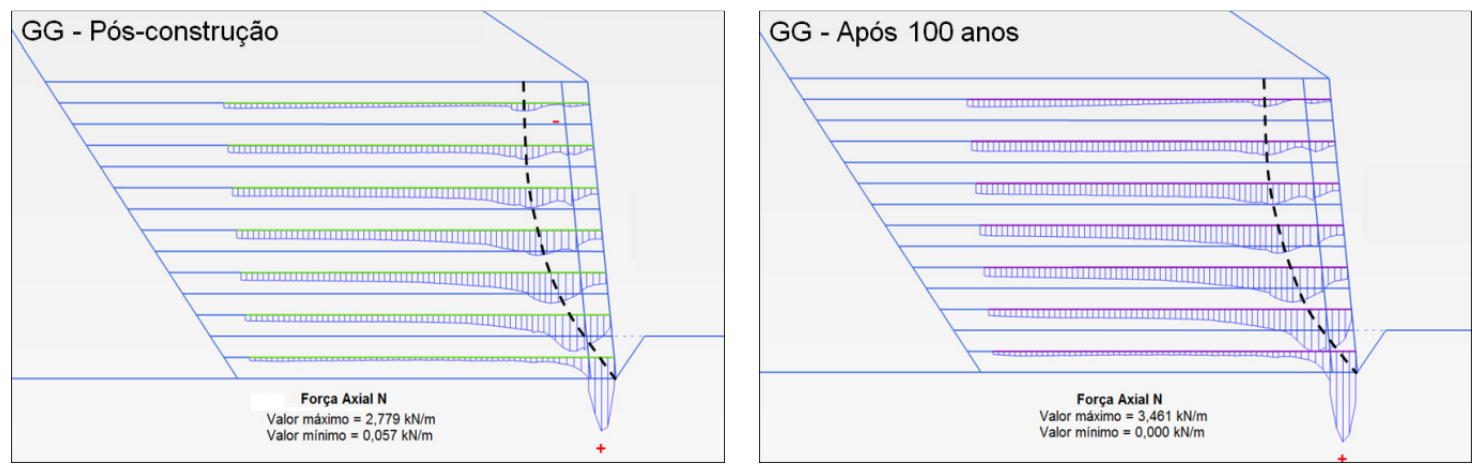

(c)

Figura 5.26 - Cargas nos reforços e posição da superfície de ruptura no período pós-construtivo e após 100 anos de construção obtidos nos modelos numéricos dos muros executados com: (a)

Geotêxtil não tecido; (b) Geotêxtil tecido; (c) Geogrelha.

De forma a validar as modelagens computacionais realizadas neste capítulo, foi elaborada a Figura 5.27, que apresenta em um mesmo gráfico, as previsões de deformações ao longo do tempo para a estrutura de referência realizada pelo Método dos Elementos Finitos, as leituras de deformações realizadas em campo, e ainda as deformações obtidas por meio dos ensaios de fluência confinada realizados no equipamento desenvolvido por Costa (2004). A Figura 5.27a mostra os resultados 
para a seção instrumentada em geotêxtil não tecido, e a Figura 5.27b apresenta os resultados para a seção em geotêxtil tecido. Lembrando que os dados se referem à linha instrumentada E02.

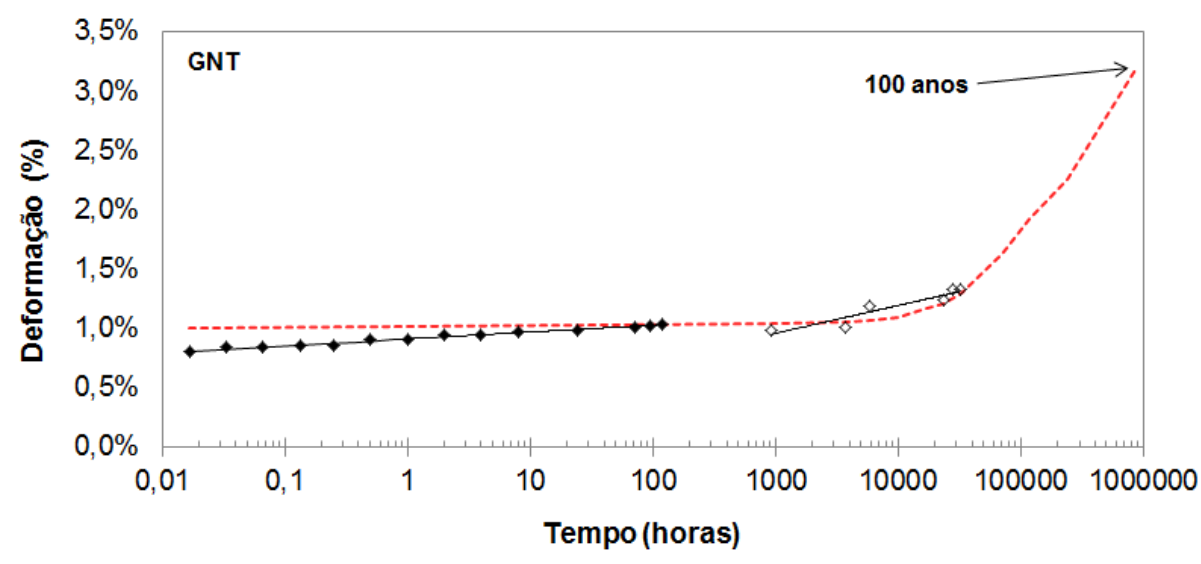

- Ensaio Confinado Equip. Costa (2004)

(a)

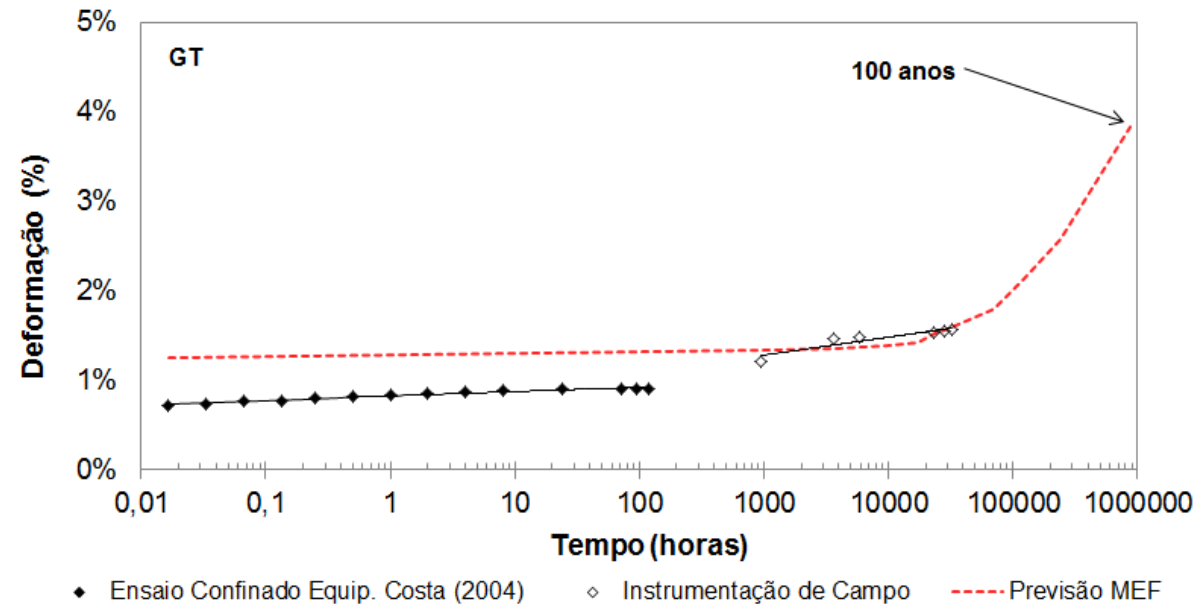

(b)

Figura 5.27 - Comparação entre os resultados dos ensaios de fluência confinada, leituras de campo e previsão de deformações por meio da modelagem computacional para: a) seção reforçada com geotêxteis não tecidos; b) seção reforçada com geotêxteis tecidos.

A Figura 5.27 mostra que houve uma boa coerência entre os resultados previstos por meio da modelagem computacional e os resultados obtidos experimentalmente. Nota-se que o melhor ajuste se deu para o caso da seção reforçada com geotêxteis não tecidos. Para o caso dos geotêxteis tecidos houve uma pequena discrepância entre os resultados previstos numericamente e os resultados dos ensaios confinados. Esta diferença já era esperada, tendo em vista que a modelagem numérica foi ajustada em função dos resultados de campo e não de laboratório. 
Apesar disso, pode-se afirmar que a modelagem computacional apresentou resultados muito satisfatórios, para ambas as seções instrumentadas, se mostrando como uma excelente ferramenta para a previsão do comportamento ao longo do tempo de estruturas reforçadas com geossintéticos.

A partir dos resultados mostrados na Figura 5.25 foi possível se estabelecer uma relação entre a posição do reforço ao longo da altura do muro e os parâmetros "a" e "b" da equação logarítmica. Isto possibilita a determinação de uma equação para o cálculo das deformações no reforço ao longo do tempo em função da altura de cobertura de solo. A relação entre a posição do reforço, normalizada pela altura do muro, e os parâmetros de deformação "a" e "b" é mostrada na Figura 5.28a para os geotêxteis não tecidos, Figura 5.28b para os geotêxteis tecidos e Figura 5.28c para as geogrelhas.
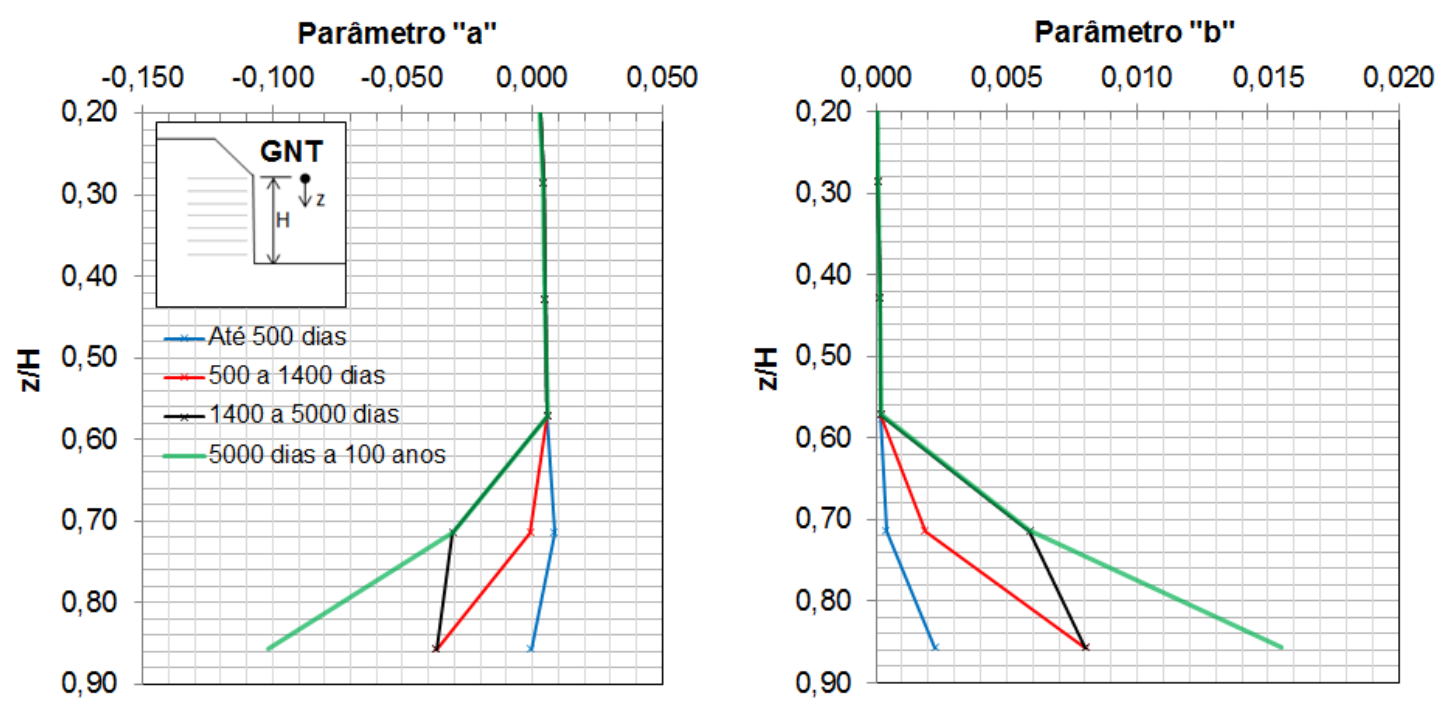

(a) 

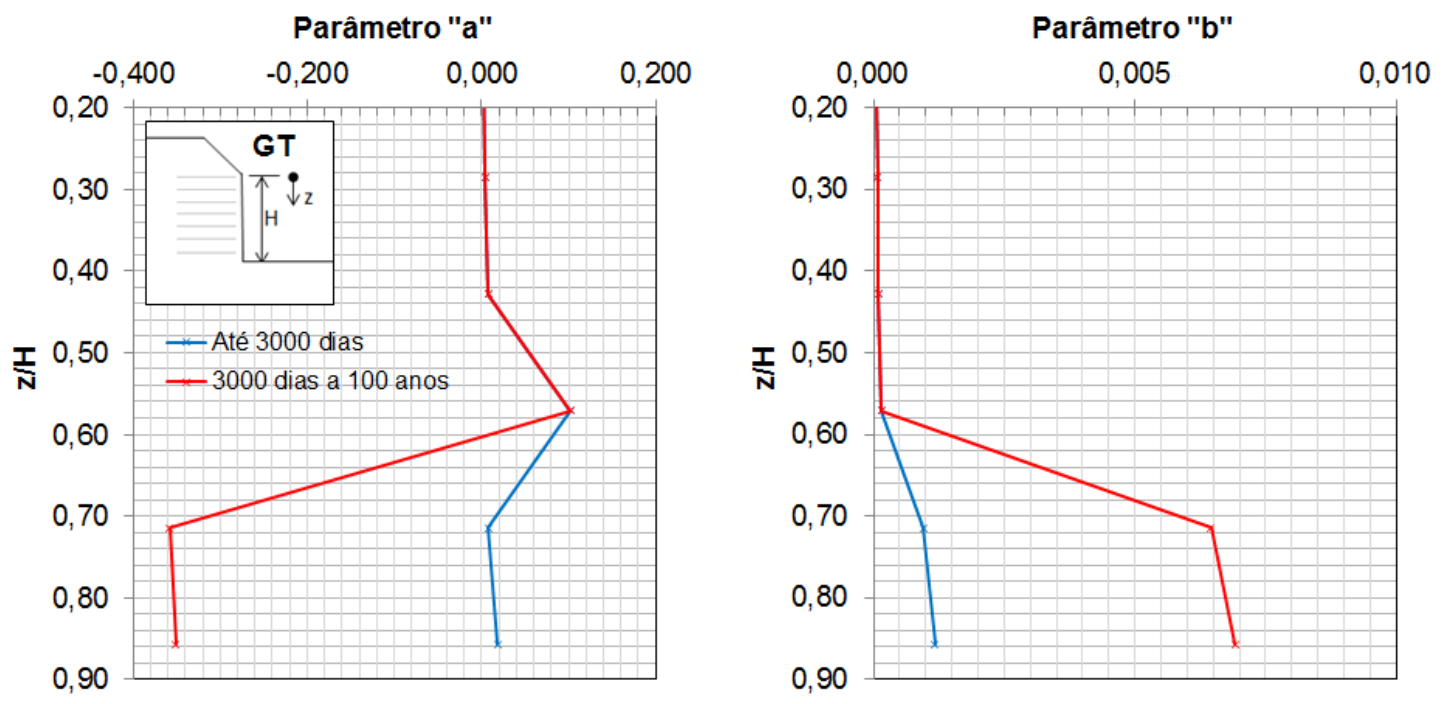

(b)
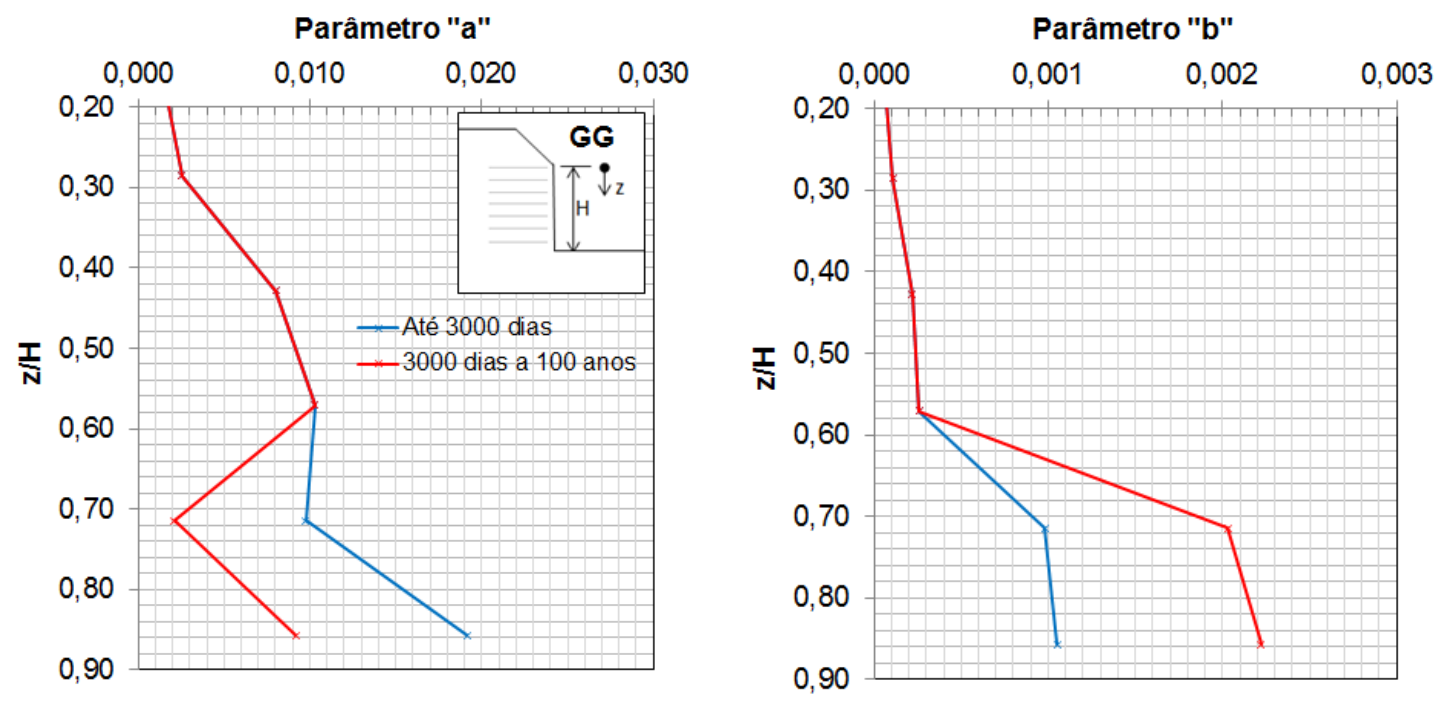

(c)

Figura 5.28 - Relação entre a posição do reforço ao longo da altura do muro e os parâmetros "a" e "b" para: (a) geotêxteis não tecidos; (b) geotêxteis tecidos; (c) geogrelhas.

\subsection{APLICAÇÃO DO MODELO ANALÍTICO}

Neste Capítulo foram apresentados os resultados do monitoramento do muro em solo reforçado, construído na cidade de Campinas, utilizado como referência para este trabalho, bem como os resultados das modelagens computacionais elaboradas para esta obra. Em função dos resultados da instrumentação da obra de referência e da modelagem computacional elaborada é possível aplicar o modelo para previsão 
de comportamento ao longo do tempo de reforços confinados apresentado no item 4.2.7 do Capitulo 4. A aplicação das equações para a obra de Campinas permite a validação do modelo proposto para um caso real de obra.

A validação do modelo foi realizada considerando como referência o nível de instrumentação E02, cuja tensão vertical sobre o reforço é de $140 \mathrm{kPa}$. Os cálculos foram realizados para os geotêxteis não tecidos e geotêxteis tecidos, para períodos de tempo de até 100 anos (876000 horas), aplicando as equações 4.2, 4.3 e 4.4 apresentadas no Item 4.2.7 do Capítulo 4.

Os cálculos dos módulos de rigidez para a validação do modelo são apresentados na Tabela 5.3.

Tabela 5.3 - Calculo do módulo de rigidez pelo modelo de comportamento proposto.

\begin{tabular}{|c|c|c|c|c|c|c|c|c|c|c|}
\hline Ref. & $\underset{\left(1 h_{\text {isol }}\right)}{J}$ & $\Delta \mathrm{J}$ & $\alpha_{J}$ & $\mathrm{~J}(1 \mathrm{~h})$ & $\mathrm{V}_{\mathrm{J}, \text { iso }}$ & $\Delta \mathrm{V}_{\mathrm{J}}$ & $\alpha_{v}$ & $\mathrm{~V}_{\mathrm{J}}$ & $\begin{array}{c}\text { Tempo } \\
\text { (h) }\end{array}$ & $\begin{array}{c}\mathrm{J} \\
(\mathrm{kN} / \mathrm{m})\end{array}$ \\
\hline & & & & & & & & & 0,017 & 49,06 \\
\hline & & & & & & & & & 0,1 & 46,39 \\
\hline & & & & & & & & & 1 & 42,92 \\
\hline & & & & & & & & & 10 & 39,45 \\
\hline \multirow[t]{9}{*}{ GNT } & 20 & 40,3 & 0,006 & 42,9 & $-0,4$ & $-1,95$ & 0,006 & $-1,51$ & 100 & 35,97 \\
\hline & & & & & & & & & 1000 & 32,50 \\
\hline & & & & & & & & & 10000 & 29,03 \\
\hline & & & & & & & & & 100000 & 25,56 \\
\hline & & & & & & & & & 876000 & 22,28 \\
\hline & & & & & & & & & 0,017 & 147,52 \\
\hline & & & & & & & & & 0,1 & 134,60 \\
\hline & & & & & & & & & 1 & 117,82 \\
\hline & & & & & & & & & 10 & 101,03 \\
\hline \multirow[t]{5}{*}{ GT } & 67 & 89,4 & 0,006 & 117,8 & $-2,8$ & $-10,47$ & 0,004 & $-7,29$ & 100 & 84,25 \\
\hline & & & & & & & & & 1000 & 67,46 \\
\hline & & & & & & & & & 10000 & 50,68 \\
\hline & & & & & & & & & 100000 & 33,89 \\
\hline & & & & & & & & & 876000 & 18,07 \\
\hline
\end{tabular}

Em função dos módulos de rigidez para os geotêxteis não tecidos e tecidos calculados a partir do modelo proposto para a previsão do comportamento de reforços confinados, é possível estimar, em função do nível de carregamento esperado, as deformações no reforço. Para a determinação das deformações foram utilizados os carregamentos obtidos nos ensaios confinados realizados no 
equipamento de interação solo-reforço desenvolvido por Costa (2004), apresentados na Figura 4.21. Considerou-se, para efeitos práticos, que não ocorreu variação do carregamento para os tempos considerados. As deformações estimadas para cada um dos reforços e para cada um dos tempos considerados nos cálculos são apresentadas na Tabela 5.4.

Tabela 5.4 - Cálculo das deformações nos reforços para diferentes tempos.

\begin{tabular}{ccccc}
\hline Reforço & $\begin{array}{c}\text { Tempo } \\
(\mathrm{h})\end{array}$ & $\begin{array}{c}\mathrm{J} \\
(\mathrm{kN} / \mathrm{m})\end{array}$ & $\begin{array}{c}\mathrm{T} \\
(\mathrm{kN} / \mathrm{m})\end{array}$ & $\begin{array}{c}\varepsilon \\
(\%)\end{array}$ \\
\hline \multirow{4}{*}{ GNT } & 0,017 & 49,06 & 0,40 & 0,82 \\
& 0,1 & 46,39 & 0,40 & 0,86 \\
& 1 & 42,92 & 0,40 & 0,93 \\
& 10 & 39,45 & 0,40 & 1,01 \\
& 100 & 35,97 & 0,40 & 1,11 \\
& 1000 & 32,50 & 0,40 & 1,23 \\
& 10000 & 29,03 & 0,40 & 1,38 \\
& 100000 & 25,56 & 0,40 & 1,57 \\
& 876000 & 22,28 & 0,40 & 1,80 \\
\hline GT & 0,017 & 147,52 & 0,70 & 0,47 \\
& 0,1 & 134,60 & 0,70 & 0,52 \\
& 1 & 117,82 & 0,70 & 0,59 \\
& 10 & 101,03 & 0,70 & 0,69 \\
& 100 & 84,25 & 0,70 & 0,83 \\
& 1000 & 67,46 & 0,70 & 1,04 \\
& 10000 & 50,68 & 0,70 & 1,38 \\
& 100000 & 33,89 & 0,70 & 2,07 \\
\hline
\end{tabular}

Para melhor visualização das deformações estimadas pelo modelo de comportamento proposto, os resultados mostrados na Tabela 5.2 foram plotados em conjunto com os resultados da instrumentação de campo e resultados da modelagem computacional (Figura 5.29). 


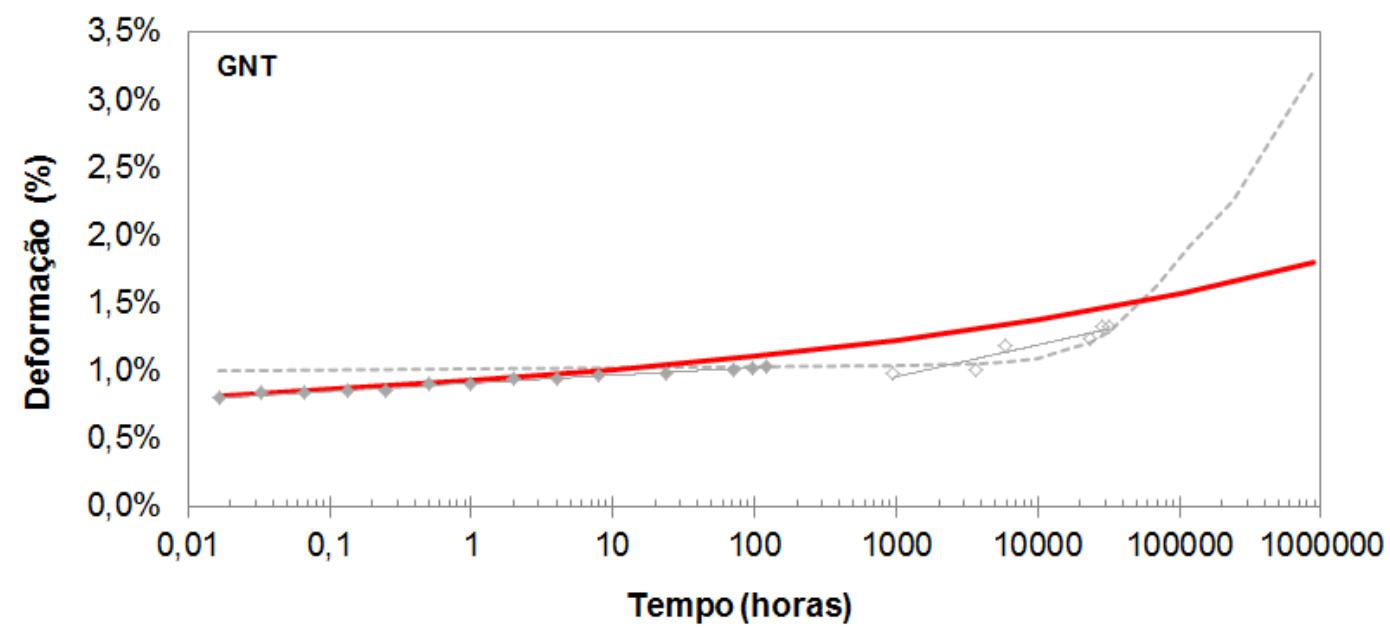

- Ensaio Confinado Equip. Costa (2004)

Instrumentação de Campo

----Previsão MEF

-Modelo de previsão de comportamento

(a)

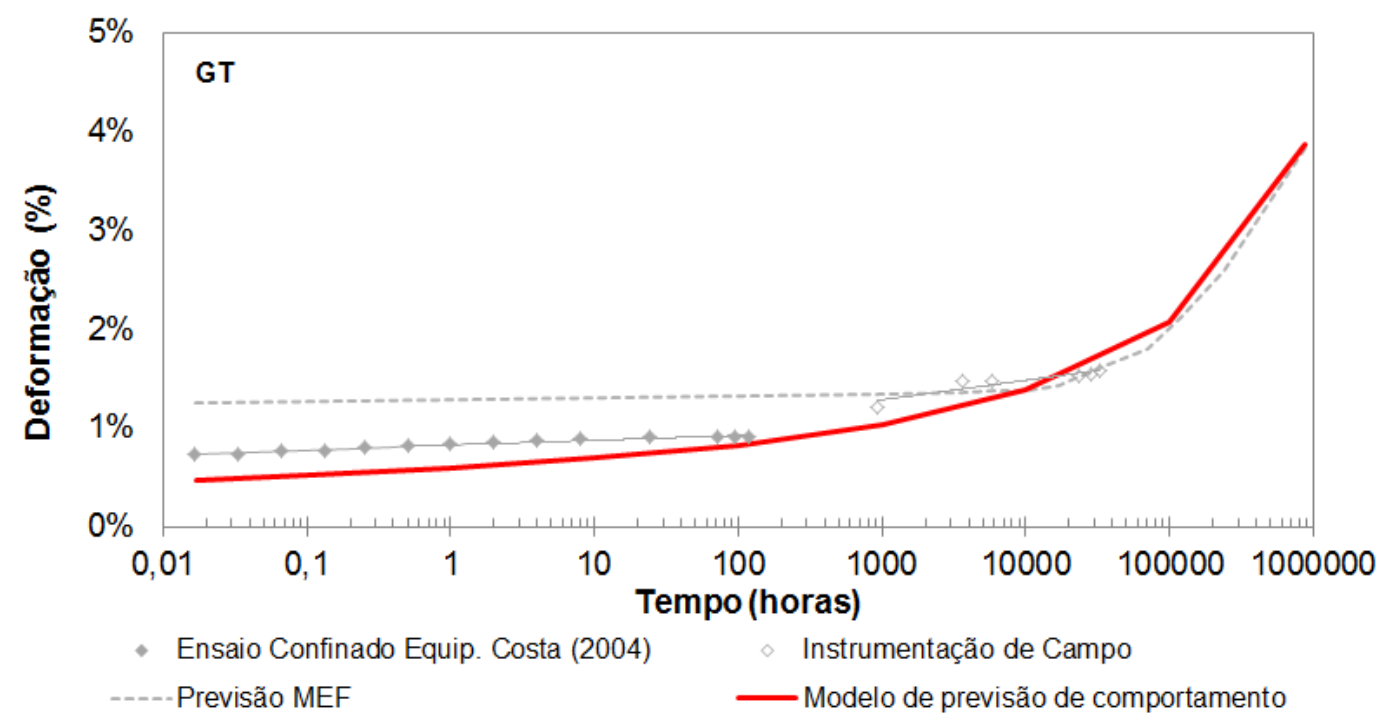

(b)

Figura 5.29 - Comparação entre os resultados da instrumentação de campo, da modelagem computacional e do modelo analítico proposto para: (a) geotêxteis não tecidos; (b) geotêxteis tecidos.

Os dados apresentados na Figura 5.29 mostram que houve um bom ajuste entre os resultados do modelo analítico proposto para a previsão do comportamento de reforços confinados e os resultados das leituras de campo e modelagem computacional. 


\subsection{SUMÁRIO DO CAPÍTULO 5}

Neste capítulo foram apresentados os resultados do monitoramento do muro em solo reforçado, construído na cidade de Campinas, utilizado como referência para este trabalho. Foram apresentados também resultados da modelagem computacional da obra de referência, possibilitando a melhor compreensão dos mecanismos que governam o comportamento ao longo do tempo de muros reforçados com geossintéticos. Para complementar as análises, o modelo analítico proposto no Capítulo 4 para a previsão do comportamento ao longo do tempo de geossintéticos confinados, foi aplicado para o caso da obra de referência.

Os resultados e as análises referentes à obra instrumentada apresentadas neste capítulo permitiram concluir que:

- Os resultados das leituras da instrumentação do muro de referência de Campinas mostraram um ótimo comportamento da estrutura ao longo dos quase quatro anos de leitura. As deformações finais registradas nesse período, para a seção em geotêxtil tecido, foram de 1,57\% para o nível de instrumentação E02 (situado a $1,60 \mathrm{~m}$ da base do muro) e 2,30\% para o nível de instrumentação E03 (situado a 5,20 $\mathrm{m}$ da base do muro). Para a seção em geotêxtil não tecido as deformações finais foram de 1,31\% para a seção instrumentada E02 e 3,26\% para a seção E03;

- As deformações registradas no muro de referência não apresentaram boa concordância com os resultados obtidos pelo método de previsão "k-stiffness modificado" proposto por Bathurst et al. (2008) e pelo método de previsão proposto por Ehrlich e Mitchell (1994). O método de Bathurst et al. (2008) indica que as deformações devem se apresentar de forma trapezoidal ao longo da altura do muro, sendo as maiores deformações situadas na região central da estrutura. $O$ método de Ehrlich e Mitchell (1994) indica que as deformações apresentam uma distribuição triangular, sendo as maiores deformações situadas no pé do muro. As deformações registradas no muro de Campinas apresentaram uma forma inversa à prevista pelo método de 
Bathurst et al. (2008), com deformações mais elevadas no pé e no topo do muro, e menores na região central. Apesar disso, as magnitudes das deformações previstas por ambos os métodos foram relativamente próximas às registradas no sistema de instrumentação;

- Observou-se ao longo das leituras de deformações na estrutura instrumentada que houve uma tendência de deslocamento da superfície potencial de ruptura ao longo do tempo para a seção em geotêxtil tecido. Este fato não ocorreu para a seção em geotêxtil não tecido;

- A comparação entre os resultados das leituras de campo para a seção instrumentada E02 e os resultados dos ensaios de fluência confinada realizados no equipamento de interação solo-reforço desenvolvido por Costa (2004) mostraram que, tanto para a seção em geotêxtil não tecido quanto para a seção em geotêxtil tecido, os níveis de deformação obtidos foram semelhantes. Entretanto, sob o aspecto de fluência, observou-se que os resultados de laboratório subestimaram as deformações reais;

- A comparação entre os resultados das leituras de campo para a seção instrumentada E02 e os resultados dos ensaios de fluência confinada realizados no equipamento de fluência confinada-acelerada desenvolvido por França (2011) mostraram que, para ambos os tipos de reforço (GT e GNT), os índices de fluência obtidos foram semelhantes. Entretanto, os níveis de deformação obtidos nos ensaios de laboratório foram significativamente menores que os registrados na obra real;

- A modelagem computacional realizada para o muro de referência mostrou que o Método dos Elementos Finitos (MEF) é uma excelente ferramenta para a previsão do comportamento ao longo do tempo de estruturas reforçadas com geossintéticos, tendo em vista que houve um bom ajuste entre os resultados obtidos numericamente e os resultados das leituras de campo e ensaios de laboratório; 
- Os modelos numéricos mostraram que, em ambas as seções (GT e GNT) houve plastificação do solo na região do pé do muro, sendo que a região plastificada se estendeu até uma altura de aproximadamente 2,0 m a partir da base da estrutura;

- A modelagem computacional permitiu a previsão do comportamento da estrutura de referência para um período de 100 anos. Para o caso da seção em geotêxteis não tecidos, a deformação máxima, obtida na seção instrumentada E02, após um período de 100 anos deve ser de $3,14 \%$. Para o caso da seção em geotêxteis tecidos a deformação esperada para o período proposto deve ser de 3,20\%;

- Além da extrapolação em termos de tempo, a modelagem computacional permitiu a extrapolação do comportamento do muro para outro tipo de reforço, a geogrelha (GG). Para este tipo de reforço, a previsão de deformação após um período de 100 anos, para a região da seção instrumentada E02, foi de 2,35\%;

- A comparação entre os resultados das leituras da obra instrumentada e dos ensaios de laboratório mostraram que as taxas de fluência de campo foram maiores que as taxas de fluência em isolamento. Para as linhas instrumentadas mais baixas (E01 e E02), este fato é explicado pela plastificação que ocorre no solo na região próxima ao pé do muro, e que atinge estas seções. A plastificação do maciço provoca uma redistribuição não linear de tensões no solo, e transfere estas tensões para o reforço. Para a linha instrumentada mais elevada (E03), a alta taxa de fluência é explicada pelos eventos externos identificados nas visitas realizadas em campo, como construções não previstas na crista do talude, possíveis danos nas inclusões na região mais elevada da estrutura e ainda danos na face envelopada;

- Os resultados obtidos na modelagem computacional permitiram a elaboração de gráficos que correlacionam a posição em relação à altura do muro $(z / H)$ e os parâmetros de deformação inicial "a" e tendência à fluência "b". Os gráficos podem ser utilizados para a 
previsão do comportamento ao longo do tempo de muros em solos reforçados com geossintéticos para um período de até 100 anos, empregando a Figura 5.28;

- O modelo analítico para a previsão do comportamento de estruturas em solo reforçado proposto no item 4.2.7 do Capítulo 4 foi aplicado para o caso da obra de referência, e mostrou um bom ajuste entre os resultados previstos e os registrados por meio da instrumentação. 


\section{CONCLUSÕES}

O presente trabalho apresentou uma investigação sobre o comportamento dependente do tempo de estruturas em solo reforçado com geossintéticos. O programa experimental conduzido nesta tese baseou-se na execução de ensaios de fluência confinada, e foi elaborado em função das características de um muro real em solo reforçado com geotêxteis, devidamente instrumentado, cujas leituras foram realizadas por um período de aproximadamente quatro anos. Adicionalmente aos ensaios de fluência confinada foram desenvolvidas modelagens computacionais que possibilitaram a extrapolação dos resultados obtidos em campo e em laboratório para períodos de tempo mais elevados.

A partir das leituras de deformações ao longo do tempo realizadas para a obra de referência, dos ensaios de fluência confinada realizados utilizando dois equipamentos distintos, e dos resultados obtidos nas modelagens numéricas, as seguintes conclusões puderam ser tomadas:

- Os ensaios de fluência confinada realizados no equipamento de interação solo-reforço desenvolvido por Costa (2004) mostraram que os parâmetros referentes às deformações iniciais (parâmetros "a" e $\varepsilon_{0}$ ) e referentes à tendência à fluência dos reforços (parâmetros "b" e T $\alpha$ ) foram reduzidos devido à presença do confinamento para os geotêxteis não tecidos, geotêxteis tecidos e geogrelhas, para todos os níveis de carregamento testados $(140,200,300$ e $400 \mathrm{kPa})$;

- Para todos os reforços avaliados (geotêxtil tecido, geotêxtil não tecido e geogrelha), observou-se que maiores níveis de carregamentos verticais aplicados ao ensaio confinado conduziram a maiores níveis de deformações, de parâmetros de fluência e de cargas nos reforços. Em todos os casos, as curvas do tipo carga-deformação obtidas para os diferentes tipos de reforço apresentaram uma forma curvada, com a concavidade da curva voltada para o canto inferior esquerdo do gráfico. Isto indica que a desaceleração das deformações nos reforços foi maior que a desaceleração das cargas, permitindo concluir que, nos 
ensaios realizados no equipamento de interação solo-reforço, a relaxação ocorre de forma mais intensa do que a fluência;

- Para o caso dos geotêxteis não tecidos (GNT) o confinamento em solo promoveu o aumento da rigidez do reforço em aproximadamente 2,5 vezes. Para os geotêxteis tecidos (GT) o aumento da rigidez em função do confinamento foi da ordem de 1,4 vezes. Já para o caso das geogrelhas (GG) o acréscimo foi da ordem de 1,8 vezes. Tais resultados mostram que os geotêxteis não tecidos sofreram maior influência pelo confinamento que os demais tipos de reforço;

- Os resultados dos ensaios confinados mostraram que a relaxação nos reforços, assim como a fluência, é dependente do nível de carregamento vertical aplicado ao ensaio, ou seja, a carga inicial no reforço e a tendência à redução da carga por relaxação são mais elevadas para carregamentos verticais maiores. Os resultados mostraram que os maiores índices de relaxação foram observados para os geotêxteis tecidos e os menores para os geotêxteis não tecidos. As geogrelhas apresentaram resultados intermediários;

- Os ensaios realizados com diferentes umidades de compactação mostraram que o melhor desempenho do conjunto solo-reforço foi obtido para os ensaios realizados com o maciço compactado na umidade ótima. As maiores deformações iniciais e índices de fluência foram obtidos para os ensaios com solo compactado com teor de umidade situado no ramo úmido. Os ensaios com solo compactado com teor de umidade situado no ramo seco apresentaram resultados intermediários. Estes resultados permitiram concluir que 0 comportamento do conjunto solo-reforço em termos de deformações instantâneas e fluência estão diretamente relacionados ao grau de compactação em que o solo se encontra;

- Os resultados dos ensaios confinados inundados mostraram que os acréscimos de carga nos reforços, decorrentes do processo de inundação, foram semelhantes aos acréscimos de deformação. Em 
termos de comportamento, isto indica que, apesar dos aumentos expressivos nos carregamentos e deformações (cerca de 100\% para GNT, 45\% para GT e 50\% para GG) a rigidez confinada dos reforços praticamente não se alterou devido à inundação;

- Os ensaios de compactação realizados no equipamento de interação solo-reforço mostraram que o processo de compactação promoveu um acréscimo de carga nos reforços. O acréscimo de carga no reforço devido aos efeitos da compactação foi de $68 \%$ para os geotêxteis não tecidos, $77 \%$ para os geotêxteis tecidos e $300 \%$ para as geogrelhas. Os resultados permitiram concluir que os acréscimos de carregamento estão associados à rigidez do geossintético e também às propriedades de interface solo-reforço;

- A partir das informações apresentadas na análise conjunta dos dados, foi possível se determinar um modelo analítico para a previsão do comportamento ao longo do tempo de reforços confinados. O modelo analítico possibilita a determinação da variação do módulo de rigidez confinada ao longo do tempo tendo como dados de entrada os resultados de ensaios de fluência em isolamento. O modelo proposto para a previsão de comportamento foi apresentado nas Equações 4.2, 4.3 e 4.4;

- Os resultados dos ensaios obtidos em ambos os equipamentos permitiram concluir que o equipamento de fluência confinada-acelerada apresentado por França (2011) é mais adequado para a verificação dos efeitos do confinamento sobre o comportamento ao longo do tempo de geossintéticos. Este tipo de equipamento, apesar de não representar de forma realista os mecanismos desenvolvidos em uma obra real de solos reforçados com geossintéticos, possui a capacidade de isolar os efeitos do confinamento em solo, além de possibilitar a execução de ensaios acelerados;

- O equipamento de interação solo-reforço desenvolvido por Costa (2004) é mais indicado para a previsão das deformações ao longo do tempo 
de estruturas reais, tendo em vista que representa de maneira mais realista os mecanismos desenvolvidos em estruturas de solo reforçado com geossintéticos;

- A modelagem computacional realizada para o muro de referência mostrou que o Método dos Elementos Finitos (MEF) é uma excelente ferramenta para a previsão do comportamento ao longo do tempo de estruturas reforçadas com geossintéticos, tendo em vista que houve um bom ajuste entre os resultados obtidos numericamente e os resultados das leituras de campo e ensaios de laboratório;

- A comparação entre os resultados das leituras da obra instrumentada e dos ensaios de laboratório mostraram que as taxas de fluência de campo foram maiores que as taxas de fluência em isolamento. Para as linhas instrumentadas mais baixas (E01 e E02), este fato é explicado pela plastificação que ocorre no solo na região próxima ao pé do muro, e que atinge estas seções. A plastificação do maciço provoca uma redistribuição não linear de tensões no solo, e transfere estas tensões para o reforço. Para a linha instrumentada mais elevada (E03), a alta taxa de fluência é explicada pelos eventos externos identificados nas visitas realizadas em campo, como construções não previstas na crista do talude, possíveis danos nas inclusões na região mais elevada da estrutura e ainda danos na face envelopada;

- A modelagem computacional permitiu a previsão do comportamento da estrutura de referência para um período de 100 anos. Para o caso da seção em geotêxteis não tecidos, a deformação máxima, obtida na seção instrumentada E02, após um período de 100 anos deve ser de $3,14 \%$. Para o caso da seção em geotêxteis tecidos a deformação esperada para o período proposto deve ser de 3,20\%;

- Além da extrapolação em termos de tempo, a modelagem computacional permitiu a extrapolação do comportamento do muro para outro tipo de reforço, a geogrelha (GG). Para este tipo de reforço, 
a previsão de deformação após um período de 100 anos, para a região da seção instrumentada E02, foi de 2,35\%;

- De forma geral, os resultados dos ensaios de laboratório, das modelagens computacionais e do monitoramento da estrutura de referência, mostraram que as tensões atuantes nos reforços foram muito baixas, e, consequentemente, as taxas de fluência também. Isto indica que, para o caso do dimensionamento de uma estrutura real sob as mesmas condições de carregamento e com o mesmo tipo de solo adotado nesta pesquisa, o Fator de Redução de fluência poderia ser negligenciado;

- O modelo analítico desenvolvido para a previsão do comportamento de estruturas em solo reforçado apresentado no Capítulo 4 foi aplicado para o caso da obra de referência, e mostrou um ótimo ajuste entre os resultados previstos e os registrados por meio da instrumentação. O modelo se mostra como uma excelente ferramenta para a previsão do comportamento de muros reforçados com geossintéticos a partir de resultados de ensaios de fluência em isolamento. 


\section{REFERÊNCIAS}

AMERICAN ASSOCIATION OF STATE HIGHWAY AND TRANSPORTATION OFFICIALS. Standard specifications for highway bridges, AASHTO, 17th Ed., Washington, D.C, EUA, 2002, 829p.

ABE, H., ONIKI, K., YAKUWA, N. Behaviors of geogrid reinforced embankment. 1989. Proceedings of Fourth IGS Japan Chapter Symposium,pp.18-22. (in Japanese).

ABRAMENTO, M. AND WHITTLE, A. Experimental Evaluation of Pullout Analyses for Planar Reinforcements. 1995. Journal of Geotechnical Engineering.V 121, I 6, p 486-492, 1995.

ABRAMENTO, M. Durabilidade e comportamento de longo prazo de geossintéticos Parte I: Propriedades mecânicas e hidráulicas. 1995 In: Geossintéticos 95. Anais. São Paulo, p. 217-226.

ADIB, M.; MITCHELL, J.K.; CHRISTOPHER, B. Finite element modeling of reinforced soil walls and embankments. 1990. Design and Performance of Earth Retaining Structures. Geotechnical Special Publication, ASCE, n.25, p.409-423, 1990.

ALI, F.H. Field Behaviour of a Geogrid-Reinforced Slope. 1993. Geotextiles and Geomembranes, Barking Essex, v.12, n.1, p.53-72.

ALLEN, T. M. Determination of long-term strength of geosynthetics: A state-of-the-art review. In: GEOSYNTHETICS'91 , 1991, Atlanta, Proceedings... Atlanta: International Geosynthetic Society, 1991. p. 351-379.

ALLEN, T. M.; CHRISTOPHER, B. R.; HOLTZ, R. D. Performance of a $12.6 \mathrm{~m}$ high geotextile wall in Seattle, Washington. 1992. In: International Symposium on Geosynthetic-Reinforced Soil Retaining Walls, Denver. Proceedings. WU, J. T. H. (ed.). Rotterdam, A. A. Balkema. P. 81-100, 1992.

ALLEN, T.M; BATHURST, R.J. Prediction of reinforcement loads in reinforced soil walls. 2003. Report WA-RD 522.2, Washington State Department ofTransportation, Olympia, Washington, 2003.

ALLEN, T. M., BATHURST, R. J. Design and performance of an 11-m high blockfaced geogrid wall. 2006. In Proceedings of the Eighth International Conference on Geosynthetics, Yokohama, Japan, September 2006, pp. 953-956. 
AMERICAN SOCIETY FOR TESTING AND MATERIALS. ASTM D 5262: Standard test method for evaluating the unconfined tension creep behavior of geosynthetics, 2007.

AMERICAN SOCIETY FOR TESTING AND MATERIALS (2001). ASTM D 6637: standard test method for determining tensile properties of geogrids by the single or multi-rib tensile method. West Conshohocken.

ANDRAWES, K. Z.; McGOWN, A.; KABIR, M. H. Uniaxial strength testing of woven and nonwoven geotextiles. 1984. Geotextiles and Geomembranes, v. 1, n. 1, p. 4156, 1984.

ANDRAWES, K. Z.; McGOWN, A; MURRAY, R. T. The load-strain-time-temperature behaviour of geotextiles and geogrids. 1986. In: International Conference on Geotextiles, 3rd. Viena, v. 3, p. 707-712, 1986.

ANDRAWES, K.Z.; McGOWN, A.; AHMAD, F. Influence of lateral boundary movements on earth pressure. 1990. International Conference of the Performance of Reinforced Soil Structures. British Geotechnical Society, Glasgow, Escócia, p.359364,1990 .

ASSOCIAÇÃO BRASILEIRA DE NORMAS TÉCNICAS. NBR 7181: Solo - análise granulométrica. Rio de Janeiro, 1984.

ASSOCIAÇÃO BRASILEIRA DE NORMAS TÉCNICAS. NBR 7182: Solo - ensaio de compactação. Rio de Janeiro, 1986.

ASSOCIAÇÃO BRASILEIRA DE NORMAS TÉCNICAS. NBR 12004/MB 3324: Solo - Determinação do índice de vazios máximo de solos não coesivos. Rio de Janeiro, 1990.

ASSOCIAÇÃO BRASILEIRA DE NORMAS TÉCNICAS. NBR 12051/MB 3388: Solo - Determinação do índice de vazios mínimo de solos não coesivos. Rio de Janeiro, 1991.

ASSOCIAÇÃO BRASILEIRA DE NORMAS TÉCNICAS. NBR 12568: Geotêxteis Determinação da gramatura. Rio de Janeiro,1992.

ASSOCIAÇÃO BRASILEIRA DE NORMAS TÉCNICAS. NBR ISO 10319:

Geossintéticos - Ensaio de faixa larga. Rio de Janeiro, 2013. 
ASSOCIAÇÃO BRASILEIRA DE NORMAS TÉCNICAS. NBR 15226: Geossintéticos - Determinação do comportamento em deformação e na ruptura, por fluência sob tração não confinada. Rio de Janeiro, 2005.

AVESANI, F. P. B. Fluência confinada e acelerada em geossintéticos. 2013. 130 p. Dissertação (Mestrado em Geotecnia) - Departamento de Geotecnia, Escola de Engenharia de São Carlos, Universidade de São Paulo, São Carlos, 2013.

BALLEGEER, J. P.; WU, J. T. H. Intrinsic confined and unconfined load-deformation properties of geotextiles. 1993. In: CHENG, S. J. C. Geosynthetics soil reinforcement testing procedures. Philadelphia. p. 16-31, 1993.

BATHURST, R. J.; BENJAMIN, D. J. Failure of a geogrid-reinforced soil wall. 1990. Transportation Research Record 1288, Washington, DC, USA, 1990, pp. 109-116.

BATHURST, R. J. Case study of a monitored propped panel wall. 1992. In: International Symposium on Geosynthetic-Reinforced Soil Retaining Walls, Dever, 1991. Proceedings. WU, J. T. H. (ed.).Rotterdam, A. A. Balkema. p. 159-166.

BATHURST, R. J., JARRETT, P. M.; BENJAMIN, D. J. A database of results from an incrementally constructed geogrid-reinforced soil wall test. 1993a. Proceedings of Soil Reinforcement: Full Scale Experiments of the 80s, ISSMFE/ENPC, Paris, France, November 1993, pp. 401-430.

BATHURST, R. J., SIMAC, M. R., CHRISTOPHER, B. R.; BONCZKIEWICZ, C. A database of results from a geosynthetic reinforced modular block soil retaining wall. 1993b. Proceedings of Soil Reinforcement: Full Scale Experiments of the 80s, ISSMFE/ENPC, Paris, France, November 1993, pp. 341-365.

BATHURST, R. J., MIYATA Y., NERNHEIM, A., ALLEN, T. M. Refinement of Kstiffness method for geosynthetic reinforced soil walls. 2008. Geosynthetics International 15(4):269-295.

BATHURST, R. J.; NERNHEIM, A., WALTERS, D.L., ALLEN, T.M., BURGUESS, P.; SAUNDERS, D.D. Influence of reinforcement stiffness and compaction on the performance of four geosynthetic-reinforced soil walls. 2009. Geosynthetics International, 16, No. 1, pp. 43-59, 2009.

BECKER, L. D. B.; NUNES, A. L. L. S. Confined creep of geotextile in a compacted sand fill. In: INTERNATIONAL CONFERENCE ON GEOSYNTHETICS, 7., 2002, Nice, Proceedings... Nice: International Geosynthetic Society, 2002. p. 1519-1522. 
BENIGNI, C.; BOSCO, G.; CAZZUFFI, D.; DE COL, R. Construction and performance of an experimental large scale wall reinforced with geosynthetics. 1996. Earth Reinforcement. Ochiai, Yasufuku \& Omine (ed.). Rotterdam, A. A. Balkema, 1996. p. 315-320.

BENJAMIM, C. V. S. Avaliação experimental de protótipos de estruturas de contenção em solo reforçado com geotêxtil. 2006. Tese (Doutorado em Geotecnia) Departamento de Geotecnia, Escola de Engenharia de São Carlos, Universidade de São Paulo, São Carlos, 2006.

BENJAMIM, C. V .S.; BUENO, B. S.; ZORNBERG, J. G. Field monitoring evaluation of geotextile-reinforced soil-retaining walls. 2007. Geosynthetics International, v. 14, n. 2, p. 100-119, 2007.

BRIGHT, D. G., COLLIN, J. G., BERG, R. R. Durability of geosynthetic soil reinforcement elements. 1994.in Tanque Verde retaining wall structures. Transportation Research Record 1439, Washington, DC, USA, 1994. pp. 46-54.

BRITISH STANDARDS INSTITUTION. BS 8006: Code of practice for strengthened/Reinforced soils and other fill. British Standard Institution, 1995.

BRITISH STANDARDS INSTITUTION. BS 6906: Methods of test for geotextiles. Determination of the tensile properties using wide width strip. British Standard Institution, 1987.

BROMS, B. e INGLESON, I. Earth Pressures Against Abutment of Rigid Frame Bridge. 1971. Geotechnique, v. 21, n. 1, pp. 15-28, 1971

BRUNO, A.C. Instrumentação de um Muro de Solo Reforçado com Geotêxteis. 1997. Dissertação (mestrado) - Universidade Federal do Rio de Janeiro, Rio de Janeiro, 1997.

BUENO, B. S. Matérias-primas. In: VERTEMATTI, J. C. Manual brasileiro de - 125 geossintéticos. 2004. São Paulo: Edgard Blücher. Cap. 2, p. 13-26, 2004.

BUENO, B.S.; ARAMAKI, R.T. Estrutura de contenção em solo reforçado com tiras de geotêxtil. 1998. XI Congresso Brasileiro de Mecânica dos Solos eEngenharia Geotécnica. Brasília, v.2, p.1079-1083, 1998.

CARRUBA, P., MORACI, N. \& MONTANELLI, F. Instrumented soil reinforced retaining wall: Analysis of measurements. 1999. Proceedings of Geosynthetics'99, IFAI, Vol. 2, Boston, Massachusetts, USA, April 1999, pp. 921-934. 
CAZZUFFI, D.; GHINELLI, A.; SACCHETTI, M.; VILLA, C. European experimental approach to the tensile creep behavior of high-strength geosynthetics. 1997. In: Geosynthetics' 97. Proceedings. California. v.1., 1997 , p.253-266.

CONSTANZI, M. A.; BUENO, B. S.; BARAS, L. C. S.; ZORNBERG, J. G. Avaliação da fluência de geotêxteis não tecidos com ensaios acelerados. 2003. Solos e Rochas, v. 26, n. 3, set. 2003.

COSTA, C. M. L. Fluência de geotêxteis. 1999. Dissertação (Mestrado em Geotecnia) - Departamento de Geotecnia, Escola de Engenharia de São Carlos, Universidade de São Paulo, São Carlos, 1999.

COSTA, C. M. L. Deformações dependentes do tempo em muros de solo reforçado com geotêxteis. 2004. Tese (Doutorado em Geotecnia) - Departamento de Geotecnia, Escola de Engenharia de São Carlos, Universidade de São Paulo, São Carlos, 2004.

COUSENS, T. W., PINTO, M. I. M. The Effect of Compaction on Model Fabric Reinforced Brick Faced Earth Retaining Walls. 1996. Earth Reinforcement, v.1, pp. 339-344, Ed. Ochiai, Yasufuku \& Omine, Balkema, Rotterdam, Holanda,1996.

Christopher, B. R. Deformation response and wall stiffness in relation to reinforced soil wall design. 1993. Ph.D. Dissertation, Purdue University, West Lafayette, Indiana, USA, 1993, 352 pp.

D'APPOLONIA, D. J., WHITMAN, R. V., e D'APPOLONIA, E. D. Sand Compaction with Vibratory Rollers. 1969 Journal of the Soil Mechanics and Foundations Division, v. 95, n. SM1, January, pp. 263-284, 1969.

Den HOEDT, G. Creep and relaxation of geotextiles fabrics. Geotextiles and Geomembranes, v. 4, n. 2, p. 83-92, 1986.

DELMAS, P.H.; GOURC, J. P.; BLIVET, J. C.; MATICHARD, Y. Geotextile reinforced retaining structures: a few instrumented examples. 1988. In: INTERNATIONAL GEOTECHNICAL SYMPOSIUM ON THEORY AND PRACTICE OF EARTH REINFORCEMENT. Proceedings...Fukuoka, Japan, 1988.

DOURADO-NETO, D.; NIELSEN, D. R.; HOPMANS, J. W. Software to model soil water retention curves. Scientia Agricola, Vol. 57, n. 1, 2001, pp. 191-192.

DUNCAN, J. M., SEED, R. B. Compaction-Induced Earth Pressures Under KOConditions. 1986. Journal of Geotechcnical Engineering, ASCE, v.112, n. 1 (Jan), pp. 1- 22, 1986. 
EHRLICH, M.; BECKER, L. D. B. Muros e Taludes de Solo Reforçado: Projeto e Execução. 2009. São Paulo: Oficina de Textos. Coleção Huesker: Engenharia com geossintéticos, 2009. 126p.

EHRLICH, M., MITCHELL, J. K.. Working Stress Design Method for Reinforced Soil Walls. 1994. Journal of Geotechnical Engeneering, v.120, n. 4 (April), 1994, pp. 625645.

ERHLICH, M.;VIANNA, A. J. D.; FUSARO, F. Comportamento de um muro de solo reforçado. 1994. In: Congresso Brasileiro De Mecânica Dos Solos E Engenharia De Fundações, 10, 1994, Foz do Iguaçu. Anais. São Paulo, ABMS, 1994, p. 819-824.

EHRLICH, M., MIRMORADI, S. H. \& SARAMAGO, R. P. Evaluation of the effect of compaction on the behavior of geosynthetic-reinforced soil walls, 2015. J. Geotextiles Geomembranes 34, No. Oct, 108-115, 2012.

FAHEL, A.R.; PALMEIRA, E.M.; CAMPOS, L.E.P. Danos em estruturas reforçadas com geossintéticos sobre fundação em solo mole. 1999, Geossintéticos 99, $3^{\circ}$ Congresso Brasileiro de Geossintéticos, Rio de Janeiro, Brasil, p.67-74, 1999.

FANNIN, R .J. \& HERMANN, S. Performance data for a sloped reinforced soil wall. 1990. Canadian Geotechnical Journal, 27, No. 5, 676-686.

FANNIN, R.J. Long-Term Variations of Force and Strain in a Steep GeogridReinforced Soil Slope. 2001. Geosynthetics International, v.8, n.1, p.81-96.

FARRAG, K.; SHIRAZI, H. Development of an accelerated creep testing procedure for geosynthetics - Part 1: Testing. Geotechnical Testing Journal, v. 20, n. 4, 1997, p. $414-422$,

FARRAG, K. Development of an accelerated creep testing procedure for geosynthetics - Part 2: Analysis. Geotechnical Testing Journal, v. 21, n. 1, 1998, p.38-44.

FARRAG, K., ABU-FARSAKH, M. \& MORVANT, M. Stress and strain monitoring of reinforced soil test wall. 2004. Transportation Research Record: Journal of Transportation Research Board, No.1868, National Research Council, Washington, D.C., pp 204-266.

FERRY, J. D. Viscoelastic properties of polymers. 3. ed. New York: John Wiley \& Sons, 1980.641p. 
FEDERAL HIGHWAY ADMINISTRATION. FHWA 1998. Mechanically stabilized earth walls and reinforced soil slopes design and construction guidelines. FHWA-SA96-071, Elias, V.; Christopher, B.R., 1998, Washington, DC, September, 371p.

FRANÇA, F. A. N. Novo equipamento para realização de ensaios confinados e acelerados de fluência em geossintéticos. 2011. 263 p. Tese (Doutorado em Geotecnia) - Departamento de Geotecnia, Escola de Engenharia de São Carlos, Universidade de São Paulo, São Carlos, 2011.

GOMES, R.S. Interação solo-reforço e mecanismos de ruptura em solos reforçados com geotêxteis.1992. 271p. Tese de doutorado - Escola de Engenharia de São Carlos/USP, São Carlos, 1992.

GOTTARDI, G.; SIMONINI, P. Time and temperature effects on the behaviour of geosynthetics-reinforced walls. 2000. In: EuroGeo 2000, European Geosynthetics Conference, 2nd. Proceedings. Bologna, v. 1, p.175-180.

HELWANY, M. B. Long-term soil-geosynthetic interation in geosynthetic-reinforced soil structures. 1993. Denver. 265 p. Tese (Doutorado) - University of Colorado at Denver.

HELWANY, S. M. B.; SHIH, S. Creep and stress relaxation of geotextile-reinforced soils. Geosynthetics International, v. 5, n. 4, 1998, p. 425-434.

HO, S.K.; ROWE, R.K. Effect of wall geometry on the behaviour of reinforced soil walls. Geotextiles and Geomembranes. 1996. Barking Essex, v.14, p.521-541,1996.

INGOLD, T. S. The Effects of Compaction on Retaining Walls. 1979. Geotechnique, v. 29, n. 3, pp. $265-283,1979$.

INTERNATIONAL ORGANIZATION FOR STANDARDIZATION. ISO 13431: Geotextile and geotestile related products - Determination of tensile creep and creep rupture behaviour. Switzerland, 1998.

ITOH, M., KUMAGAI, K., ITOH, A. \& SHIMIZU, H. Test construction of steep embankment reinforced with geotextiles in the valley. 1988. Proceedings of Third IGS Japan Chapter Symposium, pp. 129-135. (in Japanese).

JEON, H. Y.; KIM, S. H.; YOO, H. K. Assessment of long-term performances of polyester geogrids by accelerated creep test. Polymer Testing, v. 21, n. 5, 2002, p. 489-495. 
JEWELL, R. A.; GREENWOOD, J. H. Long term strength and safety in steep soil slopes reinforced by polymer materials. 1988. Geotextiles and Geomembranes, v. 7, n. 1-2, p. 81-118, 1988.

JONES, C. J. F . P.; CLARKE, D. The residual strength of geosynthetic reinforcement subjected to accelerated creep testing and simulated seismic events. Geotextiles and Geomembranes, v. 25, n. 3, 2007, p. 155-169.

JONES, C.J.F.P. Construction Influences on the Performance of Reinforced Soil Structures. 1990. Performance of Reinforced Soil Structures. International ReinforcedSoil Conference, British Geotechnical Society, p.97-116, 1990.

JONES, C.J.F.P.; ASAN, C.A. Discussions on Geosynthetic-Reinforced Retaining Walls. 1992. Ed. by WU, J.T.H, Balkema, Roterdam, 1992, p.366-368. 1992.

JONES, C. J. F. P. Geosynthetic in reinforced structures. In: II EUROPEAN GEOSYNTHETICS CONFERENCE, Eurogeo, 2000. Proceedings... Bologna, Italia, 2000.

KAMIJI, T. S. M. M. Fluência de geotêxteis não tecidos através de ensaios confinados. 2006. Dissertação (Mestrado em Geotecnia) - Departamento de Geotecnia, Escola de Engenharia de São Carlos, Universidade de São Paulo, São Carlos, 2006.

KARPURAPU, R.; BATHURST, R.J. Numerical investigation of controlled yielding of soil-retaining wall structures. 1992. Geotextiles and Geomembranes, Barking Essex, v.11, p.115-131, 1992.

KAZIMIEROWICZ-FRANKOWSKA, K Deformations of model reinforced-soil retaining walls due to creep and reinforcement pullout. Geosynthetics International, v. 10, n. 5, p. 153-163, 2003.

KAZIMIEROWICZ-FRANKOWSKA, K Correlation between the results of creep and relaxation tests of geotextiles. Geosynthetics International, v. 12, n. 5, p. 269-275, 2005.

KAZIMIEROWICZ-FRANKOWSKA, K Creep properties of geosynthetics during increasing loading and after partial unloading. In: INTERNATIONAL CONFERENCE ON GEOSYNTHETICS, 8., 2006, Yokohama, Proceedings... Yokohama: International Geosynthetic Society, 2006. p. 1605-1608. 
KNIGHT, M. A. \& VALSANGKAR, A. J. Instrumentation and performance of tilt-up panel wall. 1993. Proceedings of Geosynthetics'93, IFAI, Vancouver, British Columbia, Canada, Vol. 1, pp. 123-136.

KOERNER, R. M.; LORD JR., A. E.; HALSE, Y. H. Long-term durability and aging of geotextiles. 1998. Geotextiles and Geomembranes, v. 7, n. 1-2, p. 147-158, 1988.

KOERNER, R. M.; SOONG, T. Geosynthetic reinforced segmental retaining walls.2001. Geotextiles and Geomembranes, v. 19, p. 359-386, 2001.

KOERNER, R.. M. Designing with geosynthetics. 6. ed. Xlibris Corporation, 2012. $526 \mathrm{p}$.

LANZ, D.; PALMEIRA, E.M. Distribuição de tensões e deformações em estruturas de arrimo reforçadas com geossintéticos. 1994. X Congresso Brasileiro de Mecânica dos Solos e Engenharia de Fundações, v.3, p.833-840, Foz do Iguaçu, 1994.

LESHCHINSKY, D. et al. Creep and stress relaxation of geogrids. Geosynthetics International, v. 4, n. 5, p. 463-479, 1997.

LEVACHER, D.; BLIVET, J. C.; MSOUTI, F. Tensile and creep behavior of geotextiles. In: Geotextiles, Geomembranes and Related Products, 5th. Proceedings. Singapore. v.3, p. 1131-1134, 1994.

LOIOLA, F. L. P. Estudo Numérico da Influência da Face no Comportamento de Muros de Solo Reforçado. 2001. Dissertação (Mestrado) - COPPE/UFRJ, Rio de Janeiro, 2001.

MARQUES, G. L. O. Uso de geotêxteis em muros de contenção de pequeno porte. 1994. Viçosa. 126 p. Dissertação (Mestrado) -Universidade Federal de Viçosa.

MATICHARD, Y.; LECLERCQ, B.; SEGOUIN, M. Creep of geotextiles: soil reinforcement applications. 1990. In: Geotextiles, Geomembranes and Related Products, 4th, The Hague, 1990. Proceedings. Rotterdam, Balkema. v.2, p. 661-665.

MCGOWN, A.; ANDRAWES, K. Z.; KABIR, M. H. Load-extension testing of geotextiles confined in-soil. In: INTERNATIONAL CONFERENCE ON GEOTEXTILES, 2., 1982, Las Vegas, Proceedings... Las Vegas, 1982. p. 793-798.

McGOWN, A.; ANDRAWES, K.Z.; MURRAY, R.T. Controlled yielding of the lateral boundaries of soil retaining structures. 1988. Geotechnical Special Publication, ASCE, v.18, p.193-210, 1988. 
McGOWN, A.; ANDRAWES, K. Z.; PRADHAN, S.; KHAN, A. J. Limit state design of geosynthetic reinforced soil structures. 1998. In: International 325. Conference on Geosynthetics. Geotextiles, 6th. Proceedings. Atlanta, v. 1, p. 143-179.

MENDES, M.J. Comportamento Carga-Alongamento de Geotêxteis não Tecidos submetidos à tração confinada. 2006. Dissertação de Mestrado, Publicação G.DM146/06, Universidade de Brasília, Brasília, DF, 152p, 2006.

MENDES, M. J. A.; PALMEIRA, E. M. Efeitos da impregnação na rigidez de geotêxteis não tecidos em ensaios de tração confinada. In: SIMPÓSIO BRASILEIRO DE GEOSSINTÉTICOS, 5., 2007, Recife, Proceedings... Recife: Associação Brasileira de Geossintéticos, 2007.

MIKI, H.; HAYASHI, Y.; YAMADA, K.; TAKASAGO, T.; SHIDO, H. Plane train tensile strength and creep of spun-bonded non woven. 1990. In: Geotextiles, eomembranes and Related Products, 4th. The Hague, 1990. Proceedings. Rotterdam, Balkema, v.2, p.667-672.

MIKI, H., KUDO, K., TAKI, M., FUKUDA, N., IWASAKI, K. \& NISHIMURA, J. Experimental study on full scale geogrid reinforced embankment. 1992. Proceedings of IS-Kyushu 92, Second International Symposium on Earth Reinforcement, Fukuoka, Japan, pp. 269-274.

MIRMORADI, S. H. \& EHRLICH, M. Modeling of the compaction-induced stress on reinforced soil walls, 2015. J. Geotextiles Geomembranes 43, No. 1, 82-88.

MITCHELL, J.K.; VILLET, W.C.B. Reinforcement of earth slopes and embankments. 1987. National Cooperative Higway Research Program Report. n.290, 1987.

MIYATA, Y.; BATHURST, R. J. Prediction model of reinforcement load for geogrid soil walls with facing batter. Geosynthetics Engineering Journal, Japan, Chapter of IGS, v. 23, 2008, p. 195-200.

MSOUTI, M. F.; BLIVET, J. C.; LEVACHER, D. Comportement au fluage des géotextiles en reforcement mécanique. 1997. Études et recherches des laboratories des Ponts et Chaussées, GT n. 63.

NAEMURA, S.; \& MIKI, H. Design and Construction of Geotextile Reinforced Soil for Road Earthworks in Japan. 1996. Geosynthetics International, v.3, n.1, p.49-62.

NATIONAL CONCRETE MEASONRY ASSOCIATION. NCMA 1998. Segmental retaining walls- seismic design manual, 1. e., Bathurst (Editor), Herndon, Virginia, EUA. 
NAKANE, A., NAGAOKA, T., ONODERA, M. \& SHIMADA, I. Test construction of retaining wall reinforced with geotextiles. 1990. Proceedings of Fifth IGS Japan Chapter Symposium, pp. 23-29. (in Japanese).

ONODERA, S., FUKUDA, N. \& NAKANE, A. (2004). Long-term behavior of geogrid reinforced soil walls. 1994. Proceedings of GeoAsia 2004, Seoul, Korea, pp. 225264.

OCHIAI, Y. \& FUKUDA, N. Experimental study on geotextile -reinforced soil walls with different facings. 1996. Proceedings of EuroGeo1, First European Conference on Geosynthetics, Maastricht, The Netherlands, pp. 79-86.

PATIAS, J. Avaliação de solos não convencionais em estruturas de solo reforçado. 2005. Dissertação de mestrado - Escola de Engenharia de São Carlos, Universidade de São Paulo, São Carlos, 2005.

PEDROSO, E.O. Estruturas de contenção reforçadas com geossintéticos. 2000. Dissertação (mestrado) - Escola de Engenharia de São Carlos, Universidade de São Paulo, São Carlos, 2000.

PETRICK, P.M.; BASLÍK, R. Design of Geotextiles reinforcing embankments with reference to long-term loading. 1988. Geotextiles and Geomembranes, Barking Essex, 1988, v.7, p.71-79.

PORTELINHA, F. H. M. Avaliação experimental da influência do avanço do umedecimento no comportamento de muros de solos finos reforçados com geotêxteis não tecidos. 2012. Tese (Doutorado em Geotecnia) - Departamento de Geotecnia, Escola de Engenharia de São Carlos, Universidade de São Paulo, São Carlos, 2012.

PUBLIC WORKS RESEARCH INSTITUTE (PWRI), Sumitomo Kensetsu Co., Ltd. and Tekken Kensetsu Co., Ltd. 1988. Retaining Soil Wall with Geotextile. Cooperative Research Report in Public Works Research Institute, Ministry of Construction, Tsukuba, Japan, 68 pp. (in Japanese)

PWRC. Technical Report on Rational Design Method ofReinforced Soil Walls. 1995. Public Works Research Center, Tsukuba, Ibaraki, Japan, 278 pp. (in Japanese).

PWRC. Design and Construction Manual of Geosynthetics Reinforced Soil (revised version). 2000. Public Works Research Center, Tsukuba, Ibaraki, Japan, 305 p. (in Japanese). 
PWRC. Technical Report for PWRC Certification of Construction Material, Products and Technique: Geogrid Tensar (Certificated No. 0201), 2002. Public Works Research Center, Tsukuba, Ibaraki, Japan, 235 pp. (in Japanese)

RICCIO FILHO, M. V. Comportamento de um Muro de Solo Reforçado com Solos Finos Tropicais. 2007. Tese (Doutorado em Geotecnia) - COPPE/UFRJ, Rio de Janeiro, 2007.

ROWE, P. W. A Stress-strain Theory for Cohesionless Soil with Applications to Earth Pressures at Rest and Moving Walls, 1954, Geotechnique, v. 4, n. 2, pp. 70-88, 1954.

ROWE, R.K.; HO, S.K. A review of the behavior of reinforced soil walls. 1992. In: International Symposium on Earth Reinforcement, Fukuoka, 1992. Proceedings. OCHIAI, H.; HAYASHI, S.; OTANI, J. (ed.) Rotterdam, A. A., Balkema, v. 2. P. 801830.

ROWE, R.K.; HO, S.K. Horizontal deformation in reinforced soil walls. 1998. Canadian Geotechnical Journal, v.35, p.312-327, 1998.

RIMOLDI, P.; MONTANELLI, F. Creep and accelerated creep testing for geogrids. In: GEOSYNTHETICS '93, 1993, Vancouver, Proceedings... Vancouver: International Geosynthetic Society, 1993. p. 773-787.

SARAMAGO, R. P. Estudo da Influência da Compactação no Comportamento de Muros de Solo Reforçado com a Utilização de Modelos Físicos. 2002. Tese (Doutorado em Geotecnia) - COPPE/UFRJ, Rio de Janeiro, 2002.

SAWICKI, A.; KAZIMIEROWICZ-FRANKOWSKA, K. Creep behavior of geosynthetics. Geotextiles and Geomembranes, v. 16, n. 6, p. 365-382, dez. 1998.

SCAFFARO, R.; DINTCHEVA, N. T.; LA MANTIA, F. P. A new equipment to measure the combined effects of humidity, temperature, mechanical stress and UV exposure on the creep behavior of polymers. 2008. Polymer Testing, v. 27, n. 1, p. 49.

SEGRESTIN, P.; FREITAG, N. Opinions about creep rupture in soil reinforcement design. In: INTERNATIONAL CONFERENCE ON GEOSYNTHETICS, 8., 2006, Yokohama, Proceedings... Yokohama: International Geosynthetic Society, 2006. p. 1595-1598. 
SHRESTHA, S. C.; BELL, J. R. Creep behavior of geotextiles under sustained loads. 1982. In: International Conference on Geotextiles, 2nd. Proceedings. Las Vegas, v. 3, p. 769-774.

SIMONINI, P.; GOTTARDI, G. The viscoplastic behavior of a geogrid-reinforced model wall. Geosynthetics International, v. 10, n. 1, p. 34-46, 2003.

SOWERS, G. F., ROBB, A. D., MULLIS, C. H., e GLENN, A. J. The Residual Lateral Pressures Produced by Compacting Soils. 1957 Proceedings of the 4th International Conference on Soil Mechanics and Foundation Engineering, pp. 243-247, Londres, Inglaterra, 1957.

TAJIRI, N., SASAKI, H., NISHIMURA J., OCHIAI Y. \& DOBASHI K. Fullscale failure experiments of geotextile-reinforced soil walls with different facings. 1996. Proceedings of IS-Kyushu 96, Third International Symposium on Earth Reinforcement, Fukuoka, Japan, 1996, pp. 525-530.

THAMM, B. R., KRIEGER, B., LESNIEWSKA, D. Full Scale Teste of a Geotextile Reinforced Soil Wall. 1990. Performance of Reinforced Soil Wall, Proceedings of the International Reinforced Soil Conference, Britsh Geotechnical Society, Glasgow, 1012 September, 1990.

THORNTON, J. S.; ALLEN, S. R.; THOMAS, R. W. Approaches for the prediction of long term viscoelastic properties of geosynthetics from short term tests. In: GEOSYNTHETICS '97, 1997, Atlanta, Proceedings... Atlanta: International Geosynthetic Society, 1997. p. 277-291.

THORNTON, J. S. Characterization of short and long term creep and relaxation properties of a polypropylene geogrid. 2001. In: Geosynthetics 2001. Proceedings. Oregon. v.2, p. 835-845.

TSUKADA, Y.; OCHIAI, Y; MIYATAKE, H.; TAJIRI, N. Field performance test of a geosynthetic-reinforced soil wall with rigid facing. 1998. Sixth International Conference on Geosynthetics. Atlanta, Georgia, EUA, v.1, p.577-580.

VAN GENUCHTEN. A closed-form equation for predicting the hydraulic conductivity. Soil Science of America Journal, v. 44, n. 5, 1980, p. 892-898.

VAN ZANTEN, R. V. Geotextiles and geomembranes in civil engineering. 1986. Rotterdan, Balkema, 1986. 
VERTEMATTI, J. C. Manual Brasileiro de Geossintéticos. São Paulo: Edgard Blücher, 2004.

VILAR, O. M.; BUENO, B. S. Some Topics Regarding the Influence of Non-saturation on the Behavior of Reinforced Soil Structures Built with Tropical Soils. 2008. In: First Pan American Geosynthetics Conference \& Exhibition, 2008, Proceedings..., Cancun, 2008, v. 1. p. 272-280.

WALTERS, D.; ALLEN, T.M.; BATHURST, R.J. Conversion of geosynthetic strain to load using reinforcement stiffness. 2002. Geosynthetics International, v. 9, n. 5-6, p. 483-523.

WILLIAMS, M. L.; LANDEL, R. F.; FERRY, J. D. The temperature dependence of relaxation mechanisms in amorphous polymers and other glass-forming liquids. Journal of the American Chemical Society, v. 77, n. 14, 1995, p. 3701-3707.

WU, J. T. H. Geosynthetic-reinforced soil retaining walls. 1992. In: International Symposium on Geosynthetic-Reinforced Soil Retaining Walls, Dever, 1992. Proceedings. WU, J. T. H. (ed.).Rotterdam, A. A. Balkema.

WU, J. T. H.; HELWANY, S. M. B. A performance test for assessment of long-therm creep behavior of soil-geosynthetic composites. Geosynthetics International, v. 3, n. 1, 1996, p. 107-124.

WU, C. S.; HONG, Y. S. Creep behavior of geotextile under confining stress. In: Geotextiles, Geomembranes and Related Products, 5th. Proceedings. Singapore. v.3, 1994, p. 1135-1138.

YAMANOUCHI, T., FUKUDA, N., ODA, H., MARUYAMA, K., NAGATA, T., KOBAYASHI, K. \& MORIHATA, I. Test construction works for polymer grid reinforcement retaining wall. 1986. Proceedings of the 21st Japanese Geotechnical Society Conference, pp. 549-553. (in Japanese).

YUAN, Z.; SWAN, R. H.; BACHUS, R. C. Soil Confinement effect on stress-strain properties of geosynthetics. 1998. In: International Conference on Geosynthetics, 6th. Proceedings, Atlanta, v. 2, 1998, p. 523-528.

ZORNBERG, J.G.; SITAR, N.; MITCHELL, J.K. Performance of geosynthetic reinforced slopes at failure. 1998. Journal of Geotechnical and Geoenvironmental Engineering, v.124, n.8, p.670-683, 1998. 
ZORNBERG, J. G.; BYLER, B. R.; KNUDSEN, J. W. Creep of geotextiles using timetemperature superposition methods. Journal of Geotechnical and Geoenvironmental Engineering, v. 130, n. 11, 2004, p. 1158-1168.

ZORNBERG, J.G.; LESHCHINSKY, D. Comparison of international design criteria for geosynthetic-reinforced soil structures. 2003. Landmarks in Earth Reinforcement, Ochiai, H., Otani, J., Yasufuku, N., and Omine, K. (Editors), Fukuoka, Japan, November, 2003, v. 2, p. 1095-1106.

ZORNBERG, J. G.; MITCHELL, J. K. Reinforced soil structures with poorly draining backfills. 1994. Part I: Reinforcement interaction and functions. Geosynthetics International, v. 1, n. 2, p. 103-147, 1994. 